\title{
Румянцев М.Б.
}

..........

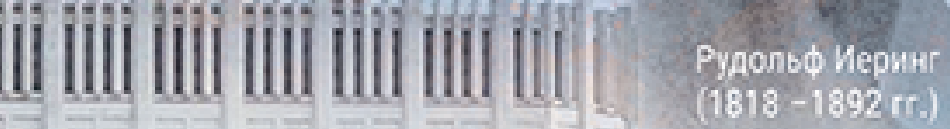

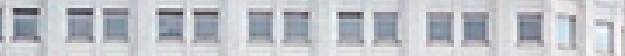

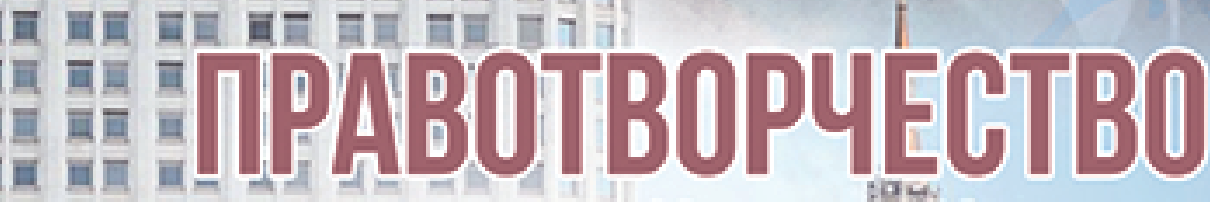

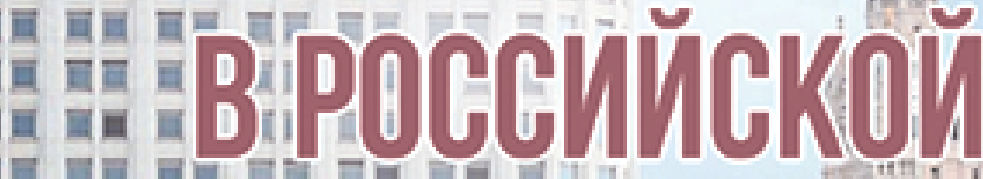

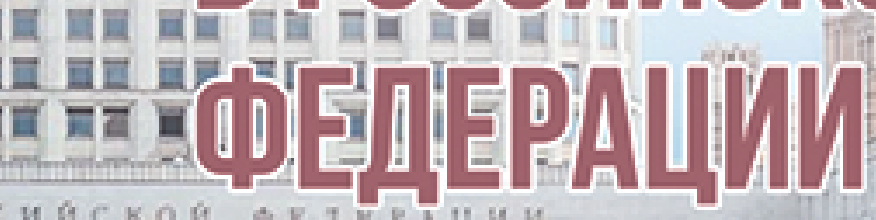

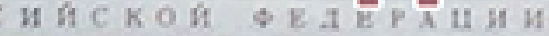
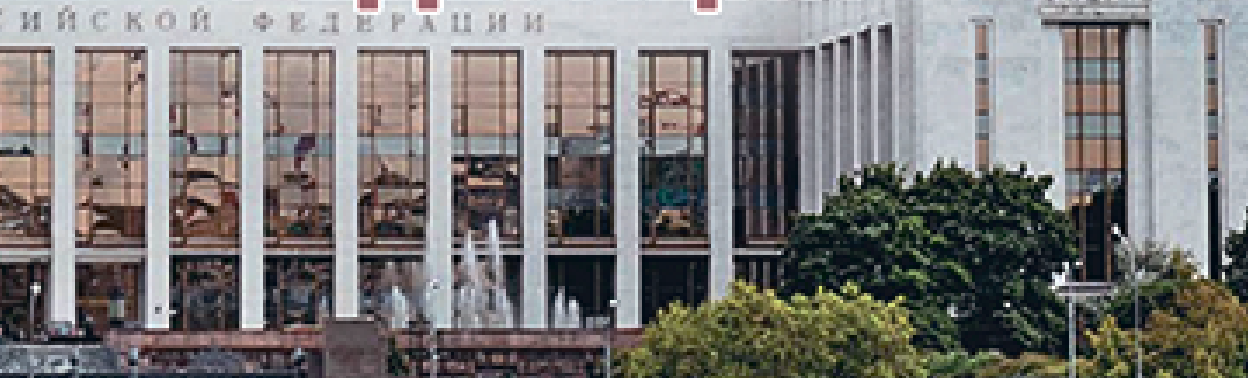

atin

m

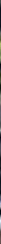


Румянцев Михаил Борисович

\section{ПРАВОТВОРЧЕСТВО В РОССИЙСКОЙ ФЕДЕРАЦИИ}

Монография 
УДК 34

ББК 67.0

P86

\section{Рецензенты:}

Беликова Ксения Михайловна, д-р юрид. наук, профессор ФГАОУ ВО «Российский университет дружбы народов»

Васильев Федор Петрович, д-р юрид. наук, главный научный сотрудник научно-исследовательского центра (НИЦ) Академии управления МВД России, член Российского профессорского собрания (РПС)

Румянцев, М. Б.

Р86 Правотворчество в Российской Федерации: монография / М.Б. Румянцев. - Чебоксары: ИД «Среда», 2019. - 324 с.

ISBN 978-5-6042436-5-7

В монографии рассмотрена тема правотворчества как комплексной обобщающей науки.

В работе справедливо отмечается регулятивный характер правотворчества как института общественных отношений, а также сложный многоаспектный характер, сочетающий в себе процесс, деятельность и правовой институт.

Автором предпринята попытка впервые дать ретроспективное определение принципам правотворчества как первичным стимулам.

ISBN 978-5-6042436-5-7

DOI $10.31483 / \mathrm{a}-72$

(C) М.Б. Румянцев, 2019

(С) ИД «Среда», 2019 


\section{ОГЛАВЛЕНИЕ}

ВВЕДЕНИЕ .5

ГЛАВА 1. КРАТКАЯ ХАРАКТЕРИСТИКА ПРАВОТВОРЧЕСТВА КАК МНОГОГРАННОГО ЮРИДИЧЕСКОГО ЯВЛЕНИЯ .......15

$\S 1.1$. Диахронический срез философско-правовых оснований правотворчества 15

$\S 1.1 .1$. Доконтовские попытки осмысления создания законов как юридической науки 15 §1.1.2. Позитивизм О. Конта - основа правотворчества как современной юридической науки. .18

§1.1.3. Развитие юридических наук в Новое и Новейшее время: краткий обзор …................................................................21

1.1.4. Зарождение юридической техники ................................ 23

§1.2. Научное определение понятия «правотворчество» ....................24

\$1.2.1. Современные проблемы теории создания законов. Соотношение понятий правотворчества и юридической техники .......................... 24

$\S 1.2 .2$. Соотношение теоретического и эмпирического в создании законов... 29 §1.2.3. Определение правотворчества ..................................... 32

\$1.3. Теоретический уровень правотворчества ............................ 33

\$1.3.1. Вводные замечания ...................................................... 33

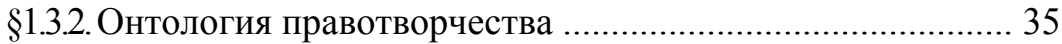

\$1.3.3.Гносеология правотворчества ........................................ 38

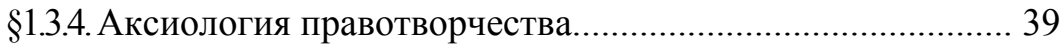

§1.3.5. Логика и методология правотворчества .......................... 42

\$1.3.6. Социальная философия правотворчества ......................... 47

\$1.4. Правотворчество как прикладная наука ............................. 48

\$1.4.1. Эмпирический уровень правотворчества ............................... 48

\$1.4.2. Понятие, структура и признаки правотворчества как юри-

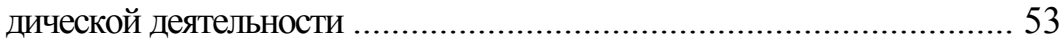

§1.5. Выводы по исследованию правотворчества как юридического

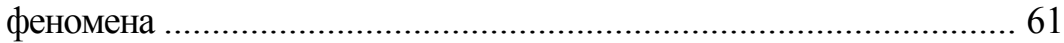

ГЛАВА 2. ОБЬЕКТ ИССЛЕДОВАНИЙ ЭМПИРИЧЕСКОГО ПРАВОТВОРЧЕСТВА: ВИДЫ ПРАВОТВОРЧЕСКОГО ПРОЦЕССА 62

$\S 2.1$. Предмет изучения теории правотворчества. Виды право-

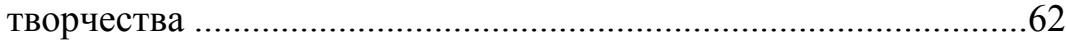

\$2.2. Виды правотворческого процесса................................... 72

§2.3. Классификация правотворчества по видам ........................ 83

2.4. Законотворчество ....................................................... 91 


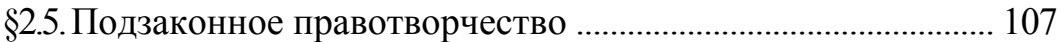

§2.6. Муниципальное правотворчество ................................. 122

\$2.7. Локальное правотворчество ........................................... 142

\$2.8. Судебное правотворчество ......................................... 154

ГЛАВА З. ТЕОРЕТИКО-ПРАВОВОЕ ИССЛЕДОВАНИЕ СООТНОШЕНИЯ ПРАВОТВОРЧЕСТВА И ПРИКЛАДНОЙ ЮРИДИЧЕСКОЙ НАУКИ, ЮРИДИЧЕСКОЙ ТЕХНИКИ .................. 165

§3.1.Принципы правотворчества и их классификация ............. 165

§3.2. Институционализация принципов правотворчества как способ перевода научных категорий в правотворческие решения ............ 174 §3.3. Формирование и развитие системы принципов правотворчества, их значение для нормативного закрепления надлежащей модели правового регулирования общественных отношений .......186 §3.4. Созидающее правотворчество и приемы юридической

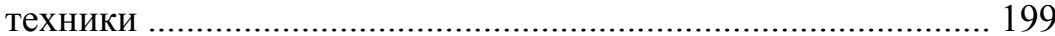

\$3.4.1. Принципы созидающего правотворчества ..................... 199 §.3.4.2. Соотношение нормативного и духовного в созидающей правовой норме и особенности её структуры ....................... 210 §.3.4.3. Модификатор правовой нормы в созидающем право-

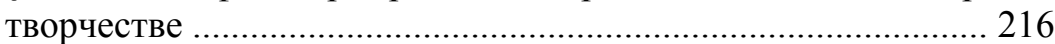

ГЛАВА 4. МЕХАНИЗМ ПРАВОТВОРЧЕСТВА ……..................... 225

§4.1. Стадии правотворческого процесса и их роль в балансе ветвей власти .............................................................. 225

$\S 4.2$. Планирование и прогнозирование в ходе правотворческой

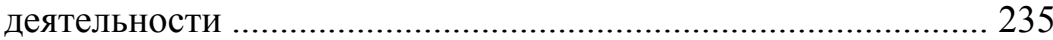

$\S 4.3$. Выбор нормативного правового акта в процессе правотворчества 247 \$4.4. Юридический состав правотворческого решения ........... 257

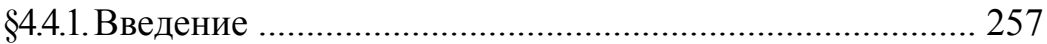

\$4.4.2. Задачи юридической науки ......................................... 257

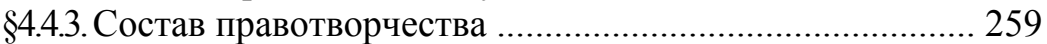

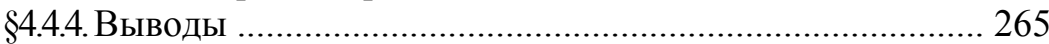

$\S 4.5$.Научное обоснование правотворческого решения .......... 265

\$4.6. Качество правотворчества .......................................... 273

\$4.7.Понятие и особенности отраслевого правотворчества ... 282

\$4.7.1.Правотворчество в сфере конституционного права ..... 285

$\$ 4.7 .2$. Угловное правотворчество ...................................... 288

\$4.7.3.Правотворчество в сфере гражданского права ............. 297

СПИСОК ЛИТЕРАТУРЫ ................................................. 305 


\section{ВВЕДЕНИЕ}

Актуальность темы исследования. Совершенствование правовой системы Российской Федерации в настоящее время зависит от востребованной практики и научно обоснованной потребности развития, общей теории правотворчества как самостоятельной юридической науки. Формирование всей нормативной правовой базы страны ведется без долгосрочного планирования и прогнозирования правотворческой деятельности при малозначительном участии в данном процессе юридической науки. Теория правотворчества, которая и должна составлять научную основу разработки всех правотворческих решений, переживает период стихийного хаотического становления без четких ориентиров и приоритетов познания социально-правовой действительности, востребованных практикой государственного строительства.

Действующее законодательство, регламентирующее правотворческий процесс на всех его уровнях, ориентирует органы правотворчества на издание одиночных нормативных правовых актов, а не на образование цельной, непротиворечивой правовой системы страны. Это приводит к тому, что более половины издаваемых подзаконных актов на нижнем уровне правового регулирования (ведомственное и муниципальное правотворчество), признаются недействующими в силу их юридического несовершенства. Возникло очевидное противоречие: имеющиеся потребности научного осмысления и теоретического обоснования правотворческой деятельности, с одной стороны, не востребуются органами правотворчества, которые продолжают издавать нормативные правовые акты методом проб и ошибок, а с другой, - не находят достаточного отражения в теории правотворчества, которая формируется противоречиво, непредсказуемо и внесистемно. Наука о правотворчестве и практика выработки правотворческих решений развиваются без существенного взаимодействия. Требуется выработка новых подходов направленных на объединение этих двух основополагающих начал правотворчества в единый научно-практический процесс.

Актуальность темы монографического исследования проявляется в четырех основных аспектах: научно-теоретическом, нормативно-правовом и доктринальном, социально-правовом.

Научно-теоретический аспект. Правотворческая деятельность в настоящее время осуществляется преимущественно с использованием имеющегося практического опыта создания норм права и нормативных правовых актов. Научное познание данного процесса значительно отстает от насущных потребностей правового регулирования общественных отношений, в условиях проводимых социально-экономических и правовых реформ.

Теория правотворчества, не имея систематизированного вектора развития, топчется на месте, достаточно долго уясняет предмет, принципы и методы своего научного познания, а также сущность отдельных видов правотворчества, не выработав в полной мере необходимый ей термино- 
логический и понятийный аппарат, его научно обоснованные дефиниции, не сформулировав и тем, более не разработав круг проблем, находящихся в сфере ее постоянных интересов, не выявив особенности отраслевого правотворчества и не сформировав теоретическую базу, отражающую эту специфику при выработке правотворческих решений. Остаются почти вне научного понимания такие категории правотворчества как понятие правотворческого решения, его юридический состав, виды и научное обоснование, качество и эффективность правотворчества, модельное правотворчество. Не имеют достаточной теоретической базы проблемы, связанные с разработкой планов издания нормативных правовых актов, прогнозирования возможных последствий от их действия, рассчитанных на длительную перспективу. Существующая практика создания образцов закрепления типичных общественных отношений в нормах права также осуществляется вне их теоретического обоснования.

Таким образом, в настоящее время важнейшей задачей познания правотворческой деятельности является формирование целостной системы знаний, позволяющей перевести процесс издания нормативных правовых актов на научную основу. Задачей данной юридической науки должно быть не только теоретическое обеспечение совершаемой в процессе правотворчества деятельности, но и научное обоснование объективной необходимости выбора тех или иных мер юридического воздействия на общественные отношения с целью достижения их максимальной эффективности. Тем самым будет осуществлен перевод ныне применяемого эмпирического правотворчества на правотворчество более высокого уровня, имеющего в своей основе юридическую науку.

Нормативно-правовой аспект. Отсутствие на протяжении длительного времени единой законодательной регламентации правотворческой деятельности привело к тому, что на различных уровнях правового регулирования были изданы и действуют многочисленные нормативные правовые акты локального значения, которые не согласуются между собой и не направлены на формирование целостной правовой системы Российской Федерации.

Однако и данная проблема обусловлена, прежде всего, тем, что отсутствует теоретическая база, которая необходима для системного научного постижения сущности правотворчества как единого нормообразующего процесса протекающего на всех уровнях правового регулирования. Требуется глубокое теоретическое обоснование выработки нормативно-правового регулирования правотворчества как единого механизма формирования правовой системы в целом, а также всех ее отраслей либо тех или иных уровней деятельности правотворческих органов.

Таким образом, ожидаемый федеральный закон «О нормативных правовых актах в Российской Федерации» может быть сформирован как системообразующий нормативный правовой акт лишь в случае его всестороннего теоретического обоснования, когда содержащиеся в нем предписания создадут так необходимый механизм выработки целостной правовой системы страны и одновременно позволяющий издавать соче- 
тающиеся с ней отдельные правовые акты всех отраслей и всех уровней правового регулирования.

Доктринальный аспект. Процесс познания объективной действительности создает условия для постоянного развития науки. Это присуще и юридической науке. На определенном этапе своего развития она осознает необходимость систематизации и оптимизации накопленного научного знания, что создает объективные предпосылки для формирования отдельных отраслей и подотраслей права. Построение научного знания по системным принципам способствует углубленному познанию правовой действительности, выявлению новых возможностей правового регулирования общественных отношений, что подтверждает история юридической науки.

На современном этапе развития правотворчества, когда востребованность теоретического обоснования правотворческих решений обусловлена запросами деятельности правотворческих органов, когда в теории права сформировалась значительная сумма научных знаний по вопросам выработки нормативных правовых актов, возникла объективная необходимость выделения теории правотворчества в самостоятельную юридическую науку, имеющую прикладное значение.

Сказанное позволяет утверждать, что обширная правовая проблематика, отражающая многочисленные стороны правотворчества в его материальном и процессуальном выражении, требует самостоятельного системного анализа как целостного правового явления для решения стратегического правового регулирования отношений, связанных с изданием нормативных правовых актов.

Социально-правовой аспект. Стремление индивида к комфортному выживанию при минимуме своих усилий и, как правило, за счет других менее защищенных индивидов, привело к образованию человека нового типа. Для него ради достижения комфорта в своем выживании значительно выгодней тем или иным путём идти в обход закона, нежели в его исполнение. Порожденные таким образом коррупция, лоббизм, правовой нигилизм и др. отрицательный социально-правовые феномены не только способствуют кризисным тенденциям в праве как самом сильном и авторитетном регуляторе общественных отношений, но и нарушают естественные связи по линиям индивид - общество - государство, индивид государство, ставя под угрозу человека как вида социального. Общение человека в конечном итоге определяет всё его существование, и его разрыв губителен. Поэтому новыми задачами права в этом свете являются стимулирование общения между индивидами, и следовательно, развитие саморегуляции общественных отношений в диалектически единых рамках закона - достаточно строгих для пресечения и предотвращения правонарушений, - и в то же время, достаточно мягких для минимизации усилий индивида по выживанию за счёт преимуществ от правомерного поведения, а не от противоправного, ставящего одних его жертв за грань выживания, а других подвергающего остракизму и разрыву социальных связей. Reasonableperson должен видеть в праве стимул для выживания, а не меру его пресечения.

Всё это возможно в рамках новой юридической науки - теории правотворчества. 


\section{Правотворчество в Российской Федерации}

Степень разработанности темы исследования. В российской и зарубежной юридической литературе имеется значительное количество публикаций, посвященных вопросам правотворчества, в том числе монографий, диссертаций, статей и учебно-методических пособий. Уже в советский период юридическая наука обратилась к исследованию правотворчества, в результате чего появились такие работы как «Правотворчество в СССР» (отв. ред. А.В. Мицкевич. М., 1974) и «Научные основы советского правотворчества» (под ред. Р.О. Халфиной. М., 1981). Примерно в этот же период в зарубежной литературе были опубликованы работы Д. Гарнер (TheHistoryofLocalGovemmentinEngland. L., 1982; Beликобритания. Центральное и местное управление. М., 1984), А. Нащиц (Правотворчество: теория и законодательная техника. М., 1974), а также исследование болгарских ученых (Законодательный процесс. София. 1985). В этот период существенный вклад в развитие науки о правотворчестве внесли Сенека, О. Конт, Дж. Локк, Ш.-Л. де Монтескьё, Рудольф Иеринг , С.С. Алексеев, В.К. Бабаев, В.М. Баранов, А.Б. Венгеров, Н.В. Витрук, Б.В. Дрейшев, И.Ф. Казьмин, Д.А. Керимов, В.Н. Кудрявцев, В.В. Лазарев, Г.В. Мальцев, М.Н. Марченко, А.В. Мицкевич, А.С. Пиголкин, С.В. Поленина, Н.С. Самощенко, В.М. Сырых, Ю.А. Тихомиров, Р.О. Халфина, А.Ф. Черданцев и другие ученые, работы которых составили теоретическую основу данного исследования.

В современный период правотворческая проблематика многократно расширилась, добавились неизвестные ранее темы, связанные с реформированием государственного устройства, изменением российской правовой системы и законодательства, совершенствованием юридической техники и информационных технологий. Разнообразные проблемы правотворчества теперь нашли свое освещение в работах Ю.Г. Арзамасова, К.В. Агамирова, Н.П. Алешковой, В.Ю. Багдасарова, В.М. Баранова, М.С. Белоусовой, С.В. Бошно, С.Н. Болдырева, О.В. Бондаренко, А.С. Борисова, В.И. Власова, Н.А. Власенко, В.И. Гладких, Д.Б. Горохова, В.В. Джура, А.В. Дербиной, Д.С. Дерхо, Г.Б. Евстигнеевой, Т.А. Желдыбиной, Е.А. Звягиной, В.Д. Зорькина, А.В. Иванчина, А.В. Илларионова, Т.В. Кашаниной, Е.В. Каменской, Е.А. Каминской, Т.В. Кашаниной, В.М. Корельского, Л.Р. Клебанова, М.Л. Козлова, М.П. Костенко., А.В. Краснова, П.В. Крашенинникова, В.В. Кулакова, С.В. Липень, Лукьянова А.И., Любимова Н.А., И.Б. Ломакиной, А.П. Мазуренко, А.В. Малько, А.А. Маковского, Г.В. Мальцева, А.Г. Матвеева, Г.А. Мартьянова, С.А. Марковой-Мурашовой, П.А. Меркулова, Т.Н. Москальковой, Ю.В. Неделько, Н. Неновски, И.Ю. Остапович, В.Д. Перевалова, В.А. Потапова, О.В. Попова, В.Д. Рузановой, В.А. Рыбакова, В.А. Сапун, Е.В. Семьянова, К.О. Сергеевой, С.В. Синюкова, А.В. Скоробогатова, А.А. Со, И. Е. Ситниковой, С. Г. Соловьева, В.В. Субочева, Ю.А. Тихомирова, В.В. Трофимова, Я.В. Турбовой, Д.С.-М. Тэпс, С.В. Филатова, О.А. Фомичевой, К.М. Хутова, В.М. Шамарова, Е. Ширяева, С.П. Чередниченко, Е.Ю. Чмыхало и других авторов.

Следует отметить, что проблемам правотворчества посвящены диссертационные исследования многих авторов: С.В. Синюкова - «Меха- 
низм правотворчества». Саратов, 2013; Е.А. Каминской - «Муниципальное правотворчество в механизме правообразования». Белгород, 2013; Н.П. Алешковой - «Конституционно-правовые основы муниципального правотворчества в Российской Федерации». Екатеринбург, 2010; А.В. Дербиной - «Правосознание как элемент позиции субъекта правотворчества». Самара, 2011; К.О. Сергеевой - «Муниципальное правотворчество в Российской Федерации». М., 2013; И.Е. Ситниковой - «Политический плюрализм и правотворчество в современном российском государстве». Казань, 2015; О.В. Бондаренко - «Судебная практика и уголовное правотворчество». М., 2013; А.В. Иванчина - «Внутренняя и внешняя законодательная техника в структуре уголовного правотворчества». Рязань, 2014; А.П. Мазуренко - «Правотворческая политика как фактор модернизации правотворчества в России». Саратов, 2011; С.В. Липень - «Идеи правотворчества и правореализации в политикоправовой мысли России XIX - начала XX в.». М., 2013 и т. д.

Указанные авторы в своих работах актуализируют и проблему повышения научно-теоретического значения выработки правотворческих решений, создания научных основ правотворчества в целом.

Наиболее радикально проблему научно-теоретического обеспечения правотворчества предлагает решать Ю.Г. Арзамасов, под руководством которого было издано учебно-методическое пособие по выработке нормативно-правовых актов различной юридической силы (от законодательных до локальных нормативных правовых актов) ${ }^{1}$. Как обоснованно пишет Ю.Г. Арзамасов «в современных условиях проведения правовой реформы актуальной задачей является радикальное реформирование юриспруденции с выделением самостоятельных норм прикладного характера для общей теории права и государства, среди которых достойное место должна занять наука о нормотворчестве и юридической техники нормография» ${ }^{2}$.

Такой подход является не только актуальным, но и правильным, поскольку в настоящее время становится очевидным, что теория правотворчества отстает от запросов практики выработки правотворческих решений и пока не стала фундаментом правотворческой деятельности. Предложенная научному миру наука о правотворчестве - нормография вполне соответствует заявленной цели: она содержит в основном методику выработки тех или иных видов правотворческих решений. Но теория правотворчества, как самостоятельная юридическая наука не должна преследовать столь узкую научную задачу. В круг интересов теории правотворчества должно входить все многообразие правотворческой деятельности, начиная от предпроектного изучения предмета правового регулирования, научного обоснования необходимости и возможности упорядочения общественных отношений с помощью норм права и кон-

${ }^{1}$ Нормография: теория и методология нормотворчества: учеб.-метод. пособ. / под ред. Ю.Г. Арзамасова. - М., 2007.

${ }^{2}$ Указ. соч. - С. 23. 


\section{Правотворчество в Российской Федерации}

чая их нормативным закреплением в ходе осуществления правотворческого процесса на том или ином его уровне.

Кроме того теория правотворчества должна располагать своим терминологическим аппаратом, иметь идеализированные теоретические модели правотворческих решений типичных социальных ситуаций, выработать научные критерии обоснованности, качественности и эффективности таких решений, создать свои методические подходы в разрешении всех правотворческих задач, выработать единообразные, простые и доступные субъектам правотворчества, юридические понятия, категории и т. д. Эта сторона теории правотворчества не нашла достаточного отражения в нормографии.

Таким образом, современное состояние знаний о теории правотворчества как целостной систематизированной юридической науке, являющейся основой правотворческой деятельности, недостаточно. Требуются дальнейшие комплексные исследования всей области правотворчества как единого материального и процессуального правового явления, определяющего качество и социальную целостность формирующейся правовой системы Российской Федерации.

Цель и задачи исследования. Целью исследования является разработка концепции, структуры и основных понятий теории правотворчества как прикладной юридической науки, позволяющей перевести правотворческую деятельность из сферы эмпирического поиска необходимых правотворческих решений в область научного знания, создающей надежные основы выработки и принятия непротиворечивых, обоснованных, системообразующих нормативных правовых актов на всех уровнях правового регулирования, исполнение которых добровольным правомерным поведением индивида в большей степени, нежели запретами и принуждением.

Достижение данной цели обусловило постановку и решение следующих задач:

1) изучить историю возникновения и развития социально-правовых идей о создании законов, проследить их эволюцию, понять суть позитивизма как истока современной правотворческой мысли;

2) изучить правотворчество как единого правового явления, являющегося источником формирования, как отдельных нормативных правовых актов, так и всей правовой системы страны;

3) проанализировать высказанные в юридической литературе подходы в понимании правотворчества и определение присущих ему признаков, характеризующих его как самостоятельное научное направление в юриспруденции, имеющее свои цели, принципы, задачи и предмет исследования, а также свою нормативно-правовую базу, хотя и требующую совершенствования;

4) осуществить углубленный анализ правовой сущности правотворчества с разграничением его материальных и процессуальных показателей, выявление их роли в создании норм права, правовых институтов и отраслей права, а также уяснить их отличительные особенности; 
5) классифицировать правотворчество по видам и определить оптимальные критерии, позволяющие рассматривать его как единую целостную систему издания нормативных правовых актов на всех уровнях правового регулирования с множеством правотворческих органов, имеющих общую теоретическую базу;

6) определить функциональные и процессуальные особенности принципов правотворчества, установить их влияние на формирование содержания нормативно-правовых актов;

7) провести комплексный теоретико-правовой анализ принципов правотворчества, дать им определение и показать перспективы их дальнейшего развития и функционирования;

8) установить признаки научного обоснования издаваемых правотворческих решений и его взаимосвязи с качеством и эффективностью нормативных правовых актов;

9) изучить возможности совершенствования издаваемых нормативных правовых актов в ходе процессуальной деятельности правотворческих органов путем реализации конкретных предложений юридической науки;

10) исследовать влияния планирования и прогнозирования в правотворчестве на выработку качественных правотворческих решений, формирование непротиворечивой правовой системы страны;

11) изучить механизм выбора нормативного правового акта в процессе правотворчества, выявить его общие принципы при регулировании общественных отношений, имеющих признаки различных отраслей права.

12) дать теоретическое обоснование и объяснить практическое значение юридического состава правотворческого решения;

13) создать алгоритм отраслевого правотворчества, выявить его специфику и методику научного познания;

14) исследовать специфику правотворчества в таких отраслях конституционное, уголовное и гражданское право.

Объектом исследования являются общественные отношения, связанные с осуществлением правотворчества, выработкой нормативных правовых актов всех уровней правового регулирования.

Предмет исследования составляет отражение явлений правотворчества как новой прикладной юридической науки, её парадигматики, методов, отдельные институтов и их системные связи в Конституции РФ и нормативно-правовых актах, регламентирующих правотворческую деятельность, научной юридической литературе по теме диссертации, актах Конституционного и Верховного Суда РФ, учебниках и учебнометодических пособиях, различных диссертационных исследованиях, затрачивающих вопросы правотворчества.

Методологическая основа научного исследования. Особенности темы исследования, а также поставленные в ней цели и задачи обусловили необходимость использования различных общих и специальных методов научного познания. Его общенаучными методами являются диалектический подход к пониманию социально-правовой действительности, анализа и синтез, индукция и дедукция, абстрагирование, модели- 
рование, а также системный и функциональный подход при изучении конкретных нормативных предписаний, признаков и специфических особенностей нормативно-правовых документов. Специальные методы представлены в ходе обоснования теоретических положений нужными статистическими сведениями, полученных в результате анализа тех или иных количественных показателей. Частно-научные методы нашли свое выражение в таких видах как формально-юридический, который применялся при выработке терминологических понятий теории правотворчества, а также сравнительно-правовой метод, позволяющий познавать сущность исследуемых понятий в результате их сравнительного анализа. Помимо перечисленных, в работе были использованы и некоторые иные научные приемы и способы исследования социально-правовых процессов, которые выработаны современной наукой.

Особое значение в работе отведено методам системного и функционального анализа объекта исследования, что позволило выявить новые знания о его структуре, отраслевой принадлежности, способности к урегулированию нормами права, наличия межотраслевых связей и т. д.

Нормативную основу работы составили положения Конституции РФ, конституционных и обычных законов РФ, указов Президента и постановлений правительства РФ, нормативных правовых актов субъектов федерации, ведомственных и муниципальных правовых актов.

Эмпирическая база включает в себя правотворческую практику Конституционного Суда и Верховного Суда РФ, судов общей юрисдикции и арбитражных судов.

Научная новизна исследования состоит в том, что впервые теория правотворчества рассматривается как самостоятельная юридическая наука, имеющая прикладной характер, представленная как целостная, систематизированная концепция научного познания социальноправовых явлений и закрепления их в виде объективно необходимых и реально возможных нормативных предписаний. В диссертации нашли дальнейшее развитие многие научные идеи в области теории правотворчества, которые получили свое обоснование в виде самостоятельных правовых категорий и правовых институтов. К их числу относятся такие правовые институты как юридический состав правотворческих решений, качество правотворчества, научная обоснованность выбора правотворческого решения, мониторинг правотворчества и другие. Впервые на уровне диссертационного исследования проанализированы особенности отраслевого правотворчества, в том числе конституционного, уголовного и гражданского права.

Данная монография позволяет перевести существующие ныне эмпирические методы правотворчества на научную основу, поскольку сформирована целостная теоретическая база выработки правотворческих решений, высказаны обоснованные предложения по дальнейшему совершенствованию всей системы правотворчества.

Решения, которые к тому же имеют объективный и субъективный характер. 
Важнейшим признаком отрасли права является ее стабильность, способность к постоянному развитию и обновлению без ущерба для ее качества и эффективности. В связи с этим правотворческие решения должны вытекать из объективных потребностей общественных отношений к изменению, которые обуславливаются политическими, экономическими и социальными причинами. Наличие субъективных обстоятельств, влияющих на правотворческое решение, дестабилизирует отрасль права, поскольку они связаны с закреплением в нормах права определенных интересов, не отвечающих объективным потребностям сложившихся общественных отношений. Поэтому проекты правотворческих решений должны проходить не только правовую экспертизу, но и общественное обсуждение, в процессе которых будет найден наиболее оптимальный его вариант.

Теоретическая значимость результатов исследования заключается в том, что сформированные в данной работе положения и выводы развивают и обогащают теорию правотворчества новыми знаниями о ней, способствуют выделению ее в самостоятельную юридическую науку прикладного характера. Кроме того, в работе сложилась структура теории правотворчества, позволяющая рассматривать ее как самостоятельный институт научного познания и выработки обоснованных предложений по изданию норм права, правовых институтов и нормативных правовых актов на всех уровнях правового регулирования. Проведенное исследование также позволяет оценить теорию правотворчества как единую систематизированную учебную дисциплину, необходимую субъектам.

правотворчества для повышения их профессионализма. Заложенный в работе потенциал может служить основой для проведения дальнейших исследований по углублению знаний, как самой теории правотворчества, так и всех отраслей права, а также при разработке концепций по различным проблемам правотворчества.

Практическая значимость результатов исследования состоит в том, что вытекающие из работы положения дают возможность их использования:

1) в деятельности правотворческих органов при выработке нормативных правовых актов и их совершенствовании;

2) в правоприменительной деятельности судебных органов при толковании и конкретизации нормативных правовых актов;

3) в учебном процессе в рамках изучения курса теории государства и права либо при изучении спецкурсов по правотворческой деятельности органов правотворчества;

4) для подготовки соответствующих учебников и учебнометодических пособий;

5) на курсах повышения квалификации специалистов в сфере правотворческой деятельности (особенно на уровне ведомственного и муниципального правотворчества);

6) в практике деятельности различных юридических служб, связанных с изданием нормативных актов локального уровня; 
7) в процессе осуществления правовых экспертиз в ходе разработки и принятия нормативных правовых актов на всех уровнях правового регулирования.

Степень достоверности и апробация результатов исследования.

Положение и выводы данного исследования обсуждались на различных научных и научно-практических конференциях «Международная научно-практическая конференция по актуальным направлениям гуманитарных и социально-экономических исследований. 2018», Молодёжь и XXI век-2018. VIII Международная молодёжная научная конференция. Юго-западный государственный Университет. 2018», «Татищевские чтения: актуальные проблемы науки и практики. XV Международная научно-практическая конференция. 2018», «Современное российское право: взаимодействие науки, нормотворчества и практики. Московская юридическая неделя. Материалы XIII Международной научнопрактической конференции (Кутафинские чтения). Московский государственный юридический университет имени О.Е. Кутафина (МГЮА); Московский государственный университет имени М.В. Ломоносова. 2018.; «Человек, общество и культура в XXI веке. Сборник научных трудов по материалам Международной научно-практической конференции. Белгород.2017»VI-й международной научно-практической конференции. Инновации в науке и практике. Прага, 2018.

По теме исследования опубликовано 23 (двадцать три) научные статьи в журналах (утвержденных ВАК Минобрнауки России), в которых долэнны быть опубликованы основные научные результаты диссертаций на соискание ученой степени кандидата наук и доктора наук.

Работа состоит из введения, четырёх глав, двадцати трёх параграфов, параграфов и заключения. Внутри параграфов возможно деление на подразделы. 


\section{ГЛАВА 1. КРАТКАЯ ХАРАКТЕРИСТИКА ПРАВОТВОРЧЕСТВА КАК МНОГОГРАННОГО ЮРИДИЧЕСКОГО ЯВЛЕНИЯ}

\section{§1.1. ДИАХРОНИЧЕСКИЙ СРЕЗ ФИЛОСОФСКО- ПРАВОВЫХ ЗНАНИЙ О СОЗДАНИИ ЗАКОНОВ}

\section{§1.1.1. ДОКОНТОВСКИЕ ПОПЫТКИ ОСМЫСЛЕНИЯ СОЗДАНИЯ ЗАКОНОВ КАК ЮРИДИЧЕСКОЙ НАУКИ}

Общество людей существовало с незапамятных времен. При этом по мере усложнения его и появления новых социально-экономических отношений и связанных с ними политических и духовных структур неизменно происходило усложнение и изменение общественных отношений, связанных с распределением тех или иных благ или ценностей. Для сохранения стабильности общества, предотвращения распада его или хаоca, внутри необходима всегда система регуляции общественных отношений, которая бы помогала поддерживать заинтересованности членов правоотношений в той системе распределения благ, которая сложилась в данном социуме при данных социально-экономических условиях.

Понятие всеобщего блага - это фундаментальный закон и общая тенденция развития европейской политико-юридической культуры. Член общества, независимо от его социального положения, получал право на собственную долю в распределении продукта и безопасность, в обмен на то, что часть своих прав и свобод делегировал обществу и государству. Такое делегирование должно осуществляться на основе тех или иных регуляторов общественных отношений, при этом в европейском обществе с самого раннего этапа помимо внеправовых социальных норм возникла потребность в создании сильных правовых - регуляторов и гарантов исполнения делегирования прав и обязанностей члена социума по поддержания своего места в общественной структуре. Для достижения этой цели всё яснее осознавалась необходимость создания науки про «само создание» таких регуляторов - методики создания законов.

В частности, Сенека вводит понятие «сожитие». Основой его он видит эталоны, по которым возможно создание справедливых и действенных законов, которым охотно подчинялись бы все - от солдата до императора.

Общее благо членов данного социально-политического сообщества это благо всех его членов на основе естественно-правового поведения (и, следовательно, общесправедливого) участников правоотношений, признания блага каждого ${ }^{3}$.

\footnotetext{
${ }^{3}$ Нерсесянц В.С. Философия права. - М.: Норма, 2006. - С. 96.
} 


\section{Правотворчество в Российской Федерации}

Всеобщее благо выделялось также Платоном и Демокритом как самый мощный стимул для правомерного поведения граждан при участии в тех или иных правоотношениях, прямо или косвенно связанных с распределением продукта и благ. Платон понимал власть государства как самый мощный стимулятор правомерного поведения участников правоотношений - делегирующих часть своих свобод для защиты со стороны государства. При этом также признавалась необходимость создания действующих и справедливых законов, Платон близко подошел к идее создания методики творения их, для чего предлагал использовать некоторые космические идеи, бесполезно до того витающие в их мире. Эти идеи должны были послужить для увеличения справедливости государства при централизации распределения благ, усилении контроля над действиями отдельного гражданина. Платон подошел к идее, что созданием законов должны заниматься специально подготовленные люди философы, которые не имеют мирских забот, так как обеспечены продуктом и благами, и могут лишь черпать идеи и создавать по ним законы.

Подобную же постановку вопроса о правотворчестве мы наблюдаем и у Цицерона, а также в Римской республике и ранней империи с их respopuli - общенародным делом, а также богатой юридической традицией.

В Средние века идее правотворения уделялось меньше внимания, главным образом из-за теологического толкования создания законов, как исключительной прерогативы Божьей Милости. Именно такая идея выражена в сочинении Аврелия Августина $(354$ - 430 гг.) «О граде Божьем», рассматривающем государство и законы, а также методику создания законов как наказание за первородный грех. Государство земное, земной град, с его неравенством, несправедливым распределением благ и эксплуатацией человека человеком противопоставлялся Граду Божьему - совершенному небесному социально-политическому организму. Поэтому Средние века, особенно в ранний их период, - это период отступления назад в идее создания правотворчества как целостной системы знаний.

Исключение составляет здесь, пожалуй, Византия. Особое внимание к ней привлекают те её страницы, которые связаны с созданием крупнейшей правовой кодификации всех времен - свода законов Юстиниана. Значение его двоякое: во-первых, он даёт наиболее систематическое изложение римского классического права и римской юриспруденции вообще; во-вторых, он послужил основным источником рецепции римского права в Средние века - со всеми вытекающими из этого последствиями.

Кодификационные работы были выполнены в небывало короткий срок - за пять лет, с 529 по 534 год н.э. ${ }^{4}$

Для наших целей важно то, что на данном этапе была впервые показана тесная связь правотворчества как научного явления с юридической техникой - и как научным явлением, и как практическим инструментом в создании законов. В отличие от Западной Европы, у Византии и Юсти-

\footnotetext{
${ }^{4}$ Черниловский 3.М. Всеобщая история государства и права. - М.: Юристъ, 1996. - С. 205. 
ниана интерес к законотворчеству был большим. Деятельность непосредственного творителя-кодификатора и мастера юридической техники Трибониана показала, что основными инструментами служили:

1. Грамотная компиляция римских законов и сочинений римских юристов (в частности, Гая), позволяющая наполнить тот или иной раздел четким непротиворечивым содержанием.

2. Ясное структурирование разделов работы в направлении создания законов как respopuli.

3. Применение стимулирования субъектов правоотношений к правомерному поведению в виде закладывания в разделы положений и изначально правомерном характере поведения субъектов правоотношений и доброй воле (современная преюдиция).

Результатом этого стало создание Дигестов или Пандектов как теоретической части, и Институций как практической и учебной части для обучения юристов.

Таким образом, уже с самого раннего этапа развития европейского общества осознавалась и выводилась сложность и многоуровневость правотворчества как социально-правового явления. Позже мы скажем и о более значимом в теоретическом плане аспекте. Недостатком всех ранних осмыслений правотворчества и практических попыток нахождения методики создания законов было отсутствие формальнодогматического закрепления основных понятий юриспруденции вообще - начиная от понятия «всеобщего блага» до понятия « правотворчество». Это делало шаткой и неустойчивой почву для нахождения определения. Требовались новые подходы к рассмотрению создания законов как догматического отражения возникновения, развития и отмирания регулируемых общественных отношений, выяснения на теоретическом уровне круга общественных отношений, подлежащих правовому регулированию.

Такие попытки были предприняты в Новое Время на основе учений о естественном праве. Они связаны с именами Дж. Локка, Т. Гоббса, Ш.-Л. де Монтескьё и др. Благо - это юридически закреплённый интерес. А, следовательно, важно не только его формализация как предпосылка, но методика юридического закрепления. Следовательно, стимулирование исполнения законов участниками правоотношений должно осуществляться по пути формального закрепления их интересов в нормативных актах. До этого момента правотворческий механизм как орудие поддержание системы общественного распределения мертв, он не действует ни в части саморегулирования, ни в части охраны системы распределения. Господствует лишь естественное, как сейчас бы мы его назвали субъективное право, предполагающее не императивное подчинение ограничениям и запретам, а лишь диспозитивное регулирование общественных отношений. Субъективные права участников общественных отношений с неизбежностью сталкиваются. Это состояние Локк, Гоббс, Руссо и Монтескьё и ряд других авторов называют « естественным состоянием» или 


\section{Правотворчество в Российской Федерации}

«войной всех против всех». Участник правоотношений имеет лишь две альтернативы:

1) отвоевать свое естественное право;

2) заключить договор. В первом случае неизбежно происходит разрушение межличностных связей с распадом и десоциализацией - распадом общества и личности. Во втором - накладываются излишние обязательства и создается неопределенность моделей социально положительного поведения (не говоря уже о том, что сами авторы по-разному понимали заключение общественного договора). Однозначно встают два вопроса: как создать методику по созданию регулятора (-ов) общественных отношений? Какие из общественных отношений должны быть урегулированы? (Договор кого с кем, выражаясь словами авторов, необходимо заключить?) Дальнейший поиск этой методики стал возможен лишь с развитием в конце XVIII века немецкой классической философии, доказавшей необходимость создания законов на основе «категорического императива» Канта, чтобы в методику правотворчества закладывалось не только естественное право, но и подчинение.

Таким образом, по доконтовским взглядам на создание законов как научно-юридический процесс можно сделать два вывода.

1. Была осознана необходимость в создании методики для «самого создания» регуляторов общественных отношений.

2. Создание законов уже тогда начало ощущаться как сложный и многоуровневый процесс, состоящий из эмпирической, практической и теоретической частей (звеньев). Требовались новые подходы к решению проблемы, прежде всего, поиск методологической основы.

\section{§1.1.2. ПОЗИТИВИЗМ О. КОНТА - ОСНОВА ПРАВОТВОРЧЕСТВА КАК СОВРЕМЕННОЙ ЮРИДИЧЕСКОЙ НАУКИ}

Как уже нами было выяснено в предыдущем разделе работы, учеными кругами в Европе отчетливо ощущалась потребность в нахождении методики, некого алгоритма создания законов. Требовалась иная методологическая основа, которую не могли дать ни сама по себе идея всеобщего блага, ни естественного договора, ни иная. Таковой идеей суждено было стать позитивизму О. Конта - который послужил вообще основой для создания сегодняшней науки и как социального явления, и как упорядоченной системы знаний.

Позитивизм, созданный О. Контом, имеет две основные составляющие: философию и политику. Философия является основанием, а политика - целью системы гармонии разума и общественности.

Истинная философия, по Конту, - это орудие придания гармонии личному, и, особенно, коллективному бытию человека. Такая постановка задач философии как нельзя лучше отвечает философско-правовому обоснованию идеи правотворчества как отдельной отрасли знаний. Именно диалектическое единство человека как биологического и социального организма порождает стимулирование к правомерному поведе- 
нию в процессе реализации личного, коллективного и видового выживания. Методика создания его регуляторов должна строиться, соответственно, также на диалектическом единстве естественного права и «категорического императива», а также с применением обоснованных и апробированных ранее в Античную Эпоху (см. Римское Право) или при кодификации Юстинианом (см. выше) позитивных по содержанию и форме техник, которые стали бы практическим инструментом по созданию регуляторов общественных отношений.

Конт признает поражение теологической системы в упорядочении практической стороны жизни человека. «Теологическая систематизация, - пишет он, - самопроизвольно вытекала из аффективной жизни и этому единственному началу она обязана своим первоначальным главенством и своим окончательным разложением» ${ }^{5}$.

Главными орудиями создания методики правотворения как юридической деятельности, и как отрасли научного знания, становятся положения Конта:

1) активная жизнь;

2) систематизация на основе положительного знания.

Фактически, эти две установки предопределяют постановку двух основных вопросов правотворчества как теоретической науки:

1) как стимулировать лиц - участников правоотношений к активному правомерному поведению;

2) как упорядочить общественные отношения и определить тот их круг, который подлежит правовому регулированию?

Активная жизнь понимается в широком смысле, и как социально активное поведение субъекта, и как функционирование различных институтов общества, его групп, и государства в целом. У Конта задача регулирования общественных отношений не выступает ни в качестве императива, ни в качестве естественного права, он видит её шире и динамичнее: методика создания регулятора общественных отношений - это не сборник запрещающих или вседозволяющих догм, но положительные предписания, разъясняющие модели поведения субъектам правоотношений. Соответственно, активная жизнь - это совместное удовлетворение членами общества и государства своих потребностей на выживание позитивными дозволенными способами, избежать «войны всех против всех» надежно позволяет система разъяснений, которая позволяет субъектам правоотношений не попадать в сложные или двусмысленные ситуации. Активная жизнь - это, таким образом, урегулированная при помощи средств, созданных по позитивной методике, самодостаточная жизнь и функционирование субъектов и их институтов, в процессе которых создаются новые положительные знания. Активная жизнь, таким образом, привносит в функционирование государственных и общественных институтов созидающий момент, так как сама построена на созида-

\footnotetext{
${ }^{5}$ Конт Огюст. Общий обзор позитивизма / пер. с франц. Шапиро, под ред. М.Н. Радлова. M., 2012. - C. 55.
} 


\section{Правотворчество в Российской Федерации}

ющих методиках. Конт спокойно относился к революционным преобразованиям общества, которые он часто называл реформами. Он рассматривал их как ступенчатый переход к новым общественным отношениям.

Систематизация - это кодификация норм права и наполнение нормы права единым смыслом. В систематизации санкций правовых норм можно видеть основное начало юридической техники.

Таким образом, учение Конта о методике создания регуляторов общественных отношений образует позитивность. Это сложное явление, в котором диалектически взаимодействуют два основных начала:

1) полезность - то есть понятие толкования, наполнения единым смыслом и систематизации (см. выше) - соотносимо с понятием юридическая техника;

2) реальность - то есть позитивное существование методики по созданию регуляторов общественных отношений, в том числе, и правовых норм - соотносимо с понятием правотворчества.

Конт вводит понятие социальное чувство как стимула к правомерному поведению. Фактически, оно равно сегодняшнему понятию ответственность, но не в юридическом, а в моральном смысле. Вырабатывается оно на основе правотворческих решений, созданных по позитивным предписывающим методикам.

В целом, в плане выражения черт науки о создании норм права, можно характеризовать позитивизм Конта следующими основными чертами:

1) «антифаталистичность» позитивистской философии. В философии, как и в политике, отсутствует предопределение, диктующее поведение людей в социуме и отрицающее их подчинение позитивным знаниям;

2) подчинение наук низшего уровня наукам высшего. При этом науки высшего уровня не могут существовать без наук уровня низшего, которые этим наукам доставляют полезность - то есть добавляют в них практический созидающий момент и вносят саморегуляцию. Именно этот момент и необходимо использовать при теоретическом конструировании науки о правотворчестве - имея в виду его сложный многоуровневый характер. В дальнейшем мы остановимся на этом моменте более подробно;

3) подлинно научное знание должно быть получено специальными науками.

В целом, философское знание Конта явилось той самой основой, на которой могла возникнуть наука о создании норм права - правотворчество. 


\section{§1.1.3. РАЗВИТИЕ ЮРИДИЧЕСКИХ НАУК В НОВОЕ И НОВЕЙШЕЕ ВРЕМЯ: КРАТКИЙ ОБЗОР}

В Новое и Новейшее время продолжалось развитие Общей Теории Государства и Права. Наука проходила путь накопления нового знания в области теории и техники создания новых законов. « Правоведение приобретает статус социальной, общественной науки, призванной исследовать процессы функционирования и развития государства и права...» Продолжалось отступление от теологических методик формирования регуляторов общественных отношений, или от методик, основанных на естественном праве, наука получила методологию для создания «науки о законах». Тем не менее, методологически теория создания законов правотворчества и техника их создания ещё не различались. Ведущими компонентами юридической науки « становятся общая теория государства и права, история государства и права, а также науки гражданского, административного, уголовного, финансового и иных отраслей права» ${ }^{7}$.

Новый шаг в развитии знаний о правотворчестве был сделан с появлением формально-догматической юриспруденции И. Бентама. В философию юридической науки вводится система дозволений и запретов, однако, уже не с созерцательной компонентой, как императив Канта, а с позитивистской - как полученные специальными науками с полезными и реальными методиками.

Правовое государство Канта и Гегеля признаётся всего лишь идеалом, которому реальное состояние дел в государствах не соответствует, так как людскую алчность и злость никакие законы того времени остановить были не в состоянии. Пример Гегеля, видевшего в «действительном» прусском полицейском государстве нечто «разумное», в этом отношении смешон, как пример наивности философа. Тем не менее, позитивизм продолжал укреплять позиции, сводя разрозненные эмпирические знания о науке правотворчества в систему, нуждавшуюся в теоретическом осмыслении при помощи ясной и четкой методологии.

«Во второй половине XIX века, когда начала укрепляться и набирать силу позитивистская философия, были предприняты попытки размежевать науку, философию, религию и другие формы духовной деятельности человека» ${ }^{8}$.

Возрастание людских пороков, алчности, чему в немалой степени способствовало глубоко зашедшее к концу XIX века в результате колониальных захватов и начала монополизации, способствовало распространению выживания одних за счет других. Происходил разрыв между нормами и поступками. Все сильнее проявлялись кризисные тенденции в правотворческом сознании, так как правотворческие решения, даже выработанные по методике с диспозитивными началами, становились скорее плодами споров, а не рациональной деятельности. Для более успеш-

\footnotetext{
${ }^{6}$ Сырых В.М. История и методология юридической науки. - М.: Норма, Инфра-М, 2017. C. 155.

${ }^{7}$ Указ. соч. - С. 156.

${ }^{8}$ Жоль К.К. Философия и социология права. - М.: Юнити, 2005. - С. 16.
} 
ной правотворческой деятельности требовался синтез позитивистской методологии и эмпирических знаний о политико-юридических закономерностях развития права как системы.

Это соединение произошло, правда, привело к начальному отрицанию правотворчества как науки. Соответствующая доктрина получила название « юридический позитивизм» и была связана с именем Джона Остина $(1790-1859)$. Основные взгляды ученого-правоведа изложены в труде ««Лекции о юриспруденции, или Философия позитивного закона». Право, согласно Остину, есть приказ власти под угрозой применения санкции. Оно служит для управления разумными, то есть, понимающими необходимость делегирования некоторых своих свобод, людьми. Право не надо создавать, его надо исполнять. Позитивные законы, в отличие от морали, создаются политиками. Любое государственное властное предписание - позитивно, несоблюдение его карается санкциями. Поэтому задача правотворческого органа, как вытекает из взглядов ученого, - это не создание норм права, а толкование написанных норм. Догматическая юриспруденция должна трансформироваться в социальную. Последняя должна принимать во внимание и те общественные отношения, которые порождают правовые нормы. Таким образом, несмотря на отрицание в целом правотворчества как науки, впервые, по сути, был поставлен вопрос о круге общественных отношений, подлежащих правовому регулированию. Как это часто бывает в развитии общества, сфера знаний о правотворчестве прошла через своё отрицание, чтобы потом, обогатившись постановкой новых вопросов, при своём повторном утверждении, выйти при их помощи на новый уровень, поставить перед собой новые задачи.

Юридический позитивизм в целом определял развитие правовой мысли на протяжении всей истории XIX - XX веков. Правда, на государственном уровне отказа от правотворчества как процесса не произошло, но именно юридический позитивизм привел к двум важным последствиям для правовой науки.

1. Правотворчество стало рассматриваться почти исключительно как вид юридической деятельности, а не как отдельная наука соответствующего таксономического уровня. Основной наукой, согласно канонам юридического позитивизма, стала считаться теория государства и права. Это породило отсутствие должного внимания к методике создания и принятия законов, что в какой-то степени перечеркнуло достижения О. Конта в данной области.

2. Со времен Остина в правовом регулировании общественных отношений стал превалировать императивный метод, основанный на запретах и санкциях.

3. Доброта нравов стала пониматься исключительно как выполнение позитивных норм права, основанных, как правило, на запретах. Тем самым, был фактически, поставлен знак равенства между добросовестностью и правомерным поведением, что не одно и то же.

4. Как следствие этого, через определённый промежуток времени, позитивистская юридическая наука (Теория Государства и Права) обратила внимание на случаи правомерного, но недобросовестного поведения субъектов правоотношений (в частности, злоупотребления правом, хотя этот случай не охватывает всех случаев недобросовестного поведения), 
которым она не могла противостоять. В XXI веке, когда случаев таких стало большинство, эта наука уже не смогла справиться со своей задачей общественного регулятора, что породило кризисные тенденции в праве 9

\section{§1.1.4. ЗАРОЖДЕНИЕ ЮРИДИЧЕСКОЙ ТЕХНИКИ}

Зарождение юридической техники как правового феномена связано с именем Рудольфа фон Иеринга $(1818$ - 1892). В своей работе «Дух римского права на различных ступенях своего развития» (1905) ученый обобщил взгляды кодификаторов римского права, в том числе Юстиниана, а также философско-правовые взгляды Локка, Ф. Бэкона, Монтескьё и других.

«Юридическая техника» - выступает у Иеринга как некий методологический инструмент создания позитивных государственных предписаний, которые должны давать гарантию выживания индивидов при самореализации их в социуме. Главным аспектом её Иеринг считает плановость. Характерно, что несмотря на большую роль юридической техники в создании законов, исследователь-практик не выделяет её в качестве отдельной части науки законотворения, а видит в ней «плановый практический способ реализации права». Право - это в смысле юридического позитивизма обязательные для исполнения государственные предписания, которые необходимо выразить логико-языковыми приёмами и компактным способом подачи информации донести до индивида и общества.

Автором впервые в истории науки о создании законов дана классификация известных на тот момент правил юридического формулирования законов. Иерингом обоснована автономность юридической техники, как формы реализации права: по его мнению, она противопоставлена как содержанию правовой нормы (то есть, её конечного результата). Автор использует гегелианский тезис «всё разумное действительно», и для него реализация задач юридической деятельности заключена в положении « Право существует для того, чтобы оно осуществлялось» ${ }^{10}$.

Немецким исследователем большое внимание уделялось облегчению усвоения права, при этом, как простыми обывателями, так и органами правосудия. Количественное и качественное упрощение даёт юристу инструмент для проведения положительных предписаний государства в массы, таким образом, юридическая техника выступает как средство упорядочения общественных отношений. По Иерингу, этому служит сведение сложного материала к его составляющим при сохранении идиоматического смысла всей нормы. Главный стимул для субъекта правоотношений для добросовестного исполнения законов - донесение до него простого понятного субъективного права, в случае нарушения которого простой и понятные закон будет на стороне этого субъекта.

\footnotetext{
${ }^{9}$ Власенко Н.А. О кризисных тенденциях в праве // Юридическая техника. - 2014. - №8. С. 40-45; Власенко Н.А. Законодательная технология. Теория. Опыт. Правила. - Иркутск, 2001 и т. п. работы.

${ }^{10}$ Глухарева Л.И. Рудольф фон Иеринг - основатель юридической техники // Вестник РГГУ. Сер. Экономика. Управление. - 2016. Право. - №4. - С. 27.
} 


\section{Правотворчество в Российской Федерации}

Главное достижение таких приемов юридической техники - это наглядность конструкций и «логическое сжатие» материала.

Как итоги, отметим следующие положительные достижения.

1. Формулирование «позитивных предписаний» Конта - Остина в логически сжатом завершенном виде и донесение их до участников правоотношений и правоприменителей.

2. Выделение понятия «юридическая техника» как совокупности методик, приёмов и средств, которые могут и должны использоваться для деятельности правотворческих органов

3. Создание дополнительного стимула для субъекта правоотношений в виде доступности и понятности правовой нормы.

\section{§1.2. НАУЧНОЕ ОПРЕДЕЛЕНИЕ ПОНЯТИЯ «ПРАВОТВОРЧЕСТВО»}

\section{\$1.2.1. СОВРЕМЕННЫЕ ПРОБЛЕМЫ ТЕОРИИ СОЗДАНИЯ ЗАКОНОВ. СООТНОШЕНИЕ ПОНЯТИЙ ПРАВОТВОРЧЕСТВА И ЮРИДИЧЕСКОЙ ТЕХНИКИ}

Современная наука представлена значительными работами Н.А. Власенко, В.М. Баранова, Т.В. Кашаниной, А.Н. Миронова, В.Н. Карташова, А.С. Пиголкина, Ю.А. Тихомирова ${ }^{11}$ и др.

Разберем вкратце их общетеоретические установки. Н.А. Власенко делает установку на технологию выработки законодательного решения и упорядочение с помощью неё юридической деятельности в виде создания, изменения или отмены правовых норм. Также одним из главных мерил эффективности создания норм права им видится затрата материальных, физических и управленческих ресурсов на решение проблемы урегулирования тех или иных общественных отношений. При анализе главным управленческим и практическим методом выступает юридическая техника, правотворчество как феномен является лишь её частью. Вместе с тем автором осознается многоуровневость понятия. Не все приемы и способы юридической техники умещаются в понятие законодательного процесса. В.М. Баранов акцентирует внимание на закономерностях юридической техники, в которой он видит автономную дисциплину. Закономерности - это скорее не общие, а специальные, касающиеся отдельных правовых явлений, в том числе, и правотворчества, как

\footnotetext{
${ }^{11}$ Власенко Н.А. Законодательная технология. Теория. Опыт. Правила. - Иркутск, 2001; Власенко Н.А., Стародубцев С.В. Основы теории юридических документов. - М. 2006; Баранов В.М. Юридическая техника / под ред. В.М. Баранова. В 2-х т. - М.:, Юрайт. 251 с.; Юридическая техника: учебник / Т.В. Кашанина. - 2-е изд., пересмотр. - М.: Норма; ИНФРА-М, 2011. - 496 с.; Карташов В.Н. Законодательная технология субъектов Российской Федерации / В.Н. Карташов, С.В. Бахвалов. - Ярославль: ЯрГУ, 2010. - 368 с.; Пиголкин А.С. Совершенствование законодательной техники // Советское государство и право. - 1968. - №1; Тихомиров Ю.А. Законодательная техника: понятие и элементы // Законодательная техника: науч.-практ. пособ. / под ред. Ю.А. Тихомирова. - М., 2000.
} 
производного юридической техники. Т. Кашанина занимает позицию, что науку о государстве необходимо отделить от науки о праве - дуализм, а юридическая техника - всего лишь часть теории права. В теории права, пишет она, можно выделить по крайней мере три относительно автономных раздела:

- догма права (устоявшиеся положения, начала, основы действующего права). Сюда относятся знания о том, что есть нормы права, субъективные права и юридические обязанности, нормативные акты, индивидуальные предписания, т. е. то, что составляет нормальное развертывание юридической реальности, или материю права;

- юридическая техника (способы установления, опубликования, систематизации, толкования и реализации правовых норм, т. е. правила осуществления юридической деятельности);

- правовая конфликтология (учение о правовой патологии).

Вопрос, надо ли относить юридическую технику к юриспруденции, не сразу стал очевидным ${ }^{12}$.

Правотворчество в самостоятельную науку автором не выделяется. Юридическая техника автором трактуется как система научных знаний ${ }^{13}$. Карташов разделяет понятия законодательная техника и правотворчество, но при этом правотворчество автор относит исключительно к деятельности практической, Эта деятельность служит для упорядочения поведения Российской Федерации, субъектов российской федерации и муниципальных образований как целостных социальных организмов. Тихомиров В.Ю. стоит на позиции разграничения законодательной техники и правотворчества. Первую он считает частью юридической деятельности, призванной обеспечить социальную адекватность права (имеет нечто общее с социальным чувством О. Конта). Юридическая деятельность и законодательная техника разделяются на этапы, стадии, части. Законодательная техника должна придавать нормативным актам структурность - этапы, стадии не должны нарушать цельность формально-юридической мысли. Правотворчество осмысливается как дисциплина вспомогательная, как один из этапов законодательной техники. А.С. Пиголкин в целом разделяет понятия законодательная техника и правотворчество, а последнее выделяет в качестве источника формирования права. В.М. Карташов главной считает юридическую технологию, которую понимает двояко:

1) как совокупность процессов, планирования и выработки и обнародования нормативных актов;

2) как совокупность средств, способов наиболее эффективной практики создания законов. Последняя категория ближе всего к понятию правотворчества как системы научных знаний.

\footnotetext{
${ }^{12}$ Юридическая техника: учебник / Т.В. Кашанина. - 2-е изд., пересмотр. - М.: Норма; Инфра-М, 2011. - 496 с.; Муромцев Г.И. Юридическая техника: некоторые аспекты содержания понятия // Проблемы юридической техники: сб. ст. / под ред. В.М. Баранова. Н. Новгород, 2000; Алексеев С.С. Восхождение к праву. Поиски и решения. - М., 2001.

${ }^{13}$ Юридическая техника: учебник / Т. В. Кашанина. - 2-е изд., пересмотр. - М.: Норма; Инфра-М, 2011. - С. 27.
} 


\section{Правотворчество в Российской Федерации}

Таким образом, теоретическая позиция ученых в целом не отрицает правотворчество. Более того, из неё можно вывести, что этот юридический феномен имеет сложный характер. Ниже мы скажем, как относятся между собой основные положения юридической науки по поводу правотворчества, как в синхронном, так диахроническом плане.

Всеми исследователями подчеркивается комплексный характер науки о создании законов. Вместе с тем, слишком дробное разделение науки на мелкие таксономии не оправдано, так как теряется онтологическая сторона. Поэтому высказываются вполне обоснованные предположения о недопустимости излишнего дробления научных знаний. « Обоснование юридической техники как самостоятельной науки без веских на то аргументов проблемно в смысле перспектив теории права и стабильности её структуры» ${ }^{14}$.

Основными проблемами юридической техники и правотворчества на сегодняшний день являются:

1) необходимость выработки и закрепления иерархии нормативных правовых актов по их видовым классификационным признакам ${ }^{15}$;

2) соотношение видов правовых актов по вектору правотворческой политики: федеральных конституционных законов и федеральных законов ${ }^{16}$;

3) координация предмета совместного ведения федерального законотворчества и законотворчества субъектов федерации ${ }^{17}$;

4) эффективность правового регулирования юридической практики субъектов Федерации, в частности, опережение и дублирование законотворческих решений ${ }^{18}$.

\footnotetext{
${ }^{14}$ Юридическая техника: учеб. пособ. / Н.А. Власенко, А.И. Абрамова, Г.Т. Чернобель. - 2-е изд., перераб. и доп. - М.: Юстиция, 2016. - С. 6.

${ }^{15}$ Поленина С.В. Инициативный проект федерального закона о законах и иных нормативно-правовых актах РФ / С.В. Поленина, Б.М. Лазарев, Р.З. Лившиц [и др.] // Государство и право. - 1995. - №3. - С. 57-68; Юртаева Е.А. Закон о нормативно-правовых актах и практика российского правотворчества // Журнал российского права. - 2006. - №5. - С. 12-22

16 Тихомиров Ю.А. Закон о нормативных правовых актах - актуальная повестка дня / Ю.А. Тихомиров, Т.Н. Рахманина, А.Г. Хабибулин // Журнал российского права. - 2006. №5. - C. 88-93.

${ }^{17}$ Сырых В.М. Предмет и система законодательной техники как прикладной науки и учебной дисциплины // Законотворческая техника современной России: состояние, проблемы, совершенствование: сб. ст.: в 2 т. - Н. Новгород, 2001. Т. 1; Пиголкин А.С. Подготовка проектов нормативных актов (Организация и методика). - М., 1968; Пиголкин А.С. Совершенствование законодательной техники // Советское государство и право. - 1968. - №1. С. 50-57; Пиголкин А.С. Язык советского закона и юридическая терминология // Правоведение. - 1968. - №5. - С. 45-51.

18 Закон: создание и толкование / под ред. А.С. Пиголкина. - М., 1998; Баранов В.М. Инициативная программа спецкурса «Юридическаятехника» / В.М. Баранов, М.Ю. Варьяс, Е.Н. Салыгин // Проблемы юридической техники: сб. ст. / под ред. В.М. Баранова. Н. Новгород, 2000. - 330 с.; Правотворчество и технико-юридические проблемы формирования системы российского законодательства в условиях глобализации: сб. ст. / под общ. ред. С.В. Полениной, В.М. Баранова и др. - М., 2007; Карташов В.Н. Правотворческая практика субъектов Российской Федерации (некоторые проблемы законодательной технологии). - Ярославль, 2007.
} 
5. Самую важную проблему представляет собой соотношение императивного и диспозитивного метода правового регулирования в праве. Фактически, с диахронической точки зрения встает вопрос о соблюдении контовской « положительной морали» ${ }^{19}$.

В своих работах авторы неизменно разграничивают понятия юридической (законодательной) техники и правотворчества. Достоинствами в плане структурирования правотворчества служат:

1) выделение нескольких уровней правотворческого знания, хотя с разными составляющими и их таксономией;

2) выделение и исследование отдельных практических методик создания законов;

3) попытки заложить в техники инструментарий активного и добросовестного исполнения законов.

Главным недостатком работ является отсутствие теоретического обобщения всех знаний о методах, способах и приёмах создания законов.

Продолжая традиции Конта-Остина, все современные работы развивают и совершенствуют позитивистские начала. К таковым можно отнести:

1) развиваются идеи по предпроектной подготовке нормативного правового акта, в частности, уделяется немалое внимание таким составляющим, как усмотрение, прогнозирование, планирование, мониторинг, что соответствует установке Конта на активную жизнь;

2) установка на закрепление принципов правотворчества свидетельствует не только о проявлении активной жизни, но и систематизации;

3) правовая дефиниция - это прямое позитивное толкование сущности правового понятия или термина путем выделения его активных или сущностных черт в их систематическом изложении.

Другим недостатком, вытекающим из первого, является отсутствие комплексного подхода. Анализ юридической литературы в сфере правотворчества дает однозначный ответ: современная научная мысль не рассматривает этот важнейший аспект правовой деятельности как единый научный процесс. Так, например, А.В. Дербина под правотворчеством понимает «форму государственной профессиональной деятельности, направленную на формирование, принятие норм права (а также их изменения и отмену) уполномоченными субъектами с применением определенных методов, средств и способов в рамках соответствующих процедур с целью удовлетворения потребностей в урегулировании общественных отношений» ${ }^{20}$. А.П. Мазуренко под правотворчеством понимает «завершающий этап правообразования, состоящий в деятельности управомоченных субъектов по созданию, изменению или отмене правовых норм в целях урегулирования общественных отношений и совер-

\footnotetext{
${ }^{19}$ См., например: Законодательная техника: науч.-практ. пособ. / Л.Ф. Апт, Н.А. Власенко, В.Б. Исаков, С.В. Кузнецов [и др.]; под ред.: Ю.А. Тихомирова. - М.: Городец, 2000.

${ }^{20}$ Дербина А.В. Правосознание как элемент правовой позиции субъекта правотворчества: автореф. дис. ... к.ю.н. - Самара, 2011. - С. 8.
} 


\section{Правотворчество в Российской Федерации}

шенствования наличной системы права» ${ }^{21}$. По мнению С.В. Синюкова, «правотворчество - это комплексный социальный институт правовой культуры, включающий механизмы научно-философского, социальнопсихологического, формально-юридического правоприменительного воспроизводства права» ${ }^{22}$. Имеются и другие, не противоречащие друг другу формулировки правотворчества ${ }^{23}$.

Между тем, правотворчество не просто содержит отдельные механизмы юридической деятельности, но само по себе представляет сложный многогранный механизм. Будучи одним из видов юридической деятельности, оно содержит много сторон в их системных связях.

С учетом того, что в основе дифференциации подходов различных авторов в определении правотворчества находится неоднозначное понимание ими содержания этого термина, Е.В. Семьянов вполне обоснованно выделяет следующие определения правотворчества:

1) правотворчество как законодательство, или создание нормативноправовых актов особого вида, закрепляющих основы правовой системы с последующим уточнением их положений в подзаконных актах, причем у последних имеется единственно возможная функция - разъяснение или уточнение закона без изменения его первоначального смысла;

2) правотворчество как нормотворчество, или создание общеобязательных правил поведения;

3) правотворчество как правообразование и правоустановление ${ }^{24}$.

Таким образом, современные научные подходы в понимании правотворчества не учитывают такой аспект как общая теория его научного осмысления, основанного на знании присущих именно ему закономерностей, принципов и методов этого процесса. Отраслевое правотворчество, лишенное опоры на общетеоретические знания научного понимания самой природы создания правовых норм, правовых институтов и законодательных актов, постоянно дает сбои, влекущие за собой непрерывное изменение и дополнение уже действующего законодательства. Это касается всех без исключения отраслей права. Например, О.В. Бондаренко указывает, что «обновление УК достигло того критического уровня, когда требуется кардинальная рационализация уголовного

${ }^{21}$ Мазуренко А.П. Правотворческая политика как фактор модернизации правотворчества в России: автореф. дис. ... д.ю.н. - Саратов, 2011. - С. 11.

${ }^{22}$ Синюков С.В. Механизм правотворчества: автореф. дис. ... к.ю.н. - Саратов, 2013. - С. 8.

${ }^{23}$ Попов О.В. Теоретико-правовые вопросы судебного правотворчества в РФ: автореф. дис. ... к.ю.н. - Тольятти, 2004. - С. 6; Алешкова Н.П. Конституционно-правовые основы муниципального правотворчества в Российской Федерации: автореф. дис. ... к.ю.н. - Екатеринбург, 2010. - С. 9; Илларионов А.В. Акты правотворчества в Российской Федерации. - Омск, 2008. - С. 7; Каминская Е.А. Муниципальное правотворчество в механизме правообразования: автореф. дис. ... к.ю.н. - Белгород, 2013. - С. 8; Евстигнеева Г.Б. Судебные решения как источник права: автореф. дис. ... к.ю.н. - М., 2007. - С. 7; Венгеров А.Б. Теория государства и права // Теория государства и права: учебник для юрид. вузов. 3-е изд. - М.: Юриспруденция, 2000. - 528 с.; и др.

${ }^{24}$ Семьянов Е.В. Судебное правотворчество: вопросы общей теории права: автореф. дис. ... к.ю.н. - М., 2005. - С. 6. 
правотворчества» ${ }^{25}$. И это правильная, вполне обоснованная позиция. Возрастающая с каждым годом разность между количеством заявленных в органы правосудия преступлений и количеством фактически расследованных свидетельствует о необходимости такого шага законодателя. При этом рационализация уголовного правотворчества должна учитывать не только совершенствование норм уголовного права, но и реальные возможности следственных и судебных органов по их качественному рассмотрению. Представляется, что уголовному преследованию должны подвергаться только лица, совершавшие тяжкие и особо тяжкие преступления. Преступления небольшой и средней тяжести необходимо перевести в категорию административных преступников либо декриминализировать. Одновременно «процедуру досудебного и судебного производства по уголовным делам в отношении лиц, обвиняемых в совершении преступлений средней тяжести, целесообразно существенно упростить, а меры государственного реагирования на такого рода деяния сделать более экономичными и гуманными» ${ }^{26}$. С учетом этого понятно, что правотворчество в конкретной отрасли права должно опираться на определенную базу общих требований, предъявляемых в целом к данному юридическому процессу.

Сказанное выше невольно приводит к выводу, что отсутствует четкое понимание соотношения эмпирического материала и его теоретического осмысления.

\section{§1.2.2. СООТНОШЕНИЕ ТЕОРЕТИЧЕСКОГО И ЭМПИРИЧЕСКОГО В СОЗДАНИИ ЗАКОНОВ}

Среди ученых по этой проблеме сформировалось несколько направлений:

1. Сепаратистская школа ученых - эмпириков. Согласно ей юридическая техника и эмпирической научно-практическое знание не связаны с юридической наукой. Подход заложен Ж. Рипером. В советское время в явном виде её представлял Л.С. Явич, в системном отношении этот подход представлял М.М. Гродзинский ${ }^{27}$.

2. Комплексная школа, согласно представителям которой практические знания развивают теоретические концепции и упорядочивают содержание правовых норм.

3. Житейская школа, основанная Р. Иерингом (см. выше) - она связывает практические науки (юридическую технику) и эмпирические зна-

\footnotetext{
${ }^{25}$ Бондаренко О.В. Судебная практика и уголовное правотворчество: автореф. дис. ... к.ю.н. - М., 2013. - С. 9.

${ }^{26}$ Иншаков С.М. Латентная преступность как показатель эффективности уголовной политики // Российский следователь. - 2008. - №14.

${ }^{27}$ Гродзинский М.М. Об усовершенствовании законодательной техники // Социалистическая законность. - 1957. - №1. - С.11-18; Явич Л.С. Советское право - регулятор общественных отношений в СССР. - Сталинабад, 1957.
} 


\section{Правотворчество в Российской Федерации}

ния с потребностями самой жизни - то есть с существованием самого права. Идеи Иеринга развивал французский правовед Ф. Жени.

4. Школа «обратного» обоснования - подчинения высших, По Конту, наук - низшим. Сложилась в советский период. Наиболее ярким представителем её стали Брауде И.Л. Он трактует теорию права как неотъемлемую часть юридической техники, выводя, таким образом, эмпирическую и практическую часть из теоретической. Даже такие теоретические вопросы, как разграничение отраслей права, должна решать, согласно его воззрениям, законодательная техника ${ }^{28}$. Другой яркий представитель её - С.С. Алексеев ${ }^{29}$.

Отдельным ученым свойственна особая позиция в этом вопросе. В качестве разновидности 4-й позиции можно выделить позицию О.А. Красавчикова, который к юридической технике относит практически все основные виды юридической деятельности, в том числе и осуществление права, а правотворчество на всех его уровнях выступает лишь производным эмпирической науки ${ }^{30}$. Почти аналогичную позицию занимал и Н.Г. Александров ${ }^{31}$. Сюда можно отнести и В.А. Ойгензихта с наделением силой правотворчества юридических презумпций и категорий должного, например, риска ${ }^{32}$.

Мы можем констатировать, что данное соотношение описается на следующие важнейшие составляющие:

1. Анализ общественных отношений и степени воздействия на них нормативно-правовых актов позволяет фиксировать результаты познания правовой действительности при проведения правовой политики как на уровне государства, так и на уровне Субъекта Федерации и муниципального образования.

2. На этапе теоретического познания, полученное знание о поведении индивида в рамках его выживания, взаимодействия его с другими, с социальными группами и социальных групп между собой, существует в голове исследователя как предпосылка анализа - источника предположений и гипотез, объяснения реальных фактов, формулируются эскизы понятий и определений правовых дефиниций. В частности, это важно для планирования и прогнозирования в ходе правотворческой деятель-

\footnotetext{
${ }^{28}$ Брауде И.Л. Очерки законодательной техники. - М., 1958; Брауде И.Л. Вопросы законодательной техники // Советское государство и право. - 1957. - №8.; Брауде И.Л. Избранное: Очерки законодательной техники. Некоторые вопросы системы советского права. М.: Институт законодательства и сравнительного правоведения при Правительстве Российской Федерации, 2010. - 160 с.

${ }^{29}$ Алексеев С.С. Общая теория права: в 2 т. - М., 1981. Т. 1. - 359 с.

${ }^{30}$ Красавчиков О.А. Юридическая техника и вопросы дальнейшего совершенствования советского гражданского законодательства // Советское государство и права в период развернутого строительства коммунизма. - Л., 1961. - 107 с.

${ }^{31}$ Право и законность в период развернутого строительства коммунизма / Н.Г. Александров. - М.: Госюриздат, 1961. - 271 с.

32 Ойгензихт В.А. Проблема «риска» в гражданском праве. - Душанбе, 1972. - 224 с.; Ойгензихт В.А. Презумпции в советском гражданском праве. - Душанбе, 1976. - 190 с.
} 
ности. Этим формируется позитивная активная предпроектная компонента правотворческого процесса.

3. Эмпирические знания об общественных отношениях используются для характеристики изменений и поправок к действующим законам, для облегчения восприятия субъектами правоотношений, правоприменительными и правоохранительными органами сложных положений правовых норм. Здесь применяется позитивистский метод Иеринга « логически сжатого донесения до масс».

4. Факты, полученные в ходе сбора информации об общественных отношениях, служат средством верификации выводов и правотворческих решений, в том числе, обосновывают применение тех или иных методов и приёмов юридической техники.

Теоретическое знание, как свидетельствуют работы по философии права ${ }^{33}$ - это внутреннее содержание права, лишённое внешней оболочки. Только практика - эмпирическая правотворческая наука и юридическая техника способны верифицировать теорию, то есть, по О. Конту ${ }^{34}$ послужить теми науками низиего уровня, которые обязаны подчиняться высшей науке - Теории Правотворчества, но в то же время, свочми позитивными эмпирическими знаниями, методами и техниками произвести апробацию и верифицировать её, без чего Теория правотворчества не может существовать.

Следовательно, создание законов как система знаний должна состоять из теоретической науки и одной или нескольких верифицирующих её эмпирических / практических наук низшего уровня.

\footnotetext{
${ }_{33}^{3}$ Алексеев С.С. Философия права: история и современность. Проблемы. Тенденции. Перспективы. - М. Норма, 1999. - 329 с.; Бачинин В.А. Энциклопедия философии и социологии права / под ред. Н.И. Мацнева. - СПб.: Юридический центр Пресс, 2006. - 1091 с.; Бахрах Д.Н. Очерки теории российского права. - М.: Норма, 2010. - 287 с.; Керимов Д.А. Философские основания политико-правовых исследований. - М. Мысль, 1986. - 332 с.; Нерсесянц В.С. Право и закон: их различие и соотношение // Вопросы философии. 1988. - №5; Нерсесянц В.С. Философия права: учебник для вузов. - М.: Норма, 2005. - 656 с.; и др. работы.

${ }^{34}$ Конт Огюст. Дух позитивистской философии: слово о положительном мышлении / пер. с франц. И.А. Шапиро. - М.: Либроком, 2012. - 76 с.
} 


\section{§1.2.3. ОПРЕДЕЛЕНИЕ ПРАВОТВОРЧЕСТВА}

Как следует выше из краткого диахронического и синхронного научного анализа, научное определение правотворчества должно содержать как отражение его эмпирической, так и теоретической основы. Эмпирическую часть этой отрасли знаний составляют методы, техники и приёмы кодификации права, выработки норм на основе стимулирования участников правоотношений - то есть, практико-эмпирические элементы. В Теоретическую же часть заложены общественные отношения, которые должны быть урегулированы.

Таким образом, мы приходим к следующему определению.

Правотворчество - это юридическая наука, устанавливающая, какие общественные отношения нуждаются в правовом регулировании, определяющая возможность и сочиальную необходимость их упорядочения нормами права, изучающая правотворческий прочесс, а также особенности правотворчества по каждому его виду и в каждой отрасли права.

Одновременное правотворчество изучает особенности выработки правовых норм методами юридической техники, стимулирующих их реализацию за счет установленных ими правил поведения участников (субъектов) правоотношений в виде стимулирующих её приемов (созидающее правотворчество).

Таким образом, мы приходим к сложной двухуровневой науке.

Теоретический уровень составляют онтология, гносеология, методология и логика, а также социальная философия правотворчества. Эмпирический уровень - это виды правотворчества (объект исследований), правотворческий процесс и правотворческое решение, составляющие вместе правотворческий механизм, а также юридическая техника, позволяющая создавать, систематизировать и придавать юридическую силу нормам права. Без практической эмпирической части теоретический уровень существовать не может. Но прикладная часть эмпирическая 8 плане позитивистского научного знания подчинена теоретической науке. Эмпирический уровень правотворчества и юридическая техника тесно соприкасаются друг с другом, так как правотворчество является фундаментальной основой юридической деятельности ${ }^{35}$.

35 Чешуина С.И. Юридическая деятельность: монография / под ред. С.И. Чешуина, И.Е. Ильичёва. - Белгород: Институт социологии права, 2009. - С. 12. 


\section{§1.3. ТЕОРЕТИЧЕСКИЙ УРОВЕНЬ ПРАВОТВОРЧЕСТВА §1.3.1. ВВОДНЫЕ ЗАМЕЧАНИЯ}

Переходя к теоретической части, необходимо отметить, в частности, проблемы, что особенностью формирования современного законодательства является его нестабильный характер. Правотворчество основывается на практическом опыте создания правовых актов с учетом требований соответствующих законов, регламентирующих порядок их обсуждения и принятия ${ }^{36}$. Совершенствование законодательства осуществляется в процессе его применения под воздействием правоприменительной практики и отраслевой юридической науки. Это свидетельствует о том, что правотворчество в Российской Федерации формируется на основе проб и ошибок, что заведомо предопределяет нестабильность правовых норм, их оторванность от реальной потребности в регулировании общественных отношений. А если учесть, что правотворческий процесс находится к тому же под постоянным давлением парламентского лобби, то становится очевидным: несовершенство нашего законодательства является серьезной проблемой в развитии органов государственной власти, экономики, демократии и социальной структуры общества. Получается, что законодатель при формировании законодательных актов и правовых норм руководствуется не общими правилами и закономерностями, присущими правотворчеству как социально-правовому явлению, а только частными подходами, выработанными отраслевыми юридическими науками.

В рамках чего возможно системность? В дальнейшем мы дадим ответ на данный вопрос.

Пока отметим, что современное правотворчество, и как юридический феномен, и как юридическая деятельность, должна, по нашему мнению отвечать на два главных вопроса.

1. Какие общественные отношения нуждаются в правовом регулировании?

2. Как повысить исполнимость законов?

В юридической литературе отмечается, что «развитие теории правотворчества и правореализации с одной стороны, процесс их общей интеграции, а с другой - процесс все большей конкретизации научного знания, предполагающий последовательную разработку все более специальных научных идей и категорий, уточнение взаимосвязи между ними» ${ }^{37}$. Эта мысль совершенно объективно характеризует создавшееся положение в исследовании правотворчества в целом и присущих ему

\footnotetext{
${ }^{36}$ См., например: глава 12. Порядок внесения законопроектов в Государственную Думу и их предварительное рассмотрение, предусмотренной постановлением ГД Федерального Собрания РФ от 22.01.1998 г. №2134-11 ГД «О регламенте Государственной Думы Федерального Собрания Российской Федерации».

37 Липень С.В. Идеи правотворчества и правореализации в политико-правовой мысли России XIX - начала XX в.: автореф. дис. ... д-ра юрид. наук. - М., 2013. - С. 8.
} 


\section{Правотворчество в Российской Федерации}

особенностей, связанных с формированием отдельных отраслей права. Накопившийся научный потенциал в этой сфере юриспруденции позволяет сделать новый шаг: обособить и выделить в отдельную отрасль права общую теорию правотворчества.

Необходимость создания такой теоретической юридической науки обусловлена следующими причинами:

1) потребностями законотворческой деятельности различных властных субъектов, в обязанности которых входит правовое регулирование происходящих в реальной действительности общественных отношений;

2) переход на более высокий уровень правотворчества, когда конкретный правовой акт и правовая норма устанавливаются не методом проб и ошибок, а на основе единой научной базы с учетом их имплементации не только в отраслевую систему права, но и в юридическую, экономическую и социально-политическую систему страны;

3) наличием возможности обобщения накопившихся серьезных научных исследований различных видов правотворчества, что создает предпосылки их системного осмысления и формирования на этой базе новых подходов в его реализации;

4) недостаточность законодательства, регламентирующего правотворчество, а также потребность в его дальнейшем совершенствовании на основе научного понимания диалектики его развития в современных условиях;

5) отсутствие целостного подхода при разработке отдельных правовых норм, институтов и законодательных актов, что обуславливает ошибки и противоречия в правовом регулировании, создает трудности в правоприменении и недостаточно эффективно применяются правовые запреты и поощрения. Об этом отмечается и в юридической литературе. Так, А.П. Мазуренко в своей докторской диссертации приходит к выводу, что проводившаяся в нашей стране на протяжении последних десятилетий не вполне эффективная правотворческая политика породила «противоречие между реальными общественными отношениями и существующей системой российского права, призванной регулировать эти отношения. Данное противоречие образует важнейшую социальнополитическую проблему, требующую своего научного осмысления и практического решения» ${ }^{38}$.

${ }^{38}$ Мазуренко А.П. Правотворческая политика как фактор модернизации правотворчества в России: автореф. дис. ... д.ю.н. - Саратов, 2011. - С. 22. 


\section{§1.3.2. ОНТОЛОГИЯ ПРАВОТВОРЧЕСТВА}

Онтология правотворчества включает в себя способы нахождения и исследования материала по зарождению, развитию и отмиранию общественных отношений, подлежащих правовому регулированию, соотношению диспозитивного и императивного методов, соотношению и применимости приёмов методов и способов юридической техники для наполнения нормы, призванной регулировать общественные отношения единым содержанием, а также анализ и систематизация этих данных.

Онтология правотворчества представляет собой универсальную картину общественных отношений, подлежащих правовому регулированию. Или уже урегулированных нормами права. Материализм был более близок к разрешению этой задачи, но не справился с ней. Каждое урегулированное или нуждающееся в урегулировании нормами права правоотношение представляет собой единство общего и конкретного. Данную задачу можно решить, объединив юридический позитивизм и материализм: позитивное нужно использовать как исполнение государственных предписаний и законов. Общее взаимодополняющее развитие юридически позитивистски и материалистических оснований можно представить по законам материалистической диалектики: тезис - антитезис - синтез. В нашем случае развитие будет выглядеть следующим способом: исполнение закона - нарушение закона - санкция. Позитивизм юридической техники будет предполагать активность (стимулирование) в регулировании общественных отношений плюс системность воздействия, что согласно Джону Остину равно исполнению позитивных государственных предписаний, а также согласно задачам правотворчества полному охвату круга общественных отношений. Онтология правотворчества всегда развивается в рамках всеобщего и конкретного.

Познание правовой действительности в рамках правотворческого процесса должно осуществляться независимо от эмоций и взглядов познающего субъекта. Личные интересы и выгоды познающего правовую действительность с целью разработки правотворческого решения остаются на заднем плане. Для выработки стабильных правотворческих решений необходимо избавить весь правотворческий процесс от таких субъективных факторов, как лобби, непрофессионализм, регионализм и др. - только тогда изменяющиеся объективно общественные отношения, нуждающиеся в правовом регулировании, получат по-настоящему объективное (а фактически, это означает - эффективное) правовое регулирование, адекватно выраженное в правотворческом решении. Объективность в правотворчестве как в науке, и как в юридической науке, в частности, - предполагает принятие решений независимо от личных корыстных установок субъекта правотворчества или влияние на проводимый им научный и юридический процесс чужой воли. Взвешивание и анализ объективных фактов, требующих урегулирования общественных отношений - вот что должно стать главной доминантой научного анализа в правотворчестве, как в новой науке. 


\section{Правотворчество в Российской Федерации}

В качестве свидетельства необходимости урегулирования общественных отношений нормами права могут выступать:

1. Наличие требующих правового регулирования общественных отношений как эмпирический факт (либо как факт, устанавливаемый путем экономических, социологических и иных исследований), либо как выведенное из логических рассуждений свойство правовой действительности. При этом понятие логически выведенный подразумевает не только принятый на основе применения законов формальной логики факт, но и также установленный на основании иррациональной потребности низших слоев общества в справедливости и порядке. То есть, по возможности, следует иногда прислушиваться к voxpopuli (voceapoporului).

2. Наличие пробелов в праве, которое также устанавливается либо эмпирическим путем (тогда применяется аналогия права), либо логическим путем (когда для ликвидации пробела применяется аналогия закона). Таким образом, в правотворческом познании, как и во всяком научном, взаимодействуют эмпирическая и логическая основы.

Практическое знание, которое имеет научное значение, получаемое субъектом правотворчества независимо от своих интересов и на основании эмпирических фактов и логических рассуждений, должно быть выражено в специально выработанной юридической наукой системе понятий. Особенностью научного языка правотворчества является то, что понятия в таком языке должны быть не только научно обоснованы, но и юридически точны, отражать правовую сущность того или иного явления объективной действительности. Унификация юридической терминологии позволяет достичь непротиворечивых результатов процесса языкового оформления правотворческих решений, что обеспечит их внутреннюю и внешнюю согласованность ${ }^{39}$.

В отличие от доказательности правотворческого познания, система понятий должна строиться только на законах формальной логики, так как полученное на эвристическом этапе новое юридическое знание имеет двойственную природу: с одной стороны, оно является научным, но с другой - санкционируется силой государственного принуждения. В данном аспекте вскрывается важнейшая сторона правотворчества как новой науки: она имеет диалектически взаимодействующие научное и юридическое начала. Современный этап развития правотворчества в России характеризуется низким качеством правовых актов, одной из главных причин этого как раз и служит отсутствие единых научно обоснованных и законодательно закрепленных понятий, регламентирующих подготовку, принятие, вступление в силу, поправки и отмену действия нормативных актов. Закон «О нормативно-правовых актах», если он будет принят позволит выверить, хотя бы отчасти, и юридически закрепить правотворческую терминологию, что неизбежно сделать необходимым включить правотворческое знание в состав новой отрасли научного знания.

39 Туранин В.Ю. Теория и практика использования законодательных дефиниций. - М., 2009. - C. 51. 
Точность обозначения юридического понятия является концептуальной основой для существования юридического термина ${ }^{40}$.

Далее, в правотворческом знании не просто констатируется факт объективной правовой действительности, но и приводятся необходимые основания, по которым тот или иной факт можно считать истинным. Обоснование правотворческого решения - это длительный, распадающийся на много этапов процесс изучения и выбора лучшего варианта правового решения из всех возможных. Необходима комплексная оценка того экономического, политического или социального эффекта, который окажет нормативно-правовой акт и выбор конкретной формы нормативно-правового акта. Принципами достаточного основания здесь служат:

1) качественные показатели правовой стабильности выбранного нормативного акта и соответствие нормативного акта потребностям общественной жизни;

2) правильное место данного нормативного акта в урегулировании данных общественных отношений;

3) отсутствие противоречия норм правового акта с другими нормами права.

Сведения, которые сообщаются в правотворчестве, как в новой науке, должны касаться сущности эмпирического знания - решения по урегулированию нормами права нуждающихся в этом общественных отношений. Поскольку должны вырабатываться предложения, каждый раз отвечающие своим особым условиям, то для достижения этого должны быть установлены постоянные логические связи между ключевыми регламентирующими правотворческий процесс понятиями. Мы приходим к выводу, что правотворческое новое знание, также как и любое юридическое знание, - должно непременно быть систематизировано - то есть заключено в цельную однородную форму понятий с логическим связями между ними. Необходимы также связи с другими юридическими абстракциями, присущими правовому регулирования в отдельных отраслях права, например, с такими, как необходимая оборона, источник повышенной опасности, делимый вред и др. Данные логические связи и понятия, как и их ключевые узлы, образуют научные категории, например, принципы правотворчества ${ }^{41}$. Значит, правотворческому знанию в полной мере присущ признак системности.

Все результаты правотворческого научного процесса должны непременно применяться в создании новых нормативных актов. Иными словами, правотворчество неотделимо от практики, само его существование объясняется чисто практическими потребностями законодателя и правоприменителя. В процессе применения различных правотворческих решений происходит непрерывное совершенствование разработанных од-

\footnotetext{
${ }^{40}$ Туранин В.Ю. Юридическая терминология в российском законодательстве. - Белгород, 2009. - C. 15.

${ }^{41}$ Подробнее о принципах правотворчества см.: Каменская Е.В. Региональное правотворчество в Российской Федерации: автореф. дис. ... к.ю.н. - М., 2005. - С. 11.
} 


\section{Правотворчество в Российской Федерации}

нажды правотворческих решений, их системное улучшение, качественно новое обновление системы логических связей и понятий, « отшлифовка» при помощи юридической техники всех трех составляющих правовой нормы - гипотезы, диспозиции и санкции. Это значит, что на определенном этапе накопления количественных системных изменений возможно появление на основе выработанных правотворческих решений нового юридического знания, это значит, в свою очередь, что правотворчество способно к развитию и внутренней саморегуляции.

Из всего приведенного выше можно сделать вывод, что правотворческое познание обладает всеми критериями научного познания.

\section{§1.3.3. ГНОСЕОЛОГИЯ ПРАВОТВОРЧЕСТВА}

Гносеология правотворчества объясняет закономерности зарождения, развития и отмирания общественных отношений, подлежащих правовому регулированию. Первичным объектом познания служат общественные отношения, урегулированы или нуждающиеся в правовом урегулировании.

Гносеология правотворчества устанавливает стадии и процедуры научного познания, критерии которым должно удовлетворять полученное эмпирическое и теоретическое знание. Теория в правотворчестве представляет собой совокупность достоверных знаний, и, в связи с этим их верификации служит та часть юридической техники, которая посвящена выработке дефиниций. Формирование системности в правотворчестве - это выработка с помощью юридической техники системы категорий и понятий, раскрывающий исследуемый объект во всей полноте его граней, связей и закономерностей, а также системных (парадигматических) отношений. Это ярко выраженный позитивистский момент в гносеологии правотворчества.

«Неверное толкование гносеологических категорий, допускаемое представителями конкретных наук, порождает устойчивые недоразумения и ошибки в решении вопросов конкретно-научного знания, создает дополнительные затруднения на пути успешного развития науки. Убедительная иллюстрация сказанному - понимание юристами судебной практики как правоположений, сформулированных на основе той или иной категории уголовных или гражданских дел. Интерпретация понятия «судебная практика» в смысле, не соответствующем содержанию родовой философской категории «практика», негативно сказалось на состоянии всей юридической науки ${ }^{42} \gg$.

В гносеологии правотворчества центральной является соотношение права и закона. Право - это совокупность «позитивных предписаний», обязательных для исполнения, закон - созданное методами конкретизирующей юридической техники, «логического сжатия», качественного и количественного упрощения средство выполнения объективно существующих властных позитивных предписаний, имеющих цель создать комфорт для выживания индивидов, общества как совокупности инди-

${ }^{42}$ Сырых В.М. История и методология юридической науки. - М.: Норма, 2017. - С. 82. 
видов и саморегуляции за счет снижения нагрузки на правоприменительные правоохранительные органы. Право - цель , а закон - средство добровольного и добросовестного законопослушного поведения индивида- участника правоотношений.

\section{§1.3.4. АКСИОЛОГИЯ ПРАВОТВОРЧЕСТВА}

Аксиология правотворчества занимается системой ценностей и руководящих ориентиров, при помощи которых создаются, конкретизируются, систематизируются и исполняются нормы права. Главным правовым идеалом в правотворчестве является правомерное добросовестное поведение индивида, направленное на соблюдение закона и субъективных прав других индивидов - участников правоотношений. А́сиологическому сущему в правотворчестве свойственны имманентность и апостериорность. Ценности задают правотворчеству как эмпирическому и практическому процессу определённую целевую направленность, основополагающую при выработке акта, а также при его кодификации, наполнении единым содержанием и введении влияющих на поведение людей составляющих его санкций.

В правотворчестве как системе знаний, а также как в юридической деятельности, руководящими ценностями являлись принципы правотворчества.

В юридической литературе принципам правотворчества уделяется значительное внимание, поскольку именно принципы предопределяют не только целевую направленность законодательного акта, но и характер его реализации, а также социально-политические, экономические и правовые последствия. В настоящее время выделяют принципы федерального $^{43}$ и регионального ${ }^{44}$ правотворчества. В целом пока нет единства мнений о видах принципов правотворчества. Большинство ученых называет такие принципы как законность, демократизм, научность (В.К. Бабаев, А.Б. Венгеров, А.В. Малько, Н.И. Матузов, А.С. Пиголкин и др. $)^{45}$. Помимо указанных принципов другие авторы называют еще принцип

\footnotetext{
${ }^{43}$ Семьянов Е.В. Судебное правотворчество: вопросы общей теории права: автореферат дис. ... к.ю.н. - М., 2005. - С. 7.

44 Каменская Е.В. Региональное правотворчество в Российской Федерации: автореф. дис. ... к.ю.н. - М., 2005. - С. 11.

${ }^{45}$ Бабаев В.К. Формальная определённость и возможности формализации законодательства // Советское государство и право. - 1978. - №4. - С. 45; Венгеров А.Б. Теория государства и права // Теория государства и права: учебник для юрид. вузов. - 3-е изд. - М.: Юриспруденция, 2000. - 528 с; Малько А.В. Теория государства и права. - М., 1999. С. 222; Теория государства и права: курс лекций / Под ред. Н.И. Матузова, А.В. Малько. 3-е изд., перераб. и доп. - М.: Норма; Инфра-М, 2012; Пиголкин А.С. Федеральные основы системы российского законодательства // Соотношение законодательства Российской Федерации и законодательства субъектов Российской Федерации. - М., 2003, Теория государства и права: учебник / А.С. Пиголкин, А.Н. Головистикова, Ю.А. Дмитриев, А.Х. Саидов / под ред. А.С. Пиголкина. - М.: Юрайт-Издат, 2005. - 613 с.; Петров А.В. Теория государства и права: учеб. пособ. - Челябинск: ЮУрГУ, 2014. - 238 с.; и др.
} 


\section{Правотворчество в Российской Федерации}

гуманизма (М.Н. Марченко, В.С. Нерсесянц) ${ }^{46}$, принцип профессионализма (И.Н. Сенякин, А.С. Пиголкин) ${ }^{47}$, принцип постоянного развития и своевременного осуществления правотворчества (Р.Ф. Васильев ${ }^{48}$; принцип конституционности (М.Н. Марченко) ${ }^{49}$, принцип гласности (С.А. Комаров, А.В. Малько) $)^{50}$, принцип оперативности (А.Ф. Черданцев $)^{51}$, принцип исполнимости (А.В. Венгеров) ${ }^{52}$, принцип планирования и строгой дифференциации правовых полномочий (С.А. Комаров) ${ }^{53}$, и др. Е.В. Каменская, приходит к выводу, что принципы правотворчества подразделяются на универсальные (гуманизм, демократизм, законность), общие, относящиеся как к федеральному, так и к региональному правотворчеству (гласность; научность; профессионализм; оперативность и динамичность правотворчества; соблюдение правил правотворческой техники; планирование и прогнозирование; финансовое обеспечение и материальная достаточность; принцип информационно-правового обеспечения правотворческой деятельности) и региональные принципы (системности; принцип взаимосогласованности и взаимодополняемости федерального и регионального правотворчества в сфере совместной компетенции; принцип дифференциации правотворческих полномочий и иерархичности нормативных правовых актов компетентных правотворческих органов субъекта РФ; принцип учета социальной, исторической и иной специфики субъекта РФ; принцип взаимосвязи теории с практикой $)^{54}$. Е.В. Семьянов считает, что следует отказаться от выделения принципа исполнимости в качестве самостоятельного, поскольку создание нормы права - это следствие и проявление принципов законности и системности $^{55}$. Представляется, что исполнимость является важнейшим принципом правотворчества. Может быть, поэтому на сегодняшний день в Государственной Думе остаются без рассмотрения отдельные важные для страны законопроекты (например, Административный процессуальный кодекс), ибо учитываются возможности их исполнимости.

\footnotetext{
${ }^{46}$ Марченко М.Н. Проблемы теории государства и права. - М., 2013. - 704 с.; Нерсесянц В.С. Общая теория права и государства. - М., 1999. - 552 с. [Электронный ресурс]. - Режим доступа: https://moluch.ru/archive/13/1086/ (дата обращения: 09.06.2018).

${ }^{47}$ Специальные нормы советского права / под ред. М.И. Байтина. - Саратов: Изд-во Сарат. ун-та, 1987. - 97 с.

${ }_{48}$ Васильев А.М. Правовые категории. Методологические аспекты разработки системы категорий теории права. - М.: Юрид. лит., 1976. - 264 с.

${ }^{49}$ Общая теория государства и права. Академический курс в 2-х т. / под ред. М.Н. Марченко. Т. 2 Теория права. - М., 1998. - 622 с.

${ }^{50}$ Малько А.В. Теория государства и права. - М., 1999. - 448 с.; Комаров С.А. Общая теория государства и права. - М.: Юрайт, 1998. - С. 295.

${ }^{51}$ См., например: Черданцев А.В.Теория государства и права: учебник для вузов. - М.: Юрайт, 2000. - 432 с.

52 Венгеров А.Б. Теория государства и права// Теория государства и права: учебник для юрид. вузов. - 3-е изд. - М.: Юриспруденция, 2000. - 528 с.

53 Общая теория государства и права: учебник для бакалавриата и магистратуры / С.А. Комаров. - 9-е изд., испр. и доп. - М.: Юрайт, 2017. - С. 288-295.

${ }^{54}$ Каменская Е.В. Указ соч. - С. 12.

${ }^{55}$ Семьянов Е.В. Указ соч. - С. 6.
} 
Рассмотрев принципы правотворчества с самых различных сторон, авторами не сделан самый главный вывод, что принципы правотворчества делятся на материальные и процессуальные. Между тем такое деление очень важно: оно показывает функциональную роль того или иного принципа в механизме принятия правотворческого решения. Материальность или процессуальность позволяют придавать тому или иному принципу правотворчества различную социальную направленность, определяют в конечном итоге его регулятивный потенциал.

Анализ указанных выше принципов дает возможность заключить, что учеными проделана большая работа по осмыслению сущности правотворчества. Однако, исследования в этом направлении необходимо продолжить. Так, остается вне поля зрения важнейший аспект правотворческой деятельности - его целесообразность. Более того, обоснованные юридической наукой принципы правотворчества остаются в основном в качестве научных категорий, а не правовых, что резко снижает эффективность правового регулирования. Требуется более глубокое их изучение, систематизация и определения каждому из них своего места в правотворческом процессе путем закрепления в правовых нормах. Оставаясь вне правового поля, принципы лишь априори воздействуют на правотворчество. Кроме того, принципы правотворчества фактически должны последовательно закрепляться на каждой его стадии и поэтапно передавать законопроект на оформление в нем очередных основополагающих начал. Ибо, как удачно высказалась Е.В. Каменская, «принципы правотворчества находятся в состоянии сложного взаимодействия» ${ }^{56}$.

Все это свидетельствует о необходимости исследования принципов правотворчества в системе единой науки о правотворчестве, что позволит рассматривать их как единый комплекс исходных идей при выработке правовых норм, который имеет между собой логически обусловленные связи, определенную степень интеграции и иерархию.

На современном этапе развития юридической науки субъектом правотворчества должны реализовываться идеалы гражданского общества, прав и свобод человека, а также обновленный принцип консолидации (вместо разделения) властей. Гарантия соблюдения прав и законных интересов индивида должна стать стимулом правомерного поведения, так же, как и учёт интересов всех, или, по крайней мере, самых слабых участников правоотношений. Свобода - как осознанная необходимость и уважение к свободам других - вот руководящий ориентир при конструировании норм права.

Это позволит сформировать высшую ценность - гармоничную законопослушную личность, имеющую желание не только подчиняться, но и своим поведением служить примером исполнения законов, интересы которой защищены, а если это самый слабый из субъектов правоотношений, - то защищены особо.

\footnotetext{
${ }^{56}$ Каменская Е.В. Указ. соч. - С.11.
} 


\section{§1.3.5. ЛОГИКА И МЕТОДОЛОГИЯ ПРАВОТВОРЧЕСТВА}

Основными задачами логики в правотворчестве служат:

1) формулировка совокупности принципов познания;

2) раскрытие системы общих методов познания;

3) применение законов мышления;

4) формулирование нормативов мышления.

Эмпирическому уровню правотворчества как науки соответствует логический приём описание. В ходе описания сначала описываются и характеризуются признаки общественных отношений, которые далее делятся на существенные и несущественные. Существенные - это признаки, дающие предпосылки для урегулирования общественных отношений нормами права. Научное описание общественных отношений, явление и процессов, характерное для теоретического правотворчества, осуществляется при помощи разработанных наукой юридической наукой понятий, знаков, терминов и категорий, содержание которых должно соответствовать базовым научным понятиям. После описания, следует сравнение, как логический приём более высокого уровня. Сравнение широко применимо в таких видах правотворческой деятельности, как конкретизация и толкование норм права. При этом следует соблюдать два основных правила: проводить сравнения по однородным основаниям и сравнивать наиболее существенные признаки. Далее следует более высокий приём логики - определение. В нем раскрывается сущность какого-либо явления общественных отношений или поведения индивида, и на этом основании определяется его место в системе общественных отношений, а также степень роли в общественной жизни. Это исключительно важно, чтобы определить степень нормативного воздействия на данные отношения, метод правового регулирования (императивный, либо диспозитивный) и выбор нормативного акта в процессе правотворчества.

Классификация должна широко применяться в теоретической части правотворчества. Анализ и синтез будут подробнее рассмотрены ниже. Существенную роль должно играть и различное соотношение диалектической и формальной логики: чем от теоретического до эмпирического уровня правотворчества как науки удельный вес формальной логики должен возрастать. Долю алгебраических логических вычислений в юридической технике также необходимо увеличивать.

Научные методы - это совокупность приемов и способов, с помощью которых осуществляется воздействие на общественные отношения в целях их правового регулирования ${ }^{57}$. За счет методов постигается предмет, выявляются новые знания, что позволяет совершенствовать законодательство и нормотворчество в целом.

Поскольку правотворчество представляет собой сложный многоуровневый пласт знаний, то его методы тоже изменяются с учетом конкретного вида правотворчества. Именно определенные группы общественных отношений, составляющие тот или иной предмет, предопреде-

${ }^{57}$ Теория права и государства: учебник / под ред. В.В. Лазарева. - М., 1999. - С. 18. 
ляют выбор метода их правового регулирования. По сути, предмет является материальным критерием, а метод его формально-юридическим отражением. Предмет отвечает на вопрос, что регулирует право, а метод - как регулирует ${ }^{58}$.

В методологическом отношении в правотворчестве, как науке, в первую очередь, должны применяться всеобщие методы:

Общенаучный диалектический. Диалектика - рассматривает все правовые явление, связанные с созданием, функционированием и отменой норм права в единстве противоположностей и в развитии. Всякое новое явление неизбежно возникает на основе тех, что отмирают. Это происходит на основе диалектического закона перехода количества в качество, когда накапливающиеся количественно предпосылки аннигиляции того или иного правового или правотворческого явления на определенном уровне дают качественный переход: исчезновение старого правового явления и зарождение на его основе нового. Диалектика бывает материалистическая и идеалистическая.

Тем не менее, в противовес диалектике существует и метафизический подход, который рассматривает все правовые явления как неизменные, застывшие в развитии величины.

Соотношение диалектики и метафизики показывает, что в современный период они используются не как равноценные методы. Метафизический подход применяется исключительно редко, поскольку все социально-правовые явления находятся в постоянном развитии. Даже такие понятия, как свобода или гуманизм в разные исторические эпохи понимались по-разному, хотя они и наиболее стабильны.

Правотворчество - это длящийся во времени творческий процесс, включающий в себя определенные этапы познания социально-правовой действительности и реагирования на нее. Он включает в себя:

1) осознание необходимости правового регулирования определенной группы общественных отношений, что обуславливает совершение таких действий как обнаружение признаков проблемной ситуации, сбор информации по ней, анализ проблемной ситуации на основе собранной информации, принятие решения о разработке правового документа ${ }^{59}$;

2) квалификацию их правовой принадлежности;

3) разработка концепции нормативного правового акта по правовому закреплению этих отношений;

4) создание проекта нормативного правового акта с отражением в нем метода правового регулирования;

5) обсуждение, доработка и принятие документа;

6) введение его в действие.

На данных этапах правотворчества используются методы анализа и синтеза различных групп общественных отношений с целью выявления

\footnotetext{
${ }_{58}^{58}$ Малько А.В. Теория государства и права. - М., 1999. - С. 153.

${ }^{59}$ Нормотворчество: научно-практическое пособие / Т.Н. Москалькова, В.В. Черников. М.: Проспект. 2011. - С. 138.
} 


\section{Правотворчество в Российской Федерации}

определенных объединяющих признаков, закономерностей, необходимости правового их урегулирования. Как справедливо отмечает С.Г. Соловьев, объективная необходимость правового регулирования предполагает социальную значимость этих отношений, невозможность их упорядочения при помощи других социальных норм ${ }^{60}$. Кроме того, необходимость их правового урегулирования вытекает также из того, что данные общественные отношения представляют собой «повторяющиеся, типичные ситуации» $^{61}$, а не единичные случаи, которые не требуют правового регулирования.

Для познания предмета правотворчества, определения значимости и возможности правового регулирования, используются также сравнительный и статистический методы, что позволяет выявить качественные и количественные его особенности.

Применяются также общенаучные методы:
1) анализ;
2) синтез;
3) системный подход;
4) функциональный подход.

Анализ - это изучение социально-правовых явлений при выявлении степени нуждаемости их в урегулировании нормами права по частям с целью выявления определенных закономерностей.

Синтез - это изучение социально-правовых явлений, нуждающихся в урегулировании нормами права, путем их объединения в определенную группу по каким-либо особенностям, по свойствам, и установление на этой основе закономерностей.

Системный подход - это изучение общественных отношений и регулирующих их норм права, а также отношений, возникающих в поле правотворчества в определенной системе (например, по институтам, по отраслям права).

В правотворчестве как науке, безусловно, должен применяться и функциональный подход - изучение социально-правовых явлений с точки зрения их функционального назначения.

В правотворчестве должны применяться и специальные научные методы. Рассмотрим их подробнее:

1. Важное место в новой правовой науке занимает применение формально-юридического метода. Он представляет собой принцип, в соответствие с которым вырабатываются новые понятия, дефиниции и категории, использующиеся затем во всех отраслях права. Выработка понятийного аппарата правотворчества как новой науки должна производиться на основе однозначного логического толкования понятий. Формально - юридический метод должен закрепить такие важные новые в юридической науке понятия, как качество правотворчества, мониторинг правотворческой деятельности, юридический состав правотворческого

\footnotetext{
${ }^{60}$ Соловьев С.Г. Понятие предмета правового регулирования и его взаимосвязь с другими юридическими категориями // Вестник Пермского университета. - 2012. - №1 (15). - С. 48. ${ }^{61}$ Алексеев С.С. Восхождение к праву. Поиски и решения. - М., 2002. - С. 219.
} 
решения. Все эти новые понятия сыграют ключевую роль в выработке качественных правотворческих решений, будут способствовать повышению качества законодательных актов.

2. Второй по значимости метод правотворчества - сравнительноправовой. Возможны два его варианта - сравнение социально-правовых явлений внутри правовой системы одного государства - внутренний сравнительно-правовой и сравнение аналогичных социально-правовых явлений разных государств - внешний сравнительно - правовой.

Использование внутреннего сравнительного метода может быть эффективным, плодотворным при условии сопоставления однотипных предметов правотворчества, между которыми существует определенная общность, что позволяет проводить их оценку по наиболее важным, существенным признакам. Так, для выработки норм правового регулирования определенной отрасли права проводится сравнительное исследование общественных отношений именно в этой сфере. Выявляется степень их урегулированности, надежность действующего механизма правового регулирования и его эффективность. Установление группы общественных отношений, не имеющих правового регулирования и нуждающихся в нем, обуславливает поэтапный процесс реагирования уполномоченного субъекта правотворчества на данный факт, результатом которого будет принятие определенного нормативного правового акта по урегулированию этих отношений в целом либо частично при обнаружении пробелов в праве.

3. При применении статистического метода социально-правовые явления изучаются методом уяснения их количественного значения, что позволяет установить степень распространенности того или иного явления. Метод играет важную роль при изучении латентных правонарушений, так как очень часто они связаны с пробелами в праве. Также этим методом можно непосредственно выявлять пробелы в правовом регулировании, предотвращать дублирование законов и т. п. Таким образом, статистический метод важен не только для самого правотворчества, но и для правоприменения.

4. Метод анкетирования - установление реального состояния действия нормативно-правовых актов путем проведения письменных опросов (населения, отдельных категорий граждан, специалистов). Метод имеет значение как средство обратной связи и мониторинга правотворческих решений. Существенную роль он играет и при выявлении степени исполнения законов. Важное значение он приобретает при выяснении степени легитимности законов, доверия к законам граждан. Анкетирование специалистов может также проводиться с целью сбора предложений по возможным пробелам права и способам их устранения.

Существуют и другие методы исследований - логический, грамматический, исторический (ретроспективный) и другие.

Большое значение имеет грамматический метод в правотворчестве, поскольку неграмотно составленное предложение может исказить весь смысл закона. Именно поэтому существует множество разъяснений 


\section{Правотворчество в Российской Федерации}

Пленума Верховного Суда РФ, в которых недостаточно грамотно составленные нормы права раскрываются по их содержанию - они получают легальное толкование.

Большое значение в правотворчестве имеют методы, использующиеся в юридической технике. Именно с помощью юридической техники субъект правотворчества добивается формирования нужного ему нормативно-правового акта.

Важным методом юридической техники является конкретизация тех или иных норм права и юридических понятий. Субъект правотворчества разрешает дилемму: либо ему излагать нормативный акт лаконично, общими терминами, либо раскрывать правовую норму пространно развитием (изложением) всех сторон. Лаконизм часто приводит к недостаточной ясности нормы права, а излишняя конкретизация - к многословию, а возможно и к тавтологии.

Следует учитывать возможности юридической техники, под которой понимается «система средств, правил и приемов подготовки и упорядочения правовых актов, применяемая в целях обеспечения их совершенства и повышения эффективности» ${ }^{62}$. Аппарат средств юридической техники имеет большое разнообразие и легко может быть использован в правотворчестве любого вида, его можно приспосабливать и корректировать применительно к различным отраслям и правовым институтам, условиям и целям издания того или иного акта ${ }^{63}$. По мнению Н.Б. Ломакиной и Д.С. Тэпс, в основу работы над внешней формой готовящихся актов правотворчества должны быть положены:

1) точность и определенность юридической формы - формулировок, выражений и отдельных терминов правового акта;

2) ясность и доступность его языка;

3) полнота регулирования соответствующей сферы отношений, отсутствие в нем пробелов и упущений;

4) конкретность регулирования, четкое определение всех его необходимых элементов, борьба с декларативностью;

5) максимальная экономичность, компактность законодательных формул;

6) системное построение права, его цельность и сбалансированность;

7) унификация, единообразие формы и структуры законодательных актов, способов изложения правовых предписанийб4.

Из перечисленного видно, что средства юридической техники в основном направлены на шлифовку текста нормативного правового акта или нормы права с целью наиболее точного воплощения в них юридических предписаний. Но этим реализуется, и другая функция средств юридической техники - обеспечивается наполнение правовой нормы инфор-

\footnotetext{
${ }^{62}$ Малько А.В. Указ. соч. - С. 150.

${ }^{63}$ Ломакина Н.Б. Методология правотворчества: теория и практика, направления совершенствования / Н.Б. Ломакина, Д.С. Тэпс // Пробелы в российском законодательстве. 2012. - №4. - C. 25.

${ }^{64}$ Ломакина Н.Б., Тэпс Д.С. Указ. соч. - С. 26. 
мационным содержанием. За счет этого достигается необходимый баланс содержания ${ }^{65}$ и формы нормативного правового акта и нормы права, что свидетельствует об их качестве. Единство формы и содержания правотворческих решений обеспечивается также за счет использования различных методик, отражающих особенности каждого его вида.

В юридической литературе высказана мысль, что хорошим методом апробации качества принимаемого закона может быть правовой эксперимент $^{66}$. Представляется, что это перспективный путь к совершенствованию правотворчества в России. Несомненно, то, что правотворчество в различных отраслях права будет стимулировать появление и некоторых особых методик, присущих именно этой сфере правоотношений. Развитие демократических институтов, усиление контроля общества за деятельностью органов власти будет порождать новые формы правового регулирования. И это, в свою очередь, будет порождать новые возможности методического обеспечения меняющейся правовой действительности.

В качестве выводов можно сказать следующее:

1) в правотворчестве все методы могут использоваться с учетом конкретных обстоятельств, что может дать положительный результат;

2) специальные методы юридической техники могут помочь конкретизировать понимание тех или иных правовых понятий. Именно они могут сыграть решающую роль в правильном доступном изложении конкретной юридической нормы, то есть, конкретного правового решения.

\section{§1.3.6. СОЦИАЛЬНАЯ ФИЛОСОФИЯ ПРАВОТВОРЧЕСТВА}

Социальная природа человека оказывает наиболее сильнее влияние на развитие правовой системы, общества и государства. Социальный человек реализует свои потребности во взаимодействии с другими членами общества. Главным для социального человека остаются все те же три типа выживания: индивидуальное, групповое и общественное. Стремление к выживанию за счет других проявлялось в человеке постоянно. При резком доминировании её возможны конфликты, сопровождающиеся распадом социума, поэтому выживание человека во всех его видах должно подчиняться и в определенной мере, ограничиваться, при помощи законов. На определенных стадиях развития человеческого общества это было возможно с помощью естественного права. Но со временем потребовались позитивистские нормативные предписания Остина - Конта. Происходит постепенное возрастание потребности в регулятивной функции права.

\footnotetext{
${ }^{65}$ О требованиях, предъявляемых к содержанию законодательства, см.: Остапович И.Ю. Сущность и особенности юридической формы воздействия на правотворчество // Мир науки, культуры, образования. - 2011. - № 4 (29). - С. 294.

${ }^{66}$ Липень С.В. Идеи правотворчества и правореализации в политико-правовой мысли России XIX - начала XX в.: автореф. дис. ... д-ра юрид. наук. - М., 2013. - С. 12.
} 


\section{Правотворчество в Российской Федерации}

Потребность в стимулировании комфортного выживания за счет правомерного поведения, а не противоправного становится новой аксиологической ценностью с развитием общества.

Взаимодействие человека во имя выживания должно регулироваться созидающими законами и не допускать как недостатка, так и избытка правового регулирования. Встаёт вопрос о том, какой круг общественных отношений и какими общественными регуляторами должен быть охвачен.

Центральной идеей социальной философии правотворчества как науки должно стать следующее положение. Необходима саморегуляция общества как союза участников правоотношений с учетом, и, при необходимости защита интереса каждого, а не стихийная борьба за выживание, «война всех против всех». Саморегуляция общества позволит снизить нагрузку на правоприменительные и правоохранительные органы, что позволит пустить людской ресурс общества на развитие и совершенствование производственных отношений и подъем производительных сил.

Таким образом, истинно позитивистские законы - те, которые учитывают интересы всех субъектов правоотношений, а наиболее значительно - слабейшего из участников. Санкции должны следовать только за нарушение общественных норм, а активное правомерное поведение стимулироваться применением специальных модификаторов.

\section{§1.4. ПРАВОТВОРЧЕСТВО КАК ПРИКЛАДНАЯ НАУКА §1.4.1. ЭМПИРИЧЕСКИЙ УРОВЕНЬ ПРАВОТВОРЧЕСТВА}

Эмпирическая часть правотворческого знания представляет науку прикладного характера, имеющую в своем составе и предмет правотворчества всех уровней. Этим предметом выступают виды правотворчества. Их особенности будут рассмотрены ниже

Целью прикладного правотворчества является выработка научно обоснованных правил подготовки и принятия нормативно-правовых актов, отраслей, институтов и норм права на основе исторической преемственности и традиций российского законодательства. Правотворчество должно иметь научно обоснованные наиболее рациональные способы возведения приемлемых для государства общественных отношений в правовую форму. Общая теория правотворчества должна стать основной при создании любого конкретного законодательного акта, поскольку она будет вырабатывать необходимую правовую терминологию, сопутствующую ему, обосновывать границы возможного и невозможного в правовом регулировании общественных отношений, учитывать предполагаемую эффективность принимаемого закона, степень реализуемости и согласованности с другими нормативными актами, потенциальной способностью государственного аппарата по исполнению его предписаний, финансовые издержки и т. д.

Задача прикладного правотворчества - изучение объективных закономерностей и правовых связей, возникающих в процессе правотворче- 
ства, определение критериев его оптимизации, осуществление контроля над исполнением нормативно правовых актов, анализ их эффективности и т. д. Важнейшей задачей общей теории правотворчества является создание алгоритма правового регулирования для определенных групп общественных отношений. Это позволит не только поднять правотворчество на научные основы, но и унифицировать его процесс. Субъекты правотворчества, руководствуясь выявленными закономерностями и его принципами, смогут более качественно и в минимальные сроки разрабатывать и принимать нормативно-правовые акты. Кроме того, задачей теории правотворчества является и его оптимизация, совершенствование системы правил юридической техники, сокращение множественности законов и устранение конкуренции нормативно-правовых актов.

Прикладное правотворчество, исследуя концептуальные проблемы разработки и принятия законодательных актов, сможет вырабатывать конкретные научные рекомендации по вопросам оптимизации данного процесса.

Всякая самостоятельная наука имеет и свой, только ей присущий предмет изучения. Предметом прикладного правотворчества как юридической науки является обширная сфера общественных отношений, связанных с порядком правового регулирования законотворчества, его нормативно-правовой базы, особенностей правотворчества отдельных отраслей права, его специфики как на региональном и федеральном уровне, изучение судебного правотворчества и его роли в деятельности правоохранительных органов.

Общественные отношения в области правотворчества в настоящее время получают правовое оформление в основном эмпирическим путем без серьезного научного обоснования, что обуславливает нестабильность, а отчасти и противоречивость законодательства, его коррупционную направленность. Отраслевые нормативно-правовые акты зачастую не учитывают финансовые возможности государства по их реализации и объем потенциальной нагрузки на органы государственной власти, связанный с их исполнением; правовое регулирование, как правило, основывается на возможностях государственного принуждения, а не на добровольном и добросовестном действии участвующих в правоотношении субъектов.

Современное действующее законодательство, регламентирующее правотворчество, не носит комплексный характер, что создает предпосылки каждому его субъекту руководствоваться своими правилами при формировании, например, региональных нормативно-правовых актов ${ }^{67}$. Предметом ведения правотворчества в таких случаях служат региональные акты, которые не всегда согласуются не только между собой, но,

\footnotetext{
${ }^{67}$ См. подробнее: Дербина А.В. Правосознание как элемент правовой позиции субъекта правотворчества: автореф. дис. ... к.ю.н. - Самара, 2011. - С. 8.
} 


\section{Правотворчество в Российской Федерации}

порой, и с Регламентом Государственной Думы РФ, предусматривающей соответствующие процедуры для федерального законодательства ${ }^{68}$.

Методами правотворчества как юридической науки, безусловно, является весь основной спектр научного познания социально-правовой действительности, присущий данной многообразной среде. К числу таких методов следует отнести всеобщий диалектический метод познания мира, общенаучные методы (анализ, синтез, системный и функциональный подход), а также частнонаучные методы: формально-юридический, сравнительно-правовой, логический, социологический, статистический, грамматический и др. Перечень методов, которые могут быть использованы при исследованиях правотворчества, не может быть исчерпывающим. С развитием этой науки могут появиться новые методы познания, в том числе и совершенно специфические, характерные только при изучении этой сферы правоотношений.

В юридической литературе высказана мысль, что хорошим методом апробации качества принимаемого закона может быть правовой эксперимент ${ }^{69}$. Представляется, что это перспективный путь к совершенствованию правотворчества в России. Несомненно, то, что правотворчество в различных отраслях права будет стимулировать появление и некоторых особых методик, присущих именно этой сфере правоотношений. Развитие демократических институтов, усиление контроля общества за деятельностью органов власти будет порождать новые формы правового регулирования. И это, в свою очередь, будет порождать новые возможности методического обеспечения меняющейся правовой действительности.

Правотворческие методы в целях сохранения единства всей правовой системы должны основываться на сочетании централизации и децентрализации в правообразовании ${ }^{70}$. Это создает условия подготовки и принятия законодательных актов высокого качества и востребованности, что обеспечит их стабильность и надежность в правовом регулировании общественных отношений.

Правотворчество, являясь разновидностью научной правовой деятельности, осуществляется на определенных принципах, в соответствии с которыми создаются нормы права и что обеспечивает качество и эффективность законодательства. Принципы - это основополагающие начала идеи в соответствии, с которыми протекает правотворчество. Одновременно принципы заключают в себе представления общества и государства, о том, что с их помощью процесс правотворчества будет наиболее рациональной формой выработки законов и других нормативных правовых актов.

\footnotetext{
${ }^{68}$ Постановление Государственной Думы РФ от 22.01.1998 г. №2134-11-ГД.

${ }^{69}$ Липень С.В. Идеи правотворчества и правореализации в политико-правовой мысли России XIX - начала XX в.: автореф. дис. ... д-ра юрид. наук. - М., 2013. - С. 12.

${ }^{70}$ Синюков С.В. Механизм правотворчества: автореф. дис. ... к.ю.н. - Саратов, 2013. - С. 9. 
Необходимо констатировать, что в настоящее время при всей важности данной теории правотворчества в практике, в создании законов она играет малозначительную роль. Это объясняется несколькими причинами:

1) отсутствием закона о нормативно-правовых актах (по нашему мнению, необходимо создавать Кодекс о правотворческой деятельности);

2) нежелание депутатов Госдумы связывать себя нормами, ограничивающими их современное свободное право издавать нормативные акты без учета правил их формирования;

3) отсутствие в российском законодательном процессе сформированных традиций выработки нормативно-правовых актов, так как в Советское время нормотворчество осуществлялось в ограниченных масштабах по сравнению с современным этапом. Современное правотворчество по объему превышает советское в сотни раз.

Однако теория правотворчества должна в наши дни играть главную роль в научном обеспечении формирования правовой базы страны. На это указывают и наличие большого количества дублирующего законодательства, а также большое количество противоречащих норм; отсутствие планирования и прогнозирования; накопление большого количества нормативных актов, регулирующих второстепенные отношения; поспешность разработки нормативных актов и др.

Отсутствие четких правил правотворческой деятельности на всех её уровнях приводит к дублированию, а порой и к противоречию правовых норм.

Правотворчество как юридическая наука в настоящее время должна быть выделена из Теории государства и права, поскольку современные условия интенсивной правотворческой деятельности требуют создания самостоятельного научного аппарата, с помощью которого необходимо формировать нормы права. Для этого сейчас имеются все необходимые условия:

1) запрос со стороны практики создания нормативно-правовых актов;

2) имеется значительная нормативно-правовая база (например, Регламент Госдумы РФ, различная документация по принятию нормативных актов);

3) имеются серьезные научные наработки, раскрывающие научную и юридическую сущность общей теории правотворчества (очерчен круг принципов правотворчества, активно изучается методология правотворчества, имеются научный классификации видов правотворчества, по каждому виду имеются научные публикации, многие проблемы активно исследуются наукой: например, понятие состава правотворчества, соотношение норм права и законов и т. д.

В методологическом отношении правотворчество как наука первоначально будет использовать общенаучные методы познания, так и общеюридические методы. В дальнейшем не исключено появление своих методов познания, присущих именно теории правотворчества. Необходимо вырабатывать процедуры познания правой действительности, вырабо- 


\section{Правотворчество в Российской Федерации}

танные на основе общенаучного диалектического метода и метода ретроспективного анализа в сочетании со сравнительно-правовым анализом.

К Общему Прикладному Правотворчеству постепенно будут добавляться различные эмпирические правовые науки, которые будут играть вспомогательную роль в выработке научно обоснованных правотворческих решений. В первую очередь, к ним следует отнести дисциплины, которые углубляют познание по отдельным видам правотворчества (теория законотворчества, подзаконного правотворчества и т.д.), а также по особенностям реализации правотворческих решений в отраслях права. На основании пересекающихся подразделов Общего Прикладного Правотворчества сформируются смежные юридические дисциплины: Например, Уголовное Правотворчество, Конституционное Правотворчество и др.

Рассматривая правотворчество как самостоятельную прикладную юридическую науку необходимо учитывать и ее законодательное обеспечение. С этой точки зрения правотворческая деятельность нуждается в серьезном пополнении ее нормативно-правовой базы. Фактически в настоящее время к числу законодательных актов, регулирующих правотворческий процесс, относятся: Конституция РФ, Регламент Государственной Думы РФ, региональные нормативные акты по вопросам формулирования норм права (например, закон Вологодской области «Об областных нормативных правовых актах» от 17.01.2001 г. №647-03 с последующими изменениями и дополнениями ${ }^{71}$, а также акты действующего отраслевого законодательства, имеющего закрепление принципов, а в ряде случаев и механизма его изменения и дополнения (например, Бюджетный кодекс РФ). По мнению ученых, исследующих правотворчество, для разрешения вопросов координации правотворческой работы и повышения качества законодательства на всех уровнях правовой системы необходимо принятие федерального закона «О правотворчестве в Российской Федерации» ${ }^{72}$, дополнить Регламент Государственной Думы с целью совершенствования процесса правотворчества ${ }^{73}$, разработать и утвердить «Концепцию правотворческой политики в Российской Федерации» ${ }^{74}$, оптимизировать механизм учета мнения субъектов Российской Федерации в правотворческом процессе ${ }^{75}$, дополнить федеральный закон «Об общих принципах организации местного самоуправления в Российской Федерации» от 06.10.2003 №131-Ф3, где предусмот-

\footnotetext{
71 Закон Вологодской области «Об областных нормативных правовых актах» от 17.01.2001 г. № 647-03 с последующими изменениями и дополнениями // СПС Консультант Плюс.

${ }^{72}$ Каменская Е.В. Указ соч. - С. 6; Дербина А.В. Указ. соч. - С. 8

${ }^{73}$ Бондаренко О.В. Указ соч.

${ }^{74}$ Мазуренко А.П. Указ. соч. - С. 22.

${ }^{75}$ Мартьянов Г.А. Теория и методика оптимизации участия законодательных (представительных) органов государственной власти субъектов Российской Федерации в федеральном законотворческом процессе: автореферат дис. ... к.ю.н. - СПб., 2010. - С. 7.
} 
реть порядок согласования разногласий в процессе правотворчества ${ }^{76}$ и т. д. Имеются и более решительные предложения. Так, О.В. Бондаренко пишет: «Интенсивное (по объему), хаотичное (оперативная реакция на отдельные преступления), многократное (редактирование отдельных статей закона несколько раз за малый период времени) и даже возвратное (смена одних нормативных решений на строго противоположные) обновление УК достигло того критического уровня, когда требуется кардинальная рационализация уголовного правотворчества» ${ }^{77}$.

Все это обуславливает однозначный вывод: правотворческий процесс нуждается в серьезном усовершенствовании на базе создания единого законодательства, охватывающего весь комплекс назревших проблем. Кроме того, рационализация правотворчества должна быть направлена на достижение более эффективного законодательства как по степени урегулированности общественных отношений, так и по снижению нагрузки на правоохранительные органы и финансовой затратности, снятию излишней урегулированности, не имеющих широкого распространения эксцессов, повышения его стабильности.

\section{§1.4.2. ПОНЯТИЕ, СТРУКТУРА И ПРИЗНАКИ ПРАВОТВОРЧЕСТВА КАК ЮРИДИЧЕСКОЙ ДЕЯТЕЛЬНОСТИ}

Правотворчество как юридическая категория не имеет законодательного определения. В науке также нет единства мнений в ее понимании. Одни авторы считают, что правотворчество представляет собой деятельность государственных органов по принятию, изменению и отмене правовых норм ${ }^{78}$. Другие применяют широкий подход в понимании правотворчества. Так, С.В. Синюков рассматривает правотворчество как многоаспектный институт современного правового регулирования, который имеет сложную разноуровневую организацию, включающую элементы правообразования, нормообразования, законотворчества, правореализации и правосознания ${ }^{79}$. В юридической литературе высказаны и другие позиции в понимании правотворчества. По мнению О.В. Попова, правотворчество - «это завершающая стадия формирования права, когда к объективному процессу подключается государство, переводя процесс формирования права в государственную деятельность по созданию пра-

\footnotetext{
${ }^{76}$ Сергеева К.О. Муниципальное правотворчество в Российской Федерации: дис. канд. юрид. наук. - М., 2013. - С. 11.

${ }_{77}^{77}$ Бондаренко О.В. Указ. соч. - С. 10.

${ }^{78}$ Малько А.В. Теория государства и права. - М., 1999. - С. 144; Чередниченко С.П. Судебное правотворчество: автореф. дис. ... к.ю.н. - М., 2005. - С. 7; Дербина А.В. Правосознание как элемент правовой позиции субъекта правотворчества: автореф. дис. ... к.ю.н. Самара, 2011. - С. 8; и др.

${ }^{79}$ Синюков С.В. Механизм правотворчества: автореф. дис. ... к.ю.н. - Саратов, 2013. - С. 8.
} 


\section{Правотворчество в Российской Федерации}

вовых норм» ${ }^{80}$. Г.Б. Евстигнеева считает, что «правотворчество в собственном смысле - это официальное создание, формирование нормативно-правовых текстов, норм права» ${ }^{81}$. Имеется множество и других определений правотворчества.

Анализ, высказанных в юридической литературе точек зрения на правотворчество, позволяет заключить, как справедливо отмечает Е.В. Семьянов, что в настоящее время присутствуют три подхода в определении этого понятия:

1) правотворчество как законодательство, или создание нормативноправовых актов особого вида, закрепляющих основы правовой системы с последующим уточнением их положений в подзаконных актах;

2) правотворчество как нормотворчество, или создание общеобязательных правил поведения;

3) правотворчество как правообразование и правоустановление ${ }^{82}$.

Наличие многообразия авторских позиций в определении правотворчества вытекает не только из сложности социально-правового явления, которое оно характеризует, но и в отсутствии четкого разграничения между правотворчеством как юридической категорией и правотворчеством как правовым институтом.

Правотворчество как юридическая категория представляет собой научное понятие самого термина, включающего в себя наиболее общие и существенные признаки, которые отражают его суть и правовой смысл. По мнению А.С. Пиголкина, юридический термин - «это слово (или сочетание), которое употреблено в законодательстве, является обобщенным наименованием юридического понятия, имеющего точный и определенный смысл и отличается смысловой однозначностью, функциональной устойчивостью» ${ }^{83}$.

В нашем случае термин «правотворчество» законодательно не определено, что обуславливает его толкование различными авторами в широких границах от правовой категории до правового института.

Правотворчество как правовой институт представляет собой совокупность правовых норм, регулирующих общественные отношения в сфере создания новых, а также изменения и отмены устаревших правовых норм.

Однако, даже рассматривая правотворчество только в рамках правовой категории, остается потенциал для его неоднозначного понимания и толкования. Это вытекает из того, что созданием норм, регулирующих общественное поведение людей, занимаются разнообразные государственные органы и должностные лица, общественные и корпоративные

\footnotetext{
${ }^{80}$ Попов О.В. Теоретико-правовые вопросы судебного правотворчества в РФ: автореф. дис. ... к.ю.н. - Тольятти, 2004. - С. 6.

${ }^{81}$ Евстигнеева Г.Б. Судебное решение как источник права: автореф. дис. ... к.ю.н. - М., 2007. - C. 7.

${ }^{82}$ Семьянов Е.В. Судебное правотворчество: вопросы общей теории права: автореф. дис. ... к.ю.н. - М., 2005. - С. 5.

${ }^{83}$ Язык закона / под ред. А.С. Пиголкина. - М. Юрид. лит., 1990. - С. 65.
} 
организации. Все они осуществляют, предусмотренную законодательством, в рамках своей компетенции нормотворческую деятельность. Таким образом, у исследователей проблем правотворчества объективно возникает необходимость определения границ этого понятия. Их выбор и порождает многообразие точек зрения на сущность правотворчества. Как отметил Е.В. Семьянов, в основании существующих подходов определения понятия правотворчества находится различный объем его понимания учеными-юристами ${ }^{84}$. И с этим следует согласиться.

Вместе с тем, для изучения проблем правотворчества важное значение имеет установление допустимых рамок его толкования. И это связано с видами правотворчества.

Очевидно, что законотворчество является наиболее наглядным и убедительным способом реализации правотворчества. И большинство ученых под данным термином понимают, прежде всего, процесс создания правовых норм, а также их изменение и отмену. При этом многие авторы законотворчество рассматривают как конечную стадию правоустановления, то есть формирования права ${ }^{85}$. Такой подход в понимании правотворчества и обуславливает отождествление его с законотворчеством. Его сторонниками, как мы видим из выше приведенных цитат, являются О.В. Попов и Г.Б. Евстигнеева, а также многие другие ученые.

Но рассмотрение правотворчества в таком узком аспекте значительно обедняет и упрощает существующую фактическую правовую действительность, что, в конечном счете, лишает возможности его изучения во взаимосвязи всех видов его проявления. Не взывает сомнения, что нормотворчество является одной из сторон правотворчества. Как справедливо отметила И.Е. Ситникова, нормотворчество, хотя и имеет общую цель с правотворчеством - создание норм права, но данное понятие будет правильнее употреблять применительно к деятельности министерств и ведомств, а также организаций и предприятий ${ }^{86}$. Нормотворчество составляет реальную основу функционирования законодательства и правовой системы в целом. И оно протекает в однотипных для законотворчества условиях: регулируется законом, осуществляется компетентными органами и должностными лицами, его фундаментом являются, в большинстве своем, те же принципы, преследует одинаковые цели - регулирование общественных отношений в сфере создания правил поведения людей и т.д. Все это, несомненно, составляет одну из сторон правотворчества, что и учитывается многими исследователями, которые рассматривают его в широком, а не узком аспекте.

Разграничение понятий «правотворчество», «законотворчество» и «нормотворчество» позволяет конкретизировать сферу правотворения, выявить существующие между ними особенности, выработать наиболее

\footnotetext{
${ }^{84}$ Семьянов Е.В. Указ. соч.

${ }^{85}$ См., например: Ситникова И.Е. Политический плюрализм и правотворчество в современном российском государстве: автореф. дис. ... к.ю.н. - Казань, 2010. - С. 8.

${ }^{86}$ Ситникова И.Е. Указ. соч.
} 


\section{Правотворчество в Российской Федерации}

эффективные методы достижения задач, связанных с регулированием процесса формирования правил поведения людей как в масштабах всего государства, его субъекта либо отдельно взятой организации или предприятия. O соотношении этих понятий с максимальной точностью высказалась Н.П. Алешкова: «Законотворчество - деятельность по принятию правовых актов в виде законов, нормотворчество - по изданию нормативных правовых актов, а правотворчество - по изданию правовых актов вообще. В любом случае, они являются нетождественными по отношению и к результату правотворчества, и к субъекту правотворчества» ${ }^{87}$. К этому следует добавить, что с точки зрения общей теории правотворчества все эти три юридических понятия находятся в тесном взаимодействии между собой и нуждаются в системном изучении и реализации в практику.

Таким образом, правотворчество в рамках юридической категории необходимо понимать в широком смысле с учетом всех возможных форм его проявления как тех, которые носят обыденный характер (законотворчество, нормотворчество), так и представляющих исключительный характер (например, референдум или правовой эксперимент). Исследование правотворчества как правового института не может быть корректным в аспекте анализа его категоральных свойств и форм, поскольку в таком случае происходит подмена его юридического смысла. Не может юридический термин одновременно выполнять роль правовой нормы и тем более правового института. Хотя терминологически в юриспруденции такое совмещение правого термина и правового института, как в нашем случае, иногда допускается. Например, источник повышенной опасности, необходимая оборона, аренда, дознание, оправданный риск и т. д.

Правотворчество, как сложное социально-правовое явление обладает рядом признаков, которые необходимо учитывать в процессе формирования норм права. Основными из них, наиболее проблемными, являются следующие:

1) это комплексное юридическое понятие, которое объединяет и представляет разноуровневую систему правового регулирования общества и государства. С учетом этого необходимо учитывать, что «уровень и культура правотворчества, а соответственно и качество принимаемых нормативных актов, - это показатель цивилизованности и демократии общества» ${ }^{88}$. Поэтому субъекты правотворчества разного уровня должны осуществлять свою правотворческую деятельность на профессиональной основе, отражая особенности не только страны, но и своего региона;

2) в правотворческом процессе участвуют субъекты с различным правовым статусом, в рамках, установленных для них процессуальных норм (процедур), предусмотренных не только Конституцией РФ, но также регламентами, уставами и законодательными актами. При этом мно-

\footnotetext{
${ }^{87}$ Алешкова Н.П. Конституционно-правовые основы муниципального правотворчества в Российской Федерации: автореф. дис. ... к.ю.н. - Екатеринбург, 2010. - С. 8.

${ }^{88}$ Малько А.В. Теория государства и права. - М., 1999. - С. 144.
} 
жественность нормативно-правовых актов создает трудности в их качественной реализации, так как они недостаточно систематизированы, допускают пробелы в регулировании правотворчества, а правовое регулирование корпоративных, общественных и производственных организаций зачастую осуществляется в отрыве от общероссийского и регионального законодательства.

В юридической литературе правотворчество в зависимости от субъектов подразделяется на такие виды:

1) непосредственное правотворчество народа в процессе проведения референдумов (всенародное голосование по наиболее важным вопросам государственной и общественной жизни);

2) правотворчество государственных органов (Государственная Дума, Правительство РФ);

3) правотворчество уполномоченных Конституцией и законами должностных лиц государства (Президента РФ, министров);

4) правотворчество органов местного самоуправления;

5) правотворчество общественных организаций (например, профсоюза);

6) корпоративное правотворчество 89 ;

3) несовершенство правотворчества, вытекающее из-за слабого законодательного обеспечения этого процесса, а также иных факторов. В связи с этим С.В. Синюков в качестве проблем правотворчества называет следующие: отсутствие плановости; избыточность регулирования; недифференцированность правовой формы правотворческих решений; смешение предметов законодательного и подзаконного регулирования; бюрократизм правотворческой процедуры ${ }^{90}$.

Повышение качества правотворчества возможно путем совершенствования всего законодательства на базе создания единого нормативноправового акта, регулирующего правотворческий процесс в масштабах всей страны, в регионах и других сферах общественной жизни. Здесь важны также профессионализм и добросовестность субъектов правотворческой деятельности;

4) правотворчеству присущи существенные отраслевые особенности, вытекающие из методов и принципов правового регулирования, его целей и задач, юридической техники, а также значения возможных правовых последствий от его реализации. Очевидно, что правотворчество в сфере уголовного законодательства, которое строится на презумпции невиновности, и правотворчество, формирующее гражданское законодательство, основанное на презумпции виновности, нуждаются в различных подходах правового регулирования.

В юридической литературе отмечается, что многократное, хаотичное, интенсивное обновление УК РФ «достигло того критического уровня, когда требуется кардинальная рационализация уголовного правотворче-

\footnotetext{
${ }^{89}$ Аналогичное деление на виды правотворчества в регионах. Каменская Е.В. Региональное правотворчество в Российской Федерации: автореф. дис. ... к.ю.н. - М., 2005. - С. 9.

${ }^{90}$ Синюков С.В. Механизм правотворчества: автореф. дис. ... к.ю.н. - Саратов, 2013. - С. 8.
} 


\section{Правотворчество в Российской Федерации}

ства» ${ }^{91}$. Это значит, что дальнейшее обновление уголовного законодательства традиционными методами неэффективно. Нужны новые подходы. И, по нашему мнению, в их основе должны лежать новые принципы наказания за совершенное преступление. В том числе, такие как неотвратимость наказания, поощрение исправительного поведения осужденного, применение мер реабилитационного характера к лицам, отбывших уголовное наказание и нуждающихся в государственной поддержке в период их адаптации к условиям социальной среды.

Правотворчество имеет значительные особенности и на региональном уровне, в корпоративных и общественных организациях. Поэтому возникает объективная необходимость в его систематизации, выявлении имеющихся взаимосвязей и особенностей между ними с целью выработки единых подходов в правовом регулировании.

Правотворчество в настоящее время пока не выделилось в самостоятельную частнонаучную юридическую науку, а является составной частью теории государства и права, что стало предпосылкой формирования большего количества нормативных правовых актов, созданных методом проб и ошибок. И это касается не только отдельных правовых норм, но и объемных законов, в том числе кодексов. Учитывая это, по нашему мнению, уже наступило время для создания единой общей теории правотворчества. И если с научной точки зрения в юридической литературе уже накопилось достаточно исследовательского материала для обеспечения теоретического потенциала этой науки, то ее законодательная база пока недостаточна. Требуется основополагающий федеральный систематизирующий закон о правотворчестве на всех его уровнях;

5) правотворчество связано с изданием нормативных актов, которые порождают различные по своему значению правовые последствия: законные, подзаконные акты, нормы общественных и корпоративных организаций. С учетом этого А.В. Малько делит правотворчество на:

- законотворчество;

- делегированное правотворчество (нормотворчество органов исполнительной власти, осуществляемое по поручению парламента, например, Правительства РФ);

- подзаконное правотворчество (нормотворческая деятельность структурами, не относящимися к высшим представительным органам - президентом, правительством, министерствами, ведомствами, местными органами государственного управления, губернаторами, главами администраций, руководителями предприятий, учреждений, организаций $)^{92}$.

Степень правовой урегулированности этих видов правотворчества различна, что сильно влияет на его качество. Кроме того, нормативные правовые акты, принимаемые на местах, зачастую противоречат федеральному законодательству в том числе и Конституции РФ, обладают ненужной громоздкостью, противоречивостью, коррумпированностью.

${ }^{91}$ Бондаренко О.В. Судебная практика и уголовное правотворчество: автореф. дис. ... к.ю.н. - М., 2013. - С. 6.

92 Малько А.В. Теория государства и права. - М., 1999. - С. 146. 
По нашему мнению, необходимы обстоятельные системные исследования порядка разработки и принятия всех видов нормативных правовых актов с целью построения единообразных непротиворечивых моделей правотворчества во всех сферах правового регулирования. На этой основе будет возможно разработать и соответствующее законодательство, которое должно быть единым для всех субъектов правотворчества, что обеспечит не только правовую культуру, но и правовую стабильность и надежность;

6) правотворчество в правовом регулировании традиционно придерживается в основном запретов и дозволений, что обуславливает постоянное государственное присутствие в процессе реализации складывающихся правоотношений. Правотворчество слабо внедряет модели правоотношений, в которых их субъекты поощряются к самоурегулированию возникающих конфликтов, в которых они были бы заинтересованы в законопослушном поведении. По нашему мнению, правотворчество должно быть нацелено на максимальную разгрузку государства от участия в контроле за ходом реализации правоотношений в стране. Все правоохранительные органы, в том числе и суды, следует разгрузить от чрезмерной, в основном малопродуктивной деятельности, которая вытекает не столько из важности разрешаемых дел, а из недостаточно продуманных правотворческих решений. Нужна новая правотворческая политика, которая сочетала бы простоту и качество реализации правоотношений, заинтересованность и ответственность их субъектов, оперативность реагирования государственных и общественных структур на допущенные нарушения законодательства. Представляется, что в этом аспекте часть своих полномочий государство может передать общественным организациям. Например, народным палатам районов и городов (либо общественным комиссиям). Некоторые гражданские, административные и уголовные дела с согласия сторон также можно передать указанной общественной организации. В отношении работников государственных структур, в случае их неправомерных действий, народная палата должна иметь право заявить ходатайство о наказании виновного, в том числе о снятии с должности, которое имело бы обязательную силу. Тем самым с государственных органов будет снята часть нагрузки и одновременно повышена активность населения в реализации законодательства.

В юридической литературе также обоснована мысль, что «созрела крайняя необходимость выработки комплексного нормативного блока, направленного на четкое регулирование правотворческой деятельности всех без исключения субъектов правотворчества...Сегодня настоятельно требуется принятие законов, четко закрепляющих и регламентирующих правосубъектность и правовой статус субъектов правотворческой деятельности, принципы их деятельности, порядок взаимодействия со всеми федеральными и региональными органами, а также органами местного самоуправления» ${ }^{3}$. Несомненно, что концепцию подобного нормативного законодательства необходимо разрабатывать на базе общей теории правотворчества как самостоятельной юридической науки, поскольку такой подход требует систематизации всех видов правотворчества, ана-

\footnotetext{
93 Дербина А.В. Правосознание как элемент правовой позиции субъекта правотворчества: автореф. дис. ... к.ю.н. - Самара, 2011. - С. 8.
} 


\section{Правотворчество в Российской Федерации}

лиза их взаимодействия и соотношения, установления границ правового регулирования;

7) в современных условиях правотворчество подвержено существенному влиянию отрицательных субъективных факторов, что проявляется в лоббизме, коррумпированности, регионализме, поспешности, непрофессионализме и т. д. По мнению С.В. Синюкова, эта проблема связана с отсутствием у граждан прямого доступа к правотворческой инициативе, деформации неформального влияния на правотворческой процесс ${ }^{94}$.

Отчасти это правильно. Однако большое значение имеют и другие факторы: включение в состав законодательных органов лиц, располагающих огромными капиталами, а также лиц, находящихся в услужении олигархов. Если к этому добавить откровенный подкуп продажных так называемых «народных представителей», то становится ясно, что правотворчество не может не быть ущербным, поскольку изначально создается для закрепления своей экономической власти классом власть имущих. Конечно, повышение гласности, прозрачности правотворческой деятельности способствовало бы снижению влияния отрицательных факторов на правотворчество, но для этого необходимо менять весь законодательный процесс, что в нынешних условиях нереально. Существующая экспертиза законопроектов на коррупционность малоэффективна, поскольку сбой дает существующая система правотворчества, а не только отдельные ее элементы. Как уже отмечалось необходимо законодательно закреплять комплексный нормативный блок по четкому регулированию правотворческой деятельности всех без исключения субъектов правотворчества.

Имеются и другие насущные проблемы, отражающие признаки правотворчества:

1) слабая оперативность и эффективность правового урегулирования отдельных вопросов общественной жизни;

2) недостаточная открытость, кулуарность публичного по своему назначению процесса правотворчества;

3) целевая направленность отдельных видов правотворчества не всегда отвечает реализации его принципов;

4) не достигает стабильности закрепленных правоотношений в процессе правотворчества, связанные с частым их изменением;

5) принятие правотворческих решений при отсутствии правотворческой политики государства ${ }^{95}$ и т. д.

Таким образом, правотворчество как правовой инструмент в регулировании общественных отношений нуждается в серьезном системном совершенствовании путем законодательного закрепления единого комплексного блока нормативных правил, закрепляющих правотворческую деятельность всех его субъектов. Дальнейшее научное исследование правотворчества и связанных с ним проблем, более глубокое понимание взаимосвязи и различия отраслевого правотворчества, перспективы его развития необходимо проводить в системе общей теории правотворчества. Это даст возможность рассматривать конкретные правотворческие решения в системе правотворческого процесса в целом.

\footnotetext{
${ }_{94}^{94}$ Синюков С.В. Механизм правотворчества: автореф. дис. ... к.ю.н. - Саратов, 2013. - С. 9.

${ }^{95}$ См.: подробнее: Мазуренко А.П. Правотворческая политика как фактор модернизации правотворчества в России: автореф. дис. ... д-ра юрид. наук. - Саратов, 2011. - С. 11.
} 


\section{§1.5. ВЫВОДЫ ПО ИССЛЕДОВАНИЮ ПРАВОТВОРЧЕСТВА КАК ЮРИДИЧЕСКОГО ФЕНОМЕНА}

Просуммируем и обобщим всё сказанное выше. Видно, насколько многогранно и сложно явление правотворчества. И всё же оно сводимо к следующим основным этапам исследования правовой действительности.

(1) На первом этапе происходит выявление тех общественных отношений, которые подлежат урегулированию нормами права.

(2) Далее следует обоснование необходимости урегулирования данных отношений нормами права.

(3) Далее доказывается объективная возможность придать общественным отношениям правовой характер.

(4) Далее изыскиваются и находятся организационные возможности и материальные ресурсы для придания правового характера.

(5) После этого находятся методы и способы осуществления перевода общественных отношений в русло правового регулирования.

Применяя стадии научного познания, легко выявить, что (1) и (2) легко сгруппировать вместе, также как и (3) и (4). Следовательно, (1) и (2) вместе составляют эвристический этап научного исследования, соответствующий логическому описанию, а (3) и (4) - эмпирический этап, соответствующий прикладному правотворчеству и юридической технике (5) - это переход к более высокому уровню - теоретическому обобщению, что соответствует теоретическому правотворчеству. В совокупности это позволяет выйти на высший теоретический этап:

(6) Перевод правотворчества в разряд целенаправленной деятельности всех субъектов, издающих нормативные акты. Это - диалектически завершающая стадия, так как результаты научного познания на ней получают государственное санкционирование.

Таким образом, в правотворчестве, как юридическом феномене, диалектически взаимодействуют научное познание и практическая юридическая деятельность, научное начало, вытекающее из процесса познания действительности и юридическое, связанное с санкционированием результатов научного познания и теоретического осмысления государством. 


\section{ГЛАВА 2. ОБЪЕКТ ИССЛЕДОВАНИЙ ЭМПИРИЧЕСКОГО ПРАВОТВОРЧЕСТВА: ВИДЫ ПРАВОТВОРЧЕСКОГО ПРОЦЕССА}

\section{§2.1. ПРЕДМЕТ ИЗУЧЕНИЯ ТЕОРИИ ПРАВОТВОРЧЕСТВА. ВИДЫ ПРАВОТВОРЧЕСТВА}

Важное значение для понимания правотворчества в целом имеет изучение его предмета. В любой науке под ее предметом понимают ту сферу знаний, которую она изучает. Предметом общей теории правотворчества является правотворческая деятельность, в процессе которой происходит правовое регулирование общественных отношений. Поскольку правотворчество представляет собой сложное комплексное социальноправовое явление, то и его предмет - различные группы однородных общественных отношений, определяющих в своей совокупности вид правотворчества. Это обстоятельство обуславливает необходимость изучения знаний о правотворчестве как дифференцированно, так и в системе, что позволит выявить особенности всех его сторон.

В современной юридической науке предмет правотворчества исследуется недостаточно, особенно с позиций его общей теории. Проблема состоит в том, что правотворчество - это правовое явление, которое объединяет в себе разнообразные виды правового регулирования общественных отношений. Общим у этого процесса является создание нормативных правил по упорядочению этих отношений, тогда как субъекты правотворчества, их статус и порядок осуществления ими своей деятельности различны. С учетом этого, в юридической литературе нет единого общепризнанного подхода определения вида правотворчества, которые, в своей совокупности, и должны стать предметом его изучения. По мнению одних авторов существует пять основных видов правотворчества:

1) законотворчество;

2) подзаконное правотворчество;

3) локальное правотворчество местного самоуправления;

4) прямое правотворчество;

5) договорное нормотворчество ${ }^{96}$. По мнению других, в зависимости от субъекта «видами правотворчества можно считать непосредственное правотворчество - референдумное законотворчество, прямое правотворчество, включая правотворчество законодательных органов, нормотворчество различных органов государственной власти, судебное правотворчество, муниципальное нормотворчество, локальное правотворчество органов управления юридических лиц, договорное правотворчество рав-

\footnotetext{
${ }^{96}$ Общая теория государства и права. Академический курс в 2-х т. / под ред. М.Н. Марченко. - Т. 2. Теория права. - М., 2000. - С. 163-164.
} 
ноправных субъектов» ${ }^{97}$. Имеются и другие подходы в определении правотворчества ${ }^{98}$. Мы будем придерживаться первых двух подходов в определении видов правотворчества, поскольку они дают наиболее четкую их дифференциацию.

Правотворчество - это урегулирование общественных отношений с помощью норм права в различных сферах жизнедеятельности человека. Как справедливо отмечает И.Ю. Остапович «если имеет место наличие фактически сложившихся отношений в обществе, которые не закреплены в праве, то правотворчество закрепляет их в создаваемых правовых нормах ${ }^{99}$.

Предметом изучения общей теории правотворчества являются особенности правотворения в целом, а также каждого конкретного его вида в отдельности. Как уже отмечалось, объединяющим началом этого процесса выступают правовые нормы, регулирующие общественные отношения. Но и само создание норм права, не унифицировано законодательно и поэтому все виды правотворчества представляют собой действительно творческих характер, протекающий в рамках зачастую не столько правовых предписаний, а только правовых предпочтений их творцов. Возникает противоречие: с одной стороны, имеется устойчивая тенденция роста количества законов, тогда как с другой - «общественное развитие требует появления новых законов» ${ }^{100}$. И причин такого явления множество. Это не только нарушение принципов юридической техники творения законов (как отмечают И.Б. Ломакина и Д.С. Тэпс ${ }^{101}$ ), но и лоббизм, коррупционность, отсутствие учета научных достижений в той или иной сфере правотворчества, его кулуарность, когда законопроекты не представляются на общественное обсуждение, а принимаются как на конвейере, иногда без должного обстоятельного обслуживания даже на заседаниях Государственной Думы РФ. Среди таких причин, несомненно, следует указать и на недостаточное комплексное исследование предмета правотворчества в масштабах единой теории правотворчества, а также на отсутствие общего законодательства, по урегулированию правотворчества в Российской Федерации ${ }^{102}$.

\footnotetext{
${ }^{97}$ Багдасаров В.Ю. Основания классификации правотворчества. // Журнал российского права. - 2012. - №11. - С. 50.

${ }_{98}$ Правотворчество в СССР / под ред. А.В. Мицкевича. - М., 1974. - С. 96; Васильев А.В. Правотворчество в советском социалистическом обществе: дис. ... к.ю.н. - М., 1971. С. 43 ; Осипов М.Ю. Понятие и соотношение правового регулирования и правотворчества. - М., 2010. - С. 41; и др.

${ }^{99}$ Остапович И.Ю. Сущность и особенности неюридической формы воздействия на правотворчество // Мир науки, культуры, образования. - 2011. - №4. - С. 293.

${ }^{100}$ См. подробнее: Ломакина И.Б. Методология правотворчества: теория и практика, направления совершенствования / И.Б. Ломакина, Д.С. Тэпс // Проблемы в российском законодательстве. - 2012. - №4. - С. 24.

101 Ломакина И.Б., Тэпс Д.С. Указ. соч.

102 См. подробнее: Каменская Е.В. Региональное правотворчество в Российской Федерации: автореф. дис. ... к.ю.н. - М., 2005. - С. 6; Сапун В.А. Правотворчество и законотворчество: стратегия и тактика формирования права и закона / В.А. Сапун, Я.В.Турбова // Юридическая техника. - 2015. - №9.
} 


\section{Правотворчество в Российской Федерации}

Правотворчество в целом, осуществляемое всеми его субъектами, характеризуется решением одинаковых задач: урегулирование общественных отношений нормами права, то есть непосредственное создание правил поведения людей в конкретных жизненных ситуациях. Поэтому оно имеет общие особенности, которые сводятся к таким последовательным действиям:

1) выявление потребностей в правовом регулировании определенной группы общественных отношений;

2) решение вопроса о выборе направления и способа правового регулирования, в том числе обоснование потребности данного нормотворчества;

3) выработка концепции правового акта;

4) разработка проекта необходимого правового акта, предполагающая учет всех имеющихся достижений юридической науки в данной сфере правового регулирования, исторических традиций и норм международного права;

5) осуществление процедурных правил принятия конкретного вида правотворчества, в том числе обсуждение компетентным органом, внесение изменений и дополнений в текст проекта нормативного акта и его утверждение;

6) опубликование принятого нормативного правового акта и его вступление в силу. Это общая схема этапов правотворчества, каждый из которых имеет свои особенности, присущие только ему. Научно обоснованное правотворчество должно оказывать эффективное воздействие на общественные отношения и обладать качествами, свойствами, которые обеспечивают такое воздействие ${ }^{103}$.

В поле зрения юридической науки находится, прежде всего, законотворчество, поскольку именно на его базе основывается как правотворчество в целом, так и отдельные его виды. Законотворчество является сложной юридической категорией. Оно включает в себя референдумное законотворчество, федеральное законотворчество и законотворчество субъектов федерации. С точки зрения волеизъявления субъектов, его формирующих, оно представляет собой законотворчество всего народа, либо законотворчество избранных им своих представителей в лице членов Федерального Собрания РФ и на местах - в лице представительной власти субъектов федерации.

Следует отметить, что референдумное законотворчество в современной России применялось один раз, когда принималась Конституция Российской Федерации (12 декабря 1993 г.). Данный вид законотворчества является исключительным способом правотворчества. Он не может иметь широкое распространение, поскольку связан с большими финансовыми затратами, хотя по сути является наиболее объективным мерилом легитимности законодательства. Вместе с тем, ряд законодательных

103 Афанасьева Л.В. Нормы права и их действие (вопросы теории): дис. ... к.ю.н. - М., 2000. - C. 162. 
актов принимался с учетом их общественного обсуждения, что в определенной степени способствовало повышению их качества.

Референдумное законотворчество не лишено недостатков присущих правотворчеству в целом, поскольку на всенародное голосование представляется уже готовый законопроект, который может содержать их целый букет: от пробелов в правовом регулировании и противоречий отдельных норм до коррупционности и двусмысленности правовых предписаний. Это видно и на примере конституции РФ, где допущен явный перекос в закреплении разделения властей. Исполнительная власть имеет явное преимущество перед законодательной, а судебная поставлена в зависимость от той же исполнительной власти, прокуратура закреплена в судебной системе и по сути не имеет самостоятельного конституционного закрепления в отдельной ее главе ${ }^{104}$. Представляется, что референдумное законотворчество может быть использовано в случае, если представительная власть не может принять законопроект в связи с отклонением его оппозицией, но актуальность закона велика и требуется волеизъявление народа для разрешения возникшего спора в среде законодателей. Референдумное законотворчество по способу образования правовых норм и методов регулирования общественных отношений ничем не отличается от обычного законотворчества. Может быть оправданным такой подход, когда на всенародное голосование выносятся два альтернативных законопроекта, что возможно только при наличии сильной оппозиции.

Федеральное законотворчество, хотя и урегулировано Регламентом Государственной Думы Федерального Собрания Российской Федерации ${ }^{105}$, в настоящее время обладает значительными недостатками, о которых справедливо отмечается в юридической литературе. Проблема состоит в том, что Регламент ГД РФ определяет процедурные вопросы законотворчества, тогда как основная масса недостатков связана с его содержанием.

На наш взгляд, это обусловлено в первую очередь тем, что законотворчество осуществляется в отрыве от целей социальноэкономического развития страны. Законодатель, не имея четкого представления какие конкретные результаты ему надо достичь, вынужден постоянно заниматься регулированием уже возникших стихийно и существующих в реальной действительности общественных отношений. При этом иногда это приходится делать в авральном порядке, что еще больше влияет на качество законотворчества. На необходимость учета в процессе правотворчества появляющегося в его результате законодательства обратил внимание и С.А. Белоусов ${ }^{106}$.

\footnotetext{
${ }^{104}$ См. подробнее: Сапун В.А., Турбова Я.В. Указ соч.

${ }^{105}$ Постановление Государственной Думы РФ от 26.01.1998 №2134-II ГД.

${ }^{106}$ Белоусов С.А. Правотворчество и законодательный дисбаланс: диалектика взаимосвязи // Вестник ВГ. - 2015. - №1. - С. 64.
} 


\section{Правотворчество в Российской Федерации}

В юридической литературе вполне справедливо отмечают такие недостатки законотворчества, как хаотичность в формировании массива нормативных правовых актов, несоблюдение приоритетов правового регулирования, принятие новых законов без их увязки с существующим законодательством и нормами международного права, их бессистемность $^{107}$, отсутствие прогнозирования и планирования ${ }^{108}$ и т. д. Все это и характеризует полное отсутствие взаимосвязи между законотворчеством и каким-либо долгосрочным социально-экономическим планом страны. Государство откликается на постоянные вызовы общественного развития путем принятия законов, которые ориентированы на разрешение конкретных проблем без системного анализа с учетом перспектив развития страны.

Законотворчеству субъектов федерации присущи аналогичные недостатки, к числу которых прибавляются многочисленные факты вступления отдельных норм их законодательства в противоречие с федеральными законами. При этом на уровне субъектов федерации отсутствует единый нормативный правовой акт о порядке рассмотрения и принятия данного законодательства, что порождает существенную разницу в подходах на местах к законотворчеству.

Законотворчество как предмет общей теории правотворчества, нуждается в выработке научно обоснованных требований к его качеству. Не вызывает сомнений, что при разработке новых законов субъекты законотворчества должны опираться на установленные общегосударственные планы, быть с ними взаимосвязанными, обеспечивать их качественную реализацию. С учетом этого необходимо осуществлять планирование законотворчества, а также прогнозирование возможных результатов от действия предлагаемых законов. При этом следует исходить из имеющейся потребности формирования в России единой непротиворечивой правовой системы. По мнению Л.В. Андриченко, для этого следует создать необходимые системообразующие механизмы согласования, координации, планирования ${ }^{109}$.

Но кроме этого законотворчество должно базироваться, помимо общепринятых правил юридической техники создания норм права, правовых институтов, а также отраслей права, на таких требованиях к его результатам, как:

1) длительный срок действия законов;

107 Лопатин В.Н. Конституционная законность и проблемы нормотворчества в России // Журнал российского права. - 2004. - №5. - С. 8, а также Тиунова Л.Б. Системные связи правовой действительности: методология и теория. - СПб., 1991. - С. 86.

${ }_{108}$ Власенко Н.А. О кризисных тенденциях в праве; Павлушкин А.В. Современное правотворчество: новые возможности для общества и государства / А.В. Павлушкин, А.С. Павловский // Журнал российского права. - 2015. - №3. - С. 151.

${ }^{109}$ Обзор выступлений за круглым столом, состоявшемся 26.01.2015 по теме «Актуальные проблемы правотворчества и проект федерального закона «О нормативных правовых актах в Российской Федерации» в статье А.В. Павлушкина и А.С. Павловского «Современное правотворчество: новые возможности для общества и государства» // Журнал российского права. - 2015. - №3. - С. 151. 
2) обязательное наличие механизмов их реализации;

3) возможность фактического исполнения законов гражданами, юридическими лицами и государством;

4) использование императивного метода правового регулирования только ради достижения максимального положительного эффекта для государства и общества;

5) контроль общества на всех этапах правотворческой деятельности, включая и реализацию законов.

Подзаконное правотворчество составляет огромный массив деятельности государственных исполнительных органов и их должностных лиц. Эта правотворческая деятельность по регулированию общественных отношений для указанных субъектов является одновременно и обязанностью. По данным Ю.Г. Арзамасова ежегодно происходит значительный рост несекретных нормативных актов различных ведомств, что «объясняется, прежде всего, реализацией норм положений о федеральных органах исполнительной власти, предусматривающих принятие ведомственных подзаконных актов» ${ }^{110}$.

Порядок подзаконного правотворчества регламентирован «Правилами подготовки нормативных правовых актов федеральных органов исполнительной власти и их государственной регистрации», утвержденных постановлением Правительства Российской Федерации 13.08.1997 №1009 ${ }^{111}$, а также аналогичными правовыми документами субъектов федерации.

В юридической литературе нет единства мнений о сущности подзаконного правотворчества. Так, С.Н. Болдырев не относит его к правотворчеству, а считает нормотворчеством. Отличие нормотворчества от правотворчества, по определению данного автора состоит в том, что субъектами нормотворчества являются органы исполнительной власти, а не представительные органы ${ }^{12}$. Данный подход, хотя и верно определяет основное отличие в образовании правовых норм (есть и другие отличительные признаки), является неудачным. Во-первых, другие виды правотворчества тоже отличаются между собой по субъекту создания норм права. То есть это основание деления на виды правотворчества является общим критерием, а не уникальным. Во-вторых, и это главное, такой подход не рассматривает все правотворчество как единую систему образования, формирования норм, регулирующих общественные отношения.

\footnotetext{
110 Арзамасов Ю.Г. Ведомственный нормотворческий процесс: структура содержание, перспективы развития (ч. 2) // Сводный реферативный сборник журнала Представительная власть - XXI век: законодательство, комментарии, проблемы. - 2007. - № 4-6. - С. 13-14.

${ }^{111}$ Постановление Правительства РФ от 13 августа 1997 г. №1009 «Об утверждении Правил подготовки нормативных правовых актов федеральных органов исполнительной власти и их государственной регистрации» [Электронный ресурс]. - Режим доступа: http:// base.garant.ru/166045/\#ixzz3r6uNCxJE

${ }^{112}$ Болдырев С.Н. Нормотворчество и правотворчество: проблемы соотношения (техникоюридический аспект) // Вестник Волгоградской Академии МВД России. - 2011. - №17. C. 18.
} 


\section{Правотворчество в Российской Федерации}

С точки зрения предмета исследования, единой теории правотворчества приоритетным является общий подход в понимании особенностей образования правовых норм. Вычленение, в данном случае, из общей системы ее части не дает основания исключать нормотворчество из сферы правотворчества.

Подзаконное правотворчество отличается от законотворчества, прежде всего предметом правового регулирования, то есть характером регулируемых ими общественных отношений. Законы придают правовой характер наиболее важным, основополагающим общественным отношениям, тогда как подзаконные акты направлены на урегулирование менее значимых отношений, в первую очередь связанных с реализацией законов. И сами подзаконные акты издаются на основе законов и в их исполнение.

И хотя по масштабам охвата правового поля подзаконные акты зачастую уступают законам, находясь у них как бы в соподчинении, тем не менее, они содержат такие же нормы права, регулирующие общественные отношения, как и законодательные нормы. Это их объединяет. Именно в таком аспекте и необходимо рассматривать систему подзаконного правотворчества. Данный подход позволяет находить, с одной стороны, общие признаки правотворчества в целом, а с другой, - специфические особенности его видов - законотворчества и подзаконного правотворчества.

Судебное правотворчество является одним из видов формирования правовых норм. Оно не конкурирует с законотворчеством, а лишь дополняет его в случаях, когда необходимо восполнить обнаружившиеся пробелы в праве. Одновременно следует учитывать, что судебное правотворчество - это результат деятельности суда, лишь сопутствующий его основному назначению - рассмотрению конкретных дел и принятию по ним решений. Поэтому судебное правотворчество - это не основная функция суда. Тем более, что российское законодательство не предусматривает его в качестве источника права. Сущность судебного правотворчества состоит в том, что судебные акты подчинены закону, не могут его изменить или отменить, но могут уточнить смысл закона и это равнозначно изменению самого закона ${ }^{113}$. Как справедливо отмечает Т.А. Желдыбина, «судебное нормотворчество - побочная деятельность высшего судебного органа - возникает тогда, когда в процессе осуществления своих функций суд сталкивается с пробелом в праве или законе, с неконституционным законом, с нормой правового акта, требующей ее толкования〉 ${ }^{114}$. Кроме того, нормативность судебного правотворчества сугубо утилитарна - разрешение конкретного дела. Создан-

\footnotetext{
113 Семьянов Е.В. Судебное правотворчество (вопросы общей теории права): дис. ... к.ю.н. - М., 2005. - С. 8-9.

114 Желдобина Т.А. О судебном правотворчестве. По материалам круглого стола «К 150-летию судебной реформы 1864 года» //Вестник Саратовской государственной юридической академии. 2015. - №2. - C. 27-28.
} 
ная судом норма распространяется на схожие случаи, но время ее действия ограничено до принятия новой нормы закона ${ }^{115}$.

Исследование судебного правотворчества показывает возрастание роли судебной практики совершенствованием законодательства, особенно таких его отраслей, как гражданское и уголовное право ${ }^{116}$. Судебное правотворчество способствует формированию единообразного понимания и применения норм права. Однако судебное правотворчество не является прецедентным правом, поскольку создаваемые в ходе этого процесса нормы являются временными и после принятия закона прекращают своей действие. Но имеется и противоположная точка зрения, которая вытекает из судебной практики, но не закона.

Таким образом, судебное правотворчество является важным средством восполнения пробелов в праве, при регулировании общественных отношений, а также устранения неясностей в законодательстве. Изучение судебного правотворчества позволяет выявлять уровень качества законотворчества, поскольку судебная практика постоянно воспроизводит его достоинства и разрешает недостатки.

Следующим видом правотворчества, как предмета научного исследования, является муниципальное правотворчество. Единообразного понятия этого процесса в юридической науке нет, как нет и его узаконенной дефиниции. По мнению К.О. Сергеевой, «под муниципальным правотворчеством необходимо понимать деятельность уполномоченных субъектов местного самоуправления по принятию письменного документа, направленного на установление, изменение или отмену правовых норм, имеющих общеобязательное предписание постоянного или временного характера, рассчитанных на многократное или однократное применение на территории муниципального образования, и адресованного неопределенному кругу лиц, либо конкретному субъекту общественных отношений» ${ }^{117}$. Примерно такие же, но более развернутые понятия муниципального правотворчества дают Е.А. Каминская ${ }^{118}$, Н.П. Алешкова ${ }^{119}$ и другие авторы.

Муниципальное правотворчество осуществляется населением муниципального образования, органами местного самоуправления и их должностными лицами в пределах своих полномочий, установленных Кон-

\footnotetext{
${ }^{115}$ Гук П.А. Судебная практика как форма судебного нормотворчества в правовой системе России: процессы демократизации // Юридическая техника. Ежегодник. - 2014. - №8. C. $129-130$.

${ }^{116}$ См. подробнее: Долинская В.В. Судебные акты как источники гражданского права // Цивилист. - 2007. - №2. - С. 8; Мкртумян А.Ю. Судебная практика как источник гражданского права России // Гражданское право. - 2008. - №4. - С. 13.

117 Сергеева К.О. Муниципальное правотворчество в Российской Федерации: дис. ... к.ю.н. - М., 2013. - С. 5.

118 Каминская Е.А. Муниципальное правотворчество в механизме правообразования: дис. ... к.ю.н. Белгород, 2013. - С. 7.

119 Алешкова Н.П. Конституционно-правовые основы муниципального правотворчества в Российской Федерации: дис. ... к.ю.н. - Екатеринбург, 2010. - С. 8.
} 


\section{Правотворчество в Российской Федерации}

ституцией РФ, федеральным законом от 6 октября 2003 г. №131-Ф3 «Об общих принципах организации местного самоуправления в Российской Федерации» ${ }^{120}$, а также их Уставами. В современной России муниципальное правотворчество в соответствии со статьями 130-132 Конституции РФ проявляется в таких формах как:

1) непосредственное правотворчество, осуществляемое населением на основе прямого волеизъявления в процессе референдума, выборов или схода граждан (в населенных пунктах численностью до 100 человек);

2) правотворчество органов местного самоуправления и их должностных лиц по вопросам местного значения;

3) правотворчество органов местного самоуправления и их должностных лиц по реализации отдельных государственных полномочий, переданных им на основе закона;

4) правотворчество органов местного самоуправления и их должностных лиц, связанное с реализацией прав органов местного самоуправления на решение вопросов, не отнесенных к вопросам местного значения.

В юридической литературе отмечается, что муниципальное правотворчество включает в себя несколько стадий:

1) подготовку проекта нормативного акта (предварительная стадия);

2) его обсуждение и принятие (основная стадия);

3) введение его в действие (решающая стадия) ${ }^{121}$. Формирование правотворческих документов (нормативных актов муниципальных образований) включает в себя по сути те же этапы, что и законотворчество.

Муниципальное правотворчество имеет неразрывную связь с государственным правотворчеством и это проявляется в том, что оно:

1) носит публичный характер;

2) используется в качестве способа реализации полномочий муниципального образования;

3) нацелено на оперативное выявление потребностей по регулированию общественных отношений местного значения;

4) закрепляет действия уполномоченных органов по управлению муниципальным образованиям;

5) регулирует решение публичных вопросов, не относящихся к ведению государства и субъектов федерации, но имеющих значение для местного населения;

6) выявляет принципиально новые общественные отношения, развитие или сдерживание которых требует государственного вмешательства либо корректировки публично-властного регулирования ранее существовавших отношений;

7) используется в качестве механизма детализации установленных на государственном уровне норм с учетом местных особенностей;

8) отражает установленные государством меры дозволенного поведения муниципального образования по решению возложенных на него задач ${ }^{122}$.

\footnotetext{
${ }^{120} \mathrm{C} 3$ РФ.

${ }_{121}$ Алешкова Н.П. Указ. соч.

122 Там же. - С. 9.
} 
В соответствии со ст. 43 Федерального закона №131 правовые акты, принятые на местном референдуме (сходе граждан), входят в систему муниципальных правовых актов. По юридической силе они приравниваются к Уставу муниципального образования, имеют прямое действие и применяются на всей территории муниципального образования.

Таким образом, муниципальное правотворчество, хотя и обладает признаками, присущими правотворчеству в целом, оно имеет и свои особенности, связанные с его субъектами и порядком осуществления правотворческого процесса, который имеет порой даже демократичнее формы, чем законотворчество и подзаконное правотворчество.

Локальное правотворчество органов управления юридических лиц, по мнению В.Ю. Багдасарова, является частным правотворчеством в отличие от публичного, поскольку их органы управления не подчиняются логике административно - территориального деления ${ }^{123}$. Иногда к локальному правотворчеству относят и правотворчество органов местного самоуправления (муниципалитетов, администраций городов и районов) $)^{124}$.

Локальное правотворчество осуществляется в целях регулирования отношений в процессе деятельности юридического лица ${ }^{125}$. При этом они регулируют не отдельный случай либо конкретное общественное отношение, а повторяющиеся типичные ситуации или вид отношений, присущих данному корпоративному коллективу, что обуславливает возможность их многократного применения. Принимаемые в процессе локального правотворчества нормы имеют общий характер, то есть, рассчитаны на многих лиц. По своему содержанию нормы локального правотворчества представляют волеизъявление коллектива юридического лица, и сфера их действия ограничивается сферой его интересов, в пределах которых осуществляется деятельность.

Вместе с тем локальное правотворчество протекает в соответствии с законодательством России и ее субъектов и не может выходить за его рамки. По сути, локальное правотворчество представляет собой правовое поле различных хозяйствующих субъектов и общественных организаций, которое предоставлено государством под их юрисдикцию в связи с невозможностью и ненужностью государственного регулирования происходящих там межличностных отношений. Несомненно, особенности внутри корпоративных отношений знают лучше всего члены конкретного юридического лица, и их урегулирование должным образом

\footnotetext{
${ }^{123}$ Багдасаров В.Ю. Основания классификации правотворчества // Журнал российского права. - 2012. - №11. - С. 54.

${ }^{124}$ См., например: Меркулова К.Ю. Проблемы правотворчества в российском законодательстве / К.Ю. Меркулова, А.И. Пушкарь // Вестник Московского гуманитарноэкономического института. - 2015. - №1. - С. 84; Арзамасов Ю.Г. Ведомственный нормотворческий процесс: структура, содержание, перспективы развития (ч. 1) // Сводный реферативный сборник журнала Представительная власть - XXI век: законодательство, комментарии, проблемы. - 2007. - №4-6. - С. 13-14.

${ }^{125}$ См. подробнее: Кашанина Т.В. Корпоративное (внутрифирменное) право: учеб. пособ. М.: Норма, 2003. - C. 3-4.
} 


\section{Правотворчество в Российской Федерации}

государство возлагает на это юридическое лицо. Такой подход является наиболее удобным и для государства, и для юридического лица. Обладая правотворческой свободой, юридическое лицо регламентирует свою деятельность не только наиболее эффективно, но и максимально оперативно, что практически невозможно на уровне государственного законодательного регулирования, учитывая порядок осуществления законодательного процесса.

Локальное правотворчество представляет собой достаточно демократичный и эффективный способ правового регулирования отношений, складывающихся внутри конкретных коллективов юридических лиц. Правовой основой их деятельности служат уставы, а также Кодексы корпоративного поведения ${ }^{126}$, которые разрабатываются и утверждаются самими хозяйствующими субъектами либо общественными организациями.

Таким образом, предметом изучения общей теории правотворчества является сама правотворческая деятельность, связанная с регулированием общественных отношений, имеющих различный уровень значимости и степень распространенности. Она может осуществляться в нескольких правотворческих формах, что обуславливает, при изучении каждой из них, необходимость выявлять их особенности и учитывать в правовом регулировании.

Высшей формой правотворчества является законотворчество. Его потенциал, как регулятора и стимулятора упорядочения общественных отношений в настоящее время снижается в силу низкого качества принимаемых законов. Требуется незамедлительная разработка правовых гарантий качества законопроектов. Представляется, что критерии, характеризующие высокое качество законов, законодатели могут разработать совместно с правоприменителями на основе достижений юридической науки.

\section{§2.2. ВИДЫ ПРАВОТВОРЧЕСКОГО ПРОЦЕССА}

Важное значение для понимания правотворчества в целом имеет изучение его предмета. В любой науке под ее предметом понимают ту сферу знаний, которую она изучает. Предметом общей теории правотворчества является правотворческая деятельность, в процессе которой происходит правовое регулирование общественных отношений. Поскольку правотворчество представляет собой сложное комплексное социальноправовое явление, то и его предмет - различные группы однородных общественных отношений, определяющих в своей совокупности вид правотворчества. Это обстоятельство обуславливает необходимость изучения знаний о правотворчестве как дифференцированно, так и в системе, что позволит выявить особенности всех его сторон.

В современной юридической науке предмет правотворчества исследуется недостаточно, особенно с позиций его общей теории. Проблема

\footnotetext{
${ }^{126}$ См., например: Кодекс корпоративного поведения, утвержденный распоряжением Федеральной комиссии по рынку ценных бумаг от 4 апреля 2002 г. №421/p.
} 
состоит в том, что правотворчество - это правовое явление, которое объединяет в себе разнообразные виды правового регулирования общественных отношений. Общим у этого процесса является создание нормативных правил по упорядочению этих отношений, тогда как субъекты правотворчества, их статус и порядок осуществления ими своей деятельности различны. С учетом этого, в юридической литературе нет единого общепризнанного подхода определения вида правотворчества, которые, в своей совокупности, и должны стать предметом его изучения. По мнению одних авторов существует пять основных видов правотворчества:

1) законотворчество;

2) подзаконное правотворчество;

3) локальное правотворчество местного самоуправления;

4) прямое правотворчество;

5) договорное нормотворчество ${ }^{127}$.

По мнению других, в зависимости от субъекта «видами правотворчества можно считать непосредственное правотворчество - референдумное законотворчество, прямое правотворчество, включая правотворчество законодательных органов, нормотворчество различных органов государственной власти, судебное правотворчество, муниципальное нормотворчество, локальное правотворчество органов управления юридических лиц, договорное правотворчество равноправных субъектов» ${ }^{128}$. Имеются и другие подходы в определении правотворчества ${ }^{129}$. Мы будем придерживаться первых двух подходов в определении видов правотворчества, поскольку они дают наиболее четкую их дифференциацию.

Правотворчество - это урегулирование общественных отношений с помощью норм права в различных сферах жизнедеятельности человека. Как справедливо отмечает И.Ю. Остапович «если имеет место наличие фактически сложившихся отношений в обществе, которые не закреплены в праве, то правотворчество закрепляет их в создаваемых правовых нормах» ${ }^{130}$.

Предметом изучения общей теории правотворчества являются особенности правотворения в целом, а также каждого конкретного его вида в отдельности. Как уже отмечалось, объединяющим началом этого процесса выступают правовые нормы, регулирующие общественные отношения. Но и само создание норм права, не унифицировано законода-

\footnotetext{
${ }^{127}$ Общая теория государства и права. Академический курс в 2-х т. / под ред. М.Н. Марченко. - Т. 2 Теория права. - М., 2000. - С. 163-164.

${ }^{128}$ Багдасаров В.Ю. Основания классификации правотворчества. // Журнал российского права. - 2012. - №11. - С. 50.

${ }^{129}$ Правотворчество в СССР / под ред. А.В. Мицкевича. - М., 1974. - С. 96; Васильев А.В. Правотворчество в советском социалистическом обществе: дис. ... к.ю.н. - М., 1971. С. 43; Осипов М.Ю. Понятие и соотношение правового регулирования и правотворчества. - М., 2010. - С. 41; и др.

${ }^{130}$ Остапович И.Ю. Сущность и особенности не юридической формы воздействия на правотворчество // Мир науки, культуры, образования. - 2011. - №4. - С. 293.
} 


\section{Правотворчество в Российской Федерации}

тельно и поэтому все виды правотворчества представляют собой действительно творческих характер, протекающий в рамках зачастую не столько правовых предписаний, а только правовых предпочтений их творцов. Возникает противоречие: с одной стороны, имеется устойчивая тенденция роста количества законов, тогда как с другой - «общественное развитие требует появления новых законов» ${ }^{131}$. И причин такого явления множество. Это не только нарушение принципов юридической техники творения законов (как отмечают И.Б. Ломакина и Д.С. Тэпс ${ }^{132}$ ), но и лоббизм, коррупционность, отсутствие учета научных достижений в той или иной сфере правотворчества, его кулуарность, когда законопроекты не представляются на общественное обсуждение, а принимаются как на конвейере, иногда без должного обстоятельного обслуживания даже на заседаниях Государственной Думы РФ. Среди таких причин, несомненно, следует указать и на недостаточное комплексное исследование предмета правотворчества в масштабах единой теории правотворчества, а также на отсутствие общего законодательства, по урегулированию правотворчества в Российской Федерации ${ }^{133}$.

Правотворчество в целом, осуществляемое всеми его субъектами, характеризуется решением одинаковых задач: урегулирование общественных отношений нормами права, то есть непосредственное создание правил поведения людей в конкретных жизненных ситуациях. Поэтому оно имеет общие особенности, которые сводятся к таким последовательным действиям:

1) выявление потребностей в правовом регулировании определенной группы общественных отношений;

2) решение вопроса о выборе направления и способа правового регулирования, в том числе обоснование потребности данного нормотворчества;

3) выработка концепции правового акта;

4) разработка проекта необходимого правового акта, предполагающая учет всех имеющихся достижений юридической науки в данной сфере правового регулирования, исторических традиций и норм международного права;

5) осуществление процедурных правил принятия конкретного вида правотворчества, в том числе обсуждение компетентным органом, внесение изменений и дополнений в текст проекта нормативного акта и его утверждение;

\footnotetext{
${ }^{131}$ См. подробнее: Ломакина И.Б. Методология правотворчества: теория и практика, направления совершенствования / И.Б. Ломакина, Д.С. Тэпс // Проблемы в российском законодательстве. - 2012. - №4. - С. 24.

132 Ломакина И.Б., Тэпс Д.С. Указ. соч.

${ }^{133}$ См. подробнее: Каменская Е.В. Региональное правотворчество в Российской Федерации: автореф. дис. ... к.ю.н. - М., 2005. - С. 6; Сапун В.А. Правотворчество и законотворчество: стратегия и тактика формирования права и закона / В.А. Сапун, Я.В. Турбова // Юридическая техника. - 2015. - №9.
} 
6) опубликование принятого нормативного правового акта и его вступление в силу. Это общая схема этапов правотворчества, каждый из которых имеет свои особенности, присущие только ему. Научно обоснованное правотворчество должно оказывать эффективное воздействие на общественные отношения и обладать качествами, свойствами, которые обеспечивают такое воздействие ${ }^{134}$.

В поле зрения юридической науки находится, прежде всего, законотворчество, поскольку именно на его базе основывается как правотворчество в целом, так и отдельные его виды. Законотворчество является сложной юридической категорией. Оно включает в себя референдумное законотворчество, федеральное законотворчество и законотворчество субъектов федерации. С точки зрения волеизъявления субъектов, его формирующих, оно представляет собой законотворчество всего народа, либо законотворчество избранных им своих представителей в лице членов Федерального Собрания РФ и на местах - в лице представительной власти субъектов федерации.

Следует отметить, что референдумное законотворчество в современной России применялось один раз, когда принималась Конституция Российской Федерации (12 декабря 1993 г.) Данный вид законотворчества является исключительным способом правотворчества. Он не может иметь широкое распространение, поскольку связан с большими финансовыми затратами, хотя по сути является наиболее объективным мерилом легитимности законодательства. Вместе с тем, ряд законодательных актов принимался с учетом их общественного обсуждения, что в определенной степени способствовало повышению их качества.

Референдумное законотворчество не лишено недостатков присущих правотворчеству в целом, поскольку на всенародное голосование представляется уже готовый законопроект, который может содержать их целый букет: от пробелов в правовом регулировании и противоречий отдельных норм до коррупционности и двусмысленности правовых предписаний. Это видно и на примере конституции РФ, где допущен явный перекос в закреплении разделения властей. Исполнительная власть имеет явное преимущество перед законодательной, а судебная поставлена в зависимость от той же исполнительной власти, прокуратура закреплена в судебной системе и по сути не имеет самостоятельного конституционного закрепления в отдельной ее главе ${ }^{135}$. Представляется, что референдумное законотворчество может быть использовано в случае, если представительная власть не может принять законопроект в связи с отклонением его оппозицией, но актуальность закона велика и требуется волеизъявление народа для разрешения возникшего спора в среде законодателей. Референдумное законотворчество по способу образования правовых норм и методов регулирования общественных отношений ничем не

\footnotetext{
${ }^{134}$ Афанасьева Л.В. Нормы права и их действие (вопросы теории): дис. ... к.ю.н. - М., 2000. - C. 162.

${ }^{135}$ См. подробнее: Сапун В.А., Турбова Я.В. Указ соч.
} 


\section{Правотворчество в Российской Федерации}

отличается от обычного законотворчества. Может быть оправданным такой подход, когда на всенародное голосование выносятся два альтернативных законопроекта, что возможно только при наличии сильной оппозиции.

Федеральное законотворчество, хотя и урегулировано Регламентом Государственной Думы Федерального собрания Российской Федерации ${ }^{136}$, в настоящее время обладает значительными недостатками, о которых справедливо отмечается в юридической литературе. Проблема состоит в том, что Регламент ГД РФ определяет процедурные вопросы законотворчества, тогда как основная масса недостатков связана с его содержанием.

На наш взгляд, это обусловлено в первую очередь тем, что законотворчество осуществляется в отрыве от целей социальноэкономического развития страны. Законодатель, не имея четкого представления какие конкретные результаты ему надо достичь, вынужден постоянно заниматься регулированием уже возникших стихийно и существующих в реальной действительности общественных отношений. При этом иногда это приходится делать в авральном порядке, что еще больше влияет на качество законотворчества. На необходимость учета в процессе правотворчества появляющегося в его результате законодательства обратил внимание и С.А. Белоусов ${ }^{137}$.

В юридической литературе вполне справедливо отмечают такие недостатки законотворчества, как хаотичность в формировании массива нормативных правовых актов, несоблюдение приоритетов правового регулирования, принятие новых законов без их увязки с существующим законодательством и нормами международного права, их бессистемность $^{138}$, отсутствие прогнозирования и планирования ${ }^{139}$ и т. д. Все это и характеризует полное отсутствие взаимосвязи между законотворчеством и каким-либо долгосрочным социально-экономическим планом страны. Государство откликается на постоянные вызовы общественного развития путем принятия законов, которые ориентированы на разрешение конкретных проблем без системного анализа с учетом перспектив развития страны.

Законотворчеству субъектов федерации присущи аналогичные недостатки, к числу которых прибавляются многочисленные факты вступления отдельных норм их законодательства в противоречие с федеральными законами. При этом на уровне субъектов федерации отсутствует еди-

\footnotetext{
${ }^{136}$ Постановление Государственной Думы РФ от 26.01.1998 №2134-ІІ ГД.

${ }^{137}$ Белоусов С.А. Правотворчество и законодательный дисбаланс: диалектика взаимосвязи // Вестник ВГУ. - 2015. - №1. - С. 64.

138 Лопатин В.Н. Конституционная законность и проблемы нормотворчества в России // Журнал российского права. - 2004. - №5. - С. 8; Тиунова Л.Б. Системные связи правовой действительности: методология и теория. - СПб., 1991. - С. 86.

${ }^{139}$ Власенко Н.А. О кризисных тенденциях в праве; Павлушкин А.В. Современное правотворчество: новые возможности для общества и государства / А.В. Павлушкин, А.С. Павловский // Журнал российского права. - 2015. - №3. - С. 151.
} 
ный нормативный правовой акт о порядке рассмотрения и принятия данного законодательства, что порождает существенную разницу в подходах на местах к законотворчеству.

Законотворчество как предмет общей теории правотворчества, нуждается в выработке научно обоснованных требований к его качеству. Не вызывает сомнений, что при разработке новых законов субъекты законотворчества должны опираться на установленные общегосударственные планы, быть с ними взаимосвязанными, обеспечивать их качественную реализацию. С учетом этого необходимо осуществлять планирование законотворчества, а также прогнозирование возможных результатов от действия предлагаемых законов. При этом следует исходить из имеющейся потребности формирования в России единой непротиворечивой правовой системы. По мнению Л.В. Андриченко для этого следует создать необходимые системообразующие механизмы согласования, координации, планирования ${ }^{140}$.

Но кроме этого законотворчество должно базироваться, помимо общепринятых правил юридической техники создания норм права, правовых институтов, а также отраслей права, на таких требованиях к его результатам, как:

1) длительный срок действия законов;

2) обязательное наличие механизмов их реализации;

3) возможность фактического исполнения законов гражданами, юридическими лицами и государством;

4) использование императивного метода правового регулирования только ради достижения максимального положительного эффекта для государства и общества;

5) контроль общества на всех этапах правотворческой деятельности, включая и реализацию законов.

Подзаконное правотворчество составляет огромный массив деятельности государственных исполнительных органов и их должностных лиц. Эта правотворческая деятельность по регулированию общественных отношений для указанных субъектов является одновременно и обязанностью. По данным Ю.Г. Арзамасова ежегодно происходит значительный рост несекретных нормативных актов различных ведомств, что «объясняется, прежде всего, реализацией норм положений о федеральных органах исполнительной власти, предусматривающих принятие ведомственных подзаконных актов» ${ }^{141}$.

\footnotetext{
${ }^{140}$ Обзор выступлений за круглым столом, состоявшимся 26.01.2015 по теме «Актуальные проблемы правотворчества и проект федерального закона «О нормативных правовых актах в Российской Федерации» в статье А.В. Павлушкина и А.С. Павловского «Современное правотворчество: новые возможности для общества и государства». // Журнал российского права. - 2015. - №3. - С. 151.

141 Арзамасов Ю.Г. Ведомственный нормотворческий процесс: структура содержание, перспективы развития (ч. 2) // Сводный реферативный сборник журнала Представительная власть - XXI век: законодательство, комментарии, проблемы. - 2007. - №4-6. - С. 13-14.
} 


\section{Правотворчество в Российской Федерации}

Порядок подзаконного правотворчества регламентирован «Правилами подготовки нормативных правовых актов федеральных органов исполнительной власти и их государственной регистрации», утвержденных постановлением Правительства Российской Федерации 13.08.1997 №1009 ${ }^{142}$, а также аналогичными правовыми документами субъектов федерации.

В юридической литературе нет единства мнений о сущности подзаконного правотворчества. Так, С.Н. Болдырев не относит его к правотворчеству, а считает нормотворчеством. Отличие нормотворчества от правотворчества, по определению данного автора состоит в том, что субъектами нормотворчества являются органы исполнительной власти, а не представительные органы ${ }^{143}$. Данный подход, хотя и верно определяет основное отличие в образовании правовых норм (есть и другие отличительные признаки), является неудачным. Во-первых, другие виды правотворчества тоже отличаются между собой по субъекту создания норм права. То есть это основание деления на виды правотворчества является общим критерием, а не уникальным. Во-вторых, и это главное, такой подход не рассматривает все правотворчество как единую систему образования, формирования норм, регулирующих общественные отношения. С точки зрения предмета исследования, единой теории правотворчества приоритетным является общий подход в понимании особенностей образования правовых норм. Вычленение, в данном случае, из общей системы ее части не дает основания исключать нормотворчество из сферы правотворчества.

Подзаконное правотворчество отличается от законотворчества, прежде всего предметом правового регулирования, то есть характером регулируемых ими общественных отношений. Законы придают правовой характер наиболее важным, основополагающим общественным отношениям, тогда как подзаконные акты направлены на урегулирование менее значимых отношений, в первую очередь связанных с реализацией законов. И сами подзаконные акты издаются на основе законов и в их исполнение.

И хотя по масштабам охвата правового поля подзаконные акты зачастую уступают законам, находясь у них как бы в соподчинении, тем не менее, они содержат такие же нормы права, регулирующие общественные отношения, как и законодательные нормы. Это их объединяет. Именно в таком аспекте и необходимо рассматривать систему подзаконного правотворчества. Данный подход позволяет находить, с одной стороны, общие признаки правотворчества в целом, а с другой, - специфи-

\footnotetext{
142 Постановление Правительства РФ от 13 августа 1997 г. №1009 «Об утверждении Правил подготовки нормативных правовых актов федеральных органов исполнительной власти и их государственной регистрации» [Электронный ресурс].- Режим доступа: http:// base.garant.ru/166045/\#ixzz3r6uNCxJE

143 Болдырев С.Н. Нормотворчество и правотворчество: проблемы соотношения (техникоюридический аспект) // Вестник Волгоградской Академии МВД России. - 2011. - №17. C. 18 .
} 
ческие особенности его видов - законотворчества и подзаконного правотворчества.

Судебное правотворчество является одним из видов формирования правовых норм. Оно не конкурирует с законотворчеством, а лишь дополняет его в случаях, когда необходимо восполнить обнаружившиеся пробелы в праве. Одновременно следует учитывать, что судебное правотворчество - это результат деятельности суда, лишь сопутствующий его основному назначению - рассмотрению конкретных дел и принятию по ним решений. Поэтому судебное правотворчество - это не основная функция суда. Тем более, что российское законодательство не предусматривает его в качестве источника права. Сущность судебного правотворчества состоит в том, что судебные акты подчинены закону, не могут его изменить или отменить, но могут уточнить смысл закона и это равнозначно изменению самого закона ${ }^{144}$. Как справедливо отмечает Т.А. Желдобина, «судебное нормотворчество - побочная деятельность высшего судебного органа - возникает тогда, когда в процессе осуществления своих функций суд сталкивается с пробелом в праве или законе, с неконституционным законом, с нормой правового акта, требующей ее толкования» ${ }^{145}$. Кроме того, нормативность судебного правотворчества сугубо утилитарна - разрешение конкретного дела. Созданная судом норма распространяется на схожие случаи, но время ее действия ограничено до принятия новой нормы закона ${ }^{146}$.

Исследование судебного правотворчества показывает возрастание роли судебной практики совершенствованием законодательства, особенно таких его отраслей, как гражданское и уголовное право ${ }^{147}$. Судебное правотворчество способствует формированию единообразного понимания и применения норм права. Однако судебное правотворчество не является прецедентным правом, поскольку создаваемые в ходе этого процесса нормы являются временными и после принятия закона прекращают своей действие. Но имеется и противоположная точка зрения, которая вытекает из судебной практики, но не закона.

Таким образом, судебное правотворчество является важным средством восполнения пробелов в праве, при регулировании общественных отношений, а также устранения неясностей в законодательстве. Изучение судебного правотворчества позволяет выявлять уровень качества

144 Семьянов Е.В. Судебное правотворчество (вопросы общей теории права): дис. ... к.ю.н. - М., 2005. - С. 8-9.

145 Желдобина Т.А. О судебном правотворчестве. По материалам круглого стола «К 150-летию судебной реформы 1864 года» // Вестник Саратовской государственной юридической академии. 2015. - №2. - С. 27-28.

${ }^{146}$ Гук П.А. Судебная практика как форма судебного нормотворчества в правовой системе России: процессы демократизации // Юридическая техника. Ежегодник. - 2014. - №8. C. $129-130$.

${ }^{147}$ См. подробнее: Долинская В.В. Судебные акты как источники гражданского права // Цивилист. - 2007. - №2. - С. 8; Мкртумян А.Ю. Судебная практика как источник гражданского права России // Гражданское право. - 2008. - №4. - С. 13. 


\section{Правотворчество в Российской Федерации}

законотворчества, поскольку судебная практика постоянно воспроизводит его достоинства и разрешает недостатки.

Следующим видом правотворчества, как предмета научного исследования, является муниципальное правотворчество. Единообразного понятия этого процесса в юридической науке нет, как нет и его узаконенной дефиниции. По мнению К.О. Сергеевой, «под муниципальным правотворчеством необходимо понимать деятельность уполномоченных субъектов местного самоуправления по принятию письменного документа, направленного на установление, изменение или отмену правовых норм, имеющих общеобязательное предписание постоянного или временного характера, рассчитанных на многократное или однократное применение на территории муниципального образования, и адресованного неопределенному кругу лиц, либо конкретному субъекту общественных отношений» ${ }^{148}$. Примерно такие же, но более развернутые понятия муниципального правотворчества дают Е.А. Каминская ${ }^{149}$, Н.П. Алешкова ${ }^{150}$ и другие авторы.

Муниципальное правотворчество осуществляется населением муниципального образования, органами местного самоуправления и их должностными лицами в пределах своих полномочий, установленных Конституцией РФ, федеральным законом от 6 октября 2003 г. №131-Ф3 «Об общих принципах организации местного самоуправления в Российской Федерации» ${ }^{151}$, а также их Уставами. В современной России муниципальное правотворчество в соответствии со статьями 130-132 Конституции РФ проявляется в таких формах как:

1) непосредственное правотворчество, осуществляемое населением на основе прямого волеизъявления в процессе референдума, выборов или схода граждан (в населенных пунктах численностью до 100 человек);

2) правотворчество органов местного самоуправления и их должностных лиц по вопросам местного значения;

3) правотворчество органов местного самоуправления и их должностных лиц по реализации отдельных государственных полномочий, переданных им на основе закона;

4) правотворчество органов местного самоуправления и их должностных лиц, связанное с реализацией прав органов местного самоуправления на решение вопросов, не отнесенных к вопросам местного значения.

В юридической литературе отмечается, что муниципальное правотворчество включает в себя несколько стадий:

1) подготовку проекта нормативного акта (предварительная стадия);

2) его обсуждение и принятие (основная стадия);

\footnotetext{
148 Сергеева К.О. Муниципальное правотворчество в Российской Федерации: дис. ... к.ю.н. - М., 2013. - С. 5.

149 Каминская Е.А. Муниципальное правотворчество в механизме правообразования: дис. ... к.ю.н. - Белгород, 2013. - С. 7.

${ }^{150}$ Алешкова Н.П. Конституционно-правовые основы муниципального правотворчества в Российской Федерации: дис. ... к.ю.н. - Екатеринбург, 2010. - С. 8.

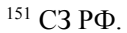


3) введение его в действие (решающая стадия) ${ }^{152}$. Формирование правотворческих документов (нормативных актов муниципальных образований) включает в себя по сути те же этапы, что и законотворчество.

Муниципальное правотворчество имеет неразрывную связь с государственным правотворчеством и это проявляется в том, что оно:

1) носит публичный характер;

2) используется в качестве способа реализации полномочий муниципального образования;

3) нацелено на оперативное выявление потребностей по регулированию общественных отношений местного значения;

4) закрепляет действия уполномоченных органов по управлению муниципальным образованиям;

5) регулирует решение публичных вопросов, не относящихся к ведению государства и субъектов федерации, но имеющих значение для местного населения;

6) выявляет принципиально новые общественные отношения, развитие или сдерживание которых требует государственного вмешательства либо корректировки публично-властного регулирования ранее существовавших отношений;

7) используется в качестве механизма детализации установленных на государственном уровне норм с учетом местных особенностей;

8) отражает установленные государством меры дозволенного поведения муниципального образования по решению возложенных на него задач 153 .

В соответствии со ст. 43 Федерального закона №131 правовые акты, принятые на местном референдуме (сходе граждан), входят в систему муниципальных правовых актов. По юридической силе они приравниваются к Уставу муниципального образования, имеют прямое действие и применяются на всей территории муниципального образования.

Таким образом, муниципальное правотворчество, хотя и обладает признаками, присущими правотворчеству в целом, оно имеет и свои особенности, связанные с его субъектами и порядком осуществления правотворческого процесса, который имеет порой даже демократичнее формы, чем законотворчество и подзаконное правотворчество.

Локальное правотворчество органов управления юридических лиц, по мнению В.Ю. Богдасарова, является частным правотворчеством в отличие от публичного, поскольку их органы управления не подчиняются логике административно - территориального деления ${ }^{154}$. Иногда к локальному правотворчеству относят и правотворчество органов местного самоуправления (муниципалитетов, администраций городов и районов) ${ }^{155}$.

\footnotetext{
${ }^{152}$ Алешкова Н.П. Указ. соч.

153 Там же. - С. 9.

${ }^{154}$ Багдасаров В.Ю. Основания классификации правотворчества // Журнал российского права. - 2012. - №11. - С. 54.

${ }^{155}$ См., например: Меркулова К.Ю. Проблемы правотворчества в российском законодательстве / К.Ю. Меркулова, А.И. Пушкарь // Вестник Московского гуманитарно-экономического института. - 2015. - №1. - С. 84; Арзамасов Ю.Г. Ведомственный нормотворческий процесс: структура, содержание, перспективы развития (ч. 1) // Сводный реферативный сборник журнала Представительная власть - XXI век: законодательство, комментарии, проблемы. - 2007. - №4-6. - С. 13-14.
} 


\section{Правотворчество в Российской Федерации}

Локальное правотворчество осуществляется в целях регулирования отношений в процессе деятельности юридического лица ${ }^{156}$. При этом они регулируют не отдельный случай либо конкретное общественное отношение, а повторяющиеся типичные ситуации или вид отношений, присущих данному корпоративному коллективу, что обуславливает возможность их многократного применения. Принимаемые в процессе локального правотворчества нормы имеют общий характер, то есть, рассчитаны на многих лиц. По своему содержанию нормы локального правотворчества представляют волеизъявление коллектива юридического лица, и сфера их действия ограничивается сферой его интересов, в пределах которых осуществляется деятельность.

Вместе с тем локальное правотворчество протекает в соответствии с законодательством России и ее субъектов и не может выходить за его рамки. По сути, локальное правотворчество представляет собой правовое поле различных хозяйствующих субъектов и общественных организаций, которое предоставлено государством под их юрисдикцию в связи с невозможностью и ненужностью государственного регулирования происходящих там межличностных отношений. Несомненно, особенности внутри корпоративных отношений знают лучше всего члены конкретного юридического лица и их урегулирование должным образом государство возлагает на это юридическое лицо. Такой подход является наиболее удобным и для государства, и для юридического лица. Обладая правотворческой свободой, юридическое лицо регламентирует свою деятельность не только наиболее эффективно, но и максимально оперативно, что практически невозможно на уровне государственного законодательного регулирования, учитывая порядок осуществления законодательного процесса.

Локальное правотворчество представляет собой достаточно демократичный и эффективный способ правового регулирования отношений, складывающихся внутри конкретных коллективов юридических лиц. Правовой основой их деятельности служат уставы, а также Кодексы корпоративного поведения ${ }^{157}$, которые разрабатываются и утверждаются самими хозяйствующими субъектами либо общественными организациями.

Таким образом, предметом изучения общей теории правотворчества является сама правотворческая деятельность, связанная с регулированием общественных отношений, имеющих различный уровень значимости и степень распространенности. Она может осуществляться в нескольких правотворческих формах, что обуславливает, при изучении каждой из них, необходимость выявлять их особенности и учитывать в правовом регулировании.

Высшей формой правотворчества является законотворчество. Его потенциал, как регулятора и стимулятора упорядочения общественных

\footnotetext{
${ }^{156}$ См. подробнее: Кашанина Т.В. Корпоративное (внутрифирменное) право: учеб. пособ. М.: Норма, 2003. - С. 3-4.

${ }^{157}$ См., например: Кодекс корпоративного поведения, утвержденный распоряжением Федеральной комиссии по рынку ценных бумаг от 4 апреля 2002 г. № 421/p.
} 
отношений в настоящее время снижается в силу низкого качества принимаемых законов. Требуется незамедлительная разработка правовых гарантий качества законопроектов. Представляется, что критерии, характеризующие высокое качество законов, законодатели могут разработать совместно с правоприменителями на основе достижений юридической науки.

\section{§2.3. КЛАССИФИКАЦИЯ ПРАВОТВОРЧЕСТВА ПО ВИДАМ}

Правотворчество - сложное многоуровневое правовое явление. В этот по настоящему творческий процесс вовлечены практически все органы и должностные лица представительной и исполнительной власти, а также многие органы и должностные лица негосударственных структур (муниципалитетов, предприятий, учреждений и общественных организаций). Поэтому вырабатываемые в процессе их деятельности нормативные правовые акты имеют различную юридическую силу, неодинаковое действие в пространстве, во времени и по кругу лиц, предназначены для регулирования общественных отношений в публичной и частной сферах, имеют многообразные правовые формы, создаются субъектами, как правило, не имеющих специальных знаний в области правотворчества и т. д. Отрицательным фактором, влияющим на качество издаваемых правотворческих решений, является тот факт, что правотворческая деятельность законодательством урегулирована недостаточно и что «в настоящее время есть только отдельные законодательные нормы, касающиеся подготовки, принятия и оформления нормативных актов. Эти нормы, содержащиеся в отдельных законодательных актах, фрагментарны, не сведены воедино» ${ }^{158}$. Как справедливо отметил А.В. Мицкевич «принятие единых правил будет способствовать улучшению стиля и формы принимаемых актов, укрепит научные основы правотворчества, внесет в это важное государственное дело необходимый порядок и единообразие» ${ }^{159}$.

Таким образом, правотворчество представляет собой в общем виде, с одной стороны, недостаточно урегулированную законом деятельность уполномоченных на то субъектов, а с другой, - создание в ее процессе различных по функциональному назначению и качественным показателям нормативных правовых актов. Все это серьезно затрудняет возможности систематизации всей совокупности правотворческой деятельности и выявления ее видов. Однако, учитывая, что этот процесс является творческим, в основе которого лежит метод научного познания правовой действительности в области формирования норм права, то классификация правотворчества по видам должна строиться по принципу выделения из единого общего понятия, имеющего присущие ему объединяю-

158 Борисов А.С. Некоторые проблемы современного правотворчества в России / А.С. Борисов, П.А. Меркулов // Социум и власть. - 2015. - №3 (53). - С. 67.

${ }^{159}$ Правотворчество в СССР / под ред. проф. Л.И. Мицкевича. - М., 1974. - С. 162. 


\section{Правотворчество в Российской Федерации}

щие признаки, особенное, характеризующее его видовую специфику.

Как отмечается в юридической литературе общими признаками, объединяющими правотворчество в одно структурированное сложное понятие, являются такие:

1) это деятельность, выражающая волю народа (в идеале), а на практике - волю политических сил, находящихся у власти;

2) осуществляемая специально уполномоченными субъектами;

3) в определенных процессуальных формах, урегулированных законодательно;

4) по созданию, изменению и отмене правовых норм ${ }^{160}$.

Можно считать, что это наиболее удачное определение понятия правотворчества, поскольку оно отражает обе стороны его сущности и процессуальную, связанную с порядком принятия норм права, и нормообразующую, связанную с их формированием и функционированием.

Вместе с тем, классификация правотворчества должна осуществляться с учетом принципов полноты, достаточности, исключительности и единства (монизма) ${ }^{161}$. Это позволяет типологизировать ${ }^{162}$ правотворчество как единую систему и выявить ее особенности по различным классифицирующим основаниям. Учет указанных принципов создает научную базу выбора критериев классификации правотворчества, является методологическим средством обеспечения ее объективности и обоснованности.

Проблема состоит в том, чтобы с помощью классификации правотворчества выявить имеющуюся в нем систему взаимосвязанных между собой всех его видов для их дальнейшего теоретического исследования и практического использования в ходе создания правовых норм.

Здесь требуется уточнить следующее. Нашей задачей является достижение объективного и в то же время оптимально доступного знания о видах правотворчества с целью их последующего изучения, а не исчерпывающего определения всех его возможных видов в зависимости от выработанных юридической наукой критериев. Достижение полноты и объективности классификации возможно лишь на основе монизма правотворческих проявлений, а не способов деления их на виды. Важно установить реально существующие виды правотворчества в одном измерении, а не всю их совокупность, возникающую на основе определения различных научных критериев, что может дать ценную, но не актуальную в данном случае информацию. Под единым измерением понимается классификация всего многообразия правотворчества с помощью одного или нескольких критериев одновременно, если это дает объективную их группировку по видам. Тем более, что оба эти подхода применялись в юридической науке 163 .

\footnotetext{
160 См. подробнее: Борисов А.С., Меркулов П.А. Указ соч. - С. 66.

${ }^{161}$ См. подробнее: Багдасаров В.Ю. Основания классификации правотворчества // Журнал российского права. - 2012. - №11. - С. 49.

${ }_{162}$ Власов В.И. Теория государства и права. - Ростов н/Д., 2002. - С. 264.

${ }^{163}$ Общая теория государства и права. Академический курс в 2-х т. / под ред. М.Н. Марченко. - Т. 2. Теория права. - М., 2000. - С. 163-164.
} 
Рассмотрим некоторые примеры классификации правотворчества по видам, предложенные учеными. Подавляющее большинство из них определяют виды правотворчества по одному критерию. Чаще всего по субъекту правотворчества. По данному критерию выделяются следующие его виды:

1) моносубъектное (издание правового акта осуществляет одно лицо, например, президент) и полисубъектное (когда разработка и принятие нормативного правового акта связаны с коллегиальной деятельностью) ${ }^{164}$;

2) непосредственное правотворчество народа в процессе проведения референдума; прямое правотворчество государства в лице его различных органов; правотворчество общественных организаций ${ }^{165}$.

3) индивидуальное правотворчество (осуществляется одним субъектом) и совместное правотворчество (правотворческие решения принимаются несколькими субъектами) ${ }^{166}$;

4) правотворчество государственных органов и общественных организаций (уполномоченных органами государства) ${ }^{167}$;

5) правотворчество высших (на уровне федерации и ее субъектов) и местных органов государственной власти; непосредственное правотворчество самого народа в процессе проведения референдума; договорное правотворчество субъектов федерации, содержащее общеобязательные веления ${ }^{168}$ и т. д.

Недостатком таких классификаций правотворчества является определение его видов слишком обобщенными группами, что требует дальнейшего их деления на подвиды и не отвечает принципу достаточности.

Наиболее удачное, по нашему мнению, определение видов правотворчества, когда критерием классификации являются их субъекты, предложил В.Ю. Багдасаров. Проведенное им исследование позволило выделить следующие их виды:

1) непосредственное правотворчество - референдумное законотворчество;

2) прямое правотворчество, включая правотворчество законодательных органов;

3) нормотворчество различных органов государственной власти;

4) судебное правотворчество;

5) муниципальное правотворчество;

6) локальное правотворчество органов управления юридических лиц;

7) договорное правотворчество равноправных субъектов ${ }^{169}$.

\footnotetext{
${ }^{164}$ См. подробнее: Власов В.И. Указ. соч. - С. 264.

${ }^{165}$ См. подробнее: Правотворчество в СССР / Под ред. А.В. Мицкевича. - М., 1974. C. $43-44$.

${ }^{166}$ См. подробнее: Осипов М.Ю. Понятие и соотношение правового регулирования и правотворчества. - М., 2010. - С. 41.

${ }^{167}$ См. подробнее: Теория государства и права / под ред. В.М. Корельского, В.Л. Перевалова. - М., 1998. - С. 291.

${ }^{168}$ Марченко М.Н. Проблемы теории государства и права. - М., 2013. - С. 664.

${ }^{169}$ Багдасаров В.Ю. Указ. соч. - С. 51.
} 


\section{Правотворчество в Российской Федерации}

При данной классификации осуществляется наиболее приемлемая группировка правотворчества по видам, позволяющая их всестороннее раздельное изучение. Использование в ней различных терминов обозначения одного и того же правового явления (правотворчество и нормотворчество) по всей видимости автором оценивается как равноценные понятия, что в целом не противоречит предложенной им классификационной модели деления правотворчества на виды. Этот подход вполне приемлем, поскольку в юридической литературе многие авторы придерживаются такой научной позиции, когда термины правотворчество и нормотворчество (включая и ведомственное нормотворчество) отождествляются.

Так, Н.М. Конин считает, что правотворчество - это синоним нормотворчества, поскольку «форма управления - это действия, которые проявляются в том, что предписывают субъектам права правила, нормативы, регламенты, которые рассматриваются и утверждаются в установленном порядке соответствующими звеньями государственного аппарата, вследствие чего они становятся правовыми нормами, правилами, требованиями» ${ }^{170}$. Аналогичной позиции придерживаются и многие другие авторы ${ }^{171}$.

В юридической науке предложены и многие другие критерии деления правотворчества на виды:

1) по характеру правотворческих полномочий правотворчество может быть непосредственным (когда правотворческая деятельность является основной функцией его субъекта) и делегированным, которое осуществляется по специальному разрешению ${ }^{172}$;

2) по источнику издания правотворческого акта - публичным и частным ${ }^{173}$. Публичное правотворчество бывает санкционированным, и непосредственным. Санкционированное правотворчество - это когда «источником права данного вида правотворчества является уже сложившееся в обществе правило поведения, которое не создается государством, но, одновременно, имеет юридическую силу, гарантируется и санкционируется государством, признавая значимость и обязательность социальной нормы» ${ }^{174}$.

По мнению В.Ю. Багдасарова, данный вид правотворчества представляет собой косвенное правотворчество «когда суверен разрешает (санкционирует) или допускает (молчаливо санкционирует) действие каких-либо нормативных предписаний, например: государство допускает фактически создание норм права судами вопреки отсутствию такого законодательного разрешения, государство не вмешивается в действие

\footnotetext{
${ }^{170}$ Конин Н.М. Административное право России. - М., 2006. - С. 27.

${ }^{171}$ См. подробнее: Болдырев С.Н. Нормотворчество и правотворчество: проблемы соотношения (технико-юридический аспект) // Вестник Волгоградской Академии МВД России. 2011. - №17. - С. 18-19.

172 Власов В.И. Указ. соч. - С. 264.

${ }^{173}$ Абдулаев М.И. Теория государства и права. - М., 2004. - С. 241.

${ }^{174}$ Фомичева О.А. К вопросу о содержании понятия и видовой классификации современного правотворчества / О.А. Фомичева, Д.В. Пахомова // Вестник московской финансовоюридической академии. - С. 255.
} 
парламентского или иного прецедента либо обыкновения. Санкционирование как вид (способ) правотворчества представляет собой последующее одобрение (молчаливое или текстуальное) уже существующей нормы» ${ }^{175}$.

Непосредственное правотворчество проявляется в процессе создания правовой нормы управомоченным органом. Частное правотворчество согласование воли участвующих субъектов и выработка взаимовыгодных условий сотрудничества сторон. Оно подразделяется на договорное и локальное правотворчество.

3) по уровню действия правотворческих актов: международноправового уровня, общегосударственного, регионального, местного (муниципального), локального (уровень юридического лица) ${ }^{176}$;

4) по признакам состава правотворчества, который понимается как «совокупность признаков, необходимых для социально-юридической актуализации правотворческого результата» и включает в себя четыре элемента: объект, объективную сторону, субъект и субъективную сторону. Проведенное В.Ю. Багдасаровым исследование оснований классификации правотворчества, предложенных различными учеными, показывает, что все они могут быть сведены в четыре взаимосвязанные группы, отражающие указанные выше элементы состава правотворчества:

1) субъект правотворчества;

2) объект правотворчества (система источников права);

3) объективная сторона правотворчества;

4) субъективная сторона правотворчества.

Такой подход классификации правотворчества дал возможность ученому выявить не разрозненную совокупность критериев, а открытую систему критериев, которая позволяет включать в нее новые основания и тем самым получать новые знания об изучаемом предмете ${ }^{177}$.

Нет сомнения, что выявленная возможность классификации правотворчества по признакам его состава является серьезным достижением теории правотворчества. Изучение тех или иных классификационных особенностей правотворчества теперь можно осуществлять в плановом порядке, а не по стихийному определению такой потребности. Кроме того, новые критерии классификации правотворчества могут быть не только встроены в уже существующую систему таковых, но и оценены с точки зрения их значения для индивидуализации определенных его видов.

Анализируя существующие подходы классификации правотворчества можно сказать, что все они формализованы и не всегда преследуют конкретные цели. За исключением классификации по признакам состава правотворчества, целью которого является выявление всех возможных критериев по его элементам. Однако, учитывая, что правотворчество многоуровневое, сложное правовое явление, вполне допустимо выявление его видов на основании двух и более критериев, действующего одновременно. Например, один критерий отражает показатели процессу-

\footnotetext{
${ }^{175}$ Багдасаров В.Ю. Указ. соч. - С. 52.

${ }^{176}$ Осипов М.Ю. Указ. соч. - С. 40-41.

${ }^{177}$ Багдасаров В.Ю. Указ. соч. - С. 50-56.
} 


\section{Правотворчество в Российской Федерации}

альной стороны правотворчества, а второй - его результат ${ }^{178}$.

Это могло бы показать связь правотворческих решений со способом их разработки и принятия. По указанным критериям правотворчество может быть:

1) строго регламентировано законом, когда упорядочен порядок выработки норм права и процесс их принятия субъектами правотворчества (Регламент ГД РФ);

2) без законодательного нормирования порядка формирования норм права при наличии строгих правил их утверждения (ведомственные правовые акты);

3) полностью не урегулировано законодательством в силу его временной невостребованности (референдумное правотворчество);

4) частично урегулированное законом при наличии свободной выработки норм права в пределах предоставленной компетенции (судебное, муниципальное и локальное правотворчество).

Указанный подход изучения свойств правотворчества можно рассматривать как метод программирования его классификационных критериев. Формируя их определенную комбинацию можно приблизительно установить качественные показатели конкретного вида правотворчества, а также уже действующего или готовящегося к изданию нормативного правового акта. На основании данного подхода можно разработать и специальную компьютерную программу оценки качества правотворческого решения, выработанного любым субъектом правотворчества. И более того - он позволяет осуществлять предварительную правовую экспертизу всех правовых документов, подготовленных к изданию, на определение наличия в них признаков противоречивости, соответствия их реквизитов установленным законом требованиям, наличия признаков лоббирования или коррупционности и т. д.

Принципиальное значение имеет вопрос о введении в практику выявления видов правотворчества двух и более критериев, действующих одновременно. По мнению В.Ю. Багдасарова, использование одновременно нескольких критериев для классификации видов правотворчества является не достоинством, а недостатком, поскольку происходит дублирование их показаний, нарушается полнота охвата изучаемых феноменов $^{179}$. Данное утверждение обосновано автором только одним примером, что не может служить доказательством непригодности такого подхода при изучении его классификационных возможностей в иных случаях. А то, что в процессе классификации происходит дублирование задействованных критериев, повышает надежность полученного результата, так как уже не один, а два или более критериев подтверждают полученный результат.

Следует также иметь в виду, что целью классификации является определение его видов для изучения имеющихся особенностей как с

\footnotetext{
${ }^{178}$ См. подробнее: Теория государства и права / под ред. В.М. Корельского, В.Д. Перевалова. - М., 1998. - С. 291.

${ }^{179}$ Багдасаров В.Ю. Указ. соч. - С. 50.
} 
процессуальной стороны (порядка придания юридической силы нормам права), так и нормотворческой (порядка образования правовых норм). Поэтому проблема состоит не в том, сколько будет использовано критериев для выявления основных, образующих целостную систему, видов правотворчества, а в обосновании объективности полученного результата, его достоверности, пригодности для последующего теоретического изучения и практического применения.

Именно с учетом этих обстоятельств большое значение приобретает не только выбор тех или иных критериев классификации правотворчества на виды, но и оценка качественной характеристики полученного результата. К числу признаков, свидетельствующих об индивидуализации конкретного вида правотворчества, выявленного в результате проведенной классификации, а также о ее полноте, относятся следующие:

1) делению подверглась вся система правотворческой деятельности, рассматриваемая как одно целое правовое явление;

2) полученный результат представляет собой ряд обособленных, индивидуализированных частей единой системы;

3) каждый обособленный вид правотворчества имеет специфический, присущий только ему способ образования правовых норм, вытекающий из компетенции его субъектов, процессуальной формы, целей правового регулирования и сферы действия правотворческих решений;

4) определившиеся виды правотворчества в результате классификации могут быть всесторонне исследованы с помощью научного аппарата, выработанного юридической наукой.

Используя указанные признаки можно определить качество полученного результата классификации правотворчества на виды, его пригодность для последующего всестороннего изучения и выработки конкретных предложений по улучшению нормотворческих решений.

Анализ существующей системы правотворчества в нашей стране предопределяет, по нашему мнению, необходимость классифицировать его виды одновременно по двум критериям: юридической силе принимаемых актов и субъекту, издающему правовые нормы. В соответствии с первым критерием правотворчество подразделяется на законотворчество и подзаконное нормотворчество ${ }^{180}$, а второй - конкретизирует их виды. Такой подход позволяет сформировать цельную и в то же время четкую систему видов правотворчества, каждый из которых имеет самостоятельное, обособленное значение, что дает возможность их последующего изучения в данном исследовании. К числу таковых относятся следующие:

1) референдумное законотворчество,

2) непосредственное законотворчество,

3) делегированное законотворчество,

4) подзаконное правотворчество органов государственной власти;

5) судебное правотворчество,

6) муниципальное правотворчество,

${ }^{180}$ См. подробнее: Власов В.И. Указ. соч. - С. 265. 
7) локальное правотворчество,

8) договорное правотворчество.

Достоинство указанной классификации состоит в том, что она:

1) связывает виды правотворчества в единую систему,

2) отражает особенности всех видов правотворчества,

3) четко устанавливает границы правотворческой деятельности по каждому виду,

4) показывает их взаимосвязанность между собой.

Таким образом, классификация правотворчества по видам является научной базой их теоретического исследования и практического использования в ходе выработки правотворческого решения.

Основная проблема классификации правотворчества состоит в ее объективности и обоснованности, полноте, достоверности полученного результата, его пригодности для последующего теоретического изучения и практического применения. Поэтому большое значение приобретают не только критерии, предназначенные для выделения конкретных видов правотворчества, но и признаки, отражающие их качественные показатели, что свидетельствует о возможности или невозможности использования полученного результата в правотворческой деятельности.

Системное использование критериев правотворчества дает возможность максимального выявления его видов и тем самым расширяет их научное познание.

Перспективным направлением использования классификационных свойств критериев правотворчества может быть их программирование с целью выявления качества издаваемых нормативных правовых актов, в том числе определения противоречий между нормами права, установление соответствия реквизитов правовых документов установленным законом требованиям, наличия признаков лоббирования или коррупционности и т.д. 


\section{§2.4. ЗАКОНОТВОРЧЕСТВО}

Развитие всей системы общественных отношений, особенно в экономической и социальной сферах, напрямую зависит от эффективности гражданского, финансового, трудового, пенсионного и других видов законодательства. Принципиально важно реализовать законотворческую деятельность не только в соответствии с запросами времени, но и на основе научно аргументированной правовой доктрины закона как ключевого нормативного правового акта Российской Федерации. Законотворчество - это деятельность высших государственных представительных органов власти по выработке и изданию нормативных правовых актов, а также по их изменению и отмене. Законотворческая функция присуща и высшим представительным органам субъектов федерации. Законотворчество включает в себя две стороны:

1) формирование норм права (правовых институтов и отраслей права);

2) придание им юридической силы в порядке установленных процедур.

В процессе законотворческой деятельности издаются законы, которые представляют собой нормативно-правовые акты высшей юридической силы (по отношению к иным нормативным актам) и совместно с Конституцией РФ являются основными источниками права.

Характерными признаками законотворчества являются следующие:

1) оно осуществляется специально созданными правотворческими органами государства - Государственной Думой и Советом Федерации в масштабах всей страны и высшими представительными органами субъекта федерации - в пределах этих территориальных образований;

2) оно протекает в строго урегулированном нормами права процессуальном порядке. Следует отметить, что действующий ныне «Регламент Государственной Думы Федерального Собрания Российской Федерации» ${ }^{181}$. устанавливает порядок рассмотрения и принятия законодательных актов, а также порядок рассмотрения предложений о поправках и пересмотре положений Конституции РФ (глава 16), что, по мнению ряда ученых, значительно сужает возможности правового воздействия на повышения качества принимаемых законов. За пределами правового регулирования остаются важные вопросы оптимизации федерального законотворческого процесса, суть которого состоит в снижении количества субъектов права законодательной инициативы (их более 700) путем выработки понятия консолидированной законодательной инициативы субъектов федерации (большое количество поступающих от них законопроектов невозможно рассмотреть в установленные сроки) ${ }^{182}$, либо в пределах одной парламентской фракции, что позволит избежать дублирования при внесении законопроектов и их количественного сокраще-

${ }^{181}$ Постановление от 22 января 1998 г. №2134-II ГД «О Регламенте Государственной Думы Федерального Собрания Российской Федерации» [Электронный ресурс]. - Режим доступа: http://www.consultant.ru/law/review/lawmaking/reglduma/

${ }^{182}$ См. подробнее: Совет Федерации Федерального Собрания Российской Федерации. Доклад «О состоянии законодательства в российской Федерации» // СПС Консультант Плюс. 


\section{Правотворчество в Российской Федерации}

ния, а значит, это будет способствовать повышению качества законотворческой деятельности ${ }^{183}$. Отсутствует и регламентация предварительного этапа конституционного правотворчества, что может быть устранено путем издания федерального закона «О конституционном мониторинге»184. Наиболее существенным недостатком процессуальной стороны законотворчества является отсутствие научно обоснованной концепции развития законодательства и его взаимосвязи с экономическими, политическими и социальными реформами ${ }^{185}$;

3) связано с урегулированием наиболее важных, имеющих основополагающее значение для государства общественных отношений. Издание каждого закона должно быть научно обоснованным, вытекать из объективной потребности в нем, а не быть единственным средством правового регулирования общественных отношений. Как справедливо отметил Ю.А. Тихомиров в своем выступлении на круглом столе 26.01.2015 г. на тему: «Актуальные проблемы правотворчества и проект федерального закона «О нормативных правовых актах в Российской Федерации» нарастание потока нормативных правовых актов сверху вниз не всегда приводит к положительному результату. В связи с этим представляют интерес локальные нормативные правовые акты, поскольку чем больше эффект саморегуляции с их помощью, тем меньше необходимость в принятии законов, указов, постановлений и инструкций ${ }^{186}$. Вместе с тем, наиболее значимыми общественными отношениями, регулируемые законами являются: вопросы в сфере конституционного регулирования; отношения, определяющие порядок образования и функционирования органов государственной власти и местного самоуправления; отношения связанные с закреплением прав, свобод и обязанностей человека и гражданина; а также порядок создания и деятельности общественных организаций; вопросы обороны и безопасности; бюджета; международные отношения; основные вопросы в области экономики и др.;

4) издаваемые в его результате правовые акты обладают высшей юридической силой и общеобязательны, то есть должны исполняться всеми государственными органами, должностными лицами, гражданами, общественными организациями и юридическими лицами без исключения;

5) направлено на стабилизацию общественных отношений на длительную перспективу, что должно способствовать уверенному развитию

\footnotetext{
${ }^{183}$ См. подробнее: Мартьянов Г. А. Теория и методика оптимизации участия законодательных (представительных) органов государственной власти субъектов Российской Федерации в федеральном законотворческом процессе: автореф. дис. ... к.ю.н. - СПб., $2010-$ С. 15-18, Борисов А.С. Некоторые проблемы современного правотворчества в России / А.С. Борисов, П.А.Меркулов // Социум и власть. - 2015. - №3 (53). - С. 68.

${ }^{184}$ См. подробнее: Дерхо Д.С. К вопросу о необходимости нормативной регламентации предварительного этапа конституционного правотворчества // Апробация. - 2015. - №8 (25). - C. 27-30.

185 Мазуренко А.П. К вопросу о методах правотворческой политики // ЮристъПравоведъ. - 2007. - №5. - С. 26.

${ }^{186}$ Выступление Ю.А. Тихомирова на круглом столе // Журнал российского права. 2015. - №3. - C. 147.
} 
всего спектра регулируемых отношений, особенно экономических, финансовых и социальных. Стабильность права, законодательства в первую очередь, означает постоянство всех его системообразующих факторов целей, основных принципов функционирования, пространственновременной идентичности, внутренних и внешних системных связей, и, конечно, нормативно-правового материала. Отклонение от этих параметров ведет к утрате стабильности ${ }^{187}$.

Стабильность закона обеспечивается особым порядком его принятия, изменения и отмены только в случаях большой общественной необходимости. Однако Российская Федерация в настоящее время находится в состоянии переходного периода и многие, нуждающиеся в правовом регулировании, общественные отношения характеризуются неустойчивостью. Их динамика предопределяется противоречиями развития общества переходного периода, что, в свою очередь, требует обновления и дополнения законодательства. Нестабильность регулируемых общественных отношений обусловливает нестабильность законодательства ${ }^{188}$. «Законы должны приниматься с изначальным расчетом на максимально возможную продолжительность действия во времени за счет всесторонней продуманности, а не за счет вносимых изменений» ${ }^{189}$.

Имеются и другие предпосылки нестабильности, издаваемых в процессе законотворчества нормативных правовых актов:

a) отсутствие научной базы ${ }^{190}$ его осуществления;

б) недостаточность правового урегулирования законотворческого процесса;

в) поспешность принятия законодательных правовых документов, что исключает их глубокую проработку и апробацию (официальное одобрение, основанное на проверке, испытании и широком обсуждении с участием общественных организаций);

г) наличие лоббирования и коррупциогенности;

д) низкий профессионализм субъектов законотворчества;

е) отсутствие плановой разработки и принятия законов, что создает противоречивость и несогласованность отдельных правовых норм в нормативных актах, принятых с нарушением правил последовательности их издания и т. д. Таким образом, нестабильность законотворческих решений обуславливают как объективные, так и субъективные факторы;

1) формирует законодательную базу страны как постоянно развивающуюся правовую систему, обеспечивая поддержание правового комфорта для субъектов правоприменения. Это означает, что состояние правовой системы находится в процессе постоянного совершенствования,

${ }^{187}$ Сорокин В.В. Концепция эволюционного преобразования правовых систем в переходной период. - Барнаул, 2002. - С. 95.

${ }^{188}$ Рыбаков В.А. Правотворчество в переходной период развития права. // Юридическая техника. - 2015. - №9. - С. 653.

${ }^{189}$ Рыбаков В.А. Указ. соч. - С. 654.

${ }^{190}$ См. подробнее: Желдыбина Т.А. О судебном правотворчестве. Вестник Саратовской государственной юридической академии. - 2015. - №2 (103). - С. 26. 


\section{Правотворчество в Российской Федерации}

что издаваемые законодательные акты содержат простые, доступные понятные правовые нормы, сформирован четкий терминологический аппарат, присущий данной отрасли права, отсутствуют внутренние и внешние противоречия норм права, сведены к минимуму отсылки к другим нормативным правовым актам, отсутствуют пробелы правового регулирования и т. д. Одним словом, законотворчество должно обеспечивать «создание наилучших условий и максимальных удобств для пользования и правильного применения законов, для отыскания необходимых правовых положений, достижения их полноты, точности, легкой обозримости и компактности» ${ }^{191}$.

При формировании норм права в процессе законотворческой деятельности необходимо учитывать также определенный набор обязательных требований, предъявляемых к ее результатам, что будет отражать их качественную содержательную сторону. В юридической литературе называются такие, как:

1) соответствие норм права прогрессивно развивающимся общественным отношениям, социальным интересам и потребностям;

2) правильность определения необходимости правовой регламентации тех или иных общественных отношений;

3) законность самих нормативных актов, их соответствие нормами международного права, конституции, другим вышестоящим актам, соответствие норм права принятым в обществе нормами морали, обычаям, идеям добра, справедливости, гуманизма, общечеловеческим ценностям, ясность, понятность, доступность правовых предписаний;

4) правильность определения уровня правовой регламентации;

5) отсутствие противоречий между нормами права;

6) их систематизированность;

7) наличие необходимых служебных норм, характер юридических санкций $^{192}$.

Таким образом, законотворчество характеризуется как присущими только ему видовыми признаками, отличающими его от иной правотворческой деятельности, так и обширной системой требований, раскрывающих качественный уровень, издаваемых законодательных актов. При этом качественные показатели законотворчества являются общими для всех видов правотворчества, поскольку его результаты (законодательство) составляют основу последующей правотворческой деятельности и, следовательно, заложенный в нем потенциал обуславливает уровень издаваемых подзаконных нормативных правовых актов.

В соответствии с выработанной нами системой видов правотворчества (см. параграф 2.1 настоящей работы) законотворчество может быть референдумным, непосредственным и делегированным. Рассмотрим последовательно каждый из названных видов.

\footnotetext{
191 Ломакина И.Б. Методология правотворчества: теория и практика, направления совершенствования / И.Б. Ломакина, Д.С. Тэпс // Пробелы в российском законодательстве. 2012. - №4. (29). - С. 294.

192 Остапович И.Ю. Сущность и особенности неюридической формы воздействия на правотворчество // Мир науки, культуры, образования. - 2011. - №4 (29). - С. 294.
} 
Высшим выражением воли народа являются референдум и свободные выборы (ч. 3 ст. 3 Конституции РФ). Референдум - это всенародное голосование с целью выявить общественное мнение по какому-либо важному государственному вопросу ${ }^{193}$.

Референдум, как вид законотворчества, - это процесс утверждения (или отклонения) в ходе тайного голосования граждан проекта какоголибо правового документа. Референдумы могут иметь федеральный, региональный и местный уровень (ст. 32 и ст. 130 Конституции РФ). Порядок проведения референдумов в Российской Федерации установлен федеральным конституционным законом «О референдуме Российской Федерации» №5-ФКЗ от 28.06.2004 г., который не предусматривает его частое использование в жизни государства ${ }^{194}$.

Референдум Российской Федерации может быть проведен по законопроектам, действующим законам и другим вопросам государственного значения. Референдум Российской Федерации наряду со свободными выборами является высшим непосредственным выражением власти народа.

Вопрос, выносимый на референдум, не должен противоречить Конституции РФ, ограничивать, отменять или умалять общепризнанные права и свободы человека и гражданина, конституционные гарантии реализации таких прав и свобод.

Важное значение имеет правильная постановка вопроса, который должен лежать в основе всенародного опроса. Закон о референдуме требует, чтобы вопрос, выносимый на референдум, был сформулирован однозначно, когда исключается возможность его множественного толкования, чтобы полностью исключалась неопределенность правовых последствий принятого на референдуме решения. Это положение является гарантией реализации истинного волеизъявления народа. Закон о референдуме предусматривает и обязательность его проведения, если определенный вопрос в соответствии с международным договором Российской Федерации подлежит вынесению на всенародные голосования. При этом принятие федеральным органом государственной власти (иными государственными органами) решения по этому вопросу не допускается.

Если на референдум выносится законопроект, то Центральная избирательная комиссия обеспечивает своевременное опубликование его текста в целях всенародного обсуждения. Одновременно указанная комиссия оказывает содействие средством массовой информации в проведении мероприятий, направленных на разъяснение содержания законопроекта, подлежащего утверждению на референдуме.

Таким образом, референдумное законотворчество представляет собой форму всенародного одобрения уже подготовленного проекта какоголибо законодательного акта. При этом, как показывает практика проведения референдума по утверждению ныне действующей Конституции

${ }^{193}$ Булыко А.Н. Большой словарь иностранных слов. - М., 2010. - С. 501.

${ }^{194}$ Собрание законодательства РФ. 


\section{Правотворчество в Российской Федерации}

Российской Федерации, несовершенство выносимого на всенародное голосование правового документа не может быть помехой для его одобрения. Повысить качество, выносимых на референдум проектов законодательных актов, возможно только в случае наличия не одного, а двух и более альтернативных правовых документов, по которым проводится всенародное голосование. Закон о референдуме допускает такую возможность.

Следует сказать, что в юридической литературе высказана иная точка зрения на референдумное законотворчество. Так, Д.С. Дерхо пишет, что «ныне действующая Конституция РФ принята посредством всенародного голосования (референдума), поэтому не является результатом деятельности какого-либо государственного органа, а наделена силой Основного закона страны путем прямого проявления народной воли» ${ }^{195}$. Автор опускает вопрос о том, как готовился проект Конституции РФ. Получается, что народ реализовывал не только процессуальную фазу ее принятия, что очевидно, а и нормотворческую, что не соответствует действительности, и это тоже очевидно.

Референдумное законотворчество может иметь объективную необходимость лишь в тех случаях, когда возникает сложная парламентская борьба различных партий вокруг конкретного законопроекта и в качестве компромисса принимается решение о проведении референдума. При этом все заинтересованные стороны надеются, что в ходе подготовки к референдуму они сумеют завоевать симпатии граждан и спорный правовой документ будет принят с учетом их предложений. Поэтому референдум с точки зрения повышения качественных характеристик законодательных актов, одобряемых народом на нем, не может быть эффективным, если нет их альтернативных вариантов, либо не осуществляется воплощение предложений, высказанных гражданами, в нормах законопроекта.

Все это свидетельствует о том, что референдумное законотворчество не может стать генератором качественного законодательства. Сомнительным является и значение референдума в формировании действенной системы права, поскольку качество закона не зависит от количества голосов, отданных гражданами в его поддержку. Не может референдум быть и эффективным средством для решения правовых конфликтов. Так, М.В. Баглай считает, что использование различного уровня референдумов в политической жизни страны не может выполнить умиротворяющую роль, скорее может быть наоборот ${ }^{196}$.

Таким образом, референдумное законотворчество - это исключительная форма издания законодательных актов, когда нет возможности выработать их соответствующими представительными органами, либо когда его необходимость вытекает из прямого указания закона или международного договора Российской Федерации. Вместе с тем, это весьма

\footnotetext{
195 Дерхо Д.С. К вопросу о сущности и динамике конституционного правотворчества в Российской Федерации // Вестник ЮУрГУ. - 2014. - Т. 14. - №1. - С. 81.

${ }^{196}$ Баглай М.В. Конституционное право Российской Федерации. - М., 2000. - С. 107. 
перспективное направление повышения качества и эффективности законодательства, если в процессе совершенствования референдумное законотворчество будет сопровождаться серьезной работой по учету предложений граждан либо осуществляется на альтернативной основе.

Вторым видом законотворчества является непосредственная правотворческая деятельность органов представительной власти, для которых разработка и принятие законов - основная функция осуществления властных полномочий.

Законодательные акты, действующие на всей территории стран, вырабатывают Государственная Дума и Совет Федерации Федерального Собрания Российской Федерации. Законодательство субъектов федерации - высшими представительными органами этих территориальных образований. Законотворческий процесс урегулирован соответствующими регламентами Государственной Думы ${ }^{197}$ и Совета Федерации ${ }^{198}$, а также регламентами деятельности представительных органов субъектов федерации ${ }^{199}$.Законодательные акты, указанных представительных органов, имеют высшую юридическую силу на своей территории и принимаются по усложненным процедурам с целью обеспечения их качества и стабильности. Правотворчество высших представительных органов иногда называют парламентским ${ }^{200}$ с учетом того, что независимо от их официального названия, по своим функциям все эти государственные учреждения предназначены для разработки и принятия законов. В Российской Федерации образовано 86 парламентов: Федеральное Собрание - парламент Российской Федерации и региональные парламенты представительные органы 85 ее субъектов.

Многообразие субъектов, занимающихся непосредственно законотворчеством, а также обособленность законодательного регулирования их деятельности порождает серьезные трудности в формировании единой правовой системы страны. Возникают противоречия между нормами различного уровня правового регулирования, закрепляются нестандартные подходы юридического урегулирования одинаковых по своей сущности общественных отношений, нарушается системность законодательства, допускаются пробелы в праве и даже ошибки не только техникоюридического характера, но и содержательного. К числу таковых, по справедливому мнению, М.С. Белоусовой, относятся следующие: неверное установление предмета правового регулирования, произвольное определение его способов, неправильное закрепление характера и объема полномочий субъектов права, несбалансированность норм публичных институтов и правового поведения, недооценка вероятных коллизий,

\footnotetext{
197 [Электронный ресурс]. - Режим доступа: http://www.consultant.ru/law/review/lawmaking/ reglduma/

198 [Электронный ресурс]. - Режим доступа: http://www.consultant.ru/law/review/lawmaking/ reglsovet/

${ }^{199}$ См., например: Устав Сахалинской области от 09.07.2001 №270 (в ред. от 23.09.2013 №88-30) // СПС Консультант Плюс.

200 Фомичева О.А. К вопросу о содержании понятия и видовой классификации своевременного правотворчества / О.А. Фомичева, Д.В. Пахомова // Вестник Московской финансово-юридической академии. - 2007. - №3. - С. 257.
} 


\section{Правотворчество в Российской Федерации}

нарушение баланса законов и подзаконных актов, формирование ложных «юридических образов» субъектов права ${ }^{201}$.

Общим недостатком законотворчества (и всего правотворчества в целом) является то, что оно ориентировано на принятие отдельных законов (как и отдельных подзаконных актов, издаваемых в соответствии с ними), а не на формирование единой непротиворечивой правовой системы $^{202}$. По словам Л.Б. Тиуновой, «законодательная деятельность скорее хаотична, нежели планомерна или системна: она одновременно преследует конкретно-исторические цели и выражает волю конкретных субъектов правотворчества» ${ }^{203}$. Подобного мнения придерживаются В.Н. Лопатин, указывая на такие недостатки законотворчества как несоблюдение приоритетов правового регулирования, принятия новых законов без их увязки с существующим законодательством и нормами международного права ${ }^{204}$, а также Е.А. Звягина, отметившая пробельность и коллизионность федерального и регионального законодательства, несформированность правового поля правотворчества в области местного самоуправления ${ }^{205}$.

Учитывая эти и им подобные обстоятельства, в юридической литературе все настоятельнее озвучиваются предложения по кардинальному разрешению всех законотворческих (правотворческих) проблем. В частности, А.В. Дербина считает, что созрела крайняя необходимость выработки комплексного нормативного блока, направленного на четкое регулирование правотворческой деятельности всех без исключения субъектов правотворчества. Законодательно требуется определить общие принципы взаимодействия высших представительных органов власти федерации и ее субъектов, регулирующих отношения между ними как институциональные составляющие единой законодательной власти. Для этого необходимо регламентировать «правосубъектность и правовой статус субъектов правотворческой деятельности, принципы их деятельности, порядок взаимодействия со всеми федеральными и региональными органами, а также органами местного самоуправления» ${ }^{206}$. Аналогичную позицию занимают и многие другие авторы ${ }^{207}$.

\footnotetext{
${ }^{201}$ Белоусова М. С. Правотворческая функция российского государства. // Вестник Челябинского государственного университета. - 2010. - №19 (200). Право. - Вып. 24. - С. 12.

${ }^{202} \mathrm{C}$. подробнее: Современное правотворчество: новые возможности для общества и государства // Журнал российского права. - 2015. - №3. - С. 151.

203 Тиунова Л.Б. Системные связи правовой действительности: методология и теория. СПб., 1991. - С. 86.

204 Лопатин В.Н. Конституционная законность и проблемы нормотворчества в России // Журнал российского права. - 2004. - №5. - С. 8.

205 Звягина Е.А. Правотворчество в области местного самоуправления (на примере Пензенской области) // Известия ПГПУ. - 2007. - №3 (7). - С. 61.

206 Дербина А.В. Правосознание как элемент правовой позиции субъекта правотворчества: автореф. дис. ... к.ю.н. - Самара, 2011. - С. 16.

${ }^{207}$ См., например: Соловьев О.Г. О нормативном закреплении основных требований и правил законодательный техники // Вестник ЯрГУ. Серия Гуманитарные науки. - 2010. - №4 (14). - С. 44; Бондаренко О.В. Судебная практика и уголовное правотворчество: автореф. дис. ... к.ю.н. - М., 2013. - С. 12.
} 
Высказана даже идея принятия федерального закона «О конкретизации права» ${ }^{208}$. Однако она не нашла поддержки в юридической науке, поскольку пока не принят даже закон «О нормативных правовых актах в Российской Федерации», в котором отчасти может быть решена и проблема конкретизации норм права.

Таким образом, анализ высказанных в литературе критических замечаний, относящихся к непосредственному законотворчеству, показывает, что подавляющее большинство из них связано с выработкой норм права, а не с процессом их юридической актуализации (правилами возведения в закон). И это вполне объяснимо. До сих пор законотворческая практика руководствуется лишь накопленным опытом создания правовых норм. Надежных теоретических разработок, охватывающих весь процесс их формирования (с момента возникновения потребности в правовом регулировании конкретных общественных отношений и до ее разрешения в виде юридической нормы) нет. Максимально на что могут рассчитывать субъекты законотворчества - это ориентироваться на теоретическую модель определенных норм, разработанной в Модельных кодексах ${ }^{209}$. Научное значение такого модельного законотворчества состоит в разработке развернутых теоретических представлений о том, каким образом (по содержанию и по форме) должны быть решены проблемы соответствующей отрасли права на перспективу ${ }^{210}$. То есть и модельное (теоретическое и практическое) законотворчество не раскрывает методику, или хотя бы общие подходы, сущности процесса выработки норм права. Отсутствие научно обоснованных способов познания социальноправовой действительности, надежного правового механизма поэтапной выработки юридического регулятора общественных отношений в виде нормы права и является первопричиной законодательной лихорадки, проявляющейся бесконечным количеством разнообразных недостатков. Но упрекать в этом следует, прежде всего, субъектов законотворчества, которые неохотно поддерживают связь с юридической наукой. Теория правотворчества в настоящее время накопила значительные знания в области выработки законодательных норм, которые в последующем возможно будут воплощены в правотворческий документ по урегулированию данного процесса. А пока что имеются самые общие правовые нормы, отражающие процесс нормообразования.

В настоящее время сформировалось обоснованное представление о том, что создание правовых норм в законотворчестве состоит из трех этапов:

1) предпроектного, когда выявляется потребность в регулировании определенных общественных отношений;

\footnotetext{
${ }^{208}$ См. подробнее: Ершов В.В. Конкретизация Конституции России: теоретические и практические проблемы // Российское правосудие. - 2013. - №12. - С. 22.

209 См., например: Уголовный закон. Опыт теоретического моделирования / Под ред. В.Н. Кудрявцева и С.Г. Келиной. - М., 1987.

${ }^{210}$ Там же. С. 4.
} 


\section{Правотворчество в Российской Федерации}

2) проектного, включающего в себя подготовку концепции законодательного акта, составление текста законопроекта, согласование проекта и проведение правовой экспертизы;

3) принятие закона путем обсуждения законопроекта в ходе осуществления установленных регламентом процедур.

На первом этапе происходит осознание необходимости урегулирования правовыми средствами определенного круга социальных связей либо внесения изменений в действующий нормативный массив. Алгоритм выявления данной потребности в классическом виде состоит из следующих шагов: обнаружение признаков проблемной ситуации; сбор информации, относящейся к проблеме; анализ проблемной ситуации на основе собранной информации; принятие решения о разработке правового документа ${ }^{211}$.

Данный этап является одним из наиболее важных, поскольку предопределяет не только вид законодательного акта, но также его содержание, форму, структуру и качество. Важность данного этапа обусловлена также и тем, что он практически не урегулирован правом и, по сути, оставлен на полное усмотрение субъекта правотворчества. Так, обнаружение признаков проблемной ситуации возможно в результате анализа поступающих в законотворческий орган предложений, заявлений и жалоб граждан. Однако если аналитическая работа по этой информации не налажена, то вероятность выявления потребности в правовом регулировании проблемной ситуации снижается. Сбор информации может состоять в целенаправленном социологическом исследовании общественноправовых тенденций в развитии государства.

Но если такая работа не проводится, то субъект законотворчества не сможет досконально изучить проблемную ситуацию и даже если будет разработан и принят закон по ее урегулированию, высока вероятность его малой эффективности и недолговечности. Для выработки качественных законопроектов необходимо проводить постоянный мониторинг действующих законов. И по устоявшемуся правилу изучения правоприменения должно осуществляться в первую очередь на предпроектным этапе нормотворчества с целью формирования качественной, непротиворечивый системы нормативных актов ${ }^{212}$.

Таким образом выявление потребности в правовом урегулировании проблемной ситуации осуществляется не по случайному стечению обстоятельств, а в результате кропотливый целенаправленной работы по сбору информации, ее тщательному анализу, а также с учетом результатов мониторинга действующего законодательства. Для улучшения предпроектного этапа законотворчества учеными предлагается урегулировать его нормами права ${ }^{213}$. И с этим следует согласиться.

\footnotetext{
${ }^{211}$ См. подробнее: Москалькова Т.Н. Нормотворчества: науч.-практ. пособ. / Т.Н. Москалькова, В.В. Черников. - М.: Проспект, 2011. - С. 138.

${ }^{212}$ Малько А.В. Технико-юридические основы правотворчества / А.В. Малько, А.Н. Бабенко // Журнал российского права. - 2012. - № 8. - С. 127.

${ }^{213}$ См., например: Дерхо Д.С. К вопросу о необходимости нормативной регламентации предварительного этапа конституционного правотворчества // Апробация. - 2015. - №8 100
} 
Второй этап выработки нормы права (правового института или отдельного законодательного акта) связан с подготовкой законопроекта. Регламент Государственной Думы Российской Федерации устанавливает лишь формальные (процессуальные) требования, сопровождающие поступления законопроекта для его обсуждения и принятия (ст. 105), это:

1) пояснительная записка к законопроекту, которая должна содержать предмет законодательного регулирования; концепцию предлагаемого законопроекта и мотивированное обоснование необходимости его принятия;

2) текст законопроекта;

3) перечень законов и иных нормативных правовых актов, подлежащих признанию утратившими силу, приостановлению, изменению или принятию в связи с созданием данного закона;

4) финансово-экономическое обоснование, если реализация закона потребует материальных затрат.

Документы, прилагаемые к законопроекту, имеют важное нормобразующее значение, поскольку они характеризуют его качественные особенности.

Предмет законодательного регулирования показывает круг общественных отношений, которые будут регламентированы законом. Это та сфера общественных отношений, на которую распространяется право, и которая находится под его юрисдикцией. Он является главным материальным критерием разграничения норм права по отраслям, так как имеет объективное содержание, предопределен самим характером общественных отношений и не зависит в принципе от воли законодателя ${ }^{214}$. Формируя предмет законодательного регулирования, автор законопроекта тем самым дает возможность оценить его соответствие разработанным в проекте правовым предписаниям, а также его необходимость. На основе анализа предмета правового регулирования можно установить степень воздействия государства на общественные отношения. «Если отношения, объективно не нуждаются в правовом регулировании, но фактически получили его, то это означает, что государство излишне вмешивается в межличностные отношения, не оставляя личности пространства для самовыражения и саморегулирования. К беспорядку в обществе приводят ситуации, когда общественные отношения требуют правового регулирования в силу социальной значимости... но не получают его» ${ }^{215}$.

Концепция законопроекта включает в себя характеристику предмета и цели, содержит основные положения, структуру и предполагаемый результат его действия.

Создание норм права, их текстуального выражения, по сути, возлагается на разработчиков законопроекта. Правотворческий орган при под-

(35). - C. 30 .

214 Теория государства и права: курс лекций / под ред. Н.И. Матузова, А.В. Малько. - М., 1997. - C. 353-354.

${ }^{215}$ Соловьев С.Г. Понятие предмета правового регулирования и его взаимосвязь с другими юридическими категориями // Вестник Пермского университета. - 2012. - Вып. 1 (15). - С. 49. 


\section{Правотворчество в Российской Федерации}

готовке текста законопроекта использует собранную информацию на предпроектном этапе, изучает и учитывает практику применения законодательства по теме проекта, выявляет общественную потребность в правовом регулировании, причины и условия влияющие на эффективность законодательства, использует поступившие предложения от граждан, общественных организаций и органов власти, рекомендации научных учреждений, ученых и специалистов, а также учитывает опыт правового регулирования в других государствах.

Выработка конкретных норм права - это выбор категорий, понятий и правовых дефиниций в проектах законов и иных нормативных правовых актов, что самым непосредственным образом касается содержания акта, его идеологии и методов решения задач государственного значения через механизм правового регулирования ${ }^{216}$.

Текстуальное оформление каждой правовой нормы субъектом законотворчества осуществляется путем выбора разработанных юридической практикой или теорией права модели их образования. Это может быть общепризнанная модель практического выражения правовых предписаний по регулированию определенных общественных отношений. Она используется как удобная текстуальная форма заключения юридических правил в нормы закона. Это может быть и разработанная теорией правотворчества идеализированная модель правовой нормы, которая используется как примерный образец, схема, в соответствии с которой правотворческий орган вырабатывает свой вариант конкретной нормы, пригодной для правового регулирования в данном случае. В первом варианте норма права полностью воспроизводит свою модель, меняя лишь текстуальную форму, а во втором - от идеализированной модели воспринимаются только некоторые её элементы, необходимые для формирования правовой нормы соответствующего содержания.

Вместе с тем не исключается и третий вариант, когда норма права создается как результат самостоятельной творческой деятельности субъекта законотворчества в образе коллегиального органа или физического лица. Но, как отмечается в юридической литературе, сегодня все реже упоминаются отдельные личности, как авторы проектов нормативных актов, потому что все чаще наблюдается копирование содержание таковых из известных законов других стран или модельных законов ${ }^{217}$. Представляется, что это объективный фактор, поэтому законотворческий процесс в целом должен быть процессуально регламентирован таким образом, чтобы личное в нормообразовании не приводило к произволу, работало на пользу всему процессу и способствовало созданию эффективного законодательства, служащего интересам всего общества ${ }^{218}$. Ни-

\footnotetext{
${ }^{216}$ Бачило М.Л. О методологии юридической техники законодательства. // Государство и права. - 2006. - №6. - С. 18.

${ }^{217}$ Баранов В.М. Личное в правотворчестве: утопия, антропологические ресурс или необходимое технико-юридическое средство повышения качества / В.М. Баранов, В.В. Трофимов // Вестник Нижегородской академии МВД России. - 2015. - №2 (30). - С. 11.

${ }^{218}$ Там же. С. 16.
} 
велирование личности в законотворчестве обуславливается и постоянно возрастающим объемом исследовательских работ при подготовке законопроектов, которую выполняют коллегиально в целях повышения их качества.

Нормотворчество, при всей его подверженности следованию рационализму, использованию наработанных моделей воплощения юридических правил в текстуальные формы, должно одновременно осуществляться с учетом всех требований юридической техники. Эти требования универсальным и могут быть применены при издании самых разнообразных норм всех отраслей права ${ }^{219}$. К числу таковых принято относить следующие:

1) точность и определенность юридической формы (формулировок, выражений и отдельных терминов закона с целью достижения наибольшего соответствия замысла законодателя и воплощением его в законодательной формуле);

2) ясность и доступность языка закона для тех, на которых он распространяет свое действие;

3) полнота регулирования соответствующей сферы отношений, отсутствие в нем пробелов и упущений;

4) конкретность регулирования, четкое определение всех его необходимых элементов, борьба с декларативностью законов;

5) максимальная экономичность, оптимальная емкость, компактность законодательных формул;

6) системное построение права, его цельность, сбалансированность, логическая последовательность изложения мысли законодателя;

7) унификация, единообразие формы и структуры законодательных актов, способов изложения правовых предписаний ${ }^{220}$.

При использовании в различных законах одних и тех же терминов в одинаковом значении необходимо дать им и одинаковые определения, отражающие их единый смысл. Такая унификация юридической терминологии позволяет достичь непротиворечивых результатов языкового оформления законотворческих решений ${ }^{221}$.

После подготовки проекта законодательного акта наступает третий этап законотворчества. Утвержденный проект в установленном порядке направляется для его обсуждения и принятия субъекту законотворчества, где он окончательно дорабатывается в ходе трех чтений. Но это уже процессуальная сторона законотворчества, о которой подробно бу-

\footnotetext{
${ }^{219}$ См. подробнее: Ломакина Ч.Б. Методология правотворчества: теория и практика, направления совершенствования / Ч.Б. Ломакина, Д.С. Тэпс // Пробелы в российском законодательстве. - 2012. - №4. - С. 25-26.

${ }^{220}$ По мнению Е.В. Каменской, необходимо принять федеральный закон, закрепляющий правила правотворческой техники и порядок их применения во всех видах правотворческих процесса. См. подробнее: Каменская Е.В. Региональное правотворчество в Российской Федерации: автореф. дис. ... к.ю.н. - М., 2005. - С. 12.

${ }^{221}$ См. подробнее: Туранин В.Ю. Теория и практика использования законодательных дефиниций: монография. - М., 2009. - С. 51.
} 


\section{Правотворчество в Российской Федерации}

дет изложено в главе 3 этой работы.

Таким образом, подготовка законопроекта представляет собой этап нормообразования будущего законодательного акта. Он сопряжен с выработкой юридических правил регулирования общественных отношений в соответствии с поставленными целями законодателя на основании заданных принципов и методов законотворчества. Поэтому выбор норм права для правового регулирования носит целенаправленный характер, поскольку они есть не что иное, как систематизированное использование правовых категорий, понятий и дефиниций для воплощения в законодательном акте с их помощью замысла субъекта правотворчества. Создание норм права - это деятельность по использованию накопленного практического опыта их текстуального технико-юридического оформления в сочетании с разработанными теорией права научными рекомендациями в сфере законотворчества.

Третьим видом издания законодательных актов является делегированное законотворчество.

В юридической литературе не выработан единый подход в понимании делегированного законотворчества. Одни авторы понимают его в узком смысле. Например, по мнению А.В. Малько, делегированное правотворчество представляет собой нормотворческую деятельность органов исполнительной власти, прежде всего правительства, осуществляемой по поручению парламента в связи с необходимостью оперативного решения определенных проблем нормативных актов, входящих в компетенцию представительного органа 222 . Из этого видно, что полномочия предоставляются для устранения дефектов нормативных актов более высокой юридической силы с помощью конкретизирующего правового регулирования органов исполнительной власти соответствующей компетенции.

Имеется и более широкий подход в понимании делегированного правотворчества. Так, О.А. Фомичева и Д.В. Пахомова под делегированным правотворчеством понимает «деятельность государственных органов или должностных лиц, а также отдельных негосударственных организаций, связанную с принятием нормативно-правовых актов на основании поручения иного органа или должностного лица. Делегирование полномочий допускается только по определенному кругу вопросов, при этом вышестоящий орган может передавать полномочия только в пределах своей компетенции, то есть не может передать больше полномочий, чем сам обладает» ${ }^{223}$. При таком подходе делегированное правотворчество связывается не только с оперативным устранением проблем нормативных правовых актов, изданных представительным органом власти, но и с предоставлением полномочий по изданию нормативных актов регулятивного характера в иных целях. Фактически речь идет о приобретении более высоких правотворческих функций органом нижестоящего

\footnotetext{
${ }^{222}$ Малько А.В. Теория государства и права. - М., 1999. - С. 146.

${ }^{223}$ Фомичева О.А. К вопросу о содержании понятия и видовой классификации современного правотворчества / О.А. Фомичева, Д.В. Пахомова // Достижения вузовской науки. 2014. - №10. - C 253-262.
} 
статуса за счет полномочий вышестоящего. Такая позиция авторов не противоречит законодательству и сложившейся практике принятия правотворческих решений.

И в первом и во втором случаях речь идет о делегированном правотворчестве на уровне подзаконного нормотворчества, поскольку исполнительные органы власти даже при наличии императивного поручения от законодательной власти не могут издавать нормативные правовые акты в виде законов.

Однако действующее законодательство не исключает, а реально допускает возможность осуществления именно делегированного законотворчества. Проблема состоит в том, что в настоящее время нет четкости в регулировании пределов правотворчества с учетом разграничения полномочий между органами власти разных территориальных уровней ${ }^{224}$. В соответствии со ст. 76 Конституции РФ по предметам совместного ведения Российской Федерации и ее субъектов издаются федеральные законы и принимаемые в соответствии с ними законы и иные нормативные правовые акты субъектов федерации. Но если субъекту федерации будет делегировано право по какому-либо конкретному вопросу осуществить правовое регулирование самостоятельно, хотя это и касается предмета совместного ведения, такое правовое регулирование может быть связано с изданием закона субъекта федерации. Следовательно, и в теоретическом и в практическом аспекте делегированное законотворчество допускается.

Таким образом, в зависимости от органа, которому поручается оперативное устранение возникшей правовой неурегулированности, а также вида нормативного правового акта, принимаемого в связи с этим, возможно осуществление как делегированного законотворчества, так и делегированного правотворчества.

Представляется, что законодательно необходимо урегулировать пределы правотворчества на всех его уровнях с четким определением обстоятельств, дающих право на делегирование правотворчества одним субъектом правотворчества другому. По нашему мнению, такими обстоятельствами могут быть только два их вида:

1) необходимость оперативного устранения пробела в праве, поскольку это создает проблемы правоприменения, ошибки в судебной практике, снижает эффективность действующего закона;

2) утрата статуса первостепенной важности определенной группы общественных отношений в связи с изменением социальноэкономической и политической ситуации в стране, что обуславливает понижение рейтинга их правовой регламентации. Это дает право на урегулирование такого рода общественных отношений, потерявших свое прежнее значение, субъектом более низкого ранга без снижения качества правового регулирования в целом.

Поводом делегирования полномочий одного субъекта правотворчества другому могут быть:

1) обнаружение пробела в праве, оперативное устранение которого

${ }^{224}$ Современное правотворчество: новые возможности для общества и государства // Журнал российского права. - 2015. - №3. - С. 151. 


\section{Правотворчество в Российской Федерации}

возможно лишь минуя длительный процесс законотворчества;

2) достоверное установление факта перемены социальноэкономической ситуации в стране, изменение вектора оценки происходящих реальных событий, свидетельствующих о потере актуальности применяющихся подходов в правовом регулировании тех или иных общественных отношений. Именно при наличии данного обстоятельства законотворческому органу субъекта федерации может быть делегировано право на самостоятельное решение вопросов, ранее принимавшихся совместно с Российской Федерацией.

Подводя итог проведенного исследования особенностей законотворчества можно сделать следующие выводы:

1. Выработка норм права в ходе законодательной деятельности регламентирована недостаточно, особенно на предпроектном и проектном этапах. Это обуславливает различную степень научного познания предмета правотворчества и в конечном счете порождает значительные колебания качества принимаемых законодательных актов.

2. Референдумное законотворчество - это способ утверждения подготовленного законопроекта в обход парламента в связи с его отсутствием либо, когда он не отражает волю народа, либо в случае вынесения парламентом решения об утверждении законопроекта таким путем. Всенародное голосование отражает лишь отношение граждан к законопроекту, оно не может повлиять на его качество при отсутствии альтернативного варианта такого законопроекта.

3. Непосредственное законотворчество представляет собой формирование норм права в ходе предпроектного и проектного нормотворчества с последующей их доработкой при обсуждении в установленных законом процедурах. Непосредственное законотворчество осуществляют высшие представительные органы власти, для которых издание законов, является основной функцией. Создание норм права - это деятельность по текстуальному оформлению воли законодателя в правовые формы.

4. Делегированное законотворчество - передача законотворческих полномочий нижестоящему субъекту правотворчества с целью оперативного устранения пробелов в праве либо в связи с понижением рейтинга правовой регламентации определенной группы общественных отношений. Делегированное законотворчество может быть в форме подзаконного правотворчества либо законотворчества субъекта федерации. 


\section{§2.5. ПОДЗАКОННОЕ ПРАВОТВОРЧЕСТВО}

Существует огромный массив общественных отношений, для упорядочения которых нет необходимости использовать законотворчество. Регулирование таких общественных отношений осуществления нормами подзаконного правотворчества, которые принимаются и вводятся в действие органами государства, не относящиеся к его высшим представительным органам. Подзаконное правотворчество необходимо для обеспечения применения закона. Это связано с тем, что законодательные нормы зачастую носят слишком общий, абстрактный характер, что не всегда позволяет их применение без дополнительной конкретизации нормами подзаконного правотворчества. Кроме того, имеется множество жизненных ситуаций, регулирование которых целесообразно передать на более низкий уровень в соответствии с компетенцией субъектов подзаконного правотворчества. Тем самым будет обеспечена разработка правил регулирования данной жизненной ситуации органом, который более квалифицировано может их выработать, поскольку обладает необходимой компетенцией, и в более короткий срок, чем законодательный орган.

Подзаконное правотворчество в отличие от законотворчества имеет перед ним такие преимущества как оперативность, гибкость, меньшая степень формализации процесса разработки и принятия норм права, более высокая компетентность субъектов правотворчества, способность к урегулированию разнородного спектра общественных отношений, отличающихся между собой как по своему составу, так и по степени распространенности (например, в масштабах государства, субъекта федерации, региона, ведомства, отдельного производственного коллектива или общественной организации $)^{225}$. Подзаконное правотворчество осуществляется уполномоченными на то субъектами на основании и во исполнение закона.

В юридической литературе отмечается, что «подзаконное правотворчество должно иметь статус делегированного правотворчества, так как его осуществляют органы исполнительной власти на основе и в соответствии с законами» ${ }^{226}$.

В принципе данное утверждение соответствует общему представлению о делегированном правотворчестве, поскольку нет четких критериев разграничения этих понятий. Используя такой широкий подход, можно представить и всякое иное правотворчество (за исключением законодательства) как подзаконное правотворчество. Что, в общем, тоже не будет противоречить истине. Однако мы установили, что в зависимости от субъекта, правотворчество подразделяется на:

1) подзаконное, которое осуществляется непосредственно органами исполнительной власти и их должностными лицами, или ведомственное нормотворчество 227 ;

\footnotetext{
${ }^{225}$ Малько А.В. Теория государства и права. - М., 1999. - С. 146.

${ }^{226}$ Власов В.И. Теория государства и права. - Ростов н/Д., 2002. - С. 265

${ }^{227}$ См. подробнее: Арзамасов Ю.Г. Ведомственный нормотворческий процесс: структура, содержание, перспективы развития (ч. 1) // Представительная власть - XXI век: законодательство, комментарии, проблемы. - 2007. - №4-6. - С. 13-14.
} 


\section{Правотворчество в Российской Федерации}

2) муниципальное, деятельность органов местного самоуправления, их должностных лиц и населения муниципального образования по выработке норм права 228 ;

3) локальное, связанное с регламентацией общественных отношений в сфере деятельности корпораций и общественных организаций ${ }^{229}$;

4) судебное, осуществляемое судами в процессе своей деятельности и связанное с толкованием норм права и устранением выявленных пробелов в праве $\mathrm{e}^{230}$.

Из данной классификации видно, что хотя это есть разновидности подзаконного правотворчества, тем не менее между ними существует разница в субъекте, сфере регулируемых общественных отношений, целях правового регулирования, масштабах действия принимаемых нормативных актов и т. д. Поэтому все эти виды правотворчества исследуются в данной работе раздельно, что будет способствовать выявлению их специфических признаков. В юридической литературе, например, называется «особый вид правотворчества, примыкающий к подзаконному правотворчеству, - правотворчество органов местного самоуправления и негосударственных юридических лиц» ${ }^{231}$.

Основной отличительный признак подзаконного правотворчества состоит в том, что оно исходит от различных управомоченных законом структур и должностных лиц исполнительной власти: президента, правительства, министерств, ведомств, государственных, местных органов государственного управления, губернаторов, глав администраций.

Следует иметь в виду, что необходимость функционирования подзаконного правотворчества обусловлена спецификой законотворчества. Законодатель не имеет возможности в процессе правового регулирования досконально устанавливать правила поведения субъектов всех складывающихся правоотношений. Поэтому представительные органы власти, издавая законодательные акты, стремятся в первую очередь урегулировать общественные отношения, которые имеют наиболее важное, принципиальное значение. Окончательную конкретизацию правил поведения в той или иной жизненной ситуации законодатель передает нижестоящим субъектам правотворчества в соответствии с их компетенцией. Кроме того учитывается и специфика отраслевого законотворчества. Те отрасли права, где используется в основном диспозитивный метод правового регулирования, потенциально тяготеют к формированию их норм в обобщенном виде, поскольку субъекты правоотношений конкретизируют их в своих соглашениях (гражданское право). А отрасли права, в

\footnotetext{
${ }^{228}$ См. подробнее: Каминская Е.А. Муниципальное правотворчество в механизме правообразования: автореф. дис. ... к.ю.н. - Белгород, 2013. - С. 10

${ }^{229}$ См. подробнее: Потапов В.А. Корпоративные нормативные акты как вид локальных актов: автореф. дис. ... к.ю.н. - М., 2008. - С. 11.

${ }^{230}$ См. подробнее: Чередниченко С. П. Судебное правотворчество: автореф. дис. ... к.ю.н. M., 2005. - C. 14.

${ }^{231}$ Теория государства и права / под ред. В.М. Корельского, В.Д. Перевалова. - М., 1998. C. 298.
} 
которых применяется императивный метод, нормы права имеют конкретный характер (уголовное право). Это различие вытекает из того, что российская правовая система допускает возможность формирования большинства отраслей права на базе единства законов и, развивающих их нормы, подзаконных актов ${ }^{232}$. При издании закона необходимо учитывать, чтобы он не содержал исключительно общие нормы. Иначе такой закон может превратиться в декларацию или констатацию состояния $^{233}$. К тому же конкретизация его норм с превалированием норм подзаконного акта обусловит такое соотношение между ними, когда подзаконный акт будет восприниматься сильнее закона ${ }^{234}$.

Необходимо также учитывать, что в Российской Федерации законы издаются на двух уровнях - федеральном и ее субъектов. Это порождает сложную коллизию иерархии норм права между законами субъекта федерации и нормами подзаконных актов федерального значения (например, указов президента РФ). В таком случае законодательство субъекта федерации должно соответствовать не только Конституции и законодательству РФ, а также Конституции данного субъекта, но и подзаконным нормам права, изданным президентом России в счет развития того или иного федерального закона. Получается, что с формальной стороны законодательство субъектов федерации также в отдельных случаях подпадает под признак подзаконного нормативного акта. Устраняются такие правовые коллизии путем своевременного внесения необходимых изменений и дополнений в федеральное законодательство, что обусловливает потребность проведения аналогичной корректировки законодательства и у его субъектов. Так в случае издания президентом РФ указов, восполняющих пробелы в праве, допущенных в сфере регулирования общественных отношений федеральными законами, президент в месячный срок вносит в Государственную Думу в порядке реализации своего права законодательной инициативы соответствующие проекты федеральных законов, которые парламент рассматривает в первую очередь.

Второй отличительный признак подзаконного правотворчества связан с его функциональным назначением, той ролью, которую оно выполняет в правовом регулировании общественных отношений. Нормы подзаконного правотворчества имеют своей целью раскрыть содержание обобщенных норм законодательства, конкретизировать их, а в отдельных случаях восполнить пробелы, имеющиеся в нем (до их устранения самими законодателем), а также изменение, дополнение и отмена устаревших норм подзаконного правотворчества, либо регулирование общественных отношений нижнего уровня, не поддающихся законодательному нормированию.

\footnotetext{
${ }^{232}$ См. подробнее: Иванов С.А. Соотношение закона и подзаконного нормативного правового акта Российской Федерации: монография. - М.: Народный учитель, 2002. - С. 105-106.

${ }^{233}$ Толстик В.А. Иерархия источников российского права: дис. д-ра юрид. наук. - Н. Новгород, 2002. - С. 89.

${ }^{234}$ Ткачева С.Г. Конкретизация закона и его судебное толкование: автореферат дис. к.ю.н. M., 1973.- C. 7.
} 


\section{Правотворчество в Российской Федерации}

Следовательно, нормы подзаконного правотворчества не являются основным средством правового регулирования общественных отношений.

Их функция: создание механизма реализации норм, установленных законодательством. По своему статусу они являются производными, поскольку издаются в форме правил, порядков, положений, инструкций, регламентов, либо иной форме, установленной федеральным законом. Конкретизирующая роль норм подзаконного правотворчества сводится не к уточнению содержания правоотношений, установленных законом, а к их объективизации, наполнению смыслом и энергией функционирования.

Так, в форме инструкций принимаются подзаконные нормативные акты, конкретизирующие вопросы применения определенных правовых актов, изданных в обобщенном виде, что затрудняет их реализацию. В форме правил принимаются подзаконные нормативные правовые акты, определяющие требования к осуществлению какой-либо деятельности.

Именно в них предусматриваются правовые нормы, регулирующие самый нижний, основной пласт общественных отношений, находящийся за пределами законодательства. Если регламентируется статус какоголибо государственного органа либо органа местного самоуправления, а также их структурных подразделений, такой подзаконный нормативный правовой акт издается в форме положения. Регламентами называются подзаконные нормативные акты, определяющие порядок деятельности государственных органов, органов местного самоуправления и их структурных подразделений. Подзаконные нормативные правовые акты в форме порядка издаются в тех случаях, когда требуется регламентация последовательности осуществления какой-либо деятельности или взаимосвязанных между собой действий.

С учетом сказанного, по своему функциональному назначению подзаконное правотворчество может быть следующих видов:

1) регулятивным, в процессе которого устанавливаются правила осуществления определенной деятельности, оформляемых в виде инструкций и регламентов. По мнению Е.А. Звягиной, подзаконное правотворчество в области местного самоуправления нуждается в научном осмыслении, поскольку происходит разрыв между динамично развивающимися общественными отношениями в этой сфере и малоподвижным действующим законодательством, призванным стимулировать эффективное развитие этих отношений ${ }^{235}$. В целом данная позиция отражает правильно сложившуюся ситуацию. Юридическая наука (в данном случае теория правотворчества), не имея плана целенаправленного развития, неравномерно изучает те или иные особенности подзаконного правотворчества. Практика принятия разного уровня актов подзаконного правотворчества не имеет необходимого научного обеспечения. Это обстоятельство снижает качество подзаконных нормативных правовых актов, особенно актов регулятивной направленности. Здесь важно уста-

235 Звягина Е.А. Правотворчество в области местного самоуправления в Российской Федерации: правовые пробелы теории и практики (на примере Пензенской области) // Известия ПГПУ. - 2007. - №3 (7). - С. 59. 
новить и научно обосновать степень соотношения законодательного и подзаконного нормотворчества при регулировании общественных отношений. Очевидно, что закон, как нормативный акт более высокой юридической силы, не может содержать все необходимые подробности правового регулирования, что превратило бы его в некий универсальный правовой акт, заменяющий собой существование подзаконных актов. Такой подход снижал бы стабильность закона, поскольку закрепление в нем конкретных нормативов, а также процедур приведет к постоянному его изменению и дополнению, вытекающих из непрерывно меняющихся его переменных показателей (тарифов, лимитов, квот, минимального размера оплаты труда и т. д.). Как справедливо отмечено в юридической литературе, законы, рассчитанные на длительное действие, указывают участвующих в правоотношениях субъектов, их полномочия и формы взаимодействия. Специализированные правовые акты, в том числе изданные в ходе подзаконного правотворчества, призваны конкретизировать действие общих законодательных положений, оттенять нюансы и специфику их реализации в конкретном регионе, тем самым сужая объем и сферу действия исходного закона ${ }^{236}$;

2) конкретизирующим: оно раскрывает содержание обобщенных норм законодательства. «Конкретизация - объективное свойство правового регулирования, заключающееся в переходе от неопределенности юридического предписания к его определенности» ${ }^{237}$. Подзаконная конкретизация одновременно должна отражать в себе разумное сочетание норм общего характера (содержащихся, как правило, в актах законодательства) и, раскрывающих их юридический смысл, конкретизирующих правовых норм, которые свойственны подзаконному правотворчеству.

Конкретизация хотя и объективное, но в то же время, строго обусловленное явление, необходимость которого предопределяет правовая природа требующего детализации нормативно-правового акта. В зависимости от полноты внесения ясности в содержание общих норм конкретизируемого нормативного акта подзаконная конкретизация может быть:

a) недостаточной (когда не обеспечена полнота понимания норм исходного нормативного правового акта, что ведет к искаженному применению норм этого акта, судебным ошибкам и спорам, а в конечном счете - к многочисленным изменениям и дополнениям подзаконного нормативного акта);

б) избыточной (когда подзаконные нормы, конкретизирующие исходный правовой акт, содержат излишнюю правовую информацию, не требующейся для раскрытия правового смысла исходного нормативного правового акта);

\footnotetext{
${ }^{236}$ См. подробнее: Голенок С.Г. Конкретизация как прием юридической техники в региональном нормотворчестве // Юридическая техника. - 2007. - №1 - С. 231.

${ }^{237}$ Власенко Н.А. Конкретизация в праве: методологические основы исследования // Журнал российского права. - 2014. - №7. - С. 63.
} 


\section{Правотворчество в Российской Федерации}

в) адекватной, когда степень детализации норм исходного нормативного правового акта позволяет эффективно применять его нормы.

О важности сбалансированности законов и подзаконных актов указывает М.С. Белоусова, которая справедливо считает, что отсутствие этого признака правового регулирования является серьезным препятствием на пути реализации нормативного правового акта в целом ${ }^{238}$. Избыточность норм правового регулирования В.А. Рыбаков рассматривает как стремление урегулировать многие виды второстепенных общественных отношений законами, что порождает параллелизм и дублирование правотворческой деятельности ${ }^{239}$. Устранение указанных недостатков подзаконного правотворчества (и правотворчества в целом) необходимо проводить путем гармонизации права. Это комплексное понятие под которым понимается достижение такой цели правотворчества, когда происходит объединение и согласование всех составляющих его элементов: правовых принципов и норм, правовых институтов, нормативноправовых актов и практики правоприменения ${ }^{240}$. Это значит, что создание, функционирование и реализация правовых предписаний осуществляется как единый процесс, вобравший в себя все лучшие качества составляющих его элементов;

3) правонаделяющим (управомачивающим), когда подзаконными нормативными актами осуществляется регламентация статуса определенного государственного органа, либо органа местного самоуправления, а также их структурных подразделений. Такими подзаконными нормативными правовыми актами являются различные положения. Например, правительством РФ постановлением от 02.04.2002 г. №207, утверждено «Типовое положение о юридической службе федерального органа исполнительной власти ${ }^{241}$. Нормами этого положения юридические службы наделены правом осуществления правовой экспертизы проектов подзаконных нормативных актов федеральных органов исполнительной власти. Оценку качества конкретного проекта нормативного акта юридическая служба обязана представить в соответствующем экспертном заключении. По мнению Ю.Г. Арзамасова, для повышения результативности нормативной работы во всех юридических службах (правовых департаментах, управлениях) федеральных органов исполнительной власти целесообразно было бы создать аналитические отделы, которые бы не только анализировали нормативную деятельность своего

\footnotetext{
${ }^{238}$ Белоусова М.С. Правотворческая функция российского государства // Вестник Челябинского государственного университета. - 2010. - №19 (200). Право. - Вып. 24. - С. 11-13.

${ }^{239}$ Рыбаков В.А. Правотворчество в переходный период развития права. // Юридическая техника. - 2015. - №9. - С. 654

${ }^{240} \mathrm{C}$ м. подробнее: Маркова-Мурашова С. А. Поиск правовой гармонии как цель правотворчества XXI века. Поиск правовой гармонии как цель правотворчества XXI века // Известия Тульского государственного университета. - 2012. - №1. - Ч. 2. - С. 119-124.

${ }^{241}$ Постановление Правительства РФ от 02.04.2002 №207 «Об утверждении типового положения о юридической службе федерального органа исполнительной власти» [Электронный ресурс]. - Режим доступа http://www.consultant.ru/document/cons_doc_LAW_36128/
} 
органа и других субъектов, а также осуществляли мониторинг правоприменительной деятельности ${ }^{242}$. Это предложение остается актуальным, поскольку контроль за качеством издаваемых подзаконных правовых актов усиливается, о чем наглядно свидетельствует постановление правительства РФ от 30.01.2015 №83 «О проведении оценки фактического воздействия нормативных правовых актов, а также о внесении изменений в некоторые акты правительства Российской Федерации» ${ }^{243}$.

Видами управомачивающего подзаконного правотворчества могут быть:

а) в зависимости от субъекта, осуществляющего подзаконное правотворчество: федеральное (подзаконные акты издаются президентом и органами исполнительной власти РФ); региональное (правотворческую деятельность осуществляют высшие органы исполнительной власти субъектов федерации. Например, Правительство Сахалинской области 26.01.2010 г. своим постановлением №12 утвердило Положение о видах правовых актов, принимаемых (издаваемых) органами исполнительной власти Сахалинской области $\left.{ }^{244}\right)$;

б) в зависимости от количества субъектов, подпадающих под действие подзаконного правового акта: типовое (акты подзаконного нормотворчества адресуются неопределенному количеству субъектов, которые реализуют их путем введения индивидуализирующих реквизитов), индивидуализированное (создается акт подзаконного правотворчества в расчете на установление статуса конкретного органа или должностного лица);

в) в зависимости от длительности времени, на которое рассчитан акт подзаконного правотворчества: постоянного действия (срок действия подзаконного акта не устанавливается), временного действия (издается, как правило, в связи с необходимостью быстрого установления статуса вновь образованной государственной структуры для осуществления специфических функций, не имеющих аналогии в сфере государственного и муниципального управления);

4) позиционирующим, когда в подзаконном правотворческом акте устанавливается обязательная последовательность в осуществлении ка-

\footnotetext{
${ }^{242}$ Арзамасов Ю.Г. Ведомственный нормативный процесс: структура, содержание, перспективы развития (ч. 2). Сводный реферативный сборник журнала «Представительная власть - XXI век: законодательство, комментарии, проблемы». - 2007. - №4-6. - С. 13-14.

${ }^{243}$ Постановление Правительства РФ от 30.01.2015 №83 (ред. от 30.06.2016) «О проведении оценки фактического воздействия нормативных правовых актов, а также о внесении изменений в некоторые акты Правительства Российской Федерации» (вместе с Правилами проведения оценки фактического воздействия нормативных правовых актов) [Электронный pecypc]. - Режим доступа http://www.consultant.ru/document/cons_doc_LAW_174824/

${ }^{244}$ Постановление Правительства РФ от 30.01.2015 №83 (ред. от 30.06 .2016$)$ «О проведении оценки фактического воздействия нормативных правовых актов, а также о внесении изменений в некоторые акты Правительства Российской Федерации» (вместе с Правилами проведения оценки фактического воздействия нормативных правовых актов) [Электронный pecypc]. - Режим доступа http://www.consultant.ru/document/cons_doc_LAW_174824/
} 


\section{Правотворчество в Российской Федерации}

кой-либо деятельности или выполнении взаимосвязанных действий. Например, регулирование кассовых операций согласно федеральному закону «О Центральном банке Российской Федерации (Банке России)» относится к функциям Центрального банка $Р \Phi^{245}$. Конкретизируется порядок ведения кассовых операций подзаконными нормативными актами Центрального банка РФ, которые обязательны для исполнения всеми банками, предприятиями, учреждениями и иными организациями вне зависимости от их организационно-правовой формы и подчиненности. Аналогичный подход предусмотрен и при регистрации сделок куплипродажи недвижимости и прав на нее. Федеральным законом «О государственной регистрации прав на недвижимое имущество и сделок с ним» от 21.07.1997 г. предусматривается ведение «Единого государственного реестра» органами юстиции ${ }^{246}$. Министерство юстиции конкретизирует нормы федерального закона в данной сфере своими подзаконными нормативными правовыми актами. В подобных подзаконных актах нормируется последовательность и полнота выполнения той или иной деятельности. Отклонение от установленного порядка может существенно запутать объективную картину учетов или сделать их невозможными вообще.

Позиционирующее подзаконное правотворчество может осуществляться как на федеральном, так и на региональном и муниципальном уровнях. Оно может быть использовано и для установления порядка разработки и принятия подзаконных нормативных правовых актов, порядка назначения и проведения правовых экспертиз и т. д. Например, согласно п. 3 ст. 35 Устава Сахалинской области ${ }^{247}$ органы исполнительной власти и руководители указанных органов принимают (издают) правовые акты по вопросам своей компетенции. Порядок принятия (издания) и опубликования указанных правовых актов определяются правительством Сахалинской области ${ }^{248}$. Примеры можно продолжить, ибо на уровне подзаконного правотворчества позиционирующее регулирование общественных отношений имеет широкое распространение.

Таким образом, функциональная предназначенность подзаконного правотворчества отражает многообразие его регулятивной способности, а также степень использования в практической деятельности субъектов, издающих нормы права.

Следующим признаком подзаконного правотворчества является его обусловленность и неразрывная связанность с законодательством. Пра-

\footnotetext{
${ }^{245} 10.07 .2002$ №86-Ф3 (действующая редакция, 2016) [Электронный ресурс]. - Режим доступа http://www.consultant.ru/document/cons_doc_LAW_37570/

246 Федеральный закон «О государственной регистрации прав на недвижимое имущество и сделок с ним» от 21.07.1997 №122-Ф3 (действующая редакция, 2016) [Электронный ресурс]. - Режим доступа http://www.consultant.ru/document/cons_doc_LAW_15287

${ }^{247}$ Устав Сахалинской области от 09.07.2001 №270 (в ред. от 23.09.2013 №88-30). Принят областной думой 28.06.2001 // Губернское ведомство. - 11.07.2001; 25.09.2013 // СПС Консультант Плюс.

${ }^{248}$ СПС Консультант Плюс.
} 
вовая обусловленность вытекает из природы издаваемых в нашей стране нормативно-правовых актов высшей юридической силы. Поскольку общественные отношения регулируются в них достаточно обобщенными нормами (в целях придания им универсального характера) без учета сопутствующих им особенностей, в конечном результате получаются правовые абстракции, которые не всегда можно реализовать в практической деятельности без их дополнительного нормативного разъяснения. В качестве примера можно привести такую правовую абстракцию как источник повышенной опасности ${ }^{249}$. Определение понятия источника повышенной опасности в ст. 1079 ГК РФ не позволяет единообразно оценить его сущность, что порождает многочисленные ошибки и противоречия судебных решений. Поэтому в каждом конкретном случае, когда требуется установить наличие потенциальной опасности изучаемого физического объекта, необходимо обратиться к его техническим и производственным характеристикам, не содержащихся в тексте законодательства. Однако было бы удобнее правоприменителю, если б существовал некий подзаконный правовой акт, который установил наконец правила признания тех или иных материальных объектов источниками повышенной опасности.

Другим примером может служить бланкетная норма уголовного закона. В данном случае правовая абстракция имеет серьезную подзаконную нормативную бузу. Каждый раз правоприменитель для понимания бланкетной нормы, предусмотренной конкретной нормой УК РФ, обращается к имеющемуся подзаконному нормативному правовому акту, где дается подробная регламентация сущности запрещенного общественно опасного деяния. Так, если лицо совершило транспортное преступление, заключающееся в нарушении правил управления автотранспортным средством, то соответственно необходимо обратиться к такому подзаконному правовому акту как Правила дорожного движения 250 .

Подзаконное правотворчество обуславливается содержанием и степенью объективной потребности законодательных актов в дальнейшем более доскональном раскрытии их правовых норм, имеющих абстрактный, общий вид. Указанная потребность может вытекать из прямого указания закона, из предписаний президента РФ и решений Конституционного Суда РФ. Она может быть выявлена и в процессе научной и правоприменительной деятельности, а также субъектами правотворчества самостоятельно. В таком случае издание необходимого подзаконного акта осуществляется в установленных законом порядке возбуждения соответствующей правотворческой инициативы и реализации необходимых процедур.

\footnotetext{
${ }^{249}$ См. подробнее: Румянцев М.Б. Правовое регулирование отношений из причинения вреда источником повышенной опасности в Российской Федерации и США: монография. - М., 2015. - C. 106-143.

${ }^{250}$ Правила дорожного движения РФ [Электронный ресурс]. - Режим доступа: https://pddrussia.com/
} 


\section{Правотворчество в Российской Федерации}

Определение наличия потребности в издании подзаконного нормативного правового акта - важнейшее условие его объективизации в правовом поле регулирования общественных отношений. Поскольку в противном случае его регулятивное значение будет равно нулю. Нормы подзаконного правотворчества должны работать, не быть «пустым звуком», не превращаться в ненужные невостребованные циркуляры ${ }^{251}$. Об удачном сочетании норм законодательного и подзаконного правотворчества свидетельствует то обстоятельство, что правоприменительная практика реализации найденной их совокупности осуществляется без затруднений и является эффективной.

Подзаконному правотворчеству присущ и такой признак как многообразие по уровню профессионализма и юридической грамотности субъектов, издающих и применяющих его нормы. Это вызывает трудности, вытекающие из качества издаваемых норм, которые содержат ошибки не только технико-юридического, но и содержательного характера $^{252}$. По результатам исследования подзаконного правотворчества, осуществляемого субъектами Дальневосточного федерального округа, А.А. Со констатировал о наличии большого количества правотворческих ошибок в их деятельности. Автор классифицировал следующие их разновидности: юридические, грамматические, фактографические, стилистические и логические. Большинство правотворческих ошибок - грамматические и фактографические ${ }^{253}$. Следует учитывать, что «нечетная, небрежно сформулированная либо сознательно искаженная дефиниция начинает подменять подлинную сущность понятия и неверно ориентирует познавательную деятельность» ${ }^{254}$.

О низком качестве подзаконного правотворчества свидетельствует и результат проведенного анализа регистрационной работы Министерством юстиций РФ. Установлено, что было отказано в государственной регистрации всех представленных на регистрацию ведомственных нормативных актов Роспатента, 40 \% представленных актов Минобрнауки России, 26,6 \% Минтранса России и т. д. Вместе с тем, Минюст России отметил высокое качество издаваемых нормативных правовых актов таких государственных учреждений как Минобороны России, МВД России, Банк России и некоторых других ${ }^{255}$. Усугубляет общее состояние качества подзаконного правотворчества то обстоятельство, что при наличии многообразия его субъектов нет единообразной регламентации

\footnotetext{
${ }^{251}$ Арзамасов Ю.Г. Ведомственный нормотворческий процесс: структура, содержание, перспективы развития (ч. 1) // Сводный реферативный сборник журнала «Представительная власть - XXI век: законодательство, комментарии, проблемы». - 2007. - №4-6. С. 13-14.

${ }^{252}$ Белоусова М.С. Указ. соч. - С. 12.

${ }^{253}$ См. подробнее: Со А.А. Подзаконное правотворчество и юридическая техника (на примере органов исполнительной власти субъектов РФ Дальневосточного федерального округа) // Власть. - 2015. - №1. - С. 161.

${ }^{254}$ Губаева Т.В. Язык и право. - М.: Норма, 2007. - С. 68.

${ }^{255}$ Государственная регистрация нормативных правовых актов Федеральных органов исполнительной власти // Бюллетень Министерства юстиции Российской Федерации. 2005. - №10. - С. 79.
} 
их деятельности. Выработанные субъектами федерации правила подготовки и принятия подзаконных нормативных правовых актов противоречивы, не имеют общих подходов разработки таких правовых документов, не согласованы между собой. В них, по сути, отражается региональная специфика издания подзаконных нормативных правовых актов, а не общепринятые в масштабах страны стандарты. Тем самым подрывается единообразие правового регулирования, основанного на общности законов и, развивающего эти законы, подзаконного правотворчества.

Созрела насущная необходимость издания комплексного законодательного акта, направленного на четкое регулирование правотворческой деятельности всех без исключения субъектов правотворчества ${ }^{256}$.

Попытки совершенствования правотворчества всех уровней на основе лишь технико-юридических средств не могут дать требуемый в настоящее время качественный результат. Нужны единые подходы в правовом регулировании одинаковых общественных отношений на всей территории страны, нужны координация и взаимодействие между субъектами правотворчества, их нацеленность на выработку совершенной правовой системы государства, а не на издание отдельных подзаконных нормативных правовых актов, пусть даже самого высокого качества.

Таким образом, исследование специфических признаков подзаконного правотворчества показывает о его высоком регулятивном потенциале и неразрывной связанности с законотворческим процессом. Подзаконное правотворчество выполняет не только конкретизирующую роль в реализации законодательных предписаний, восполнении пробелов в праве, но одновременно выступает в качестве самостоятельного регулятора общественных отношений в тех случаях, когда эти отношения не поддаются законодательному урегулированию из-за их малозначительности либо нецелесообразности законодательного регулирования.

В юридической литературе нет единого подхода в определении видов подзаконного правотворчества. Отчасти это объясняется тем, что само подзаконное правотворчество не имеет однозначного понимания. Одни авторы понимают его в широком смысле, исходя из того, что любое правотворчество, которое осуществляется на основании закона или в его исполнение, является подзаконным, таким образом, причисляя к его числу муниципальное и локальное правотворчество 257 . Другие, в качестве подзаконного правотворчества рассматривают только правотворчество государственных органов исполнительной власти и их должностных лиц. Это, по нашему мнению, оправдано, поскольку его виды четко обособляются по субъекту подзаконного правотворчества, что дает возможность их раздельного изучения с учетом индивидуализирующих особенностей каждого из них. Например, Ю.Г. Арзамасов подзаконное правотворчество также рассматривает в узком смысле, понимая его как сумму трех его видов:

1) нормотворчество высших органов исполнительной власти, результатом которого являются нормативные указы президента, постановления и другие нормативные акты правительства;

${ }^{256}$ См. подробнее: Дербина А.В. Правосознание как элемент правовой позиции субъекта правотворчества: автореф. дис. ... к.ю.н. - Самара, 2011. - С. 11.

${ }^{257}$ Малько А.В. Теория государства и права. - М., 1999. - С. 141-142. 


\section{Правотворчество в Российской Федерации}

2) ведомственное правотворчество;

3) нормотворчество органов государственной власти субъектов федерации 258 . Указанное деление подзаконного правотворчества на виды имеет своим основанием статус субъекта правотворчества.

Такая классификация подзаконного правотворчества на виды позволяет определить параметры интенсивности издания субъектами правотворчества нормативных правовых актов, их эффективность, соответствие федеральному законодательству и т. д. Установлено, например, что на каждые 10 изданий законов приходится от 100 до 140 нормативных актов правительства ${ }^{259}$. Количество ведомственных нормативных правовых актов увеличивается примерно в той же пропорции. Аналогичное подзаконное правотворчество субъектов федерации измеряется уже шестизначными числами. По данным Минюста РФ, по состоянию на январь 2013 г. В Федеральном регистре правовых актов субъектов федерации было зарегистрировано 722740 нормативных правовых актов, из них действующими являлись 455077, а федеральному законодательству соответствовали только 232687, что составляет 51,1 процента ${ }^{260}$. Это показывает не только масштабы подзаконного правотворчества, но и степень его восприятия норм федерального правотворчества.

По характеру инициирования издания правового акта подзаконного правотворчества можно выделить следующие его виды:

1) по прямому указанию закона (например, ст. 36 Конституции РФ устанавливает права частной собственности на землю. В ч. 3 этой статьи предусматривается оговорка, что условия и порядок пользования землей определяется на основании федерального закона. В соответствии с этим был принят Земельный кодекс Р $\Phi^{261}$ );

2) по решению вышестоящего органа исполнительной власти;

3) по решению субъекта подзаконного правотворчества. Подобные решения субъекта должны приниматься в пределах своих полномочий ${ }^{262}$. На практике ведомственное правотворчество в сфере регулирования прав граждан и их объединений зачастую подменяет собой закон «Главная причина такого положения - падение регулирующего воздействия законов - заключается в возрастании роли органов исполнительной власти при разрешении общественных проблем, в снижении значения парламента и органов местного самоуправления на фоне растущей комфор-

\footnotetext{
${ }^{258}$ См. подробнее: Арзамасов Ю.Г. Ведомственный правотворческий процесс: структура, содержание, перспективы развития (ч. 1) // Представительная власть - XXI век: законодательство, комментарии, проблемы. - 2007. - №4-6. - С. 13-14.

${ }^{259}$ Теория государства и права / под ред. В.М. Корельского, В.Д. Перевалова. - М., 1998. C. 298.

${ }^{260}$ Ордина О.Н. О проблемах создания единого правового пространства России // Государственная власть и местное самоуправление. - 2013. - №6.

${ }^{261}$ СЗ РФ. Гл. XVI.

${ }^{262}$ Арзамасов Ю.Г. Указ. соч. - С. 13.
} 
табельности и цивилизованности жизни или наоборот, на фоне нищеты и диктатуры бюрократического аппарата» ${ }^{263}$;

4) в порядке делегирования своих полномочий вышестоящим субъектом подзаконного правотворчества нижестоящему;

5) по решению суда (например, признание Конституционным Судом РФ конкретного закона или отдельных его положений неконституционным, что обусловливает необходимость для субъекта правотворчества издания аналогичного закона с устранением допущенных отступлений от Конституции РФ) ${ }^{264}$.

Подзаконное правотворчество в зависимости от места, занимаемого в системе права, может быть следующих видов:

1) отраслевым, если его нормы дополняют и конкретизируют кодифицированное законодательство;

2) подотраслевым, когда раскрывается содержание норм права отдельных законодательных актов, составляющих подотрасль права;

3) институтообусловленным, то есть издаваемым для конкретизации норм правовых институтов (например, институт задержания преступника находит свою конкретизацию в Положении о содержании под стражей; институт необходимой обороны - в Правилах определения тяжести телесных повреждений и т. д.);

4) нормообразующее подзаконное правотворчество, когда осуществляется совершенствование его норм путем отмены дополнения, изменения.

Следует сказать, что в юридической литературе аналогичным путем выделяются такие виды правотворчества, как системное и единичное. Системное, то есть кодифицированное правотворчество образуется в результате «формулирования и введения в правовую систему юридических норм по целым блокам, укрупненным группам, отраслям права», тогда как единичное правотворчество «осуществляется путем формирования отдельных, изолированно взятых юридических норм» для внесения дополнений и изменений в кодифицированные акты ${ }^{265}$.

По степени научной обоснованности подзаконное правотворчество делится на следующие виды:

1) научно-обоснованное, которое осуществляется в результате проведенного научного исследования, имеющее серьезную доказательную базу. Такое подзаконное правотворчество вытекает, прежде всего, из его теоретического обоснования, научного осмысления ${ }^{266}$. Являясь результатом научных исследований, вырабатываемые нормы подзаконного правотворчества одновременно должны учитывать перспективу развития общественных отношений и соответствующих им законодательных норм права;

\footnotetext{
${ }^{263}$ Власов В.И. Указ. соч. - С. 265.

264 Желдыбина Т.А. О судебном правотворчестве // Вестник Саратовской государственной юридической академии. - 2015. - №2 (103). - С. 28.

${ }^{265}$ Алексеев С.С. Общая теория права: учебник. - М., 2008. - С. 228.

${ }^{266}$ См. подробнее: Миренский Б.А. Методологические основы и методы совершенствования законодательства. - Нукус, 1990. - С. 102.
} 


\section{Правотворчество в Российской Федерации}

2) эмпирически обоснованное, то есть нормы подзаконного правотворчества вырабатываются на основе имеющегося опыта как в сфере правоприменения, так и в сфере нормообразования субъектов правотворчества. Данный способ подзаконного правотворчества в настоящее время имеет самое широкое распространение. Но это не свидетельствует о его неполноценности или тем более ущербности. Данный подход в нормотворчестве - естественная дань его субъектов имеющемуся у них опыту выработки норм подзаконного правотворчества. Как правило, результатом такого нормотворчества являются качественные, совершенные правовые акты;

3) актуализированное подзаконное правотворчество, которое осуществляется на злобу дня в спешном порядке, в обход предусмотренных законодательством процедур. Качество такого правотворчества резко снижается, поскольку поспешность способствует упрощенному пониманию возникающих правотворческих проблем и такому же способу их решения. В юридической литературе отмечается, что поспешность издания норм права, погоня за количеством принимаемых законов, «приводит к закону на уровне подзаконного нормотворчества, вырабатывает отношение к законотворческой деятельности, как к «взбесившемуся принтеру» ${ }^{267}$.

Подзаконное правотворчество можно классифицировать на виды и по другим основаниям:

1) по действию во времени (постоянного действия и временное);

2) по методу правового регулирования общественных отношений (диспозитивное, императивное, рекомендательное, декларативное);

3) по действию в пространстве (федеральное, региональное, местное, корпоративное);

4) по количеству участвующих в нормотворческом процессе субъектов (коллегиальное, единоличное);

5) по количеству субъектов, которым оно адресовано (общего назначения и специализированное);

6) по степени урегулированности общественных отношений (полного, частичного и примерного урегулирования);

7) по способу выработки правовых норм (модельное, эвристическое и комбинированное);

8) по предмету регулирования (административное, трудовое, гражданско-правовое, финансовое и т. д.).

В юридической литературе в зависимости от субъекта называются следующие виды нормативных правовых актов издаваемых в процессе осуществления ими подзаконного правотворчества:

1) указы и распоряжения президента РФ, которые обязательны к исполнению на всей территории страны. Нормативные указы президента издаются в случае обнаружения пробелов в праве. Действие таких указов

${ }^{267}$ Российская газета. - 27.06.2013. 
ограничено временем, необходимым для законодательного устранения пробелов в праве;

2) постановления и распоряжения правительства РФ, их действие распространяется по всей территории страны и обязательно к исполнению всеми физическими, юридическими и должностными лицами, которым они адресованы. Нормативные акты правительства издаются на основании и во исполнении законов, а также указов президента;

3) приказы, инструкции, положения министерств, ведомств и государственных комитетов - ведомственные подзаконные акты, принимаемые на основании законов, указов и распоряжений президента РФ, постановлений и распоряжений правительства РФ, а также в соответствии с ними. Эти подзаконные нормативные правовые акты в основном регулируют общественные отношения, протекающие в пределах соответствующих структур. Однако подзаконные акты таких государственных органов как министерство финансов, Центральный банк, министерство внутренних дел и др. выходят за пределы конкретного министерства и ведомства и могут действовать на всей территории страны;

4) решения и постановления местных органов государственной власти в лице их законодательных органов;

5) решения, постановления и распоряжения местных органов государственного управления (областных глав администрации, губернаторов и др. $)^{268}$.

Следует иметь в виду, что подзаконное правотворчество осуществляется при наличии таких отрицательных факторов как:

1) низкая нормативно-правовая обеспеченность этой правотворческой деятельности;

2) отсутствие научной базы по изучению теоретических основ правотворчества вообще и подзаконного, в частности;

3) закрытый (исключающий участие общественных организаций) процесс выработки нормативно-правовых актов, что способствует возможности проявления коррупции;

4) отсутствие эффективного контроля со стороны государства за качеством создаваемых правовых документов.

Таким образом, подзаконное правотворчество в узком смысле является нормотворчеством органов государственной исполнительной власти и их должностных лиц по изданию нормативных правовых актов, конкретизирующих законодательные нормы, восполняющие пробелы в праве, регулирующие общественные отношения, не подпадающие под законодательное урегулирование в силу их малозначительности или нецелесообразности.

Подзаконное правотворчество является надежным правовым инструментом детализации законодательных норм, которая может быть осуществлена путем урегулирования общественных отношений (не урегулированных законом), их конкретизации, закрепления статуса опреде-

\footnotetext{
${ }^{268}$ См. подробнее: Малько А.В. Теория государства и права. - М., 1999. - С. 140-142.
} 


\section{Правотворчество в Российской Федерации}

ленного органа или должностного лица, установления порядка правотворческой деятельности.

Подзаконное правотворчество воспринимается как вспомогательное средство правового регулирования общественных отношений и тем самым ему отводится второстепенная роль при выработке правотворческих решений. Однако это не так. Фактическое значение подзаконного правотворчества определяется в эффективности правового регулирования. Закон работает в полную силу только в тех случаях, когда к нему придается подзаконный нормативный акт высокого качества. Из этого видно, что по своему функциональному назначению подзаконное правотворчество занимает равноценное законодательству положение. Более того, в отдельных случаях нормами подзаконного правотворчества слабый, недостаточно качественный закон может быть наполнен недостающим ему содержанием.

\section{§.2.6. МУНИЦИПАЛЬНОЕ ПРАВОТВОРЧЕСТВО}

Местное самоуправление в Российской Федерации гарантировано Конституцией РФ и осуществляется гражданами путем референдума, выборов и других форм прямого волеизъявления в городских и сельских поселениях, а также иных территориях с учетом сложившихся там традиций (ст. 130, 131).

Важнейшей конституционной гарантией является то, что органы местного самоуправления самостоятельно управляют муниципальной собственностью, формируют, утверждают и исполняют местный бюджет, устанавливают местные налоги и сборы, осуществляют охрану общественного порядка, а также решают иные вопросы местного значения. Это значит, что выполняя управленческие функции, органы местного самоуправления (муниципалитеты) наделены правом издания соответствующих нормативных правовых актов для регламентации той или иной деятельности. Следовательно, правотворчество - главный инструмент муниципальной власти в решении стоящих перед ней задач местного значения.

Муниципальное правотворчество имеет три уровня регламентации: федеральный, субъектов федерации и местный. Однако это не означает, что их совместное регулирование данной сферы деятельности муниципалитетов сформировало надежный и эффективный механизм выработки нормативных правовых актов местного самоуправления.

Тем более, как отмечается в юридической литературе, отдельные сферы муниципального правотворчества на федеральном уровне отрегулированы детальнейшим образом (например, вопросы, связанные с процедурой назначения, подготовки муниципальных выборов, их проведения, подведения итогов выборов, определения результатов выборов и т. д.), что исключает участие в правовом регулировании этих вопросов 
на нижестоящих уровня ${ }^{269}$. Такой подход свидетельствует, что по данным вопросам совместного ведения федеральных и региональных органов места для отражения каких-либо особенностей практически нет. К тому же правовое регулирование муниципального правотворчества всех трех уровней недостаточно согласовано между собой и, что самое главное, не предусматривает правил формирования единой правовой системы страны в процессе издания нормативно правовых актов любого уровня, в том числе и местного самоуправления. Даже качественные нормативные правовые акты, если они не встроены в единую правовую систему государства, значительно теряют свой регулятивный потенциал, снижают свою эффективность.

Это касается и муниципальных нормативных правовых актов, которые вырабатываются и принимаются в ходе правотворчества на уровне местного самоуправления. Имеющиеся особенности в этой сфере правотворчества недостаточно изучены юридической наукой и нуждаются в серьезном теоретическом осмыслении.

Сущность научной проблемы правотворчества в области местного самоуправления состоит в наличии противоречий между изменяющимися отношениями в этой области, складывающихся в процессе реформ основ государственной и общественной жизни России и статичным (малоподвижным) действующим законодательством, призванным стимулировать эффективное развитие этих отношений, а также между осуществляющейся на всей территории России практикой правотворчества в области местного самоуправления и недостаточным теоретическим пониманием данного правового явления. Реальная самостоятельность местного самоуправления невозможна без научного обеспечения процессов правотворчества всех уровней, гармонизирующих интересы Российской Федерации, ее субъектов и муниципальных образований ${ }^{270}$. Поэтому обособленное изучение муниципального правотворчества является и средством познания этой правовой действительности и методом выделения ее из всего многообразия видов правотворчества.

Законодательного определения понятия муниципального правотворчества не имеется. Его сущность определяется в результате анализа присущих ему признаков, которые характеризуют данное правовое явление как самостоятельный вид правотворчества.

При этом может быть два подхода выявления признаков муниципального правотворчества:

1) формально-правовой,

2) функционально-правовой. В первом случае признаки муниципального правотворчества отражают внешнюю сторону данного правового

\footnotetext{
${ }^{269}$ Ниматулаева Р.А. Выборы в органы местного самоуправления: актуальные вопросы (на примере Республики Дагестан) // Конституционное и муниципальное право. - 2016. №9. - C. 71.

${ }^{270}$ Аничкин Е.С. Факторы единства и многообразия конституционного законодательства РФ // Конституционное и муниципальное право. - 2005. - №2.
} 


\section{Правотворчество в Российской Федерации}

явления, акцентируя внимание на его правовые свойства. К числу таких признаков, например, Н.П. Алешкова относит:

1) самостоятельность местного самоуправления в осуществлении муниципального правотворчества в пределах своих полномочий;

2) законность правотворческой деятельности;

3) открытость результатов муниципального правотворчества;

4) участие населения в муниципальной правотворческой деятельности;

5) обеспечение прав и свобод граждан;

6) учет исторических и иных местных традиций;

7) подконтрольность государству при реализации переданных государственных полномочий;

8) защита интересов муниципального образования ${ }^{271}$.

Во втором случае признаки муниципального правотворчества выделяются с учетом их функционального назначения. Рассматривая в таком аспекте, можно выделить следующие признаки муниципального правотворчества:

1) это составная часть правотворчества в целом, которая наряду с общими признаками, указывающими на его родовую принадлежность, обладает и специфическими особенностями, выделяющими его в качестве самостоятельной правовой категории;

2) по своему правовому назначению выполняет одновременно две функции: а) способствует формированию единой правовой системы страны (как часть общей правотворческой структуры), отражая ее цели, задачи, принципы и методы; б) регулирует общественные отношения местного значения путем учета их специфических особенностей в издаваемых нормативных правовых актах;

3) субъекты муниципального правотворчества (каждый в отдельности) наделяются присущей только им компетенцией, которую реализуют в отношении своего предмета правового регулирования. Выход за пределы установленных законом границ не допускается. Однако, именно нечеткость регламентации правового статуса и компетенции субъектов, а также предметов ведения в области местного самоуправления характеризует современное состояние муниципального правотворчества во многих субъектах Российской Федерации ${ }^{272}$. Это обстоятельство затрудняет выработку качественных нормативных правовых актов в области местного самоуправления;

4) структура муниципального правотворчества включает в себя несколько видов:

а) непосредственное правотворчество, осуществляемое его населением, на основе предусмотренных Конституцией РФ форм прямого волеизъявления;

\footnotetext{
271 Алешкова Н.П. Конституционно-правовые основы муниципального правотворчества в Российской Федерации: автореф. дис. ... к.ю.и. - Екатеринбург, 2010.

${ }^{272}$ См., например: Звягина Е.А. Правотворчество в области местного самоуправления в Российской Федерации: правовые пробелы теории и практики (на примере Пензенской области) // Известия ПГПУ. - 2007. - №3. - С. 62.
} 
б) правотворчество органов и должностных лиц местного самоуправления;

в) правотворчество органов и должностных лиц местного самоуправления по вопросам исполнения отдельных государственных полномочий, переданных органам местного самоуправления на основе закона;

г) правотворчество органов и должностных лиц местного самоуправления по реализации прав органов и должностных лиц местного самоуправления на решение вопросов, не отнесенных к вопросам местного значения ${ }^{273}$;

5) регламентация муниципального правотворчества осуществляется на всех трех его уровнях (федеральном, региональном и местном), что призвано придать ему целенаправленный и систематический характер, поскольку «системность правового регулирования невозможна вне системного правотворчества» ${ }^{274}$;

6) отсутствие единого законодательного акта, объединяющего правотворчество всех трех уровней в целостную систему издания нормативных правовых актов, что создает определенные трудности в сфере местного самоуправления. Наряду с федеральным законом от 06.10.2003 г. №131-Ф3 «Об общих принципах организации местного самоуправления в Российской Федерации» ${ }^{275}$ в большинстве субъектов федерации действуют региональные нормативные акты, так или иначе нормирующие сферу муниципального правотворчества ${ }^{276}$. Данное обстоятельство свидетельствует о необходимости издания закона «О нормативных правовых актах в Российской Федерации», о котором ведутся дискуссии уже более десяти лет.

В своей совокупности указанные признаки характеризуют муниципальное правотворчество как целостное правовое явление, представляющее собой обособленную часть единой комплексной системы правотворчества уполномоченных законом субъектов всех трех уровней (федерального, регионального и местного), отражающего общие (присущие правотворчеству в целом) и родовые (составляющие специфику местного самоуправления) их свойства, которое направлено на регулирование общественных отношений местного значения (на формирование бюджета, налогов, управление собственностью, дорожным строительством, организация охраны общественного порядка, экологического контроля

273 Сергеева К.О. Муниципальное правотворчество в Российской Федерации: автореф. дис. .... к.ю.н. - М., 2013. - С. 10.

${ }^{274}$ Синюков С.В. Механизм правотворчества: автореф. дис. ... к.ю.н. - Саратов, 2013. C. 11 .

${ }^{275}$ СЗ РФ. - 2003. - Ст. 3822.

${ }^{276}$ См., например: Закон Белгородской области «Об особенностях организации местного самоуправления в Белгородской области» от 30.03 .2005 №177, а также Постановление правительства Сахалинской области «Об утверждении Положения о видах правовых актов, принимаемых (издаваемых) органами исполнительной власти Сахалинской области и их разновидностями, а также порядке их принятия (издания) и опубликования» от 26.01.2010 №12 // СПС Консультант Плюс. 


\section{Правотворчество в Российской Федерации}

и т. д. $)^{277}$. Муниципальное правотворчество, регулируя вопросы местного значения, развивает и конкретизирует правотворческие решения вышестоящих субъектов, воплощая их в свои правовые нормы.

В обобщенном виде муниципальное правотворчество это:

1) деятельность, связанная с выработкой и принятием норм права по вопросам местного значения;

2) деятельность, которую осуществляют уполномоченные на то субъекты (органы местного самоуправления и их должностные лица) либо все население муниципального образования в результате проведения местного референдума;

3) деятельность, урегулированная нормами права федерального, регионального и местного уровня, включающая две взаимосвязанные фазы:

а) нормотворческую (выработка текстуального содержания будущей нормы права);

б) процессуальную (последующее ее редактирование и придание юридической силы путем осуществления специальных правотворческих процедур).

Из сказанного вытекает следующее определение понятия муниципального правотворчества, - это деятельность, уполномоченных законом субъектов (или всего населения муниципального образования в ходе местного референдума) по изданию норм права для регулирования вопросов местного значения, которая включает две фазы:

1) нормотворческую (выработка текстуального содержания будущей нормы права);

2) процессуальную (последующее ее редактирование и придание юридической силы путем осуществления правотворческих процедур).

В юридической литературе представлены в основном более развернутые определения понятия муниципального правотворчества. Так, Е.А. Каминская считает, что «муниципальное правотворчество - особая творческая деятельность органов местного самоуправления, их должностных лиц и населения муниципального образования, основанная на законе и иных нормативно-правовых актах, осуществляемая в рамках делегированных государством полномочий, по созданию, совершенствованию и отмене муниципальных нормативных правовых актов, направленных на удовлетворение потребностей и интересов населения, а также по санкционированию в качестве правовых уже существующих социальных норм, регулирующих вопросы местного значения определенного муниципального образования, законность которой обеспечена контролем и надзором соответствующих государственных органов и возложенной на органы местного самоуправления и их должностных лиц ответственностью, наступающей на основании решения суда, если эта деятельность противоречит Конституции Российской Федерации, федеральному законодательству, законодательству субъектов Российской

${ }^{277} \mathrm{Cм}$. подробнее о вопросах местного значения: Федеральный закон «Об общих принципах организации местного самоуправления в Российской Федерации» от 6 октября 2003 г. №131-ФЗ. Ст. 14. СЗ РФ. - Ст. 3822. 
Федерации, уставу муниципального образования и принятым в соответствии с ним нормативно-правовым актам» ${ }^{278}$.

Столь развернутое определение муниципального правотворчества можно квалифицировать как процессуально-описательное, когда акцент делается на формальную сторону создания норм права ${ }^{279}$. Достоинство такого определения муниципального правотворчества состоит в широком охвате правотворческих процессов, имеющих существенное значение в формулировании норм права местного самоуправления, а также значения их взаимосвязи между собой. Недостаток - излишняя громоздкость, непригодность использования такого определения муниципального правотворчества в качестве его дефиниции.

Более краткое определение понятия муниципального правотворчества представлено К.О. Сергеевой. По мнению данного автора, под муниципальным правотворчеством «необходимо понимать деятельность уполномоченных субъектов местного самоуправления по принятию письменного документа, направленного на установление, изменение или отмену правовых норм, имеющих общеобязательное предписание постоянного или временного характера, рассчитанных на многократное или однократное применение на территории муниципального образования, и адресованного неопределенному кругу лиц, либо конкретному субъекту общественных отношений» 280 .

Это упрощенный подход к определению муниципального правотворчества. Оно состоит из двух частей. В первой формулируется сущность процессуальной стороны муниципального правотворчества («деятельность уполномоченных субъектов местного самоуправления по принятию письменного документа, направленного на установление, изменение или отмену правовых норм»), а во второй перечисляются признаки норм права, которыми должны обладать нормы муниципального права и которыми, естественно, обладают любые другие нормы права. Такое определение понятия муниципального правотворчества тоже неприглядно для использования в качестве соответствующей дефиниции из-за упрощенности и недостаточной полноты отражения в нем сущности рассматриваемого правового явления.

Имеются и другие подходы в определении понятия муниципального правотворчества ${ }^{281}$.

\footnotetext{
${ }^{278}$ Каминская Е.А. Муниципальное правотворчество в механизме правообразования: автореф. дис. ... к.ю.н. - Белгород, 2013. - С. 10-11.

${ }^{279}$ См. подробнее: Марченко М.Н. Проблемы теории государства и права. - М., 2013. C. $660-661$.

${ }^{280}$ Сергеева К.О. Муниципальное правотворчество в Российской Федерации: автореф. дис. ... к.ю.н. - М., 2013. - С. 10.

${ }^{281}$ См., например: Алешкова Н.П. Конституционно-правовые основы муниципального правотворчества Российской Федерации: автореф. дис. ... к.ю.н. - Екатеринбург, 2010. С. 11 ; Фомичева О.А. К вопросу о содержании понятия и видовой классификации современного правотворчества / О.А. Фомичева, Д.В. Пахомова // Вестник Московской финансово-юридической академии // Достижения вузовской науки. - 2008. - №6. - С. 257.
} 


\section{Правотворчество в Российской Федерации}

Важное значение в формулировании норм муниципального правотворчества имеют его принципы, которые не закреплены законодательно, но реально должны учитываться в процессе нормообразования. В теории правотворчества принято делить его принципы на универсальные, общие и специальные ${ }^{282}$. Универсальные принципы, которые присущи праву вообще, независимо от его отрасли, это: гуманизм, демократизм, законность, разумность, справедливость. Данные принципы составляют фундамент не только правовой системы государства, но и всей его идеологической и нравственной надстройки. По степени воплощения этих принципов в реальную жизнь общества оценивается политический режим государства и состояние прав и свобод его граждан, приверженность к общечеловеческим ценностям, провозглашенным Всеобщей декларацией прав и свобод человека и гражданина.

Общие принципы относятся к правотворчеству любого уровня. К их числу относятся: гласность, научность, профессионализм, оперативность, соблюдение правил юридической техники, планирование и прогнозирование, системность, материальная обеспеченность, а также исполнимость правовых решений. Указанные принципы обеспечивают качественный уровень правотворческой деятельности, стабильность правовых предписаний и в то же время своевременную корректировку с учетом изменяющихся общественных отношений, характеризуют их обоснованность и реализуемость в процессе правоприменения, создают необходимый его правовой комфорт.

Специальные принципы дополняют вышеперечисленные более широкого диапазона действия основополагающие начала правотворчества. Они отражают потребности правового регулирования на уровне субъектов федерации и местного самоуправления. По сложившемуся в юридической науке представлению к таким принципам следует отнести: принцип взаимосогласованности и взаимодополняемости правотворчества всех его уровней; принцип дифференциации правотворческих полномочий субъектов правотворчества, принцип учета социальной, исторической, культурной и иной специфики конкретного территориального образования, принцип взаимосвязи теории с правотворческой практикой, принцип конкретизации правовых норм общего характера в нормах нижнего уровня действия, принцип устранения пробельности в праве и др.

Все виды принципов имеют условную дифференциацию, поскольку в процессе осуществления правотворчества учитываются определенной совокупностью, в зависимости от уровня правового регулирования. На нижнем уровне, к которому относится муниципальное правотворчество, находят свою реализацию принципы всех его видов. Тем самым обеспечивается единство правотворческого процесса на всех уровнях, достигается одновременно и учет имеющихся его особенностей с их отражением в нормах права.

В соответствии со ст. 4 Федерального закона «Об общих принципах организации местного самоуправления в Российской Федерации» право-

${ }^{282}$ Каменская Е.В. Региональное правотворчество в Российской Федерации: автореф. дис. ... к.ю.н. - М., 2005. - С. 12. 
вую основу местного самоуправления составляет общепризнанные принципы и нормы международного права, Конституция Российской Федерации, Федеральные конституционные и иные федеральные законы, издаваемые в соответствии с ними другие нормативные правовые акты (указы и распоряжения президента РФ, постановления и распоряжения правительства РФ, иные нормативные правовые акты федеральных органов исполнительной власти), конституции (уставы), законы и иные нормативные правовые акты субъектов федерации, уставы муниципальных образований, решения принятые на местных референдумах и сходах граждан и иные муниципальные правовые акты.

Вместе с тем, наличие многообразия актов правового регулирования местного самоуправления ${ }^{283}$ создает и многообразие правотворческой деятельности, осуществляемой субъектами, наделенными специфическими полномочиями федерального, регионального и местного уровня, что обуславливает серьезные предпосылки к возникновению дефектов правотворчества. К тому же субъекты муниципального правотворчества в целом, не ограничены законом в своем творческом усмотрении при выработке текстуального содержания будущей правовой нормы. Это не всегда идет на пользу качеству правотворчества, так как возникает широкий диапазон текстуального оформления в нормах права регулируемых ими однородных общественных отношений в различных регионах страны. Требуемой идентичности понимания юридических предписаний не возникает, создаются трудности в правоприменении и правотолковании. По мере правового регулирования количество разнообразных дефектов правотворчества нарастает как «снежный ком», что крайне негативно сказывается на результатах муниципального правотворчества ${ }^{284}$.

Учитывая эти обстоятельства, органы государственной власти оказывают помощь органам местного самоуправления при осуществлении последними правотворческой деятельности: разрабатывают модельные нормативные правовые акты, принимают методические рекомендации для реализации вопросов местного значения ${ }^{285}$. Однако иногда и в указанных образцах правотворческих документов, предназначенных для муниципальных правотворческих органов допускаются юридические ошибки, что совершенно недопустимо ${ }^{286}$. По нашему мнению, это обусловлено небрежностью и поспешностью при выработке таких документов.

Проблема качественной неоднозначности нормативных правовых актов муниципального правотворчества связана не только с многообразием

\footnotetext{
${ }^{283}$ В настоящее время 203 закона регулируют компетенцию муниципальной власти. В этих законах предусмотрены полномочия и права органов местного самоуправления, которые не согласуются с вопросами местного значения. См. подробнее: Местное право. - 2013. №2. - C. 4.

${ }^{284}$ Масловская Т.С. Владение юридической техникой - основа грамотности юриста. Томск, 2002. - С. 45.

285 Загидуллин Р.И. Использование методических рекомендаций органов государственной власти в муниципальном правотворчестве // Конституционное и муниципальное право. 2016. - №1. - С. 71.

286 Загидуллин Р.И. Указ. соч. - С. 72.
} 


\section{Правотворчество в Российской Федерации}

субъектов и нормативного регулирования этой деятельности. Как справедливо отметил М.Н. Марченко правообразование включает в себя не только правотворческий, но и весь предшествующий ему подготовительный процесс формирования права. Качество издаваемых норм права «зависит не только, а зачастую и не столько от уровня собственно самой правотворческой деятельности государственных органов, сколько от уровня проводившихся до принятия того или иного правового акта подготовительных работ» ${ }^{287}$. В связи с этим в юридической литературе неоднократно высказывалось предложение о необходимости регламентации предварительного этапа правотворческой деятельности 288 . И это предложение заслуживает реализации в законодательстве. В частности потому, что на предварительной стадии подготовки (выработки) правотворческого решения изучаются имеющиеся потребности правового регулирования тех или иных общественных отношений. Подготавливаемый правовой документ будет эффективным, если в нем в максимальной степени найдут отражение выявленные потребности правового регулирования, а также правильно определена его внутренняя структура, форма, место в системе других нормативных правовых актов и т. д.

Учитывая важность этой проблемы муниципального правотворчества, в некоторых регионах России законодательно закрепляют необходимость предварительного изучения общественного мнения по вопросам готовящихся решений субъектов правотворчества. Так, в соответствии с законом Белгородской области №24 от 08.12.2015 г. введено правило о проведении опроса населения по вопросам местного значения, результаты которого учитываются органами местного самоуправления при принятии своих решений ${ }^{289}$. Но результат опроса имеет рекомендательный характер.

Вместе с тем, решение непосредственно населением вопросов местного значения можно достичь путем проведения местного референдума. Конституция Российской Федерации предусматривает возможность проведения референдума на муниципальном уровне, что закреплено в ч. 2 ст. 130. В развитие этой конституционной нормы федеральный закон «Об общих принципах организации местного самоуправления в Российской Федерации» ${ }^{290}$ от 6.10.2005 № 131-Ф3 предусмотрел данную форму непосредственного участия населения в решении вопросов местного значения в ст. 22. Местный референдум проводится на всей территории муниципального образования (ч. 2 ст. 22). В поселении с численностью жителей менее 100 человек, обладающих избирательным правом, для

\footnotetext{
${ }^{287}$ Марченко М.Н. Проблемы теории государства и права. - М., 2013. - С. 661.

${ }^{288}$ См., например: Дерхо Д.С. К вопросу о необходимости нормативной регламентации предварительного этапа конституционного правотворчества // Апробация. - 2015. №8 (35). - С. 28.

289 Закон Белгородской области от 30.03.2005 г. №177 «Об особенностях организации местного самоуправления в Белгородской области». Статья 6.5 введена в действие законом №24 от 08.12.2015.

${ }^{290}$ СЗ РФ. - 2005. - Ст. 3822.
} 
решения вопросов местного значения проводится сход граждан (ч. 1 ст. 25 закона). При этом сход граждан осуществляет полномочия представительного органа муниципального образования, в том числе отнесенных к исключительной компетенции данного представительного органа. Таким образом, законодательно закреплена альтернатива представительному органу власти муниципального образования, что, несомненно, повышает демократические начала местного самоуправления.

В юридической литературе высказано мнение, что граждане не могут обладать властью, результатом которой их волеизъявления оформляются в нормы права обязательные для всех. Анализируя указанную позицию Н.П. Алешкова приходит к выводу, что такой подход не основан на законе. В обоснование своего мнения она пишет: «Основным способом реализации полномочий органов государственной власти и местного самоуправления для достижения поставленной цели является нормотворчество, т.е. способность придавать своим велениям общеобязательный характер. Однако такой способностью на муниципальном уровне обладают не только органы местного самоуправления, но и население муниципального образования непосредственно (ч. 1 ст. 7 ФЗ №131) через механизм референдума и сход граждан (ст. 22, 25 Ф3 №131)» ${ }^{291}$. И это правильный вывод. Хотя очевидно, что наличие возможности граждан иногда (на местном референдуме, сходе) участвовать в формировании отдельных нормотворческих решений не является формой настоящего народовластия, когда они имели бы право отстранять от власти чиновников, утративших народное доверие (расхитителей, взяточников, коррупционеров, бездельников, лиц, совершивших уголовные преступления и т. д.). Тем более, что решение о назначении местного референдума принимается представительным органом муниципального образования как самостоятельно, так и по инициативе граждан или общественных объединений (ч. 3 ст. 22 Ф3 №131). В последнем случае выдвижение инициативы затруднено необходимостью сбора подписей в ее поддержку, что ставит общественные объединения в худшие условия, чем органы представительной власти.

Решения на местном референдуме в соответствии с законом ФЗ №131 принимаются в следующем порядке:

1) принимаются путем голосования;

2) проведенный подсчет голосов оформляется протоколом участковыми комиссиями по проведению референдума;

3) общие итоги голосования устанавливает избирательная комиссия муниципального образования путем составления протокола, подписанного всеми членами комиссии (в трех экземплярах);

4) результаты референдума определяет избирательная комиссия муниципального образования путем суммирования данных всех протоколов, представленных участковыми комиссиями и оформленных итого-

${ }^{291}$ Алешкова Н.П. Конституционно-правовые основы муниципального правотворчества в Российской Федерации: автореф. дис. ... к.ю.н. - Екатеринбург, 2010. - С. 14. 


\section{Правотворчество в Российской Федерации}

вым протоколом. К протоколу, подписанному всеми членами избирательной комиссии, прилагается сводная таблица результатов голосования по всем участкам;

5) принятое на местном референдуме решение, а также итоги голосования подлежат официальному опубликованию по истечении 10 дней после определения окончательного результата. Принятое решение вступает в силу со дня его опубликования ${ }^{292}$.

Принятое на местном референдуме решение подлежит обязательному исполнению на территории муниципального образования и не нуждается в утверждении какими-либо органами государственной власти, их должностными лицами или органами местного самоуправления.

Вместе с тем, правовые акты, принятые на местном референдуме (сходе граждан) являются составной частью системы муниципальных правовых актов (п. 1 ч. 1 ст. 43 Ф3 №131), они обладают и высшей юридической силой наряду с уставом муниципального образования (ч. 2 ст. 43 Ф3 №131), имеют прямое действие и применяются на всей его территории. Иные муниципальные акты не должны противоречить не только уставу муниципального образования, но и правовым актам, принятым на местном референдуме (сходе граждан).

По мнению Ю.А. Тихомирова, природа решений института прямой демократии выражается в том, что граждане и их объединения, социальные общности сами вырабатывают правила поведения, нормы и добровольно им следуют. Происходит фиксированное прямое волеизъявление, которое становится юридически значимым решением - актом. И его следует включить в общую систему правовых актов, отмечая их высокую Значимость и ценность ${ }^{293}$.

Таким образом, непосредственное правотворчество граждан муниципальных образований закреплено законодательно и это свидетельствует об усилении демократических начал представительной власти местного самоуправления. Но и преувеличивать значение местного референдума (схода) тоже не следует, поскольку данная форма волеизъявления населения муниципального образования имеет исключительный характер и практически не оказывает серьезного влияния на деятельность исполнительной власти. Это надо помнить тем сторонникам «подлинного народовластия», которые вопреки здравому смыслу считают, что возможность участвовать граждан в референдуме решают все проблемы эффективности правотворчества, не замечая существующего всевластия исполнительной власти в лице зачастую алчных и коррумпированных чиновников.

Основной формой муниципального правотворчества является деятельность органов и должностных лиц местного самоуправления по изданию нормативных правовых актов, связанных с решением вопросов местного значения.

${ }^{292}$ СЗ РФ. - 2003. - №40. - Ст. 3822.

${ }^{293}$ Тихомиров Ю.А. Правовые акты: учеб.-практ. и справ. пособ. / Ю.А. Тихомиров, И.В. Котелевская. - М., 1999. - С. 250. 
Поскольку выработка норм права всегда есть творческий процесс, когда субъект правотворчества «формулирует и изобретает (в пределах объективно отведенных ему параметров) право» ${ }^{294}$, это обуславливает значительные трудности при создании качественных и эффективных правотворческих решений. Здесь приходится решать те же проблемы, что и при подготовке любых иных нормативных правовых документов (законов, подзаконных актов) - текстуальное формулирование будущих правовых предписаний. Это сложный вид деятельности, требующий не только высокого профессионализма, но и умения прогнозировать, предвидеть возможные последствия от действия того или иного правового документа. Как уже отмечалось, эти обстоятельства являются причиной снижения качества правотворчества на уровне местного самоуправления. Для устранения имеющихся недостатков в нормотворчестве предпринимаются различные меры: повышается профессиональный уровень субъектов правотворчества ${ }^{295}$, разрабатываются модельные нормативные правовые акты ${ }^{296}$, повышается качество предпроектного изучения вопросов правового урегулирования проблемных жизненных ситуаций ${ }^{297}$, допускается выработка правотворческих решений на альтернативной основе и т. д.

В юридической литературе называются следующие проблемы муниципального правотворчества. Первая группа проблем относится к его предпроектному этапу:

1) проблемы повышения качества правотворческой деятельности уполномоченных на то субъектов;

2) проблемы изучения состояния правового регулирования принимаемого муниципального правового акта;

3) проблемы согласованности этого акта с другими актами и обеспечение внутренней непротиворечивости его норм между собой;

4) проблемы планирования и прогнозирования правотворческого процесса;

5) проблемы использования правил и приемов юридической техники в нормообразовании;

6) проблемы разграничения понятий юридической и правотворческой техники.

Вторая группа проблем связана с проектным этапом муниципального правотворчества, это:

1) проблемы подготовки и обсуждения проекта муниципального правового акта;

\footnotetext{
${ }^{294}$ Баранов В.М. Личное в правотворчестве: утопия, антропологический ресурс или необходимое технико-юридическое средство повышения качества / В.М. Баранов, В.В. Трофимов // Вестник Нижегородской академии МВД России. - 2015. - №(30). - С. 16.

${ }^{295}$ Борисов А.С. Некоторые проблемы современного правотворчества в России / А.С. Борисов, П.А. Меркулов // Социум и власть. - 2015. - №3 (53). - С. 68.

296 Звягина Е.А. Указ. соч. - С. 62.

${ }^{297}$ Куксин И.Н. О некоторых проблемах предпроектного этапа муниципального правотворческого процесса / И.Н. Куксин, Е.А. Каминская // СПС Консультант Плюс.
} 


\section{Правотворчество в Российской Федерации}

2) проблемы, возникающие в ходе принятия решения по проекту муниципального правового акта;

3) проблемы актуализации правового акта в общественную среду, доведение его до адресата ${ }^{298}$.

Из перечисленных проблем подробнее следует остановиться на разграничении понятий «юридическая техника» и «правотворческая техника». Резкое возрастание правотворческой деятельности создает предпосылки для углубленного рассмотрения правил (своеобразных технологических стандартов) на базе которых она осуществляется. Высказанное И.А. Семеновым определение того, что рассматриваемые понятия есть не разные обозначения одного и того же явления, а два самостоятельные элемента правотворческого процесса, хотя и тесно связанных между собой ${ }^{299}$ является вполне обоснованным. К такому же выводу приходят И.Н. Куксин и Е.А. Каминская, указывая на то, что термин «юридическая техника» имеет более широкое значение, чем термин «правотворческая техника», которую они понимают как «правила распределения нормативного материала внутри акта в определенном порядке и логической последовательности на части и их согласование» ${ }^{300}$. По нашему мнению, понятие «юридическая техника» характеризует особенности технологии формирования (создания) норм права в процессе правотворчества, а «правотворческая техника» - термин процессуальный. Эти два понятия отражают содержание (юридическая техника) и форму (правотворческая техника) единого правотворческого процесса. С этой точки зрения высказанное указанными выше авторами мнение о сущности понятия «правотворческая техника» представляется правильным. Правотворческая техника - это все то, что используется в качестве определенных инструментов связанных с окончательным редактированием текстов издаваемых норм права уже сформулированных с помощью юридической техники и придания им юридической силы: законодательная инициатива, правовая экспертиза, общественное обсуждение, правотворческие процедуры, способы компоновки нормативных актов, их систематизация, кодификация и т. д. В настоящее время теория юридической техники недостаточно разработана, не имеет градации с учетом отражения нормотворческой и процессуальной стороны правотворчества. Этим и объясняется обозначенная проблема соотношения понятий «юридическая техника» и «правотворческая техника».

Для решения всех указанных проблем требуется серьезная исследовательская работа, имеющая научную основу, объединяющая усилия значительного числа специалистов, которые должны обладать высокими профессиональными знаниями и четкими представлениями о сущности своей деятельности, а также тех последствиях, которые обусловит разработанный ими правовой документ. Общая схема деятельности субъектов

\footnotetext{
${ }^{298}$ Куксин И.Н., Каминская Е.А. Указ. соч. - С. 66.

${ }^{299}$ Семенов И.А. Законодательная техника в уголовном правотворчестве. - Тюмень, 1998. C. 59.

${ }^{300}$ Куксин И.Н., Каминская Е.А. Указ. соч. - С. 67.
} 
муниципального правотворчества такова: изучение состояния правового регулирования общественных отношений, подпадающих под действие разрабатываемого правового акта, анализ действующего и зарубежного законодательства по вопросам проектируемого акта, изучение опыта работы по подготовке проектов муниципальных правовых актов в различных системах местного самоуправления ${ }^{301}$, обобщение предложений ученых и практических работников, касающиеся данной сферы правового регулирования, формирование и анализ информации по проблемам муниципального правотворчества (статической, нормативно-правовой и теоретико-правовой направленности). Итогом этой масштабной и длительной работы может стать тот нормативный правовой акт, который и урегулирует конкретную проблемную ситуацию в муниципальном образовании.

В юридической литературе не делается разделения муниципального правотворчества на собственно нормообразование (текстуальное оформление будущей нормы права) и процессуальное наделение ее юридической силой в ходе осуществления установленных законом процедур, поскольку законодательно - это единый процесс выработки нормы права. Однако издание нормы права включает в себя обе эти стороны правотворчества, что отражается и на подходах ученых к его пониманию. Так, М.А. Васильев в качестве стадий нормотворчества в ходе муниципального правотворчества называет такие его фазы, которые можно отнести к формированию непосредственно нормы права, а потом к ее дальнейшему совершенствованию и приданию ей юридической силы. По мнению данного ученого нормотворчество муниципальных образований включает следующие стадии:

1) изучение, анализ общественных явлений в муниципальном образовании, выявление потребности их правовой регламентации;

2) определение местных органов-субъектов права, которые наделены компетенцией на принятие правового решения по данному вопросу местного значения, а также определение вида правового акта;

3) принятие решения о подготовке правового акта;

4) разработка концепции будущего правового акта;

5) подготовка проекта правового акта;

6) предварительное рассмотрение проекта акта;

7) общественное обсуждение проекта;

8) официальное рассмотрение проекта акта соответствующим органом с соблюдением необходимых, законом установленных и обнародованных процедур;

9) принятие правового акта, его окончательное оформление, подписание, опубликование, вступление в законную силу.

Указанный список стадий нормотворчества муниципального правотворчества включает в себя обе его стороны и создание нормы права

${ }^{301}$ Андреева Л.И. Правотворчество органов местного самоуправления: по материалам Новгородской области: дис. ... к.ю.н. - СПб., 1999. - С. 177. 


\section{Правотворчество в Российской Федерации}

(правового акта) и придание юридической силы путем предусмотренных законом процедур.

Муниципальное правотворчество возбуждают предусмотренные законом Ф3 №131 субъекты нормотворческой инициативы, которые разрабатывают проект муниципального правового акта самостоятельно или коллегиально путем создания рабочей группы или комиссии. Если создается комиссия по подготовке проекта нормативного акта, в нее включаются помимо специалистов-практиков, ученые, депутаты, представители заинтересованных организаций и общественных объединений.

Проекты муниципальных правовых актов могут вноситься депутатами представительного органа муниципального образования, иными выборными органами местного самоуправления, главой местной администрации, органами территориального общественного самоуправления, инициативными группами граждан, а также иными субъектами правотворческой инициативы, установленными уставом муниципального образования (ст. 46 ФЗ №131).

По справедливому мнению В.А. Щепачева, разработка проектов правовых актов муниципального уровня должна осуществляться на плановой основе, что придаст целенаправленность деятельности субъектов правотворчества, обеспечит стимулирование интенсивного развития основных сфер социально-экономической жизни, демократических институтов, защиту прав населения, соблюдение компетенции правотворческого органа ${ }^{302}$. Планирование одновременно позволяет выявить потребность в подобном нормативном правом акте, его целесообразность, соотнести планируемый нормативный правовой акт с действующими, исключить дублирование и коллизионность на стадии подготовки проекта, исключить путаницу в очередности издания необходимых нормативных правовых актов, что может негативно отразиться на их качестве ${ }^{303}$. Планирование позволяет также осуществлять разработку муниципальных правовых актов в соответствии с основными направлениями законодательной политики государства в целом. «Эта политика, в свою очередь, является выражением объективных общественных потребностей, а также позиции, занятой руководящими социальными силами в отношении этих общественных потребностей» ${ }^{304}$. Кроме того, следует учитывать возможности муниципального образования по реализации предлагаемого правового решения в жизнь. Поскольку материальные, социальноэкономические условия постоянно изменяющийся фактор, то и уровень нормативно-правового регулирования будет изменяться, так как в нем находит свое формально-юридическое оформление ${ }^{305}$.

Повышению качества муниципального правотворчества способствуют разработанные в некоторых субъектах федерации правила подготов-

\footnotetext{
302 Щепачев В.А. Прогнозирование и планирование в муниципальном правотворчестве // Конституционное и муниципальное право. - 2009. - №18. - С. 21.

${ }^{303}$ Куксин И.Н., Каминская Е.А. Указ. соч. - С. 66.

${ }^{304}$ Нашиц А. Правотворчество: теория и законодательная техника. - М., 1974. - С. 100-101.

${ }^{305}$ См. подробнее: Марченко М.Н. Проблемы теории государства и права. - М., 2013. - С. 677.
} 
ки нормативных правовых актов ${ }^{306}$. Это вынужденный шаг, поскольку отсутствует аналогичное федеральное законодательство.

Таким образом, правотворческая деятельность органов и должностных лиц местного самоуправления является составной частью правотворчества в целом и она основана на общих принципах и единой политике государства. При разработке нормативно-правовых документов местного уровня используются те же технико-юридические средства, что и при выработке аналогичных актов более высокого уровня ${ }^{307}$. Однако в нормативных правовых актах муниципального уровня отражаются свои специфические потребности, поскольку они регламентируют вопросы местного значения. В юридической литературе высказано предложение о разработке федерального закона, закрепляющего правила правотворческой техники и порядок их применения во всех видах правотворческой деятельности. Наличие такого нормативного акта, несомненно, будет способствовать повышению качества муниципального правотворчества. Нормативные правовые акты, принимаемые органами местного самоуправления и населением на местном референдуме (сходе), входят в систему нормативных правовых актов Российской Федерации ${ }^{308}$. Это означает, что по своей природе, источнику, порядку образования и юридическим свойствам, по целевой и социальной направленности они обладают аналогичными признаками, что и у нормативных правовых актов государственных органов. Тем самым обеспечивается единство всей правовой системы страны.

Вместе с тем муниципальное правотворчество связано и с регулированием исполнения отдельных государственных полномочий, переданных органам местного самоуправления на основе закона (ч. 2 ст. 132 Конституции РФ). Наделение органов местного самоуправления отдельными государственными полномочиями Российской Федерации осуществляется федеральными законами, а отдельными государственными полномочиями субъектов Российской Федерации - законами субъектов федерации. Наделение государственными полномочиями иными нормативными правовыми актами кроме законов не допускается. Срок наделения отдельными государственными полномочиями может быть неограниченным, либо, если данные полномочия имеют определенный срок, то в его пределах. Органы государственной власти осуществляют контроль за ходом исполнения органами местного самоуправления отдельных

\footnotetext{
${ }^{306} \mathrm{C}$., например: Кодекс о нормативных правовых актах Чукотского автономного округа от 24.02.2009 №25-03 (в ред. от 30.05.2014 №37-03); Положение о видах правовых актов, принимаемых (издаваемых) органами исполнительной власти Сахалинской области и их руководителями, а также порядка их принятия и опубликования от 26.01 .2010 №12 (в ред. 05.07.2013 №342) и др. // СПС Консультант Плюс.

307 Каменская Е.В. Региональное правотворчество в Российской Федерации: автореф. дис. ... к.ю.н. - М., 2005. - С. 12.

${ }^{308}$ Гошуляк В.В. Конституционное и уставное законодательство субъектов Российской Федерации. - М., 1999. - С. 89.
} 


\section{Правотворчество в Российской Федерации}

государственных полномочий, а также за использованием предоставленных на эти цели материальных ресурсов и финансовых средств.

В юридической литературе передача некоторых полномочий от одних органов другим на определенное время для решения тех или иных конкретных задач, расширяющих компетенцию последних, рассматривается как делегирование ${ }^{309}$. Так, Е.С. Шугрина раскрывает данный процесс следующим образом: «Передача представляет собой способ полномочий, при котором какое-либо полномочие государственного органа исключается из его компетенции и включается в компетенцию органов местного самоуправления. Делегирование - это предоставление государственным органом принадлежащего ему права решения какого-либо вопроса органам местного самоуправления на один раз, на определенный срок или бессрочно» ${ }^{310}$.

По обоснованному мнению других ученых такой подход к пониманию наделения органов местного самоуправления отдельными государственными полномочиями не согласуется с положениями действующего законодательства, поскольку законодатель не освобождает органы государственной власти от ответственности за осуществление переданных полномочий, предусматривая финансирование их реализации и контроль со стороны государственных органов. Это указывает на сохранение государственной важности решаемых в результате осуществления этих полномочий задач ${ }^{311}$. Аналогичную позицию занимает и С.С. Алексеев, который пишет, что «в отличие от простого поручения при делегировании другой орган получает такие правотворческие полномочия, которых ранее у него не было, но и орган, который произвел передачу (делегацию) не теряет своей компетенции на издание нормативных юридических актов по данному кругу вопросов» ${ }^{312}$.

Таким образом, наделение органов местного самоуправления отдельными государственными полномочиями следует рассматривать как обязывание муниципального органа на выполнение конкретного вопроса из компетенции государственного органа за его счет и под его контролем.

Федеральный закон о наделении органов местного самоуправления теми или иными полномочиями должен предусматривать не только наименование конкретного муниципального образования, на которое возлагаются передаваемые полномочия, но и регламентировать перечень его прав и обязанностей, способ расчета нормативов для определения общего объема субвенций, передаваемых местным бюджетам из федерального бюджета, для осуществления соответствующих полномочий,

\footnotetext{
${ }^{309}$ Кулушева М.А. О наделении органов местного самоуправления отдельными государственными полномочиями // Россия на пути реформ: федеральный и региональный аспекты / под ред. С.Ю. Наумова. - Саратов, 2003. С. 139.

${ }^{310}$ Шугрина Е.С. Муниципальное право: учебник. - М., 2004. - С. 355.

${ }^{311}$ Малько А.В. Муниципальное право России / А.В. Малько, С.В. Корсакова. - М.: Юрайт, 2011. - C. 370-371.

312 Алексеев С.С. Избранное. Наука права. Общесоциальные проблемы. - М., 2003. C. 154.
} 
перечень подлежащих передаче в пользование или в собственность материальных средств, порядок отчетности об осуществлении переданных государственных полномочий, а также порядок контроля над ходом их выполнения, условия и порядок прекращения реализации органами местного самоуправления этих государственных полномочий.

Поскольку уровень бюджетной обеспеченности муниципальных образований значительно отличается между собой, то государство стремится выравнивать его с учетом реальных потребностей каждого из них с помощью бюджетной политики, разрабатывая нормотворческие решения в бюджетной сфере. Например, недостающие финансовые средства для выравнивания бюджетной обеспеченности муниципальных районов, поступают в виде дотаций из региональных фондов финансовой поддержки муниципальных районов, образуемых в соответствии с Бюджетным кодексом РФ.

Кроме того, в целях предоставления местным бюджетом субсидий для долевого финансирования инвестиционных программ и проектов развития общественной инфраструктуры муниципальных образований в составе расходов бюджета субъекта федерации может быть образован фонд муниципального развития. В дальнейшем отбор муниципальных образований, которым предоставляются указанные субсидии, и их распределение между ними осуществляется по единой методике в соответствии с требованиями Бюджетного кодекса РФ.

Общий размер субвенций, предоставляемых из федерального бюджета местным бюджетам на осуществление органами местного самоуправления переданных им отдельных государственных полномочий, определяется федеральным законом о федеральном бюджете на очередной финансовый год.

В настоящее время субъектами федерации передаются органам местного самоуправления государственные полномочия по следующим видам:

1) по предоставлению мер социальной поддержки и социальному обслуживанию населения, в том числе: назначение и выплата материнской помощи различным категориям граждан (малоимущие и многодетные семьи, пенсионеры и т. д.), предоставление социальной поддержки населению по оплате жилья и коммунальных услуг, оказание медикосоциальных услуг гражданам и социальное обслуживание детей-сирот и детей, оставшихся без попечения родителей (Ставропольский край, Ростовская область и др.);

2) по регистрации актов гражданского состояния, совершение нотариальных действий и использованию архивного фонда (Краснодарский край, Республика Северная Осетия - Алания, Карачаево-Черкесская республика, Ростовская область);

3) по лицензированию розничной продажи алкогольной продукции (Ярославская область, Томская область, Саратовская область, Республика Саха (Якутия), Республика Бурятия);

4) по созданию и обеспечению деятельности административных комиссий и комиссий по делам несовершеннолетних (Ленинградская об- 


\section{Правотворчество в Российской Федерации}

ласть, Пензенская область, Тульская область, Рязанская область, Астраханская область, Брянская область, Краснодарский край);

5) по оказанию населению специальной медицинской помощи в туберкулезных, наркологических, онкологических диспансерах и других специализированных медицинских учреждениях (Ставропольский край, Воронежская область, Костромская область) ${ }^{313}$.

С каждым годом количество переданных государственных полномочий возрастает.

Следует отметить, что в настоящее время за разными уровнями власти закреплены однородные функции и сферы ответственности, но полномочия четко не разграничены. В ряде случаев формулировки как базового, так и отраслевого законодательства при описании вопросов ведения разных уровней власти, а также разных типов муниципалитетов практически идентичны или схожи до степени полного смешивания. В результате невозможно определить границы компетенции и ответственности каждого уровня власти в соответствующей сфере. Это касается, например, охраны окружающей среды, поддержки сельскохозяйственного производства, поддержки малого и среднего бизнеса, культуры, искусства, народных художественных промыслов, деятельности аварийноспасательных служб, работы с детьми и т. д. ${ }^{314}$.

В то же время реализация делегированных государственных полномочий на основе субвенций из бюджетов вышестоящего уровня не способствует укреплению налогового потенциала муниципальных образований, не стимулирует органы местного самоуправления к эффективному исполнению переданных (не собственных) полномочий, возложенных на них без их согласия и зачастую без достаточного финансового и материального обеспечения. Делегирование полномочий нижестоящим уровням публичной власти представляет собой вторичный механизм перераспределения компетенции, а потому является следствием неэффективного первичного разграничения полномочий между различными уровнями публичной власти ${ }^{315}$.

Ситуация между тем не улучшается, так как во многих отраслевых законах, принимаемых в последнее время, субъектам федераций разрешается передавать на местный уровень переданные им федеральные государственные полномочия. Это предусмотрено, например, федеральными законами «Об актах гражданского состояния», «О Всероссийской сельскохозяйственной переписи», «О ветеринарии», «О социальной защите инвалидов в Российской Федерации» и др.

Таким образом, правотворчество органов и должностных лиц местного самоуправления по вопросам исполнения отдельных государственных полномочий имеет тенденции к постоянному расширению. Это связано с

\footnotetext{
${ }^{313}$ См. подробнее: Малько А.В. Муниципальное право России / А.В. Малько, С.В. Корсакова. - М.: Юрайт, 2011. - С. 385.

314 Справочно-аналитические материалы Общероссийской общественной организации «Всероссийский совет местного самоуправления» // Местное право. - 2013. - №2. - С. 27. ${ }^{315}$ Там же. - С. 29.
} 
возрастанием количества передаваемых на муниципальный уровень государственных полномочий. При передаче указанных полномочий не всегда выдерживается принцип социально-экономической обоснованности наделения органов местного самоуправления отдельными государственными полномочиями, что снижает возможности стабильного развития муниципальных образований. По сложившемуся обоснованному мнению ученых и практических работников сферы муниципального управления в настоящее время созрела потребность в радикальном пересмотре государственного подхода о наделении отдельными полномочиями вышестоящими органами нижестоящих, так как обозначился процесс постепенного наделения органов местного самоуправления не свойственными им государственными функциями. Если этот процесс не остановить, то местное самоуправление постепенно превратится в государственное и сформируется трехступенчатая система государственной власти: федеральная, субъектов федерации и муниципальная, что противоречит Конституции РФ.

Подводя итог по вопросу в целом, можно сделать следующие выводы:

1. Муниципальное правотворчество - это деятельность уполномоченных законом субъектов (или всего населения муниципального образования в ходе местного референдума) по изданию норм права для урегулирования вопросов местного значения, которое включает две фазы:

1) нормотворческую (выработка текстуального содержания будущей нормы права);

2) процессуальную (последующее ее редактирование и придание юридической силы путем осуществления правотворческих процедур).

2. Муниципальное правотворчество - самостоятельный вид правотворчества, который в настоящее время не имеет единого законодательного урегулирования, что порождает большое количество проблем связанных с реализацией его норм, а также теоретическим осмыслением его правовых институтов, категорий и дефиниций, для разрешения которых требуются глубокие комплексные их исследования.

3. Повышение качества муниципального правотворчества возможно лишь путем совершенствования законодательства этой сферы деятельности органов местного самоуправления, повышения профессионального уровня субъектов муниципального правотворчества, внедрения предложений, выработанных юридической наукой, широкого использования модельных нормативных правовых актов муниципального уровня и постоянного мониторинга действующего блока нормативных актов в сфере муниципального управления.

4. Рост количества правотворческих решений по наделению муниципальных образований отдельными государственными полномочиями дестабилизирует систему распределения этих полномочий между государственными органами и органами местного самоуправления. Наметилась тенденция к постепенной передаче государственных полномочий органам местного самоуправления на постоянной основе, что может привести к формированию государственного управления и на уровне местного самоуправления. Перспектива получения такого результата противоречит Конституции РФ. 


\section{§2.7. ЛОКАЛЬНОЕ ПРАВОТВОРЧЕСТВО}

Одним из наиболее распространенных видов правотворчества является локальное правотворчество. Его значение в регулировании общественных отношений постоянно возрастает. Это связано в первую очередь с децентрализацией правового регулирования, а также с возрастанием роли саморегулирования, осуществляемого субъектами правотворчества основного, нижнего уровня. Та сфера общественных отношений, которая остается за пределами возможностей государственного регулирования, передана на самостоятельную ее регламентацию заинтересованных в ней субъектов. Но государство не выпустило из своего поля зрения данный процесс, сохранив за собой контроль за его ходом и возможность в случае необходимости оказать на него корректирующее воздействие.

В юридической науке не вызывает спора вопрос относительно существования такой правовой категории как локальное правотворчество. Учеными признается, что это один из видов правотворчества, осуществляемого в рамках корпораций, органов местного самоуправления, а также деятельность по изданию актов государства, имеющих ограниченную (локальную) сферу действия ${ }^{316}$.

Однако признание такого правового явления как локальное правотворчество не означает по мнению отдельных авторов, что создаваемые в этом процессе акты являются нормативно-правовыми актами. Так, разработчики проекта федерального закона «О нормативных правовых актах в Российской Федерации» в ст. 2 прямо указывают, что локальный нормативный акт, в том числе содержащий нормы права, не является нормативным правовым актом ${ }^{317}$. В связи с этим С.В. Бошно отметила: отнесение локальных нормативных актов государства (например, постановления Государственной Думы Федерального Собрания РФ, утвердившего Регламент этой палаты российского парламента) к числу тех, которые не являются нормативными, недостаточно обоснованно ${ }^{318}$. И с этим следует согласиться. Нормативность тому или иному акту придает не сфера его воздействия, а правовое значение в регулировании общественных отношений, то есть функциональное назначение. В этом смысле локальный нормативный акт выполняет достаточно широкие функции:

1) первичное регулирование общественных отношений в различных организациях в тех пределах, которые установило государство;

\footnotetext{
316 Арзамасов Ю.Г. Ведомственный нормотворческий процесс: структура, содержание, перспективы развития (ч. 1) // Сводный реферативный сборник журнала «Представительная власть - XXI век: законодательство, комментарии, проблемы». - 2007. - №4; Потапов В.А. Корпоративные нормативные акты как вид локальных актов: автореф. дис. ... к.ю.н. М., 2008. - С. 17 и др.

${ }^{317}$ Проект федерального закона «О нормативных правовых актах в Российской Федерации» // СПС Консультант Плюс.

${ }^{318}$ См.: выступление С.В. Бошно на круглом столе «Актуальные проблемы правотворчества и проект федерального закона «О нормативных правовых актах в Российской Федерации» 26.01.2015 // Журнал российского права. - 2015. - №3. - С. 149.
} 
2) осуществляет конкретизацию правовых норм, содержащихся в правовых актах государственных органов;

3) восполняет имеющиеся пробелы в праве;

4) оказывает серьезное влияние на правовую политику государства;

5) является одним из факторов, воздействующих на формирование правосознания общества ${ }^{319}$.

Следует также учитывать, что локальное правотворчество санкционировано государством. Поэтому, издаваемые локальными организациями нормы должны соответствовать действующему законодательству РФ. Лишь в тех случаях, когда необходимо ввести в правовое поле специфические, особенные сферы общественных отношений этих организаций (например, установить структуру управления, если она не определена самим государством, урегулировать взаимоотношения между ее членами, предусмотреть правовые рычаги повышения эффективности деятельности и т.д.) законом допускается издание локальных норм права. Следует иметь в виду и тот факт, что хозяйствующие субъекты разрабатывают не только нормативные акты, регулирующие взаимоотношения между его членами, но и различные технико-правовые документы, регламентирующие качество и стандарты выпускаемой продукции, устанавливают определенные требования к процессам ее производства, хранения, перевозки и т. д. Данная сфера локального правового регулирования представляет собой самостоятельный вид технической регламентации и в данной работе не рассматривается ${ }^{320}$.

Локальным нормам права, как и нормам права в целом, присущи все признаки, указывающие на их регулятивный характер. В частности, они:

1) обязательны к исполнению всеми субъектами, которым адресованы;

2) имеют формальную определенность (изданы в письменной форме в виде официальных документов, предписывающих рамки действия участвующих в общественных отношениях определенного круга лиц);

3) имеют непосредственную связь с государством, поскольку издаются на основании его предписаний и не могут противоречить действующему законодательству (к тому же обеспечиваются судебной защитой);

4) имеют представительно-обязывающий характер, что означает: одним субъектам предоставляются определенные права с возложением на других субъектов обязанности совершить действия для реализации этих прав;

5) изложение правовых предписаний в локальных нормативных актах, как правило, имеет полное совпадение с общепринятой системой построения норм права в целом;

6) рассчитаны на многократное применение ${ }^{321}$.

\footnotetext{
${ }^{319}$ См. подробнее: Потапов В.А. Указ. соч. - С. 19.

${ }^{320} \mathrm{C}$ м. подробнее: Баукен А.А. Место актов локального технико-правового регулирования в системе локальных нормативных актов // Вестник ЮУрГУ. Серия «Право». - 2014. T. 14. - №1.

${ }^{321}$ См. подробнее о признаках норм права: Малько А.В. Теория государства и права. - М., 1999. - С. 129-130; Власов В.И. Теория государства и права. - Ростов н/Д., 2002. - С. 286.
} 


\section{Правотворчество в Российской Федерации}

Из сказанного следует, что локальные нормы, регулирующие достаточно обособленную сферу общественных отношений, являются правовыми нормами особого вида. Это нормы, устраняющие правовые пробелы законотворчества и подзаконного нормотворчества, а также конкретизирующие отдельные нормы этих видов правотворчества. В иерархии значимости правовых норм по масштабам их действия локальные нормы занимают нижнюю ступень, регулируя общественные отношения в конкретных организациях и коллективах. Очевидно, что государство допускает функционирование трех видов правовых норм:

1) общегосударственные законодательные и подзаконные нормы, действующие на всей территории страны;

2) региональные, которые регулируют общественные отношения в субъектах федерации или в масштабах определенного региона;

3) локальные нормы права, которые необходимы для урегулирования общественных отношений внутри определенных организаций (включая и органы государственной власти) и коллективов 322 . Государство, не имея возможности нормировать деятельность всех существующих на его территории формально организованных групп населения, вполне логично допускает возможность им самим выработать нормы по урегулированию их взаимоотношений на основе действующего законодательства. Одновременно такой подход и наиболее разумен. Ибо никто не сможет лучше конкретного коллектива урегулировать взаимоотношения между его членами, чем этот коллектив.

Таким образом, локальное правотворчество представляет собой важнейшую нижнюю ступень в формировании правовых норм, регулирующих общественные отношения.

Но будучи недостаточно изученным правовым явлением, не имеющим законодательного определения своего юридического понятия, продолжает оставаться предметом дискуссионных споров относительно места, отведенного ему в системе правового регулирования общественных отношений, и даже возможности создавать нормы права.

Не все ученые рассматривают локальное правотворчество как нормотворческую деятельность любых обособленных коллективов по урегулированию своих внутренних потребностей. Одни авторы понимают его в узком смысле, отождествляя с правотворческой деятельностью корпораций. Так, М.Н. Марченко указывает, что главной особенностью локального правотворчества является система правотворческих полномочий, которыми обладают администрации предприятий, объединений и учреждений, имеющих право принимать локальные нормативные акты, направленные на регулирование отношений внутреннего порядка ${ }^{323}$. Примерно так же достаточно узко определяет понятие локального правотворчества С.В. Нарутто, указывая, что это деятельность по созданию, изменению и дополнению общеобязательных правил поведения по

\footnotetext{
${ }^{322} \mathrm{CM}$. подробнее о корпоративном урегулировании внутренней деятельности хозяйственного общества: Потапов В.А. Указ. соч. - С. 11.

${ }^{323}$ Проблемы теории государства и права: учебник / под ред. М.Н. Марченко. - М., 2001. - С. 342.
} 
предметам местного значения, осуществляется в определенном, установленном уставом муниципального образования и иными нормативными актами органов и должностных лиц местного самоуправления процессуальном порядке ${ }^{324}$. Другие авторы локальное правотворчество рассматривают в более широком аспекте, как деятельность администраций трудовых коллективов, государственных предприятий, акционерных обществ, производственных и других кооперативных обществ и экономических ассоциаций по изданию нормативных актов, имеющих ограниченное действие ${ }^{325}$. Более точным, по нашему мнению, является И.С. Кириленко, понимающий под локальным правотворчеством, «особый вид правотворчества, осуществляемый уполномоченными субъектами на подзаконном уровне, предметом которого является разработка, принятие и введение в действие локальных нормативных правовых актов, распространяющих свое действие на четко определенный круг субъектов в пределах конкретного предприятия, учреждения, организации или их объединений, и касающихся вопросов их функционирования» ${ }^{326}$.

Как видно из этих определений, понятие локального правотворчества формулируется с учетом сферы регулируемых общественных отношений. Различные авторы понимают ее по-разному, что и обуславливает их подходы при выработке определения локального правотворчества. Общим для всех этих определений является то, что локальное правотворчество понимается как самостоятельный вид правотворчества в целом, как одна из его разновидностей. И это главное достоинство, высказанных в юридической науке, определений локального правотворчества, что собственно и необходимо для его дальнейшего исследования.

Локальное правотворчество, будучи обособленной сферой правого регулирования, занимает свою нишу в системе правотворчества, которую невозможно заменить какой-либо иной и без которой невозможно представить завершенность правового урегулирования нижнего (основного) уровня общественных отношений, протекающих в трудовых, общественных, кооперативных, образовательных, корпоративных и в других структурных организациях и коллективах. Поэтому под локальным правотворчеством необходимо понимать правотворческую деятельность по регламентации общественных отношений в форме саморегулирования внутренней жизни любой формально определившейся организации, независимо от ее правового статуса и функционального предназначения. Отличительная особенность локального правотворчества состоит не только в сфере регулируемых общественных отношений, но и в способе такого регулирования, которое может протекать не иначе как в форме саморегулирования на основе и во исполнение законов.

\footnotetext{
${ }^{324}$ Нарутто С.В. Основные правила юридической техники разработки концепции муниципальных правовых актов по самоорганизации населения / С.В. Нарутто, А.С. Пичоанин, Л.А. Плотникова. - Хабаровск, 2003. - С. 12

${ }^{325}$ См., например: Червонюк В.И. Теория государства и права: учебник. - М., 2006. - С. 385.

${ }^{326}$ Кириленко И.С. Локальное правотворчество в современных условиях правового регулирования: вопросы теории и практики // Современное право. - 2014. - №3. - С. 10-11
} 


\section{Правотворчество в Российской Федерации}

В теории правотворчества придается важное значение выявлению признаков локального правотворчества ${ }^{327}$. Однако, пока не сформировался единый общепризнанный подход к их выделению и пониманию. Можно сказать, что идет процесс научного осмысления критериев, по которым необходимо их выделять. Наиболее полный перечень признаков локального правотворчества приводит И.С. Кириленко, к числу которых относит следующие:

1) локальное правотворчество является самостоятельным видом правотворчества и осуществляется в сфере правоотношений хозяйствования и управления;

2) осуществляется специально уполномоченными субъектами единолично или коллегиально;

3) результатом является принятие локальных нормативных правовых актов как особого вида нормативных правовых актов подзаконного уровня;

4) осуществляется в соответствии и во исполнение положений нормативных правовых актов законодательного и общегосударственного подзаконного уровней;

5) обеспечивает локальное правовое регулирование общественных отношений;

6) имеет упрощенную процедуру разработки, принятия и введения в действие ${ }^{328}$.

Анализируя указанные признаки, автор приходит к выводу, что локальное правотворчество соответствует содержанию правотворчества в целом. Тем самым подтверждая самостоятельное значение данного вида правотворчества в регулировании общественных отношений в сфере деятельности предприятий, организаций, учреждений, корпораций и других коллективных объединений. Но одновременно оно обладает специфическими особенностями, в которых протекает, что во многом затрудняет его научное осмысление, выявление истинного значения в системе правовых норм, используемых для правового регулирования. Рассмотрим эти особенности подробнее.

1. Локальное правотворчество связано с урегулированием разнообразных общественных отношений, протекающих в сфере огромного количества автономно действующих, независимых друг от друга коллективов граждан, работников хозяйствующих субъектов, государственных ведомств и органов власти. Это исключает правовое регулирование их деятельности по единому образцу, требует индивидуального подхода при ее регламентации, обуславливает такой правовой феномен, как саморегулирующее правотворчество. Так, М.П. Петров полагает, что «без передачи части правовых средств на уровень локального регулирования

\footnotetext{
${ }^{327}$ См., например: Акопова Е.М. Локальное правовое регулирование труда на предприятии // СПС Консультант Плюс; Форманюк В.В. Локальна правотвочість як одна форм активності соціального суб'екта // СПС Консультант Плюс.

${ }^{328}$ Кириленко И.С. Указ. соч. - С. 11.
} 
образовательные отношения потеряют гибкость и эффективность» ${ }^{329}$. Анализируя отношения в той же сфере образования А.Н. Козырин и Т.Н. Трошкина подчеркивают особое значение локальных нормативных актов, поскольку в них учитываются мнение работников образовательных учреждений ${ }^{330}$. Аналогичного мнения придерживаются и авторы учебника по корпоративному праву, указывая на то, что издаваемые внутри самой корпорации нормы права, регулирующие наиболее важные отношения, складывающиеся на предприятии, являются самыми значимыми среди других корпоративных норм ${ }^{331}$.

Однако, наличие большого объема документов локального регулирования, имеющих непосредственную связь с конкретными потребностями субъектов в той или иной сфере общественных отношений, содержащих помимо норм права и другие нормы (технические, бытовые, организационные и т. д.) затрудняет уяснение правовой природы норм локального правотворчества. Саморегулирующее правотворчество, как необходимая и важнейшая ступень регулирования общественных отношений, затеняется множественностью норм, имеющих иное функциональное назначение. Тем самым создается ситуация когда огромный пласт норм права не находит адекватного отражения как в теории, так и в правотворческих решениях.

2. Локальное правотворчество регулируется совокупностью различных по юридической силе нормативных правовых актов (Конституцией РФ, федеральными конституционными и иными законами, федеральными подзаконными нормативными актами, законами субъектов РФ, в том числе их Уставами, а также множеством различных нормативных правовых актов, издаваемых государственными органами во всех сферах общественной жизни). Обилие нормативного материала, которое следует учитывать в процессе создания норм локального правотворчества, порождает серьезные проблемы:

1) наблюдаются многочисленные случаи противоречия его норм с нормами федерального законодательства, а также нормами законодательства субъектов федерации;

2) идет процесс снижения качества локального правотворчества, который обусловлен одновременно и несовершенством федерального законотворчества. По мнению Е.Л. Звягиной, сдерживающим фактором развития правотворчества в муниципальных образованиях является пробельность и коллизионность федерального и регионального законодательства, несформированность правового поля правотворчества в обла-

\footnotetext{
329 Петров М.П. Локальные акты организации образования: правовая природа, виды и основания принятия // Ежегодник рос. образоват. законодательства. - 2014. - Т. 9. - С. 7-69.

${ }^{330}$ Козырин А.Н. Правовое регулирование в сфере образования: научно-практический комментарий статьи 4 Федерального закона «Об образовании в Российской Федерации» / А.Н. Козырин, Т.Н. Трошкина // Ежегодник российского образовательного законодательства. - 2013. - Т. 8. - С. 22-23.

${ }^{331}$ Гущин В.В. Корпоративное право / В.В. Гущин, Ю.О. Порошкина, Е.Б. Сердюк. - М., 2009. - C. 86.
} 


\section{Правотворчество в Российской Федерации}

сти местного самоуправления, отсутствие баланса интересов в развитии местного самоуправления ${ }^{332}$. И это касается любого вида локального правотворчества;

3) отсутствуют установленные государством образцы правотворческих решений по регулированию стандартных (характерных для многих локальных организаций) случаев, что порождает не только противоречивость в оценке типичных ситуаций различными правотворческими субъектами, но и различные (порой диаметрально противоположные) подходы в их правовом обеспечении. К тому же в основе таких подходов лежит, как правило, императивный метод правового регулирования, хотя, по нашему мнению, общественные отношения, складывающиеся в сфере отдельных коллективов и конкретных организаций, должны в первую очередь быть урегулированы с помощью диспозитивного метода. В связи с этим представляется, что для повышения эффективности локального правотворчества необходимо разработать и утвердить «Образцы правового регулирования типичных ситуаций локального характера». Тем самым государство создаст стабильную правовую базу для субъектов локального правотворчества, что обязательно повысит качественный потенциал локального правотворчества.

3. Негативным фактором, влияющим на качество локального правотворчества, является то обстоятельство, что в нем участвует многочисленная армия субъектов, которые в подавляющем большинстве не имеют юридического образования. Этот недостаток присущ субъектам правотворчества любого вида. Но на федеральном уровне правотворческие решения серьезно дорабатываются путем проведения правовых экспертиз, которые осуществляются с привлечением ученых и специалистов, имеющих практический опыт деятельности в конкретных областях юриспруденции, тогда как локальные правовые акты принимаются зачастую даже без участия обыкновенных юристов ${ }^{333}$. Усугубляется эта ситуация еще и тем, что в настоящее время отсутствует целенаправленная государственная политика по внедрению в правотворческий процесс научно обоснованных рекомендаций ученых и юристов - практиков. Не решается также проблема повышения требований к профессиональному уровню субъектов правотворчества в целом и особенно тех, которые участвуют в разработке локальных нормативных актов. Представляется, что локальные нормативные акты до их государственной регистрации должны проходить обязательную правовую экспертизу, что обеспечит повышение их качественного уровня.

4. В процессе локального правотворчества осуществляется издание большего количества нормативных правовых актов различного регулятивного назначения, не имеющих ни единой формы и содержания, ни

\footnotetext{
332 Звягина Е.Л. Правотворчество в области местного самоуправления в Российской Федерации: правовые пробелы теории и практики (на примере Пензенской области) // Известия ПГПУ. - 2007. - №3. - С. 61.

${ }^{333} \mathrm{C}$. о проблеме участия юристов в подготовке законопроектов подробнее: Борисов А.С. Некоторые проблемы современного правотворчества в России / А.С. Борисов, П.А. Меркулов // Социум и власть. - 2015. - №3 (53). - С. 67
} 
единой иерархической системы. Их объединяет только то, что они регулируют общественные отношения самого нижнего уровня, это и позволяет заключить об их ключевом значении в системе правотворчества ${ }^{334}$. Однако, многочисленность обуславливает и невозможность надежного контроля за их качеством, что порождает иллюзию стихийности, неуправляемости самого локального правотворчества. Это не так. Локальное правотворчество осуществляется строго в рамках действующего законодательства ${ }^{335}$. Издаваемые в этом процессе нормативные акты имеют уровень подзаконных актов и действуют в пределах, установленных законом. И хотя по качественным характеристикам нормативные акты локального правотворчества не всегда соответствуют современным требованиям, тем не менее они обеспечивают реальное регулирование отношений в конкретных коллективах и организациях. Однако их эффективность снижается в значительной степени тем, что государство не рассматривает саморегулирующее правотворчество в качестве равноценного и надежного способа регулирования общественных отношений. Оно постоянно пытается ограничить степень правовой саморегуляции организаций, особенно в сфере бизнеса, что приводит к неоправданным экономическим потерям, банкротствам отдельных хозяйствующих субъектов, рейдерским захватам эффективных предприятий, прекращению деятельности процветающих фирм (особенно в сфере мелкого предпринимательства) при малейшем нарушении ими действующего законодательства. Государство пытается развивать экономику не путем установления правил, выгодных для всех участников ведения бизнеса, что можно выработать только в процессе саморегулирующего правотворчества, а путем императивного навязывания субъектам экономических отношений таких правил, которые создают неравноправные отношения между партнерами, устанавливают формальные основания (не вытекающие из экономической необходимости) прекращения деятельности стабильно работающих предприятий. Законодательно закреплено всевластие чиновников, которые не имеют прямых обязанностей по развитию бизнеса, повышению его эффективности, по созданию рабочих мест, выявлению молодых талантливых предпринимателей и оказанию им помощи в осуществлении их экономических проектов. Чуть ли не на государственном уровне сформировалось мнение, что те, кто не смог реализовать себя в качестве педагога, врача или строителя, тот должен идти в бизнес. Видимо, с учетом такого подхода и формируется блок экономического законодательства. Государство, которое должно регулировать лишь деятельность участников экономических отношений, пытается одновременно регулировать и эти экономические отношения. В итоге за двадцать с

\footnotetext{
${ }^{334}$ Кириленко И.С. Локальное правотворчество в современных условиях правового регулирования: вопросы теории и практики // Современное право. - 2014. - №3. - С. 11.

${ }^{335}$ Например, приведенный М.П. Петровым анализ локальных актов по организации высшего образования показал, что в данной сфере законодательство РФ предписывает вузам издание 32 обязательных локальных нормативных актов и 23 таких актов по своему усмотрению: Петров М.П. Указ. соч. Приложение №1 и №2. - С. 42-69.
} 


\section{Правотворчество в Российской Федерации}

лишним лет построения рыночной экономики все еще не просматривается положительный результат столь продолжительной работы. И причиной этого является не многообразие нормативных правовых актов, издаваемых в сфере локального правотворчества, а излишний государственный контроль за процессом саморегулируемого правотворчества, попытка жесткого администрирования всей деятельности участников нижнего, важнейшего пласта общественных отношений ${ }^{336}$.

5. Еще одним обстоятельством, влияющим па понимание правотворческого значения локального саморегулирования, является различная степень юридической силы его нормативных правовых документов, а также широта охвата субъектов, на которых они воздействуют. Так, совершенно очевидно, что внутренние нормативные документы, принимаемые органами законодательной и исполнительной власти федерации и ее субъектов, имеют большую юридическую силу, чем, например, те нормативные акты, которые издаются в сфере корпоративного правотворчества. Данный фактор затрудняет рассмотрение локального правотворчества в единой системе субъектов этого вида правовых документов. Однако если рассматривать указанный процесс как саморегулирующуюся деятельность, то сразу же приходит понимание о целесообразности и необходимости объединения всех этих видов локального правотворчества в единую группу. Наличие различных одновременно действующих критериев локального правотворчества, характеризующих его сущность по нескольким показателям, лишь индивидуализирует каждый его вид, но не исключает из общей системы саморегулируемого правотворчества.

В этой связи становится понятно, что нормативные акты, издаваемые для внутреннего использования органами законодательной власти, являются по своей юридической силе тождественны законам, которые они разрабатывают и принимают. Это обстоятельство учитывается правообразующими субъектами более низких уровней. При разработке и создании ими своих нормативных правовых актов они используют выработанную вышестоящими органами власти технологию издания таких документов. Это, несомненно, положительно сказывается на качестве принимаемых правотворческих решений. В то же время субъекты локального правотворчества, не относящиеся к органам государственной власти, не всегда имеют надежный, апробированный ориентир разработки и принятия своих правовых документов. Это порождает не только большое разнообразие таковых, но и значительное количество недостаточно продуманных и обоснованных правовых норм, противоречащих нормам более высокой юридической силы, а то и находящимся в противоречии между собой ${ }^{337}$.

\footnotetext{
${ }^{336}$ См.: подробнее о механизме влияния государства на локальное правотворчество: Баукен А.А. Указ. соч. - С. 12.

${ }^{337}$ См. подробнее о характерных ошибках в правотворчестве: Со А.А. Подзаконное правотворчество и юридическая техника (на примере органов исполнительной власти субъектов РФ Дальневосточного федерального округа) // Власть. - 2015. - №1 . - С. 157.
} 
Кроме того, следует учитывать и широту воздействия локальных нормативных документов на субъекты их применяющие. В одних случаях количество субъектов, которым адресуется тот или иной локальный нормативный документ, может исчисляться десятками (сотнями) человек, как например, корпоративные акты, а в других - десятками тысяч и даже миллионами, если издается ведомственный локальный нормативный акт, например, министерством образования и науки. Но и в тех, и в других случаях на локальную принадлежность таких нормативных актов указывает их функциональная направленность на урегулирование своих внутренних потребностей. Все они являются нормативными актами саморегулирования, в которых наиболее гармонично отражается принцип учета общих (государственных) и специфических интересов конкретной организации, ведомства или организованного коллектива.

Таким образом, локальное правотворчество, представляя собой самостоятельный вид правового регулирования общественных отношений первичного самого многообразного уровня, сопряжено с проблемами научного и практического характера, проблемами осуществления правовой политики государства, которые требуется решать комплексно путем объединения усилий ученых и законодателей.

Правовую, регламентирующую природу локальных нормативных актов может характеризовать также их классификация. Деление локального правотворчества на виды в зависимости от субъекта, уполномоченного на издание соответствующего нормативного акта, показывает следующий результат. По этому критерию определяются такие его виды:

1) муниципальное правотворчество, которое осуществляется на уровне действия органов местного самоуправления в соответствии с федеральным законом РФ от 06.10.2003 №131-Ф3 «Об общих принципах организации местного самоуправления в Российской Федерации» ${ }^{338}$. Органы местного самоуправления по данному закону наделены определенным объемом правотворческих полномочий, но не включены в систему органов государственной власти. Субъектами муниципального правотворчества является орган или должностные лица местного самоуправления, а также граждане, проживающие на территории конкретного муниципального образования;

2) правотворчество органов законодательной и исполнительной власти, направленное на регламентацию своей внутренней деятельности. Например, постановление ГД Федерального Собрания РФ, утвердившего Регламент своей деятельности ${ }^{339}$. Этот вид локального правотворчества имеет более важное значение, чем другие аналогичные нормативные акты. Правотворческая практика субъектов федерации показывает, что правовые документы такого уровня используются в процессе издания

${ }^{338}$ Собрание законодательства РФ. - 2003. - №40. - Ст. 3822 (ред. от 30.10 .2018 (с изм. и доп., вступ. в силу с 01.01.2019).

${ }^{339}$ СПС Консультант Плюс. 
регионального законодательства в качестве своеобразного правового ориентира или образца;

3) ведомственное правотворчество, которое «имеет цель, разработку, принятие, изменение и отмену нормативно правовых актов подзаконного характера, позволяющих конкретизировать общие положения законов» ${ }^{340}$.

Субъектами этого вида правотворчества являются различные органы исполнительной власти, обладающие правом издания своих внутренних нормативных актов ${ }^{341}$;

4) корпоративное правотворчество, которое осуществляется в рамках хозяйственной деятельности различных предприятий и организаций, а также их объединений. В юридической литературе отмечается, что данный вид правотворчества имеет тенденцию к повышению своего значения под влиянием растущего количества субъектов хозяйствования ${ }^{342}$. И это так;

5) правотворчество общественных организаций. В современных условиях повышения политической активности населения, увеличения количества политических партий, участвующих в общественной жизни государства, внутренняя регламентация деятельности таких добровольных объединений граждан имеет большое практическое значение. Субъектами правотворчества общественных организаций являются их руководящие органы и съезды. Принимаемые ими нормативные акты должны соответствовать законодательству РФ, а их действие распространяется только на членов этих партий.

По юридической силе издаваемых нормативных актов локальное правотворчество можно классифицировать на такие виды:

1) локальное правотворчество органов законодательной и исполнительной власти;

2) ведомственное подзаконное правотворчество;

3) подзаконное правотворчество корпораций и общественных объединений граждан.

Локальное правотворчество можно подразделить на виды и в зависимости от степени его урегулированности законодательством РФ. К числу таковых относятся:

1) локальное правотворчество, урегулированное нормами законодательства. Например, Кодекс о нормативных правовых актах Чукотского автономного округа предусматривает правотворческие полномочия для своих ведомств ${ }^{343}$;

\footnotetext{
${ }^{340}$ Фомичева О.А. К вопросу о содержании понятия и видов классификации современного правотворчества / О.А. Фомичева, Д.В. Пахомова // Достижения вузовской науки. Сер. Юридические науки. - 2008. - №6. - С. 258.

${ }^{341}$ См., например, об особенностях локального правотворчества в сфере трудовых отношений подробнее: Шукаева Е.С. Локальное нормотворчество как способ реализации нормативной функции работодательской власти // Право и государство: теория и практика. 2015. - №7 (127).

${ }^{342}$ Кириленко И.С. Указ. соч. - С. 11.

${ }^{343}$ СПС Консультант Плюс.
} 
2 ) локальное правотворчество, не имеющее специальной правовой регламентации, а формирующееся на основании всей совокупности действующего законодательства. По мнению В.И. Маньковской, любое муниципальное образование при осуществлении нормотворческой деятельности обязано придерживаться модельных вариантов правотворчества своего субъекта ${ }^{344}$. Это, безусловно, правильный подход к повышению качества и эффективности данного вида локального правотворчества. Однако пока модельное правотворчество не имеет широкого распространения.

В зависимости от функционального назначения локальное правотворчество можно классифицировать на три основных вида:

1) регулирующее правотворческую деятельность;

2) регулирующее межличностные отношения определенных объединений граждан;

3) регламентирующее деятельность различных видов организаций и ведомств.

Подводя итог, можно сделать следующие выводы:

Локальное правотворчество занимает первоначальную важнейшую ступень в системе регулирования общественных отношений в государстве. Это объясняется тем, что государство, не имея возможности регламентировать деятельность каждого отдельного объединения граждан, предприятия либо учреждения предоставляет им право саморегулирования, оставляя за собой лишь контрольную функцию.

Локальное правотворчество имеет свои специфические особенности, которые затрудняют понимание его сущности и регулятивного значения в общественной жизни. Государство недооценивает положительные возможности саморегулирования локальных организаций (особенно в сфере экономических отношений). В связи с этим локальное правотворчество (в сфере бизнеса) находится под постоянным прессингом контролирующих государственных органов, а разрабатываемые руководящие положения, направленные на регламентацию локального правотворчества имеют излишний императивный уклон в правовом регулировании, тогда как саморегулирование изначально тяготеет к диспозитивному методу регулирования общественных отношений.

Повышение качества локального правотворчества требует новых подходов как в оценке сопутствующих ему специфических особенностей, так и в создании практических образцов правового регулирования типичных ситуаций локального характера, что позволит субъектам такого правотворчества организовать свою деятельность с учетом апробированных специалистами правовых ориентиров. Государство должно создавать условия для повышения качества саморегулирующего правотворчества, основанного на взаимном интересе участвующих в нем сторон, а не систему тотального контроля, направленного не на развитие экономических отношений, а на их удушение.

${ }^{344}$ Нормография: теория и методология нормотворчества: учеб.-метод. пособ. / под ред. Ю.Г. Арзамасова. - М., 2007. - С. 459. 


\section{§2.8. СУДЕБНОЕ ПРАВОТВОРЧЕСТВО}

Регулирование общественных отношений в Российской Федерации осуществляется с помощью законодательства, а также подзаконных нормативных актов, изданных на основе и во исполнении законов, которые в своей совокупности образуют единый систематизированный блок правовых норм - правовую систему государства. Однако в процессе правоприменения постоянно возникает потребность в толковании и конкретизации норм права, имеющих абстрактный, общий характер, что, в конечном счете, и обеспечивает возможность функционирования протекающих в обществе правоотношений.

Ведущее место в правоприменения отводится судебным органам, которые своими актами не только разрешают конкретные юридические казусы, но, вместе с тем, осуществляя толкование и конкретизацию отдельных правовых норм, вырабатывают правотворческие решения, имеющие нормативный характер. Таким образом, судебное правотворчество является важным завершающим звеном правового регулирования общественных отношений, которое используется в случаях возникновения «правового вакуума», связанного с неясностью, пробельностью, излишней абстрактностью нормативных правовых предписаний.

В юридической литературе отмечается исключительность судебного правотворчества, которое рассматривается как вторичный источник права, с помощью которого «развиваются, уточняются, конкретизируются, интерпретируются первичные нормативные правовые тексты... которые dejure имеют силу толкуемого акта, но defacto имеют большую силу. Причем вторичные источники права могут изменить смысл первичных, что нередко происходит в действительности» ${ }^{345}$. Аналогичное мнение у Т.А. Желдыбиной, которая полагает, что суд не вправе отменять или изменять закон, он может играть правоуточняющую роль в правообразовательном процессе. Судебное правотворчество, связано с восполнением пробелов в праве, не является самостоятельным, а дополняет важную функцию судебной власти - осуществление правосудия ${ }^{346}$.

Является общепризнанным и представление о том, что судебная практика способствует совершенствованию действующей нормативной правовой базы, оказывает непосредственное воздействие на повышение ее качества и эффективности, что нормотворчество судебных органов не имеет официального признания в качестве источника права в Российской Федерации ${ }^{347}$.

В ст. 126 Конституции РФ предусмотрено, что Верховный Суд РФ осуществляет в предусмотренных федеральным законом процессуальных формах судебный надзор за деятельностью судов общей юрисдик-

\footnotetext{
${ }^{345}$ Евстигнеева Г.Б. Судебное решение как источник права: автореф. дис. ... к.ю.н. - М., 2007. - C. 12.

${ }^{346}$ Желдыбина Т.А. О судебном правотворчестве // Вестник Саратовской государственной юридической академии. - 2015. - №2 (103). - С. 27

${ }^{347}$ Желдыбина Т.А. Указ. соч. - С. 26.
} 
ции и дает разъяснения по вопросам судебной практики. Эти положения вызывают споры как среди многих специалистов-практиков, так и в юридической науке, поскольку рассматриваются зачастую как скрытое нарушение независимости судов. Учитывая, что разъяснения Верховного Суда РФ по вопросам судебной практики представляют собой фактически правотворческую деятельность, тем самым подвергается сомнению и судебное правотворчество в целом. Однако это ошибочная позиция, которая не соответствует сложившейся судебной практике, а также цели судебного надзора. Как справедливо отметил М.В. Баглай, орган высшей судебной власти осуществляет надзор не путем командования нижестоящими судами, а в ходе пересмотра судебных дел в кассационном порядке, а также в порядке надзора и по вновь открывшимся обстоятельствам. Это есть контроль за качеством, законностью судебных решений, а независимость судов не подвергается сомнению. То же самое можно сказать и о сущности разъяснений Верховного суда РФ. Они служат единообразию правоприменительной практики по конкретным вопросам и приветствуются нижестоящими судами. «В законе такие разъяснения не называются обязательными, но ясно, что они имеют смысл только в том случае, если все суды будут им следовать» ${ }^{348}$.

Таким образом, опосредовано Конституция Российской Федерации допускает возможность выработки судебных правотворческих решений, что и предопределяет наличие судебного правотворчества в целом.

В юридической науке под судебным правотворчеством понимается особая деятельность судов, результатом которой является создание, отмена и изменение правовых норм ${ }^{349}$.

Имеются и более развернутые определения судебного правотворчества. Так, О.В. Попов под судебным правотворчеством понимает особую разновидность правотворчества высших органов судебной власти с целью создания необходимых условий для осуществления правосудия, не противоречащих Конституции РФ и общепризнанным принципам и нормам международного права, направленных на внесение вторичных (вспомогательных, дополнительных) изменений в действующую систему права ${ }^{350}$.

В первом случае в основе определения понятия судебного правотворчества лежит правотворческий результат судебной деятельности, который одновременно раскрывает и его правовую природу. Правотворческая деятельность судебных органов автором связывается с созданием новых норм права, отменой уже существующих, изменением устаревших.

Во втором случае судебное правотворчество обосновывается потребностью осуществления правосудия путем создания необходимых для

\footnotetext{
${ }^{348}$ См. подробнее: Баглай М.В. Конституционное право Российской Федерации. - М., 2000. - С. 663 .

349 Чередниченко С.П. Судебное правотворчество: автореф. дис. ... к.ю.н. - М., 2005. C. 12.

${ }^{350}$ Попов О.В. Теоретико-правовые вопросы судебного правотворчества в РФ: автореф. дис. .... к.ю.н. - Тольятти, 2004. - С. 13.
} 


\section{Правотворчество в Российской Федерации}

этого правовых условий за счет внесения разрешаемых законом изменений норм права.

По нашему мнению второй подход предпочтительнее, поскольку отражает специфику судебного правотворчества, указывая на его вторичное, вспомогательное значение, а также на роль в системе правотворчества в целом, подчеркивая зависимость от процесса разрешения судебных дел. Излишняя абстрактность и краткость первого определения судебного правотворчества не раскрывает его специфики, которая не может быть связана с изданием нормативных правовых актов, интерпретирующих и развивающих положения конституции и закона, поскольку это противоречит природе правосудия и задачам судебной власти ${ }^{351}$.

Специфика судебного правотворчества состоит в наличии в нем определенных признаков, которые характеризуют его как самостоятельное правовое явление, отличающееся от других видов правотворчества. Эти признаки могут раскрывать различные его особенности.

По своему функциональному назначению судебное правотворчество:

1) создает условия разрешения конкретных судебных дел;

2) устраняет пробельность и неясность отдельных норм законодательства в ходе судебного процесса;

3) дополняет правотворческую систему в целом, последовательно устраняя ее изъяны правоустановлениями, основанными на действующем законодательстве.

По правовой природе судебное правотворчество:

1) является «побочным продуктом» правосудия, поскольку всегда сопутствует ему и не может протекать вне этого процесса;

2) определяется характером разрешаемых судом дел ${ }^{352}$.

По регулятивным свойствам судебное правотворчество:

1) образует новую норму права в случае наличия пробела в законодательстве;

2) дает толкование норм права в рамках их текстуального содержания;

3) осуществляет конкретизацию норм права путем указания дополнительных сведений, вытекающих из закона.

Анализ выявленных признаков судебного правотворчества показывает, что это самостоятельный вид правотворчества, протекающий в границах судопроизводства. Правотворческая деятельность судов иногда связана с необходимостью решения судебных дел в условиях, когда для этого правовых средств недостаточно, что обуславливает потребность восполнения ими таких средств самостоятельно путем создания норм права, а также путем конкретизации законодательных предписаний.

Таким образом, судебное правотворчество - это самостоятельный вид правотворчества, протекающий в рамках компетенции судебных органов, когда имеющиеся дефекты правового регулирования устраняются с помощью правотворческих судебных решений на основании действующего законодательства в результате толкования и конкретизации

${ }^{351}$ Евстигнеева Г.Б. Указ. соч. - С. 12.

${ }^{352}$ См. подробнее: Чередниченко С.П. Указ. соч. - С. 12. 
излишне обобщенных и абстрактных правовых норм, а также путем восполнения пробелов в праве.

Судебное правотворчество инициируется путем судебного усмотрения, результатом которого является новое толкование существующих правовых норм с последующим приобретением ими признака общеобязательности ${ }^{353}$. Следует сказать, что в современный период не все ученые и специалисты-практики признают общеобязательность вырабатываемых Верховным Судом РФ правотворческих решений. Даже тех решений, которые представляют собой официальную правовую позицию по конкретному делу, связанную с тем, что нижестоящие суды по мнению Верховного Суда РФ неправильно применяют нормы права по этой категории дел. Аргументируется это тем, что в ст. 120 Конституции РФ закреплено положение о независимости судей, а в ст. 126 Основного закона не указывается, что разъяснения Верховного Суда РФ являются обязательными.

Ошибочность этой точки зрения очевидна. Независимость судей гарантирована Конституцией РФ и это не подвергается сомнению. Однако судебная практика по конкретным категориям дел в масштабах государства не должна быть противоречивой и характеризоваться взаимоисключающими решениями, вытекающими из различного понимания судами отдельных норм законодательства и подзаконных нормативных правовых актов. Для устранения возникающих в судебной практике неоднозначных, противоречивых решений определенной категории дел Верховный Суд РФ осуществляет ее обобщение и на основании этого разрабатывает предложения по вопросам, которые вызывают затруднения при их судебном рассмотрении. Эти предложения выносятся на утверждение Пленума Верховного Суда РФ, которые после их тщательного обсуждения принимаются в виде руководящих разъяснений. Значение этих разъяснений значительно повышается в связи с тем, что в их основе лежат конкретные запросы нижестоящих судов, которым необходимо знать правовую позицию высшей судебной власти по определенной категории дел, а также и тем, что при обсуждении вопросов о даче судам руководящих разъяснений Пленум заслушивает сообщения председателей Верховных Судов республик, краевых, областных, городских судов, судов автономных республик и судов автономных округов, военных судов о судебной практике по применению законодательства этой категории дел $^{354}$. Поэтому рассматривать разъяснения Пленума Верховного Суда РФ как посягательство на независимость судей не имеет смысла, поскольку это не соответствует ни законодательству, ни сложившейся практике преодоления нормативно-правового несовершенства.

\footnotetext{
${ }^{353}$ См. подробнее: Семьянов Е.В. Судебное правотворчество: вопросы общей теории права: автореф. дис. ... к.ю.н. - М., 2005. - С. 13.

${ }^{354}$ См. подробнее: Баглай М.В. Конституционное право Российской Федерации. - М., 2000. - C. 665 .
} 


\section{Правотворчество в Российской Федерации}

Таким образом, отдельные судебные акты, издаваемые в процессе правоприменительной деятельности судов могут соответствовать всем признакам права:

1) они содержат нормативные предписания;

2) обладают формальной определенностью;

3) обеспечиваются государством ${ }^{355}$;

4) рассчитаны на многократное использование судами по определенной категории дел;

5) адресуются неопределенному кругу лиц, применяющих нормы права, выработанные Верховным Судом РФ. Такие акты представляют собой официальный письменный документ судебного правотворчества, в котором сформулировано обязательное для последующего разрешения аналогичных дел правило, восполняющее пробел в позитивном праве (судебный прецедент) либо интерпретационные нормы права (в виде правовых позиций) $)^{356}$.

К числу нормативных судебных решений, которые являются формальными источниками права в Российской Федерации относятся:

1) акты Европейского Суда по правам человека, отвечающие критериям и, предусмотренным федеральным законом «О ратификации Конвенции о защите прав человека и основных свобод и Протоколов к ней»;

2) акты Конституционного Суда и конституционных (уставных) судов субъектов федерации о признании неконституционными (неуставными) подведомственных нормативных правовых актов и договоров, а также решения судов общей юрисдикции и арбитражных судов о признании недействующими подведомственных нормативных правовых актов;

3) акты судебного официального нормативного толкования Конституции РФ и конституций (уставов) субъектов федерации 357.

Следует отметить, что не все ученые относят судебные решения о признании неконституционными и недействующими тех или иных нормативных актов к числу правотворческих актов, поскольку при этом официально не формулируются новые нормы права. Это, по их мнению, правоустановительные акты, которые не содержат норм права и которые не являются источниками права в собственном смысле ${ }^{358}$.

Однако такая позиция не имеет достаточного обоснования. Если исходить из того, что судебное правотворчество есть создание, отмена и издание правовых норм (а именно там оно и понимается), то очевиден следующий вывод: правоустанавливающие судебные акты являются правотворческими решениями, имеющие своей целью повышение качества нормативных правовых актов путем отмены тех, которые не соответствуют нормативным предписаниям Конституции РФ, конституций

\footnotetext{
${ }^{355}$ Семьянов Е.В. Указ. соч. - С. 13.

${ }^{356}$ Илларионов А.В. Акты правотворчества в Российской Федерации: автореферат дис. ... к.ю.н. - Омск, 2008. - С. 12.

${ }^{357}$ Илларионов А.В. Указ. соч. - С. 13.

358 Евстигнеева Г.Б. Указ. соч. - С. 11.
} 
(уставов) субъектов федерации, а также иному законодательству Российской Федерации и ее субъектов. Отмена нормативных правовых актов один из видов правотворческой деятельности, который включает в себя весь спектр научного познания сущности регулируемых общественных отношений, результатом которого и является выработка соответствующего правового решения. Государству для улучшения правового регулирования в той или иной сфере общественных отношений иногда достаточно просто отменить определенную правовую норму или конкретный нормативный правовой акт. То же самое можно сказать и о судебном правотворчестве. Суд, признавая неконституционными или недействующими нормативные правовые акты, отменяет их функционирование, то есть препятствует нежелательному для государства и общества развитию общественных отношений, что собственно и свидетельствует о их регулятивном правотворческом предназначении.

Важнейшими видами судебного правотворчества являются судебное толкование и судебная конкретизация правовых норм.

Под толкованием норм права понимается деятельность судебных органов, направленная на установление содержания юридических норм. «Толкование неотъемлемо от правоприменения и складывается из двух составных, взаимосвязанных и взаимодополняющих частей: уяснения смысла нормы права, подлежащей применению, и разъяснения ее сущности и смыслового содержания» ${ }^{359}$.

Уяснение смысла нормативного предписания необходимо для понимания его социальной направленности: места, занимаемого в системе правового регулирования; выявления духа закона и воплощения его в текстах конкретных норм и т. д.

Толкование необходимо в связи с имеющейся абстрактностью юридических норм; терминологической спецификой; запутанностью (недостаточной четкостью) правотворческого процесса вызванного отсутствием единого законодательного регулирования; противоречивостью смысла правовой нормы, идущего от законодателя и смыслом, постигаемым правоприменителем в результате прочтения ее текста ${ }^{360}$.

Осуществление толкования правовых норм имеет своей целью:

1) правильное и, следовательно, единообразное понимание юридических предписаний;

2) правильное и единообразное их применение в судебной практике;

3) выявление истинного содержания правовых норм без искажения заложенного в нем смысла ${ }^{361}$.

С учетом этого, толкование-уяснение используется судами при разрешении конкретных дел, когда в его результате не создаются нормы

${ }^{359}$ См. подробнее: Марченко М.Н. Проблемы теории государства и права. - М., 2013. C. 693-698.

${ }^{360}$ См. подробнее: Власов В.И. Теория государства и права. - Ростов н/Д., 2002. - С. 354.

${ }^{361}$ Неделько Ю.В. Значение толкования правовых норм для правотворческой и правоприменительной деятельности // Современное право. - 2010. - №8. - С. 12. 


\section{Правотворчество в Российской Федерации}

права. Однако это не значит, что данный вид толкования имеет второстепенное значение. Если правоприменительная практика показывает отсутствие противоречивости при реализации норм права, значит нормативно-правовые акты имеют высокое качество, а профессиональный уровень судейского корпуса не вызывает затруднений в их применении. И наоборот: появление противоречивых судебных решений по определенному виду дел свидетельствует о наличии дефектов правового регулирования общественных отношений, что обусловливает необходимость для судебных органов высшей инстанции издания толкованийразъяснений.

Актами нормативного толкования являются руководящие разъяснения Пленума Верховного Суда РФ и акты разъяснения Конституционного Суда РФ. При этом нормативные акты Пленума Верховного Суда РФ принимаются на основе разрешения конкретных дел, а акты Конституционного Суда РФ в результате обнаружившейся неопределенности в вопросе о том соответствует ли Конституции РФ закон или иной нормативный акт, либо обнаружившееся противоречие в позициях сторон о принадлежности полномочия в спорах о компетенции, или обнаружившаяся неопределенность в понимании положений Конституции РФ. ${ }^{362}$

В качестве примера судебного толкования норм уголовного законодательства можно привести постановление Пленума Верховного Суда РФ №56 от 17.12.2015 «О судебной практике по делам о вымогательстве (статья 163 УК РФ) ${ }^{363}$.В пункте 8 этого постановления дается следующее толкование-разъяснение части 1 ст. 163 УК РФ: «Не образует совокупности преступлений неоднократные требования под указанной в части 1 ст. 163 УК РФ угрозой, обращенные к одному или нескольким лицам, если эти требования объединены единым умыслом и направлены на завладение одним и тем же имуществом или правом на имущество либо на получение материальной выгоды от совершения одного и того же действия имущественного характера. Как единое преступление следует квалифицировать и требование, направленное на периодическую передачу потерпевшим имущества (например, ежемесячную передачу определенной денежной суммы)».

Как видно из приведенного толкования ч. 1 ст. 163 УК РФ Пленум Верховного Суда РФ дает более узкое определение вымогательства, чем его текстуальное значение.

Судебная конкретизация правовых норм также широко применяется в ходе судебного правотворчества. Это специфическая деятельность суда, направленная на раскрытие общего содержания абстрактной нормы закона применительно к конкретным ситуациям, в результате чего создаются правовые нормы. ${ }^{364}$ Как справедливо отметил Н.А. Власенко «конкретизация - объективное свойство правового регулирования, заключающееся в переходе от неопределенности юридического предписа-

\footnotetext{
${ }^{362}$ См. подробнее: Баглай М.В. Указ. соч. - С. 660.

${ }^{363}$ Бюллетень Верховного Суда Российской Федерации. - 2016. - №2. - С. 15-17.

${ }^{364}$ Попов О.В. Указ. соч. - С. 13
} 
ния к его определенности, а также неопределенности нормы права в связи с появлением юридического факта к его качеству определенного правового (индивидуального) регулятора». ${ }^{365}$ Пример судебной конкретизации нормы права может дать указанное выше постановление Пленума Верховного Суда РФ №56 от 17.12.2015 г. В п. 15 этого постановления дается конкретизация понятий «крупный» и «особо крупный» размер имущества, которые характерны для вымогательства. Пленум Верховного Суда РФ разъяснил, что таковыми являются денежные суммы в размере более тех, которые предусмотрены в пункте 4 примечания к ст. 158 УК РФ. Это означает, что вымогательство в крупном размере будет при стоимости имущества свыше 250 тыс. рублей, а в особо крупном - свыше 1 миллиона рублей.

Таким образом, судебная конкретизация раскрывает содержание абстрактной нормы закона в процессе ее применения (реализации) в судебной деятельности путем придания ей юридической определенности. Судебная конкретизация выполняет две задачи:

1) приближение абстрактной нормы закона к конкретным жизненным ситуациям, которые он регулирует, т. е. создает условия пригодные для его непосредственного применения;

2) устранение неопределенности, неоднозначности и разнобоя в понимании и применении правовых норм, чтобы добиться стабильности правового регулирования ${ }^{366}$.

Отличие судебного толкования от судебной конкретизации состоит в следующем. Судебное толкование - это уяснение юридического смысла правового предписания и последующее его разъяснение нижестоящим судам, когда текст закона не подвергается корректировке. То есть содержание нормы права остается в пределах, установленных законом, но как ее следует понимать истолковывает суд. Решение по делу принимается на основании нормативных предписаний.

Судебная конкретизация - более сложное правотворческое явление. Раскрытие содержания правового предписания осуществляется с помощью указания на его индивидуализирующие признаки, что позволяет использовать правовые абстракции для разрешения конкретных судебных дел. Решение по делу принимается на основании конкретизирующих и нормативных предписаний.

Вместе с тем в юридической науке высказано мнение, что в настоящее время постановления Пленумов Верховного Суда РФ обладают обязательностью лишь для общих и арбитражных судов ${ }^{367}$. Это не совсем так. На заседаниях Пленума Верховного Суда РФ в обязательном порядке присутствует Генеральный Прокурор РФ, что обусловлено его компе-

\footnotetext{
${ }^{365}$ Власенко Н.А. Конкретизация в праве: методологические основы исследования // Журнал российского права. - 2014. - №7. - С. 63.

${ }^{366}$ Попов О.В. Теоретико-правовые вопросы судебного правотворчества в РФ: автореф. дис. ....к. ю. н. - Тольяти, 2004. - С. 17.

${ }^{367}$ Морозова Л.А. К вопросу о судебном правотворчестве // Юридическая техника. Ежегодник. - Н. Новгород. - 2014. - №8. - С. 290-291.
} 
тенцией. Поэтому принимаемые Верховным Судом РФ постановления автоматически санкционируются Генеральным Прокурором РФ, что порождает необходимость применения решений Пленума Верховного Суда РФ в деятельности прокуратуры и всех следственных органов государства. Что касается иных государственных структур, которым прямо не вменяется руководствоваться решениями Пленума Верховного Суда РФ, то это лишь формальная сторона существующего положения их правового статуса. Фактическая сторона состоит в том, чтобы указанные государственные структуры также использовали в своей деятельности руководящие постановления Пленума Верховного Суда РФ, поскольку отступление от установленных в них требований чревато оспариванием в суде, а это приведет к отмене решения, не согласующегося с требованиями, выработанными органом высшей судебной инстанции. Следует также иметь в виду, что Конституция РФ не предусматривает обязательность постановлений Пленума Верховного Суда РФ даже для нижестоящих судебных органов. Однако такая обязательность реализуется в силу их практической необходимости для поддержания единообразия судебной практики.

Одним из основных направлений судебного правотворчества является его пробеловосполняющая функция. По сложившемуся мнению в юридической науке - это самостоятельный вид судебного правотворчества ${ }^{368}$.

Пробел в праве представляет собой полное или частичное отсутствие в действующем законодательстве нужных для регулирования общественных отношений юридических предписаний. Возникновение пробельности в праве наступает, если сложились следующие обстоятельства правового регулирования:

1) пробел законодательства связан с необходимостью урегулирования общественных отношений;

2) отсутствует конкретная норма права, которая должна регулировать эти общественные отношения. «Отличительная черта пробела в праве, пишет В.И. Власов, - состоит в том, что те фактические обстоятельства, в отношении которых отсутствует конкретное нормативное предписание, в общем и целом правом урегулированы: законодатель выразил здесь свою волю через урегулирование аналогичных обстоятельств, через общие нормы права, общие и отраслевые правовые принципы. Таким образом, пробелы представляют собой своего рода «пропуски» в правовом пространстве, в ткани юридических норм, которые нежелательны и в принципе должны быть исключены из общего правила, адекватного правового регулирования социальной сферы» ${ }^{369}$.

Пробелы в праве устраняются с помощью правотворческого процесca, итогом которого является создание и принятие недостающей правовой нормы.

В ходе осуществления судебного правоприменения возникают ситуации, требующие преодоления пробела в праве. Поскольку суд не наделен правотворческими функциями в классическом понимании этого слова,

${ }^{368}$ Попов О.В. Указ. соч. - С. 10; Семьянов Е.В. Указ. соч. - С. 10.

${ }^{369}$ Власов В.И. Теория государства и права. - Ростов н/Д., 2002. - С. 347. 
он вынужден в процессе разрешения конкретного дела использовать иные правотворческие подходы: применять аналогию закона или аналогию права.

Аналогия закона применяется судом при разрешении конкретного юридического дела на основе правовой нормы, рассчитанной не на данный, а на сходные случаи. При этом суд обязан учитывать следующие условия:

1) рассматриваемый юридический казус имеет общую правовую урегулированность;

2) обнаружен пробел необходимой в данном случае правовой нормы;

3) наличие аналогичной нормы в смежном законодательстве, гипотеза которой предусматривает обстоятельства идентичные тем, с которыми имеет дело суд.

Аналогия права - это такое судебное решение по конкретному юридическому делу, которое вырабатывается на основе общих принципов и смысла права, поскольку нет нормы, которая бы регулировала сходный случай, возникший в той или иной жизненной ситуации. Не имеется такой нормы и в смежных отраслях права. Суд, принимает решение по делу, руководствуясь Конституцией РФ, а также своим правосознанием.

Аналогия права в уголовном и административном праве не допускается (см., например, ст. 3 УК РФ).

В юридической литературе указывается и на такой вид судебного правотворчества, как исправляющее правотворчество, под которым понимается «деятельность судов, вызванная противоречием между волей законодателя и «волей закона» и направленная на устранение этого противоречия путем отмены, изменения и дополнения норм закона при помощи применения методов аналогии права и конкретизации» ${ }^{370}$.

Как представляется, здесь речь идет о достаточно часто встречающихся ошибках изложения содержания нормы права в ее дефиниции ${ }^{371}$. Например, в ст. 3 федерального закона «О коммерческой тайне» ${ }^{372}$ понятие «коммерческая тайна» сформулировано как «режим конфиденциальности информации», что не соответствует аналогичному понятию «коммерческая тайна», данному в ст. 139 ГК РФ, которая понимается как сама информация, а не ее режим. Естественно, что такие противоречия между замыслом законодателя и реальным его воплощением в норме закона устраняются либо самим законодателем, либо судом в ходе осуществления правоприменения.

Таким образом, судебное правотворчество формирует два подхода по устранению дефектов нормативной правовой базы регулирования общественных отношений:

1) в форме официального толкования норм права и разъяснения заложенного в них смысла, когда судебные решения принимаются на ос-

\footnotetext{
${ }^{370}$ Попов О.В. Указ. соч. - С. 14.

${ }^{371}$ См. подробнее: Туранин В.Ю. Теория и практика использования законодательных дефиниций. - М., 2009. - С. 33-35.

372 Федеральный закон от 29.07.2004 №98-Ф3 «О коммерческой тайне» // СЗ РФ. - 2004. №32. - Ст. 3283 .
} 
новании нормативных предписаний, наполненных содержанием, идущего от его судебного понимания;

2) в форме судебного видоизменения норм права осуществляемого в процессе их конкретизации, восполнения пробелов и исправления допущенных дефектов законодательства на основании совместного использования судебных решений и нормативных предписаний по конкретной категории дел, выход за пределы которых не допускается.

Значение судебного правотворчества состоит в том, что оно на стадии правоприменения оказывает эффективное воздействие на общественные отношения, устраняя имеющиеся недостатки их нормативного правового регулирования и одновременно является окончательным, последним звеном в системе правотворческой деятельности, что придает ей завершенность и полноту.

Судебное правотворчество полностью основано на законе и не является самостоятельным источником права, что исключает возможность изменить или отменить закон с его помощью. Обладая такими функциями как толкование норм права, воспоминание пробелов в праве и конкретизации правовых норм, судебное правотворчество имеет реальную возможность разрешать любые правотворческие проблемы в соответствии с законом, его целями и задачами.

Следует согласиться с высказанным в юридической литературе предложением о наделении судов правотворческой функцией законодательно $^{373}$. Это не только повысило бы авторитет судов, но и возвело бы судебный прецедент в ранг правотворческого акта, что способствовало бы более качественному правовому регулированию общественных отношений, поскольку именно суды находятся под непрерывным воздействием реально протекающих общественных процессов и таким образом связаны с насущными потребностями развития права.

${ }^{373}$ Морозова Л.А. К вопросу о судебном правотворчестве // Юридическая техника. Ежегодник. - Н. Новгород. - 2014. - №8. - С. 290-291; Семьяков Е.В. Указ. соч. - С. 13. 


\section{ГЛАВА З. ТЕОРЕТИКО-ПРАВОВОЕ ИССЛЕДОВАНИЕ СООТНОШЕНИЯ ПРАВОТВОРЧЕСТВА И ПРИКЛАДНОЙ ЮРИДИЧЕСКОЙ НАУКИ, ЮРИДИЧЕСКОЙ ТЕХНИКИ}

\section{§3.1. ПРИНЦИПЫ ПРАВОТВОРЧЕСТВА И ИХ КЛАССИФИКАЦИЯ}

Для понимания правотворчества, выявления особенностей, влияющих на качество выработки законодательных актов и норм права, решающее значение имеет изучение присущих ему принципов как взаимосвязанной системы основополагающих обязательных требований, отражающих идеи правового государства и дух открытого гражданского общества. Принципы - это конкретные критерии возможного и должного в правотворении. Составляя основу правотворчества, принципы вместе с тем отражают и все его стороны: от порядка издания норм права до их содержания и реализации.

В юридической литературе нет единства мнений о видах принципов правотворчества, поскольку различные авторы присоединяют к общепризнанному перечню таковых и другие, которые не столь очевидны, но действительно существуют либо потенциально обусловлены его спецификой.

Большинство российских ученых считает, что правотворчеству присущи такие принципы как:

1) научность (ибо в процессе подготовки нормативных актов изучается социально-экономическая, политическая и иная ситуация, а также объективные потребности развития общества);

2) профессионализм, так как заниматься такой деятельностью должны специалисты - управленцы, юристы, экономисты и другие компетентные в своем деле люди;

3) законность (правотворческая деятельность должна осуществляться в пределах, установленных Конституцией, законами и подзаконными актами);

4) демократизм, который отражает степень участия граждан в правотворческом процессе, а также уровень развития процедурных норм и институтов в обществе;

5) гласность - это означает открытость правотворчества для широкой общественности;

6) оперативность, что предполагает своевременность издания нормативных актов и правовых норм для регулирования постоянно изменяющихся общественных отношений ${ }^{374}$.

\footnotetext{
${ }^{374}$ Малько А.В. Теория государства и права. - М., 1999. - С. 144-145; Марченко М.Н. Теория государства и права. - М., 1996. - С. 378-384; Спиридонов Л.И. Теория государства и права. - М., 1995. - С. 147-149; Семьянов Е.В. Судебное правотворчество: вопросы общей теории права: автореф. дис. ... к.ю.н. - М., 2005. - С. 6; и др.
} 


\section{Правотворчество в Российской Федерации}

Принципами правотворчества отдельные авторы называют также и следующие: гуманизм (М.Н. Марченко, А.С. Пиголкин); тщательность и скрупулезность подготовки проектов (В.С. Нерсесянц, А.С. Пиголкин); постоянного развития и своевременного осуществления правотворчества (Р.Ф. Васильев); связи правотворчества с практикой (И.Н. Сенякин, А.Ф. Черданцев); конституционности (М.Н. Марченко); планирования, строгой дифференциации правотворческих полномочий (С.А. Комаров); исполнимости (А.Б. Венгеров); подчиненности целям государственной власти, правозаконности и властности (М.М. Рассолов) и т. д.

Анализ предложенных учеными принципов правотворчества показывает, что в их основе нет единого критерия, по которому данные авторы их формулировали. Поскольку правотворчество является сложной правовой категорией, то и каждый из них, в соответствии со своим подходом, исследовал те или иные его стороны, что позволяло называть все новые и новые принципы, каждый из которых не противоречил другим принципам. Правда, в юридической литературе есть неуверенные попытки оспорить самостоятельное значение отдельных принципов правотворчества, но они на наш взгляд неубедительны. Например, Е.В. Семьянов считает, что принцип исполнимости «более относится к правоприменению, и рассчитывать на исполнимость при создании нормы права это следствие и проявление, прежде всего, принципов законности и системности, поэтому следует скорее отказаться от его выделения и признания его самостоятельности как принципа» ${ }^{375}$. Сомнительное предложение. Если согласиться с ним, то получается, что субъекты правотворчества не должны учитывать возможности правоприменителей по реализации их конкретного нормативно-правового акта или нормы права. Это предложение противоречит и требованиям ст. 105 Регламента Государственной Думы Федерального Собрания Российской Федерации, где прямо предусмотрено, что субъект законодательной инициативы обязан представить финансово - экономическое обоснование по реализации предложенного законопроекта ${ }^{376}$. Представляется, что у нас в России уже накопилось большое количество нормативных правовых актов, которые слабо исполняются только потому, что их разработчики не позаботились о создании механизмов реализации, заложенных в них предписаний. Взять хотя бы исполнимость взыскания различных видов штрафов, которые устанавливаются в нормативных правовых актах без реального учета материальных возможностей правонарушителей, что обуславливает в большинстве случаев невозможность их взыскания даже судебным путем.

В юридической науке отмечается, что принципы правотворчества выполняют основополагающую роль в повышении качества законодательства и других нормативных правовых актов ${ }^{377}$. Однако до сих пор не

\footnotetext{
${ }^{375}$ Семьянов Е.В. Указ. соч.

376 Постановление ГД Федерального Собрания РФ №2134-ІІ ГД от 22.01.1998.

${ }^{377}$ Синюков С.В. Механизм правотворчества: автореф. дис. ... к.ю.н. - Саратов, 2013. C. 8 .
} 
сформировалась их окончательная система, поскольку не найден единый подход понимания места каждого из них в правотворческом процессе. Видимо, поэтому российское законодательство также не содержит перечня принципов правотворчества, что создает дополнительные трудности правового регулирования общественной жизни. Вместе с тем, исследователи правотворчества вполне обоснованно называют все новые принципы, которые предлагают закрепить законодательно: принципы деятельности субъектов правотворчества ${ }^{378}$; принцип приоритета прав и свобод человека ${ }^{379}$; принципы историзма, совершенства юридической техники и строгого соблюдений стадий правотворческого процесса ${ }^{380}$, принцип преемственности юридического научного знания в правотворчестве ${ }^{381}$ и т. д.

Многообразие выявленных принципов правотворчества объясняется его сложным многоуровневым характером и одновременно богатством основополагающих идей, присущих правовому государству и современному гражданскому обществу, которые должны, безусловно, быть реализованы в процессе правотворчества. Но, по нашему мнению, законодательно могут быть закреплены не все, выявленные юридической наукой, принципы правотворчества. Это не стоит делать не только во избежание громоздкости возможного законодательного акта о правотворческой деятельности в РФ, но и в связи с открытостью перечня принципов правотворчества, который с каждым годом будет пополняться новыми и новыми принципами. Поэтому законодательно необходимо закрепить только основные принципы правотворчества, составляющие квинтэссенцию той или иной стороны данного процесса.

Принципы правотворчества - это обязательные, закрепленные в законе требования, предъявляемые к порядку создания нормативных правовых актов и правовых норм, их содержанию, форме, актуальности, возможности реализации и самих субъектов правотворчества. Эти требования, будучи руководящими идеями государства и общества, не могут действовать априори, а должны отражать волю государства, быть сформированы законодательно и тем самым определять правотворческий процесс на всех его уровнях.

Оптимизировать перечень основных принципов правотворчества, которые должны быть указаны в законе, может помочь их классификация. В юридической литературе принципы правотворчества делятся на общие (они присущи федеральному и региональному правотворчеству) и реги-

\footnotetext{
378 Дербина А.В. Правосознание как элемент правовой позиции субъекта правотворчества: автореф. дис. ... к.ю.н. - Самара, 2011. - С. 8.

${ }^{379}$ Каминская Е.А. Муниципальное правотворчество в механизме правообразования: автореф. дис. ... к.ю.н. - Белгород, 2013. - С. 12.

${ }^{380}$ Сотникова И.Е. Политический плюрализм и правотворчество в современном российском государстве: автореф. дис. ... к.ю.н. - Казань, 2010. - С. 11.

381 Липень С.В. Идеи правотворчества и правореализации в политико-правовой мысли России XIX-начала XX в.: автореф. дис. ... к.ю.н. - М., 2013. - С. 12.
} 


\section{Правотворчество в Российской Федерации}

ональные. По мнению Е.В. Каменской региональные принципы правотворчества можно условно разделить на три группы:

1) универсальные принципы (принципы права) - гуманизм, демократизм, законность;

2) общие принципы, относящиеся к правотворчеству в целом (как федеральному, так и региональному), - гласность; научность; профессионализм; оперативность и динамичность правотворчества; соблюдение правил правотворческой техники; планирование и прогнозирование; финансовое обеспечение и материальная достаточность; принцип информационно-правового обеспечения правотворческой деятельности;

3) специальные региональные принципы, - принцип системности; принцип взаимосогласованности и взаимодополняемости федерального и регионального правотворчества в сфере совместной компетенции; принцип дифференциации правотворческих полномочий и иерархичности нормативных правовых актов; принцип учета социальной, исторической и иной специфики субъекта РФ; принцип взаимосвязи теории с практикой ${ }^{382}$.

Такая классификация принципов правотворчества показывает их взаимосвязь в правотворческом процессе всех уровней, но не позволяет оценить конкретную роль каждого из них в характеристике его сторон, что лишает возможности выделить основные из них, определить необходимую и достаточную степень урегулированности собственно правотворения. Качество правотворчества связано в первую очередь, не с реализацией в законодательстве всех его принципов, а с совершенным их набором, способным ориентировать их субъектов на создание объективно обусловленных нормативно-правовых актов и норм права. Субъект правотворчества должен действовать не методом проб и ошибок, а иметь реальные ориентиры, руководствуясь которыми, знать вполне определенно какие принципы необходимо использовать для достижения поставленных целей.

Кроме того, в классификации отсутствует деление принципов правотворчества на материальные и процессуальные. А такое деление лежит в основе не только классификации, но и функционирования принципов.

Классифицируя принципы правотворчества в данном аспекте, выявляется следующая система основополагающих требований, которые должны учитываться при создании нормативных актов и норм права. Нами предлагается деление признаков правотворчества на материальные и процессуальные, которое играет главную роль в функциональной классификации принципов правотворчества. Материальные признаки связаны с содержательной стороной формируемых правовых норм, тогда как процессуальные - с техникой (порядком) их принятия.

Первыми мы назовем материальные признаки.

1. Порядок принятия норм права. Их определяют такие принципы как демократизм и гласность. Это означает, что в выработке норм права

382 Каменская Е.В. Региональное правотворчество в Российской Федерации: автореф. дис. ... к.ю.н. - М., 2005. - С. 11. 
участвует народ напрямую (при референдуме) или через своих представителей, когда правотворчество осуществляют уполномоченные Конституцией и законодательством РФ органы власти и должностные лица. Весь этот процесс протекает открыто, как в представительных органах власти, так и в ходе подготовки и принятия подзаконных нормативных актов, которые издают соответствующие должностные лица. Принятые правовые акты подлежат обязательному обнародованию. Те из правовых актов, которые не были опубликованы применению не подлежат (ч. 3 ст. 15 Конституции РФ).

2. Уровень подготовленности субъектов правотворчества к выработке норм права определяет принцип профессионализма. Это важнейший принцип правотворчества. Здесь речь идет о профессионализме в сфере правотворчества, что подразумевает не только наличие отличных знаний в области права, экономики, социологии, финансов и т. д. Субъекты правотворчества должны, прежде всего, уметь анализировать социальноэкономическую и правовую ситуацию, правильно оценивать перспективы развития нашего общества и государства и на этой основе формировать необходимые правовые нормы.

3. Юридическое качество принимаемых правовых норм обеспечивают такие принципы как законность; соблюдение правил правотворческой техники ${ }^{383}$; гуманизм; приоритет прав и свобод человека; принцип преемственности юридического научного знания и т. д. Реализуя эти принципы, субъекты правотворчества обеспечивают необходимое упорядочение общественных отношений, создают условия для их дальнейшего развития. На основании этих принципов осуществляется правотворчество во всех отраслях права, что обеспечивает его целостность, взаимосвязь и доступность.

В юридической литературе высказано мнение, что «оптимизации федерального правотворчества будет способствовать выявление эффективности последствий принятия нормативных правовых актов» ${ }^{384}$. С этим следует согласиться. По нашему мнению, исполнимость правотворческих решений напрямую связана с их результатами. Весь процесс совершенствования правотворческой деятельности, как правило, обусловлен именно недостаточной исполнимостью нормативных правовых актов, что в свою очередь порождает их неэффективность.

Далее приведем процессуальные признаки:

1. Имеет свою специфику правотворчество по формированию крупных отраслевых нормативных правовых актов. Она состоит в том, что возрастают не только объемы принимаемых юридических актов с присущими им принципами правового регулирования, которых может быть

${ }^{383}$ См. подробнее о развитии юридической техники, принципов демократизма и гласности: Липень С.В. Идеи правотворчества и правореализации в политико-правовой мысли России XIX-начала XX в.: автореф. дис. ... д-ра юрид. наук. - М., 2013. - С. 12.

${ }^{384}$ Дербина А.В. Правосознание как элемент правовой позиции субъектов правотворчества: автореф. дис. ... к.ю.н. - Самара, 2011. - С. 16. 


\section{Правотворчество в Российской Федерации}

большое количество (например, в Бюджетном кодексе их 13, а в Уголовно-процессуальном - более десяти), но и в частичном их совпадении с принципами правотворчества. Это усложняет процесс правотворчества, так как всякий раз необходимо отражать особенности именной данной отрасли права: степень урегулированности уже сформировавшихся общественных отношений, определить методы правового регулирования (диспозитивный или императивный), обосновать не только необходимость их правового регулирования, но также исполнимость и эффективность принимаемого нормативного правового акта. Поэтому именно при создании больших по объему и основополагающих по значению для той или иной отрасли права юридических актов приобретают первостепенное значение такие принципы правотворчества как научность; системность; тщательность и скрупулезность подготовки проектов; достаточная мотивированность норм права; обеспечение действенности норм права; преемственность юридического научного знания и т.д. Недооценка специфики правотворчества в той или иной отрасли права ведет к снижению его эффективности, непрерывному изменению и дополнению правовых норм и правовых институтов ${ }^{385}$.

2. Порядок выработки норм права для урегулирования общественных отношений. Эту сферу обеспечивают принципы научности, оперативности и динамичности правотворчества, планирования ${ }^{386}$ и прогнозирования, а также информационно-правового обеспечения. Руководствуясь данными принципами, субъекты правотворчества могут не только выработать правовые акты, отвечающие нуждам правового регулирования, но и совершить это своевременно и в плановом порядке.

3. Рассмотренные выше принципы правотворчества характеризуют его в основном с содержательной стороны. Но не менее важной является и форма правотворчества, которая проявляется в предусмотренных законодательством стадиях формирования правовых актов и правовых норм, а также в создании соответствующего назначения вида юридического документа. Эту сторону правотворчества определяют такие принципы как тщательность соблюдения правотворческого процесса и правотворческих процедур; иерархичность; необходимое соответствие правотворческого документа установленным законом требованиям к его форме.

4. Реализуемость норм права, создаваемых в процессе правотворчества, обеспечивает принцип их исполнимости. Данный принцип означает, что результат правотворчества возможно исполнить с учетом имеющихся экономических и финансовых ресурсов, а также действующей организационно-государственной структуры общества. Можно вспом-

\footnotetext{
385 См., например, проблемы рационализации уголовного правотворчества: Бондаренко О.В. Судебная практика и уголовное правотворчество: автореф. дис. ... к.ю.н. - М., 2013. - С. 13.

${ }^{386}$ См. подробнее о принципе планирования: Мартьянов Г.А. Теория и методика оптимизации участия законодательных (представительных) органов государственной власти субъектов Российской Федерации в федеральном законотворческом процессе: автореф. дис. ... к.ю.н. - СПб., 2010. - С. 14.
} 

правотворчества и прикладной юридической науки, юридической техники

нить, например, введение в УК РФ такого вида уголовного наказания как арест, который в течение длительного времени применять было нельзя в связи с отсутствием арестных домов в системе исправительных учреждений.

Данный принцип, по нашему мнению, следует увязывать с принципом максимального снижения нагрузки на правоохранительные органы государства в результате правотворческих решений. С этой целью в правовом регулировании необходимо шире использовать нормы, поощряющие правомерное поведение, а также саморегулирование конфликтов без обращения в правоохранительные органы.

На исполнимость правотворческих решений влияют и такие факторы как ясность и полнота юридического текста, наличие механизмов реализации принятых нормативных актов, создание предпосылок для устранения конфликтов между участниками правоотношений либо разрешения их по взаимному согласию.

Таким образом, каждая сторона правотворчества определяется некоторым набором принципов, которые в своей совокупности придают ему необходимую способность регулировать общественные отношения на высоком как социально-политическом, так и юридическом уровне. Перечень принципов правотворчества законодательно не установлен, что позволяет ученым вносить обоснованные предложения о его дополнении.

Приведенная нами классификация принципов правотворчества позволяет учитывать не только функциональное назначение каждого из них, но и признак материальности / процессуальности. Комбинация последнего признака с функциональным назначением определяет не только роль принципа в правотворении, но и его общественное и социальное значение, что важно при создании прикладной науки о правотворчестве.

Отсутствие четкого понимания функционального назначения принципов правотворчества создает недостаточную завершенность правового регулирования, заведомо исключает воплощение в нормах права необходимого ценностного потенциала.

В заключении необходимо дать определение термина принципы правотворчества. Разными авторами даются различные определения: «принципы правотворчества - это основополагающие идеи, руководящие начала, исходные положения деятельности, связанной с принятием, отменой или с заменой юридических норм, это ориентир для органов, творящих право» ${ }^{387}$. «Научно сформулированные основные начала» ${ }^{388}$ «организационные начала, которые определяют существо, характерные черты и общее направление этой деятельности» ${ }^{389}$ «деятельность уполномоченных органов по принятию, изменению и отмене правовых норм»

\footnotetext{
${ }^{387}$ Теория государства и права: курс лекций / под ред. Н.И. Матузова, А.В. Малько. - 3-е изд., перераб. и доп. - М.: Норма; Инфра-М, 2012. - С. 228.

${ }^{388}$ Венгеров А.Б. Теория государства и права // Теория государства и права: учебник для юрид. вузов. - 3-е изд. - М.: Юриспруденция, 2000. - 528 с.

389 Теория государства и права: учебник / А.С. Пиголкин, А.Н. Головистикова, Ю.А. Дмитриев [и др.]; под ред. А.С. Пиголкина. - М.: Юрайт-Издат, 2005. - 613 с.
} 


\section{Правотворчество в Российской Федерации}

${ }^{390}$ организационные начала, которые определяют существо, характерные черты и общее направление этой деятельности «основополагающие идеи (ценности), на которые должно ориентироваться правотворчество» ${ }^{391}$. «Основополагающие идеи, на которые должно ориентироваться правотворчество, реализовывать их в процессе правотворчества» ${ }^{392}$; «основополагающие идеи, руководящие начала, исходные положения деятельности, связанной с принятием, отменой или с заменой юридических норм, это ориентир для органов, творящих право» ${ }^{393}$; «основные начала осуществления правотворческой деятельности» ${ }^{394}$.

Аналогичное определение принципов правотворчества можно встретить и у других авторов ${ }^{395}$.

Авторами справедливо подчеркивается «основополагающее» начало принципов правотворчества, рядом автором упоминается связь этого начала с принципом научности, о котором подробнее мы пишем в соответствующей нашей работе ${ }^{396}$, некоторыми авторами делается акцент на функциональной стороне принципов. Но в стороне остается важный вопрос о том, почему принципы правотворчества собственно стали основополагающими и были введены в систему общественных ценностей, почему, как отмечается рядом авторов, они стали ориентирами ${ }^{397}$. Чуть ниже мы дадим ответ на этот вопрос.

При этом упоминаются различные стороны правотворчества как деятельности и процесса, определения не противоречат друг другу, объясняя правовое явление с разных сторон, но не говорится о принципах правотворчества, как средствах стимулирования социально активного правомерного поведения - цели любого типа правового регулирования и любого нормативного акта!

Необходимо подчеркнуть, что принципы правотворчества в их классическом понимании введены в научный оборот давно. Принципырегуляторы, о которых мы напишем ниже, введены в научный и юридический оборот ещё в конце XVIII века - с эпохи буржуазных революций, когда старые регуляторы в виде «страха Божьего», то есть, теологического принуждения, перестали действовать, и стали нужны новые сти-

\footnotetext{
${ }^{390}$ Академический курс в 2-х т. / отв. ред. проф. М.Н. Марченко. - Т. 2. Теория государства. - М.: Зерцало, 1998. - 622 с.

391 Черданцев А.В. Теория государства и права: учебник для вузов. - М.: Юрайт, 2000. C. 228.

392 Петров А.В. Теория государства и права: учеб. пособ. - Челябинск: ЮУрГУ, 2014. - 238 с.

393 Теория государства и права / под ред. М.Н. Марченко. - 2-е изд. - М., 1996. Лекция 22. C. 402-407.

${ }^{394}$ Комаров С.А. Общая теория государства и права. - М.: Юрайт, 1998. - С. 294.

${ }^{395}$ См., например: Лазарев В.В. Теория государства и права / В.В. Лазарев, С.В. Липень. М., 1998. Гл. 12; Общая теория права / под ред. А.С. Пиголкина. - 2-е изд. - М., 1995. Гл. 13. - С. 200-208; Спиридонов Л.И. Теория государства и права. - М., 1995. - С. 147-149.

${ }^{396}$ См. подробнее: Румянцев М.Б. Принцип научности правотворчества и его значение // Современное право. - 2016. - №4. - С. 16-20.

397 Теория государства и права / под ред. М.Н. Марченко. - 2-е изд. - М., 1996. Лекция 22. C. 405 .
} 
мулы для правомерного поведения, которое стало обеспечиваться государственным принуждением. Для того времени и до недавнего положения вещей этот шаг был прогрессивным. Фактически, принципырегуляторы, о которых мы будем писать ниже, стали играть роль модификатора поведения людей, выступая как ценностные ориентиры. Как справедливо отметил С.С. Алексеев, стали формироваться непосредственные социальные права, которые «существуют и действуют безотносительно к тому, объективированы ли они в каких-то опосредованных формах, или нет» ${ }^{398}$. Но постепенно такая форма выработки юридических актов стала терять потенциал своего воздействия на субъектов, которым адресовались нормативные акты. В конце XX и начале XXI века одного государственного принуждения стало уже недостаточно для поддержания для поддержания на высоком уровне регулируемых общественных отношений. Становится очевидным, что необходимо стимулировать лиц, которым адресуются акты, к активному исполнению их нормативных предписаний. Наступает новая эпоха, когда государство, издавая нормативно-правовые акты, должно в обязательном порядке учитывать интересы субъектов правоотношений, закрепляя в нормах права их законные интересы.

В связи с этим можно дать такое определение.

Принципы правотворчества - это первично сложивщиеся в эпоху буржуазных револючий и сочиальной борьбы модификаторы поведения человека, которые в прочессе правотворческой деятельности закладываются в нормативные акты в виде минимальных требований к характеру регулируемых правоотношений, обеспечивающих мирное сосуществование субъектов в борьбе за удовлетворение своих законных потребностей и интересов, и защищены силой государственного принуждения.

Нетрудно заметить, что в современную эпоху необходим новый модификатор, который бы гарантировал исполнение норм права не силой государственного принуждения, а добросовестным поведением субъекта. Этого требуют, прежде всего, отношения частноправовые, так в Гражданском кодексе РФ ст. 10 п. 5, говорится, что «добросовестность участников гражданских правоотношений и разумность их действий предполагаются» ${ }^{399}$. Для таких современных высоких требований необходимы новые подходы, то есть, модификатор более высокого уровня. Возможно ли правовое регулирование на таком более высоком уровне? В разделе 2.4 мы дадим ответ на это вопрос.

Между тем дальнейшее повышение эффективности правотворчества обуславливает необходимость издания общего законодательного акта о правотворчестве в Российской Федерации. В нем следует, безусловно, законодательно закрепить, в первую очередь, принципы правотворче-

\footnotetext{
${ }^{398}$ Алексеев С.С. Теория права. - М.: Бек, 1994. - С. 61.

${ }^{399}$ Гражданский кодекс Российской Федерации (часть первая) от 30.11.1994 №51-Ф3 (ред. от 29.12.2017).
} 


\section{Правотворчество в Российской Федерации}

ства. При этом, как показывает проведенный выше анализ принципов правотворчества, нет необходимости в законе перечислять каждый из уже выявленных юридической наукой. Достаточно указать важнейшие из них, которые определяют все стороны правотворчества, включая и его форму. Представляется, что проект такого закона необходимо опубликовать в печати для широкого обсуждения общественности, в ходе которого будут высказаны ценные предположения всеми субъектами правотворчества, а также учеными-специалистами в данной сфере правовой деятельности.

\section{§3.2. ИНСТИТУЦИОНАЛИЗАЦИЯ ПРИНЦИПОВ ПРАВОТВОРЧЕСТВА КАК СПОСОБ ПЕРЕВОДА НАУЧНЫХ КАТЕГОРИЙ В ПРАВОТВОРЧЕСКИЕ РЕШЕНИЯ}

Правотворческая деятельность по регулированию общественных отношений связана в первую очередь с их упорядочением нормами права, что требует выработки определённых терминологических форм и стандартов, то есть необходимо придать им формальную определённость, выразить языком общеизвестных и понятных юридической науке, и практике терминов, категорий и институтов.

Формальная определённость права наряду с нормативностью, принудительностью, динамизмом является также и специфическим свойством права как целостной системы, обеспечивающего его социальную ценность $^{400}$. Формализовать общественные отношения и придать им юридическую определённость - это значит ввести их в рамки нормативных предписаний, перевести их смысл на язык точных однозначно понимаемых юридических правил. «Формальная определённость выражается в том, что законодательным путём очерчиваются круг общественных отношений, регулируемых правом, субъекты регулирования, их права и обязанности, определяются правомерность или противоправность поведения, мера наказания за правонарушение и т. д.» ${ }^{401}$.

Устанавливая границы правового регулирования субъекты правотворчества разрешают следующие задачи:

1) определяют пределы воздействия права на поведение людей в конкретной сфере общественных отношений;

2) придают им нормативный общеобязательный характер;

3) создают возможность принудительного исполнения своих предписаний с помощью органов государства;

4) формируют критерии законности действия лиц, которым адресуют нормативно-правовой акт.

\footnotetext{
${ }^{400}$ Алексеев С.С. Социальная ценность права в советском обществе. - М., 1971. - С. 68-141.

${ }^{401}$ Бабаев В.К. Формальная определённость и возможности формализации законодательства // Советское государство и право. - 1978. - №4. - С. 46.
} 
Однако, если закрепление в нормах права тех или иных общественных отношений является их институционализацией, то аналогичный процесс, связанный с принципами правотворчества, имеет более сложный характер. Это вытекает из правовой сущности и назначения принципов правотворчества.

Принципы правотворчества - это не общественные отношения, которые необходимо перевести в нормативный режим функционирования, придать им чёткую форму и содержание, а определённые социальноэкономические и политические ценности высокого статуса, выработанные обществом и востребованные государством, «Статус ценностей в праве могут приобрести различные факты и явления материального и идеального характера - материальные предметы и блага, общественные отношения, человеческие поступки, волевые феномены (мотивы, побуждения), идеи, идеалы, цели, социальные институты. Они являются правовыми ценностями, поскольку лежат в основе права и правопорядка, они порождают в качестве идеального обоснования нормы права, закрепляются и охраняются правовыми нормами, составляют цель права и его институтов» ${ }^{402}$.

То есть в качестве ценностей, составляющих принципы правотворчества, могут быть только наиболее важные и значимые для общества и государства идеалы, достижение которых является целью права и одновременно объектом его охраны. В связи с этим Н. Неновски отмечает: «Особенно велико значение некоторых социальных ценностей, которые с течением времени приобрели характер также и правовых ценностей. В качестве высоких идеалов они пронизывают общественное правосознание и становятся основными принципами права. Таковы свобода, равенство, справедливость, демократия, порядок, безопасность, мир ${ }^{403}$.

Вместе с тем субъекту правотворчества следует учитывать, что формируя содержание нормативного правового акта, необходимо добиваться согласованности принципов права в целом и принципов, лежащих в основе определённой сферы общественных отношений, которые представляют в данный момент объект правового регулирования.

Их институционализация объективно обусловлена тем, что возводимые в принципы ценности:

1) функционируют в обществе в качестве эталона поведения или цели, идеала, лежащих в основе поступков людей;

2) они поддаются нормативному закреплению в юридических нормах;

3) придание им нормативного характера создаёт условия для реализации их в принудительном порядке, что повышает качество правового регулирования;

4) они приобретают официальный характер ценностного ориентира, которым руководствуется государство, устанавливая порядок функцио-

\footnotetext{
${ }^{402}$ Неновски Н. Право и ценности / под ред. В.Д. Зорькина. - М., 1987. - С. 176-177.

${ }^{403}$ Там же. - С. 177.
} 


\section{Правотворчество в Российской Федерации}

нирования общественных отношений в конкретной сфере правового регулирования.

Таким образом, институционализация принципов - важная задача государства по приданию правотворчеству целенаправленного характеpa, закреплению в его решениях основных направлений своего социального назначения и развития.

Поскольку принципы правотворчества в известной степени предопределяет качество издаваемого нормативного правового акта, то успех правотворческой деятельности зависит от правильности выбора тех ценностей, которые лежат в основе регулируемых общественных отношений и которые фактически определяют социальный, экономический, политический и культурный статус общества. Но сами по себе ценности, возводимые в ранг принципов правового регулирования, объективно обусловленные явления и полностью определяются уровнем сложившихся взаимоотношений между различными социальными группами и классами, а также характером воздействия на них духовно-нравственных потребностей, присущих обществу в целом. Это обязывает правотворческий орган избирать в качестве принципов только те ценности, которые имеют универсальный характер и оказывают своё влияние на всё общество, а не отдельную его часть, которые, реально в нём функционируют и показывают свою эффективность.

В юридической литературе справедливо отмечается, что основные принципы правотворческой деятельности не есть произвольные веления тех или иных органов, должностных лиц. Они должны отражать и учитывать объективные факторы, влияющие на законодательное регулирование общественных отношений в Российской Федерации, а также различные факторы общественного сознания, уровень культуры и правосознания народа и другие факторы и обстоятельства ${ }^{404}$.

«Правовая система соответствует (или должна соответствовать) ценностной системе не только в своём бытии закона, не только формально регулирующей системы. Если соответствие нормы и ценности держится только на институциональном (законодательном) уровне, в таком случае нельзя говорить и о праве в собственном смысле слова или по меньшей мере право не будет соответствовать (полностью или частично) своему понятию» ${ }^{405}$.

Отсюда вытекает, что правильный выбор ценностей, которые должны быть положены в основу правового регулирования, может осуществляться лишь на строго научной основе. Точность и полнота установления объективной необходимости правового регулирования на основе тех или иных социальных ценностей важны, прежде всего, потому, что в ряде случаев одни и те же задачи, казалось бы, могут быть решены как

\footnotetext{
404 Жинкин С.А. Некоторые проблемы реализации принципов правотворчества в современной России / С.А. Жинкин, Т.М. Чернявская // Общество и право. - 2016. - №2 (56). - С. 23. ${ }^{405}$ Неновски Н. Право и ценности / под ред. В.Д. Зорькина. - М., 1987. - С. 182.
} 
при помощи права, так и при помощи неправовых средств ${ }^{406}$. Сделать правильный выбор не только о необходимости и пределах правового регулирования, но и о тех ценностях (принципах), на основе которых оно будет осуществляться - задача науки теории правотворчества и субъектов правотворчества.

Существующая практика издания нормативных правовых актов показывает, что правотворческие принципы реализуются в основном априори, то есть без прямого их закрепления в нормах права, поскольку Федеральный закон «О нормативных правовых актах в Российской Федерации» всё ещё не принят.

Однако это не значит, что их институционализация может быть осуществлена только в результате непосредственного закрепления в законе как принципа правотворчества. Реализация тех или иных социальных ценностей, представляющих собой принципы правотворчества, может осушествляться и без их прямого формулирования в законе ${ }^{407}$ (как это в настоящее время и происходит). В таких случаях институционизируются заложенные в них требования, а сами принципы определяются в результате анализа нормативного правового акта. В определённой степени это снижает качество правотворчества, поскольку заявленные принципы служат не только ориентиром для самого правотворческого органа, но и для правоприменительных и правоохранительных органов.

Для институционализации принципов правотворчества необходимо: выполнить серьёзную научно-исследовательскую деятельность правотворческим органом.

1. Выделить те фактические обстоятельства, присущие данной группе общественных отношений, которые лежат в основе их функционирования и определяют социально-экономический, политический и культурный уровень общественной жизни в качестве ценности (идеи, блага, идеала) для закрепления её в виде ориентира правового регулирования. Указанная ценность должна вытекать из объективной потребности общества в её реализации в нормах права, оказывать воздействие на всю группу регулируемых общественных отношений, выражена как чётко обоснованная научная категория, содержащая его дефиницию ${ }^{408}$. Неправильное ошибочное определение основополагающей идеи, создающий ориентир правового регулирования для субъекта правотворчества при издании нормативного правового акта, может привести к тому, что в его основе будут закреплены ценности более низкого уровня, чем те, которые вытекают из объективной потребности, и это приведёт к неэффективности, а то и бесполезности акта. Если же ценности будут завышать возможности

\footnotetext{
${ }^{406}$ См. подробнее: Алексеев С.С. Механизм правового регулирования в социалистическом государстве. - М., 1966. - С. 76, 88 .

407 Жинкин С.А. Некоторые проблемы реализации принципов правотворчества в современной России / С.А. Жинкин, Т.М. Чернявская // Общество и право. - 2010. - №2 (56). - С. 23. ${ }^{408}$ От лат.definitio- краткое определение какого-либо понятия, содержащее наиболее существенные его признаки: Булыко А.Н. Большой словарь иностранных слов. - М., 2010. C. 191 .
} 


\section{Правотворчество в Российской Федерации}

их реализации в реальную жизнь, нормативно-правовой акт также обречён на неудачу, ибо в обществе и государстве нет объективных (материальных, социальных, политических и т. д.) условий для исполнения его предписаний ${ }^{409}$.

Именно с целью выработки научно обоснованной формулировки содержания будущего принципа правотворчества, определения возможности вложенных в данное понятие предписаний, оказывать регулятивное воздействие на общественные отношения и осуществляется кропотливая работа субъекта правотворчества по изучению различных вариантов его текстуального оформления, если речь идёт о прямом закреплении конкретной ценности в качестве определённого принципа. Лежащая в основе правотворческого принципа социальная ценность (её идеализированная модель) должна наиболее полно выражать общественные интересы и те объективно существующие закономерности, в рамках которых она будет действовать. Созданный на её основе принцип правотворчества, вместе с тем, должен с помощью юридических средств быть включён в механизм правового регулирования таким образом, чтобы, воздействуя на поведения лиц, которым адресуется нормативный правовой акт, побуждать их к его исполнению, то есть сформировать такое нормативное положение, когда соблюдение и исполнение предписаний изданного акта будет выгоднее, чем его нарушение. Поскольку интересы человека в соответствии с Конституцией РФ являются тем ориентиром, который лежит в основе деятельности субъектов правотворчества, то «механизм правового регулирования, должен быть социально ценным по своей природе, создавать режим благоприятствования осуществлению законных стремлений личности, упрочению её правового статуса» ${ }^{410}$.

То есть институционализироваться должны только законные интересы личности, понимаемые в юридической науке как «стремление субъекта пользоваться определёнными социальным благом и в некоторых случаях обращаться за защитой к компетентным органам в целях удовлетворения не противоречащих нормам права интересов, которое в определённой степени гарантируется государством в виде юридической дозволенности, отражённой в объективном праве либо вытекающей из его общего смысла» ${ }^{411}$.

Таким образом, первоначально субъект правотворчества изучает ту сферу общественных отношений, которую предстоит урегулировать нормами права; определяет ценности, объективно требующие их закрепления в нормативном правовом акте в качестве ориентиров правового регулирования; создаёт на основании проведённого исследования научную (примерную) модель их дефиниции. То есть субъект правотворчества получает ответ на следующие вопросы:

1) какие общественные отношения должны быть урегулированы правовыми средствами;

\footnotetext{
409 О факторах, влияющих на законодательное регулирование общественных отношений, см. подробнее: Жинкин С.А., Чернявская Т.М. Указ. соч. - С. 23.

${ }^{410}$ Малько А.В. Теория государства и права. - М., 1999. - С. 214.

411 Субочев В.В. Законные интересы / под ред. А.В. Малько. - М., 2012. - С. 87-88.
} 
2) по каким ценностным критериям это необходимо осуществлять;

3) какое содержание должно иметь выработанное на этой основе, понятие её дефиниции.

2. Придать формальную определённость научной дефиниции понятия социальной ценности, которая в дальнейшем будет использоваться как принцип правотворчества. «Применительно к обществу, его социальным нормам, прежде всего правовым, это выражается в типизации правила поведения, определения шаблона поведения» ${ }^{412}$. В данном случае необходимо научно выработанную дефиницию социальной ценности выразить языком юридических терминов, что достигается с помощью нормативно-правовых предписаний ${ }^{413}$. В данном случае необходимо научно выработанную дефиницию социальной ценности выразить языком юридических терминов, что достигается с помощью нормативно-правовых предписаний ${ }^{414}$. Нормативно-правовое предписание включает в себя такие признаки как: властное веление, непосредственная выраженность в правовом акте, общий нормативный характер, формальная определённость, логическая завершённость, цельность, элементарный характер ${ }^{415}$. Следовательно, субъекту правотворчества необходимо смысл научной дефиниции выразить с помощью общепринятых в юрисдикции терминов и категорий, то есть изложить её на языке права.

Если научно выработанная дефиниция отражает результат объективно протекающего процесса обобщения людьми фактов социальной действительности и познания на этом основании существующих закономерностей, которые протекают в обществе, то в своей совокупности они выражают содержание сложившихся общественных отношений, что позволяет такой дефиниции выполнять роль социального регулятора, то есть она может быть закреплена в качестве принципа правотворчества. Такой вывод вытекает из того, что: 1) выявленная ценность уже имеет общественное признание и это указывает на её высокий статус регулятора общественных отношений ${ }^{416} ; 2$ ) познаны закономерности развития общественных отношений и влияния на них выявленной ценности; 3) в своей совокупности социальная ценность и связанные с ней закономерности протекания общественных отношений выражают сущность их правового регулирования. Это значит, что выработанное правовое поня-

\footnotetext{
412 Бабаев В.К. Формальная определённость и возможности формализации законодательства // Советское государство и право. - 1978. - №4. - С. 45.

${ }^{413}$ См. подробнее: Мантурова Н.С. Социально-правовые ценности: основания для дефиниции // Вестник Челябинской государственной академии культуры и исскуств. - 2013. - №3 (35). - С. 173; Роль юридической техники в жизни современного общества: учебник по юридической технике [Электронный ресурс]. - Режим доступа: http://topuch.ru/-roleyuridicheskoj-tehniki-v-jizni-sovremennogo-obshestva/index.html (дата обращения: 10.12.2018).

${ }^{414}$ Там же. - C. 174.

415 Там же. - С. 174.

${ }^{416}$ Об иерархии правовых ценностей см. подробнее: Неновски Н. Право и ценности / под ред. В.Д. Зорькина. - М., 1987. - С. 183-194.
} 


\section{Правотворчество в Российской Федерации}

тие дефиниции принципа правотворчества имеет объективное обоснование, и она может быть закреплена как юридическая норма.

В юридической литературе даётся следующее определение термина «правовое понятие»: «Правовые научные понятия - это содержательные, предметные образы, которые воспроизводят в мышлении (идеально) объективную суть реальных процессов, правовой действительности и отношений, существующих в ней, и выражают специфически правовую качественную определённость данных процессов и явлений» ${ }^{417}$.

В нашем случае осуществляется логически обусловленная трансформация научного понятия дефиниции принципа правотворчества, как результата мыслительной деятельности субъекта правотворчества, в правовую категорию, что необходимо для того, чтобы в дальнейшем она могла быть использована для регулирования общественных отношений, то есть для перевода их в русло правовых предписаний.

Сущность принципов правотворчества состоит в том, что они «представляют собой выраженные в соответствующих нормативных актах исходные нормативно-руководящие начала, характеризующие его содержание, основы, закреплённые в нём закономерности.... С одной стороны, они выражают закономерности данного процесса, а с другой представляют собой наиболее общие нормы, которые действуют на всех его стадиях и распространяются на все субъекты. Эти нормы либо прямо сформулированы в законе, либо выводятся из общего смысла законодательства ${ }^{418}$.

Другими словами, принципы правотворчества - это те общепризнанные ориентиры, закреплённые в нормах права, либо не закреплённые, но реально учитываемые субъектами правотворчества при разработке нормативных правовых актов, которые содержат в себе действующую в обществе совокупность социально-политических и духовных идеалов, взятых в качестве критериев для формирования целостной современной правовой системы государства ${ }^{419}$.

Принципы правотворчества не только устанавливают определённый социально-политический и духовно-нравственный уровень издаваемых нормативных правовых актов, но определяют их качественные показатели, которые субъекты правотворчества должны учитывать в обязательном порядке и формировать нормы права в соответствии с их требованиями. Так принципы демократизма и гласности должны реализовываться нормами, устанавливающими порядок участия общества, народа в разработке и принятии нормативных правовых актов, а принципы научно-

\footnotetext{
${ }^{417}$ Васильев А.М. Правовые категории. Методологические аспекты разработки системы категорий теории права. - М., 1976. - С. 57.

418 Жинкин С.А. Некоторые проблемы реализации принципов правотворчества в современной России / С.А. Жинкин, Т.М. Чернявская // Общество и право. - 2010. - №2 (56). - С. 23. ${ }^{419} \mathrm{O}$ значении духовной составляющей в формировании общественного сознания см. подробнее: Романовская В.Б. Духовность и правосознание (соотношение феноменов) // Вестник Нижегородского университета им. Лобачевского. Серия Право. - 2001. - № 1. C. $161-169$.
} 

правотворчества и прикладной юридической науки, юридической техники

сти и профессионализма - порядок подготовки их проектов, использования выработанных юридической наукой предложений и рекомендаций и т. д.

Формируя содержание принципов правотворчества, необходимо смысл их требований изложить языком юридических понятий, терминов и категорий. Вместе с тем следует учитывать, что принципы правотворчества, в отличие от правовых норм, имеют самый высокий уровень воздействия на общественные отношения. В своей совокупности они образуют систему выработанных в обществе социально значимых критериев, на основании которых создаются и нормы права и формируется вся правовая система. Поэтому в качестве принципа правотворчества могут закрепляться только самые общие и значимые ценности, определяющие весь правотворческий процесс в целом.

Необходимо также учитывать и то, что государство и общество постоянно развиваются. Это обуславливает появление новых основополагающих идей и социальных ценностей, которые нуждаются в том, чтобы они были реализованы в правотворческие решения, выполнять роль новых принципов правотворчества. Но законодательно закреплять все выявленные юридической наукой принципы правотворчества нет необходимости. «Этого не стоит делать не только во избежание громоздкости возможного законодательного акта о правотворческой деятельности в Российской Федерации, но и в связи с открытостью перечня принципов правотворчества, который с каждым годом будет пополняться новыми идеями. Поэтому законодательно необходимо закреплять только основные принципы правотворчества, составляющие квинтэссенцию той или иной стороны данного процесса» ${ }^{420}$. К тому же субъекты правотворчества могут и должны учитывать в нормах права не только те социальные ценности, которые прямо сформулированы в законе в качестве принципов, но и те, которыми они фактически руководствуется, регулируя общественные отношения, без указания на них регулятивный статус.

3. Перевести научно разработанное понятие принципа правотворчества (сформулированного в виде дефиниций) в правовую категорию путём придания ему юридической силы в результате осуществления установленных законом процедур.

Сложность указанной ситуации состоит в том, что нет указанного перечня принципов правотворчества, которыми следует руководствоваться при издании нормативных правовых актов, что при выработке правотворческих решений субъект правотворчества обязан учитывать и принципы права вообще ${ }^{421}$, а также специфические принципы отдельных отраслей права, нормативную базу которых они формируют. Между всеми этими принципов (правотворчества, права в целом и отрасли права) должна быть согласованность, полностью исключающая противоречи-

\footnotetext{
420 Жинкин С.А. Некоторые проблемы реализации принципов правотворчества в современной России / С.А. Жинкин, Т.М. Чернявская // Общество и право. - 2016. - №2 (56). - С. 23. ${ }^{421}$ Принципы права в целом - это принципы, которые действуют в подавляющем большинстве отраслей права. См. подробнее: Кашанина Т.В. Структура права: монография. - М., 2017. - C. 281.
} 


\section{Правотворчество в Российской Федерации}

вость между ними, установление их взаимодействия на достижение единого результата - наиболее эффективного урегулирования общественных отношений. Поскольку официально установленного перечня принципов правотворчества пока нет (в связи с отсутствием федерального закона «О нормативных правовых актах в Российской Федерации»), то каждый субъект правотворчества, разрабатывая и принимая нормативные правовые акты своего уровня, исходит из своих же представлений о содержании принципов правотворчества, что приводит к возникновению противоречий не только между нормами права различных субъектов РФ, но и нормами права, изданными на федеральном уровне.

Надо сказать, что в настоящее время большинством субъектов Российской Федерации изданы законы, регламентирующие правотворческий процесс в своём регионе, что не противоречит федеральному законодательству (то есть они имеют на это право), но все эти нормативные акты не согласованы между собой и поэтому, в конечном счёте, не способствуют повышению качества правотворчества в целом по стране, хотя в региональном масштабе оно и улучшалось.

Указанные недостатки, как представляется, носят временный характер и постепенно будут устранены, что позволит каждый раз научно разработанную правовую дефиницию закреплять в установленных процедурах в качестве принципа правотворчества. Для этого необходимо оценить сформулированную дефиницию нормы, регулирующей общественные отношения, с точки зрения соответствия её содержанию регулятивным потребностям тех отношений, которые она должна урегулировать и той юридической форме, в которой она должна выражаться.

В качестве принципов правотворчества могут институционализироваться лишь такие положения присущие предмету правового регулирования, которые отражают его наиболее устойчивые и самые необходимые свойства и имеют общее значение для всего правотворческого процесса в целом. Наука отражает объект познания идеально, абстрактно, в системе понятий и категорий. Научные понятия и категории - инструмент теоретического познания, средство и результат правотворческого процесса. Оценка категорий теории правотворчества неотделима от изучения его положений, раскрывающих значение научных понятий и связанной с ней познавательной деятельности. «Высокая степень развития правовой теории, богатство выраженных ею знаний означает одновременно развитость и богатство понятийного арсенала, категориального аппарата, который позволяет углублять дальнейшее изучение правовой формы общественной жизни» ${ }^{422}$.

Выработанные юридической наукой правовые категории, закреплённые в нормах права, и составляет тот фундамент, на котором развиваются все отрасли права (каждая в отдельности и в своей совокупности как единая правовая система страны), а также теория правотворчества, в частности.

${ }^{422}$ См. подробнее: Васильев А.М. Правовые категории. Методологические аспекты разработки системы категорий теории права. - М., 1976. - С. 44. 
Оценка научно обоснованного текста дефиниции будущей правовой нормы, закрепляющей принцип правотворчества, осуществляется по её содержанию и по форме. Её содержание должно в полной мере отражать потребности общественных отношений в их урегулировании с учётом социальных ценностей, присущих этим отношениям и выраженных в данной норме ${ }^{423}$. Принципы правотворчества в самом общем виде создают систему важнейших критериев, по которым должны вырабатываться нормативные правовые акты и соответствии с которыми регулирование общественных отношений должно отвечать тем параметрам, одобряемых государством ценностей, которые оно возвело в ранг показателей социально-политической стабильности и благополучия общества.

Формой, в которой может быть выражен принцип правотворчества является нормативный правовой акт. В отличие от принципов права, которые могут иметь разнообразные формы выражения ${ }^{424}$ принципы правотворчества реализуются субъектами правотворческих решениях, что существенно ограничивает форму их юридического проявления. Разработка и обоснование правотворческого принципа теорией правотворчества есть только определённая модель научного представления о нём, как о регуляторе общественных отношений. Пока научное представление о данном принципе не будет закреплено в нормативном правовом акте в качестве принципа правотворчества, теоретическая модель не есть ещё его юридической формой. В противном случае постулаты теории правотворчества, не воплощённые в нормы права, играли бы такую же регулятивную роль, как и те принципы правотворчества, которые имеют прямое закрепление в правотворческих решениях, что в реальной действительности невозможно. Кроме того, издающие нормативные правовые акты субъекты, реализуют идеи, заложенные в принципах правотворчества в соответствии со своей компетенцией, то есть в рамках строго установленного законом, что исключает возможность претворения указанных принципов иным путём.

Оценив научно обоснованную дефиницию принципа правотворчества и признаков по содержанию и по форме приемлемой для институционализации, уполномоченный законом субъект правотворчества переводит её в правовую категорию, наделив юридической силой в соответствующих процедурах. Теперь принцип правотворчества, будучи выраженным в виде нормативного предписания ${ }^{425}$, обладает всеми необходимыми признаками для использования в соответствии с его предназначением осуществлять функцию регулятора общественных отношений, формировать их с учётом тех присущих ему ценностей, которые в нём закреплены законом.

\footnotetext{
${ }^{423}$ См. подробнее: Кашанина Т.В. Структура права: монография. - М., 2017. - С. 266.

${ }^{424}$ Там же. - С. 294.

${ }^{425}$ См. подробнее: Васильев А.М. Правовые категории. Методологические аспекты разработки системы категорий теории права. - М., 1976. - С. 47.
} 


\section{Правотворчество в Российской Федерации}

4. Осуществить мониторинг эффективности институционализации принципа правотворчества путём проведения контроля качества правотворческих решений, в которых он нашёл свою реализацию.

Выбор научного обоснованных ориентиров (принципов) по которым должно осуществляться правотворчество может быть ошибочным из-за комплексного характера данного понятия и сложности его юридических свойств, а также низкого уровня профессионализма субъекта правотворчества, что исключает полностью или в определённой части реализацию правотворческих решений. Например, принцип оперативности обязывает субъекта правотворчества издавать нормативно-правовой акт своевременно по мере возникновения потребностей изменяющихся общественных отношений, а забегание вперёд или отставание в издании таких актов, приводит к тому, что принимаемые правотворческие решения не реализуются и остаются бесполезными. То же самое можно сказать о принципе исполнимости правотворческих решений ${ }^{426}$. Правильный учёт готовности существующих общественных отношений к реализации нормативных предписаний обеспечивает их реализацию, ошибочный исключает её.

Избранный субъектом правотворчества критерий оценки потребностей общественных отношений в правовом урегулировании может быть занижены или завышены. Это обуславливает издание нормативного правового акта не того уровня, который на самом деле требуется. Когда законом урегулируются общественные отношения, подлежащие закреплению подзаконным актом и, наоборот, подзаконный акт регулирует отношения, нуждающиеся в закреплении их законом, создаётся не только путаница в статусе действующих нормативных предписаний, но, самое главное, происходит подмена субъектов правотворчества, когда они осуществляют деятельность, не соответствующую их компетенции.

Поэтому необходимо проконтролировать эффективность реализации нормативного правового акта, изданного с учётом требований того или иного принципа правотворчества. Принцип правотворчества можно считать эффективным, если нормативный правовой акт реализуется без затруднений и закреплённые в нём требования в полной мере находят своё выражение.

В юридической литературе отмечается, что критерии оценки принципов нигде не описаны и их определение представляется делом нелёгким $^{427}$. Аналогичная точка зрения высказана и в отношении принципов правотворчества. В частности, учёные пишут: «Необходимо разработать критерии выделения тех или иных начал в качестве принципов правотворчества, а также измеримые показатели эффективности реализации данных принципов. Это должно повысить эффективность реализации

${ }^{426}$ См. подробнее: Васильев А.М. Об исполнимости законов // Теория права: новые идеи. М., 1991. - Вып. 1. - С. 75-78.

${ }^{427}$ См. подробнее: Жан-Луи Бержель. Общая теория права / под ред. В.И. Даниленко. - М.: NotaBene, 2000. - C. 185. 
принципов правотворчества, а также качество принимаемых нормативно-правовых актов» ${ }^{428}$.

Однако доказано, что принципы правотворчества реализуются в нормативных правовых актах не произвольно по усмотрению субъектов правотворчества, а с учётом объективных потребностей социальноэкономических отношений в стране и целями издаваемого акта. В первом случае принципы правотворчества предопределяются тем, что они:

1) востребованы общественными отношениями, которые они регулируют;

2) должны соответствовать компетенции субъекта правотворчества, поскольку каждый из них обладает полномочиями на издание нормативного правового акта только своего уровня;

3) имеют обязательную научную обоснованность, свидетельствующую о целесообразности и необходимости их закреплении в нормах права;

4) создают благоприятные условия реализации нормативного правового акта.

Во втором случае, исходя из целей правового регулирования, принципы правотворчества включаются в нормативный правовой акт для решения определённых задач:

1) побуждения лиц, которым адресуется данный акт, к активному его исполнению (например, включение принципа личной заинтересованности);

2) формирование негативного отношения к деятельности, запрещённой законом (например, указание на принцип законности);

3) создания механизма реализации нормативных предписаний (например, принципы демократизма и гласности обеспечивают порядок выработки и принятия нормативных правовых актов) и т. д.

Ориентируясь на такие объективные критерии востребованности принципов правотворчества можно установить их эффективность и принять решение о необходимости институционализации каждого конкретного принципа правотворчества либо об отсутствии такой необходимости.

На основании изложенного можно сделать следующие выводы в целом по данному параграфу.

1. Институционализация принципов правотворчества - это закрепление в нормах права основополагающих идей, социальных или иных ценностей в качестве руководящих ориентиров при регулировании общественных отношений с целью формирования в обществе и государстве социальной стабильности и прогресса.

2. Перевод научно обоснованных дефиниций, определяющих содержание и форму принципов правотворчества, осуществляется в результате наделения их юридической силой в установленных законом процедурах.

3. Критериями оценки пригодности тех или иных ценностей выполнять функции принципов правотворчества могут служить:

1) объективно существующая потребность общественных отношений в урегулировании за счёт именно этих ценностей, которая устанавлива-

${ }^{428}$ Жинкин С.А. Некоторые проблемы реализации принципов правотворчества в современной России / С.А. Жинкин, Т.Н. Чернявская // Общество и право. - 2016. - №2 (56). - С. 24. 
ется на основании их незаменимой востребованности, индивидуализирующей принципы для каждой группы отношений;

2) целевая направленность нормативного правового акта, которая определяет принципы, способные её обеспечить. С учётом этого субъект правотворчества обязан до начала разработки нормативного правового акта сформировать конкретную группу принципов правотворчества, которыми он будет руководствоваться при его выработке.

\section{§3.3. ФОРМИРОВАНИЕ И РАЗВИТИЕ СИСТЕМЫ ПРИНЦИПОВ ПРАВОТВОРЧЕСТВА, ИХ ЗНАЧЕНИЕ ДЛЯ НОРМАТИВНОГО ЗАКРЕПЛЕНИЯ НАДЛЕЖАЩЕЙ МОДЕЛИ ПРАВОВОГО РЕГУЛИРОВАНИЯ ОБЩЕСТВЕННЫХ ОТНОШЕНИЙ}

Принципы правотворчества лежат в основе достаточно сложного комплексного правового явления, которое объединяет в себе признаки не только собственно деятельности уполномоченных законом субъектов по изданию нормативных правовых актов, но и изучению их объективной необходимости, а также оптимальных форм нормативного закрепления. Поэтому субъекты правотворчества руководствуются в своей деятельности не только принципами правотворчества, но и принципами права. И те, и другие принципы, хотя и выполняют схожие регулятивные функции, но имеют различные задачи.

Принципы права регулируют общественные отношения, устанавливая правовой порядок их осуществления, а принципы правотворчества порядок выработки и принятия нормативных правовых актов. В первом случае принципы лежат в основе упорядочения отношений, имеющих объективный характер, протекающих под воздействием складывающихся в обществе социально-экономических, политических, духовнонравственных и культурных процессов. Во втором - регулируют отношения, возникающие в ходе деятельности субъектов правотворчества по изданию нормативных правовых актов, то есть они направлены на регламентацию правотворческого процесса, а не на урегулирование общественных отношений. Из этого следует, что принципы правотворчества имеют задачу урегулировать интеллектуально-волевые отношения, имеющие субъективный характер, хотя они и обусловлены объективной необходимостью их реализации.

Сущность принципов права состоит в том, что «они отражают устойчивые, повторяющиеся связи между явлениями в обществе» ${ }^{429}$. Вместе с тем, необходимо учитывать и то, что «формируя и устанавливая основные начала регулирования, правовые принципы создают базовые усло-

${ }^{429}$ Кашанина Т.В. Структура права: монография. - М., 2017. - С. 264. 
вия и способность давать верное направление пониманию духа и буквы закона, как в правотворчестве, так и в правоприменении» ${ }^{430}$.

Это указывает на универсальность принципов права, их способности воздействования не только на первичные отношения, возникающие в результате естественного развития общества и государства, но и на последующие отношения, связанные с регламентацией правотворческого процесса по их урегулированию. Принципы права выражают объективную потребность общественных отношений в урегулировании, образуют систему важнейших ценностей, на которые опирается субъект правотворчества при издании нормативных правовых актов.

Принципы правотворчества также являются ориентирами, но только правотворческой деятельности и их задача - установление критериев выработки и принятия качественных нормативно-правовых актов, которые призваны регулировать общественные отношения. То есть сфера воздействия принципов правотворчества распространяется непосредственно на правотворческий процесс и связанные с ним отношения.

Однако для формирования системы принципов правотворчества определения сферы общественных отношений, на которые они воздействуют, недостаточно. Необходимо, как минимум, дополнительно установить цель нормативного правового акта, чтобы было понятно какие принципы правотворчества могут обеспечить их достижение, а также основные принципы права, с которыми эти правотворческие принципы должны корреспондировать.

Это сложная и кропотливая работа, которая, выполняется в форме научно-исследовательской и аналитически-правовой деятельности, в ходе которой первоначально разрешаются такие вопросы как цель и форма издания нормативного правового акта, модель правового регулирования, определение основных правовых принципов, подлежащих реализации в издаваемом акте. Уже после этого могут быть определены принципы правотворчества, составляющие основу разработки и принятия данного нормативного правового акта.

Среди этих вопросов основным является определение модели правового регулирования общественных отношений. Тем самым субъект правотворчества показывает уровень функционирования общественных отношений, заложенный в них внутренний потенциал по обеспечению реализации присущих им идеалов и ценностей, указывает на их объективную потребность в таком урегулировании.

Следует учитывать, что «ценности не определяют нормы, конкретные параметры и стандарты желаемого государством поведения граждан, а только задают общую направленность деятельности. Ценность фактически санкционирует тот или иной вид деятельности, направлен-

${ }^{430}$ Андриянов В.Н. О роли и сущности принципов современного административного права // Российская юстиция. - 2015. - №2. - С. 22. 


\section{Правотворчество в Российской Федерации}

ной на достижение определённого результата» ${ }^{431}$. Ценностные показатели лишь указывают вектор правотворческой деятельности, ориентируя субъект правотворчества на результат, который необходимо достичь при разработке конкретного нормативного правового акта.

Ценность, сформированная в общественном сознании, служит общепризнанным критерием социальной направленности государства, она объективно в силу своей востребованности, обуславливает содержание модели правового регулирования общественных отношений. Присущие данному обществу ценности непосредственно порождаются самим обществом и могут быть обусловлены нормами права (например, Конституцией РФ, общепризнанными принципами и нормами международного права), духовно-нравственными идеалами народа, исторически сложившимися культурными традициями и обычаями.

Модель правового регулирования общественных отношений - это установление научно обоснованных показателей состояния общества и государства, которые должны обеспечить принципы правотворчества в результате их реализации в правотворческих решениях. По своей сути, она представляет собой перечень тех основных показателей, лежащих в основе правового государства и гражданского общества, которым должен соответствовать издаваемый нормативный правовой акт и с учётом которых будут определены принципы правотворчества. Это многогранное собирательное понятие, которое формируется путём учёта множества структурных элементов, составляющих ту ли иную их объективную потребность. И в то же время указанная модель является идеализированной формой выражения этих потребностей, вытекающих из прямых нормативных предписаний, целей правового регулирования и устоявшихся общественных представлений о назначении государства и права. Идеализированной, значит созданной субъектом правотворчества в виде абстрактных критериев качества будущего нормативного правового акта для руководства ими в своей деятельности.

Одновременно модель правового регулирования общественных отношений может быть и образцом теоретического моделирования, основанного на научных представлениях возможности закрепления в нормах права идеалов правового государства гражданского общества, если она была выработана юридической наукой, в частности, теорией правотворчества. Но это не означает, что в ходе выработке нормативного правового акта субъект правотворчества сможет в полной мере выразить в нормах права параметры, заложенные в теоретической модели учёными.

Это обусловлено, прежде всего, тем, что сам процесс формирования модели правового регулирования общественных отношений носит субъективный характер, хотя и обусловлен объективными факторами. Уровень учёта объективных потребностей общественных отношений, их закрепление в нормах права зависит от профессионализма субъекта правотворчества, что заведомо предопределяет возможность отступле-

${ }^{431}$ Государство созидающее: юридическая модель и современные риски: монография / под ред. О.Н. Полухина. - М., 2016. - С. 180. 

правотворчества и прикладной юридической науки, юридической техники

ния им от созданного наукой теоретического образца, поскольку наука пока слабо влияет на правотворческий процесс. «Главное, что определяет успех правотворческой деятельности компетентных органов, - это правильное соотношение объективного и субъективного: полный учёт назревших объективных потребностей общественного развития, реальное выражение в праве воли народа, своевременное осуществление назревших правовых мероприятий, формирование воли народа с максимальным использованием достижений юридической науки и т. д.» ${ }^{432}$.

Правильное соотношение объективного и субъективного в правотворческом процессе достигается за счёт научно обоснованного выбора модели правового регулирования общественных отношений, использования в соответствии с ней необходимых принципов правотворчества, отражающих потребности каждой из сторон.

Объективная сторона показывает, что субъект правотворчества осуществляет правовое регулирование общественных отношений, нуждающихся в урегулировании нормами прав, что такая потребность возникла из их внутренних естественных процессов, обусловленных социальноэкономическим и политическим развитием общества и государства. Это также показывает, что правотворческий процесс - неизбежный и закономерный результат трансформации общественных отношений, обуславливающих уполномоченные органы принимать меры для их стабилизации и придания им нормативной урегулированности.

Субъективная сторона в свою очередь показывает, что субъект правотворчества осуществляет правотворческую деятельность исходя из присущих ему представлений и предпочтений, из уровня профессиональных знаний и опыта, и даже под влиянием лоббистского и коррупционного воздействия. Получается, что субъект правотворчества должен не только правильно оценить объективные потребности общественных отношений к их урегулированию нормами права, избрать для этого нужный нормативный правовой акт, но и преодолеть недостатки своего профессионализма, устоять под напором негативного воздействия заинтересованных лиц в издании выгодного им, но не объективно необходимого, акта. Это исключительно сложная задача, решение которой облегчается за счёт выработки модели правового регулирования общественных отношений, в результате установления ценностных ориентиров, позволяющих осуществлять правотворчество на высоком качественном уровне, то есть на уровне установленных самим субъектом правотворчества параметров.

Модель правового регулирования задаёт необходимый для сложившихся общественных отношений уровень правотворческих решений, устанавливает критерии, которым они должны соответствовать, создаёт в определённой степени барьеры, препятствующие выработке ошибочного или неэффективного нормативного правового акта в связи с изъянами профессионализма и другими факторами, отрицательно влияющими на субъекта правотворчества.

432 Алексеев С.С. Механизм правового регулирования в социалистическом государстве. M., 1966. - C. 75-76. 


\section{Правотворчество в Российской Федерации}

Таким образом, правотворчество, как деятельность уполномоченных органов по изданию нормативных правовых актов, имеет в основном субъективный характер. Однако она связана с формированием норм права по регулированию общественных отношений, вытекающих из их объективной потребности к такому урегулированию. Следовательно, принципы, которые должны лежать в основе правотворчества, отражает одновременно обе стороны данного процесса. С одной стороны, они направлены на регулирование субъективной составляющей и представляют собой критерии (принципы), определяющие сам процесс деятельности по изданию нормативных правовых актов, а с другой - объективной стороны - являются ценностными ориентирами, по которым субъекты правотворчества регулируют общественные отношения. Получается, что принципы правотворчества имеют двойное назначение: 1) внутреннее - для регулирования деятельности субъектов правотворчества в пределах своей компетенции; 2) внешнее - отражающее процесс регулирования общественных отношений, который осуществляется совместно с корреспондирующими им принципами право (общими и отраслевыми).

Анализ принципов правотворчества с учётом их функционального назначения показывает, что они действительно отражают как субъективную сторону единого процесса по изданию нормативных правовых актов, так и объективную сторону единого процесса по изданию нормативных правовых актов. Так, принципы профессионализма ${ }^{433}$, учёта правотворческого опыта ${ }^{434}$, технико-юридического совершенства ${ }^{435}$, исполнимости ${ }^{436}$, оперативности ${ }^{437}$, связи с практикой ${ }^{438}$, плановости ${ }^{439}$ и т. д. отражают в основном субъективную сторону правотворческого процесса и образуют механизм по упорядочению деятельности субъектов правотворчества при издании нормативных правовых актов. Их востребованность вытекает из необходимости решения задач правотворчества, потребности издания качественных правотворческих решений, поскольку они устанавливают ориентиры деятельности субъекта правотворчества, адресуются именно ему, что не может не обусловить повышение качества регулирования общественных отношений.

И в то же время такие принципы правотворчества как демократизм ${ }^{440}$, гласность ${ }^{441}$, конституционность ${ }^{442}$, законность ${ }^{443}$, справедливость $^{444}$,

\footnotetext{
${ }^{433}$ Марченко М.Н. Теория государства и права: учебник. - М.: МГУ, 2007. - С. 551; Рассказов Л.П. Теория государства и права: учебник. - М., 2008. - С. 315 и др.

434 Теория государства и права / под ред. В.Д. Перевалова. - М., 2007. - С. 186-187; Теория государства и права / под ред. Е.И. Темнова. - М., 2010. - С. 221.

${ }^{435}$ Марченко М.Н. Теория государства и права: учебник. - М.: МГУ, 2007. - С. 551.

${ }^{436}$ Рассказов Л.П. Теория государства и права: учебник. - М., 2008. - С. 316.

${ }^{437}$ Там же.

${ }^{438}$ Там же.

${ }^{439}$ Комаров С.А. Общая теория государства и права. Курс лекций. - М., 1996. - С. 163.

${ }^{440}$ Радько Т.Н. Теория государства и права. - М., 2009.

${ }^{441}$ Там же.

${ }^{442}$ Марченко М.Н. Указ. соч. - С. 551.

${ }^{443}$ Радько Т.Н. Указ. соч. - С. 365.

444 Лазарев В.В. Теория государства и права. Учебник / В.В. Лазарев, С.В. Липень. - М., 2000. - C. 278.
} 
научность ${ }^{445}$ являются ориентирами регулирования прежде всего объективных потребностей общественных отношений. Они корреспондируют с аналогичными принципами права и являются ориентирами при выработке норм права, т.е. регулируют процесс упорядочения общественных отношений, а попутно, в определённой степени, и процесс их создания. То есть принципы правотворчества, взаимодействуя между собой, отражает в большей степени субъективную, либо объективную сторону, но одновременно каждый из них обуславливает востребованность и противоположных принципов, способствуя тем самым повышению качества, издаваемого нормативного правового акта.

В юридической литературе отмечается, что пока ещё не сформировалась окончательная система принципов правотворчества ${ }^{446}$, поскольку «не найден единый подход к пониманию места каждого из них в правотворческом процессе. Видимо, поэтому российское законодательство также не содержит однозначного перечня принципов правотворчества, что создаёт дополнительные трудности правового регулирования общественной жизни» ${ }^{447}$. По нашему мнению, систему принципов правотворчества необходимо формировать с учётом их функционального назначения. Именно такой подход позволяет чётко установить, какую регулятивную роль исполняет каждый из них, уяснить какие ещё принципы могут обеспечить более совершенное регулирование общественных отношений. Классификация принципов правотворчества в отрыве от регулятивных свойств мало эффективна ввиду невозможности оценки их значения для правотворческой деятельности, с одной стороны, и степени обеспечения правовыми ориентирами общественных отношений для их надлежащего урегулирования, с другой.

Иными словами, следует учитывать, что с помощью принципов правотворчества можно определить качество нормативного закрепления деятельности субъектов правотворчества по изданию нормативных правовых актов (принципы-полномочия) и качество правового регулирования общественных отношений, которое они осуществляют (принципырегуляторы). Каждая из этих функций отражает специфику определённого принципа, неотделима от него и тем самым создаёт надёжный критерий для их классификации по видам. Принципы-полномочия обеспечивают эффективность деятельности субъектов правотворчества, а принципы-регуляторы придают общественным отношениям нормативный характер.

Субъект правотворчества, осуществляя выбор модели правового регулирования общественных отношений, должен разрешить следующие вопросы, касающиеся целей и содержания нормативного правового акта:

1) почему необходимо правовое регулирование общественных отношений;

${ }^{445}$ Радько Т.Н. Указ. соч. - С. 365 и др.

${ }^{446}$ Шамаров В.М. Принципы правотворчества, классификация и содержание // Вестник Екатерининского института. - 2009. - №2. - С. 23.

447 Жинкин С.А. Некоторые проблемы реализации принципов правотворчества современной России / С.А. Жинкин, Т.М. Чернявская // Общество и право. - 2016. - №2 (56). - С. 23. 


\section{Правотворчество в Российской Федерации}

2) какой конечный результат должен обеспечить изданный нормативный акт;

3) какой способ правового регулирования необходимо использовать: на основе традиционного правового регулирования общественных отношений или с учётом возможностей созидающего правотворчества, когда адресат нормативных предписаний активно включается в их реализацию;

4) какая система принципов правотворчества, взаимодействуя с общими отраслевыми принципами права, может обеспечить достижение целей издаваемого нормативного правового акта;

5) имеются ли материальные, финансовые, политические, организационные и другие возможности для реализации изданного нормативного правового акта.

Последовательно разрешая указанные вопросы, субъект правотворчества тем самым программирует качественный уровень будущего нормативного правового акта, устанавливает не только объективную необходимость его издания, но и очерчивает пределы действия акта, социальную ценность, степень заинтересованности граждан в таком правовом документе.

О необходимости правового урегулирования 448 определённой группы общественных отношений свидетельствуют такие факты, как:

1) их широкая распространённость;

2) возникновение между участниками этих отношений конфликтных ситуаций, требующих судебного вмешательства для их разрешения;

3) противоречивость судебной практики по спорам данной категории дел;

4) действующая нормативно-правовая база не предусматривает в полной мере правовое регулирование этих отношений;

5) имеющиеся правовые средства позволяют придать отношениям упорядоченный характер;

6) издаваемый нормативный правовой акт может быть успешно реализован.

Важнейшим вопросом, определяющим модель правового регулирования общественных отношений, является цель издания нормативного правового акта, указывающая на конечный результат, к которому стремится субъект правотворчества. Вне зависимости от вида и юридической силы нормативного правового акта он должен быть направлен, как и вся правовая система страны, на достижение тех идей, ценностей, идеалов, которые закреплены Конституцией РФ и вытекают из общепризнанных принципов и норм международного права. К числу других ценностей относятся, прежде всего, следующее:

1) обеспечение устойчивого поступательного социальноэкономического, политического, духовно-нравственного и культурного развития общества и государства, поддержание социальной стабильности и справедливости. Решение этих задач выполняет государство в ре-

${ }^{448}$ См. подробнее: Алексеев С.С. Механизм правового регулирования в социалистическом государстве. - М., 1966. - С. 76-77. 
зультате регулирования общественных отношений нормами права. Однако выполнить такие задачи оно может, если само будет иметь глубокую социализацию, отражать внутреннюю самобытную жизнь общества, что обеспечивает государству нравственный и правомерный характер, создаёт для власти нормальное и правомерное положение ${ }^{449}$. Это значит, что субъект правотворчества обязан издавать нормативные правовые акты, вытекающие из интересов всех социальных слоёв общества, защищать права человека и гражданина независимо от каких бы то ни было особенностей их политических, религиозных, культурных взглядов и национальной принадлежности. Субъект правотворчества - это носитель государственных полномочий по регулированию общественных отношений. В связи с этим он должен всегда достигать в своей деятельности полного сочетания целевой направленности издаваемого нормативного акта с теми целями, которое решает государство, поскольку «правовым регулированием можно назвать только такое воздействие, при котором ставятся достаточно ясно обозначение цели... Но если под воздействием законодательного акта или его норм, наступают последствия, не предусмотренные законодательством, а в некоторых ситуациях и противоречащие целям законодателя, то такое воздействие не может считаться правовым регулированием» ${ }^{450}$;

2) разрешение любых конфликтных ситуаций (межличностных, экономических, социальных, политических и др.) правовыми средствами, создание нормативной базы правового государства как модели организации современного демократического общества, что обеспечивает:

a) верховенство конституции и закона во всех сферах жизни;

б) приоритет прав и законных интересов человека и гражданина, признание их непосредственно действующими;

в) обоснованные и справедливые решения институтов государственной власти;

г) сочетание суверенитета государства с признанием в определённых пределах приоритета международных принципов и норм;

д) организация всей жизни общества на принципах демократии и права, основанного на поощрении и стимулировании активных правомерных действий ${ }^{451}$;

3) издание нормативных правовых актов, направленных на саморегулирование общественных отношений, снижение вмешательства государства в частные межличностные отношения граждан. «Степень жесткости юридического регулирования наличие ограничений для активности субъектов права зависит от политического режима, сложившегося в государстве, демонстрирующего соотношение и взаимодействие граждан-

\footnotetext{
449 Матвеева А.И. Правовые аспекты духовной социализации личности // Актуальные проблемы современной науки. - 2011. - №19. - 20 с.

${ }^{450}$ Теория государства и права. Учебник для вузов / отв. ред. В.Д. Перевалов. - М., 2004. C. 146.

${ }^{451}$ См. подробнее: Тихомиров Ю.А. Правовое государство: модели и реальность // Журнал российского права. - 2011. - №2. - С. 6-7.
} 


\section{Правотворчество в Российской Федерации}

ского общества и государства, объем экономических, социальных, политических прав и свобод личности и реальные возможности их осуществления» ${ }^{452}$. Поэтому субъекты правотворчества, имея целью издаваемых нормативных правовых актов повышение активности граждан в их реализации, должны закреплять в нормах права возможность разрешения спорных, конфликтных ситуаций в сфере частных отношений их участникам, то есть переводить такие отношения на саморегулирование. Это повысит правовую культуру населения, снизит нагрузки на судебные органы, выведет правовое регулирование общественных отношений на такой уровень, когда нормы права будут создавать условия для реализации прав, а не устанавливать порядок их осуществления, когда нормативные предписания не на прямую регулируют общественные отношения, а стимулируют участников правоотношений к правомерным действиям. «К сожалению, в отечественной доктрине и общественной практике устойчиво сохраняется стереотип публичной власти как средства принуждения, что очевидно из концепции функций государства» ${ }^{453}$. Такой подход субъекты правотворчества должны изменять в издаваемых ими нормативных правовых актах. Дозволения необходимо положить в основу не только выбора гражданами модели поведения в рамках действующего законодательства, но и самостоятельного осуществления регулирования общественных отношений частного характера, руководствуясь личными законными интересами при условии, что это не нарушает интересы других лиц, общества и государства. Более того, «частное лицо вправе самостоятельно, автономно, по своей воле и по своему интересу, независимо от усмотрения государственной власти определять юридически значимые условия своего поведения, а учреждения государственной власти - как это не парадоксально - обязаны признавать, конституировать и принудительной силой поддерживать эту юридическую значимость и обеспечивать решение всех спорных вопросов независимым судом ${ }^{454}$. В юридической литературе высказаны мнения об усилении процесса саморегулирования общественных отношений, особенно если «право активно способствует этому процессу». Это значит, что во многих сферах общественных отношений, особенно в области локального правотворчества, отдаётся предпочтение соглашениям и договорам между партнёрами вместо использования законодательных норм. «Полезный опыт «снизу» может быть узаконен в региональном и государственном масштабе. Расширение спектра социального регулирования находит выражение в появлении и использовании этических норм в «правовых рамках». Этому служат профессиональные этические кодексы, одобренные государственными органами и общественностью» ${ }^{455}$;

\footnotetext{
${ }^{452}$ Государство созидающее: юридическая модель и современные риски. Монография / под ред. О.Н. Полухина. - М., 2016. - С. 185.

${ }^{453}$ Там же. - С. 186.

${ }^{454}$ Алексеев С.С. Восхождение к праву. Поиски и решения. - М., 2002. - С. 439-440.

455 Тихомиров Ю.А. Новые векторы регулирования - «другое» право? // Журнал российского права. - 2016. - №4. - С. 9.
} 
4) использование принципов созидающего правотворчества при выработке нормативных правовых актов. Созидающее правотворчество формируется в результате учёта заинтересованности лиц, которым адресуются нормативные правовые акты, издаваемые субъектом правотворчества. Эффективность нормативных предписаний зависит не только от качества правотворческого решения, но и от избранного метода правового регулирования общественных отношений, а также от поощрения различными правовыми средствами субъектов правоотношения к его исполнению, что возможно сделать только путём возбуждения у них к этому заинтересованности ${ }^{456}$. Правовое регулирование на основе принципов созидающего правотворчества должно осуществляться на всех уровнях издаваемых нормативных правовых актов. Если, например, во исполнение нормативных правовых актов издаются конкретизирующие их подзаконные акты нижестоящими субъектами правотворчества, то и в таких случаях стимулирование заинтересованности должно находить продолжение в нормах и этих актов более низкого уровня правового регулирования. Кроме того, в отличие от обычных нормативных правовых актов, разработанных без учёта заинтересованности лиц, которым они предназначены, созидающее правотворчества должно учитывать особенности воздействия таких актов на субъектов их реализации во всех возможных формах - при соблюдении, использовании и применении. Проблема, которую необходимо решить субъекту правотворчества, состоит в том, что обычные (ординарные) нормативные акты стимулируют стороны правоотношения, в основном, к определённому поведению в рамках урегулированных нормами права общественных отношений, а вопрос о стимулировании сторон в качественном и своевременном исполнении ими нормативных предписаний, заложенных в самом акте остаётся без внимания, поскольку правотворческий орган не знает иных способов обеспечения их реализации, кроме мер государственного принуждения. Именно этот недостаток современного правотворчества необходимо преодолеть;

5) согласование между собой принципов права, принципов отраслей права и принципов правотворчества как единого регулятора подлежащих нормативному упорядочению общественных отношений, что позволит обеспечить формирование единой непротиворечивой правовой системы страны. Правотворческая деятельность в настоящее время не имеет единых стандартов, она направлена на издание отдельных нормативных правовых актов, а не, на выработку таких актов в качестве структурных элементов целостной правовой системы страны. Поэтому достижение согласованности между принципами-регуляторами разного уровня и назначения будет способствовать установлению единого правового регулирования общественных отношений. Такое согласование вполне реализуемо, исходя из того, что «принципы нижестоящего уровня не долж-

${ }^{456}$ См. подробнее: Субочев В.В. Законные интересы / под ред. А.В. Малько. - М., 2012. C. $78-110$. 


\section{Правотворчество в Российской Федерации}

ны идти вразрез с принципами более высокого уровня». Установление согласования между принципами разного уровня и назначения необходимо также и потому, что издаваемые нормативные правовые акты носят, как правило, комплексный отраслевой характер. Это важно, потому что «при решении любого юридического вопроса существенно важно с самого начала определить «отраслевую основу» намечаемого решения: от этого зависит адекватность, отработанность и действенность всего применяемого в данном случае юридического инструментария, носящему по своему содержанию отраслевой характер» ${ }^{457}$. Благодаря этому модель правового регулирования приобретает целевую направленность, так как определяет отрасль права, а значит и вид нормативного правового акта.

Таким образом, субъект правотворчества устанавливает указанные выше, а также и другие необходимые в каждом конкретном случае ориентиры, по которым определяется качественный уровень модели правового регулирования общественных отношений. Получается определённый абстрактный образец с множеством критериев, указывающих на необходимость закрепления их в нормах права. Субъект правотворчества, разрабатывая нормативный правовой акт, обязан учесть каждый из них и закрепить, заложенные в этих ориентирах ценности, нормами права. В конечном результате, созданная модель правового регулирования общественных отношений, взятая за основу, образец разрабатываемого нормативного правового акта превращается в первоначальный вариант проекта нормативного акта. В дальнейшем проект нормативного акта может быть доработан в установленных законом процедурах и принят в качестве самостоятельного юридического документа.

Принципы правотворчества являются правовой базой, фундаментом каждого нормативного правового акта. В соответствии с заложенными в них общественными идеалами и социальными ценностями вырабатывается чёткая система правовых норм, направленная на защиту и реализацию во всех сферах общественных отношений их предписаний. Являясь индикаторами, показателями социально-политической, экономической и духовно-нравственной зрелости общества и государства, принципы правотворчества, взаимодействуя с принципами права, создают надёжные критерии для формирования на их основе качественных и эффективных нормативных правовых актов и всей правовой системы страны.

Принципы правотворчества проявляют своё фундаментальное значение в связи с их нацеленностью на качественное регулирование общественных отношений, а также на обеспечение субъектов правотворчества критериями, по которым они вырабатывают нормативные правовые акты.

Конкретно значение принципов правотворчества выражается в следующем:

1) принципы правотворчества показывают, с одной стороны, уровень социально-экономических, политических и духовно-нравственных по-

${ }^{457}$ Алексеев С.С. Восхождение к праву. Поиски и решения. - М., 2007. - С. 454. 
требностей общественных отношений на котором они должны быть урегулированы нормами права (принципы-регуляторы), а с другой - устанавливают требования к субъекту правотворчества, руководствуясь которыми он должен осуществлять свою деятельность при выработке правотворческих решений (принципы-полномочия);

2) принципы правотворчества переводят процесс выработки и принятия нормативного правового акта из области эмпирического поиска нужного решения, опирающегося только на опыт, в область научного познания правовой деятельности, когда необходимые правотворческие решения определяются научным путём. Именно принципы правотворчества направлены на «решение научных вопросов правового регулирования с тем, чтобы при подготовке проекта закона всегда учитывались достижения юридической науки и не принимались научно не обоснованные решения ${ }^{458}$. Это одно из важнейших качеств принципов правотворчества, поскольку они образуют чёткую систему показателей, ориентируясь на которые, вырабатываются все нормативные правовые акты.

Важно и то, что данные показатели не создаются субъектами правотворчества, а формируются в результате естественного развития общественных отношений, то есть они имеют объективный характер. Это и предопределяет их востребованность при регулировании общественных отношений. Выявление и нормативное закрепление тех или иных потребностей общественных отношений, как принципов правотворчества, сложная научная задача для субъектов правотворчества, поскольку «при оценке роли юридических понятий на первый план выступает вопрос о том, насколько верно, адекватно, объективно отражено в них познание действительности» ${ }^{459}$;

3) принципы правотворчества закрепляются в нормативных правовых актах Российской Федерации и её субъектов, как правило, в виде нормдеклараций, что позволяет субъекту правотворчества чётко обозначить целевую направленность будущего нормативного правового акта. Нормативность принципов в целом «выступает как более высокое обобщающее свойство по сравнению с обычными нормами. Дело в том, что если основным содержанием норм права выступают формализованные правила поведения сторон в виде двусторонних требований, то принцип чаще всего формулирует идеал, т.е. идеальный ценностно-нормативный образ правовой действительности... Идеалы ставят цели, ориентиры человеческой деятельности, оценивая её через призму важнейших социально значимых идей» ${ }^{460}$. Всё это присуще и принципам правотворчества и с этой стороны они имеют важное значение, так как обуславлива-

${ }^{458}$ Строгович М.С. Избранные труды. Проблемы общей теории права. - Т. 1. - М., 1990. C. 27.

${ }^{459}$ Васильев А.М. Правовые категории. - М., 1976. - С. 81.

${ }^{460}$ ВопленкоН.Н. Понятие и классификация принципов права / Н.Н. Вопленко, В.А. Рудковский // Вестник Волгоградского государственного университета. Сер. 5. Юриспруденция. - №1 (18). - С. 37. 


\section{Правотворчество в Российской Федерации}

ют субъекта правотворчества при издании нормативного правового акта руководствуясь их предписаниями;

4) выработка нормативных правовых актов на основе определённой системы принципов создаёт для субъекта правотворчества благоприятные условия издания качественного и эффективного правового докумен$\mathrm{Ta}^{461}$. Кроме того, принципы правотворчества дают возможность правильно оценить юридическую сущность будущего нормативного правового акта, его структурную принадлежность в общей системе права, взаимосвязь с другими отраслями права. Принципы правотворчества реализуются совместно с корреспондирующими им принципами права, что способствует стабилизации действующей системы права ${ }^{462}$;

5) принципы правотворчества, в определённой степени, нивелируют недостатки профессионализма субъекта правотворчества, создают барьеры против влияния лобби и коррумпированных чиновников, поскольку задают уровень правового регулирования, указывают основные социальные ценности, которые должны быть закреплены в нормативном правовом акте. Субъект правотворчества напрямую игнорировать принципы правотворчества при выработке правового акта не может. Поэтому для повышения своего профессионализма он повышает свою юридическую грамотность, а коллегиальный правотворческий орган для подготовки проекта будущего нормативного акта приглашает специалистов из числа учёных и практических работников;

6) принципы правотворчества имеют существенное значение и в том, что они ориентируют также и правоприменителей на правильное уяснение норм правового акта, изданного на их основе (например, судей, адвокатов, нотариусов и т. д.). Такие случаи возникают, когда та или иная правовая норма изложена законодателем недостаточно ясно, понимается неоднозначно и приходится давать ей толкование;

7) в отдельных случаях принципы правотворчества совместно с принципами права могут использоваться в качестве юридического основания для устранения выявленного пробела в законодательстве.

Таким образом, подводя итог в целом по данному параграфу, можно сделать следующие выводы.

1. Принципы, лежащие в основе правотворчества, отражают одновременно две стороны этого процесса: объективную и субъективную. Объективная сторона отражает внутренние потребности общественных отношений и характеризуется тем, что в результате их естественного развития формируются свойственные обществу в целом определённые социальные ценности и общественные идеалы, которые находят всеобщее признание, становятся руководящими идеями и поэтому приобретают статус принципов, лежащими в основе правового регулирования, это принципы - регуляторы. Субъективная сторона состоит в том, что принципами правотворчества определяется и деятельность правотворче-

\footnotetext{
${ }^{461}$ Жинкин С.А., Чернявская Т.М. Указ. соч. - С. 22.

${ }^{462}$ Шамаров B.M. Теоретико-правовая учебная литература о принципах права // Вестник Екатерининского университета. - 2011. - №2 (14). - С. 52.
} 

правотворчества и прикладной юридической науки, юридической техники

ских органов по изданию нормативных правовых актов, регулирующих общественные отношения, это принципы - полномочия.

2. Принципы правотворчества, являясь показателями социальноэкономической, политической и духовно-нравственной зрелости общества и государства, взаимодействуя с принципами права, создают надёжные критерии для формирования на их основе качественных и эффективных нормативных правовых актов и всей правовой системы страны.

3. Систему принципов правотворчества необходимо формировать с учётом их функционального назначения, поскольку такой подход позволяет чётко установить, какую регулятивную роль выполняет каждый из них. Ценность такой классификации принципов правотворчества состоит в том, что она позволяет выявить те из них, которые призваны регулировать непосредственно общественные отношения, и те, которые регулируют деятельность органов правотворчества по изданию нормативных правовых актов.

4. Значение принципов правотворчества для нормативного закрепления необходимой модели правового регулирования состоит в том, что они определяют в полной мере её содержание, форму и сам процесс деятельности субъектов правотворчества, в результате которого она вырабатывается.

\section{§ 3.4. СОЗИДАЮЩЕЕ ПРАВОТВОРЧЕСТВО И ПРИЕМЫ ЮРИДИЧЕСКОЙ ТЕХНИКИ §3.4.1. ПРИНЦИПЫ СОЗИДАЮЩЕГО ПРАВОТВОРЧЕСТВА}

Эффективность нормативных правовых актов зависит не только от качества правотворческих решений, но и от методов правового регулирования, средством которых они являются. Императивный уклон правового регулирования свидетельствует об усилении вмешательства государства в формирование общественных отношений во всех сферах жизнедеятельности, а диспозитивный, наоборот позволяет субъектам правоотношений самостоятельно устанавливать и разрешать возникающие между ними различные социально-экономические связи.

Классическая схема, применяемая в процессе правового регулирования тех или иных общественных отношений, опирается на нормативное установление прав и обязанностей сторонами правоотношения, реализация которых гарантируется государством. При этом « пути воздействия права в процессе правового регулирования таковы:

а) предоставление лицам субъективных прав;

б) возложение на лиц юридических обязанностей;

в) угроза применения мер государственного или общественного принуждения;

г) обеспечение государственного принуждения» ${ }^{463}$.

${ }^{463}$ Алексеев С.С. Механизм правового регулирования в социалистическом государстве. M., 1966. - C. 22-23. 


\section{Правотворчество в Российской Федерации}

Этот порядок является универсальным и с одинаковым успехом применяется как при императивном, так и при диспозитивном методе правового регулирования. При одинаковом качестве правовых норм их эффективность может быть различной, поскольку воздействие на субъектов правоотношений они оказывают не только в силу заложенных в них предписаний, но и, в первую очередь, в силу внутренних стимулов, побуждающих каждое лицо к желанию (или нежеланию) исполнить таковые в полном объёме и в нужные сроки (или лишь бы формально от них избавиться).

Применение императивного метода правового регулирования основано на реализации обязывающей системы правовых средств, которая действует по принципу: нормативное закрепление обязанности с указанием меры юридической ответственности за её неисполнение ${ }^{464}$. Такой подход обеспечивает четкий и достаточно жесткий порядок реализации предписаний правовых норм субъектами правоотношений. Здесь обязанной стороной выступают физические и юридические лица, а обязывающей - государство, способное в принудительном порядке добиться от этих лиц исполнения своих предписаний. Данный метод используется, в основном при регулировании публичных правоотношений, одной из сторон которых является государство. Эффективность этого метода полностью зависит от качества норм права и исполнительности государственного аппарата, так как обязанные субъекты правоотношений вынуждены действовать под воздействием угрозы государственного принуждения в виде наказания, и не имеют, как правило, собственных внутренних стимулов к добровольной, а следовательно и к добросовестной реализации правовых предписаний.

Диспозитивный метод правового регулирования основан на субъективных правах и гарантиях их реализации ${ }^{465}$. Государство предоставляет право физическим и юридическим лицам действовать по своему усмотрению в сфере частноправовых отношений. «Но воспользуются ли субъекты такого рода возможностью, будут ли последовательны в своем поведении, добьются ли ожидаемого результата - все это остаётся за пределами юридической области, и, если рассматривать только данный участок складывающихся отношений (систему «право + гарантия»), то совершенно неясна результативность действия права, не говоря уже о полной неопределенности в отношении сроков, объёма ожидаемой деятельности, точных характеристик результата» ${ }^{466}$. Это происходит потому, что право в таком случае лишь даёт возможность действовать в определенном направлении и гарантирует его реализацию лишь тогда, когда сам субъект в силу внутренней потребности возьмется за использование права в своих интересах. Тем самым государство стимулирует физическое или юридическое лицо на принятие самостоятельного решения по осу-

${ }^{464}$ См. подробнее: Алексеев С.С. Восхождение к праву. Поиски и решения. - М.: Норма, 2002. - C. 293-294.

${ }^{465}$ Алексеев С.С. Указ. соч. - С. 295-296.

${ }^{466}$ Там же. - С. 296. 
ществлению разрешенной законом деятельности. В случае, если лицо будет вовлечено в определенную деятельность, то её оно должно осуществлять в рамках, установленных законом, что стимулируется системой закрепленных в юридических нормах запретов, дозволений и предписаний к активному поведению ${ }^{467}$. Нормы права устанавливают определенный правовой режим по реализации избранного субъектом вида деятельности, оставляя за пределами своего внимания степень его заинтересованности в точном, качественном и своевременном исполнении нормативно-правового акта, регламентирующего такую деятельность.

Таким образом, за пределами диспозитивного и императивного методов правового регулирования остаётся вопрос о стимулировании субъектов правоотношений (в том числе, и органов государства как участников публичных правоотношений) к исполнению нормативно-правовых актов в точном соответствие с их буквой и духом. Видимо, и по этой причине остаются нереализованными в полном объёме многие (если не большинство) нормативно-правовые акты, издаваемые в Российской Федерации (например, взимание штрафов за совершение административных проступков и уголовных преступлений, которые налагаются в судебном порядке).

Можно сделать вывод, что нормативные правовые акты стимулируют стороны правоотношений, в основном, к определенному поведению в системе сложившейся сферы общественных отношений, а вопрос о возбуждении заинтересованности сторон в качественном и своевременном исполнении ими нормативных предписаний остаётся без внимания законодателя, который не знает иных способов обеспечения их реализации, кроме мер государственного принуждения. То есть в самом нормативном правовом акте нет, как правило, норм, поощряющих стороны правоотношений к активному его исполнению.

Эффективность нормативного правового акта зависит не только от качества правотворческого решения, содержащегося в нём, но и от избранного метода правового регулирования тех общественных отношений, которые он призван урегулировать, а также от поощрения различными правовыми средствами субъектов правоотношения к его исполнению, что возможно сделать только путём возбуждения у них к этому заинтересованности.

Требуется новый подход законодателя по выработке нормативных правовых актов, степень исполнимости которых обеспечивалась бы, кроме традиционных методов, ещё и за счет продуманной системы нормативных предписаний, поощряющих их активную реализацию. Представляется, что стимулировать данный процесс можно и необходимо путём закрепления в них норм, направленных на побуждение каждой стороны правоотношения (управомоченной и обязанной) к активному исполнению заложенных в нормативно-правовом акте предписаний. Это

${ }^{467}$ Алексеев С.С. Механизм правового регулирования в социалистическом государстве. M., 1966. - C. 29. 


\section{Правотворчество в Российской Федерации}

позволит постепенно сформировать новую правовую систему государства, которая будет иметь своей целью не только урегулирование общественных отношений, но и создание юридических стимулов на быстрое и качественное исполнение каждого нормативного правового акта, что решительно повысит их созидающий социально-экономический регулятивный потенциал.

Необходимость создания нового правотворчества с уклоном правового регулирования в сторону усиления заинтересованности сторон правоотношения по активному исполнению нормативных предписаний обусловлена также и тем, что действующее законодательство в отдельных случаях закрепляет в нормах права интересы только одной стороны. Это не может не вызывать противодействия другой стороны правоотношения. Тогда реализация нормативных правовых актов затрудняется, создаётся и разрастается социальная напряженность. Например, ипотечные кредиты носят грабительский характер, поскольку заёмщик вынужден выплатить банку двойную (а то и больше) стоимость купленного жилья. У многих миллионов граждан возникала огромная задолженность перед банками из-за наступившего экономического кризиса. Люди лишались работы, а потом и жилья, которое переходило в собственность банков. Выходом из данной ситуации может стать изменение правил ипотечного кредитования, предоставление заёмщику определенных гарантий, позволяющих ему безболезненно разрешать свои финансовые проблемы при любых экономических ситуациях. Следует учитывать в законе, что банк - это мощная финансовая структура, которая способна преодолеть экономические трудности гораздо легче, чем физическое лицо. Но законодательство защищает интересы банка, а не физического лица, предусматривая возможность перехода купленного им жилья в собственность банка даже в тех случаях, когда лицо потеряло работу не по своей вине или воле. Необходимо именно для подобного рода случаев предусматривать в нормативных актах правила, побуждающие каждую из сторон к взаимной заинтересованности в реализации заключённых договоров путём взаимных уступок, а не к прекращению их по формальным основаниям с выгодой только для одной, более экономически сильной, стороны.

Созидающее правотворчество должно осуществляться на всех уровнях издаваемых нормативно-правовых актов. В его основе должны быть реализованы принципы, которые, с одной стороны, полностью соответствуют принципам правотворчества в целом, а с другой - образуют самостоятельную группу основополагающих личностных ценностей в области реализации каждым участником правоотношений своих законных интересов с учётом признания и реализации аналогичных интересов у всех остальных участвующих лиц.

К числу указанных принципов созидающего правотворчества следует отнести следующие, каждый из которых побуждает лицо добровольно действовать по активной реализации правовых предписаний. 
1. Аккаунтивность ${ }^{468}$.Это учёт материальных, личных или иных интересов каждого участника правоотношений. Как справедливо отмечает С.С. Алексеев, к решению задачи, которую преследует субъект правотворчества, необходимо подключать «деятельный интерес участников общественных отношений». Это резко повышает эффективность правового регулирования, поскольку «поставленная задача будет решаться «сама» и ожидаемый результат будет достигнут с большей степенью вероятности, нежели при обязывающей системе, основанной на обязанностях и мерах принуждения (обязанность + ответственность)» ${ }^{469}$.

Предпосылками реализации норм права в таких случаях является определённый интерес субъекта правоотношений. В качестве мотива, побуждающего активность конкретного лица по реализации нормативных предписаний, могут выступать определенные материальные потребности, либо иные ценности, которые стимулируют его к осуществлению полезной для государства деятельности. Важно, что интерес субъекта правоотношений вытекает из его внутренней потребности, а не в связи с наличием императивно установленного принуждения. Это свидетельствует о наличии объективно существующих личных потребностей у лица к исполнению нормативных предписаний, что приводит к добровольной их реализации. Законодатель, формируя те или иные нормы права, должен это обстоятельство учитывать (take in to account) и предусматривать механизмы по его использованию для повышения эффективности принимаемых нормативных правовых актов.

2. Нормозакреплённость личного интереса. Личный интерес субъекта правоотношения должен быть закреплён в нормах издаваемого правового акта, что создаёт гарантии его реализации. Сам по себе личностный интерес может проявить себя лишь при наличии объективной возможности на его успешную реализацию. Именно такую возможность и обеспечивает государство, предусматривая в нормах права определенный гарантии его фактического достижения.

Субъекту правотворчества необходимо не только урегулировать общественные отношения, но и учитывать непосредственно те личностные интересы соответствующей группы населения, которой адресуется нормативный правовой акт, и, воздействуя на их интересы, повысить эффективность правового регулирования путём нормативного установления заинтересованности в исполнении данного акта.

Таким образом, правовые нормы оказывают своё воздействие одновременно и на взаимоотношения участников общественных отношений, упорядочивая их, и на личностные потребности этих участников, стимулируя их к добровольной реализации издаваемых нормативных актов. Государственные гарантии, обеспечивающие возможность получения блага, лежащего в основе личного интереса, действуют лишь при усло-

\footnotetext{
${ }^{468}$ От англ. take in to account - принимать в интерес, в расчёт, в староанглийском account также «круг личных интересов, личных счётов».

${ }^{469}$ Алексеев С.С. Восхождение к праву. Поиски и решения. - М.: Норма, 2002. - С. 295-296.
} 
вии, что лицо исполняет нормативные предписания, предусматривая в нормах права определенные гарантии его фактического достижения.

Субъекту правотворчества необходимо не только урегулировать общественные отношения, но и учитывать непосредственно те личностные интересы соответствующей группы населения, которой адресуется нормативный правовой акт, и, воздействуя на их интересы, повысить эффективность правового регулирования путём нормативного установления заинтересованности в исполнении данного акта.

Таким образом, правовые нормы оказывают своё воздействие одновременно и на взаимоотношения участников общественных отношений, упорядочивая их, и на личностные потребности этих участников, стимулируя их к добровольной реализации издаваемых нормативных актов. Государственные гарантии, обеспечивающие возможность получения блага, лежащего в основе личного интереса, действуют лишь при условии, что лицо исполняет нормативные предписания.

3. Универсальность стимулирования заинтересованных субъектов. Это значит, что при любом методе правового регулирования личностные интересы всех участников правоотношений должны быть учтены субъектом правотворчества для повышения реализуемости издаваемого нормативного правового акта. К примеру, в нормах уголовного права следует предусмотреть правовой механизм, побуждающий лиц, совершивших преступление и отбывающих наказаний, к исправительному поведению, создающему основу для такого освобождения личности преступника от криминальных наклонностей, переводя его в категорию законопослушных граждан.

Зачастую во исполнение нормативных правовых актов издаются конкретизирующие их акты нижестоящими субъектами правотворчества. Важно, чтобы и в таких случаях стимулирование заинтересованности участников правоотношений в реализации нормативных актов нашло своё логическое продолжение в нормах и этих актов более низкого уровня правового регулирования. Необходимо добиться, чтобы эффект личной заинтересованности в исполнении правовых актов достигался на всех уровнях правотворческой деятельности и стал бы одной из целей формирования правовой системы страны.

4. Законность интересов личности. Это свидетельствует о законодательной возможности их учёта при разработке и издании нормативных правовых актов любого уровня. Одновременно они должны отвечать и общепризнанным нормам морали нашего общества. «Законный интеpec - это отраженное в объективном праве либо вытекающее из его общего смысла и в определенной степени гарантированное государством простое юридическое дозволение, выражающееся в стремлении субъекта пользоваться конкретным социальным благом, а также в некоторых случаях обращаться за защитой к компетентным органам - в целях удовлетворения своих потребностей, не противоречащих общественным» ${ }^{470}$.

${ }^{470}$ Малько А.В. Теория государства и права. - М., 1999. - С. 170. 
Законность интересов личности, хотя и вытекает из внутренних потребностей лица, имеет конкретное нормативное закрепление и соответствует существующей системе поощряемых государством индивидуальных потребностей людей. Данный принцип полностью соотносится с принципом законности правотворчества в целом.

5. Индивидуализация стимулирования лиц к исполнению норм права. Она проводится с учётом достижения целей нормативного предписания, субъектов правоотношения, вида регулируемых общественных отношений, возможных последствий от бездействия нормативных предписаний, побуждения лиц к определённому поведению и т.д. Например, лицо, совершившее преступление средней тяжести, имеет по УК РФ больше возможностей на условно-досрочное освобождение от наказания, чем лицо, совершившее тяжкое преступление. Степень опасности указанных лиц различна, и поэтому государство, стимулируя их к исправлению, устанавливает для более опасного преступника повышенные требования, которые свидетельствовали бы о его готовности стать законопослушным гражданином на свободе.

Реализация указанных выше принципов требует от субъекта правотворчества проведения глубокого изучения предмета правового регулирования, определения конкретных целей, для достижения которых необходимо стимулировать лицо к активному исполнению нормативного правового акта и т. д. Поэтому данные принципы созидательного правотворчества вытекают и находят свою конкретизацию в связи с реализацией принципа научности правотворчества в целом. Вместе с тем, созидающее правотворчество характеризуется ещё одним важнейшим принципом, который учитывает интересы не отдельных лиц или отдельных категорий таких лиц, а всего общества, - это принцип обязательного воплощения результатов обсуждения проекта нормативного правового акта в нормах вступившего в юридическую силу его окончательного варианта. Тем самым находит нормативное закрепление интерес не отдельных физических или юридических лиц, а всего общества, что, несомненно, значительно повышает реализацию любого изданного нормативного акта.

Как отмечается в юридической литературе, эффективность юридических норм, в совокупности составляющих систему правового регулирования, определяется правильностью их выбора при выработке правотворческого решения ${ }^{471}$. Это, безусловно, так. Однако имеет ли субъект правотворчества достаточный набор способов воздействия на общественные отношения, установленные законом, с целью не только их урегулирования, но и активной реализации изданного в связи с ними нормативного акта? Очевидно, нет.

Созидающее правотворчество должно опираться не только на четыре общеизвестных способа воздействия права на формирование обществен-

471 Государство созидающее: юридическая модель и современные риски / под ред. О.Н. Полухина. - М., 2016. - С. 181. 


\section{Правотворчество в Российской Федерации}

ных отношений (см. выше цитату из работы С.С. Алексеева), но и на стимулирование субъектов правоотношений к исполнению нормативных предписаний. С этой целью, как представляется, необходимо законодательно закрепить обязательный учёт субъектом правотворчества объективно существующих интересов у лиц, которым адресуются правовые нормы, для стимулирования их к реализации издаваемого нормативного акта. Кроме того, меры государственного принуждения как способ, обеспечивающий достижение нужного результата правового регулирования, необходимо заменить на государственное поощрение во всех случаях, где это гарантирует успех на достижение требуемого эффекта от применения.

Основная проблема реализуемости нормативно-правовых актов состоит не столько в том, что они недостаточно качественны, а в том, что отсутствует механизм, стимулирующий всех участников правоотношения к их активному исполнению. Государство должно минимизировать своё участие в правовом регулировании общественных отношений и сохранить за собой только контроль и всемерную поддержку процесса их саморегуляции, устанавливая для этого не столько запреты и наказания, сколько дозволения и активное нормативное поощрение добровольного исполнения издаваемых им правовых актов.

Фактически принципы созидающего правотворчества направлены на саморегуляцию общественных отношений, поскольку они могут обеспечить реализацию нормативно-правовых актов без особого участия государственных органов. Тем самым будет формироваться «положительное поле» функционирования нормативных актов, где действует в качестве стимулирующего мотива не принуждение государства, а интерес участников правоотношения.

Принципы сами по себе не могут оказать существенное влияние на содержание правотворческого решения, если их ценности, идеалы и приоритеты не закреплены в нормах права. Поэтому субъекту правотворчества важно обеспечить практическую реализацию выделяемых им принципов в нормативных предписаниях, что и гарантирует не только их воплощение в жизнь, но и эффективность принимаемых нормативных актов $^{472}$. Следует учитывать, что принципы, как правило, не всегда закрепляются напрямую в нормах права, а чаще всего отражаются только их требования в тех нормативных предписаниях, которые регулируют общественные отношения в соответствие с присущими им идеалами и ценностями. На их основе создаются механизмы правового воздействия на общественные отношения в рамках требований, установленных Конституцией РФ, что их стихийный характер, и одновременно, произвол властей.

${ }^{472}$ См. подробнее: Алексеев С.С. Восхождение к праву. Поиски и решения. - М., 2001. С. 295-296; Жинкин С.А. Некоторые проблемы реализации принципов правотворчества в современной России / С.А. Жинкин, Т.М.Чернявская // Общество и право. - 2016. - №2 (56). - C. 23. 
Для реализации каждого из принципов созидающего правотворчества необходимо:

1) обосновать их востребованность и возможность воплощения в нормах права в результате проведения научного исследования;

2) сформулировать в нормах права заложенные в них требования, направленные на активное добровольное исполнение издаваемого нормативного правового акта;

3) придать им официальный характер правового документа соответствующего уровня путём юридического закрепления в установленных законом процедурах;

4) обнародовать нормативный правовой акт, что в конечном счёте и даст возможность лицам, которым он адресован, руководствоваться его предписаниями ${ }^{473}$.

Изданный нормативно-правовой акт реализуется путём воплощения его предписаний в поведении людей, в деятельности юридических лиц и государственных органов. В отличие от ординарных нормативных актов, которые разрабатываются и принимаются без учета заинтересованности лиц, их исполняющих, созидающее правотворчество должно учитывать особенности реализации таких актов во всех его формах - при соблюдении, исполнении, использовании и применении. Это очень важный момент, поскольку субъект правотворчества должен учитывать не только заинтересованность субъекта, которому адресуется нормативный акт, но и форму, в которой он будет реализовывать заложенные в нём предписания.

Очевидно, что стимулировать реализацию нормативных предписаний проще всего в отношении лиц, которые осуществляют свои субъективные права и юридические обязанности в форме их соблюдения, исполнения и использования, что может быть обеспечено с помощью установленных самими нормативными актами гарантиями, закрепленных в них как дозволения, поощрения, позитивные обязывания. Например, запрет на рыбную ловлю в период нереста может быть компенсирован тем, что на этот период времени любителю рыбалки будет предоставлено право ловли рыбы в специально отведённых для этого закрытых водоёмах фермерского рыбохозяйства, при этом сделать сильную скидку на оплату подобного развлечения, установить бонусы за успешность ловли и т. п., поощряя его тем самым на правомерное поведение, выражающееся в соблюдении запрета.

Важной гарантией осуществления лицом субъективных прав и обязанностей является создание благоприятных условий, способствующих их полной и беспрепятственной реализации. Например, уплата налогов и других обязательных платежей в казну государства должна быть организована так, чтобы лицо без особых проблем могло исполнить свою конституционную обязанность, а не в результате длительного стояния в очередях и хождения по кабинетам чиновников.

${ }^{473}$ См. о значении обнародования правовых актов подробнее: Алексеев С.С. Механизм правового регулирования в социалистическом государстве. - М., 1966. - С. 93. 


\section{Правотворчество в Российской Федерации}

Сложнее стимулировать процесс применения юридических норм, так, как оно осуществляется при помощи компетентных государственных органов, наделённых властными полномочиями, с целью воплощения содержания правовых предписаний в жизнь и может распространяться на неограниченный круг лиц. Деятельность таких органов «специально направлена на обеспечение полного, точного и своевременного осуществления субъективных юридических прав и исполнения юридических обязанностей. Применение права - это не просто одна из форм его реализации, а такая особая форма, которая по отношению к другим выполняет обеспечительные функции, что служит одним из оснований, предопределяющих необходимость обособления применения права от других форм реализации» ${ }^{474}$.

Поэтому эффективность правового регулирования в таких случаях, регулирования, основанного на императивных предписаниях, зависит не только от качества нормативных актов, но и от профессионализма и добросовестности правоприменительных органов. Стимулировать процесс применения права, осуществляемый органом власти, возможно путём установления для конкретных исполнителей определенных законом льгот, наград, классных чинов, званий, надбавок к должностным окладам и т. п. С другой стороны, к данной категории госслужащих могут применяться и дисциплинарные взыскания, предусмотренные законом. Однако, наиболее качественный эффект в применении нормативных предписаний при их реализации могут дать наличие высокого профессионализма и дисциплинированности у госслужащих в сочетании с одновременным воздействием на них указанных выше моральных и материальных стимулов.

В целях перевода общественных отношений в русло саморегуляции необходимо в нормативно-правовых актах максимально сократить полномочия чиновников по осуществлению ими разрешительных, контролирующих и запретительных функций. Роль государства и его служащих должна в большей степени сводиться к выполнению организационных полномочий, связанных с устранением административных и материальных барьеров, борьбой с коррупцией, хищением государственной и муниципальной собственности, организацией профессионального обучения лиц, выполняющих управленческие функции, выработкой предложений по оптимизации государственного управления и т. д.

Всё это - разнообразные аспекты созидающего правотворчества. Субъекты правотворчества исполнительной власти должны быть под постоянным контролем представительных органов, прокуратуры и общественности, потому что издаваемые ими нормативные акты издаются не во исполнение законов, а взамен их, что выходит за пределы их компетенции, противоречит законодательству и подрывает авторитет правотворческих решений и государства в целом.

${ }^{474}$ Алексеев С.С. Механизм правового регулирования в социалистическом государстве. M., 1966. - C. 99. 
Таким образом, созидающее правотворчество - это установленная государством система издания нормативных правовых актов и созданного на их основе правового регулирования, основанная на принципах заинтересованности всех участников правоотношений в добровольной и качественной реализации принимаемых нормативно-правовых актов на всех уровнях государственного и муниципального управления, что создаёт условия для перевода общественных отношений на саморегуляцию.

Изложенное позволяет сделать следующие выводы.

1. Действующая в настоящее время система нормативных правовых актов недостаточно учитывает принципы заинтересованности участников правоотношений в их реализации, поскольку она ориентирована только на урегулирование общественных отношений, а активизацию, а также инициативу субъектов в их исполнении не предусматривает.

2. Государство должно свести к минимуму своё участие в правовом регулировании общественных отношений, особенно в сфере хозяйственных и межличностных отношений, и стимулировать их саморегуляцию на основании принципов активизации всех физических и юридических лиц, а также органов власти на реализацию издаваемых нормативноправовых актов на всех уровнях государственного и муниципального управления.

3. Принципы, стимулирующие реализацию нормативно-правовых актов, представляют собой объективно существующие личностные, групповые и общественные интересы, обусловленные их потребностями, не противоречащие законодательству, достижение которых связано с побуждением указанных лиц к активному исполнению нормативных предписаний. По своему происхождению они представляют собой вторичные, возникшие в ходе появления человека нового типа, и постановки в связи с этим новых задач правовой системе, стимулы, которые потенциально могут и должны способствовать добросовестному и добровольному правомерному поведению участников правоотношений. Это есть ответ на вопрос, поставленный нами в конце параграфа 2.1 о принципах правотворчества.

4. Созидающее правотворчество формируется в результате учёта заинтересованности лиц, которым адресуются нормативные правовые акты, издаваемые субъектом правотворчества.

5. Принципы правотворчества как науки и принципы созидающего правотворчества представляют собой в своей совокупности двухуровневую систему социально-правового регулирования отношений, иерархические отношения между ними в которой обусловлены: а) преемственностью принципов научного и созидающего правотворчества в историческом плане - ретроспективе; б) взаимодополняемостью потенциала методов их регулирования отношений в современном состоянии - синхронии и в) диалектической возможностью обновления правовой системы страны - в будущем (перспективе). 


\section{§3.4.2. СООТНОШЕНИЕ НОРМАТИВНОГО И ДУХОВНОГО В СОЗИДАЮЩЕЙ ПРАВОВОЙ НОРМЕ И ОСОБЕННОСТИ ЕЁ СТРУКТУРЫ}

Нормы традиций - это правила поведения, передаваемые из поколения в поколение в семье, местности, народе, которые поддерживают их самобытность и жизнеспособность, создают комфортные условия межличностного общения ${ }^{475}$.

Нормы обычаев - это устойчивые правила поведения людей, которые сохраняются в обществе длительное время и постоянно применяются в силу их эффективности, что обусловливают их практическое значение.

Нормы морали - правила поведения, сформированные и установленные самим обществом в понимании добра и зла, чести достоинства, справедливости, несправедливости и других духовных ценностей.

Достоинство указанных внеправовых социальных норм является их добровольное исполнение, что вошло в сознание и обыденную жизнь народа в силу многовекового опыта, свидетельствующего о выгоде и пользе взаимоотношений между людьми на основе идеалов духовности. Именно в этом состоит феномен заинтересованности, а отсюда и добровольность, присущей реализации данных норм.

Но их регулятивная способность всё же ограничена, поскольку они не гарантируют получение нужного государству результата. Да и лица, умышленно действующие вопреки установленным ими правилам, не могут понести иного наказания, кроме как общественного порицания, что зачастую недостаточно для их уразумения.

Анализ указанных социальных норм показывает, что только с их помощью можно создать условия для реализации требований института духовности невозможно по следующим причинам:

1) у разных народов они имеют свои особенности и не отражают, в каком объёме необходимую специфику регулирования общественных отношений;

2) эти регуляторы общественных отношений не имеют системного охвата всего многообразия духовных ценностей присущих различным народам и этносам нашей страны;

3) они не имеют универсального характера, что исключает их возможности воздействия на всех членов общества. Например, обычаи этнической, религиозной или профессиональной группы осознаются и поддерживаются не всеми членами общества, что исключает их полномасштабное влияние на регулируемые общественные отношения страны в целом;

4) крупным недостатком моральных норм является их конкуренция с нормами права, когда либо мораль разрешает, право запрещает, либо

${ }^{475}$ Теория государства и права. Курс лекций / под ред Н.И. Матузова, А.В. Малько. - М.: Юристь, 2001. - С. 322. 
право разрешает, мораль запрещает ${ }^{476}$. В первом случае лазейка для враждебных России сил создаётся чаще всего, так как, например, очернение подвига Красной Армии и Советского Народа в Великой Отечественной войне путем спекуляции на людских потерях и создания либеральными прозападными кругами мифов о « низком боевом духе красноармейцев», «толпе не умеющих воевать жестоких варваров» т. п. ${ }^{477}$ и внесение этого духовного яда в сознание подрастающего поколения нормами права не запрещено. Оно неприемлемо с точки зрения моральных норм, не обладающих такой нормативностью воздействия, как правовые нормы. Стоит отметить, что в ряде стран такие ключевые аспекты духовной жизни защищаются не только моральными, но и правовыми нормами. Например, в современной Украине оспаривание официальной концепции истории этой страны, выработанной М. Грушевским, в научных и публицистических изданиях может повлечь за собой гражданскоправовую, а в ряде случаев и административную ответственность;

5) внеправовые социальные нормы, регулирующие общественные отношения, рассчитаны только на их добровольную реализацию и поэтому с их помощью невозможно оказать существенного воздействия на лиц, умышленно посягающих на духовные ценности, нанося тем самым ущерб, например, межличностным или межнациональным отношениям либо посягающих на символы государственности или создающей угрозу терроризма.

Отсюда вытекает, что социальные нормы эффективны в основном при регулировании нижних пластов общественных отношений, когда полученный результат от их воздействия контролируется и направляется самим обществом, а возможный ущерб от неисполнения предписаний, указанных в них, не столь существенный, которым можно пренебречь.

В юридической литературе указывается, что отсутствие регулирования общественных отношений на нижнем (первичном) уровне нормами права на самом деле не естественная ситуация, а недостаток современной науки о правотворчестве.

Следовательно, для достижения высокого уровня социального регулирования на нижнем пласте общественных отношений, необходимо сочетать внеправовые социальные нормы и нормы права, построенные по канонам позитивистской юридической науки. Это обеспечит то самое единство нормативно-регулятивных систем и «даст возможность конструировать правильные социально одобренные эталоны поведения членов общества на основе широкого ценностного опыта» ${ }^{478}$.

Такой юридической наукой, формирующейся на основе юридического позитивизма, является теория правотворчества и её актуальное направление -

\footnotetext{
${ }^{476}$ Мальцев Г.В. Нравственное основание права: монография. - М.: Федеральная палата адвокатов РФ, 2016. - С. 226-243.

${ }^{477}$ См. подробнее об этом аспекте духовности: Литвиненко В.В. Людские потери на фронтах Великой Отечественной войны РККА и Вермахт. - М.: Вече, 2015. - С. 215 и др.

${ }^{478}$ Мальцев Г.В. Нравственное основание права: монография. - М.: Федеральная палата адвокатов РФ, 2016. - С. 29.
} 
созидающее правотворчество, цель которого - максимальная заинтересованность лиц, которым адресуются нормативные правовые акты, к их добровольному качественному исполнению. Это и позволит преодолеть грань несогласованности между внеправовыми и правовыми социальными нормами для более гармоничного и эффективного регулирования общественных отношений, что значительно повысит уровень духовности, а также будет возможно установить требуемый на сегодняшний день уровень духовно нравственной безопасности российского общества.

Вместе с тем нормативно-правовое регулирование в сфере духовного производства является совершенно необходимым. Без наличия мер государственного принуждения для поддержания установленных в обществе эталонов нравственности и духовности, невозможно их нормальное функционирование. И хотя, идеалы духовности опосредовано определяют всю правовую систему страны, отдельные их требования имеют прямое закрепление почти во всех отраслях права. Способом воздействия на поведение субъектов правоотношения в таких случаях являются запреты, дозволения и предписания к активному поведению ${ }^{479}$. Например, УК РФ запрещает такие аморальные поступки как кража, грабёж, разбой, исходя из требования «не укради». Их опасность для общества очень велика и поэтому указанные деяния предусматриваются в законе как преступления. Аналогичную оценку государства получают и многие другие идеалы духовности, посягательство на которые напрямую влекут уголовную ответственность - это: не убей (умышленное убийство), не предавай Родину (государственная измена), не помогай преступнику (соучастие в преступлении), не наживай добра на чужом горе (мошенничество, хищения, вымогательство) и т. д. Все эти меры уголовной ответственности направлены не только на защиту тех или иных благ личности, но в первую очередь они имеют задачу, поддержания духовнонравственных идеалов, создания благоприятных условий на дальнейшее их функционирование и процветание. Без этого невозможно существования ни общества, ни государства.

Охраняются идеалы духовности и нравственности нормами и многих других отраслей права, предусматривая за посягательство на них также административную, гражданско-правовую и дисциплинарную ответственность (к примеру, посягательство на честь и достоинство влечёт административную ответственность; посягательство на свободу договора влечёт гражданско-правовую ответственность, а контрабанду культурных ценностей, уничтожение или повреждение памятников истории и культуры - уголовную ответственность.

Все эти меры уголовной ответственности направлены не только на защиту тех или иных благ личности и общества, но в первую очередь они имеют задачу поддержания духовно-нравственных идеалов, создание благоприятных условий на дальнейшее их функционирование и

${ }^{479}$ Алексеев С.С. Механизм правового регулирования в социалистическом государстве. M., 1966. - C. 28. 
процветание. Без этого невозможно существования ни общества, ни государства.

Охраняются идеалы духовности и нравственности нормами и многих других отраслей права, предусматривая за посягательство на них также административную, гражданско-правовую и дисциплинарную ответственность (к примеру, посягательство на честь и достоинство влечёт административную ответственность; посягательство на свободу договора влечёт гражданско-правовую ответственность, а за контрабанду культурных ценностей, уничтожение или повреждение памятников истории и культуры - уголовную ответственность ${ }^{480}$.

Наличие правовой защиты духовности безусловно побуждает к исполнению ее идеалов и норм. Но, по нашему мнению, имеется потребность и возможность усилить законопослушание граждан за счет стимулирования их поведения, предусматривая его прямо в правовой норме. С этой целью следует установить ее структуру из четырех, а не из трех элементов. Помимо гипотезы, диспозиции и санкции норма права должна иметь и регулятор, изменяющий ее содержание. В случае, если лицо совершит одобряемое государством действие, это влечет смягчение возлагаемой на него ответственности, а если его действия повышают опасность, то наступает, наоборот, более строгая ответственность. В качестве термина предлагается слово модификатор (от фр. modificateur - изменение функции чего-либо).

Нормы права созидающего правотворчества должны максимально учитывать интересы тех лиц, которым адресуется правовой акт, и в модификаторе предусматривать преимущества, которые может получить лицо, если будет выполнять установленные в нем требования.

Модификатор должен располагаться после санкции правовой нормы, так как в нем могут предусматриваться изменения всех трех вышестоящих в ней элементов. Например, изменение условий исполнения договора (гипотеза) в сторону сокращения сроков доставки скоропортящихся товаров поощряется материальным вознаграждением; изменение, предусмотренных диспозицией уголовной нормы действий, в сторону снижения их общественной опасности, тоже поощряется снижением размера уголовного наказания; досрочная выплата штрафа, наложенного в судебном порядке (санкция), поощряется снижением размера этого штрафа и т. д.

В связи с этим требуют изучения и теоретического обоснования вопросы стимулирования лиц к законопослушному поведению. В первую очередь надо определить и классифицировать интересы, которые побуждают людей активно исполнять законы и другие нормативные акты, реализовывать их добровольно и качественно. Представляется, что к числу таковых относятся следующие их виды:

1) материальные,

2) моральные,

${ }^{480}$ См. подробнее: Зеленков М.Ю. Духовно-нравственная безопасность Российской Федерации: учебник для студентов вузов. - М., 2017. - С. 88-90. 


\section{Правотворчество в Российской Федерации}

3) повышающие социальный статус,

4) повышающие служебный статус,

5) соборность, т. е. стремление к участию в коллективной деятельности.

Материальные стимулы - это поощрение добровольного исполнения нормативных предписаний путем установления в норме права (в модификаторе правовой нормы) определенного денежного вознаграждения, материальных преимуществ или иной материальной выгоды для лица, которому норма предназначена. Это не означает, что каждое лицо в обязательном порядке воспользуется данной льготой, но однозначно исключает ее применение, если указанное лицо будет действовать в соответствии с ординарной нормой. То есть стимулируется изменение поведения лица в сторону выгодную и для государства, и для субъекта правоотношения путем установления гарантии, обеспечивающей достижение этим субъектом лучшего для себя результата, чем тот, который он мог бы получить, действуя в обычном порядке. Это является серьезной предпосылкой того, что лицо будет ориентировать свои действия с учетом предоставленной нормой права льготой.

К числу материальных стимулов относятся такие как установление денежных премий, надбавок к денежным окладам, выплата дополнительной платы с учетом количества и качества выполненной работы, предоставление дополнительных отпусков, получение права на бесплатное жилье (например, в служебной квартире), получение бесплатного питания, право на оплату проезда в железнодорожном транспорте к родителям и обратно во время отпуска и т. д.

Моральные стимулы направлены на удовлетворение потребностей людей в сфере духовного производства, в котором они участвуют как активные носители его ценностей. Установление в правовых нормах ориентиров, позволяющих субъекту правоприменения учитывать гарантии на получение определенных государственных наград, почетных званий или званий победителей в профессиональном мастерстве, лауреатов творческих конкурсов и т. д. побуждает лицо активно исполнять нормативные предписания, поскольку оно вполне может своим трудом достичь такого общественного признания.

Тем самым норма права воздействует на присущие человеку чувство гордости за выполненную работу, чувство удовлетворения от признания государством или коллективом, где он работает, его заслуг.

Социальный стимул - это внутренние побуждения лица улучшить свой статус в среде пребывания (по месту жительства, работы, учебы и т. д.). Мотивом для этого может служить желание изменить место работы с лучшими условиями труда и зарплаты, изменить профессию или повысить профессионализм, поступить в вуз или другое учебное заведение, получить более высокий разряд по специальности, создать семью, стать космонавтом или получить права на управление автомобилем и т. д.

Стимул к повышению своего социального статуса оказывает большое влияние на молодежь. Поэтому все нормативные правовые акты, адресованные молодежи, должны учитывать эти стимулы для побуждения молодых к активному их исполнению. Правовыми средствами можно 
успешно проводить молодежную политику, решая стратегические государственные задачи по формированию трудовых ресурсов в любой сфере деятельности и в любой местности.

Стимул повышения служебного статуса - это побуждение лица к успешному продвижению по службе, которое должно обеспечиваться за счет его личных положительных качеств (знаний, умений, трудолюбия, упорства в достижении цели, учета в работе передового опыта и т. д.). Мерами, стимулирующими продвижение по службе, могут быть перевод на вышестоящую должность, получение классного чина, присвоение очередного или внеочередного воинского или специального звания, предоставление права поступления на учебу в специальное учебное заведение и т. д.

Государственные служащие достаточно специфическая группа субъектов правоприменения и у них желание продвинуться по карьерной лестнице выражено четко и недвусмысленно. Поэтому нормативноправовой акт, адресованный госслужащим должен учитывать конкретную их категорию (военнослужащие, работники МВД, работники МЧС и т. д.), и особенности стимулирования к активному исполнению изданного акта с учетом специфики деятельности и службы каждого из них.

Соборность как стимул к совместной коллективной деятельности основывается на духовной солидарности лиц, имеющих общность взглядов по ключевым вопросам бытия, что формирует их внутреннюю мотивацию к взаимодействию ${ }^{481}$.

С целью максимального отражения в издаваемых нормативноправовых актах созидающего фактора субъекты правотворчества должны учитывать все указанные выше виды стимулирования поведения лиц, которым адресуются эти акты.

Таким образом, побудительная функция представляет собой раскрытие сущности и результатов функционирования механизма воздействия системы духовно-нравственной безопасности, на каждый из элементов нормативно-правовой системы, регулирующих общественные отношения. Именно под воздействием духовности, высокой нравственности нашего народа формируется потенциал издаваемых нормативноправовых актов.

Правовые нормы вырабатываются не как абстрактные, оторванные от жизни, издаваемые априори понятия, а отражают в себе присущую российскому многонациональному народу духовные потребности равенства, братства, свободы, дружбы и мира между всеми народами и нациями страны, справедливости, коллективного приложения усилий для отражения врагов отечества и достижения высоких результатов в труде, науке, искусстве и спорте. И в то же время духовно-нравственные ценности находятся под защитой всей правовой системы государства. Пося-

${ }^{481}$ Агутин А.В. Идеологический статус концепции прав и свобод человека и гражданина, и духовность российского народа в доктрине отечественного уголовного судопроизводства // Вестник экономической безопасности. - 2016. - №5. - С. 32. 


\section{Правотворчество в Российской Федерации}

гательство на их идеалы и выработанные веками нравственные предписания рассматриваются не только как аморальные проступки, осуждаемые обществом и наказуемые в административном порядке, но и как серьезные общественно опасные уголовно наказуемые деяния.

Нормативно-правовая и духовная составляющие - это неотделимые друг от друга стороны формирования единого социально-политического статуса государства и общества:

1) духовность определяет степень зрелости и жизненной силы народа, его устойчивость к различным внутренним и внешним отрицательным воздействиям;

2) нормативно-правовая сторона показывает степень защищенности народа и каждого в отдельности индивида от любого негативного воздействия.

Просчеты в формировании духовных ценностей народа и их защиты создают реальную угрозу не только деформации общества и государства, но и их распада.

\section{§3.4.3. МОДИФИКАТОР ПРАВОВОЙ НОРМЫ В СОЗИДАЮЩЕМ ПРАВОТВОРЧЕСТВЕ}

Действующая в настоящее время система нормативных правовых актов Российской Федерации даже при условии её идеального построения и всемерного стремления к этому законодателя не может быть высокоэффективной, поскольку она ориентирована на урегулирование общественных отношений в основном традиционными способами (императивным и диспозитивным), когда результат правового регулирования достигается за счёт государственного принуждения. Интересы субъектов, которым адресуются правовые нормы, как правило, не учитываются $^{482}$. Хотя «важно, чтобы задачи, во имя осуществления которых строится правовое регулирование, были задачами - интересами конкретных лиц, носителей субъективных прав и обязанностей. Когда задача выступает в качестве задачи - интереса, то это означает, что интерес в качестве мощного фактора как бы сопровождает деятельность по реализации задачи, поддерживая и стимулируя эту деятельность, создаёт энергию активности, которая всё время на протяжении всего пути до достижения результата будет получать своего рода подкрепление, выраженное в интересе, в заинтересованности субъектов деятельности» ${ }^{483}$.

Из этого следует, что социальная значимость правового регулирования зависит не только от выбора качества правового регулятора (нормы права), но и от избранного метода регулирования, от присущих ему свойств, которые обеспечивают достижение поставленной законодателем цели. Совершенно очевидно, что лицо, которому адресована норма права, в случае, её реализации под воздействием угрозы государственного принуждения не будет действовать столь эффективно, чем добро-

${ }^{482}$ См. подробнее: Румянцев М.Б. Созидающее правотворчество и его принципы.

${ }^{483}$ Алексеев С.С. Восхождение к праву. Поиски и решения. - М., 2002. - С. 292. 
вольное исполнение нормативного предписания в силу личной заинтересованности. Именно эти особенности должны учитываться субъектом, издающим нормативный правовой акт, с целью наделения его более мощным созидающим потенциалом.

Созидающее правотворчество - это установленная государством система издания нормативных правовых актов и созданное на их основе правовые регулирования общественных отношений, когда непосредственно в нормах права учитывается интересы тех лиц, которым они адресуются с целью побуждения к добровольному и качественному исполнению нормативных предписаний. Издание нормативных правовых актов с учётом требований созидающего правотворчества может обеспечить резкое повышение их реализуемости на всех уровнях государственного и муниципального управления. Одновременно тем самым создаются условия для перевода определённой части общественных отношений на саморегулирование, поскольку «возникает феномен самообязательности, когда добровольно принятое решение сопровождается признанием обязательств и возможных санкций» ${ }^{484}$.

Созидающее правотворчество может обеспечить повышение эффективности правового регулирования во всех сферах общественных отношений, но в первую очередь это касается частных отношений, где личная заинтересованность проявляется наиболее активно. Как справедливо отметил С.С. Алексеев частноправовые отношения «сводятся к такому юридическому порядку, в соответствии с которым отдельное, частное лицо вправе самостоятельно, автономно, по своей воле и по своему интересу, независимо от усмотрения государственной власти определять юридически значимые условия своего поведения, а учреждения государственной власти - как это ни парадоксально - обязаны признавать, конституировать и принудительной силой поддерживать их юридическую значимость и обеспечивать решение всех спорных вопросов независимым судом» ${ }^{485}$.

Таким образом, именно созидающему правотворчеству присущи, в первую очередь, свойства стимулирования субъектов правоприменения к активному, добровольному и качественному исполнения нормативных предписаний.

Но каким образом это необходимо осуществить, как в нормах права предусмотреть стимулы, побуждающие лиц, которым они адресованы, к их исполнению?

Представляется, что стимулировать активизацию граждан к исполнению правовых предписаний можно путём модернизации структуры правовой нормы. Помимо гипотезы, диспозиции и санкции норма права должна иметь и регулятор, изменяющий её содержание для быстрейшего достижения той цели, которую желает достичь субъект правотворчества.

\footnotetext{
484 Тихомиров Ю.А. Новые векторы правового регулирования - «другое» право? // Журнал российского права. - 2016. - №4. - С. 7.

${ }_{485}$ Алексеев С.С. Указ. соч. - С. 439-440.
} 


\section{Правотворчество в Российской Федерации}

Общее правило таково: если лицо совершает одобряемое государством действие (бездействие), то оно поощряется за это определённым образом, прямо указанным в норме права, если же не исполняет нормативных предписаний, тогда наступает ответственность на общих основаниях, которую предусматривает эта норма права.

Такой подход соответствует и доктрине и, в определённой степени, практике построения некоторых правовых норм действующего законодательства. Например, Ю.А. Тихомиров, характеризуя правовое государство, наряду с другими присущими ему признаками указал и такой, как «формирование правомерного поведения требует стимулирования и поощрения за активные правомерные действия» ${ }^{486}$. В статье 126 УК РФ (похищение человека) имеется примечание следующего содержания: «Лицо, добровольно освободившее похищенного, освобождается от уголовной ответственности, если в его действиях не содержится иного состава преступления». Аналогичное освобождение от уголовной ответственности предусматривается и в некоторых других статьях УК РФ (ст. 275 (государственная измена), ст. 276 (шпионаж), ст. 278 (насильственных захват власти или насильственное удержание власти), ст. 290 (дачи взятки) и т. д.). Эти примеры свидетельствуют о том, что юридическая наука признает необходимость нормативного поощрения лиц к активному исполнению установленных правом предписаний, а действующее уголовное законодательство в определённой части их реализует.

Остаётся сделать следующий закономерный шаг - распространить такой подход на все виды издаваемых нормативных правовых актов. Тем самым правое регулирование будет обеспечено не только за счёт нормативных предписаний, но и с помощью усиления активности субъектов правоприменения, которые должны иметь свой интерес к этому в каждом конкретном случае, где это только возможно. И в то же время это не означает, что в каждой норме должен в обязательном порядке предусматриваться тот или иной стимул к её активному исполнению. Как не всякая норма содержит в её нынешнем структурном построении все три элемента (гипотезу, диспозицию и санкцию), так и норма права, состоящая из четырёх элементов, не всегда будет содержать регулятор, устанавливающий стимулы и её исполнению.

В качестве термина, который должен содержать стимулирующий регулятор, предлагается слово модификатор (от фр. modificateur- изменение функции чего-либо).

Нормы права, построенные по принципам созидающего правотворчества, должны максимально учитывать интересы тех лиц, которым адресуется правовой акт, и в модификаторе предусматривать преимущество, возникающие у лица, если оно будет выполнять, установленные в нем требования.

Модификатор должен быть расположен в структуре нормы права после санкции правовой нормы, так как в нём могут предусматриваться

486 Тихомиров Ю.А. Правовое государство: модель и реальность // Журнал российского права. - 2011. - №12. - С. 7. 
изменения всех трёх вышестоящих в ней элементов как по отдельности, так и одновременно. Например, изменения условий исполнения договора (гипотеза) в сторону сокращения сроков доставки скоропортящихся товаров поощряется материальным вознаграждением; изменение предусмотренных диспозицией уголовной нормы действий в сторону снижения их общественной опасности, тоже поощряется снижением размера наказания; досрочная выплата штрафа, наложенного в судебном порядке (санкция) поощряется снижением размера штрафа и т. д.

Субъект правотворчества должен учитывать, какие меры поощрения необходимо использовать в качестве стимулов при выработке тех или иных нормативных правовых актов. Стимулы должны отражать определённые личные законные интересы, присущие той категории лиц (физических и юридических), которым адресуется правовая норма. Здесь должен иметь место избирательный подход к субъекту правоприменения, поскольку отступление от данного принципа будет снижать эффективность действия правовых норм. Поощрение лиц стимулами, которые для них не представляют личного интереса, являются бесполезными и в результате такой ошибки можно достичь обратного эффекта: норма права не будет востребована, а цель правового регулирования останется фактически не реализованной, хотя чисто номинально в соответствии с буквой закона она и прописывалась.

Следует также учитывать, что правовые нормы созидательного правотворчества оказывают своё воздействие одновременно на общественные отношения, упорядочивая их и на личностные потребности участников этих отношений, стимулируя к активной реализации издаваемых нормативных правовых актов.

Основными критериями при осуществлении выбора стимулов, используемых в качестве модификатора, являются следующие:

1) личная законная заинтересованность субъекта правоприменения в реализации нормы права. Сущность личной заинтересованности состоит в том, что её достижение осуществляется правомерным путём без нарушения требований закона и ущемления личных свобод других лиц. Так, Н.В. Витрук отмечает, что «законный интерес, как и юридическое право, есть возможность личности по пользованию различными социальными благами. Эта возможность выражается в правомочиях носителя законного интереса действовать определённым образом, требовать определённого поведения от обязанных лиц, органов, учреждений, обращаться за защитой к компетентным государственным органам и общественным организациям» ${ }^{487}$. Аналогичного мнения и 3.В. Романовская, которая пишет: «Зачисление интереса в группу охраняемых законом создаёт его носителю возможность действовать определённым образом, претендовать на определённое поведение другого лица, а в случае неудовлетво-

${ }^{487}$ Витрук Н.В. Система прав личности // Право личности в социалистическом обществе. M., 1981. - C. 109. 


\section{Правотворчество в Российской Федерации}

рения этого интереса обращаться за его защитой» ${ }^{48}$. Таким образом, в основе стимула, который использует законодатель для активизации субъекта правоприменения в реализации нормы права, должен быть интерес, который ему гарантирует закон и который он может осуществить даже с учётом обращения в государственные органы для его достижения;

2) закреплённость стимула, поощряющего к активному поведению субъекта правоприменения, в нормах права, Сам по себе личностный интерес может проявить себя лишь при наличии объективной возможности на его успешную реализацию. Именно такую выгоду и обеспечивает государство, предусматривая в нормах права определённые гарантии её фактического достижения. А.В. Малько справедливо отмечает, что законный интерес как и субъективное право, обладает некоторыми качествами правовой возможности, существующей объективно, предоставленной личности и в определённой мере гарантированной государством $^{489}$;

3) индивидуальная направленность стимулирования лиц, которым норма права непосредственно адресована, поскольку большинство нормативных правовых актов принимаются для правового регулирования деятельности некоторой социальной группы населения, а не носят абстрактный характер. При выборе того или иного стимула в таких случаях следует исходить из того, что структура законного интереса включает в себе два основных элемента:

1) стремление субъекта пользоваться конкретным социальным благом;

2) обращаться в некоторых случаях за защитой к компетентным органам государства.

Учитывая эти обстоятельства и, имея в виду, адресата правовой нормы, можно достаточно объективно предусмотреть в норме права тот модификатор, который способен оказать реальное воздействие на лицо, побуждая его к активной реализации нормативных предписаний.

4) Долговременность востребованности того стимула, который будет закреплён в модификаторе. Это важный критерий выбора того законного интереса, который должен быть закреплён в модификаторе правовой нормы, иначе правовая норма потеряет свою актуальность с исчезновением утратившего своё значение стимула.

В любом случае соответствующим государственным органом, издающим нормативные правовые акты, следует учитывать многообразие существующих законных интересов, с их непростой социальноюридической природой, с различными формами проявления в жизнедеятельности современного общества, с их постоянной изменяемостью и грамотно использовать имеющиеся в наличии правовые средства для эффективного воздействия на субъектов правоприменения в результате

\footnotetext{
${ }^{488}$ Романовская 3.В. Судебная защита охраняемого законом интереса // Вестник Львовского университета. - 1983. - Вып. 22. - С. 77 (цитировано по работе: Субочев В.В. Законные интересы / под ред. А.В. Малько. - М., 2012. - С. 83).

${ }^{489}$ Малько А.В. Законные интересы советских граждан: автореф. дис. ... к.ю.н. - Саратов, 1985. - C. 57.
} 
правильного выбора нужного в каждом конкретном случае модификатора. Так модификатором норм уголовного права по преступлениям против собственности, могут быть такие стимулы как желание избежать уголовного наказания полностью, либо избежать наказание в виде лишения свободы. С учётом этого в соответствующих нормах УК РФ необходимо предусмотреть указанные стимулы, но при условии, что лицо полностью возместит причинённый ущерб потерпевшему (в этом случае можно ставить вопрос об исключении реального наказания в виде лишения свободы и установлении уголовного наказания с испытательным сроком), либо возместит в какой-то части (это позволяет виновному рассчитывать на снижение реального срока уголовного наказания точно установленного УК РФ);

5) реализуемость выбранного для правовой нормы стимула, поскольку не всякий законный интерес может быть успешно осуществлён, дать тот результат, который подразумевал законодатель. Кроме того, законный интерес представляет собой прежде всего внутренний деятельный потенциал субъекта, активно использующего норму права, способствующий достижению определённого нужного ему результата. Это значит, что субъект, реализующий модификатор правовой нормы, понимает о возможном достижении нужного ему результата, если будет активно исполнять предписание закона. Однако хватит ли субъекту сил, настойчивости и других личных качеств для достижения той цели, которую он преследует, неизвестно. Если, например, модификатор будет устанавливать завышенные требования, которые среднестатистический субъект права не сможет их реализовать, то никакой повышенной активности в реализации нормы права, которая его предусматривает, не последует. Такая норма будет реализовываться как обычная (ординарная) норма права.

Таким образом, модификатор правовой нормы должен содержать тщательно отобранные стимулы, побуждающие субъекта права к активизации исполнения предписаний данной нормы, реально достижимую основной массой тех лиц, которым она адресуется.

Перевод правотворчества на правовое регулирование общественных отношений с обязательным отражением в нормах права стимулирующего фактора, поощряющего субъекта правоприменения к их исполнению, потребует более глубокого научного знания как об регулируемых общественных отношениях, так и об наиболее эффективных видах поощрения, которые могут быть в арсенале законодателя, и которые следует использовать при выработке нормативных правовых актов.

В связи с этим требуют изучения и теоретического обоснования вопросы стимулирования лиц к законопослушному поведению, а также к активному исполнению нормативных предписаний. Кроме того, необходимо разработать и юридическую технику реализации избираемых законодателем мер поощрения при выработке нормативных правовых актов. Это потребует формирования нового исследовательского направления в юридической науке, создание специализированных научных лаборато- 


\section{Правотворчество в Российской Федерации}

рий по изучению эффективности используемых в нормах права видов поощрения к активному исполнению предписаний закона.

Модификатор правовой нормы следует отличать от предписанийисключений и предписаний-примечаний, которые фактически носят технический характер, но тем не менее конкретизируют норму права.

В связи с этим Т.В. Кашанина пишет: «В принципе, исключения из правовых правил в определённых случаях являются необходимыми и полезными средствами формирования содержания права. Однако, когда они становятся чрезмерными, их существование не всегда воспринимаются всеми положительно... Исключения - это такой приём выражения содержания права, который позволяет изменить общее нормативное положение, не соблюдать закон, какое-либо правило, соглашение в особых или специальных целях или интересах» ${ }^{490}$.

Примеры предписаний-исключений можно найти практически в законодательстве всех отраслей права. Так, ст. 165 УК РФ (причинение имущественного ущерба путём обмана или злоупотребления доверием) указывает: «Причинением имущественного ущерба собственнику или иному владельцу имущества путём обмана или злоупотребления доверием при отсутствии признаков хищения, совершённое в крупном размере». Аналогично построена диспозиция ст. 166 УК РФ (неправомерное завладение автомобилем или иным транспортным средством без цели хищения), в которой сказано: «Неправомерное завладение автомобилем или иным транспортным средством без цели хищения». Содержание диспозиций у этих статей определяется таким образом, что состав преступлений данных деяний можно установить только в результате исключения признаков, присущих другим видам аналогичных посягательств на чужую собственность. Примеры можно продолжить. Так, ч. 2 ст. 31 УПК РФ (подсудность уголовных дел) указывает: «Районному суду подсудны уголовные дела о всех преступлениях, за исключением уголовных дел, указанных в ч. 1 (в части подсудности уголовных дел мировому судье) и ч. 3 настоящей статьи»; ст. 3.8 КоАП РФ ч. 4 предусматривает: «Лишение специального права в виде права охоты не может применяться к лицам, для которых охота является основным законным источником средства к существованию» и т. д.

Как отмечается в юридической литературе, назначение исключения уточнение общего правила, установленного законом или договором между частными лицами, когда общее правило не распространяет своё действие на какие-то обстоятельства или круг лиц.

Предписания-примечания конкретизируют отдельные, используемые в нормативных правовых актах, термины для их правильного понимания и применения в судебной практике и доктрине. Например, таких предписаний-примечаний достаточно много имеется в УК РФ:

1) ст. 158 (кража) содержит четыре:

a) раскрывает понятие хищения;

${ }^{490}$ Кашанина Т.В. Структура права. Монография. - М., 2017. - С. 119. 
б) даёт понятие значительного ущерба;

в) раскрывает, что следует понимать под помещением и хранилищем;

г) даёт понятие крупного и особо крупного размера хищения;

2) ст. 230-2 (использование в отношении спортсмена субстанций или методов запрещённых в спорте) в примечании предусматривает: «Действия настоящей статьи не распространяется на случаи, предусмотренные статьями 228-228.4 и 234 настоящего кодекса» и т. д.

Из этих примеров видно, что предписания-примечания выполняют информационную задачу и не оказывают особого влияния на содержание правовой нормы, хотя и способствуют прояснению её смысла

Кроме того, исключения и примечания не входят в структуру правовой нормы, но оказывают воздействия на результат, который может возникнуть в случае применения данной нормы. Они позволяют лишь правильно оценить основное правило, из которого исключаются или к которым прилагаются в качестве примечаний.

Этим они отличаются от модификатора, который должен включаться в структуру правовой нормы и непосредственно оказывать воздействие на поведение субъектов права, способствуя активизации исполнения правовых норм.

Как видно из некоторых примеров, показывающих о реальном существовании в отдельных случаях таких примечаний к статьям УК РФ, которые уже сейчас, по сути, исполняют роль модификаторов. Это свидетельствует об актуальности введения в структуру норм права помимо гипотезы, диспозиции и санкции также и специального регулятора. Одновременно это свидетельствует и о том, что законодатель постепенно шаг за шагом (поскольку количество примечаний к статьям УК РФ всё время увеличивается) подходит к тому рубежу, когда осознанно с целью активизации позитивного поведения лиц, совершающих преступления, возьмёт за общее правило и будет предусматривать в нормах данного кодекса стимулы к их исправительному поведению.

Следует также учитывать, что предписания-исключения и предписания-примечания выполняют техническую, информационную роль в правовой норме, тогда как модификатор должен входить в структуру и выполнять функцию регулятора общественных отношений, способствуя активизации исполнения субъектом права её предписаний.

Таким образом, на основании изложенного можно сделать следующие выводы:

1. Бурное развитие правовой базы Российской Федерации обуславливает необходимость активизации исполнения правовых предписаний путём нормативного стимулирования лиц, которым адресуются нормативные правовые акты, что будет способствовать повышению её эффективности, а также созданию условий для становления саморегулирования в отдельных сферах общественной жизни страны.

2. Одним из способов вовлечения субъектов правоотношений к активному исполнению нормативных предписаний является включение в структуру правовой нормы четвёртого её элемента - модификатора, - 
который должен содержать предписания, направленные на побуждение их к добровольному и качественному исполнению норм права.

3. Уже сейчас в действующем законодательстве встречаются многочисленные случаи, когда нормы права предусматривают стимулирование лиц к активному исполнению этих норм, что, по сути, и есть регулирование поведения людей с целью заинтересовать их к исполнению правовых предписаний. Остаётся только законодательно признать этот факт и отражать его в структуре правовой нормы в виде модификатора.

4. Юридическая наука также располагает необходимой теоретической базой, чтобы модификатор правовой нормы нашёл научное обоснование и в дальнейшем получил своё развитие путём исследования его эффективности с учётом результатов применения в законодательстве и судебной практике. 


\section{ГЛАВА 4. МЕХАНИЗМ ПРАВОТВОРЧЕСТВА §4.1. СТАДИИ ПРАВОТВОРЧЕСКОГО ПРОЦЕССА И ИХ РОЛЬ В БАЛАНСЕ ВЕТВЕЙ ВЛАСТИ}

В теории правотворчества выработка нормативных правовых актов понимается как длящийся и воспроизводимый процесс ${ }^{491}$, который охватывает не только значительный отрезок времени, но связан и с необходимостью осуществления определенных предусмотренных законом процедур.

Кроме того, отсутствие закона, который бы единообразно регулировал правотворческий процесс всех уровней, обуславливает ведущее значение Регламента Государственной Думы Федерального Собрания Российской Федерации ${ }^{492}$, который служит своеобразным образцом правотворческой деятельности в целом. Поскольку именно в этом правовом документе наиболее четко прописаны этапы выработки законодательных актов, научное познание процесса создания и принятия правовых нормативных актов рассматривается путем анализа заложенных в нем юридических предписаний. И на сегодняшний день это наиболее оптимальный подход.

Рассмотрим и мы в таком же аспекте сущность стадий правотворческой деятельности.

В юридической литературе нет общепризнанного определения понятия «стадия правотворчества» или «стадия правотворческого процесса». Понятие «стадия правотворчества» рассматривается как определенный этап создания нормативных правовых актов вообще как в рамках деятельности органа, который их издает, так и за пределами процедур этого органа, когда осуществляется предпроектное, предварительное его формирование. Следовательно, стадия правотворчества включает в себя два этапа создания норм права: 1) предпроектный и 2) проектный ${ }^{493}$.

Понятие «стадия правотворческого процесса» почти всегда рассматриваются как стадия законодательного процесса ${ }^{494}$. Так, В.И. Власов определяет правотворческий (законодательный) процесс как деятельность по созданию нормативно-правового акта, призванного урегулиро-

\footnotetext{
491 Тихомиров Ю.А. Выступление на круглом столе 26.01.2015 г. по теме: «Актуальные проблемы правотворчества и проект федерального закона «О нормативных правовых актах в Российской Федерации» // Журнал российского права. - 2015. - №3. - С. 146-147.

${ }^{492}$ Государственная Дума Федерального Собрания Российской Федерации. Постановление от 22 декабря 1998 года №2134-II ГД О регламенте Государственной Думы Федерального Собрания Российской Федерации с изменениями и дополнениями от 21 декабря 2017 года №3227-7 ГД // Собрание законодательства Российской Федерации. - 2017. - №52. Ст. 8105. 493 Теория государства и права / под ред. В.М. Корельского и В.Д. Перевалова. - М., 1998. C. 292.

${ }^{494}$ См., например: Власов В.И. Теория государства и права. - Ростов н/Д., 2002. - С. 265; Малько А.В. Теория государства и права. - М., 1999. - С. 147; Марченко М.Н. Проблемы теории государства и права. - М., 2013. - С. 666 и др.
} 


\section{Правотворчество в Российской Федерации}

вать наиболее значимых для существования государства и общества отношений 495 .

Конкретизируя понятие «законодательный процесс» М.Н. Марченко определяет его как «законодательная процедура», под которой понимает «установленный порядок прохождения проектов законов вплоть до их принятия и вступления в силу» ${ }^{496}$.

Вместе с тем, встречаются определения правотворческого процесса и в обобщенном виде, которое охватывает все его виды. Так, С.В. Филатов пишет: «Под стадией правотворческого процесса следует понимать организационно обособленный этап процедурных действий по формированию и закреплению воли государства, отдельный комплекс взаимосвязанных действий и процедур, направленный на создание нормативного правового акта» ${ }^{497}$. Однако автор, раскрывая содержание стадий правотворческого процесса, сводит их к стадиям законотворческой деятельности. То есть видит правотворческий процесс сквозь призму все того же Регламента Государственной Думы РФ.

Думается, что это правильный подход, поскольку «законодательная процедура состоит из целой серии юридически закрепленных правил, определяющих порядок подготовки и принятия законов» ${ }^{498}$.

В теории правотворчества выделяют четыре основные стадии законодательного процесса: 1) законодательная инициатива; 2) обсуждение законопроекта; 3) принятие и утверждение закона; 4) обнародование закона ${ }^{499}$. В юридической литературе называется и больше стадий законодательного процесса. Например, В.И. Власов полагает, что стадий законодательного процесса шесть ${ }^{500}$. Однако большинство исследователей законодательного процесса придерживается мнения, что выработка законодательных актов включает в себя четыре стадии. Такой же позиции будем придерживаться и мы.

Под законодательной инициативой понимается закрепленное в Конституции РФ право, указанных в ней субъектов, внести предложение об издании закона путем предоставления его проекта в законодательный орган. Право законодательной инициативы порождает у законодательного органа обязанность рассмотреть законопроект по существу, но принять его или отклонить решает законодательный орган. В соответствии с ч. 1 ст. 104 Конституции РФ право законодательной инициативы принадлежит Президенту РФ, Совету Федерации, членам Совета Федерации, депутатам Государственной Думы, Правительству РФ, законодательным (представительным) органам субъектов РФ, Конституционному

\footnotetext{
${ }^{495}$ Власов В.И. Указ. соч. - С. 265-266.

${ }^{496}$ Марченко М.Н. Указ. соч.

${ }^{497}$ Филатов С. В. Правотворческий процесс: понятие, стадии, принципы. // Государственная власть и местное самоуправление. - 2015. - №8. - С. 35.

${ }^{498}$ Марченко М.Н. Указ. соч. - С. 667.

${ }^{499}$ См., например: Комаров С.А. Общая теория государства и права. Курс лекций. - М., 1996; Лазарев В.В. Теория государства и права. Учебник / В.В. Лазарев, С.В. Липень. - М., 2000; Матузов Н.И. Теория государства и права. - М., 2005. - 192 с.; и др.

${ }^{500}$ Власов В.И. Указ. соч. - С. 266.
} 
и Верховному Суду РФ. В количественном выражении это составляет 705 субъектов законодательной инициативы ${ }^{501}$.

Предоставление права законодательной инициативы столь широкому кругу субъектов свидетельствует о демократичности конституционных предписаний. Но это одновременно порождает и серьезные трудности, связанные с невозможностью качественной реализации указанного права.

По мнению ученых сложившаяся ситуация приводит к мысли о необходимости сокращения количества субъектов права законодательной инициативы. Было бы целесообразно вместо индивидуального права законодательной инициативы для депутатов Государственной Думы ввести коллективное право ${ }^{502}$. Аналогичную позицию занимает Г.А. Мартьянов и некоторые другие ученые ${ }^{503}$.

Следует отметить, что в Российской Федерации граждане, в том числе и народ, не наделены правом законодательной инициативы, как это предусмотрено в конституциях некоторых западных стран. Например, ст. 71 Конституции Италии указывает, что «народ осуществляет законодательную инициативу путем внесения от имени не менее чем пятидесяти тысяч избирателей постатейно составленного законопроекта» ${ }^{504}$. Представляется, что это исключение народа из числа субъектов законодательной инициативы является серьезным недостатком Конституции РФ, так как государство должно чутко реагировать на острые социальные и экономические проблемы общества, учитывать складывающиеся тенденции его развития, выявлять потребности правового регулирования общественных отношений в первую очередь на основании непосредственного запроса, идущего от народа Российской Федерации, и прежде всего, от населения регионов. Актуальность данной проблемы повышается еще и в связи с тем, что правом законодательной инициативы не обладают и общественные организации, которые могли бы инициировать потребности народа в издании тех или иных законодательных актов.

В соответствии со ст. 105 Регламента Государственной Думы РФ при внесении законопроекта в законотворческий орган субъектом права законодательной инициативы должен быть предоставлен ряд документов, усложняющих законодательный процесс ${ }^{505}$.

\footnotetext{
${ }^{501}$ Борисов А.С. Некоторые проблемы современного правотворчества в России / А.С. Борисов, П.А. Меркулов // Социум и власть. - 2015. - №3 (53). - С. 68.

${ }_{502}$ Борисов А.С., Меркулов П.А. Указ. соч. - С. 68.

${ }^{503}$ Мартьянов Г.А. Теория и методика оптимизации участия законодательных (представительных) органов государственной власти субъектов Российской Федерации в федеральном законотворческом процессе. Автореферат дис. ... к.ю.н. - СПб., 2010. - С. 14; Краснова О.И. Участие органов государственной власти субъектов Российской Федерации в федеральном законодательном процессе: вопросы теории и практики / О.И. Краснова, Е.А. Пименов // Современное право. - 2010. - №8. - С. 15 и др.

${ }^{504}$ Италия. Конституция и законодательные акты. - М., 1988. - С. 41.

${ }^{505}$ Государственная Дума Федерального Собрания Российской Федерации. Постановление от 22 декабря 1998 года №2134-II ГД О регламенте Государственной Думы Федерального Собрания Российской Федерации с изменениями и дополнениями от 21 декабря 2017 года №3227-7 ГД // Собрание законодательства Российской Федерации. - 2017. - №52. Ст. 8105.
} 


\section{Правотворчество в Российской Федерации}

Усложнение порядка использования права законодательной инициативы направлено на повышение качества законопроектов, исключение из плана правотворческой деятельности тех, которые не имеют существенного значения для правового регулирования общественных отношений (например, таких законопроектов, которые реально имели место в деятельности Государственной Думы, как запрещение курения за рулем автомобиля, запрещение тонизирующих напитков, объявление выходным днем День космонавтики ${ }^{506}$ и т. д.).

Следующая стадия законодательного процесса - обсуждение внесенного в порядке законодательной инициативы законопроекта. Первоначально законопроект и материалы к нему поступает в профильный комитет, который определяет его соответствие указанным выше требованиям ст. 104 Регламента ГД РФ.

На этой стадии осуществляется неофициальное и официальное обсуждение законопроекта.

Как справедливо отметил М.Н. Марченко неофициальное обсуждение проектов законов имеет большое значение не только для повышения качества конкретного закона, но и всего законодательства, поскольку на данном этапе законопроект проходит всестороннюю юридическую, экономическую, социально-политическую и иную экспертизу ${ }^{507}$. В ходе такого обсуждения вскрываются недостатки и других законодательных актов, которые в дальнейшем совершенствуются путем внесения в них соответствующих изменений и дополнений.

Официальное обсуждение сводится к проведению научной экспертизы законопроекта, получения отзывов, предложений и замечаний от государственных органов власти, других государственных структур и общественных организаций.

Правовая экспертиза законопроекта проводится на его соответствие Конституции РФ, федеральным конституционным и федеральным законам, основанным отраслевым законодательным актам ${ }^{508}$.

Отзывы, предложения и замечания депутатов ГД РФ и других субъектов права законодательной инициативы по законопроекту, а также заключение Общественной палаты по результатам экспертизы законопроекта рассматриваются на заседании ответственного комитета.

Обсуждение законопроекта в комитетах ГД РФ проходит открыто с приглашением представителя субъекта права законодательной инициативы, внесшего законопроект. Данная стадия необходима для того, чтобы довести законопроект до нужного качества: устранить противоречия, пробелы, неточности и прочие дефекты.

\footnotetext{
${ }^{506}$ Синюков С.В. Механизм правотворчества. Автореферат дис. ... к.ю.н. - Саратов, 2013. C. 13

${ }^{507}$ Марченко М.Н. Указ. соч. - С. 671.

${ }^{508}$ Нормография: теория и технология нормотворчества: учебник для бакалавриата и магистратуры / под ред. Ю.Г. Арзамасова. - М.: Юрайт, 2017. 460 с.
} 
В соответствии с Регламентом Государственная Дума представленные ей законопроекты может рассматривать в трех чтениях. Каждое из чтений имеет свою конкретную цель.

В первом чтении обсуждается концепция законопроекта, дается оценка соответствия основных положений законопроекта Конституции РФ, его актуальности и практической значимости. По результатам обсуждения законопроекта в первом чтении Государственная Дума может принять или одобрить законопроект в первом чтении и продолжить работу над ним с учетом предложений и замечаний в виде поправок либо отклонить законопроект. В случае принятия законопроекта в первом чтении председательствующий может поставить на голосование предложение ответственного комитета о принятии закона, исключая процедуры второго и третьего чтения (при наличии заключения Правового управления Аппарата Государственной Думы, отражающего результаты правовой, юридико-технической и лингвистической экспертиз) $)^{509}$.

Государственная Дума может также принять решение о всенародном обсуждении законопроекта, принятого в первом чтении. Поправки к законопроекту, принятому или одобренному в первом чтении, вносятся в ответственный комитет в виде изменения редакции статей, либо в виде предложений. Ответственный комитет осуществляет их постатейную группировку в трех таблицах.

После этого Государственная Дума переходит ко второму чтению в процессе, которого идет детальное, постатейное обсуждение законопроекта с учетом поступивших предложений и дополнений. Если, по мнению ответственного комитета, подготовка законопроекта к рассмотрению Государственной Думой во втором чтении нецелесообразна либо законопроект утратил свою актуальность, данный комитет вносит мотивированное предложение об отклонении данного законопроекта. Таким образом, во втором чтении происходит основная деятельность законодателей по окончательной доработке внесенного на их рассмотрение законопроекта.

При рассмотрении законопроекта в третьем чтении не допускается внесение в него поправок и возвращение к обсуждению его текста в целом, а также к обсуждению его отдельных разделов, глав и статей. Решение о принятии федерального закона оформляется соответствующим постановлением Государственной Думы РФ, суть которого сводится к тому, что Государственная Дума одобряет поступивший ей на рассмотрение законопроект.

Следующая стадия законотворческого процесса - принятие и утверждение закона. Эта стадия фактически состоит из трех последовательных действий различных органов государственной власти:

1) принятие закона Государственной Думой;

\footnotetext{
509 Государственная Дума Федерального Собрания Российской Федерации. Постановление от 22 декабря 1998 года №2134-II ГД О регламенте Государственной Думы Федерального Собрания Российской Федерации с изменениями и дополнениями от 21 декабря 2017 года №3227-7 ГД // Собрание законодательства Российской Федерации. - 2017. - №52. Ст. 8105.
} 
2) одобрение закона Советом Федерации;

3) подписание закона Президентом РФ. Рассмотрим более подробно эти промежуточные стадии.

Простые федеральные законы принимаются большинством голосов от общего числа депутатов Государственной Думы, а федеральные конституционные законы считаются принятыми, если их одобрило не менее двух третей голосов от общего числа депутатов Государственной Думы. Принятые законы в течение пяти дней передаются в Совет Федерации для обсуждения ${ }^{510}$.

Одобрение принятого закона Советом Федерации также осуществляется с учетом его вида.

Вместе с тем, существуют и проблемы связанные с порядком учета отзывов субъектов федерации (их законодательных и высших исполнительных органов власти) при разработке проектов законов по вопросам совместного ведения Российской Федерации и ее субъектов. ${ }^{511}$

Страдает недостатком и федеральный закон от 6 октября 1999 г. №184-Ф3 «Об общих принципах организации законодательных (представительных) и исполнительных органов государственной власти субъектов Российской Федерации ${ }^{512}$, в котором имеется норма о создании согласительной комиссии для урегулирования возникших проблем по вопросам совместного ведения (п. 3 ст. 26.4 закона №184-Ф3). Эта норма не содержит процедурных гарантий ее реализации. Более того, если все же согласительная комиссия будет создана, то остается нерешенным вопрос о том, как следует поступить в случае недостижения ею взаимоприемлемого варианта решения проблемного вопроса ${ }^{513}$.

Принятый Государственной Думой Федеральный Закон и одобренный Советом Федерации направляется Президенту РФ на подписание. В соответствии с ч. 2 ст. 107 и ч. 2 ст. 108 Конституции РФ Президент РФ в течение 14 дней подписывает закон и передает для его опубликования (в срок не более 7 дней).

Если Президент РФ отклонил поступивший ему на подпись Федеральный Закон, то Государственная Дума и Совет Федерации в установленном Конституцией РФ порядке вновь рассматривает данный закон. Если при повторном рассмотрении Федеральный Закон будет одобрен в

\footnotetext{
${ }^{510}$ Государственная Дума Федерального Собрания Российской Федерации. Постановление от 22 декабря 1998 года №2134-ІІ ГД О регламенте Государственной Думы Федерального Собрания Российской Федерации с изменениями и дополнениями от 21 декабря 2017 года № 3227-7 ГД // Собрание законодательства Российской Федерации. - 2017. - №52. Ст. 8105 .

511 Курманов М.М. Законодательные (представительные) органы государственной власти республики в системе органов государства (компетенция, взаимодействие, ответственность). Автореферат дис. ... к.ю.н. - Казань, 2003. - С. 17.

512 [Электронный ресурс]. - Режим доступа: http://www.consultant.ru/document/cons doc_LAW_14058/

${ }^{513}$ Краснова О.И. Участие органов государственной власти субъектов Российской Федерации в федеральном законодательном процессе: вопросы теории и практики / О.И. Краснова, Е.А. Пименов // Современное право. - 2010. - №8. - С. 19.
} 
ранее принятой редакции большинством не менее двух третей голосов от общего числа членов Совета Федерации и депутатов Государственной Думы, он подлежит подписанию Президентом РФ в течение семи дней и обнародованию.

В юридической литературе отмечается, что утверждение (подписание) принятого закона главой государства является актом поддержания баланса правовой стабильности между законодательной и исполнительной ветвями власти. Средством сохранения баланса, сдерживания законодательной ветви власти исполнительной ветвью - вето главы государства, налагаемое им на принимаемые законодательным органом акты. Суть его заключается в отказе главы государства ставить свою подпись под нормативными актами, без чего они не могут получить юридической силы $^{514}$.

Однако имеется и противоположное мнение: «в конституционном тексте отсутствуют нормативные положения, которые бы создавали препятствия для противостояния власти Президента, ее обузданию, сдерживали тенденции к всевластью. Юридически президент РФ, согласно Конституции РФ, выведен из системы разделения властей, объявляется лишь гарантом Конституции. Отсюда безответственность и бесконтрольность со стороны других органов власти. В современной демократической конституции согласно стратегии правотворчества, должен быть введен разрешительный порядок деятельности Президента, при котором нормативно устанавливается жёсткий запрет совершения властных принудительных действий без прямого указания закона» ${ }^{515}$.

Обе эти точки зрения имеют право на существование. Но главная задача современной России состоит не в том, чтобы установить равновесие между законодательной и исполнительной ветвями власти, а в достижении консенсуса, согласия этих ветвей власти при решении социальнополитических и экономических проблем государства, и прежде всего регионов.

Сам принцип разделения властей отстаивали ещё французские просветители XVIII века: Ж.-Ж. Руссо, Ф. Вольтер, Д. Дидро, но окончательно его сформулировал Шарль-Луи Монтескьё в работе «О духе законов», где читаем: «В каждом государстве есть три рода власти: власть законодательная, власть исполнительная, ведающая вопросами международного права, и власть исполнительная, ведающая вопросами права гражданского. ... Последнюю власть можно назвать судебной, а вторую - просто исполнительной властью государства... Не будет свободы... если судебная власть не отделена от власти законодательной и исполнительной $\rangle^{516}$.

\footnotetext{
${ }^{514}$ Марченко М.Н. Проблемы теории государства и права. - М., 2013. - С. 673.

515 Сапун В.А. Правотворчество и законодательство: стратегия и тактика формирования права и закона / В.А. Сапун, Я.В. Турбова // Юридическая техника. - 2015. - №8. - С. 680.

${ }^{516}$ Монтескьё Шарль Луи де . О духе законов // О государственном устройстве Англии // Электронная библиотека Гражданское Общество в России [Электронный ресурс]. - Режим доступа: http://www.civisbook.ru/files/File/Monteskye.O dukhe.pdf
} 


\section{Правотворчество в Российской Федерации}

В настоящее время принцип XVIII века уже не работает в достаточную силу - из-за недостатков правотворчества. Только правотворчество как новая юридическая наука способно поднять через рассмотрение стадий правотворческого процесса на качественно новый уровень идею Просветителей, неукоснительно использовавшуюся в государственном строительстве на протяжении веков. Разделение властей как принцип было хорошо для прошлых эпох, но для сегодняшних реалий необходим качественно новый подход, который способна дать новая юридическая наука - правотворчество.

Поэтому теоретики конституционного права должны построить новую модель конституции демократического государства, в которой реализуется не принцип разделения властей, предполагающий противостояние между ними, а принцип консолидации всех ветвей власти для эффективного управления государством, основанного на поддержании единства воли всех ветвей власти в достижении стоящих перед государством задач.

Независимость ветвей власти (их разделение) не должна являться преградой, тормозом в объединении присущих им полномочий на достижение единого общегосударственного результата. Наоборот, независимость той или иной ветви власти - это узаконенная для данной ветви власти свобода деятельности по реализации единых для государства задач своими средствами и своими силами, которая одновременно дополняет и стимулирует другие ветви власти на совместное плодотворное (а не деструктивное) сотрудничество.

Принцип консолидации всех ветвей власти состоит в том, что:

1) учреждаются не три, а четыре ветви власти: законодательная, исполнительная, судебная и народного контроля;

2) каждая ветвь власти осуществляет свои полномочия на основе обязательного учета особенностей деятельности других ветвей власти, дополняя и развивая их в своих правотворческих и иных решениях;

3) при возникновении непреодолимых конфликтов интересов между ветвями власти продолжительностью более 6 месяцев осуществляется обязательная отставка всех участвующих в нем субъектов (коллегиальных и единоличных) как неспособных находить компромисс. На их место избирается (назначается) новый состав соответствующих политических деятелей;

4) общественный контроль состоит в создании народных палат, действующих вне государственного управления, на безвозмездной основе, консолидирующих все политические силы страны на каждом уровне государственной власти и муниципального управления.

Полномочия народных палат: рассмотрение жалоб и предпочтений граждан на нарушения законности со стороны чиновников и других представителей власти независимо от их служебного положения. Народная плата не имеет властных полномочий. Результатом деятельности народной палаты может быть:

1) предупреждение должностного лица о недопустимости нарушения законов и одновременное сообщение его руководителю об имевшем факте нарушения законности; 
2) предложение соответствующему государственному органу об увольнении виновного лица с должности, которое подлежит обязательному исполнению в установленный законом срок;

3) передача материалов рассмотрения жалобы гражданина в органы правосудия при наличии в действиях виновного должностного лица состава преступления.

Таким образом, принцип консолидации ветвей власти в процессе государственного управления будет постоянно стимулировать их к совершенствованию своей деятельности, устранению конфликтов интересов не путем образования большинства в парламенте и игнорирования правомерных интересов меньшинства, а путем выработки приемлемого решения для всех заинтересованных сторон (поскольку в конфликте интересом может быть не два, а несколько субъектов). Особенно эффективным может быть общественный контроль со стороны народных палат, в ходе которого будет осуществляться индивидуальная выбраковка недостойных государственных служащих, занимающих свои должности случайно или из личных низменных побуждений.

Заключительную стадию законодательного процесса представляет обнародование принятого закона. В юридической литературе отмечается, что назначение этой стадии состоит в доведении до сведения населения информации о содержании принятого закона. При этом обнародование может быть официальным и неофициальным ${ }^{517}$.

Официальное обнародование представляет собой опубликование текста принятого закона и подписанного Президентом РФ в специализированных органах печати, предназначенных для уведомления всего населения страны об издании законодательного акта. Обнародование осуществляется от имени государственного органа или самим органом, издавшим или подписавшим данный акт ${ }^{518}$.

В соответствии с ч. 2 ст. 107 Конституции РФ президент в течение четырнадцати дней подписывает федеральный закон и обнародует его. Официальными изданиями, где публикуются принятые законы, являются Собрание законодательства Российской Федерации и «Российская газета».

Наряду с официальным существует и неофициальное обнародование принятых законодательных и иных нормативных правовых актов, которое осуществляется в виде сообщения об их издании в различных печатных изданиях, не имеющих официального статуса на уведомление об издаваемых законодательных актах. Значение неофициального обнаро-

\footnotetext{
${ }^{517}$ Марченко М.Н. Проблемы теории государства и права. - М., 2013. - С. 673.

518 Федеральный закон от 14.06.1994 «О порядке опубликования и вступления в силу федеральных конституционных законов, федеральных законов, актов палат Федерального собрания»; Указ Президента Российской Федерации от 23.05.1996 г. «О порядке опубликования и вступления в силу актов Президента Российской федерации, Правительства Российской Федерации и нормативных правовых актов федеральных органов исполнительной власти» // Собрание законодательства Российской Федерации. - 1994. - №8. - Ст. 801; 1996. - №22. - Ст. 2262. - 1997. - №20. - Ст. 2242; - 1998. - №33.
} 


\section{Правотворчество в Российской Федерации}

дования законодательства состоит в том, что таким путем происходит дополнительная информация населения об издаваемых нормативных правовых актах, либо об их дополнении или изменении.

Таким образом, на стадии обнародования изданного законодательного акта обеспечивается необходимая связь между правотворческим органом и определенным кругом лиц, которым адресуется данное правотворческое решение. И хотя «адресат получит сообщение не непосредственно от адресанта, а через средства массовой информации, обязательному опубликованию в которых подлежат правовые акты» ${ }^{519}$, происходит требуемое Конституцией РФ ознакомление граждан с вновь изданным законодательным актом, что позволяет ему функционировать.

Основные выводы, вытекающие из проведённого исследования стадий законотворческого процесса.

1. Стадии законотворческого процесса - это предусмотренные законом этапы правотворческой деятельности уполномоченных субъектов по созданию нормативных правовых актов высшей юридической силы, в ходе которых возможно достижение их высокого качества путем осуществления установленных процедур с момента внесения законопроекта в порядке реализации права законодательной инициативы в законодательный орган и до вступления принятого закона в юридическую силу.

2. Для повышения качества издаваемых законодательных актов, снижения количества вносимых в Государственную Думу законопроектов до уровня реальной возможности их рассмотрения нижней палатой российского парламента в установленный срок, необходимо уменьшить количество субъектов, обладающих правом законодательной инициативы, предусмотрев в Конституции РФ право коллективной законодательной инициативы, а для субъектов федерации - право консолидированной законодательной инициативы.

3. Установленный в Конституции РФ принцип разделения властей имеет тот недостаток, что в соответствии с ним закрепляется и порядок принятия законодательных актов большинством голосов. При этом меньшинство депутатов, какие бы ценные предложения от них не поступали, не могут добиться их реализации в законодательных актах. Поэтому необходимо заменить принцип разделения властей на принцип консолидации всех ветвей власти при разработке и принятии законодательных актов.

4. Принцип консолидации всех ветвей власти состоит в том, что издаваемые законодательные акты вырабатываются на основе компромисса и взаимного уважения сторон с противоположными интересами при наличии общей цели - принятие решений во благо Российской Федерации и ее народа, прежде всего, населения регионов РФ.

5. Консолидировать деятельность трех существующих ветвей власти

возможно также за счет учреждения еще одной - общественного контроля в форме народных палат, действующих на безвозмездной основе,

519 Любимов Н.А. Правотворчество в Российской федерации: проблемы теории и практики: конспект лекций. - М.: Изд-во Московского ун-та, 2009. - С. 118. 
вне государственного управления, без вмешательства в деятельность государственных служащих, решения которых носят рекомендательный характер. Народные палаты объединяют в себе политические партии и общественные движения, а также всех граждан, заинтересованных в поддержании законности и правопорядка в стране.

\section{§4.2. ПЛАНИРОВАНИЕ И ПРОГНОЗИРОВАНИЕ В ХОДЕ ПРАВОТВОРЧЕСКОЙ ДЕЯТЕЛЬНОСТИ}

В современных условиях правотворческая деятельность должна носить целенаправленный характер, подчиняться объективным требованиям издания нормативных правовых актов в определенной логической последовательности, поскольку между ними существует внутренняя связь, обуславливающая их взаимозависимость. Учитывая это обстоятельство, возникает важное требование к правотворческой деятельности - осуществлять ее в рамках тщательно сформированных планов. В связи с этим Е.С. Строев, будучи председателем Совета Федерации Федерального Собрания РФ ставил задачу увеличения количества системных нормативных правовых актов, четко связанных друг с другом единым стратегическим замыслом, поскольку «если не будет согласованного законодательного плана, то мы все время будем блуждать в хаосе мутного потока случайных законов» ${ }^{520}$. Аналогичную позицию по данному вопросу занимает и К.И. Косачев, который предложил внести поправки в регламент Государственной Думы, чтобы «она могла работать на основе стратегического планирования рассмотрения и принятия системных законов, необходимых обществу» ${ }^{521}$.

В юридической науке эта проблема имеет следующее обоснование: «Планирование законоподготовительной деятельности в значительной степени способствует преодолению таких изъянов в нынешней практике законодательства, как нестабильность правового регулирования, излишняя поспешность в подготовке и принятии законов, несогласованность некоторых концептуальных положений взаимосвязанных законов, чрезмерная зависимость выбора темы закона от текущего момента, что зачастую ведет к противоречиям и пробелам в правовом регулировании, снижает качество законодательства» ${ }^{522}$.

Кроме того, перевод законодательства на плановую основу является серьезной предпосылкой создания «стабильной, целостной, научно-

\footnotetext{
${ }^{520}$ Строев Е.С. Прошла пора выживания, наступила пора созидания // Парламентская газета. -24.07 .2001 .

${ }^{521}$ Косачев К.И. Как избавиться от законов-пустышек // Российская газета. 09.07.2002.

522 Мазуренко А.П. К вопросу о методах правотворческой политики [Электронный ресурс]. - Режим доступа: https://cyberleninka.ru/article/v/k-voprosu-o-metodah-pravotvorcheskoy-politiki (дата обращения: 10.09.2018).
} 


\section{Правотворчество в Российской Федерации}

обоснованной системы законодательства, эффективного механизма координации законотворческой деятельности» ${ }^{523}$.

Таким образом, плановость законотворческой деятельности, с одной стороны, создает условия для устранения многих недостатков действующего законодательства, а с другой, - является основой формирования научно обоснованной законодательной базы России. Кроме того, планирование законотворчества обуславливает и многие другие факторы повышения качества правовой системы в целом: дает четкую картину подлежащих изданию подзаконных нормативных правовых актов всех уровней в будущем; позволяет определить последовательность издания законов; а также установить приоритеты правового регулирования общественных отношений; позволяет заранее выявить наметившийся пробел в законодательстве; помогает издавать законы, рассчитанные на длительную перспективу их применения; формировать законодательные блоки по отраслям права, что повышает их системообразующие свойства; заранее предвидеть возможные последствия от действия принимаемых законов и на основании этого прогнозировать тенденции развития законодательства; способствует упорядочению самого процесса законотворчества и т. д.

В настоящее время в соответствии с регламентом заседания Государственной Думы РФ проводятся на основании примерной программы законопроектной работы на текущую сессию, календаря рассмотрения вопросов Государственной Думой на текущий месяц и порядком работы очередного (дополнительного) заседания.

Примерная программа законопроектной работы Государственной Думы на текущую сессию формируется Советом Государственной Думы по предложениям ее фракций и комитетов. Она включает в себя примерную программу законопроектов, подлежащих первоочередному рассмотрению и программу законопроектной работы комитетов Государственной Думы. В течение сессии комитеты Государственной Думы вносят в Совет Государственной Думы предложения о включении в примерную программу законопроектной работы Государственной Думы законопроектов следующих видов:

1) законопроекты, внесенные в Государственную Думу президентом;

2) проект федерального закона о федеральном бюджете на очередной финансовый год и плановый период;

3) законопроекты, внесенные правительством РФ в случае необходимости оперативного законодательного регулирования в социальноэкономической сфере;

4) проекты федеральных законов о ратификации международных договоров РФ;

5) законопроекты, необходимость принятия которых вытекает из конституционных законов, обычных законов и решений Конституционного Суда РФ;

${ }^{523}$ Нормография: теория и методология правотворчества: учеб.-метод. пособ. / под ред. Ю.Г. Арзамасова. - М., 2007. - С. 169. 
6) законопроекты, внесенные в Государственную Думу во исполнение ежегодных посланий Федеральному Собранию РФ и поручений президента РФ;

7) законопроекты, внесенные в Государственную Думу во исполнение поручений Председателя Государственной Думы;

8) иные законопроекты по решению Совета Государственной Думы.

Из этого видно, что планирование законопроектной деятельности Государственной Думы РФ в значительной степени предопределяется текущими потребностями издания первоочередных законопроектов. Законотворческая деятельность все еще не имеет стратегической направленности, рассчитанной на длительную перспективу. Как отмечается в юридической литературе «наиболее существенным недостатком организационно-процессуальной стороны правотворчества является отсутствие научно обоснованной концепции развития законодательства и его взаимосвязи с экономическими, политическими и социальными реформами> ${ }^{524}$, хотя планирование законопроектной работы было введено регламентом Государственной Думы еще в 1994 году. В настоящее время планы законопроектных работ Государственной Думы составляются на каждую сессию.

В теоретическом и практическом аспекте планы законотворческой деятельности должны разрабатываться на основе анализа действующего законодательства, оценки его регулирующего воздействия на сложившиеся общественные отношения с учетом отражения в нем насущных экономических, социальных и политических потребностей общества и государства, а также с учетом научных прогнозов развития государственноправовых институтов.

Планирование правотворческой деятельности представляет собой юридическую категорию отражающую методику выработки нормативных правовых актов. Так, А.В. Старовойтов, исследуя планирование законоподготовительной и законодательной деятельности дает развернутое его определение как «специфический вид управленческой деятельности, связанной с выбором приоритетов функционирования и развития объекта управления, обладающих достаточным ресурсным обеспечением; разработкой мероприятий, обеспечивающих достижение результатов, соответствующих поставленным целям, а также последовательности, сроков реализации этих мероприятий и ответственных исполнителей» ${ }^{525}$.

Более краткое определение планирования как юридической категории дает Е.А. Никчемная. По мысли данного автора, «планирование как юридическая категория представляет собой управленческую деятельность специализированных субъектов по разработке системы целей развития того или иного объекта на определенный период времени и

524 Мазуренко А.П. К вопросу о методах правотворческой политики // ЮристъПравоведъ. - 2007. -№5. - С. 22-26.

${ }^{525}$ Старовойтов А.В. Планирование законоподготовительной и законодательной деятельности. Автореф. дис. ... к.ю.н. - М., 2002. - С. 11. 


\section{Правотворчество в Российской Федерации}

средств их реализации, проходящую в правовых формах и осуществляемую правовыми средствами» ${ }^{526}$.

Как видно из данных определений планирование понимается как специфический вид деятельности, уполномоченных на то субъектов правотворчества. Представляется, что это слишком узкий подход в понимании данного юридического феномена. По нашему мнению, планирование как юридическую категорию необходимо понимать в двух аспектах:

1) это процесс, связанный с регулированием управленческой деятельности по изданию нормативных правовых документов;

2) это одновременно и метод ее урегулирования, придания ему целенаправленной формы. То есть планирование представляет собой специфическую деятельность, связанную с упорядочением выработки нормативных правовых актов путем определения их тематики, сроков исполнения и лиц, ответственных за реализацию намеченного. И в то же время планирование - это метод познания социально-правовой действительности, который заключается в установлении важности и значимости регулируемых общественных отношений с целью установления последовательности, очередности издания требуемых нормативных правовых актов.

Таким образом, планирование как юридическая категория есть правотворческий процесс поэтапной выработки нормативных правовых актов с целью установления последовательности их издания в зависимости от важности и значимости регулируемых ими общественных отношений.

Исследование признаков, характеризующих планирование как юридическую категорию, показывает, что они также подразделяются на две самостоятельные группы и отражают процессуальную и методологическую его составляющие.

К признакам, свидетельствующим о процессуальном значении планирования правотворческой деятельности, относятся следующие:

3) оно связано с упорядочением процесса издания нормативных правовых актов, придания ему целенаправленного, а не стихийного характера;

4) урегулировано нормами права (например, Регламентом Государственной Думы РФ в статьях 50, 51), предусматривающих порядок его формирования и реализации;

5) протекает в установленном законом порядке и в установленные сроки;

6) осуществляется уполномоченными субъектами правотворчества, исключения из этого правила не допускаются;

7) имеет поэтапное продвижение законопроектов в план законопроектных работ правотворческого органа, связанное с различными процессуальными правилами, как включения в план, а также исключения из плана.

${ }^{526}$ Никчемная Е.А. Планирование как юридическая категория // Современное право. 2010. - №9. - C. 29. 
Методологические признаки планирования как юридической категории проявляются в следующих его свойствах:

1) оно позволяет устанавливать значимость регулируемых общественных отношений с учетом чего определяется последовательность, очередность издания нормативных правовых актов;

2) дает возможность подразделять нормативные правовые акты на впервые регулирующие общественные отношения или повторно, что свидетельствует о несовершенстве ранее проведенного регламентирования этих отношений;

3) вносит элемент систематизации правотворческой деятельности по различным критериям, что ведет к упорядочению всей правовой системы страны;

4) оно носит творческий характер и не имеет нормативного урегулирования, поскольку каждый планируемый к изучению правовой акт подлежит индивидуальной оценке, что позволяет определить его место в общем плане законотворческих работ;

5) в зависимости от решаемых правотворческих задач имеет разные формы реализации: а) в виде подлежащих изданию крупных блоков законодательных и иных нормативных правовых актов; б) планов основных направлений развития правовой системы; в) стратегических планов нормативного обеспечения социально-экономического развитии страны (региона); г) разработка планов-образцов правотворческой деятельности, например, для субъекта федерации ${ }^{527}$;

6) позволяет осуществлять планирование на научной основе ${ }^{528}$ (путем анализа действующего законодательства в процессе его применения, изучения предложений ученых и практических работников), а также с учетом зарубежного опыта правотворчества в той или иной сфере общественных отношений и т. д.

Отсюда видно, что планирование правотворческой деятельности должно протекать в установленной процессуальной форме, которая обеспечивает его методологическое назначение. Планирование не должно рассматриваться только как деятельность уполномоченных субъектов по формированию порядка издания нормативных правовых актов. Такой подход исключает его методологическое значение и тем самым дает ошибочное понимание данной правовой категории.

Планирование правотворческой деятельности осуществляется на принципах правотворчества, отражающих его нормообразующую и процессуальнообразующую стороны. К нормообразующим принципам, связанных с планированием правотворческой деятельности относятся такие принципы: научности, системности, законности, логической последова-

\footnotetext{
${ }^{527}$ См., например: Рекомендации по подготовке и оформлению проектов федеральных законов / Т.Н. Рахманина, В.М. Баранов, Ю.А. Тихомиров [и др.] // Проблемы юридической техники / под ред. В.М. Баранова. - Н. Новгород, 2000. - С. 803-815.

${ }^{528} \mathrm{Cм}$., например: Туранин В.Ю. Технология подготовки региональных (муниципальных) нормативных правовых актов и информационных документов / В.Ю. Туранин, Ю.П. Туранин. - Белгород, 2002. - С. 7-25.
} 


\section{Правотворчество в Российской Федерации}

тельности размещения в правотворческих планах издание нормативных правовых актов, их реализуемости и др. К процессуальнообразующим принципам относятся такие как принципы гласности, коллегиальности принятия нормативных правовых актов, обоснованности, разумности сроков рассмотрения, подлежащего изданию нормативного правового акта, осуществление планирования только уполномоченными органами и др.

Предметом законодательного регулирования являются определенные экономические, социальные, политические и иные общественные отношения. Однако не все общественные отношения подлежат урегулированию законами, большинство из них получают правовую регламентацию подзаконными актами. Поэтому и правотворческое планирование осуществляется соответственно на уровне законотворчества и подзаконного правотворчества.

До планирования законотворческой деятельности необходимо установить критерии, по которым будет возможно выделить законы в особую группу нормативных правовых актов, подлежащих изданию данным правотворческим органом. В юридической литературе к таким критериям относятся следующие:

1) значимость и стабильность регулируемых отношений, так как закон регулирует наиболее важные, устойчивые отношения в государстве и, соответственно, в регионе;

2) первичное нормативное урегулирование вопросов, которые являются исключительно и преимущественно предметом законодательного воздействия именно на данном уровне;

3) четкое уяснение места будущего закона в общей системе законодательства;

4) соответствие содержания закона предмету ведения правотворческого органа ${ }^{529}$.

На основании указанных критериев будет возможно определить перечень законов, подлежащих к изданию на определенную ближнюю и дальнюю перспективу.

Планирование правотворческой деятельности осуществляется в соответствии с поступившими предложениями субъектов права законодательной инициативы. В планах важно отражать не только необходимую последовательность издания законодательных актов в соответствии с их системообразующим значением, но и правильно отражать тенденции развития основных регулируемых сфер общественной жизни, выделяя при этом приоритетные законы ${ }^{530}$. Принцип последовательности рассмотрения законодательным органом того или иного проекта закона означает, что в первую очередь принимаются законы по более общим вопросам, а конкретизирующие их законы и подзаконные акты - во вторую.

\footnotetext{
${ }^{529}$ Туранин В.Ю., Туранин Ю.П. Указ. соч. - С. 35-36.

${ }^{530}$ Нормография: теория и методология правотворчества: учеб.-метод. пособ. / под ред. Ю.Г. Арзамасова. - М., 2007. - С. 178.
} 
Планирование к изданию целого блока законов в определенной сфере общественных отношений показывает их взаимосвязь между собой, а также позволяет оценить намечаемое правовое регулирование в комплексе, что способствует избежать дублирования, противоречий, различных несогласованностей и пробелов в законодательстве.

К числу приоритетных нормативных правовых актов относятся те из них, необходимость принятия которых вызвана социальной потребностью, острой жизненной ситуацией, а также акты, имеющие ключевое значение для определенной сферы общественных отношений (например, федеральные конституционные законы, отраслевые кодексы, законы в сфере предпринимательства, финансов и т. д.).

В юридической литературе отмечается, что «современные планы законопроектных работ больше похожи на расширенные («развернутые») повестки дня заседаний Государственной Думы, в которых обозначены главным образов этапы работ над уже подготовленными и вынесенными законопроектами, тогда как нужны именно планы подготовки проектов, с указанием кто конкретно и в какие сроки должен разработать тот или иной законопроект» ${ }^{531}$.

Для устранения указанного недостатка в первую очередь нужна современная научно обоснованная концепция, позволяющая планировать развитие российского законодательства на длительную перспективу, которая бы учитывала не только реальные потребности правового регулирования общественных отношений, но в обязательном порядке отражала бы и наметившиеся тенденции изменения общественной жизни ${ }^{532}$.

Следует отметить, что в отдельных случаях могут готовиться программы (планы) подготовки не только законодательных, но также президентских и правительственных нормативных правовых актов. Это позволяет издавать скоординированные правовые документы одновременно на различных уровнях государственной власти, оперативно включать в сферу государственного правового регулирования общественные отношения, подлежащих регламентации разными правотворческими субъектами.

Таким образом, планирование правотворческой деятельности является основой научной организации издания нормативных правовых актов. Планирование как юридическая категория включает в себя процессуальную и методологическую составляющую единого правотворческого процесса.

Однако современное планирование в сфере правотворчества базируется не только на анализе применения действующего законодательства, учете социальных, экономических и иных потребностей общества, учете рекомендаций юридической науки и практических работников, но также на использовании результатов прогнозирования развития общественных отношений на ближнюю и дальнюю перспективу. По мнению С.В. Полениной, необходимо формировать правотворческую политику таким

\footnotetext{
${ }^{531}$ Нормография. - С. 173-174.

${ }^{532}$ См. подробнее: Борисов А.С. Некоторые проблемы современного правотворчества в России / А.С. Борисов, П.А. Меркулов // Социум и власть. - 2015. - №3 (53). - С. 67.
} 


\section{Правотворчество в Российской Федерации}

образом, чтобы развитие законодательства Российской Федерации и ее субъектов по соответствующим вопросам планировалось и прогнозировалось как некое целое, скоординированное предметно и по срокам правовое явление ${ }^{533}$. Это значит, что планирование правотворчества должно вестись также с учетом прогнозирования.

Юридическое прогнозирование, - по определению Р.О. Халфиной, это систематическое и непрерывное исследование будущего состояния государственно-правовых процессов, темпов их протекания и конкретных сроков их исполнения ${ }^{534}$.

Значение юридического прогнозирования состоит в том, что с его помощью можно решать такие важные задачи, как:

1) получение на основе анализа эмпирических данных научной прогностической информации о тенденциях развития законодательства;

2) выявление социальных потребностей и круга тех общественных отношений, которые в будущем должны быть урегулированы в законодательном порядке;

3) определение наиболее перспективных форм и методов правового регулирования общественных отношений;

4) определение первоочередности подготовки законодательных и иных нормативных актов ${ }^{535}$.

Конкретизируя эти задачи, К.В. Агамиров расширяет область государственного прогнозирования, справедливо полагая, что оно направлено на:

1) получение выводов о тенденциях и путях дальнейшего развития законодательства;

2) определение важнейших проблем социального развития, взаимосвязанных с основными направлениями деятельности государства и совершенствованием действующего законодательства;

3) определение общественных отношений, которые требуют законодательного регулирования;

4) выявление методов правового регулирования, которые являются наиболее адекватными современным общественным отношениям;

5) выработку предложений по первоочередной подготовке нормативно-правовых актов;

6) получение прогнозов в конкретных областях общественных отношений в процессе планирования законодательства (политических, экономических, демографических и других прогнозов $)^{536}$.

Однако это пока только научное понимание значения юридического прогнозирования. На практике все обстоит по иному ${ }^{537}$. Правовое регулирование осуществляется методом проб и ошибок. Выявление возмож-

\footnotetext{
533 Поленина С.В. Правотворческая политика // Российская правовая политика. Курс лекций / под ред. Н.И. Матузова, А.В. Малько. - М., 2003. - С. 194-196.

${ }_{534}$ Халфина Р.О. Научные основы советского правотворчества. - М., 1981. - С. 181.

535 Мазуренко А. П. К вопросу о методах правотворческой политики // ЮристьПравоведъ. - 2007. - №5. - С. 24.

${ }_{536}$ Агамиров К.В. Прогнозные оценки и планирование законодательства на долгосрочную перспективу // Человеческий капитал. - 2014. - №04 (64). - С. 69.

${ }_{537}^{53}$ Там же. - С. 70; Платонов В.М. Законодательный процесс в Российской Федерации. Автореф. дис. ... к.ю.н. - М., 1999. - С. 3; и др.
} 
ных негативных последствий от действия принятых нормативных правовых актов происходит не до их издания путем прогнозирования, а в результате реального применения в ходе правоприменения. Достаточно вспомнить неоднократное переиздание федерального закона «О несостоятельности (банкротстве) ${ }^{538}$.

Первоначальный его вариант от 19.11.1992 г. страдал многочисленными недостатками и довольно скоро обнаружил свое несовершенство в части отсутствия детальной регламентации процедуры банкротства, a также определения понятия несостоятельности. Вместо него был издан аналогичный закон от 08.01.1998 г. №6-Ф3, который также был признан неудачным, поскольку носил «прокредиторский» характер, не учитывал интересы должников и позволял банкротить нормально функционирующие предприятия с целью передела собственности ${ }^{539}$. В связи с этим и данный закон был признан неудачным и вместо него издан аналогичный федеральный закон от 26.10.2002 г., который вроде бы устранил выявленные ранее недостатки. Однако имеющаяся судебная практика применения норм последнего закона о несостоятельности (банкротстве) показывает, что и этот его вариант не лишен серьезных недостатков, которые в конечном счете приведут к необходимости внесения в него радикальных изменений. По нашему мнению основным недостатком законодательства о банкротстве состоит в том, что государство слишком сильно вмешивается в отношения собственности, в экономические отношения предпринимателей, которые должны строиться не на императивных началах, а на диспозитивных, - в форме саморегуляции. Этот пример показывает, что проекты законов должны подвергаться экспертному прогнозированию на получение возможных негативных последствий от их применения.

Можно сказать, что значение прогнозирования состоит не столько в том, чтобы решать только указанные выше весьма актуальные задачи, а в том, чтобы своевременно выявить возможные негативные последствия от действия закона по урегулированию общественных отношений. Проектируемый закон (и тем более применяемый) не должен давать отрицательные побочные эффекты, которые превышают его положительное значение. Как показывает законотворческая практика недостаточное использование прогнозирования снижает качество правотворческих решений, а иногда, при его отсутствии, ведет к изданию законов, имеющих отрицательный потенциал, то есть приносящих не столько пользы, сколько вреда.

Как отмечается в юридической литературе, отсутствие последовательной концепции развития законодательства является серьезным пре-

${ }^{538}$ СЗ РФ. - 1996. - №25. - Ст. 2954.

${ }^{539}$ См. подробнее: Гущин В.В. Корпоративное право / В.В. Гущин, Ю.О. Порошкина, Е.Б. Сердюк. - М., 2009. - С. 184-185. 


\section{Правотворчество в Российской Федерации}

пятствием для прогностических исследований, поскольку не выявлены закономерности и тенденции развития данного процесса ${ }^{540}$.

В настоящее время в юридической науке в качестве объектов прогнозирования называются следующие их виды:

1) развитие законодательства в целом и его общих закономерностей;

2) тенденции в развитии отдельных отраслей законодательства (отраслевое прогнозирование);

3) прогнозные оценки отдельно взятого правового института;

4) тенденции и перспективы развития отдельной правовой нормы ${ }^{541}$.

Каждое из указанных направлений прогнозирования представляет определенный уровень познания правовой действительности. Первый уровень - предвидение сущности законодательства как сложной целостной системы правовых норм и институтов. Поскольку данная система имеет упорядоченный характер, имеет свою структуру, состоит из отдельных элементов взаимосвязанных между собой, обладающих различными свойствами и возможностями правового регулирования, то с помощью прогнозирования необходимо выявить тенденции ее развития, что даст основу для выработки конкретных планов издания законодательных актов.

Прогнозирование на уровне отрасли права будет лежать в основе оценки необходимости ее правового развития, совершенствования путем внесения соответствующих изменений и дополнений в нормы и правовые институты. Этот уровень прогнозирования в настоящее время, по сути, является наиболее востребованным, хотя и менее всего реализуемым на практике. Издаваемые, как на конвейере, изменения и дополнения по всем отраслям права вытекают изначально из несовершенства ранее принятых нормативных правовых актов, которые должны приниматься «на максимально возможную продолжительность действия во времени за счет всесторонней продуманности, а не за счет вносимых изменений» ${ }^{542}$. Прогнозирование законотворчества на отраслевом уровне возможно только с привлечением ученых и специалистов-практиков, что в настоящее время не всегда делается даже на предпроектной стадии изучения предмета правового регулирования. Этот дефект законотворчества является серьезным препятствием решения задачи его оптимизации, сокращения излишней множественности нормативных правовых актов, устранения неравномерности развития отдельных отраслей и подотраслей права, повышения роли закона в жизни общества ${ }^{543}$.

Прогнозирование развития отдельного правового института по сложившемуся в юридической науке мнению не применяется ${ }^{544}$. Предпо-

540 Мазуренко А.П. К вопросу о методах правотворческой политики // ЮристъПравоведъ. - 2007. - №5. - С. 25.

${ }_{541}$ Мазуренко А.П. Указ. соч.; Агамиров К.В. Указ. соч. - С. 68.

542 Рыбаков В.А. Правотворчество в переходной период развития права // Юридическая техника. - 2015. - №9. - С. 654.

${ }^{543}$ Белоусов С.А. Правотворчество и законодательный дисбаланс: диалектика взаимосвязи // Вестник ВГУ. - 2015. - №1. - С. 66.

${ }^{544}$ Агамиров К.В. Указ. соч. - С. 69; Ломтева В.С. Прогнозирование в правотворчестве и правоприменении. Дис. ... к.ю.н. - М., 2006. - С. 76. 
сылками того, что такое прогнозирование не осуществляется, является наличие значительного количества обобщений судебной практики, в которых дается оценка многим правовым институтам различными судебными органами, что и служит основой для их совершенствования в процессе правотворчества.

Прогнозирование на уровне правовой нормы в определенной степени подменяется оценкой возможного последствия от ее действия, которая дается субъектом права законодательной инициативы при разработке концепции законопроекта. И хотя результат правотворческого решения не есть прогнозирование развития нормы права, законодателю этого достаточно.

Правовая норма представляет собой модель будущего общественного отношения, является образцом деятельности и проведения тех социальных субъектов, на которых законодатель распространяет регулирующую силу и действие данной правовой нормы ${ }^{545}$. Поэтому субъект правотворчества должен сформулировать ее содержание таким образом, чтобы она была рассчитана на долгосрочную перспективу применения. А это возможно все же на основе тщательно проведенного прогнозирования развития этих общественных отношений в будущем. Оценка нормы права субъектом права законодательной инициативы по результату, который может быть получен от ее применения, как и учет обобщений судебной практики применения норм права являются лишь оценочными элементами системы критериев научного прогнозирования. Следовательно, выработать модель нормы права, которая бы действовала эффективно и длительное время возможно все же в результате прогнозирования.

По нашему мнению самостоятельным объектом прогнозирования необходимо выделить и такой как определение теоретической и практической обоснованности принятия тех или иных нормативных правовых актов. В системе нормативных правовых актов Российской Федерации и ее субъектов существует большое количество правовых документов, которые имеют межотраслевое значение либо относятся к отрасли права, которая еще только формируется и поэтому эти нормативные правовые акты как бы выпадают из поля зрения науки. Прогнозирование таких актов на их практическую целесообразность и разработку теоретических моделей будет представлять повышение качества и эффективности правового регулирования общественных отношений.

В юридической литературе отмечается, что планирование правотворческой деятельности должно опираться на результаты прогнозирования, в процессе которого необходимо выявлять:

1) потребность в правовом регулировании новых общественных отношений или изменении и дополнении действующих норм;

2) вид акта (закон, указ, постановление и т. д.) и субъект, принимающий этот акт;

3) субъекта права законодательной инициативы;

4) ответственных за разработку акта;

5) срок внесения акта в соответствующий правотворческий орган;

${ }^{545}$ Халфина Р.О. Научные основы советского правотворчества. - М., 1981. - С. 201. 
6) порядок прохождения акта (в том числе возможность всенародного обсуждения);

7) концепцию акта, его содержание и конечную цель;

8) социально-экономическое, политическое и идеологическое обеспечение акта;

9) вероятность принятия или отклонения акта;

10) способы обсуждения, экспертизы и апробации акта;

11) вывод об эффективности акта;

12) предложение о включении акта в план законодательных работ субъекта права законодательной инициативы ${ }^{546}$.

Осуществление прогнозирования по всем указанным направлениям формирует надежную методологическую базу качества издаваемых нормативных правовых актов, что обуславливает эффективное правовое регулирование общественных отношений. Однако на сегодняшний день прогностическая деятельность субъектов правотворчества отсутствует и планирование правотворческой деятельности ограничивается лишь краткосрочными (текущими) планами. Планы издания нормативных правовых актов, рассчитанных на долгосрочную перспективу, не составляются. По справедливому замечанию К.В. Агамирова, такое положение обусловлено тем, что законотворчество традиционно определяется как деятельность органов государственной власти, состоящая в принятии, изменении или отмене правовых норм. Между тем стадия прогнозирования предполагает деятельность не только (и не столько) представителей власти, но и экспертов, ученых, не относящихся к государственным служащим $^{547}$. Именно поэтому в юридической литературе высказывается мысль о необходимости регламентации предпроектной деятельности субъектов правотворчества с целью расширения круга лиц, участвующих в формировании тех или иных законопроектов ${ }^{548}$. Но пока и это предложение не нашло законодательного воплощения.

Таким образом, прогнозирование развития законодательства имеет своей целью выявление имеющихся закономерностей данного процесса, установление наметившихся тенденций их изменения в будущем, что является научной основой для планирования правотворчества на долгосрочную перспективу.

\footnotetext{
${ }^{546}$ Агамиров К. В. Указ. соч. - С. 70.

${ }^{547}$ Там же.

${ }^{548}$ См., например: Дерхо Д.С. К вопросу о необходимости нормативной регламентации предварительного этапа конституционного правотворчества // Апробация. - 2015. №8 (35). - C. 28.
} 


\section{§4.3. ВЫБОР НОРМАТИВНОГО ПРАВОВОГО АКТА В ПРОЦЕССЕ ПРАВОТВОРЧЕСТВА}

Правовое регулирование - это сложная научная познавательная деятельность, которая связана не только с оценкой общественных отношений по их способности к упорядочению с помощью норм права, но и с выбором необходимого для этого нормативного правового акта. С одной стороны, определяется способность общественных отношений объективно, по своей природе поддаваться нормативно-организованному воздействию в существующих условиях нуждаться в таком воздействии при помощи юридических норм и всех иных юридических средств, образующих механизм правового регулирования ${ }^{549}$. С другой стороны, осуществляется выбор нормативного правового акта с помощью которого возможно установление правового режима регламентации того или иного вида общественных отношений ${ }^{50}$. Например, Гражданский кодекс РФ определяет режим регламентирования отношений по использованию имущества, по установлению правового положения участников гражданско-правовых отношений, а Уголовный кодекс РФ регламентирует отношения, связанные с правовым воздействием на лицо, совершившее преступление. Субъект правотворчества первоначально решает вопрос о возможности и необходимости правового регулирования общественных отношений, а после этого, - как, с помощью каких правовых средств можно его осуществить.

Процесс выбора требуемого нормативного правового акта для урегулирования определенных общественных отношений является исключительно творческим и законодательно не урегулирован в силу того, что он всегда протекает в индивидуализированной форме и сопряжен с поиском юридической формы не для абстрактных, а совершенно обособленных, имеющих свою специфику, общественных отношений.

Деятельность по выбору необходимого в каждом конкретном случае нормативного правового акта для урегулирования общественных отношений можно разделить на два этапа:

1) изучение особенностей общественных отношений, потенциально нуждающихся в их нормативном урегулировании;

2) выбор требуемого для этого нормативного правового акта, способного удовлетворить их уникальные потребности.

Социальные связи, которые устанавливаются между людьми, достаточно разнообразны, имеют различное назначение и степень влияния на формирование общественных отношений, что предопределяет возможность и необходимость их регламентации правом. Поэтому не все общественные отношения урегулированы нормами права. Но те общественные отношения, которые все же урегулированы правом, в юридической

\footnotetext{
${ }^{549}$ Алексеев С.С. Теория права. - М.: Бек, 1995. - С. 211.

${ }^{550}$ См. подробнее: Теория государства и права / под ред. В.М. Корельского, В.Д. Перевалова. - М., 1998. - С. 269.
} 


\section{Правотворчество в Российской Федерации}

литературе подразделяются на объективно нуждающиеся в правовом регулировании и объективно не нуждающиеся в правовом регулировании ${ }^{551}$.

Каждое исторически конкретное общество объективно требует строго определенной меры правового регулирования («не больше» - «не меньше»), иначе неизбежны отрицательные последствия для социальной системы - ее неорганизованность или, наоборот, ее излишняя регламентация ${ }^{552}$. Сущность этих последствий состоит в том, что при недооценке значения правового регулирования, необоснованного отказа от упорядочения общественных отношений нормами права «в обществе возникает угроза произвола, хаоса, непредсказуемости в тех областях человеческих отношений, которые можно и нужно упорядочить с помощью права. А когда сфера правового регулирования неоправданно расширена, особенно за счет централизованного государственно-властного воздействия, создаются условия для укрепления тоталитарных режимов, заурегулированности поведения людей, ведущего к социальной пассивности, безинициативности членов общества» ${ }^{553}$.

Правовому регулированию подлежат общественные отношения, которые отражают следующие признаки: 1) в них сочетаются индивидуальные интересы людей и интересы всего общества; 2) в этих отношениях регулируются взаимные интересы их участников, каждый из которых идет на частичное ущемление своих интересов ради удовлетворения интересов других; 3) отношения строятся на основе определенных правил, которые признают и выполняют все члены общества; 4) соблюдение установленных правил обеспечивается принудительной силой государства $^{554}$. Общественные отношения, не отвечающие указанным требованиям, регулируются иными социальными нормами или не регулируются вообще.

Более сложным правотворческим решением является выбор правового акта, требуемого для регулирования большой группы схожих между собой общественных отношений. В юридической литературе указывается, что нормативный правовой акт характеризуется следующими признаками: 1) издается компетентными органами государства или в соответствии с конституцией принимается непосредственно населением путем референдума; 2) содержит нормы права (устанавливает, отменяет или изменяет их); 3) обладает юридической силой, охраняется и обеспечивается государством; 4) издается в виде письменного документа с установленной структурой и необходимыми атрибутами; 5) носит легитимный характер ${ }^{555}$.

\footnotetext{
${ }^{551}$ Соловьев С.Г. Понятие предмета правового регулирования и его взаимосвязь с другими юридическими категориями // Вестник Пермского университета. - 2012. - №1 (15). - С. 48. ${ }_{552}$ Алексеев С.С. Общая теория права: в 2 т. - М., 1981. - Т. 1. - С. 48.

553 Теория государства и права / под ред. В.М. Корельского, В.Д. Перевалова. - М., 1998. C. 259.

554 Там же. - С. 259.

${ }^{555}$ Там же. - С. 285
} 
Сложность выбора в каждом конкретном случае требуемого нормативно правового акта для регулирования общественных отношений обусловлена следующими обстоятельствами.

1. Необходимо решить вопрос о его виде: закон или подзаконный акт? Данное решение должно быть обоснованным и вытекать из действительных потребностей регулируемых общественных отношений. Для этого следует отобрать и проанализировать по возможности все ранее изданные по данному вопросу нормативные акты (международные договора, регулирующие соответствующий круг общественных отношений; действующие акты российского законодательства, в том числе и законодательные акты субъектов федерации; нормативные акты иностранных государств, которые отражают сферу общественных отношений, подлежащих нормативному закреплению) ${ }^{556}$. Ошибочное решение данного вопроса ${ }^{557}$ может привести к тому, что общественные отношения, не представляющие социальной значимости, будут урегулированы законом, что подрывает авторитет законодательства, поскольку допускается несоответствие принимаемых нормативных правовых актов объективным законам общественной жизни ${ }^{58}$. Неприемлемо и решение, когда вместо потенциально необходимого закона издается нормативный правовой акт более низкой юридической силы. В этом случае завышаются регулятивные возможности подзаконного нормативного правового акта, что ведет к замене субъекта правотворчества, подмене законодательства ведомственным нормотворчеством.

Выработать обоснованное решение могут способствовать критерии разграничения закона и подзаконного нормативного акта. В юридической литературе к их числу относят содержательный и нормативноюридический критерии.

Содержательный критерий показывает социальную ценность общественных отношений, их стабильность и значимость во взаимоотношениях между людьми, степень актуализации потребности в нормативном воздействии на них. Это означает, что общественные отношения, имеющие более высокие показатели по их влиянию на функционирование социально-экономической и политической жизни государства требует законодательного закрепления, а сопутствующие им, вспомогательные отношения - закрепляются подзаконными нормативными правовыми актами.

Нормативно-юридический критерий характеризует правовую природу закона и подзаконного акта, что позволяет более точно оценить их

\footnotetext{
${ }^{556}$ Нормография: теория и методология правотворчества: учеб.-метод. пособ. / под ред. Ю.Г. Арзамасова. - М., 2007. - С. 158.

${ }^{557}$ См. подробнее о юридических ошибках правотворчества: Лашков А.С. Правотворческие ошибки. Проблемы теории и практики. Автореферат дис. ... к.ю.н. - СПб., 1999; Чинарян Е.О. Понятие и общая характеристика законодательной ошибки // Современное право. -2010 . - №9. - С. 22-26.

${ }_{558}$ Рыбаков В.А. Правотворчество в переходный период развития права // Юридическая техника. - 2015. - №9. - С. 654.
} 
потенциальные возможности нормативного закрепления тех или иных общественных отношений в соответствующих нормах права. Данный критерий требует оценки по таким показателям как:

1) соответствие содержания избираемого акта предметам ведения Российской Федерации и ее субъектов;

2) четкое уяснение места будущего нормативного правового акта в общей системе права, в том числе в отрасли, подотрасли, институте права;

3) соответствие содержания и объема нормативного регулирования компетенции правотворческого органа;

4) учет требований Конституции РФ, федеральных конституционных и обычных законов о порядке осуществления правового регулирования тех или иных общественных отношений ${ }^{59}$.

В юридической литературе высказано недостаточно обоснованное предложение о необходимости нормативного закрепления вопросов, которые должны быть урегулированы только законом ${ }^{560}$. Представляется, что это не будет способствовать улучшению выбора нормативного правового акта, необходимого для регламентации общественных отношений. В настоящее время социально-экономические и политические отношения в стране находятся в постоянном развитии, их социальная и правотворческая значимость постоянно меняется. С учетом этого и законодатель должен оперативно менять свою правовую политику. При наличии нормативного перечня вопросов, подлежащих урегулированию только законом, потребуется каждый раз изменять и дополнять его в случае возникновения необходимости оперативно издавать закон, который не предусмотрен этим перечнем.

2. Если проведенное исследование общественных отношений показывает, что имеются объективные потребности в издании законодательного акта, то требуется обосновать его уровень (федеральный или субъекта федерации). Это важный вопрос, так как в соответствии со ст. 72 Конституции РФ большое количество полномочий находится в совместном ведении Российской Федерации и ее субъектов. При этом в федеральных нормативных правовых актах не допускается включение предписаний по вопросам, составляющих предметы ведения органов власти субъектов Российской Федерации. И, наоборот, нормативные правовые акты субъектов федерации также не должны содержать нормоположения по вопросам, отнесенным к ведению федеральных органов власти.

В настоящее время для выработки качественных нормативных правовых актов федерального уровня установлена такая форма взаимодействия между федеральными и региональными субъектами органов правотворчества как представление отзывов на проекты федеральных законов, рассмотренных Советом ГД и касающихся регулирования вопросов сферы совместного ведения Российской Федерации и ее субъек-

\footnotetext{
${ }_{559}^{550 р м о г р а ф и я: ~ т е о р и я ~ и ~ м е т о д о л о г и я ~ п р а в о т в о р ч е с т в а: ~ у ч е б .-м е т о д . ~ п о с о б . ~ / ~ п о д ~ р е д . ~}$ Ю.Г. Арзамасова. - М., 2007. - С. 164.

${ }^{560}$ Там же. - С. 165.
} 
тов $^{561}$. Что касается установления контроля со стороны федеральных органов власти за ходом правотворчества в субъектах федерации, то он пока остается мало эффективным, о чем свидетельствует статистика: нормативные правовые акты субъектов федерации не соответствуют федеральному законодательству почти в $70 \%$ случаев их официального издания ${ }^{562}$. И многие из них не являются действующими по причине ошибочного выбора нормативного правового акта для осуществления правового регулирования тех или иных общественных отношений. Это обусловлено в значительной степени тем, что интересы субъектов федерации не находят достаточно полного отражения в федеральных законах и данное обстоятельство подталкивает их представительные (законодательные) и высшие исполнительные органы государственной власти к поиску мер защиты своих региональных потребностей через собственное нормотворчество, которое не всегда является качественным ${ }^{563}$.

Следовательно, установление уровня правового регулирования в каждом случае дает возможность точно определить, какой вид законодательного акта (федеральный или субъекта федерации) должен быть выбран.

3. При фактическом установлении необходимости издания федерального нормативного правового акта, решается вопрос о его статусе: будет ли это закон, указ президента или постановление правительства. Следует исходить из того, что общественные отношения, подлежащие законодательному урегулированию всегда именуют высокую социальную востребованность, стабильность и охватывают широкий круг заинтересованных в них субъектов. Законодательные акты составляют костяк правовой системы государства и должны приниматься с изначальным расчетом на максимально возможную продолжительность действия во времени, поскольку «один и тот же вопрос общественной или государственной жизни предположительно может решаться бесконечным множеством нормативных актов даже одного уровня» ${ }^{564}$.

Оценивая общественные отношения, подлежащие правовому регулированию, требуется точно определить какой именно федеральный закон в данном случае необходимо принимать: конституционный или обычный. Для этого в первую очередь формулируют проблему, которая

\footnotetext{
${ }^{561}$ См. подробнее: Краснова О.И. Участие органов государственной власти субъектов Российской Федерации в федеральном законодательном процессе: вопросы теории и практики / О.И. Краснова, Е.А.Пименов // Современное право. - 2010. - №8. - С. 17.

562 Рыбаков В.А. Правотворчество в переходный период развития права // Юридическая техника. - 2015. - №9. - С. 654.

${ }^{563}$ Сырых В.М. Совершенствование механизма согласования интересов Российской Федерации и ее субъектов в процессе подготовки и принятия федеральных законов // Законодательные (представительные) органы власти субъектов Российской Федерации. Практика. Мнения. Проблемы. - 1999. - Вып. 2. - С. 7.

564 Рыбаков В.А. Правотворчество в переходный период развития права // Юридическая техника. - 2015. - №9. - С. 654.
} 


\section{Правотворчество в Российской Федерации}

должна быть решена с помощью федерального закона, а после - определяется его статус.

Федеральные конституционные законы принимаются по наиболее важным, определяющим направлениям общественного и государственного устройства Российской Федерации. Федеральные конституционные законы издаются в соответствии с прямыми предписаниями Конституции РФ. Например, ст. 118 Основного закона предусматривает необходимость издания федерального конституционного закона, закрепляющего судебную систему Российской Федерации. Аналогичное предписание содержится и в ст. 128 , в которой указывается о необходимости издания федерального конституционного закона о порядке образования и деятельности Конституционного Суда и Верховного Суда Российской Федерации. Конституционные законы принимаются также и по вопросам:

1) о принятии в Российскую Федерацию и образование в ее составе нового субъекта;

2) об изменении статуса субъекта РФ;

3) о государственном гербе, гимне и флаге Российской Федерации;

4) о референдуме;

5) о военном положении;

6) о чрезвычайном положении;

7) о Конституционном Собрании РФ.

Федеральный конституционный закон обладает более высокой юридической силой по сравнению с федеральным законом. Нормы федерального конституционного закона занимают промежуточное положение между нормами федерального закона и конституционными нормами, они также обладают повышенной стабильностью.

Обычные федеральные законы, как уже отмечалось выше, принимаются не только в связи с наличием соответствующих предписаний Конституции РФ, но и по иным основаниям ${ }^{565}$. Поэтому для принятия решения об издании простого федерального закона необходимо провести серьезную подготовительную аналитическую работу с целью определения его правового статуса и отраслевой принадлежности.

Исследуя общественные отношения с точки зрения возможности их законодательного закрепления, необходимо оценить правовое воздействие на них действующих законов. Наряду с изучением возможностей их правового регулирования российским законодательством важно проанализировать зарубежный опыт законодательного регулирования в соответствующей сфере, а также решения Конституционного Суда РФ по делам о проверке конституционности тех или иных нормативных правовых актов. Это будет способствовать правильному определению статуса закона отраслевой принадлежности и выбора его вида: кодифицированного акта, специализированного отраслевого закона либо законодатель-

${ }^{565}$ Нормография: теория и методология правотворчества: учеб.-метод. пособ. / под ред. Ю.Г. Арзамасова. - М., 2007. - С. 158. 
ного акта по изменению, дополнению, отмене норм права или отдельных положений указанных актов ${ }^{566}$.

Выбор отраслевой принадлежности разрабатываемого законодательного акта осуществляется на основании выявления единообразия и родовой близости, подлежащих правовому регулированию общественных отношений, что позволяет закрепить их путем издания кодифицированного законодательства. Повышение уровня системности нормативного акта является важным условием усиления регулирующего воздействия конкретной отрасли права на общественные отношения. Это позволяет реализовать принцип приоритета кодекса как закона, стоящего во главе соответствующей отрасли права, по отношению к иным правовым предписаниям, имеющих смежные сферы правового регулирования ${ }^{567}$.

Указы президента регулируют, как правило, наиболее важные отношения, которые в последующем в основном закрепляются и нормами законодательства. Фактически данные акты, имеющие вроде бы временный характер, могут действовать продолжительное время на всей территории Российской Федерации ${ }^{568}$.

Если сущность правового регулирования общественных отношений состоит в том, что требуется конкретизация уже действующих законодательных предписаний, тогда решается вопрос о выборе нормативного правового акта путем оценки правотворческих возможностей указа президента и постановления правительства.

Нормотворческая деятельность правительства характеризуется в первую очередь тем, что она направлена на издание правотворческих решений, развивающих и конкретизирующих правовые положения актов, обладающих большей юридической силой, а также на установление правил правового регулирования общественных отношений, не нуждающихся в законодательном закреплении. Помимо этого, правительством принимаются нормативные акты, отменяющие или изменяющие нормы ведомственных актов, не соответствующих Конституции и законодательству РФ, либо предписаниям указов президента и постановлений правительства РФ.

Таким образом, исследование потребностей общественных отношений в правовом регулировании на базе последовательной оценки потенциальных регулятивных возможностей тех или иных юридических средств, позволяет выявить конкретную их форму и тем самым предопределить выбор требуемого вида нормативного правового акта, подлежащего изданию на уровне высшей законодательной либо исполнительной государственной власти.

4. Следующий этап выбора вида нормативного правового акта, необходимого для юридического закрепления общественных отношений,-

\footnotetext{
${ }^{566}$ Там же. - С. 162.

567 Рузанова В.Д. Приоритет Гражданского кодекса Российской Федерации как фактор системности гражданского законодательства [Электронный ресурс]. - Режим доступа: www.alrf63.ru/dejure

${ }^{568}$ См. подробнее: Кутафин О.Е. Предмет конституционного права. - М., 2001. - С. 193.
} 


\section{Правотворчество в Российской Федерации}

определение правотворческих возможностей ведомственных и муниципальных юридических документов.

Такая необходимость возникает в тех случаях, когда общественные отношения, подлежащие правовому урегулированию, имеют ограниченный характер и распространяют свое действие лишь на определенной территории или на специализированную группу субъектов. Это свидетельствует о необходимости издания нормативных правовых актов на уровне федеральных ведомств или муниципалитетов.

Ведомственное правотворчество - подзаконное регулирование общественных отношений федеральными органами исполнительной власти нижнего звена. Оно характеризуется множественностью субъектов правотворчества и требует, чтобы, издаваемые министерствами и ведомствами нормативные правовые акты, соответствовали предписаниям Конституции, законодательству, указам президента и постановлениям правительства Российской Федерации. Возможность их принятия, как правило, регламентирована законами и другими актами, занимающими более высокое положение в иерархии правовых актов. Значительная часть ведомственных нормативных правовых актов принимается в обязательном порядке на основании прямых предписаний закона, указов президента и постановлений правительства РФ. Вместе с тем по своему статусу министерства и ведомства имеют право издавать указанные акты и по собственной инициативе (по вопросам, отнесенным законодательством к их компетенции). Функциональное назначение ведомственных нормативных правовых актов заключается в детализации, конкретизации, дополнении, восполнении общей правовой нормы применительно к условиям конкретного государственного учреждения с учетом его специфики ${ }^{569}$.

Учитывая эти обстоятельства, выбор ведомственного нормативного правового акта предопределяется действующим законодательством, но по своему содержанию данный юридический документ полностью зависит от деловой компетенции правотворческого органа, его издающего. В настоящее время качество ведомственных правовых актов имеет общую тенденцию к снижению, о чем свидетельствует статистика их государственной регистрации в Министерстве юстиции Российской Федерации. ${ }^{570}$ Поэтому, если при определении вида нормативного правового акта, необходимого для регулирования общественных отношений, выбор делается в пользу издания ведомственного акта, данное обстоятельство обязывает правотворческий орган максимально отразить в нем требования предписаний правовых документов более высокой юридической силы.

\footnotetext{
${ }^{569}$ См. подробнее: Феклин С.И. Нормативные правовые и локальные акты в сфере образования: метод. пособ. - М., 2011. - С. 16-17.

570 Арзамасов Ю.Г. Ведомственный нормотворческий процесс: структура, содержание, перспективы развития (ч. 2). // Сводный реферативный сборник журнала «Представительная власть - XXI век: законодательство, комментарии, проблемы». - 2007. - №4-6. - С. 13-14.
} 
Необходимость издания муниципального нормативного правового акта возникает в тех случаях, когда, подлежащие правовому урегулированию общественные отношения, действуют на территории муниципального образования и относятся к наиболее многочисленным их видам нижнего звена, которые законодательному упорядочению не поддаются. Сложность выработки муниципальных нормативных правовых актов состоит, прежде всего, в необходимости отражения в них не только интересов местного значения, но и их гармонизации с интересами Российской Федерации в целом и ее субъектов ${ }^{571}$.Затрудняет выработку муниципальных нормативных актов и недостаточное их теоретическое осмысление, слабое научное и методологическое обеспечение процесса правотворчества в данной сфере правового регулирования ${ }^{572}$. Но тем не менее, при издании муниципальных нормативных правовых актов следует учитывать, что для субъектов, которым они адресуются, одновременно обязательны нормативные предписания правовых документов и вышестоящих органов государственной власти. Это значит, что нормативные акты муниципальных образований должны соответствовать федеральному законодательству и его субъектов, но не заменять и подменять его.

5. Выбор нормативного правового акта в процессе правотворчества осложняется и тем, что в нем должны найти отражение имеющиеся юридические связи не только между его нормами и правовыми институтами, но и со всеми отраслями права и правовой системой государства, занимая в ней четко отведенное ему место и юридический статус.

Следует учитывать, что нормативные правовые акты принимаются различными правотворческими органами, отличающиеся между собой по статусу и компетенции, по самым разнообразным вопросам. Такая ситуация не может не влиять на природу действующих законов и подзаконных актов, которые порой могут между собой находиться в противоречии. Поэтому прежде чем общественные отношения будут упорядочены, необходимо чтобы сами нормативные акты были приведены в соответствующую систему ${ }^{573}$ с отражением в них всех имеющихся связей с другими правовыми нормами и отраслями права.

В качестве конкретного вида нормативного правового акта может быть создан Кодекс, определенный закон или подзаконный акт, регламентирующие отрасль права либо группу однородных, схожих между собой общественных отношений, а также нормативный правовой акт муниципального образования.

Все нормативные правовые акты представляют свое внешнее выражение в определенной структурированной ферме, закрепляемой в соот-

\footnotetext{
${ }^{571}$ Аничкин Е.С. Факторы единства и многообразия конституционного законодательства РФ // Конституционное и муниципальное право. - 2005. - №2. - С. 37.

572 Звягина Е.А. Правотворчество в области местного самоуправления в Российской Федерации: правовые проблемы теории и практики (на примере Пензенской области) // Известия ПГПУ. - 2007. - №3 (7). - С. 59.

${ }^{573}$ Малько А.В. Теория государства и права. - М., 1999. - С. 149.
} 


\section{Правотворчество в Российской Федерации}

ветствующих разделах, главах, статьях, параграфах, пунктах, которые должны быть взаимосвязаны не только между собой, но иметь также четкую юридическую связь с нормами иных отраслей права. Это сложная, кропотливая исследовательская работа правотворческих органов, которая требует значительных интеллектуальных и материальных затрат и продолжительного времени для выработки по настоящему научно обоснованных правовых документов, независимо от их юридической силы, сферы действия и целевой направленности.

Таким образом, выбор нормативного правового акта, необходимого для закрепления тех или иных общественных отношений в нормах права, представляет собой научно-исследовательский процесс поиска наиболее оптимального варианта систематизированного юридического документа, пригодного для этих целей.

Данный процесс не урегулирован нормами права и является исключительно творческим, потому что он протекает в индивидуализированной форме, и каждый раз касается не абстрактных, а совершенно определенных отношений, нуждающихся в нормативном упорядочении.

Выбор, необходимого в каждом конкретном случае, нормативного правового акта для урегулирования общественных отношений протекает поэтапно:

1) первоначально они всесторонне изучаются с целью установления потребности в нормативном их регулировании;

2) после установления такой потребности осуществляется выбор требуемого для этого нормативного правового акта.

Наличие объективных потребностей общественных отношений к урегулированию нормами права устанавливается путем выявления признаков, указывающих на их способность к нормативному закреплению и наличие объективной необходимости для этого.

Выбор юридической формы закрепления общественных отношений связан с научным исследованием способности конкретного нормативного правового акта в своем содержании выразить обнаружившиеся потребности этих отношений и, вместе с тем, образовать механизм воздействия на них с целью придания им упорядоченного функционирования.

Определение вида нормативного правового акта, необходимого для урегулирования конкретных общественных отношений, связано с последовательным решением таких научно-практических вопросов как оценка социальной значимости этих отношений, возможность их закрепления в нормах права, установление отраслевой принадлежности и уровня правового регулирования, наличие взаимосвязи с родственными общественными отношениями, выработка подходящей модели их юридического выражения. 


\title{
§4.4. ЮРИДИЧЕСКИЙ СОСТАВ ПРАВОТВОРЧЕСКОГО РЕШЕНИЯ
}

\author{
\$4.4.1. ВВЕДЕНИЕ
}

В основе выработки современного правотворческого решения пока не лежит единый научный подход, если не считать концепции проекта нормативного правового акта, разрабатываемой субъектом законодательной инициативы. Такая концепция индивидуализирована и рассчитывается в обоснование необходимости принятия конкретного юридического документа. Не вызывает сомнений полезность и действенность этого метода создания проектов правовых норм. Однако, творческая свобода субъектов права законодательной инициативы, не протекающая в рамках обязательного отражения в проектах элементов юридического состава правотворчества, обуславливает создание недостаточно качественных и эффективных нормативных правовых актов.

Это связано с тем, что разработчики проектов таких актов не имеют единых научных ориентиров, которые должны лежать в основе предлагаемых ими правотворческих решений. Будучи различными по содержанию, что закономерно вытекает из характера регулируемых общественных отношений, они, вместе с тем, в значительной степени отличаются также и по своему качеству, поскольку в основе их выработки лежат различные критерии его определения, избираемые субъектами правотворчества по своему усмотрению. Формирование правотворческих решений без наличия базовых ориентиров полностью зависит не только от правовой позиции их разработчиков, но и степени понимания ими сущности правотворческого процесса. Эти обстоятельства в значительной степени и предопределяют наличие в современном правотворчестве различных по своему качественному уровню правовых норм и нормативных актов.

\section{§4.4.2. ЗАДАЧИ ЮРИДИЧЕСКОЙ НАУКИ}

Юридическая наука должна упорядочить процесс выработки нормотворческих решений, переведя его в рамки состава правотворчества. Тем самым субъекты правотворчества будут иметь научно обоснованный набор ориентиров объективного и субъективного характера, по которым смогут (как по своеобразным образцам) создавать конкретные нормы права. Наличие такого правового оценочного аппарата одновременно будет способствовать и упрощению правотворчества, что также повысит его качество.

Высказанная в юридической литературе точка зрения о том, чтобы «будущий закон о нормативных актах не облегчал и упрощал, но всемерно усложнял и затруднял процесс правотворчества» ${ }^{574}$ не имеет

\footnotetext{
${ }^{574}$ См.: выступление К.В. Всеволжского на круглом столе по теме «Актуальные проблемы правотворчества и проект федерального закона «О нормативных правовых актах в Российской Федерации»//Современное правотворчество: новые возможности для общества и государства / А.В. Павлушкин, А.С. Павловский // Журнал российского права. - 2015. №3. - C. 150 .
} 


\section{Правотворчество в Российской Федерации}

научного обоснования. Она продиктована исключительно корпоративными потребностями предпринимателей, чьи интересы автор данного предложения и представлял. Нестабильность законодательства, о которой вел речь представитель предпринимательства, действительно порождает серьезные трудности в данной сфере общественных отношений, но это не значит, что этот порок можно устранить путем усложнения и затруднения правотворчества. Скорее наоборот, усложнение правотворчества с неизбежностью обусловит снижение его качества, а это в свою очередь приведет к необходимости внесения все новых и новых поправок нормативных правовых актов в целях их совершенствования. Таким образом, проблема стабильности законодательства вытекает из его качества, а не из возможности оперативного издания нормативных правовых актов.

В современный период необходимость введения в теорию и практику правотворчества понятия «состав правотворчества» обосновал И.И. Шувалов ${ }^{575}$. Постепенно данный подход, учитывающий структурные составляющие правотворчества, как метода выработки норм права, нашел дальнейшее развитие в юридической науке. Так, А.В. Дербина пишет: «Совершенствование системы правотворческой деятельности возможно только посредством целенаправленного правового воздействия на все структурные элементы юридического состава правотворчества (субъект, объект, предмет, нормативный правовой акт (правовой текст), горизонтальные и вертикальные связи между субъектами правотворческой деятельности, нормативная правовая регламентация деятельности субъектов)» ${ }^{576}$. Использовал категорию «состав правотворчества» и В.Ю. Багдасаров, исследуя основания классификации видов правотворчества. Полученный результат позволил ему заключить, что «выявлена не какаято совокупность разнородных критериев, а система критериев, которая соотнесена с компонентами состава правотворчества и позволяет включать в нее новые основания классификации, т. е. она открыта для новых Знаний» ${ }^{577}$.

Под составом правотворчества данный автор понимает «совокупность признаков, необходимых для социально-юридической актуализации правотворческого результата. Состав правотворчества включает субъект, объект, объективную и субъективную стороны» ${ }^{578}$. Другими словами, можно сказать, что состав правотворчества представляет собой научную абстракцию совокупности объективных и субъективных признаков, необходимых для выработки правотворческого решения и оцен-

\footnotetext{
575 Шувалов И.И. Правотворчество в механизме управления обществом: необходимость комплексного исследования. - М., 2005. - С. 41. В советский период аналогично высказывались А.А. Ушаков и В.П. Реутов в работе. «Об идейно-тематическом содержании нормативных актов» // Советское государство и право. - 1976. - №11. - С. 107-108.

576 Дербина А.В. Правосознание как элемент правовой позиции субъекта правотворчества. Автореф. дис. ... к.ю.н. - Самара., 2011. - С. 11.

577 Богдасаров В.Ю. Основания классификации правотворчества. // Журнал российского права. - 2012. - №11. - С. 56.

${ }^{578}$ Там же. - C. 50.
} 
ки его качества. Это своеобразный образец, включающий в себя набор необходимых и достаточных признаков, которыми должно обладать всякое правотворческое решение. При этом выработка нормы права определяется юридическим составом, учитывающим элементы, характерные для данного вида правотворчества. Выработка института либо отрасли права сопряжена с расширением количества признаков (элементов) состава правотворчества. Теперь помимо обычных объективных и субъективных признаков устанавливаются также структурные и функциональные связи, характерные для тех или иных институтов и отраслей права. Например, институт необходимой обороны структурирован в системе обстоятельств, исключающих общественную опасность деяния, и по своему функциональному назначению рассматривается уголовным законодательством как общественно полезное деяние, хотя по объективным признакам имеет непосредственную связь с противоправными действиями, посягающими на жизнь и здоровье человека. Однако, причинение физического вреда лицу при отражении его общественно опасного посягательства на человека либо интересы общества и государства не признается преступлением. Состав правотворческого решения в данном случае сформирован таким образом, чтобы деяние, которое формально содержит все признаки преступления, было выведено за рамки общественно опасных действий в силу их полезности для государства, общества и человека, стимулируя тем самым активное противостояние граждан преступлениям.

\section{§4.4.3. СОСТАВ ПРАВОТВОРЧЕСТВА}

Следует различать понятия «состав правотворчества» и «состав правонарушения» ${ }^{579}$, поскольку их содержание раскрывается путем использования однотипных терминов.

Объект состава правотворчества - это общественные отношения, подлежащие правовому урегулированию. Круг этих отношений подлежит специальному научному исследованию с целью выявления необходимости и возможности придания им правовой регламентации. Они должны поддаваться правовому регулированию и объективно нуждаться в нем ${ }^{580}$. Правотворческое решение, воздействуя на общественные отношения, придает им упорядоченный характер, стимулируя их полезную направленность, создает условия для развития и функционирования, либо, наоборот, способствует постепенному затуханию и отмиранию, как вредоносных и контрпродуктивных для общества и государства.

Следует сказать, что В.Ю. Багдасаров в качестве объекта правотворчества признает систему источников права ${ }^{581}$. Действительно в основе

\footnotetext{
${ }^{579}$ См. подробнее: Теория государства и права. Учеб. для юрид. вузов и факультетов / под ред. В.М. Корельского, В.Д. Перевалова. - М., 1998. - С. 410-411.

${ }^{580}$ Соловьев С.Г. Понятие предмета правового регулирования и его взаимосвязь с другими юридическими категориями // Вестник Пермского университета. - 2012. - №1 (15). - С. 47.

${ }^{581}$ Багдасаров. Указ. соч. - С. 50.
} 


\section{Правотворчество в Российской Федерации}

правотворческого решения лежат нормативные правовые акты ${ }^{582}$ либо отдельные нормы права. Однако в процессе их создания субъекты нормотворчества регулируют общественные отношения, что и обуславливает необходимость рассматривать их именно в качестве объекта правотворчества.

Объект правонарушения - это тоже общественные отношения, но совершенно другие, - те, которым причинен вред противоправными действиями правонарушителя. Но и эти, находящиеся под неблагоприятным воздействием, общественные отношения нуждаются в урегулировании нормами права. Одновременно возникает потребность использования регулятивной и охранительной функции права. Объекты состава правотворчества и состава правонарушения в таких случаях пересекаются, но выполняют различные задачи.

Объект состава правотворчества отражает общественные отношения, вытекающие из конфликта интересов, сложившихся между правонарушителем и государством, что обуславливает необходимость использования регулятивной функции права. Объект правонарушения свидетельствует о характере и степени причинения вреда конкретным общественным отношениям, что говорит о необходимости их охраны. Поэтому правотворческое решение будет направлено на устранение возможности возникновения конфликта, а решение по конкретному правонарушению на применение к правонарушителю меры юридической ответственности.

Следовательно, правотворческое решение в таких случаях выполняет двойную функцию: показывает, каким образом регулируются общественные отношения, связанные с правонарушениями (для этого формируется система запрещенных государством деяний, посягающих на эти отношения), и одновременно предусматривает меру юридической ответственности за их совершение (в виде конкретного наказания за отдельно взятое противоправное деяние).

Объективная сторона состава правотворчества характеризуется конкретной деятельностью по выработке правотворческого решения. Масштабы ее весьма обширны и включают такие действия как:

1) изучение выявленной потребности в урегулировании нормами права актуальной социальной проблемы (сбор информации, проведение необходимых социологических исследований, осуществление различных расчетов с целью оценки эффективности тех или иных вариантов решений и выбор на этой основе лучшего из них);

2) подготовка проекта нормативного правового акта (изучение и учет существующей в стране практики применения норм права по теме проекта; установление реальной общественной потребности в правовом регулировании; определение обстоятельств, влияющих на эффективность правотворческих решений; обобщение и использование предложений различных государственных органов, политических партий и граждан, а

\footnotetext{
${ }^{582}$ См. подробнее: Теория государства и права. Учеб. для юрид. вузов и факультетов / под
} ред. В.М. Корельского, В.Д. Перевалова. - М., 1998. - С. 288. 
также научных учреждений, ученых и специалистов-практиков; разработка концепции проекта; составление текста проекта) $)^{583}$;

3) апробация проекта нормативного правового акта (общественное обсуждение; согласование на предмет его правовой и экономической целесообразности; проведение различных экспертиз - правовой, антикоррупционной и т. д.);

4) принятие нормативного правового акта в соответствии с Конституцией и законодательством РФ (внесение проекта в правотворческий орган, рассмотрение его в процессе существующих процедур, принятие решения об издании данного нормативного правового акта);

5) подписание, официальное опубликование и вступление в силу нормативного акта.

Таким образом, объективная сторона правотворчества включает в себя многообразные виды научного познания социально-правовой действительности и выработку на этой основе объективно необходимого правотворческого решения. Данный процесс является длящимся и занимает порой длительный отрезок времени ${ }^{584}$. Это обуславливает необходимость привлечения различных специалистов для изучения возникающих правотворческих проблем, что способствует ускорению принятия решения, а также повышению его качества. Именно признаки объективной стороны являются тем инструментом, с помощью которого субъекты правотворчества реализуют «два главных требования к правовому акту: содержательность, обусловленную правильным отражением регулируемых общественных отношений, а также строгое и четкое оформление текста с помощью правил юридической техники» ${ }^{585}$. При этом, как совершенно справедливо отметил В.А. Рыбаков, неясность текста нормативного акта может породить не только трудности юридического плана, но и возможность судебных инстанций «выбирать» из нескольких возможных «одинаково законных» решений спорной ситуации то, которое «удобнее» правоприменителю или для кого-либо из участников процес$\mathrm{ca}^{586}$. Отсюда понятно, что целью правотворческого решения должно быть создание условий и максимальных удобств для пользования и правильного понимания и применения вырабатываемых норм права (нормативных актов), достижения их полноты, точности, легкой обозримости и компактности ${ }^{587}$.

\footnotetext{
${ }^{583} \mathrm{O}$ причинах низкого качества проектов нормативных правовых актов смотри: Борисов А.С. Некоторые проблемы современного правотворчества в России / А.С. Борисов, П.А. Меркулов //Социум и власть. - 2015. - №3 (53). - С. 67.

${ }^{584}$ Спирин М.Ю. Теоретические проблемы законотворческой деятельности в Российской Федерации. - Самара, 2000. - С. 26.

585 Белоусова М.С. Правотворческая функция российского государства. // Вестник Челябинского государственного университета. - 2010. - №19 (200). - С. 12.

${ }^{586}$ Рыбаков В.А. Правотворчество в переходной период развития права // Юридическая техника. - 2015. - №9. - С. 656.

587 Ломакина И.Б. Методология правотворчества: теория и практика, направления совершенствования / И.Б. Ломакина, Д.С.-М. Тэпс // Проблемы в российском законодательстве. - 2012. - №4. - С. 25.
} 


\section{Правотворчество в Российской Федерации}

Субъекты состава правотворчества - это различные органы представительной и исполнительной власти, их должностные лица, а также общественные и корпоративные организации, наделенные законодательством Российской Федерации правом издания норм права. Круг субъектов правотворчества является достаточно обширным, что обуславливает проблему качества издаваемых ими нормативных правовых актов. С одной стороны, уровень юридической подготовленности создателей правовых норм, как правило, не соответствует их статусу, а с другой, - отсутствует единообразное законодательное закрепление требований, предъявляемых к качеству правотворческого решения. К тому же субъекты правотворчества зачастую не прибегают к помощи юридической науки в своей деятельности (например, при подготовке материалов к проектам нормативных актов; для проведения сравнительных исследований действующих правовых актов; редко практикуется привлечение ученых в качестве членов комиссий и рабочих групп, а также для консультирования и обсуждения готовых проектов нормативных актов, повышения юридической грамотности субъектов правотворчества ${ }^{588}$ и т. д.). Этот недостаток присутствует в деятельности практически всех субъектов правотворчества, включая и тех, которые формируют нормативные акты локального характера ${ }^{589}$. Следует отметить, что в проекте федерального закона «О нормативных правовых актах в Российской Федерации» сформулировано требование обязательного участия юридической службы правотворческого органа или юриста в разработке нормативных правовых актов (ст. 18), что, несомненно, повысит качество правотворчества ${ }^{590}$. Однако, этот проект «закона о законах» не принят, так как «по всей видимости, депутаты не хотят связывать себя жесткими правилами и процедурами по разработке и принятию законов» ${ }^{591}$.

Субъект правотворчества является основным элементом юридического состава правотворчества. Он не только генерирует правотворческие решения, но одновременно и регулирует их востребованность, качество и эффективность. Как отмечается в юридической литературе, правотворчество с неизбежностью проявляясь как субъективный процесс, в своей основе должно иметь объективные предпосылки, иначе оно «становится не средством упорядочения общественных отношений, а орудием произвольного управления и манипулирования» ${ }^{592}$.

\footnotetext{
${ }^{588}$ Борисов А.С., Меркулов П.А. Указ. соч. - С 67-68.

589 Потапов В.А. Корпоративные нормативные акты как вид локальных актов. Автореф. дис. ... к.ю.н. - М., 2008. - С. 13.

${ }^{590}$ Проект федерального закона «О нормативных правовых актах в Российской Федерации». [Электронный ресурс]. - Режим доступа: http://base.consultant.ru/cons/cgi/ online.cgi?req $=$ doc; base $=\mathrm{PRJ} ; \mathrm{n}=127365$

${ }^{591}$ Соловьев О.Г. О нормативном закреплении основных требований и правил законодательной техники // Вестник ЯрГУ. Серия гуманитарные науки. - 2010. - №4 (14). - С. 45.

592 Белоусов С.А. Правотворчество и законодательный дисбаланс: диалектика взаимосвязи // Вестник ВГУ. Серия Право. - 2015. - №1. - С. 65.
} 
Субъекты правотворчества в силу своего статуса имеют обязанность выработки правовых актов высокого качества и эффективности, но с учетом объективной необходимости этих актов. Именно поэтому требуется четкое закрепление в законодательстве компетенции субъектов правотворчества по каждому виду принимаемых ими источников пра$\mathrm{Ba}^{593}$. Реализация цели правотворчества по созданию норм права и качественному регулированию общественных отношений осуществляется не спонтанно, а в результате преодоления имеющихся противоречий различных позиций и взглядов субъектов правотворчества, которые обусловлены не только объективными, но и субъективными обстоятель-

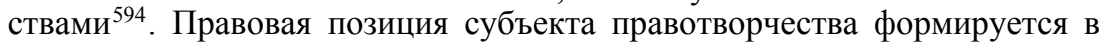
результате взаимодействия множества факторов, порождающих сугубо субъективные представления о происходящих в обществе и государстве процессах. К числу таковых А.В. Дербина относит:

1) социальную, экономическую, политическую, религиозную, культурную и территориальную среду, а также обычаи и традиции, в которых протекает жизнедеятельность субъекта;

2) определенную сумму правовых знаний, установок и ценностей;

3) средства массовой информации;

4) мнение народных масс;

5) социально-психологические и физиологические особенности личности субъекта;

6) лоббистское влияние со стороны определенного круга лиц;

7) правосознание, как главный фактор, определяющий правовую позицию ${ }^{595}$.

Все это оказывает влияние на правовую позицию конкретного субъекта правотворчества. Но не только это. Она формируется также и под воздействием тех идеалов и целей, которыми руководствуется субъект правотворчества в жизни. Именно под воздействием данного фактора субъект правотворчества действует с максимальным учетом интересов общества и государства либо, наоборот, - в угоду корыстолюбивого лобби. Конечно, субъективное восприятие социально-правовой действительности не может не оказывать влияния на формирование правовой позиции субъекта правотворчества. Она может быть и ошибочной. Однако гласность и открытость правотворчества дает возможность устранения этого недостатка в процессе обсуждения проектов нормативных правовых актов. Поэтому всякое правотворческое решение вырабатывается в процессе столкновения различных взглядов на требующую урегулирования общественную ситуацию, в процессе которого субъекты правотворчества приходят к определенному консенсусу на основе взаимных уступок и достижения компромисса.

${ }^{593}$ Каменская Е.В. Региональное правотворчество в Российской Федерации. Автореф. дис. ... к.ю.н. - М., 2005. - С. 6.

${ }^{594}$ Ситникова И.Е. Политический плюрализм и правотворчество в современном российском государстве. Автореф. дис. ... к.ю.н. - Казань, 2010. - С. 8.

${ }^{595}$ Дербина А.В. Указ. соч. - С. 7. 


\section{Правотворчество в Российской Федерации}

Субъективную сторону правотворчества составляют цели, задачи и мотив правотворчества, которые преследуют их субъекты в конкретном нормативном правовом акте. Основной целью правотворчества является урегулирование общественных отношений путем введения их в правовые рамки, устанавливаемые тем или иным нормативным актом. Задачи - осуществить его наиболее качественно, добиться, чтобы выработанные правовые нормы были доступными в их понимании и применении, а также эффективными.

Наличие цели правотворчества является его движущей силой, источником избирательности в деятельности субъектов правотворчества, когда их творческий потенциал направлен на выполнение определенной задачи, что предполагает четкое понимание остроты и важности решаемых ими проблем.

В основе каждого правотворческого решения первоначально лежит субъективная идея о необходимости правового регулирования конкретных общественных отношений. Но не всякая идея может найти правовую форму, быть реализована в конкретном нормативном акте. Это обусловлено тем, что в начале субъекты правотворчества изучат общественные отношения, которые не имеют правовой регламентации, потом будет дана характеристика их состояния, проведена оценка возможности и объективной необходимости правового урегулирования, проанализированы возможные последствия, связанные с изданием нормативного акта и на этой основе принято окончательное решение. Оно может быть, как положительным, так и отрицательным.

В юридической литературе различают формально-юридические и фактические цели, преследуемые нормами действующего законодательства. По этому поводу А.В. Скоробогатов и А.В. Краснов пишут, что если легально по закону «целями юридической ответственности выступают предупреждение, воспитание, восстановление нарушенного состояния, то фактически мотивация правоприменителя (и иных заинтересованных и связанных с ним лиц) может быть иной: выполнение плана по раскрываемости, пополнение бюджета, получение экономической выгоды от устранения конкурентов, личная месть, устранение политических конкурентов и т. д.» ${ }^{596}$. Для устранения такого недостатка правотворчества имеется только один путь: повышение его качества и открытость, гласность правоприменения. Первое снизит возможности толковать нормы права в интересах правоприменителя, а второе - делать это безнаказанно.

\footnotetext{
${ }^{596}$ Скоробогатов А.В., Краснов А.В. Правовая реальность России: константы и переменные // Актуальные проблемы экономики и права. - 2015. - №2. - С. 163.
} 


\section{§4.4.4. ВЫВОДЫ}

Таким образом, введение в юридическую науку и практику понятия «юридический состав правотворчества» будет способствовать повышению качества издаваемых нормативных правовых актов. Состав правотворчества представляет собой научную абстракцию совокупности объективных и субъективных признаков, необходимых для выработки правотворческого решения и оценки его качества.

Проведенное исследование показывает, что основным звеном юридического состава правотворчества являются его субъекты, которые реализуют правотворческие цели путем осуществления своих полномочий различных форм деятельности, направленных на издание норм права. Правотворческое решение может быть выработано в строгих рамках состава правотворчества путем квалификации его признаков по всем четырем элементам: объекту, объективной стороне, субъекты и субъективной стороне.

Введение в практику правотворчества разработку и принятие нормативных правовых актов на основе признаков всех элементов его состава правотворчества повысит не только их качество, но и научность, системность, эффективность, правовую завершенность данных актов.

\section{§4.5. НАУЧНОЕ ОБОСНОВАНИЕ ПРАВОТВОРЧЕСКОГО РЕШЕНИЯ}

Издание нормативного правового акта - не только правотворческий, но и научный процесс. Это два взаимосвязанных вида деятельности. Определяющим из них является научное обоснование выработки и принятия правотворческого решения. Даже если будет принят федеральный закон «О нормативных правовых актах в РФ» или «Кодекс правотворческой деятельности в РФ», что предпочтительнее, научное обеспечение готовящихся к изданию новых правовых актов сохраняет свое первостепенное значение. Издание законодательного акта о правотворческой деятельности создаст правовую основу прежде всего развития общей теории правотворчества, что непосредственно повысит ее научный потенциал и позволит рассматривать каждое правотворческое решение сквозь призму научного знания о нем во всем многообразии имеющихся связей в действующей правовой системе страны.

Выработка научно обоснованного правотворческого решения это длительный, постоянно обновляемый процесс до принятия, во время принятия и после принятия правотворческого решения в виде нормативного правового акта или даже отдельной нормы права. Совершенствование правотворческого решения может быть обусловлено изменяющимися общественными отношениями, достижениями юридической науки либо требованиями изменившегося законодательства.

Как отмечается в юридической литературе «активизация роли ученых-юристов в правотворчестве - необходимое условие повышения качества принимаемых нормативных правовых актов, и предпосылка эф- 
фективности содержащихся в них норм» ${ }^{597}$, а научная обоснованность формируемых правил поведения - объективная база правотворчества ${ }^{598}$. Это, безусловно, есть важнейшее условие выработки качественного правотворческого решения.

Однако проблема научной обоснованности принимаемых правотворческих решений требует более рационального подхода. Участие ученых - это, несомненно, положительный момент. Но остается за рамками правотворчества их роль в данном процессе. Она может быть и малозначительной, поскольку выбор таковых полностью возложен на приглашающих их субъектов правотворчества. И не всегда участвующие в разработке и экспертизе нормативных правовых актов ученые являются специалистами в соответствующей проблематике ${ }^{599}$.

Поэтому научная обоснованность правотворческих решений должна опираться на более надежный фундамент, а именно на общую теорию правотворчества как самостоятельную юридическую науку, предметом изучения которой являются правотворческие решения и сопутствующие им процессы, имеющая свои методы познания, цели и задачи и основанная на присущем только ей законодательстве. При таком подходе научное обоснование правотворческого решения будет формироваться на объективных знаниях, выработанных юридической наукой, а не на субъективной оценке качества разрабатываемого нормативного правового акта, которая может быть ошибочной или даже иметь коррупционную, лоббированную подоплеку.

Обоснование правотворческого решения представляет собой процесс поэтапного изучения и определения лучшего варианта из всех возможных путем оценки и выбора нормативного правового акта, необходимого для урегулирования конкретных общественных отношений. Но до этого требуется установить объективную потребность нормативного правового регулирования этих общественных отношений. В юридической науке данный этап правотворческой деятельности называется предпроектным выявлением «необходимости урегулирования правовыми средствами определенного круга социальных связей либо внесения изменений в действующий нормативный массив» ${ }^{600}$.

Наличие указанной потребности определяется на основании следующих действий:

1) обнаружение признаков проблемной ситуации;

2) сбор информации, относящейся к этой проблеме;

3) анализ проблемной ситуации на базе собранной информации;

\footnotetext{
${ }^{597}$ Борисов А.С. Некоторые проблемы современного правотворчества в России / А.С. Борисов, П.А. Меркулов // Социум и власть. - 2015. - №3 (53). - С. 67.

${ }_{598}$ Дерхо Д.С. Общие подходы к определению и структурированию руководящих начал (принципов) конституционного правотворчества. // Апробация. - 2015. - №3 (30). - С. 91.

599 Борисов А.С., Меркулов П.А. Указ. соч. - С. 67.

${ }^{600}$ Соловьев С.Г. Понятие предмета правового регулирования и его взаимосвязь с другими юридическими категориями // Вестник Пермского университета. - 2012. - №1 (15). - С. 49.
} 
4) принятие решения о разработке правового документа ${ }^{601}$. Принятие решения об издании определенного нормативного правового акта для регулирования общественных отношений должно вытекать из установленной объективной потребности путем тщательной оценки его потенциальной способности создать правовой механизм воздействия на проблемную ситуацию. При этом научное познание должно протекать в рамках последовательного решения таких задач:

1) обоснование выбора нормативного правового акта (норм права), необходимо для урегулирования общественных отношений в данной конкретной социальной ситуации. Правильность выбора возможна только с учетом многочисленных факторов, связанных с функционированием этих общественных отношений. К числу таковых относятся: определение их принадлежности к сфере публичных или частных отношений; выбор конкретной отрасли права, нормы которой могут наиболее качественно их урегулировать; выбор метода правового регулирования; четкое представление целей, достижение которых ставит перед собой субъект правотворчества; полный охват регулируемых общественных отношений нормами избранного нормативного правового акта;

2) глубокий анализ состояния урегулированности общественных отношений в соответствующей сфере. Следует учитывать, что в юридической науке общественные отношения подразделяют на фактически урегулированные нормами права и не урегулированные нормами права, но объективно нуждающиеся в нем. При этом урегулированность общественных отношений нормами права не всегда объективно обоснована $^{602}$, что создает серьезные трудности при выработке правотворческих решений. Избыточность правового регулирования, как и наличие пробелов в законодательстве обусловлены правотворческими ошибками ${ }^{603}$. Все это требует по-настоящему научного подхода в определении урегулированности общественных отношений нормами права. Предпосылкой создания нормативных правовых актов «является познание тех сложных условий, факторов и обстоятельств, развивающихся общественных отношений, правовое регулирование которых диктуется нуждами социального прогресса» ${ }^{604}$. Это значит, что при осуществлении анализа состояния урегулированности общественных отношений необходимо учитывать не столько формальное наличие нормативных правовых актов, сколько их фактическую регулятивную способность. Исходить следует из реальных потребностей правового регулирования изучаемых общественных отношений, а не из количества уже действующих нормативных правовых актов в данной сфере, поскольку их регулятивный потен-

\footnotetext{
${ }^{601}$ Москалькова Т.Н. Нормотворчество: науч.-практ. пособ. / Т.Н. Москалькова, В.В. Черников. - М.: Проспект, 2011. - С. 138.

${ }^{602}$ См. подробнее: Соловьев С.Г. Указ. соч. - С. 48.

${ }^{603}$ Костенко М.П. Пробел в праве как разновидность правотворческой ошибки // Известия Южного федерального университета. Технические науки. - 2008. - №10. - С. 117-123.

${ }^{604}$ Ширяев Ю.Е. Современное понятие и сущность правотворчества и законотворчества // Человеческий капитал. - 2012. - №3 (39). - С. 86.
} 


\section{Правотворчество в Российской Федерации}

циал может быть незначительным. Как отмечается в юридической литературе увеличение числа нормативных правовых актов «не свидетельствует о повышении уровня правовой урегулированности общественных отношений и укреплении законности» ${ }^{605}$;

3) выявление качественных показателей выбранного нормативного правового акта, определяющих уровень его стабильности и соответствия потребностям общественной жизни. По мнению В.А. Рыбакова, в настоящее время в нашей стране имеется много законов и дефицит качества норм $^{606}$. Вырабатываемые нормы права сохраняют тенденцию стремительного видоизменения. Зачастую невозможно даже уяснить причину изменения тех или иных норм права. Некачественные правотворческие решения не могут быть стабильными. Они вырабатываются субъектами правотворчества без учета объективных потребностей общества, что обрекает их на короткую жизнь. Выбор определенного нормативного правового акта для урегулирования конкретных общественных отношений должен быть не только объективно необходимым, но и тщательно и всесторонне разработанным юридическим документом, учитывающим перспективы развития общества и государства. То есть содержащиеся в нем нормы права работают не только на текущие потребности, но и на потребности, которые могут возникнуть в будущем. Критериями качества являются степень правильности определения потребности общественных отношений в правовом урегулировании, выбор научно обоснованных правовых средств и методов для этого, наличие возможности проведения контроля за ходом применения правотворческих решений ${ }^{607}$;

4) определение круга общественных отношений, подпадающих под действие избранного нормативного правового акта. Здесь важно установить такие обстоятельства: а) выявленная группа общественных отношений нуждается в правовом регулировании; б) эти отношения объективно по своей природе могут поддаваться нормативно-правовому воздействию $^{608}$. Правовое регулирование установленного круга общественных отношений возможно лишь в тех случаях, когда они обладают признаками, указывающими на возможность их упорядочения, заключения в рамки определенных правил поведения с помощью норм права, данного нормативного правового акта. К числу таких признаков относятся следующие:

a) изучаемая группа общественных отношений представляет собой внешне выраженные акты поведения людей, их взаимодействия;

б) это волевые целенаправленные отношения;

\footnotetext{
${ }^{605}$ Борисов А.С., Меркулов П.А. Указ. соч. - С. 67.

${ }^{606}$ Рыбаков В.А. Правотворчество в переходной период развития права. // Юридическая техника. - 2015. - №9. - С. 656.

${ }^{607}$ См. подробнее: Румянцев М.Б. Качество правотворчества: проблемы и перспективы совершенствования // Социально-политические науки. - 2016. - №1 . - С.64.

${ }^{608}$ Алексеев С.С. Теория права. - М.: Бек, 1995. - С. 211.
} 
в) это устойчивые типичные повторяющиеся отношения (нетипичные немногочисленные и разовые случаи не могут быть предметом правового регулирования в силу их социальной не востребованности);

г) эти отношения поддаются внешнему контролю, что позволяет проследить реализацию субъектами правоотношений предписаний правовых норм,

д) выявленная группа общественных отношений в силу своей неурегулированности не имеет правомерных вариантов поведения, что порождает произвол в действиях участников правоотношений ${ }^{609}$ (как, например, это сложилось сейчас в сфере коллекторского бизнеса);

5) изучение возможности урегулирования данных общественных отношений различными видами (отраслями) права и определение наиболее выгодного варианта. Как известно, именно общественные отношения являются материальным критерием разграничения норм права по отраслям, поскольку их содержание носит объективный характер и не зависит от воли законодателя ${ }^{610}$. В большинстве случаев содержание складывающихся общественных отношений заведомо диктует (предопределяет) отрасль права, нормы которой могут быть использованы для их урегулирования. Однако, в некоторых случаях выбор отрасли права не является очевидным. Возникает дилемма выбора отрасли права, нормы которой наиболее качественно урегулировали бы данный круг общественных отношений. Здесь требуется учитывать специфику общественных отношений (отражают ли они частный или публичный интерес), выполняемые ими функции (способствуют развитию межличностных взаимосвязей или осуществляют роль защиты от нежелательного негативного воздействия на них), возможные способы их правового урегулирования в соответствии с поставленными целями. Учитывая многоаспектность стоящих перед субъектом правотворчества целей правового регулирования, избираемый вид правотворческого решения может сочетать в себе одновременно нормы различных отраслей права, поскольку возникает необходимость и урегулировать конкретный круг общественных отношений, используя диспозитивный метод, и осуществить их охрану с помощью императивного метода. В таких случаях разрабатываются межотраслевые нормативные правовые акты, сочетающие в себе нормы права различной отраслевой принадлежности;

6) анализ соотношения, разрабатываемого нормативного правового акта с уже действующими законами и подзаконными актами. Трудности, связанные с разработкой нормативного правового акта для регулирования общественных отношений, вытекают не только из сложности познания сущности этих отношений, но и прямой или косвенной их урегулированности другими уже действующими законами и подзаконными актами. Усложняет восприятие истинной картины урегулированности общественный отношений и противоречие между реальными обществен-

${ }^{609}$ Соловьев С.Г. Указ. соч. - С. $47-48$.

${ }^{610}$ Теория государства и права: курс лекций / под ред. Н.И. Матузова, А.В. Малько. - М.: Юристь, 1997. - С. 353-354. 


\section{Правотворчество в Российской Федерации}

ными отношениями и существующей системой российского права, призванной регулировать эти отношения, которое образует важнейшую социально-политическую проблему, требующую своего научного осмысления и практического решения ${ }^{611}$. Все это свидетельствует, что при разработке любого нормативного правового акта необходимо досконально изучить уже действующие законодательные акты и акты подзаконного правотворчества в данной сфере общественных отношений. Целью этого должно быть недопущение возможных противоречий норм готовящегося к изданию нормативного правового акта с нормами действующих правовых документов, а также сокращение излишней множественности законов, устранение конкуренции нормативных правовых актов ${ }^{612}$. Особенно важным в этом аспекте является приведение в соответствие с Конституцией РФ тех законов и подзаконных актов, которые искажают ее текст либо вступают с ней в противоречие ${ }^{613}$, что можно осуществлять в процессе анализа соотношения, разрабатываемого нормативного правового акта с уже действующим законодательством. Кроме того, в процессе изучения взаимосвязи планируемого нормативного правового акта с другими аналогичными актами необходимо соблюдать их согласованность, исключить любые внутренние противоречия между его нормами ${ }^{614}$;

7) определение места готовящегося к изданию нормативного правового акта в правовой системе страны. Принцип системности является важнейшим принципом правотворчества. Каждое правотворческое решение должно занимать логически обусловленную для него ячейку в системе законодательства и подзаконного правотворчества страны. Об отсутствии должной систематизации правотворчества в настоящее время отмечают многие авторы ${ }^{615}$. Системность правотворчества создает условия для осуществления его на плановой основе, придает ему целенаправленный характер, непротиворечивость вырабатываемых правотворческих решений. В соответствии с принципом системности разрабатываемый нормативно правовой акт не только должен войти составной частью в структуру действующей правовой системы, но, вместе с тем, стать надежным скрепляющим ее звеном. Если речь идет об отрасли права - звеном, восполняющим пробелы правового регулирования той

\footnotetext{
${ }^{611}$ Мазуренко А.П. Правотворческая политика как фактор модернизации правотворчества в России. Автореф. дис. ... д-ра юрид. наук. - Саратов, 2011. - С. 18.

${ }^{612}$ Дербина А.В. Правосознание как элемент правовой позиции субъекта правотворчества. Автореф. дис. ... к.ю.н. - Самара, 2011. - С. 15.

${ }^{613}$ Сапун В.А. Правотворчество и законотворчество: стратегия и тактика формирования права и закона / В.А. Сапун, Я.В. Турбова // Юридическая техника. - 2015. - №9. - С. 682.

${ }^{614}$ Куксин И.Н. О некоторых проблемах предпроектного этапа муниципального правотворческого процесса / И.Н. Куксин, Е.А. Каминская // Вестник МГПУ. Серия «Юридические науки». - 2015. - С. 65.

${ }^{615}$ Рыбаков В.А. Указ. соч. - С. 654; Мазуренко А.П. К вопросу о методах правотворческой политики // Юристъ-Правоведъ. - 2007. - №5. - С. 16; Филатов С.В. Правотворческий процесс: понятие, стадии, принципы // Государственная власть и местное самоуправление. - 2015. - №8; Потапов М.Г. Система норм права и система нормативных правовых актов субъектов Федерации // Журнал российского права. - 2010. - №12. - С. 61; и др.
} 
или иной группы общественных отношений. В случае если идет подготовка издания межотраслевого нормативно правового акта, - он занимает соответствующее место в структуре правотворческих решений, являясь самостоятельным нормативным правовым актом. При выборе нормативного правового акта субъектом правотворчества очень важно правильно определять его вид, поскольку стремление урегулировать многие виды второстепенных отношений законами снижает качество правотворческих решений, нивелирует их регулятивный потенциал, смещает акценты правовой политики государства, преувеличивая значение заурядных социальных явлений, невольно занижая тем самым ведущую роль ключевых;

8) изучение возможности выработки правотворческих решений с помощью общепринятых в юриспруденции терминов, категорий и средств юридической техники. Выбор нормативного правового акта определяется также и с учетом его потенциальной возможности изложения правотворческого решения с помощью устоявшихся юридических терминов и категорий, средств юридической техники. Точность и ясность юридических формулировок, логическая взаимосвязь и объективная обусловленность норм права, присущих конкретному нормативному правовому акту, полностью зависит от используемых субъектами правотворчества однозначно понимаемых понятий и терминов, а также от средств юридической техники ${ }^{616}$. Термин - название определенного понятия в юриспруденции ${ }^{617}$. Точность обозначения юридического понятия является концептуальной основой для существования юридического термина ${ }^{618}$. Правотворческие решения формируются с помощью выработанных юридической наукой правил создания нормативных правовых актов. Этому способствуют применяемые при разработке их текстов приемы юридической техники. Под юридической техникой понимается совокупность правил, средств и приемов разработки, оформления, и систематизации нормативных правовых актов в целях их ясности, понимаемости и эффективности ${ }^{619}$. Использование новых терминов и нетипичных понятий значительно снижает регулирующую способность нормативных правовых актов, создает трудности в правоприменении, порождает конфликты между участниками правоотношений. Новые термины и понятия должны устанавливаться субъектом правотворчества в случаях объективной необходимости и обязательно с раскрытием их юридического содержания. Целью таких нововведений является - создание наилучших условий и максимальных удобств для пользования и правильного при-

\footnotetext{
${ }^{616}$ Теория государства и права. - М., 1998. - С. 312-313.

${ }^{617}$ Савицкий В.М. Язык процессуального закона. Вопросы терминологии. - М., 1987. C. 21.

${ }^{618}$ Туранин В.Ю. Юридическая терминология в российском законодательстве. - Белгород, 2009. - C. 15.

${ }^{619}$ Теория государства и права. - М., 1998. - С. 313.
} 


\section{Правотворчество в Российской Федерации}

менения правотворческих решений, достижения их полноты, точности, легкой обозримости и компактности ${ }^{620}$.

Субъект правотворчества, осуществив анализ предпроектного изучения объективной потребности издания определенного нормативного правового акта, принимает решение о необходимости создания его проекта. Это порождает последовательную цепь дальнейших действий, направленных на более глубокое научное обоснование разрабатываемого правотворческого решения: выработка концепции будущего нормативного правового акта, включение в план субъектов правотворчества, разработка проекта, представление его органом законодательной инициативы, предварительное рассмотрение проекта, правовая экспертиза, процедурное рассмотрение проекта, принятие, подписание и вступление в законную силу. При этом каждое из указанных действий вносит свою долю обоснования в пользу необходимости издания разрабатываемого правотворческого решения. Конечно, каждый вид правотворческого решения имеет свои особенности выработки, обсуждения, принятия, подписания и вступления в силу, но всех их объединяет одно: создаваемый нормативный правовой акт проходит постепенное качественное совершенствование. На каждом из указанных этапов осуществляется научное постижение заложенных в проект нормативного акта регулятивных возможностей, а также его связей с нормами всех иных отраслей права. Это позволяет проводить научно обоснованную оценку качества и эффективности нормативных правовых актов, в период их создания и функционирования с учетом изменяющихся общественных отношений, достижений юридической науки и требований постоянно меняющегося законодательства.

Таким образом, научное обоснование правотворческих решений имеет два аспекта измерения:

1) объективно обусловленное, показывающее необходимую степень точности и полноты отражения в нем действительных потребностей общественных отношений в урегулировании нормами права;

2) номинально возможное, отражающее фактический уровень научного обоснования правотворческих решений. Второй показатель всегда будет ниже первого в силу субъективных обстоятельств: поспешности в разработке правотворческого решения, низком профессионализме субъектов правотворчества, допущенных ошибок в оценке содержания общественных отношений либо в оценке возможностей изданного нормативного правового акта, влияния лобби на субъектов правотворчества и т. д. Вместе с тем, снижение воздействия субъективных факторов на субъектов правотворчества в процессе разработки и принятия правотворческих решений возможно, в первую очередь, на основе положений и выводов, а также научно обоснованных предложений общей теории правотворчества.

620 Ломакина И.Б. Методология правотворчества: теория и практика, направления совершенствования / И.Б. Ломакина, Д.С.-М. Тэпс // Пробелы в российском законодательстве. 2012. - №4. - С. 25. 


\section{§4.6. КАЧЕСТВО ПРАВОТВОРЧЕСТВА}

ФормированиеэффективнойистабильнойправовойсистемывРоссийскойФедерации - одна из важнейших проблем современного правотворчества. В ее основе лежат многочисленные факторы, хорошо известные юридической науке, которые и обуславливают состояние качества российского правотворчества. Сложилось достаточно обоснованное мнение, что «правотворчество в переходной период отличается резкой активизацией правотворческого процесса, отсутствием стабильности созданных правотворческих нормативных актов, низким их качеством, отсутствием должной согласованности в деятельности субъектов правотворчества, широким использованием в правотворчестве рецепции права» ${ }^{621}$. Можно сказать, что это диагноз правотворчества в целом. И как сопутствующей ему болезни, и как объективно сложившегося правового явления. Находясь в тесной взаимосвязи, указанные последствия правотворчества порождают друг друга, создают предпосылки дальнейшего снижения качества нормативных правовых актов. Поскольку это объективное правовое явление, наука пытается упорядочить его, придав ему планомерность, обоснованность и эффективность, что, безусловно, повысит качество правотворчества.

Одновременно ученые предлагают хорошо аргументированные способы устранения тех или иных выявленных ими конкретных недостатков правотворчества, что, несомненно, также будет способствовать повышению его качества в случае их реализации. К числу таковых относятся предложения:

1) о переходе от хаотичного правотворчества к осуществлению его на плановой основе с прогнозированием на длительный срок ${ }^{622}$;

2) о соблюдении правил юридической техники в процессе правотворчества $^{623}$ (предлагается даже принятие Федерального Закона, закрепляющего правила правотворческой техники и порядок их применения во всех видах правотворческого процесса ${ }^{624}$ );

\footnotetext{
${ }^{621}$ Рыбаков В.А. Правотворчество в переходной период развития права. // Юридическая техника. - 2015. - №9. - С. 657.

${ }^{622}$ Власенко Н.А. О кризисных тенденциях в праве// Юридическая техника. - 2014. - №8. C. 43; Борисов А.С. Некоторые проблемы современного правотворчества в России / А.С. Борисов, П.А. Меркулов // Социум и власть. - 2015. - №3 (53). - С. 67; Белоусова М.С. Правотворческая функция российского государства // Вестник Челябинского государственного университета. - 2010. - №10. - С. 12; и др.

623 Ломакина И.Б. Методология правотворчества: теория и практика, направления совершенствования / И.Б. Ломакина, Д.С.-М. Тэпс // Пробелы в российском законодательстве. 2012. - №4. - С. 25; Соловьев О.Г. О нормативном закреплении основных требований и правил законодательной техники // Вестник ЯрГУ. Серия Гуманитарные науки. -2010. №4 (14). - С. 43-45; и др.

${ }^{624}$ Каменская Е.В. Региональное правотворчество в Российской Федерации. Автореф. дис. „.. к.ю.н. - М., 2005. - С. 6.
} 


\section{Правотворчество в Российской Федерации}

3) о повышении требований к профессиональному уровню субъектов правотворчества ${ }^{625}$;

4) о снижении чрезмерной интенсивности темпов законодательной деятельности ${ }^{626}$;

5) о нестабильности правового регулирования, поспешности в издании нормативных правовых актов ${ }^{627}$;

6) о необходимости повышения качества правотворческой деятельности ${ }^{628}$;

7) об искоренении практики принятия нормативных правовых актов без учета актуальных публичных интересов ${ }^{629}$;

8) о недопущении ошибок содержательного характера в процессе правотворчества (неверное установление предмета правового регулирования, неправильное закрепление характера и объема полномочий субъектов права, несбалансированности норм публичных институтов и правового поведения, сохранение юридических пробелов и недооценку вероятных коллизий, нарушение баланса законов и подзаконных актов) $)^{630}$.

Перечень предложений, направленных на повышение качества правотворчества, можно продолжить. Все они имеют научное обоснование и могут быть с успехом реализованы в процессе правотворчества. Каждое из них направлено на устранение определенных конкретных неблагоприятных результатов, обуславливающих снижение качества правотворчества. Реализация этих многочисленных идей по совершенствованию правотворчества действительно может дать некоторый положительный результат, как и ожидают их авторы, но в целом кардинального изменения не произойдет. И не может произойти в силу объективных причин, суть которых в следующем:

1) основная масса, высказанных в литературе, предложений направлена на устранение последствий, возникающих от несовершенного правотворчества, а не причин, их обусловивших;

2) правовая категория «качество правотворчества» не имеет ни законодательного закрепления, ни однозначного научного понимания, что затрудняет ее реализацию в нормах права и ведет к произвольному толкованию в теоретических разработках. По справедливому мнению Л.В. Андриченко главный недостаток юридического качества нормативных правовых актов, создаваемых в процессе правотворчества, состоит в том, что они ориентированы на принятие отдельных законов и подза-

\footnotetext{
${ }^{625}$ Борисов А.С., Меркулов П.А. Указ. соч. - С 68.

${ }^{626}$ Пиголкин А.С. Федеральные основы системы российского законодательства. // Соотношение законодательства Российской Федерации и законодательства субъектов Российской Федерации. - М., 2003. - С. 28.

${ }^{627}$ Белоусов С.А. Правотворчество и законодательный дисбаланс: диалектика взаимосвязи // Вестник ВГУ. Серия Право. - 2015. - №1. - С. 67.

${ }^{628}$ Рыбаков В.А. Указ. соч. - С. 656.

${ }^{629}$ Тихомиров Ю.А. Правовое регулирование: теория и практика. - М., 2010. - С. 200.

${ }^{630}$ Белоусова М.С. Правотворческая функция российского государства. // Вестник Челябинского государственного университета. - 2010. - №19. - С. 12.
} 
конных актов, а не на формирование единой и непротиворечивой правовой системы ${ }^{631}$. Поэтому как не совершенствуй правотворчество если оно не имеет целью создание единой непротиворечивой системы права, качество не будет обеспечено;

3) правотворческое решение принимается, как правило, спонтанно, без учета перспектив развития правовой системы государства и вне его увязывания с долгосрочными планами социально-экономической политики страны и общества, без прогнозирования возможных последствий от реализации принимаемых нормативных правовых актов. А.П. Мазуренко считает, что это обусловлено отсутствием «научно обоснованной концепции развития законодательства и его взаимосвязи с экономическими, политическими и социальными реформами» ${ }^{632}$. А прогнозирование, осуществляемое в процессе правотворчества, имеет целью выявление и учет потребностей в законодательном урегулировании общественных отношений, научное предвидение ближайших и отдаленных последствий действия законодательных актов, их эффективности, а также ожидаемых изменений в формах и методах правового регулирования ${ }^{633}$, чего не наблюдается в деятельности его субъектов;

4) правотворчество - это способ реализации правовой политики государства, воплощение в юридические формы результатов противостояния, борющихся за власть политических партий, социальных групп, классов и даже экономических объединений и кланов. Поэтому вряд ли можно признать качественным правотворческое решение (пусть оно отвечает даже самым строгим требованиям правил юридической техники), которое не удовлетворяет одну из заинтересованных сторон. Здесь проблема не в том, что определенная политическая сила потерпела фиаско, не получив в правотворческом решении отражения своих интересов. Проблема в том, как урегулированы общественные отношения, отвечает ли это интересам страны и всего народа. То есть было ли найдено наилучшее решение правового регулирования конкретной социальноэкономической либо иной ситуации. В демократических государствах такие правотворческие решения достигаются за счет консолидации общества и взаимных уступок заинтересованных сторон. В нашей стране парламентским большинством правящей партии, что не всегда отвечает интересам всего народа. В последнем случае неизбежно происходит разрыв между содержанием и формой правотворческих решений. Отсюда вытекает и их качество: они малоэффективны, нестабильны, попусти-

\footnotetext{
${ }^{631}$ Павлушин А.В. Современное правотворчество: новые возможности для общества и государства / А.В. Павлушин, А.С. Павловский // Журнал российского права. - 2015. №3. - C. 131.

${ }^{632}$ Мазуренко А.П. К вопросу о методах правотворческой политики // Правотворческие ошибки: понятие, виды, практика и техника выявления и устранения в постсоветских государствах. Материалы международного круглого стола 29-30 мая 2008 г. / под ред. В.М. Баранова, И.М. Мацкевича. - М.: Проспект, 2009.

${ }^{633}$ Юрина Т.С. О роли юридического прогнозирования. // Вестник волжского университета им. Татищева. - 2001. - №14. - С. 292- 293.
} 
тельствуют коррупции, произволу, создают предпосылки хищениям и росту преступности. По справедливому заключению А.В. Скоробогатова и А.В. Краснова происходит разрыв между правовыми (определяемых законами) и фактическими (существующими в реальной действительности) общественными отношениями. Поэтому «факт принятия юридической нормы не есть достаточное условие для ее реализации обществом» ${ }^{634}$;

5) правотворческие решения с неизбежностью реализуют принцип законности, то есть отражают требования Конституция РФ и всего российского законодательства. Но Конституция РФ содержит ряд положений, которые создают преимущества исполнительной власти перед законодательной и судебной, что противоречит закрепленной ею же декларации о их равенстве. Этот изъян последовательно закрепляется во всем последующем законодательстве, принимаемом в развитие конституционных положений. Не имеют достаточного законодательного обеспечения права и свободы человека и гражданина, провозглашенные в ст. 17 Конституции РФ, которые должны соответствовать общепризнанными принципам и нормам международного права. Это порождает всевластие государственных структур, а иногда является почвой и для произвола отдельных представителей государственного аппарата. С учетом этого В.А. Сапун и Я.В. Турбова констатируют, что «Конституция РФ в этой части не может служить основой стратегии и тактики правотворческой деятельности в условиях современного демократического общества» ${ }^{635}$. Возникает объективное препятствие для реализации качественного правотворческого решения, поскольку оно не может быть таковым уже в силу действующего законодательства;

6) правотворчеству сопутствуют многочисленные недостатки системообразующего характера, которые оказывают серьезное влияние на его качество;

а) в этом аспекте следует назвать в первую очередь длительное отсутствие федерального закона «О нормативных правовых актах в Российской Федерации», который должен занять особое место и фактически сформировать правовую систему Российской Федерации ${ }^{636}$, заложив основу не только формы и содержания нормативных правовых актов, но и их качества;

b) не менее важным является и затянувшийся процесс формирования общей теории правотворчества как единой самостоятельной юридиче-

\footnotetext{
${ }^{634}$ Скоробогатов А.В. Правовая реальность России: константы и переменные / А.В. Скоробогатов, А.В. Краснов // Актуальные проблемы экономики и права. - 2015. - №2. - С. 163.

${ }^{635}$ Сапун В.А. Правотворчество и законотворчество: стратегия и тактика формирования права и закона / В.А. Сапун, Я.В. Турбова // Юридическая техника. - 2015. - №9. - С. 680.

${ }^{636}$ Выступление Ю.А. Тихомирова на круглом столе // Павлушкин А.В., Современное правотворчество: новые возможности для общества и государства / А.В. Павлушкин, А.С. Павловский // Журнал российского права. - 2015. - №3. - С. 147.
} 
ской науки ${ }^{637}$. Изучение всех особенностей правотворчества как единого системного явления даст возможность познать не только его сущность, но и выработать научно обоснованные рекомендации по созданию эффективных и качественных нормативных правовых актов;

c) не сформировалась и единая практика применения правотворческих решений, их имплементации с нормами международного права. Неизвестно как влияет на правотворческий процесс опыт применения действующего законодательства, а также имеющиеся рекомендации российских ученых-юристов и юристов-практиков по его совершенствованию. Происходит заметный разрыв между теорией выработки правотворческих решений и практикой реального их создания. Это обстоятельство обусловило необходимость подразделять цели правотворчества на формально-юридические и фактические цели, которые преследуют нормы действующего законодательства ${ }^{638}$. Тем самым формируются критерии, по которым будет возможно определить фактическое качество норм права. В идеале заявленные формально-юридические цели, заложенные в процессе правотворчества, должны полностью совпадать с целями правовых норм, достигаемых при их реализации.

d) не всегда оправдано использование в правотворчестве рецепции права, то есть заимствование правового опыта других государств. Как оценил Ю.А. Тихомиров, российские демократы пытались сразу и полностью пересадить западную систему правового государства на отечественную почву. Причем интенсивность этого процесса имела форму юридической эпидемии ${ }^{639}$. Рецепция права, осуществляемая механически без учета правовых традиций и менталитета народа, не будет способствовать повышению качества правотворчества ${ }^{640}$;

е) с методологической стороны, правотворчество, подчиняясь общей стратегии превалирования исполнительной власти над другими ее ветвями, осуществляется в явно императивно-запретительном направлении. В юридической литературе отмечается, что «в основном, принимаемые законы носят запретительный, а то и репрессивный характер. Запреты (а не дозволения) выдвигаются на первое место, что характерно именно для авторитетного режима. Такое законотворчество порождает соответствующее подзаконное регулирование ${ }^{641}$. Диспозитивный метод правового регулирования рассматривается скорее, как фактор неизбежности, а не эффективное средство воздействия на общественные отношения. Что касается методов поощрения и позитивных обязываний, то они остаются практически вне поля зрения субъектов правотворчества. Тем более редко используется правовое регулирование методом разрешения конфлик-

\footnotetext{
${ }^{637}$ См. подробнее: Румянцев М.Б. Правотворчество как юридическая наука // Законодательство и экономика. - 2015. - №5. - С. 39-44.

${ }^{638}$ Скоробогатов А.В., Краснов А.В. Указ. соч. - С. 163.

639 Тихомиров Ю.А. Курс сравнительного права. - М., 1996. - С. 55.

${ }^{640}$ См. подробнее: Лукьянов А.И. Законодательный процесс в России // Журнал российского права. - 1997. - №4. - С. 19.

${ }^{641}$ Сапун В.А., Турбова Я.В. Указ. соч. - С. 680.
} 


\section{Правотворчество в Российской Федерации}

тов между его участниками без участия властных структур, что могло бы значительно снизить вмешательство государства в межличностные отношения людей, а также ликвидировать излишнюю загруженность правоохранительных органов делами второстепенной важности. Другими словами, можно сказать, что не формируется система правового регулирования конфликтов интересов путем достижения консенсуса на основании взаимных уступок и компромисса сторон.

Таким образом, наличие указанных, а также и ряда других не менее значимых объективных факторов, воздействующих на правотворческий процесс, не позволяют кардинально изменить его качество. Проблема повышения качества правотворчества может быть успешно решена только на основе устранения причин, порождающих объективные трудности выработки нормативных правовых актов, а не путем постоянного устранения конкретных последствий, обусловленных ими, что в юридической науке окрестили как «латание дыр» ${ }^{642}$.

Вместе с тем требования, предъявляемые к содержанию, вырабатываемых в процессе правотворчества, законодательных актов, по мнению В.С. Афанасьева и И.Ю. Остапович, сводятся к следующему:

1) соответствие норм права прогрессивно развивающимся общественным отношениям, социальным интересам и потребностям;

2) правильность определения необходимости правовой регламентации тех или иных общественных отношений;

3) законность самих нормативных актов, их соответствие нормам международного права, конституции, другим вышестоящим актам, соответствие норм права принятым в обществе нормам морали, обычаям, идеям добра, справедливости, гуманизма, общечеловеческим ценностям, ясность, понятность, доступность правовых предписаний;

4) отсутствие противоречий между нормами права;

5) их систематизированность;

6) наличие необходимых служебных норм, характер юридических санкций $^{643}$. Наполнение в процессе правотворчества нормативных правовых актов указанными качественными свойствами задача исключительно сложная, поскольку требует от субъектов правотворчества не только глубокого познания регулируемых общественных отношений и средств правового инструментария, но и преодоления давления со стороны вездесущего лобби, заинтересованного в ином правотворческом решении.

Качество правотворчества - это воплощение в нормах права истинных (реально существующих) потребностей общественных отношений в правовом урегулировании. Степень такого воплощения может быть различной, то есть иметь определенную градацию, отражающую целевую

\footnotetext{
${ }^{642}$ Власенко Н.А. Разумность, право, правотворчество // Юридическая техника. - 2012. №6. - C. 125.

${ }^{643}$ Остапович И.Ю. Сущность и особенности юридической формы воздействия на правотворчество // Мир науки, культуры, образования. - 2011. - №4 (29). - С. 294.
} 
направленность правотворчества, его надежность, законченность. С учетом этого можно выделить три основных вида качества правотворчества:

1) актуализированное (приближенное), когда нормативные правовые акты (нормы, институты права) издаются на злобу дня при решении насущных и уже неотложных правотворческих задач, что происходит, как правило, в спешке без серьезного изучения возможных проблем, связанные с их применением в настоящем и будущем;

2) гарантированное, когда нормативные правовые акты принимаются на основании тщательных, надежных исследований всех обстоятельств, влияющих на принятие правотворческого решения, а также с учетом прогнозирования последствий от его реализации;

3) целенаправленное, когда решается задача достижения не только необходимого правового регулирования общественных отношений, но одновременно и побуждения (или даже принуждения) к изменению существующих общественных отношений в нужную для государства сторону. Как справедливо отметил Д.А. Керимов, в ряде случаев правотворческие органы создают правовые нормы, способствующие возникновению и дальнейшему развитию таких отношений, которые отсутствуют в реальной действительности, но могут и должны существовать, так как содействуют прогрессу в жизни общества ${ }^{644}$. Однако, по нашему убеждению, предпосылками для этого все же должны служить наметившиеся тенденции в социально-экономической жизни общества, а также готовый к обновлению правовой менталитет народа. Если предлагаемый идеал не воспринимается обществом, то конфликтная ситуация неизбежна, «как она может быть неизбежна и при искажении этого идеала на практике, когда в нормах права провозглашается одно, а в действительности складываются совершенно иные правила поведения» ${ }^{645}$.

Имеющийся в литературе хронологический анализ статистики издания в Российской Федерации нормативных правовых актов ${ }^{646}$ показывает, что подавляющее большинство из них по своему качеству являются актуализированными. К их числу относятся даже такие крупные юридические акты как кодексы, а также основополагающие законы, регламентирующие финансовую, коммерческую, предпринимательскую деятельность и другие сферы экономики, которые по идее рассчитаны на длительное и стабильное применение. Низкое их качество вызывает необходимость не только постоянного изменения и дополнения содержащихся в них правовых норм, но даже и неоднократного полного обновления. Получается, что нормативные правовые акты создаются не путем научного постижения социально-правовой действительности, а методом проб и ошибок.

В юридической литературе порой отождествляются такие понятия как «эффективность», и «качество» правотворчества, хотя это совершен-

${ }^{644}$ Керимов Д.А. Свобода, право и законность в социалистическом обществе. - М., 1960. C. 122 .

${ }^{645}$ Скоробогатов А.В., Краснов А.В. Указ. соч. - С. 164.

${ }^{646}$ Рыбаков В.А. Указ. соч. - С. 652-653. 


\section{Правотворчество в Российской Федерации}

но различные по содержанию термины. Категория «качество» по «Словарю русского языка» - это совокупность существенных признаков, свойств, особенностей, отличающих предмет или явление от других и придающих ему определенность. И в то же время - это важный признак, показывающий достоинства чего-либо. Понятие «эффективность» характеризуется как действенность использования чего-либо, возможность достижения желаемого эффекта ${ }^{647}$. С учетом этого, качество правотворчества отражает его внутреннюю, содержательную сторону, а эффективность - внешнюю, показывающую возможности реализации его предписаний в процессе правоприменения. Для выработки качественного правотворческого решения необходим комплекс мер правового и научного характера по созданию соответствующего уровня норм права, тогда как его эффективность достигается за счет специальных механизмов по их реализации. Эффективность обеспечивает реализуемость норм права независимо от их качества, тогда как некачественное правотворчество исключает его эффективность, даже если реализуются созданные им предписания.

Следует также учитывать, что качественное правотворчество - понятие комплексное, которое выходит за рамки выработки текста норм права, с помощью которых, в конечном счете, и регулируются общественные отношения. Качество правотворчества достигается путем последовательного поэтапного научно обоснованного наполнения его свойствами, придающими ему потенциальную возможность создавать правовые нормы на уровне лучших образцов. Важнейшим является первоначальный этап, когда происходит сбор информации, проводятся расчеты и социологические исследования, оценка вариантов решения и выбор лучшего из них. Именно на этой стадии начинается процесс придания правотворчеству качественных свойств, закладываются основы будущего объективно обоснованного правового решения. Здесь критериями качества являются степень правильности определения потребности общественных отношений в правовом урегулировании, выбор научно обоснованных правовых средств и методов для этого, наличие возможности проведения контроля за ходом применения правотворческих решений.

Правотворчество обладает гибкой системой повышения качества нормативных правовых актов в процессе их выработки, что обеспечивается за счет поэтапного обсуждения, проведения экспертиз, внесения многочисленных изменений и дополнений в их тексты с привлечением общественности, ученых и юристов - практиков. И важно то, что работа над повышением качества правотворческой продукции не прекращается вплоть до отмены того или иного устаревшего нормативного правового акта.

Наиболее рациональный подход повышения качества правотворчества состоит в определении научно обоснованного набора методов при-

${ }^{647}$ Ожегов С.И. Словарь русского языка. - М., 1990. - С. 272, 910. 
дания ему все более совершенных свойств и достоинств на каждом его этапе:

1) при изучении наличия объективной потребности общественных отношений в правовом урегулировании;

2) при выработке текста норм права;

3) при осуществлении процедур, связанных с их принятием;

4) в процессе контроля за ходом реализации норм права;

5) при мониторинге результатов правоприменения. Повышению качества будет способствовать и высказанное в юридической науке предложение о необходимости создания современной научно-обоснованной концепции, позволяющей планировать развитие российского законодательства, с определением в нем перечня приоритетных законов на ближайшую перспективу, последовательности их принятия, исходя из интересов и потребностей населения и государства ${ }^{648}$.

Все это обусловит создание системы непрерывного обеспечения качества правотворчества с момента обнаружения потребности в урегулировании общественных отношений нормами права и до момента прекращения действия этих норм.

Таким образом, качество правотворчества - это важнейший критерий воплощения в нормах права потребностей общественных отношений в правовом урегулировании. На качество правотворчества воздействуют многие обстоятельства объективного и субъективного характера. Проведенное исследование показывает, что в настоящее время быстрого и кардинального повышения качества правотворчества осуществить невозможно в силу объективных причин. Однако, если целенаправленными действиями в плановом порядке постепенно устранять те объективные причины, которые не требуют радикальных изменений правовой системы, сложившейся в стране (например, системообразующего характера), то положительный сдвиг несомненно произойдет. Для этого требуется не только политическая воля законодателей, но и огромный совместный труд ученых, практических работников в сфере юриспруденции и субъектов правотворчества.

${ }^{648}$ Борисов А.С., Меркулов П.А. Указ. соч. - С. 97. 


\section{§4.7. ПОНЯТИЕ И ОСОБЕННОСТИ ОТРАСЛЕВОГО ПРАВОТВОРЧЕСТВА}

Формой выражения правотворческой деятельности являются нормативные правовые акты и их правовые нормы, которые находят свое официальное юридическое определение в правовой системе государства. Содержание нормативных правовых актов вытекает из объективных и субъективных потребностей общества, которые, в основном, и предопределяют законодательную политику. Но правотворческий процесс, связанный с формированием отраслевого правотворчества, осуществляется в ходе серьезного противостояния политических, социальноэкономических и других интересов различных классов, групп населения и находящихся у власти, руководящих обществом, элит ${ }^{649}$. В одних случаях, когда интересы противостоящих сторон совпадают, правотворческие решения в максимальной степени отражают объективные потребности правового регулирования сложившихся общественных отношений, а в других, - полностью зависят от соотношения действующих политических сил. Это значит, что правотворческие решения принимаются под воздействием и субъективных факторов, отражающих интересы одной из противостоящих сторон.

Таким образом, отраслевое правотворчество связано не только непосредственно с выработкой норм права, правовых институтов и нормативных правовых актов, но и с отражением в них правовыми средствами субъективных потребностей определенных политических сил.

Трудность формирования отраслевого правотворчества состоит и в том, что субъекту правотворчества необходимо одновременно учитывать многие обстоятельства, влияющих на качество и эффективность правотворческих решений:

1) свойства общественных отношений, подлежащих правовому урегулированию, их способность функционировать в определенных границах, очерченных нормами права (они должны обладать признаком норморегулируемости);

По мнению С.Г. Соловьева, общественные отношения должны обладать следующими свойствами:

a) это внешне выраженные акты поведения людей;

б) это волевые целенаправленные отношения;

в) это устойчивые типичные повторяющиеся отношения, поскольку единичные или немногочисленные акты поведения людей не дают основания для возникновения норм права;

г) они поддаются контролю, иначе не будет возможности определить соответствует ли поведение субъекта установленным правовым предписаниям;

${ }^{649}$ См. подробнее: Нашиц А. Правотворчество: теория и законодательная техника. - М., 1974. - C. $100-101$. 
д) они должны предполагать возможность выбора из нескольких вариантов поведения. Но даже обладая указанными свойствами, общественные отношения должны объективно нуждаться в правовом регулировании в силу их социальной значимости и невозможности упорядочения иными социальными нормами ${ }^{650}$;

2) пригодность избранных правовых средств конкретной отрасли права для целей правового регулирования. Это означает их нормопригодность, свидетельствующая о возможности, подлежащих применению норм права, к урегулированию определенных общественных отношений.

3) способность самих органов правотворчества к изданию необходимых правовых моделей для правового регулирования общественных отношений, что можно назвать нормоспособностью;

4) закрепление в нормах отраслевого права ее основополагающих принципов, задач, терминологического аппарата и целостной непротиворечивой системы нормоположений, направленных на урегулирование определенной сферы сходных между собой общественных отношений (признак нормозакрепленности);

5) возможность реализации издаваемых нормативных правовых актов (норм права) в той интерпретации, которая дается правотворческим органом $^{651}$. Для этого необходимо, чтобы правотворческие решения базировались на точном знании того, насколько эффективны существующие правовые установления, в чем причины их недостаточной эффективности, каковы, следовательно, пути издания действенных, поддающихся исполнению нормативных правовых актов ${ }^{652}$;

6) иерархичность и системность правотворческих решений. Иерархия нормативных правовых актов предполагает последовательность их расположения от низших видов к высшим с учетом юридической силы, а также соподчиненности по отношению к иным нормативным правовым актам. Системность - это гармоничное согласование всех норм, составляющих нормативный правовой акт, между собой и правовыми нормами актов действующего законодательства. Это означает, что каждое правотворческое решение должно органично войти в единую правовую систему ${ }^{653}$. Из этого следует, что издаваемый нормативный правовой акт (норма права) в обязательном порядке должен занять свое, присущее только ему место в правовой системе страны.

Важное содержательное значение имеет и правильный выбор вида нормативного правового акта для урегулирования общественных отношений каждой отрасли права. Суть этой проблемы состоит в следую-

\footnotetext{
${ }^{650}$ Соловьев С.Г. Понятие предмета правового регулирования и его взаимосвязь с другими юридическими категориями // Вестник Пермского университета. - 2012. - №1(15). - С. 47-78.

${ }^{651}$ См. подробнее: Марченко М.Н. Проблемы теории государства и права. - М., 2013. C. 677.

${ }^{652}$ Миренский Б.А. Методологические основы и методы совершенствования законодательства. - Нукус, 1990. - С. 101-102.

${ }^{653}$ Вишневский А.Ф. Теория и практика подготовки проекта нормативного правового акта / А.Ф. Вишневский, В.Н. Дмитрук. - Мн., 2005. - С. 48.
} 
щем. Первичное урегулирование общественных отношений отраслевого масштаба должно быть осуществлено в рамках законодательного акта. Иной подход исключается. Следовательно, избранный вид законодательного акта должен позволять наиболее полно напрямую урегулировать общественные отношения либо без необходимости их последующей конкретизации в актах подзаконного правотворчества, либо свести их издание к минимуму. Решается эта проблема путем оценки возможностей издания кодифицированного нормативного правового акта или в иной юридической форме, если достигается тот же результат.

Отраслевую специфику отражают и методы правового регулирования, поскольку они зависят от регулируемых общественных отношений. Те отрасли права, общественные отношения которых строятся на координации целей и интересов сторон во взаимоотношении между ними, регулируются диспозитивным методом, допускающим выбор поведения участников правоотношений. К числу таких отраслей права относятся частно-правовые, - гражданское, семейное, трудовое, предпринимательское и др. А отрасли права, общественные отношения которых основаны на соблюдении субординации между их участниками, регулируются императивным методом, не допускающим выбора поведения субъектов правоотношений, это: конституционное право, уголовное право, административное право и другие отрасли права.

На основании изложенного можно сделать следующие выводы:

1. Отраслевое правотворчество - это целенаправленная деятельность уполномоченных субъектов правотворчества по изданию нормативных правовых актов необходимой юридической силы для обеспечения правового регулирования конкретной сферы однородных общественных отношений как единого систематизированного блока норм права, правовых институтов и подотраслей права.

2. Сложность формирования отраслевого правотворчества состоит в том, что правотворческий орган должен одновременно учитывать многие обстоятельства, относящиеся к форме и содержанию правотворческого решения, которые к тому же имеют объективный и субъективный характер. 


\section{§4.7.1. ПРАВОТВОРЧЕСТВО В СФЕРЕ КОНСТИТУЦИОННОГО ПРАВА}

В теории правотворчества мало рассматриваются вопросы, связанные с нормотворческим формированием отраслей права. В том числе это касается и конституционного правотворчества. Объясняется данный феномен тем, что:

1) указанная сфера отношений недостаточно урегулирована нормами законодательства;

2) правотворчество осуществляет немногочисленная группа уполномоченных на то субъектов, что порождает иллюзию их профессионализма и возможности обходиться без скрупулезной регламентации нормотворчества;

3) научный аппарат, отражающий специфику правотворчества, пока еще разработан слабо;

4) отсутствует эффективная связь между наукой о правотворчестве и деятельностью субъектов правотворчества ${ }^{654}$, то есть наука и практика об одном и том же объекте сосуществуют в автономном режиме, хотя и разрабатывают единый пласт общественных отношений.

Таким образом, конституционное правотворчество следует понимать в двух аспектах:

1) в широком смысле, когда имеется в виду процесс формирования всей системы конституционного законодательства, то есть создания законодательных актов во исполнение Конституции РФ;

2) и в узком - при пересмотре ее положений и внесении в нее поправок (к главам 3-8). Конституционный Суд РФ в своем постановлении от 31.10 .1995 г. пришел к выводу, что внесение поправок в Конституцию РФ должно реализовываться в форме специального правового акта о конституционной поправке, имеющего особый статус и отличающийся как от федерального закона, так и от федерального конституционного закона ${ }^{655}$. Данное постановление Конституционного Суда РФ обусловило издание федерального закона «О порядке принятия и вступления в силу поправок к Конституции Российской Федерации» от 04.03.1998 г. (с изменениями и дополнениями от 8 марта 2015 года), которым регулируется порядок принятия поправок к главам 3-8 Конституции РФ $\Phi^{656}$.

Следует отметить, что указанные выше проблемы Конституции РФ возможно устранить путем внесения соответствующих поправок, поскольку это не связано с необходимостью изменения ее глав 1, 2 и 9.

Представляется, что в Российской Федерации происходит постепенное усиление общественного контроля за деятельностью представитель-

\footnotetext{
${ }^{654}$ См.: подробнее: Борисов А.С. Некоторые проблемы современного правотворчества в России / А.С. Борисов, П.А. Меркулов // Социум и власть. - 2015. - №3 (53). - С. 67.

${ }^{655}$ Постановление Конституционного Суда РФ от 31.10.1995 г. // Собрание законодательства Российской Федерации от 6 ноября 1995 г. №45. - Ст. 4408.

${ }^{656}$ С3 РФ [Электронный ресурс]. - Режим доступа: http://base.garant.ru/178225/
} 


\section{Правотворчество в Российской Федерации}

ных органов власти путем учреждения Общественной Палаты ${ }^{657}$, одной из задач которой является проведение экспертизы федеральных законов и проектов законов субъектов РФ, а также проектов нормативных правовых актов органов исполнительной власти РФ и проектов правовых актов органов местного самоуправления. Усиливается общественный контроль и за деятельностью органов власти, и с помощью созданного Общероссийского Народного Фронта. Это свидетельствует, что имеющиеся недостатки Конституции РФ в сфере закрепления принципа разделения властей в определенной степени нивелируются, хотя сама по себе на длительную перспективу данная проблема остается. И рано или поздно должна быть решена.

Основополагающим моментом конституционного правотворчества в узком смысле является научное обоснование целей и задач, которые, должны быть достигнуты в результате действия Конституция РФ. Для этого формируется система принципов конституционного правотворчества $^{658}$. В своей совокупности они должны отражать представление о Конституции РФ как о нормативном правовом акте высшей юридической силы, который является своеобразным признаком государственности, юридическим фундаментом государственной и общественной жизни, главным источником национальной системы права ${ }^{659}$. Это достигается за счет того, что в ней закрепляются и гарантируются государством основные права и свободы человека и гражданина, устанавливаются основы Конституционного строя, федеративное устройство Российской Федерации, а также структура и взаимодействие между собой представительной, исполнительной и судебной ветвей власти, статус и полномочия Президента и Правительства РФ и т. д.

Важно учитывать и тот факт, что конституционное законодательство осуществляет социальное регулирование между классами и различными слоями населения (вне зависимости от их экономических, национальных, религиозных и других отличительных особенностей) и тем самым создает правовую основу их сосуществования путем создания условий реализации их интересов и достижения общественного согласия без революций и потрясений.

Это сложное и, безусловно, приоритетное направление конституционного правотворчества, поскольку оно закрепляет принцип равноправия всех людей, в том числе их прав и свобод независимо от классовой и социальной принадлежности. И здесь важно обеспечить государству роль надклассового, беспристрастного регулятора общественных интересов, которое только и может осуществлять урегулирование возможных

\footnotetext{
${ }^{657}$ Федеральный закон от 04.04.2005. «Об общественной палате» // С3 РФ. - 2005. - №15. Ст. 1277.

${ }^{658}$ См. подробнее: Дерхо Д.С. Общие подходы к определению и структурированию руководящих начал (принципов) конституционного правотворчества // Апробация. - 2015. - №3 (30). - C. 92.

${ }^{659}$ Смоленский М.Б. Конституционное право: учебник для бакалавров / М.Б. Смолевской, М.В. Алексеева. - Ростов н/Д., 2013. - С. 45.
} 
конфликтных ситуаций в стране. Как справедливо пишет Г.В. Мальцев «при конструировании институтов, предназначенных регулировать конфликты между участниками будущих правовых отношений, определенно чувствуется невысказанная в тексте закона, но вполне уловимая «симпатия законодателя» к одной из сторон. Внешне она выражается в мелких процедурных деталях, созданием определенных препятствий для одних и небольших уступках для других» ${ }^{660}$.Такой подход совершенно недопустим. Конкретизация конституционных норм должна быть скрупулезно точной, создающей реальные возможности их реализации без всяких конфликтов на равноправной основе всех заинтересованных участников.

Однако это не значит, что конкретизация предписаний Основного закона должна исключить возможность саморегуляции общественных отношений. Совсем наоборот. Регулируя основные сферы жизнедеятельности государства и общества, что и должно быть исключительно выверенным и оправданным процессом, Конституция РФ сохраняет широкую возможность развития саморегуляции отношений в области экономической, политической, культурной, социальной и межличностной деятельности. Именно такой подход и должен отличать конституционное правотворчество. Саморегуляция общественных отношений является способом осуществления субъектами складывающихся правоотношений принадлежащих им прав и свобод по своему усмотрению, а также эффективным фактором снижения излишней нагрузки на государственные органы власти и судебную систему в процессе их деятельности. Одновременно это свидетельствует и о степени демократизации общества, способности разрешать возникающие конфликты и противоречия путем достижения консенсуса, что обуславливает его консолидацию, сплоченность. Процессы саморегуляции общественных отношений могут быть скорректированы субъектами законотворчества только в тех случаях, если они «не соответствуют интересам общества и государства» ${ }^{661}$. Это и происходит, когда осуществляется дополнение либо изменение конституционного законодательства.

Конкретизация конституционных норм осуществляется путем издания различных нормативных правовых актов: конституционных и обычных федеральных законов, указов Президента РФ, постановления Правительства РФ, решений Конституционного Суда. В процессе правотворческой деятельности по изданию указанных нормативных правовых актов всегда должен соблюдаться принцип верховенства Конституции РФ. Это значит, что ее предписания должны воплощаться в конкретизирующем акте абсолютно единично без каких-либо изменений, полностью исключая любую оправдывающую мотивацию (например, из желания повышения качества деятельности того или иного государственного органа). В случае необходимости придания конституционным нормам

\footnotetext{
${ }^{660}$ Мальцев Г.В. Социальные основания права. - М., 2007. - С. 399.

${ }^{661}$ Соловьев С.Г. Понятие предмета правового регулирования и его взаимосвязь с другими юридическими категориями // Вестник Пермского университета. - 2012. - Вып. 1 (15). C. 49 .
} 


\section{Правотворчество в Российской Федерации}

более удачных формулировок и тем более расширения полномочий органов власти, либо, наоборот, их ограничения, требуется принятие поправки к Конституции РФ.

Конституционное правотворчество следует рассматривать в двух аспектах:

1) в узком смысле, как деятельность по совершенствованию Основного закона, которая в современных условиях нуждается в регламентации и пред проектной ее стадии, а также в издании закона о Конституционном Собрании, которое имеет исключительное право на пересмотр первой и второй главы Конституции РФ;

2) в широком смысле - деятельность по конкретизации конституционных предписаний с целью формирования эффективной правовой системы, что придаст конституционным нормам конкретный юридический потенциал их реализуемости.

\section{\$4.7.2. УГОЛОВНОЕ ПРАВОТВОРЧЕСТВО}

Недостаточное теоретическое осмысление и отсутствие сформированной научной базы в области правотворческой деятельности оказывает существенное влияние на весь правотворческий процесс, в том числе и на уголовное правотворчество.

В юридической литературе справедливо отмечается о бессистемности развития законодательства, недопустимо высокой скорости изменений и дополнений, вносимых в уголовное законодательство ${ }^{662}$ (за 16 лет применения УК РФ в него было внесено более трех тысяч изменений и дополнений $\left.{ }^{663}\right)$, о необходимости кардинальной рационализации уголовного правотворчества ${ }^{664}$, об отсутствии стабильности правотворческой продукции ${ }^{665}$ и т. д. Все это так. Выявлена и проанализирована масса имеющих место факторов, порождающих указанные недостатки, что, безусловно, способствует повышению качества и эффективности правотворчества. Однако этого недостаточно. Пока что нет единого системного понимания ситуации, сложившейся в правотворчестве в целом и в области уголовного правотворчества в частности (впрочем, как и в любой другой отрасли российского права).

Имеется в виду оценка выявленных недостатков уголовного правотворчества с позиций общей теории правотворчества как единой юридической науки о правотворчестве. Такая оценка должна быть направлена не только на устранение конкретного недостатка, но и на устранение системообразующих факторов, генерирующих их, которые не учитыва-

\footnotetext{
${ }^{662}$ Соловьев О.Г. О нормативном закреплении основных требований и правил законодательной техники // Вестник ЯрГУ. Серия Гуманитарные науки. - 2010. - №4(14), - С. 43.

${ }_{663}$ Акутаев Р.М. Правовая культура сквозь призму современной правовой реальности // Российская юстиция. - 2013. - №2. - С. 65.

${ }^{664}$ Бондаренко О.В. Судебная практика и уголовное правотворчество. Автореф. дис. ... к.ю.н. - М., 2013. - С. 11 .

${ }^{665}$ См. Рыбаков В.А. Правотворчество в переходный период развития права // Юридическая техника. - 2015. - №9. - С. 653.
} 
ются в процессе правотворчества, но являющиеся постоянными источниками недостаточно продуманных и обоснованных правотворческих решений. Фактически за пределами научного познания в настоящее время остается огромная сфера правотворчества, связанная с его особенностями в различных отраслях права. Очевидно, что правотворчество в каждой отрасли имеет свою специфику. Это, к сожалению, не находит законодательного отражения, а также пока что не стало объектом пристального внимания науки.

И хотя не подвергается сомнению аксиома о том, что изменения норм уголовного кодекса обусловлены в первую очередь, объективными процессами, которые вытекают из непрерывной трансформации экономической, политической и социальной действительности в нашем обществе, имеются и другие факторы, которые оказывают влияние на качество правотворчества в данной отрасли права.

Правотворчество в сфере уголовного права характеризуется определенными особенностями, вытекающими из предмета и методов правового регулирования. При этом «непосредственной целью уголовного правотворчества является создание такого уголовного закона, который максимально отражал бы состояние и потребности общества и был бы способен эффективно воздействовать на регулируемые им общественные отношения» ${ }^{666}$. Это значит, что уголовное правотворчество имеет четкие качественные ориентиры, которые вытекают из объективных потребностей общества и которые должны обязательно учитываться наряду с его принципами. Правотворческое решение - это, прежде всего, форма выражения содержания правил регулирования общественных отношений, имеющая определенную специфику, выработанную практикой и юридической наукой. Содержание правотворческих решений всегда детерминированы потребностями общества, тогда как их юридическое закрепление в виде норм и институтов права в значительной степени носят субъективный характер.

Уголовное право, как юридическая наука, в определенной степени рассматривает особенности выработки норм права и правовых институтов своей отрасли ${ }^{67}$, что, по сути, вызывает необходимость научного познания не свойственных для него правотворческих проблем, относящихся к теории правотворчества.

Если исходить из того, что уголовное право есть совокупность юридических норм, определяющих задачи, принципы, основание и условия уголовной ответственности, а также преступность и наказуемость общественно опасных деяний, признаваемых преступлениями ${ }^{668}$, то в данном

\footnotetext{
${ }^{666}$ Непомнящая Т.В. Современная российская уголовная политика: проблемы правотворчества и правоприменения //Вестник Томского государственного университета. - 2015. №2 (16). - С. 86.

${ }^{667}$ Курс уголовного права. Общая часть / под ред. Н.Ф. Кузнецовой, И.М. Тяжковой. - Т. 1. - М., 2002. - C. 2.

${ }^{668}$ См. подробнее: Уголовное право. Общая часть / под ред. Н.И. Ветрова, Ю.И. Ляпунова. - М., 1997. - С. 11.
} 


\section{Правотворчество в Российской Федерации}

определении правотворческая функция не выделена в качестве приоритета этой науки.

Вместе с тем и теория правотворчества не может рассматривать вопросы выработки правотворческих решений в области уголовного права в отрыве от этой науки, поскольку в них отражаются проблемы правового регулирования данной отрасли права. Граница разделения научных интересов уголовного права и теории правотворчества определяется предметом правового регулирования, который находится в пределах их взаимодействия между собой. При этом издаваемые правотворческим органом нормы уголовного права, устанавливаются в результате определения какие общественно опасные деяния признаются преступлениями и какие за них следуют наказания. Одновременно с позиций теории правотворчества разрешается вопрос, почему необходимо то или иное общественно опасное деяние признать преступлением и почему за него требуется установить именно данное конкретное наказание.

Таким образом, правотворческие решения, хотя и принимаются в сфере уголовного права, они всегда вырабатываются на основании присущих теории правотворчества научных подходов и, выработанных ею, правотворческих правил, которые К.М. Хутов и И.В. Поликарпова разделяют на общие и специальные ${ }^{669}$.

По мнению указанных авторов к общим правилам формирования норм уголовного права относятся такие, как:

2) соответствие уголовно-правовых норм Конституции РФ и международному праву;

3) отсутствие противоречий между нормами уголовного права и иных отраслей права, единство их понятийного аппарата;

4) разделение и непротиворечивость материальных и процессуальных норм;

5) сосредоточение всех уголовно-правовых норм в едином уголовноправовом акте;

6) экономичность, емкость, компактность изложения нормативного материала в УК РФ;

7) включение в Уголовный кодекс всех новых уголовных законов.

К специальным относятся правила:

1) структуризации уголовного кодекса;

2) языкового оформления уголовно-правовых предписаний;

3) конструирования составов преступлений;

4) построения санкций уголовно-правовой нормы. 670

Предложенное деление правил формирования нормативных предписаний УК РФ на общие и специальные является достаточно условным, поскольку они применимы при создании любых иных правовых норм

669 Хутов К.М. Теоретические правила создания уголовно-правовых предписаний / К.М. Хутов, И.В. Поликарпова // Актуальные вопросы борьбы с преступлениями. - 2015. №2. - С. 39.

${ }^{670}$ Там же. - C. $39-41$. 
отраслевого правотворчества. Правильнее будет, если правила выработки норм уголовного права разделить на те, которые отражают специфику правового регулирования и те, которые связаны с юридической техникой их оформления, то есть правила, относящиеся к содержанию уголовноправовых норм и юридической формы их закрепления.

8) Общие правила выработки уголовно-правовых предписаний, прежде всего, связаны с решением вопроса о целесообразности и необходимости криминализации определенной группы общественно опасных деяний и отнесения их к числу преступлений ${ }^{671}$. Для решения данного вопроса требуются объективные и субъективные условия установления уголовного правового запрета. К числу объективных П.С. Дагель относил:

1) степень общественной опасности деяния;

2) степень распространенности его в обществе;

3) невозможность успешной борьбы с общественно опасными деяниями менее репрессивными, не уголовно-правовыми мерами.

К субъективным условиям ученый относил:

1) осознание объективных потребностей общества в криминализации выявленных общественно опасных деяний;

2) наличие для этого определенного уровня общественного правосознания ${ }^{672}$.

Более широкий подход в понимании условий, требуемых для установления уголовно-правового запрета, у А.И. Коробеева. По мнению данного ученого, все факторы, служащие основаниями установления уголовно-правового запрета, в зависимости от их содержания объединяются в три группы:

1) юридико-криминологические;

2) социально-экономические;

3) социально-психологические.

В группу юридико-криминологических оснований входят:

1) степень общественной опасности деяния;

2) относительная распространенность деяний и их типичность;

3) динамика деяний с учетом причин и условий, их порождающих;

4) возможность воздействия на эти деяния уголовно-правовыми средствами при отсутствии возможности успешной борьбы менее репрессивными средствами;

5) возможности системы уголовной юстиции.

В группу социально-экономических оснований входят:

1) причиняемый деяниями материальный и моральный ущерб;

2) отсутствие возможности побочных последствий уголовноправового запрета;

3) наличие материальных ресурсов для реализации уголовноправового запрета.

\footnotetext{
${ }^{671}$ См. подробнее: Плохова В.И. Криминологическая и правовая обоснованность составов ненасильственных преступлений против собственности. Дис. ... д-ра юрид. наук. - Екатеринбург, 2003. - С. 20.

672 Дагель П.С. Условия установления уголовной наказуемости // Правоведение. - 1975. №4. - C. 69-70.
} 


\section{Правотворчество в Российской Федерации}

Группу социально-психологических оснований составляют: 1) определенный уровень общественного правосознания и психологии; 2) исторические традиции ${ }^{673}$.

Следует также учитывать и такой фактор формирования норм уголовного права как политика государства в области уголовного правотворчества. Как справедливо заметил А.П. Мазуренко, «в результате проводившейся в нашей стране на протяжении последних десятилетий не вполне эффективной правотворческой политики сложилось противоречие между реальными общественными отношениями и существующей системой российского права, признанной регулировать эти отношения» ${ }^{674}$.

Представляя собой субъективный фактор в уголовном правотворчестве, правотворческая политика отражает не только субъективные потребности в упорядочении общественных отношений, но и вполне материальные интересы господствующего класса предпринимателей и правящей элиты государства. Достаточно вспомнить ситуацию с уголовным наказанием в виде конфискации имущества, которое без каких-либо объективных причин исключили из УК РФ еще в 2003 г., несмотря на бурный протест большинства виднейших российских ученых и практиков $^{675}$.И таких примеров в уголовном правотворчестве (особенно в сфере экономических преступлений) имеется большое количество.

К числу общих факторов, которые следует учитывать при разработке норм права в сфере уголовного правотворчества, относится и выработка концепции предлагаемого законопроекта (ст. 105 Постановления ГД ФС РФ от 22.01.1998 №2134-II ГД).

Концепция разрабатываемого нормативного правового акта создает научную основу претворения в жизнь целей и задач законодателя в области уголовного права, поскольку в ней очерчивается круг отношений, которые будут урегулированы этим нормативным актом, а также дана их характеристика и обоснование необходимости издания предлагаемого законопроекта ${ }^{676}$. Концепция фактически предопределяет и содержание, и ракурс правового регулирования, создает четкое представление какие отношения должны быть урегулированы и почему. Ошибочное концептуальное определение круга подлежащих урегулированию общественных отношений, степени общественной опасности деяния и предлагаемых способов зашиты в дальнейшем сказывается на качестве уголовного законопроекта. Указанные аспекты концепции нормативного правового акта должны быть максимально обоснованными в результате проведенных научных исследований, убедительно свидетельствующих о пра-

\footnotetext{
${ }^{673}$ Полный курс уголовного права: в 5 т. / под ред. А.И. Коробеева. - Т. 1. - СПб., 2008. C. 106-107.

${ }^{674}$ Мазуренко А.П. Правотворческая политика как фактор модернизации правотворчества в России. Автореф. дис. ... д-ра юрид. н. - Саратов, 2011. - С. 19.

${ }^{675}$ Соловьев О.Г. Инструментарий правотворческой техники нуждается в законодательном оформлении // Законы России: опыт, анализ, практика. - 2012. - №10. - С. 95-98.

${ }^{676}$ Белоусов С.А. Правотворчество и законодательный дисбаланс: диалектика взаимосвязи // Вестник ВГУ. Серия Право. - 2015. - №1 . - С. 67.
} 
вильности и объективной необходимости предлагаемых правотворческих решений.

Сущность проектируемого решения проверяется путем оценки ряда важнейших криминологических показателей: социальной вредоносности деяния, его относительной распространенности и типичности, а также динамики деяния с учетом причин и условий, его порождающих. 677

Общественная опасность деяния - это материальный признак преступления, раскрывающий его социальную сущность ${ }^{678}$. Общественная опасность деяния в формальных и материальных составах преступлений проявляется по-разному. В каждом конкретном случае законодатель обязан оценить общественную опасность деяния с точки зрения вредоносности для общества, государства и граждан, необходимости признания его в качестве преступления. Рассматривая то или иное деяние как общественно опасное, государство должно правильно установить тот вред, который может быть причинен под его воздействием, сопоставить ценность охраняемого объекта и тех последствий, которые могут наступить в результате действия уголовно-правовой нормы, выработанной в целях его защиты.

Действующий УК РФ содержит нормы, в которых общественная опасность деяния определяется без учета данного требования, что обуславливает возникновение определенных препятствий развития экономики страны, вместо того, чтобы всемерно стимулировать его. Так, ст. 171 УК РФ предусматривает уголовную ответственность за незаконное предпринимательство.

Наказание может быть назначено (в зависимости от вида этого преступления) не только в виде штрафа, но даже лишения свободы сроком до пяти лет. Ошибочность данного правотворческого решения не вызывает сомнений. Имеется в виду применение такой меры наказания, как лишение свободы. Изначально было понятно, что если лишать свободы предпринимателя, пусть и незаконно ведущего свой бизнес, это приведет к закрытию успешного предпринимательства. Для экономики совершенно невыгодный вариант. Следовательно, напрашивалось вполне логическое решение: предпринимателя оштрафовать, официально легализовать его деятельность и заставить платить налоги. Хотя можно таких активных предпринимателей наказывать еще мягче: официально легализовывать их бизнес и взыскивать с них налоги за определенный срок незаконной деятельности. И пусть продолжают работать. Но правотворческое решение в данном случае не учитывало ни интереса предпринимателей, ни интересы общества и государства. Списать эту правотворческую ошибку на изменившиеся экономические условия общества тоже невозможно, поскольку указанная уголовно-правовая норма была выработана в условиях действия рыночной экономики. И таких примеров

\footnotetext{
${ }^{677}$ Иванчин А.В. Внутренняя и внешняя законодательная техника в структуре уголовного правотворчества. Монография. - Рязань, 2014. - С. 10.

${ }^{678}$ См. подробнее: Курс уголовного права. Общая часть / под ред. Н.Ф. Кузнецовой, Н.М. Тяжковой. - Т. 1. - М., 2002. - С. 225.
} 


\section{Правотворчество в Российской Федерации}

можно привести множество, поскольку ошибочность некоторых правотворческих решений не вызывает сомнений.

В подобных случаях законодатель действует по шаблону: допустил нарушение установленных правил поведения или деятельности - получай наказание. Как это может в дальнейшем повлиять на ту же экономику или социальную сферу не просчитывается. Поскольку подобные расчеты лежат вне пределов науки уголовного права и пока еще не введены в орбиту интересов общей теории правотворчества, которая могла бы их осуществлять.

Сказанное позволяет заключить, что одной из причин выработки нестабильных правотворческих решений, является отсутствие научно обоснованного выявления степени общественной опасности потенциального негативного явления (экономического, политического, социального, культурного и т. д.) и ошибочное зачисление его в разряд таких, регулирование которых должно осуществляться именно нормами уголовного права.

Теория уголовного права под общественной опасностью понимает «определенное объективное антисоциальное состояние преступления, обусловленное всей совокупностью его отрицательных свойств и признаков и заключающее в себе реальную возможность причинения вреда (ущерба) общественным отношениям, поставленным под охрану закона» ${ }^{679}$. Степень общественной опасности определяется величиной ущерба, характером вины, стойкостью низменных мотивов и целей преступления и т. д. ${ }^{680}$.

Общественную опасность представляют не только уголовно наказуемые деяния, но и деликты, а также административные и дисциплинарные проступки. Однако законодатель не всегда находит правильные критерии отличия между ними, особенно если в законотворчестве избирает карательный уклон ${ }^{681}$. Это приводит к тому, что в нормах уголовного права не всегда учитываются такие обстоятельства как незначительность общественно опасного деяния, совершение его впервые, раскаяние виновного в содеянном, устранение причиненного вреда, примирение сторон, возможность исправления виновного без применения мер уголовного наказания и т. д.

Объективная необходимость в урегулировании тех или иных общественных отношений именно нормами уголовного права определяется такими критериями как социальная значимость этих отношений, а также невозможностью их урегулирования с помощью других социальных

\footnotetext{
679 Ляпунов Ю.И. Общественная опасность деяния как универсальная категория советского уголовного права. - М., 1989. - С. 39.

${ }^{680}$ См. подробнее: Уголовное право / под ред. Н.И. Ветрова, Ю.И. Ляпунова. - М., 1997. C. 128 .

${ }^{681}$ Сапун В.А. Правотворчество и законотворчество: стратегия и тактика формирования права и закона / В.А. Сапун, Я.В. Турбова // Юридическая техника. - 2015. - №9. - С. 680.
} 
норм $^{682}$. В уголовном правотворчестве иногда эти критерии не учитываются, что приводит к изданию необоснованно жестких (а иногда и наоборот) мер наказания.

В процессе выработки правотворческого решения в области уголовного права законодатель зачастую учитывает только полученный результат от функционирования действующих норм права, тогда как надо исходить, прежде всего, из их целесообразности, объективной необходимости. Такие правотворческие решения не выражают весь спектр хорошо продуманных и взвешенных оценок последствий, возникающих в результате их реализации, который должен учитываться в действительности. Отсюда возникает и непрерывная череда изменений и дополнений норм уголовного права: выявляется и устраняется один недостаток потом второй, третий и т.д.

Уголовное правотворчество нуждается в проведении научного прогноза ожидаемых положительных и отрицательных последствий, которые возникают в результате издания данного конкретного правотворческого решения. Их оценка должна лежать в основе выбора оптимального варианта правового регулирования всякой социально-экономической проблемы. По справедливому определению А.П. Мазуренко прогнозирование на уровне отдельной отрасли права должно вестись на этапе разработки и составления планов развития этой отрасли. Прогнозирование правового института осуществляется путем оценки состояния его элементов в настоящее время и ожидаемых тенденций развития в будущем ${ }^{683}$. В нашем случае прогнозирование возможных последствий от действия издаваемой в ходе уголовного правотворчества нормы права представляет собой научное предвидение ближайших и отдаленных результатов действия законодательных актов, их эффективности, а также ожидаемых изменений в формах и методах правового регулирования ${ }^{684}$. Прогнозирование - это системное исследование определенных общественных отношений на предмет возможности их защиты нормами уголовного права, а также оценка эффективности определенной модели правовой нормы, разработанной законодателем.

Анализ вносимых в статьи УК РФ изменений и дополнений показывает, что в процессе уголовного правотворчества прогнозирования наступления возможных последствий от действия этих норм права не осуществлялось, что с неизбежностью и обусловило в дальнейшем их неоднократную корректировку.

Уголовное законодательство должно приниматься с расчетом на максимально возможную продолжительность действия во времени за счет

\footnotetext{
${ }^{682}$ Соловьев С.Г. Понятие предмета правового регулирования и его взаимосвязь с другими юридическими категориями // Вестник Пермского университета. - 2012. - № 1 (15). - С. 48. ${ }^{683}$ Мазуренко А.П. К вопросу о методах правотворческой политики // СПС Консультант Плюс.

${ }^{684}$ Полелина С.В. Правотворческая политика // Российская правовая политика. Курс лекций / под ред. Н.И. Матузова, А.В. Малько. - М., 2003. - С. 292-293.
} 


\section{Правотворчество в Российской Федерации}

всесторонней продуманности, а не за счет вносимых изменений ${ }^{685}$. В идеале изменения и дополнения в него должны быть обусловлены изменяющимися общественными отношениями, а не допущенными многочисленными ошибками законодателя.

К числу общих особенностей формирования норм уголовного права следует отнести и учет последствий, которые могут возникнуть в смежных (с регулируемыми) общественных отношений, как принимаемый уголовно-правовой акт (норма права) повлияет на их состояние и развитие.

Например, как он будет воздействовать на такие процессы как латентизация, коррупциогенность, рецидивность преступности, а также на раскрываемость, предусмотренных им преступлений

В юридической литературе отмечается, что высокая степень латентности преступности ставит на поверку дня необходимость изменения государственного подхода в борьбе с преступностью, которая в нынешних условиях должна быть реализована путем дифференциации усилий правоохранительных органов и всего общества. В этой связи С.М. Иншаков пишет: «На выявление тяжких и особо тяжких преступлений, которые дегуманизируют социальную жизнь и ставят под угрозу общественную и государственную безопасность, общество должно выделить дополнительные ресурсы. Борьба с этими преступлениями должна быть усилены и ужесточена. Значительная часть преступлений небольшой тяжести, вероятно, имеет смысл переоценить с позиций декриминализации. Процедуру досудебного и судебного производства по уголовным делам в отношении лиц, обвиняемых в совершении преступлений средней тяжести, целесообразно существенно упростить, а меры государственного реагирования на такого рода деяния сделать более экономичными и гуманными» ${ }^{686}$.

Указанный путь снижения латентизации преступности действительно имеет перспективу на реализацию. Здесь мы имеем, с одной стороны, декриминализацию преступлений, которые чаще всего и остаются вне поля зрения правоохранительных органов, а с другой, усиление работы по борьбе с тяжкими и особо тяжкими преступлениями, что также является основой сокращения их латентности. Качество реализации указанного подхода сокращения латентности преступлений в Российской Федерации полностью зависит от выработки и принятия хорошо просчитанных правотворческих решений.

Таким образом, на основании изложенного, можно сделать следующие выводы, связанные с выработкой правотворческих решений:

1. Действующее уголовное законодательство необходимо гуманизировать в отношении лиц, совершивших преступления небольшой тяжести, а также в отношении лиц, совершивших преступления средней тяжести при смягчающих обстоятельствах. Лица, совершающие тяжкие и

\footnotetext{
${ }^{685}$ Рыбаков В.А. Правотворчество в переходной период развития права. Выступление на круглом столе // Юридическая техника. - 2015. - № 9. - С. 654.

${ }^{686}$ Иншаков С.М. Латентная преступность как показатель эффективности уголовной политики // Российский следователь. - 2008. - №14. - С. 24.
} 
особо тяжкие преступления, рецидивисты и коррупционеры должны нести уголовную ответственность по принципу все более строгой их изоляции от общества после совершения ими каждого нового преступления.

2. Для лиц, отбывших наказание в виде лишения свободы, по их желанию, государство должно законодательно предусмотреть право на адаптацию к условиям жизни на свободе, гарантируя им определенные условия к существованию.

3. В процессе разработки норм УК, а также при их изменениях и дополнениях необходимо обязательное научное обоснование для правильного определения круга, подлежащих урегулированию, общественных отношений, степени общественной опасности посягательств на них, адекватности мер наказания, прогнозирования возможных последствий от действия этих норм (положительных и отрицательных: латентность, рецидив, коррупциогенность, высокая сложность их раскрываемости).

4. В процессе выработки норм уголовного права следует стремиться к снижению количества бланкетных диспозиций, снижению судейского усмотрения при установлении видов и размеров наказания, а также к точности и ясности юридических терминов, доступности понимания текстов установленных видов преступлений.

5. Уголовное законодательство должно усилить охрану собственности, интересов предпринимателей, экономическую основу государства путем радикального пересмотра действующих норм права. За экономические преступления необходимо установить в основном экономическую ответственность, а лишение свободы - только в случае совершения их с насилием, вымогательством, рейдерством.

\section{§4.7.3. ПРАВОТВОРЧЕСТВО В СФЕРЕ ГРАЖДАНСКОГО ПРАВА}

В теории правотворчества пока меньше всего уделяется внимания научному постижению проблем, связанных с выработкой норм права и правовых институтов в области гражданского права. Правотворческие решения в этой отрасли права принимаются эмпирическим путем без теоретического обоснования, что снижает их качество и приводит к необходимости постоянного изменения и дополнения действующего законодательства, вызванных, как правило, субъективными, а не объективными факторами. «Наука существенно отстает от потребностей правовой политики и от правовой жизни, которые «идут» во многом на ощупь, двигаются методом «проб и ошибок»... Отсюда и шараханье властных структур, которые не имеют в своей основе надежных и национально выверенных правовых ориентиров, прогрессивной юридической идеологии, базирующейся на общецивилизационных ценностях и особенностях российской правовой жизни» ${ }^{687}$.

${ }^{687}$ Малько А.В. Правовая политика - категория XXI века и ее роль в Евразийской интеграции // Евразийский юридический журнал. - 2014. - №4 (71). - С. 11. 


\section{Правотворчество в Российской Федерации}

Критериями качества правотворческих решений в сфере гражданского права являются такие показатели:

1) соответствие избранных норм права регулируемым общественным отношениям, отражение в них объективно существующих потребностей в их юридическом закреплении;

2) полнота и точность правового урегулирования, исключающая как наличие пробелов в праве, так и дублирование, избыточность нормотворчества;

3) законность правотворческих решений, их соответствие Конституции и законодательным актам РФ, нормам международного права, а также принятым в обществе нормам морали, обычаям, идеям добра, справедливости, гуманизма, общечеловеческим ценностям ${ }^{688}$;

4) гармоническое включение выработанных норм права и правовых институтов в целостную нормативную систему гражданского права;

5) отсутствие противоречий между нормами права как в сфере гражданского права, так и с нормами права иных отраслей права;

6) отражение в нормах гражданского права имеющейся взаимосвязи с другими отраслями права, единство их понятийного аппарата;

7) максимальное сосредоточение норм права, правовых институтов и подотраслей гражданского права в едином кодифицированном акте;

8) закрепление приоритета ГК РФ в процессе регулирования общественных отношений при издании норм гражданского законодательства;

9) выразительность юридического языка, ясность и доступность правовых предписаний, точность словесного обозначения юридических понятий ${ }^{689}$.

Вместе с тем, указанные критерии качества правотворческих решений по сути являются результатом научного познания подлежащих правовому регулированию общественных отношений и избранных форм их юридического выражения. Само научное познание представляет собой исследование социально-правовой реальности с целью упорядочения протекающих в ней процессов юридическими средствами. Оно состоит в последовательном теоретическом обосновании следующих параметров:

1) принадлежности исследуемых общественных отношений к числу тех, которые необходимо регулировать именно нормами гражданского права;

2) выбора нужных правовых средств;

3) оценки возможных положительных и отрицательных последствий от действия избранных норм права;

4) их сочетаемость с иными правовыми нормами в достижении цели правового регулирования;

5) выбора метода правового регулирования;

6) оценки полноты правового регулирования и т. д.

${ }^{688}$ Остапович И.Ю. Сущность и особенности юридической формы воздействия на правотворчество // Мир науки, культуры, образования. - 2011. - №4 (29). - С. 294.

${ }^{689}$ См. подробнее: Туранин В.Ю. Юридическая терминология в российском законодательстве. - Белгород, 2009. - С. 15. 
Таким образом, определение критериев качества правотворческих решений гражданского права должно осуществляться в результате их теоретического обоснования (в настоящее время проводится на уровне эмпирического анализа правотворческим органом), что позволяет выявлять их лучшие варианты.

Выбор той или иной формы правового регулирования зависит от содержания регулируемых отношений, а также от других условий (принципов, целей, отрасли права), которые вместе взятые требуют от законодателя избрать для данных отношений именно такой, а не иной способ их юридического построения, чтобы сделать правовое регулирование наиболее эффективным, целесообразным, способствующим прогрессу, воплощению в жизнь гуманистических идеалов правового общества ${ }^{690}$.

Правовое регулирование в гражданском праве осуществляется в основном с помощью диспозитивного метода, то есть оно построено на координации целей и интересов сторон в общественном отношении, когда их субъекты обладают свободой установления взаимоотношений между собой. Императивный метод, основанный на обязывании и запрете совершения определенных действий, также используется в регулировании гражданско-правовых отношений, но в исключительных случаях, когда требуется ограничить поведение их участников, добиться от них выполнения взятых на себя обязательств либо защитить публичные интересы.

Учитывая это, можно говорить, что, в зависимости от метода правового регулирования, выработались некоторые стандарты правового выражения взаимодействия между участниками гражданско-правовых отношений, которые закрепляются в нормах права.

В теоретическом аспекте существующие модели нормативного закрепления имущественных отношений в сфере гражданского права, особенно с отражением их функционального назначения в регулировании рыночной экономики, недостаточно изучены. Это сказывается и на практике формирования эффективной системы гражданско-правовых норм, призванных стимулировать ее развитие. Законодатель, не имея четкой теории закрепления нормами гражданского права потребностей в области экономики, ориентируясь только на собственный опыт, используя не всегда оправданно рецепцию иностранного права, пока не сформировал качественную систему правовых норм, отвечающих запросам осуществляемых экономических реформ. Об этом свидетельствуют и многочисленные экономические правонарушения, часто совершаемые под прикрытием норм гражданского права. Практика применения действующего

ГК РФ в новых экономических условиях выявила недостаточную «завершенность в законе ряда классических гражданско-правовых, институтов, таких как недействительность сделок, создание, реорганизация и ликвидация юридических лиц, законные проценты, уступка требований и перевод долга, залог и т. д.» Обширная практика применения этого

\footnotetext{
${ }^{690}$ Черепахин Б.Б. К вопросу о частном и публичном праве. - М., 1994. - С. 34.
} 


\section{Правотворчество в Российской Федерации}

законодательства показала, что многие общие положения ГК нуждаются в дополнениях и детализации, отсутствие которых не может быть восполнено судебным толкованием ${ }^{691}$.

Однако решить данную проблему совершенствования ГК РФ без ее научного осмысления, без выработки научно обоснованного набора необходимых для этого правовых средств невозможно.

Надежным способом закрепления потребностей рыночной экономики в нормах гражданского права является разработка их научных моделей, отражающих типичные виды имущественных правоотношений. Такие модели представляют собой идеализированный вариант регулирования гражданско-правовых отношений. Поскольку они отражают не реальную, а потенциально возможную экономическую ситуацию. По своей структуре идеализированная модель включает в себя полный набор элементов, которые необходимы для правового регулирования общественных отношений с учетом особенностей избранного для этого метода (диспозитивного или императивного). Например, в классическом виде идеализированной формой нормы права является построение ее структуры с указанием трех ее элементов - гипотезы, диспозиции и санации. Однако в реальной действительности нормы гражданского права не всегда имеют в своем нормативном закреплении полный их набор. Это обусловлено тем, что общественные отношения, подлежащие урегулированию нормами гражданского права, в силу использования диспозитивного метода, нуждаются лишь в законодательном закреплении диспозиции правовой нормы. Ее гипотеза (условия действия нормы) и санация за нарушение правил, установленных диспозицией, субъекты конкретных правоотношений устанавливают по обоюдному соглашению.

При таком подходе более важным становится не установленные каноны закрепления имущественных правоотношений в нормах права, а обеспечение экономической свободы в процессе их функционирования, что обусловливает необходимость отступления от идеализированной структуры нормы права и создания ее реального образца. Учитывая потребности рыночной экономики, требуется переосмыслить многие правовые институты гражданского права, научно обосновать их регулятивную способность, создать эффективную юридическую базу социально экономических преобразований в стране.

С учетом этих потребностей «Концепция развития гражданского законодательства Российской Федерации» предусматривает необходимость существенного обновления ГК РФ как системного характера, так и дальнейшего детального развития гражданского законодательства «путем восполнения обнаружившихся в нем пробелов превращения в общие нормы (генерализации) ряда имеющихся частных правил, пополнения законодательства новыми институтами, уточнения норм, допускающих неоднозначное толкование» ${ }^{692}$.

\footnotetext{
${ }^{691}$ Концепция развития гражданского законодательства Российской Федерации // Вестник Высшего Арбитражного Суда РФ. - 2009. - №11. - С. 11.

${ }^{692}$ Вестник Высшего Арбитражного Суда РФ. - 2009. - №11. - С. 13.
} 
К числу проблем ГК РФ, имеющих системный характер, относятся следующие:

1) регулирование корпоративных отношений по созданию юридических лиц, участию в них и связанные с таким участием обязательства;

2) создание комплекса взаимосвязанных институтов вещного права на основе права собственности, объединенных развернутой системой общих норм вещного права.

Эти направления правотворческой деятельности имеют не только практическое, но и теоретическое значение. Так, ст. 2 ГК РФ в качестве предмета гражданского права предусматривает корпоративные отношения, но правовая регламентация статуса юридических лиц закреплена в различных законодательных актах, нормы которых не всегда согласуются между собой и нормами Гражданского кодекса РФ.

Нуждаются в радикальном теоретическом переосмыслении и вопросы законодательного закрепления различных правовых институтов, связанных с правом собственности. Конституция РФ не только закрепила право частной собственности (ст. 8), но и провозгласила право частной собственности на землю и другие природные ресурсы (ст. 9). Однако в действующем российском законодательстве не создана система стабильных вещных прав на землю, участки недр и водные объекты. Кроме того указанные объекты права частной собственности закреплены в законодательстве различных отраслей права. Объединение всех этих институтов в системе законодательства гражданского права будет способствовать гармонизации его норм с земельным, водным, лесным законодательством и законодательством о недрах ${ }^{693}$.

В связи с этим актуализируется и научная проблема согласования правовых норм указанных отраслей права между собой. Здесь важно выявить приоритеты при выборе способа правового регулирования и соответствующих правовых средств. В основе правотворческого решения в каждом конкретном случае может быть только содержание регулируемых общественных отношений, а не благие намерения и субъективное усмотрение законодателя. Перевод некоторых объектов правового регулирования в сферу гражданского права должен иметь серьезные научные доказательства, иначе произойдет не улучшение, а, наоборот, ухудшение экономического климата в стране.

Оценка подлежащих правовой трансформации объектов со смешанными предметами правового регулирования должна отражать следующие показатели:

1) определение значения подлежащих правовому регулированию общественных отношений для функционирования и развития экономики;

2) выявление видов отраслевой принадлежности этих отношений и анализ потенциальных возможностей каждой из них создать эффективный правовой механизм по их урегулированию;

\footnotetext{
${ }^{693} \mathrm{C}$. подробнее: Концепция развития гражданского законодательства Российской Федерации // Вестник Высшего Арбитражного Суда РФ. - 2009. - №11. - С. 51.
} 


\section{Правотворчество в Российской Федерации}

3) обоснование необходимости правового урегулирования данных общественных отношений именно нормами гражданского права;

4) установление объективно существующих взаимосвязей различных видов общественных отношений, составляющих в данном случае предмет правового регулирования;

5) выработка норм гражданского права, необходимых для урегулирования данных общественных отношений, имеющих внутреннюю связь с близкими к ним иным общественным отношениям, которые тоже требуют нормативного закрепления;

6) внесение изменений и дополнений в смежные отрасли права с отражением в них правовых предписаний, предусмотренных в нормах гражданского права, что будет означать юридическое закрепление имеющихся между ними объективных связей.

Развитие гражданского законодательства будет идти и по пути устранения обнаружившихся в нем пробелов, превращения частных нормативных предписаний в общие, конкретизации и уточнения норм, допускающих неоднозначность их понимания. Целью совершенствования норм гражданского права в этом случае является обеспечение эффективного функционирования экономики страны. Правотворческая деятельность и в данном направлении должна проводиться на строго научной основе. Теория правотворчества может и обязана «находить «золотую» середину между ненужной конкретизацией и полной абстракцией, из которой ничего нельзя понять» ${ }^{694}$. И хотя «Концепция развития гражданского законодательства Российской Федерации» опирается на объективную доктринальную оценку действующего ГК РФ ${ }^{695}$, в ней специально не предусматривается возможность использования теории правотворчества в процессе его совершенствования, без которой, по нашему мнению, обойтись невозможно. Это вытекает из того, что именно теория правотворчества должна научно обосновать пределы абстракции и конкретизации норм гражданского права в ходе их оптимизации, выработать критерии их качественного уровня, эффективности в регулировании общественных отношений.

Важнейшим научным направлением в теории правотворчества на сегодняшний день является исследование проблем согласования долгосрочных планов социально-экономического развития страны, юридической науки и законодательства в области гражданского права ${ }^{696}$. Поскольку «доктрина должна идти впереди законодателя и правоприменителя» ${ }^{697}$, возникает объективная необходимость научного определения

\footnotetext{
${ }^{694}$ Маковский А.Л. Уроки Гражданского кодекса Франции // Журнал зарубежного законодательства и сравнительного правоведения. - 2014. - №6. - С. 1025.

${ }^{695}$ Вестник Высшего Арбитражного Суда РФ. - 2009. - №11. - С. 10.

${ }^{696}$ См. выступление Ю.А. Тихомирова на круглом столе по теме «Актуальные проблемы правотворчества и проект федерального закона «О нормативных правовых актах в Российской Федерации» // Журнал российского права. - 2015. - №3. - С. 147.

${ }^{697}$ Малько А.В. Правовая политика - категория XXI века и ее роль в Евразийской интеграции // Евразийский юридический журнал. - 2014. - №4 (71). - С. 9.
} 
возможностей отражения в нормах законодательства планов социальноэкономического развития страны, выработки оптимальных юридических механизмов, способствующих данному процессу.

В юридической литературе было высказано вполне аргументированное предложение о необходимости проведения в России масштабной правовой реформы, потому что «если не сформировать в стране правовую реформу, то и остальные реформы, прежде всего создание правовой, конституционной экономики, с очень большой вероятностью начнут буксовать» ${ }^{698}$.

Для этого необходимо повышение качества правотворчества, планомерное издание новых нормативных правовых актов в соответствии с действующими концепциями экономического, социально-политического и правового развития Российской Федерации, постоянное обновление действующего гражданского и другого законодательства, приводя его в соответствие с потребностями развивающихся общественных отношений, выявление и устранение субъективных факторов, снижающих эффективность правового регулирования в условиях проводимых реформ. Как показывает анализ внесенных поправок в действующее законодательство в целом, сейчас во всех отраслях права назрела необходимость разработки планов их радикального совершенствования, что может быть закреплено в соответствующих научно обоснованных концепциях, как это сделано в сфере гражданского права ${ }^{699}$.

Наиболее приемлемый вариант устранения выявленных недостатков гражданского законодательства представляет собой следующую деятельность правотворческого органа:

1) координация и согласование планов экономического развития, планов издания нормативных правовых актов и Концепции правовой политики на длительную перспективу;

2) проведение постоянных научных исследований протекающих социально-экономических и правовых явлений с целью выработки обоснованных предложений по их юридическому закреплению нормами гражданского права;

3) установление четких связей между конкретными плановыми экономическими мероприятиями и соответствующими правотворческими решениями, обеспечивающих их реализацию, которые вместе с тем согласуются с концепцией правовой политики государства;

4) осуществление постоянного правового мониторинга действующего гражданского законодательства и постоянная его корректировка для приведения в соответствие с изменяющимися общественными отношениями, а также с изменениями концепции правовой политики.

\footnotetext{
698 Зорькин В.Д. Тезисы о правовой реформе в России // Россия и Конституция в XXI веке. - М., 2007. - С. 224, 227.

${ }^{699} \mathrm{Cм.,} \mathrm{например,} \mathrm{обоснованное} \mathrm{предложение} \mathrm{о} \mathrm{необходимости} \mathrm{радикального} \mathrm{совершен-}$ ствования уголовного права: Бондаренко О.В. Судебная практика и уголовное правотворчество. Автореф. дис. ... к.ю.н. - М., 2013. - С. 10.
} 
На основании проведенного анализа проблем правотворчества в области гражданского права можно сформировать следующие выводы.

1. Научное осмысление правотворческой деятельности в сфере гражданского права осуществляется недостаточно, хотя оно и является определяющим фактором в юридическом закреплении проводимых социально-экономических реформ. Об этом свидетельствует не только медленно реализуемая «Концепция развития гражданского законодательства Российской Федерации», но и незначительное количество публикаций в юридической литературе по данной проблематике. Продолжает оставаться актуальным утверждение А.В. Малько о том, что «наука существенно отстает от потребностей правовой политики и от правовой жизни, которые «идут» во многом на ощупь, двигаются методом «проб и ошибок» ${ }^{700}$.

2. Основополагающим направлением современного гражданского правотворчества является реализация в законодательстве согласованных между собой планов социально-экономического развития страны, «Концепции развития гражданского законодательства Российской Федерации» путем выработки объединяющих их скоординированных правотворческих решений.

3. Приоритет гражданского права при наличии его взаимосвязи с другими отраслями права определяется с учетом следующего правила: «В случае конкуренции нескольких предметов правового регулирования преимущество имеет тот из них, который оказывает преобладающее влияние на конкретную жизненную ситуацию, отражая основную сущность общественных отношений и тенденцию их развития».

${ }^{700}$ Малько А.В. Правовая политика - категория XXI века и ее роль в Евразийской интеграции // Евразийский юридический журнал. - 2014. - №4 (71). - С. 11. 


\section{СПИСОК ЛИТЕРАТУРЫ \\ СТАТЬИ, МОНОГРАФИИ, ДИССЕРТАЦИОННЫЕ ИССЛЕДОВАНИЯ}

1. Абдулаев М.И. Теория государства и права. - М.: Финансовый Контроль, 2004. - 410 с.

2. Авакьян С.А. Нужна ли конституционная реформа в России? // Конституционное и муниципальное право. - 2013. - №3. - С. 33-37.

3. Агамиров К.В. Прогнозные оценки и планирование законодательства на долгосрочную перспективу // Человеческий капитал. - 2014. №04 (64). - С. 67-71.

4. Агутин А.В. Идеологический статус концепции прав и свобод человека и гражданина, и духовность российского народа в доктрине отечественного уголовного судопроизводства // Вестник экономической безопасности. - 2016. - №5. - С. 32.

5. Акутаев Р.М. Правовая культура сквозь призму современной правовой реальности // Российская юстиция. - 2013. - №2. - С. 65.

6. Алексеев С.С. Восхождение к праву. Поиски и решения. - М.: Норма, 2001. -752 c.

7. Алексеев С.С. Механизм правового регулирования в социалистическом государстве. - М., 1966. - 187 с.

8. Алексеев С.С. Проблемы теории права: Курс лекций в двух томах. - Т. 2. - Свердловск, 1973. - 401 с.

9. Алексеев С.С. Общая теория права в 2 т. - Т. 1. - М., 1981. - 359 с.

10. Алексеев С.С. Теория права. - М.: Бек, 1995. - 320 с.

11. Алексеев С.С. Философия права: История и современность. Проблемы. Тенденции. Перспективы. - М.: Норма, 1999. - 329 с.

12. Алешкова Н.П. Конституционно-правовые основы муниципального правотворчества в Российской Федерации. Автореф. дис. ... к.ю.н. - Екатеринбург, 2010.

13. Аничкин Е.С. Факторы единства и многообразия конституционного законодательства РФ // Конституционное и муниципальное право. 2005. - №2. - C. 37.

14. Арзамасов Ю.Г. Ведомственный нормотворческий процесс: структура, содержание, перспективы развития (ч. 1) //Сводный реферативный сборник журнала Представительная власть - XXI век: законодательство, комментарии, проблемы. - 2007.

15. Арзамасов Ю.Г. Концепция мониторинга нормативных правовых актов / Ю.Г. Арзамасов, Я.Е. Наконечный. - М., 2011. - 208 с.

16. Бабаев В.К. Формальная определённость и возможности формализации законодательства // Советское государство и право. - 1978. №4. - С. 45

17. Багдасаров В.Ю. Основания классификации правотворчества // Журнал российского права. - 2012. - №11. - С. 49-58.

18. Баглай М.В. Конституционное право Российской Федерации. М.: Норма, 2000. -784 с. 


\section{Правотворчество в Российской Федерации}

19. Баранов В.М. Юридическая техника. В 2-х т. / под ред. В.М. Баранова. - М.: Юрайт. -251 с.

20. Баранов В.М. Инициативная программа спецкурса «Юридическая техника» / В.М. Баранов, М.Ю. Варьяс, Е.Н. Салыгин // Проблемы юридической техники: сб. ст. / под ред. В.М. Баранова. - Н. Новгород, $2000 .-330 \mathrm{c}$.

21. Баранов В.М. Личное в правотворчестве: утопия, антропологический ресурс или необходимое технико-юридическое средство повышения качества / В.М. Баранов, В.В. Трофимов // Вестник Нижегородской академии МВД России. - 2015. - №(30). - С. 16-18.

22. Баукен А.А. Место актов локального технико-правового регулирования в системе локальных нормативных актов // Вестник ЮУрГУ. Серия «Право». - 2014. - Т. 14. - №1.

23. Бахрах Д.Н. Очерк теории российского права. - М.: Норма, 2010. $-287 \mathrm{c}$.

24. Бачило И.Л. Мониторинг правовой системы - путь к управлению правового государства // Вестник Совета Федерации. Мониторинг права в Российской Федерации. - 2006. - №4-5. - С. 21.

25. Бачило М.Л. О методологии юридической техники законодательства // Государство и право. - 2006. - №6. - С. 185-204.

26. Бачинин В.А. Энциклопедия философии и социологии права / под ред. Н.И. Мацнева. - СПб.: Юридический центр Пресс, 2006. - 1091 с.

27. Белоусова М.С. Правотворческая функция российского государства // Вестник Челябинского государственного университета. - 2010. №19 (200). - C. 11-12.

28. Белоусов С.А. Правотворчество и законодательный дисбаланс: диалектика взаимосвязи // Вестник ВГУ. - 2015. - №1. - С. 63-68.

29. Болдырев С.Н. Нормотворчество и правотворчество: проблемы соотношения (технико-юридический аспект) //Вестник Волгоградской Академии МВД России. - 2011. - №17. - С. 18.

30. Бондаренко О.В. Судебная практика и уголовное правотворчество. Автореф. дис. ... к.ю.н. - М., 2013.

31. Борисов А.С. Некоторые проблемы современного правотворчества в России / А.С. Борисов, П.А. Меркулов // Социум и власть. 2015. - №3 (53). - С. 65-69.

32. Брагинский М.И. Договорное право. Книга вторая. Общие положения / М.И. Брагинский, В.В. Витрянский. - М.: Статут, 1999. - 848 с.

33. Брауде И.Л. Избранное: Очерки законодательной техники. Некоторые вопросы системы советского права. - М.: Институт законодательства и сравнительного правоведения при Правительстве Российской Федерации, 2010. -160 с.

34. Брауде И.Л. Вопросы законодательной техники// Советское государство и право. - 1957. - №8.

35. Булыко А.Н. Большой словарь иностранных слов. - М., 2010.

36. Васильев А.М. Правовые категории. Методологические аспекты разработки системы категорий теории права. - М.: Юрид. лит., 1976. $264 \mathrm{c}$ 
37. Витрук Н.В. Система прав личности // Право личности в социалистическом обществе. - М., 1981. - С. 109.

38. Вишневский А.Ф. Теория и практика подготовки проекта нормативного правового акта / А.Ф. Вишневский, В.Н. Дмитрук. - Минск: Дикта, 2005. - 147 с.

39. Власенко Н.А. Законодательная технология. Теория. Опыт. Правила. - Иркутск, 2001.

40. Власенко Н.А. О кризисных тенденциях в праве // Юридическая техника. - 2014. - №8. - С. 40-45.

41. Власенко Н.А. Разумность, право, правотворчество // Юридическая техника. - 2012. - №6. - С. 121-125.

42. Власенко Н.А. Основы теории юридических документов / Н.А. Власенко, С.В. Стародубцев. - М., 2006.

43. Власов В.И. Теория государства и права. - Ростов н/Д.: Феникс, 2002. $-512 \mathrm{c}$.

44. Вопленко Н.Н. Понятие и классификация принципов права / Н.Н. Вопленко, В.А. Рудковский // Вестник Волгоградского государственного университета. Сер. 5. Юриспруденция. - №1 (18). - С. 36-39.

45. Венгеров А.Б. Теория государства и права // Теория государства и права: учебник для юрид. вузов. - 3-е изд. - М.: Юриспруденция, 2000. $528 \mathrm{c}$.

46. Выступление С.В. Бошно на круглом столе «Актуальные проблемы правотворчества и проект федерального закона «О нормативных правовых актах в Российской Федерации» 26.01.2015 // Журнал российского права. - 2015. - №3. - С. 149.

47. Выступление Э.М. Мустафиной на шестом межрегиональном научно-практическом семинаре «Тенденции и итоги формирования института мониторинга законодательства и правоприменительной практики в субъектах Российской Федерации» от 22.04.2010 г. // [Электронный pecypc]. - Режим доступа: www.consultant.ru

48. Выступление Т.А. Петровой на круглом столе 26.01.2015 г. по теме «Актуальные проблемы правотворчества и проект федерального закона «О нормативных правовых актах в российской Федерации» // Журнал российского права. - 2015. - №3. - С. 147-148.

49. Выступление К.В. Всеволжского на круглом столе по теме «Актуальные проблемы правотворчества и проект федерального закона «О нормативных правовых актах в Российской Федерации» // Современное правотворчество: новые возможности для общества и государства / А.В. Павлушкин, А.С. Павловский // Журнал российского права. 2015. - №3. - C. 150.

50. Гладких В.И. О проблемах законодательного конструирования норм уголовного права // Человек. - 2014. - №3. - С. 33-37.

51. Голенок С.Г. Конкретизация как прием юридической техники в региональном нормотворчестве // Юридическая техника. - 2007. - №1. C. 231.

52. Государство созидающее: юридическая модель и современные риски / под ред. О.Н. Полухина. - М., 2016. 


\section{Правотворчество в Российской Федерации}

53. Гошуляк В.В. Конституционное и уставное законодательство субъектов Российской Федерации. - М.: Норма, 1999. - 438 с.

54. Гродзинский М.М. Об усовершенствовании законодательной техники // Социалистическая законность. - 1957. - №1 - С.11-18.

55. Губаева Т.В. Язык и право. - М.: Норма, 2003. - 160 с.

56. Гук П.А. Судебная практика как форма судебного нормотворчества в правовой системе России: процессы демократизации // Юридическая техника. Ежегодник. - 2014. - №8. - С. 126-130.

57. Гущин В.В. Корпоративное право / В.В. Гущин, Ю.О. Порошкина, Е.Б. Сердюк. - М.: Волтерс Клувер, 2009. - 634 с.

58. Давыдова М.А. Модельный закон субъектов Российской Федерации «О правовом мониторинге в субъекте Российской Федерации» / М.А. Давыдова, С.А. Хвалев, О.Н. Шишпаренок // Вестник Института законодательства и правовой информации им. М.М. Сперанского. 2012. - №3. - C. 25-28.

59. Дагель П.С. Условия установления уголовной наказуемости // Правоведение. - 1975. - №4. - С. 69-70.

60. Дербина А.В. Правосознание как элемент правовой позиции субъекта правотворчества. Автореф. дис. ... к.ю.н. - Самара, 2011.

61. Дерхо Д.С. К вопросу о необходимости нормативной регламентации предварительного этапа конституционного правотворчества // Апробация. - 2015. - №8 (35). - С. 28.

62. Дерхо Д.С. К вопросу о сущности и динамике конституционного правотворчества в Российской Федерации // Вестник ЮУрГУ. Серия «Право». - 2014. - Т. 14. - №1. - С. 79-85.

63. Дмитриева Л.И. Участие Президента Российской Федерации в законодательном процессе. Автореф. дис. ... к.ю.н. - М., 2005.

64. Долинская В.В. Судебные акты как источники гражданского права // Цивилист. - 2007. - №2. - С. 8.

65. Евстигнеева Г.Б. Судебное решение как источник права. Автореф. дис. ... к.ю.н. - М., 2007.

66. Ершов В.В. Правовая природа принципов российского права: теоретические и практические аспекты // Российский судья. - 2009. - №5. C. 13.

67. Жариков Ю.Г. Нормы гражданского права в сфере земельных отношений // Журнал российского права. - 2011. - №11. - С. 35.

68. Желдыбина Т.А. О судебном правотворчестве // Вестник Саратовской государственной юридической академии. - 2015. - №2 (103). C. 28.

69. Желдыбина Т.А. О значении мониторинга как самостоятельного правового института // СПС Консультант Плюс.

70. Жинкин С.А. Некоторые проблемы реализации принципов правотворчества в современной России / С.А. Жинкин, Т.М. Чернявская // Общество и право. - 2016. - №2 (56). - С. 23.

71. Жоль К.К. Философия и социология права. - М.: Юнити, 2005. $415 \mathrm{c}$. 
72. Загидуллин Р.И. Использование методических рекомендаций органов государственной власти в муниципальном правотворчестве // Конституционное и муниципальное право. - 2016. - №1. - С. 71.

73. Закон: создание и толкование / под ред. А.С. Пиголкина. - М., 1998. $-283 \mathrm{c}$.

74. Законодательная техника: науч.-практ. пособ. / Л.Ф. Апт, Н.А. Власенко, В.Б. Исаков, С.В. Кузнецов [и др.]; под ред.: Ю.А. Тихомирова. - М.: Городец, 2000. -272 с.

75. Звягина Е.А. Правотворчество в области местного самоуправления в Российской Федерации: правовые проблемы теории и практики (на примере Пензенской области) // Известия ПГПУ. - 2007. - №3 (7). C. 59.

76. Зорькин В.Д. Тезисы о правовой реформе в России // Россия и Конституция в XXI веке. - М., 2007. - С. 224, 227.

77. Иванова Л.А. Определение эффективности нормативных актов в процессе правового мониторинга. Автореф. дис. ... к.ю.н. - М., 2011.

78. Иванчин А.В. Внутренняя и внешняя законодательная техника в структуре уголовного правотворчества. Монография. - Рязань: Концепция, 2014. $-152 \mathrm{c.}$

79. Иванчигин А.В. Законодательная техника и ее роль в российском уголовном правотворчестве. - М.: Юрлитинформ, 2011. - 206 с.

80. Илларионов А.В. Акты правотворчества в Российской Федерации. Дис. ... канд. юрид. наук. - Омск, 2008.

81. Ильин А.В. Оптимизация правотворческой деятельности в современной России (вопросы теории и практики) / под ред. С.А. Комарова. СПб.: Изд-во Юридического института, 2005. - 309 с.

82. Иншаков С.М. Латентная преступность как показатель эффективности уголовной политики // Российский следователь. - 2008. - №14. C. 2.

83. Италия. Конституция и законодательные акты. - М., 1988.

84. Каменская Е.В. Региональное правотворчество в Российской Федерации. Автореф. дис. ... к.ю.н. - М., 2005.

85. Как применять закон / гл. ред. Ю.А. Тихомиров. - М.: Известия, 1993. $-61 \mathrm{c}$.

86. Карапетов А.Г. Свобода договора и пределы императивности норм гражданского права // Вестник ВАС РФ. - 2009. - №11. - С. 101.

87. Карташов В.Н. Законодательная технология субъектов Российской Федерации / В.Н. Карташов, С.В. Бахвалов. - Ярославль: ЯрГУ, 2010. -368 c.

88. Кашанина Т.В. Корпоративное (внутрифирменное) право. - М.: Норма, 2003. - 320 c.

89. Керимов Д.А. Свобода, право и законность в социалистическом обществе. - М.: Госюриздат, 1960. - 223 с.

90. Керимов Д.А. Философские основания политико-правовых исследований. - М.: Мысль, 1986. -332 с.

91. Киреев В.В. Теоретические проблемы структурирования и основные стадии процесса конституционно-правовой реформы // Вестник 
Южно-Уральского государственного университета. Серия Право. 2006. - №13. - С. 257.

92. Кириленко И.С. Локальное правотворчество в современных условиях правового регулирования: вопросы теории и практики // Современное право. - 2014. - №3. - С. 11.

93. Клебанов Л.Р. Десять лет Уголовному кодексу Российской Федерации: достоинства и недостатки // Государство и право. - 2006. №11. - С. 107-125.

94. Краснов Ю.К. Юридическая техника: учебник / Ю.К. Краснов, В.В. Надвикова, В.И. Шкатулла. - М.: Юстицинформ, 2014. - 536 с.

95. Краснова О.И. Участие органов государственной власти субъектов Российской Федерации в федеральном законодательном процессе: вопросы теории и практики / О.И. Краснова, Е.А. Пименов // Современное право. - 2010. - №8. - С. 13-20.

96. Ковалев М.И. Советское уголовное право. Советский уголовный закон: курс лекций. Вып. 2. - Свердловск: Изд-во Свердловского юридического института, 1974.

97. Козлов А.Н. Механизм построения уголовно-правовых санкций. Автореф. дис. ... к.ю.н. - М., 1991.

98. Козырин А.Н. Правовое регулирование в сфере образования: научно-практический комментарий статьи 4 Федерального закона «Об образовании в Российской Федерации» / А.Н. Козырин, Т.Н. Трошкина // Ежегодник российского образовательного законодательства. - 2013. T. 8. - C. 22-23.

99. Косачев К.И. Как избавиться от законов-пустышек // Российская газета. - 09.07.2002.

100. Костенко М.П. Пробел в праве как разновидность правотворческой ошибки // Известия Южного федерального университета. Технические науки. - 2008. - №10. - С. 117-123.

101. Комаров С.А. Общая теория государства и права. - М.: Юрайт, 1998. $-416 \mathrm{c}$.

102. Конт Огюст. Дух позитивистской философии: слово о положительном мышлении / пер. с франц. И.А. Шапиро. - М.: Либроком, 2012. $-76 \mathrm{c}$.

103. Конт Огюст. Общий обзор позитивизма / пер. с франц. И.А. Шапиро; под ред. И.С. Радлова. - 3-е изд. - М.: Либроком, 2012. - 200 с.

104. Кочетков В.В. Идея справедливости и Конституционные проблемы государства // Российский журнал правовых исследований. 2015. - №3 (4). - С. 108.

105. Красавчиков О.А. Юридическая техника и вопросы дальнейшего совершенствования советского гражданского законодательства // Советское государство и права в период развернутого строительства коммунизма. - Л., 1961. - 107 с.

106. Кривенцов П.А. Зарубежный опыт изучения латентной преступности // Актуальные проблемы российского права. - 2012. - №3. C. 254. 
107. Куксин И.Н. О некоторых проблемах предпроектного этапа муниципального правотворческого процесса / И.Н. Куксин, Е.А. Каминская // Вестник МГПУ. Серия «Юридические науки». - 2015. - С. 65.

108. Кудрявцев Н.И. Эффективность правовых норм / Н.И. Кудрявцев, В.И. Никитинский, И.С. Самощенко [и др.]. - М., 1980. - 280 с.

109. Кулаков В.В. Основные принципы гражданского права как особая форма права // Вестник Пермского университета. - 2013. - №4 (22). C. 186.

110. Кулушева М.А. О наделении органов местного самоуправления отдельными государственными полномочиями // Россия на пути реформ: федеральный и региональный аспекты / под ред. С.Ю. Наумова. - Саратов, 2003.

111. Курманов М.М. Законодательные (представительные) органы государственной власти республики в системе органов государства (компетенция, взаимодействие, ответственность). Автореф. дис. ... к.ю.н. - Казань, 2003.

112. Курс уголовного права. Общая часть / под ред. Н.Ф. Кузнецовой, И.М. Тяжковой. - Т. 1. - М., 2002. - 624 с.

113. Кутафин О.Е. Предмет Конституционного права. - М., 2000.

114. Кутафин О.Е. Муниципальное право Российской Федерации / О.Е. Кутафин, В.И. Фадеев. - М., 2004.

115. Лазарев В.В. Теория государства и права / В.В. Лазарев, С.В. Липень. - М., 1998. - 448 с.

116. Лашков А.С. Правотворческие ошибки. Проблемы теории и практики. Автореф. дис. ... к.ю.н. - СПб., 1999.

117. Лебедева Е.А. О совершенствовании системы управления в Калужской области // Журнал российского права. - 2010. - №6. - С. 137-147.

118. Лившиц Р.3. Теория права. - М.: БЕК, 1994. - 224 с.

119. Липень С.В. Идеи правотворчества и правореализации в политико-правовой мысли России XIX - начала XX в. Автореф. дис. ... д-ра юрид. наук. - М., 2013.

120. Ломакин Д.В. Акционерное правоотношение: понятие, содержание, субъекты. Дис. ... к.ю.н. - М., 1996.

121. Ломакина И.Б. Методология правотворчества: теория и практика, направления совершенствования / И.Б. Ломакина, Д.С.-М. Тэпс // Пробелы в российском законодательстве. - 2012. - №4. - С. 24

122. Ломтева В.С. Прогнозирование в правотворчестве и правоприменении. Дис. ... к.ю.н. - М., 2006.

123. Лопатин В.Н. Конституционная законность и проблемы нормотворчества в России // Журнал российского права. - 2004. - №5. - С. 8.

124. Лукьянов А.И. Законодательный процесс в России // Журнал российского права. - 1997. - №4. - С. 14-19.

125. Любимов Н.А. Правотворчество в Российской федерации: проблемы теории и практики: конспект лекций. - М.: Изд-во Московского ун-та, 2009. - 160 с.

126. Ляпунов Ю.И. Общественная опасность деяния как универсальная категория советского уголовного права. - М., 1989. 
127. Мазуренко А.П. К вопросу о методах правотворческой политики. // Правотворческие ошибки: понятие, виды, практика и техника выявления и устранения в постсоветских государствах. Материалы международного круглого стола 29-30 мая 2008 г. / под ред. В.М. Баранова, И.М. Мацкевича. - М.: Проспект, 2009.

128. Мазуренко А.П. К вопросу о методах правотворческой политики // Юристъ-Правоведъ. - 2007. - №5. - С. 16.

129. Маковский А.Л. Гражданское законодательство. Пути развития // Право и экономика. - 2003. - №3. - С. 35-38.

130. Маковский А.Л. Уроки Гражданского кодекса Франции // Журнал зарубежного законодательства и сравнительного правоведения. 2014. - №6. - C. 10-25.

131. Малько А.В. Правовая политика - категория XXI века и ее роль в Евразийской интеграции // Евразийский юридический журнал. 2014. - №4 (71). - C. 9

132. Малько А.В. Теория государства и права. - М.: Норма. 1999. $448 \mathrm{c}$.

133. Малько А.В. Технико-юридические основы правотворчества / А.В. Малько, А.Н. Бабенко // Журнал российского права. - 2012. - №8. C. 127.

134. Малько А.В. Муниципальное право России / А.В. Малько, С.В. Корсакова. - М.: Юрайт, 2011. - 398 с.

135. Малько А.В. Приоритеты правотворческой политики в сфере предпринимательства / А.В. Малько, А.П. Мазуренко, К.А. Струсь // Правовая политика и правовая жизнь. - 2010. - №2. - С. 101-102.

136. Мальцев Г.В. Нравственное основание права: монография. - М.: Федеральная палата адвокатов РФ, 2016. - 432 с.

137. Мальцев Г.В. Социальные основания права. - М., 2007.

138. Маркова-Мурашова С.А. Поиск правовой гармонии как цель правотворчества XXI века // Известия Тульского государственного университета. - 2012. - №1. - Ч. 2. - С. 119-124.

139. Мартьянов Г.А. Теория и методика оптимизации участия законодательных (представительных) органов государственной власти субъектов Российской Федерации в федеральном законотворческом процессе. Автореф. дис. ... к.ю.н. - СПб., 2010.

140. Марченко М.Н. Проблемы теории государства и права. - М., 2013.

141. Масловская Т.С. Владение юридической техникой - основа грамотности юриста // Сургутские юридические чтения: Сб. науч. трудов. Томск: Печатная мануфактура, 2002.

142. Масловская Т.С. Нормотворчество муниципальных образований в системе нормотворчества РФ // Северный регион: наука, образование, культура. - 2001. - С. 36

143. Матузов Н.И. Теория государства и права. - М., 2005. - 192 с.

144. Меркулова К.Ю. Проблемы правотворчества в российском законодательстве / К.Ю. Меркулова, А.И. Пушкарь // Вестник Московского гуманитарно-экономического института. - 2015. - №1 - С. 84-86. 
145. Миренский Б.А. Методологические основы и методы совершенствования законодательства. - Нукус: Каракалпакстан, 1990. - 192 с.

146. Миронов С.М. Теория и практика мониторинга правового правотворчества и правоприменительной практики: итоги и перспективы // Вестник Совета Федерации. Мониторинг права в Российской Федерации. -2006. - №4-5. - С. 5.

147. Мкртумян А.Ю. Судебная практика как источник гражданского права России // Гражданское право. - 2008. - №4. - С. 10-13.

148. Морозова Л.А. К вопросу о судебном правотворчестве // Юридическая техника. Ежегодник. - 2014. - №8. - С. 290-291.

149. Москалькова Т.Н. Нормотворчество: науч.-практ. пособ. / Т.Н. Москалькова, В.В. Черников. - М.: Проспект, 2011. - 384 с.

150. Муромцев Г.И. Юридическая техника: некоторые аспекты содержания понятия // Проблемы юридической техники: сб. ст. / под ред. В.М. Баранова. - Н. Новгород, 2000. - 438 с.

151. Назаренко Г. Теория и практика конструирования состава преступления: рецензия на монографию Иванчина А.В. «Конструирование состава преступления» (М.: Проспект, 2014. 352 с.) / Г. Назаренко, А. Ситникова // Уголовное право. - 2015. - №1 - С. 76-78.

152. Нарутто С.В. Основные правила юридической техники разработки концепции муниципальных правовых актов по самоорганизации населения / С.В. Нарутто, А.С. Пичоанин, Л.А. Плотникова. - Хабаровск, 2003.

153. Нашиц А. Правотворчество: теория и законодательная техника. M., 1974. $-256 \mathrm{c}$.

154. Научные основы советского правотворчества / под ред. Р.О. Халфиной. - М.: Наука, 1981. - 317 с.

155. Невеселов А.А. Правовой мониторинг и государственная политика: теоретико-правовые основы взаимодействия. Автореф. дис. ... к.ю.н. - Ростов н/Д., 2009.

156. Неделько Ю.В. Значение толкования правовых норм для правотворческой и правоприменительной деятельности // Современное право. -2010 . - №8. - С. 12.

157. Неновски Н. Право и ценности / под ред. В.Д. Зорькина. - М., 1987.

158. Непомнящая Т.В. Современная российская уголовная политика: проблемы правотворчества и правоприменения // Вестник Томского государственного университета. - 2015. - №2 (16). - С. 86.

159. Нерсесянц В.С. Общая теория права и государства. - М., 1999. $552 \mathrm{c}$.

160. [Электронный pecypc]. - Режим доступа: https://moluch.ru/ archive/13/1086/ (дата обращения: 09.06.2018).

161. Нерсесянц В.С. Философия права. - М.: Норма, 2005. - 656 с.

162. Нерсесянц В.С. Право и закон: их различие и соотношение // Вопросы философии. - 1988. - №5. 


\section{Правотворчество в Российской Федерации}

163. Нормография: теория и технология нормотворчества: учебник для бакалавриата и магистратуры / под ред. Ю.Г. Арзамасова. - М.: Юрайт, 2017. - 460 с.

164. Никитинский В.И. Об основах методологии и методики изучения эффективности действия правовых норм / В.И. Никитинский, А.Б. Венгеров // Ученые записки ВНИИС3. - Вып. 25. - М., 1971.

165. Никчемная Е.А. Планирование как юридическая категория // Современное право. - 2010. - №9. - С. 27-29.

166. Ниматулаева Р.А. Выборы в органы местного самоуправления: актуальные вопросы (на примере Республики Дагестан) // Конституционное и муниципальное право. - 2016. - №9. - С. 71.

167. Общая теория государства и права: учебник для бакалавриата и магистратуры / С.А. Комаров. - 9-е изд., испр. и доп. М.: Юрайт, 2017. C. $288-295$.

168. Общая теория государства и права. Академический курс в 2-х т. / под ред. М.Н. Марченко. - Т. 2. Теория права. - М., 1998. - 622 с.

169. Ожегов С.И. Словарь русского языка. М.: Мир и Образование; Оникс, 2011.- $736 \mathrm{c}$.

170. Ойгензихт В.А. Презумпции в советском гражданском праве. Душанбе, 1976. - 190 с.

171. Ордина О.Н. О проблемах создания единого правового пространства в России // Государственная власть и местное самоуправление. -2013 . - №6. - С. 6-8.

172. Осипов М.Ю. Понятие и соотношение правового регулирования и правотворчества. - М. Изд-во СГУ, 2010. - 221 с.

173. Остапович И.Ю. Сущность и особенности юридической формы воздействия на правотворчество // Мир науки, культуры, образования. 2011. - №4 (29). - С. 294.

174. Павлушкин А.В. Современное правотворчество: новые возможности для общества и государства / А.В. Павлушкин, А.С. Павловский // Журнал российского права. - 2015. - №2. - С. 149.

175. Петров А.В. Теория государства и права. Учебное пособие. - Челябинск: ЮУрГУ, 2014. - 238 с.

176. Петров М.П. Локальные акты организации высшего образования: правовая природа, виды и основания принятия // Ежегодник российского образовательного законодательства. - 2014. - Т. 9. - С. 42-56.

177. Петрова Е.Н. Современное методологическое значение конкретизации правовых норм для законотворческой практики в Российской Федерации // Вестник Тамбовского государственного университета им. Г.Р. Державина. - 19.07.2012. - С. 75.

178. Пиголкин А.С. Подготовка проектов нормативных актов (организация и методика). - М., 1968.

179. Пиголкин А.С. Совершенствование законодательной техники // Советское государство и право. - 1968. - №1. - С. 50-57.

180. Пиголкин А.С. Федеральные основы системы российского законодательства // Соотношение законодательства Российской Федерации и законодательства субъектов Российской Федерации. - М., 2003. 
181. Пиголкин А.С. Язык советского закона и юридическая терминология // Правоведение. - 1968. - №5. - С. 45-51.

182. Платонов В.М. Законодательный процесс в Российской Федерации. Автореф. дис. ... к.ю.н. - М., 1999.

183. Плохова В.И. Криминологическая и правовая обоснованность составов ненасильственных преступлений против собственности. Дис. дра юрид. наук. - Екатеринбург, 2003.

184. Поленина С.В. Законодательство в Российской Федерации. - М.: Изд-во ИГиП РАН, 1996. - 145 с.

185. Поленина С.В. Правотворческая политика // Российская правовая политика. Курс лекций / под ред. Н.И. Матузова, А.В. Малько. - М., 2003. $-528 \mathrm{c}$.

186. Полный курс уголовного права: в 5 т. / под ред. А.И. Коробеева. - Т. 1. - СПб., 2008.

187. Потапов В.А. Корпоративные нормативные акты как вид локальных актов. Автореф. дис. ... к.ю.н. - М., 2008.

188. Потапов М.Г. Система норм права и система нормативных правовых актов субъектов Федерации // Журнал российского права. 2010. - №12. - C. 59-73.

189. Попов О.В. Теоретико-правовые вопросы судебного правотворчества в РФ. Автореф. дис. ... к.ю.н. - Тольятти, 2004.

190. Право и законность в период развернутого строительства коммунизма / Н.Г. Александров. - М.: Госюриздат, 1961. - 271 с.

191. Правотворчество в СССР / под ред. профессора Л.И. Мицкевича. - М.: Юрид. лит., 1974. - 319 с.

192. Право и современные государства. - 2015. - №2. - С. 23-31.

193. Проблемы теории государства и права: учебник / под ред. М.Н. Марченко. - М.: Юристь, 2001. - 656 с. 2010.

194. Прокурорский надзор / под ред. Ю.Е. Винокурова. - М.: Юрайт,

195. Рабинович И.М. Конкретизация правовых норм: Общетеоретические работы / И.М. Рабинович, Г.Г. Шмелева // Правоведение. 1985. - №6. - С. 31-39.

196. Радько Т.Н. Теория государства и права. Хрестоматия. - М.: Академический проект, 2005. - 720 с.

197. Радько Т.Н. Теория государства и права. - М.: Проспект, 2009. $752 \mathrm{c}$.

198. Рарог А.И. Законодательные атаки на устои уголовного права // Государство и право. - 2013. - №1. - С. 24-32.

199. Рассказов Л.П. Теория государства и права. Учебник. - М.: РИОР, 2008. -463 с.

200. Рекомендации по подготовке и оформлению проектов федеральных законов / Т.Н. Рахманина, В.М. Баранов, Ю.А. Тихомиров [и др.] // Проблемы юридической техники / под ред. В.М. Баранова. - Н. Новгород, 2000. - С. 803-815. 


\section{Правотворчество в Российской Федерации}

201. Романовская В.Б. Духовность и правосознание (соотношение феноменов) // Вестник Нижегородского университета им. Лобачевского. Серия Право. - 2001. - №1. - С. 161-169.

202. Рузанова В.Д. Приоритет Гражданского кодекса Российской Федерации как фактор системности гражданского законодательства 160. [Электронный pecypc]. - Режим доступа: www.alrf63.ru/dejure

203. Рыбаков В.А. Правотворчество в переходный период развития права // Юридическая техника. - 2015. - №9. - С. 652-657.

204. Савицкий В.М. Язык процессуального закона. Вопросы терминологии. - М.: Наука, 1987. - 287 с.

205. Сапун В.А. Правотворчество и законотворчество: стратегия и тактика формирования права и закона / В.А. Сапун, Я.В. Турбова // Юридическая техника. - 2015. - №9. - С. 679-682.

206. Семенов И.А. Законодательная техника в уголовном правотворчестве. - Тюмень, 1998.

207. Семьянов Е.В. Судебное правотворчество: вопросы общей теории права. Автореф. дис. ... к.ю.н. - М., 2005.

208. Сергеева К.О. Муниципальное правотворчество в Российской Федерации. Дис. канд. ... юрид. наук. - М., 2013.

209. Синюков С.В. Механизм правотворчества. Автореф. дис. ... к.ю.н. - Саратов, 2013.

210. Сиотокова М.В. Основные принципы российского правотворчества // Государство и право в XXI веке. - 2014. - №1. - С. 11-14.

211. Ситникова И.Е. Политический плюрализм и правотворчество в современном российском государстве. Автореф. дис. ... к.ю.н. - Казань, 2010.

212. Скоробогатов А.В. Правовая реальность России: константы и переменные / А.В. Скоробогатов, А.В. Краснов // Актуальные проблемы экономики и права. - 2015. - №2. - С. 161-170.

213. Смоленский М.Б. Конституционное право: учебник для бакалавров / М.Б. Смолевской, М.В. Алексеева. - Ростов н/Д.: Феникс, 2013. $541 \mathrm{c}$.

214. Со А.А. Подзаконное правотворчество и юридическая техника (на примере органов исполнительной власти субъектов РФ Дальневосточного федерального округа) // Власть. - 2015. - №1. - С. 157-162.

215. Соловьев О.Г. Инструментарий правотворческой техники нуждается в законодательном оформлении // Законы России: опыт, анализ, практика. - 2012. - №10. - С. 95-98.

216. Соловьев О.Г. О нормативном закреплении основных требований и правил законодательной техники. Вестник ЯрГУ. Серия Гуманитарные науки. - 2010. - №4 (14). - С. 43-45.

217. Соловьев С.Г. Понятие предмета правового регулирования и его взаимосвязь с другими юридическими категориями // Вестник Пермского университета. - 2012. - №1 (15). - С. 47-52.

218. Сорокин В.В. Концепция эволюционного преобразования правовых систем в переходной период. Дис. ... д-ра наук. - Екатеринбург, 2003. 
219. Специальные нормы советского права / И.Н. Сенякин; под ред. М.И. Байтина. - Саратов: Изд-во Сарат. ун-та, 1987. - 97 с.

220. Спирин М.Ю. Теоретические проблемы законотворческой деятельности в Российской Федерации. Дис. канд. ... юрид. наук. - Самара, 2000.

221. Справочно-аналитические материалы Общероссийской общественной организации «Всероссийский совет местного самоуправления» // Местное право. - 2013. - №2 . - С. 27.

222. Старовойтов А.В. Планирование законоподготовительной и законодательной деятельности. Автореф. дис. ... к.ю.н. - М., 2002.

223. Строгович М.С. Избранные труды. Проблемы общей теории права. - Т. 1. - М., 1990. - 304 с.

224. Строев Е.С. Прошла пора выживания, наступила пора созидания // Парламентская газета. - 24.07.2001.

225. Субочев В.В. Законные интересы / под ред. А.В. Малько. - М.: Норма, 2008. - $496 \mathrm{c}$.

226. Сырых В.М. История и методология юридической науки. М.: Норма; Инфра-М, 2017. - 463 с.

227. Сырых В.М. Предмет и система законодательной техники как прикладной науки и учебной дисциплины // Законотворческая техника современной России: состояние, проблемы, совершенствование: сб. ст.: в 2 т. - Т. 1. - Н. Новгород, 2001.

228. Сырых В.М. Совершенствование механизма согласования интересов Российской Федерации и ее субъектов в процессе подготовки и принятия федеральных законов // Законодательные (представительные) органы власти субъектов Российской Федерации. Практика. Мнения. Проблемы. - 1999. - Вып. 2. - С. 7.

229. Теория государства и права: курс лекций / под. ред. Н.И. Матузова, А.В. Малько. - М.: Юрист, 1997. - 672 с.

230. Теория государства и права: курс лекций / под ред. Н.И. Матузова, А.В. Малько. - 3-е изд., перераб. и доп. - М.: Норма; Инфра-М, 2012.

231. Теория государства и права: учебник / А.С. Пиголкин, А.Н. Головистикова, Ю.А. Дмитриев [и др.]; под ред. А.С. Пиголкина. - М.: Юрайт-Издат, 2005. - 613 с.

232. Теория государства и права. Учебник для вузов / отв. ред. В.Д. Перевалов, науч. консультант С.С. Алексеев. - М., 2004.

233. Теория государства и права. Учеб. для юрид. вузов и факультетов / под ред. В.М. Корельского, В.Д. Перевалова. - М., 1998. - 570 с.

234. Тиунова Л.Б. Системные связи правовой действительности: методология и теория. - СПб., 1991.

235. Тихомиров Ю.А. Выступление на круглом столе 26.01.2015 г. по теме: «Актуальные проблемы правотворчества и проект федерального закона «О нормативных правовых актах в Российской Федерации» // Журнал российского права. - 2015. - №3. - С. 146-147.

236. Тихомиров Ю.А. Правовое регулирование: теория и практика. M., 2010. 


\section{Правотворчество в Российской Федерации}

237. Тихомиров Ю.А. Организация и проведение правового мониторинга // Право и экономика. - 2006. - №10. - С. 74.

238. Тихомиров Ю.А. Новые векторы правового регулирования «другое» право? // Журнал российского права. - 2016. - №4. - С. 7.

239. Тихомиров Ю.А. Об организации и проведении правового мониторинга / Ю.А. Тихомиров, А.В. Павлушкин, Д.Б. Горохов [и др.] // Журнал российского права. - 2010. - №6. - С. 125-136.

240. Тихомиров Ю.А. Закон о нормативных правовых актах - актуальная повестка дня / Ю.А. Тихомиров, Т.Н. Рахманина, А.Г. Хабибулин // Журнал российского права. - 2006. - №5. - С. 88-93.

241. Толстик В.А. Иерархия источников российского права. Дис. ... д-ра юрид. наук. - Н. Новгород, 2009.

242. Туранин В.Ю. Теория и практика использования законодательных дефиниций. Монография. - М.: МЭСИ, 2009. - 111 с.

243. Туранин В.Ю. Юридическая терминология в российском законодательстве. - Белгород: ГиК, 2009. - 140 с.

244. Туранин В.Ю. Технология подготовки региональных (муниципальных) нормативных правовых актов и информационных документов / В.Ю. Туранин, Ю.П. Туранин. - Белгород, 2002.

245. Уголовный закон. Опыт теоретического моделирования / под ред. В.Н. Кудрявцева, С.Г. Келиной. - М., 1987. - 280 с.

246. Уголовное право. Общая часть / под ред. Н.И. Ветрова, Ю.И. Ляпунова. - М., 1997. - 250 с.

247. Феклин С.И. Нормативные правовые и локальные акты в сфере образования: метод. пособ. - М., 2011. -150 с.

248. Филатов С.В. Правотворческий процесс: понятие, стадии, принципы. // Государственная власть и местное самоуправление. - 2015. №8. - С. 35 .

249. Фомичева О.А. К вопросу о содержании понятия и видовой классификации современного правотворчества / О.А. Фомичева, Д.В. Пахомова // Достижения вузовской науки. Сер. Юридические науки. - 2008. - №6. - С. 25-71.

250. Халфина Р.О. Научные основы советского правотворчества. Академия наук СССР. Институт государства и права. - М.: Наука, 1981. $-317 \mathrm{c.}$

251. Хутов К.М. Теоретические правила создания уголовно-правовых предписаний / К.М. Хутов, И.В. Поликарпова // Актуальные вопросы борьбы с преступлениями. - 2015. - №2. - С. 39-43.

252. Цветков И.В. Эффективность решений Конституционного Суда Российской Федерации в 2006 году // Налоговед. - 2007. - №11. - С. 8.

253. Червонюк В.И. Теория государства и права: учебник. - М. Инфpa-M, 2006. - 704 c.

254. Черданцев А.Ф. Логико-языковые феномены в юриспруденции. - М.: Норма; Инфра-М, 2012. - 319 с.

255. Черданцев А.В. Теория государства и права: учебник для вузов. - М.: Юрайт, 2000. -432 с. 
256. Чередниченко С.П. Судебное правотворчество. Автореф. дис. ... к.ю.н. - М., 2005.

257. Черниловский 3.М. Всеобщая история государства и права - М. Юристъ, 1996. - 576 с.

258. Черепахин Б.Б. К вопросу о частном и публичном праве. - Иркутск, 1926. -26 с.

259. Чеснокова М.Д. Мониторинг законодательства и правоприменительной практики: опыт субъектов Российской Федерации // Журнал российского права. - 2010. - №8. - С. 32.

260. Чешуина С.И. Юридическая деятельность: монография / под ред. С.И. Чешуина, И.Е. Ильичёв; Институт социологии права. - Белгород, 2009. $-214 \mathrm{c}$.

261. Чинарян Е.О. Понятие и общая характеристика законодательной ошибки // Современное право. - 2010. - №9. - С. 22-26.

262. Чмыхало Е.Ю. Правотворчество в сфере регулирования земельных отношений // Аграрное и земельное право. - 2013. - №2 (28). C. $76-80$.

263. Шамаров В.М. Принципы правотворчества, классификация и содержание // Вестник Екатерининского института. - 2009. - №2. - С. 22-24.

264. Шамаров B.M. Теоретико-правовая учебная литература о принципах права // Вестник Екатерининского университета. - 2011. - №2 (14). - C. 56-64.

265. Ширяев Ю.Е. Современное понятие и сущность правотворчества и законотворчества // Человеческий капитал. - 2012. - № 3 (39). - С. 86.

266. Шугрина Е.С. Муниципальное право: учебник. - М.: Проспект, 2004. $-656 \mathrm{c}$.

267. Шукаева Е.С. Локальное нормотворчество как способ реализации нормативной функции работодательской власти // Право и государство: теория и практика. - 2015. - №7 (127). - С. 23-30.

268. Юридическая техника: учеб. пособ. / Н.А. Власенко, А.И. Абрамова, Г.Т. Чернобель. - 2-е изд., перераб. и доп. - М.: Юстиция, 2016. $320 \mathrm{c}$.

269. Юридическая техника: учебник / Т.В. Кашанина. - 2-е изд., пересмотр. - М.: Норма; Инфра-М, 2011. - 496 с.

270. Иеринг Р. Юридическая техника / сост. А.В. Поляков. - М.: Статут, 2008.

271. Юрина Т.С. О роли юридического прогнозирования // Вестник волжского университета им. Татищева. - 2001. - №14. - С. 292-293.

272. Юртаева Е.А. Закон о нормативно-правовых актах и практика российского правотворчества // Журнал российского права. - 2006. №5. - С. 12-22.

273. Явич Л.С. Советское право - регулятор общественных отношений в СССР. - Сталинабад, 1957.

274. Язык закона / под ред. А.С. Пиголкина. - М.: Юрид. лит., 1990. $192 \mathrm{c}$. 


\section{НОРМАТИВНЫЕ АКТЫ И ЗАКОНОДАТЕЛЬСТВО}

1. Бюллетень Верховного Суда РФ [Электронный ресурс]. - Режим доступа http://xn--b1azaj.xn--p1ai/2007/postanovlenie-plenuma-vs-rf/N48ot-29.11.2007.html

2. Ведомости Федерального Собрания РФ. - 21.12.2001. - №36.

3. Вестник Высшего Арбитражного Суда Российской Федерации. 2009. - №11 (204). - C. 16.

4. Вестник ВАС РФ. - 2009. - №11. - С. 11.

5. Закон Белгородской области «Об особенностях организации местного самоуправления в Белгородской области» от 30.03.2005 №17 [Электронный ресурс]. - Режим доступа: www.consultant.ru

6. Закон Вологодской области «Об областных нормативных правовых актах» от 17.01.2001 г. №647-03 с послед. изм. и доп.

7. Закон Московской области от 05.12.2008 №193/2008-О3 (ред. от 11.03.2014) «О регистре муниципальных нормативных правовых актов Московской области» [Электронный ресурс]. - Режим доступа. www.consultant.ru

8. Закон Санкт-Петербурга от 03.12.2008 №752-138 (ред. от 02.07.2014) «О регистре муниципальных нормативных правовых актов Санкт-Петербурга» (с изм. и доп., вступ. в силу с 01.01.2015).

9. Кодекс корпоративного поведения, утв. распоряжением Федеральной комиссии по рынку ценных бумаг от 4 апреля 2002 г. №421/p.

10. «О прокуратуре Российской Федерации» от 17.01.1992 №2202-1Ф3 (действ. ред. 2016) [Электронный ресурс]. - Режим доступа: www.consultant.ru

11. Кодекс о нормативных правовых актах Чукотского автономного округа [Электронный ресурс]. - Режим доступа: www.consultant.ru

12. Конституция РФ.

13. Методика осуществления мониторинга правоприменения в Российской Федерации. Утверждена постановлением Правительства РФ от 18.08.2011 №694 [Электронный ресурс]. - Режим доступа: www.consultant.ru

14. Областной закон Ленинградской области от 16.02.2015 №5-О3 (ред. от 06.06.2016) «О проведении оценки регулирующего воздействия проектов нормативно-правовых актов Ленинградской области и экспертизы нормативных правовых актов Ленинградской области» [Электронный ресурс]. - Режим доступа: www.consultant.ru

15. Постановление ГД Федерального Собрания РФ от 22.01.1998 г. №2134-11 ГД «О регламенте Государственной Думы Федерального Собрания Российской Федерации» [Электронный ресурс]. - Режим доступа: www.consultant.ru

16. Полный сборник кодексов Российской Федерации. - М., 2008. C. $553-660$.

17. Постановление Правительства РФ от 30.01.2015 №83 // СПС Консультант Плюс. 
18. Постановление Конституционного Суда РФ от 31.10.1995 г. // Собрание законодательства Российской Федерации от 6 ноября 1995 г. №45. - Ст. 4408.

19. Приказ Генпрокуратуры РФ от 17.09.2007 №144 (ред. от 06.02.2013) «О правотворческой деятельности органов прокуратуры и улучшении взаимодействия с законодательными (представительными) и исполнительными органами государственной власти и органами местного самоуправления», « Положения об организации правотворческой деятельности в органах прокуратуры Российской Федерации» [Электронный ресурс]. - Режим доступа: www.consultant.ru

20. Постановление Конституционного Суда РФ от 18.07.2003 №13-П «По делу о проверке конституционности положений статей 115 и 231 ГПК РСФСР, статей 26, 251 и 253 ГПК Российской Федерации, статей 1, 21 , и 22 Федерального закона «О прокуратуре Российской Федерации» в связи с запросами Государственного Собрания - Курултая Республики Башкортостан, Государственного Совета Республики Татарстан и Верховного Суда Республики Татарстан» [Электронный ресурс]. - Режим доступа: www.consultant.ru

21. Постановление Правительства РФ от 02.04.2002 №207 «Об утверждении типового положения о юридической службе федерального органа исполнительной власти» [Электронный ресурс]. - Режим доступа: http://www.consultant.ru/document/cons_doc_LAW_36128

22. Проект федерального закона «О нормативных правовых актах в Российской Федерации» [Электронный ресурс]. - Режим доступа: http://base.consultant.ru/cons/cgi/online.cgi?req=doc;base $=$ PRJ; $n=127365$

23. Постановление Конституционного Суда РФ от 30.041996 №11-П «По делу о проверке конституционности пункта 2 Указа Президента РФ от 3 октября 1994 г. №1969 «О мерах по укреплению единой системы исполнительной власти в Российской Федерации» и пункта 2.3 Положения о главе администрации края, области, города федерального значения, автономной области, автономного округа Российской Федерации.

24. Постановление Конституционного Суда РФ от 31.10.1995 г. // С3 РФ от 6 ноября 1995 г. - №45. - Ст. 4408.

25. Постановление правительства Сахалинской области «Об утверждении Положения о видах правовых актов, принимаемых (издаваемых) органами исполнительной власти Сахалинской области и их разновидностями, а также порядке их принятия (издания) и опубликования» от 26.01.2010 №12 [Электронный ресурс]. - Режим доступа: www.consultant.ru

26. Распоряжение Председателя Государственной Думы Ставропольского края от 05.12.2003 г. №424-р «Об организации мониторинга законодательства и правоприменительной практики в Ставропольском крае» [Электронный ресурс]. - Режим доступа: www.consultant.ru

27. Решение Верховного Суда РФ от 18.04.2002 №ГКПИ02-399 «О признании частично недействующими отдельных пунктов Положения Банка России от 15.09.1997 №519 «О порядке подготовки и вступления в силу нормативных актов Банка России» и Указания Банка России от 
24.06.1998 №262-У, вносящего изменения в данное положение [Электронный ресурс]. - Режим доступа: www.consultant.ru

28. Решение Конституционного Суда РФ от 26.04.2016 «Об утверждении обзора практики Конституционного Суда РФ за первый квартал 2016 года» // СПС Консультант Плюс.

29. Российская газета. 07.12.1995.

30. Федеральный закон «Об исключительной экономической зоне Российской Федерации» от 17.12.1998 г. // СЗ РФ. - 21.12.1998. - №51. Ст. 6273.

31. Российская газета - Федеральный выпуск 5951 (278).

32. Постановление Минтруда РФ от 25.03.2002 №21 «Об утверждении разъяснения «О порядке применения пункта 2 статьи 31 Федерального закона «О трудовых пенсиях в Российской Федерации» (вместе с разъяснением Минтруда РФ от 25.03.2002 №2) (зарегистрировано в Минюсте РФ 22.05.2002 №3467) // С3 РФ. - 2002 - №30. - Ст. 303.

33. Совет Федерации Федерального Собрания Российской Федерации. Доклад «О состоянии законодательства в Российской Федерации» [Электронный ресурс]. - Режим доступа: www.consultant.ru

34. Уголовный кодекс РФ.

35. Указ Президента РФ от 29.05.2011 №657 «О мониторинге правоприменения в Российской Федерации» // СПС Консультант Плюс.

36. Федеральный закон от 17.07.2009 №172-Ф3 ( ред. от 21.10.2013) «Об антикоррупционной экспертизе нормативных правовых актов и проектов нормативно-правовых актов» [Электронный ресурс]. - Режим доступа: www.consultant.ru

37. Федеральный закон от 01.04.1993 г. «О Государственной границе Российской Федерации» // С3 РФ. - №50. - Ст. 5610.

38. Федеральный закон от 04.04.2005. «Об общественной палате» // СЗ РФ. - 2005. - №15. - Ст. 1277.

39. Федеральный закон от 08.01.1998 г. №6-Ф3 // С3 РФ. - 1998. №2. - Ст. 222; 2002. - №12. - Ст. 1093; №18. - Ст. 1721.

40. Федеральный закон от 14.06.1994 г. «О порядке опубликования и вступления в силу федеральных конституционных законов, федеральных законов, актов палат Федерального Собрания» // СЗ РФ. - 1994. - №8. Ст. 801.

41. Федеральный закон «Об общих принципах организации местного самоуправления в Российской Федерации» от 6 октября 2003 г. №131ФЗ. Ст. 14 // СЗ РФ. - Ст. 3822.

42. Указ Президента Российской Федерации от 23.05.1996 г. «О порядке опубликования и вступления в силу актов Президента Российской федерации, Правительства Российской Федерации и нормативных правовых актов федеральных органов исполнительной власти» // Собрание законодательства Российской Федерации. - 1994. - №8. - Ст. 801; 1996. - №22. - Ст. 2262. 1997. - №20. - Ст. 2242; 1998. - №33.

43. Указ Президента РФ от 6 апреля 2004 г. №490 «Об утверждении положения об Администрации Президента Российской Федерации» // C3 РФ. - 2004. - №22. - Ст. 2147. 
44. Федеральный закон «О континентальном шельфе Российской Федерации» [Электронный ресурс]. - Режим доступа: basegarant.ru

45. Федеральный закон от 01.04.1993 г. «О Государственной границе Российской Федерации» // С3 РФ. - №50. - Ст. 5610.

46. Федеральный закон «О несостоятельности (банкротстве) // С3 РФ. - 1996. - №25. - Ст. 2954.

47. Федеральный закон «О порядке выезда из Российской Федерации и въезда в Российскую Федерацию» // СЗ РФ [Электронный ресурс]. Режим доступа: basegarant.ru

48. Федеральный закон от 29.07.2004 №98-Ф3 «О коммерческой тайне» // СЗ РФ. - 2004. - №32. - Ст. 3283.

49. Федеральный закон «О прокуратуре Российской Федерации» от 17.01.1992 №2202-1-Ф3 (действ. ред., 2016) [Электронный ресурс]. Режим доступа: www.consultant.ru

50. Федеральный конституционный закон от 28.06.2004 г. №5-ФКЗ «О референдуме Российской Федерации» // СПС Консультант Плюс.

51. Федеральный закон от 6 октября 1999 г. №184-Ф3 «Об общих принципах организации законодательных (представительных) и исполнительных органов государственной власти субъектов Российской Федерации» [Электронный ресурс]. - Режим доступа http://www.consultant.ru/document/cons_doc_LAW_14058/ 
Научное издание

Румянцев Михаил Борисович

\title{
ПРАВОТВОРЧЕСТВО В РОССИЙСКОЙ ФЕДЕРАЦИИ
}

\author{
Монография \\ Чебоксары, 2019 г. \\ Редактор М.Б. Румянцев
}

Компьютерная верстка и правка E.B. Кузнещова

Дизайн обложки Н.B. Фирсова

Подписано в печать 26.05.2019 г.

Дата выхода издания в свет 04.06.2019 г.

Формат $60 \times 84 / 16$. Бумага офсетная. Печать офсетная.

Гарнитура Times. Усл. печ. л. 18,8325. Заказ К-480. Тираж 500 экз.

Издательский дом «Среда»

428005, Чебоксары, Гражданская, 75, офис 12

+7 (8352) 655-731

info@phsreda.com

https://phsreda.com

Отпечатано в Студии печати «Максимум»

428005, Чебоксары, Гражданская, 75

+7 (8352) 655-047

info@maksimum21.ru

www.maksimum21.ru 